\author{
В. В. ПІЧУРІН
}

\title{
Теоретико-методологічні й організаційні основи психологічної і психофізичної підготовки студентів залізничних вищих навчальних закладів у процесі фізичного виховання
}

МОНОГРАФІЯ 


\section{Рецензенти:}

д-р психол. наук, проф., зав. кафедрою педагогіки та психології

Дніпропетровського обласного інституту післядипломної педагогічної освіти I. Г. Батраченко;

д-р психол. наук, проф., проректор з виховної роботи за зв'язків з громадськістю Житомирського національного агроекологічного університету Л. П. Журавльова;

д-р наук з фізичного виховання та спорту, доц., проф. кафедри фізичної підготовки Харківського університету Повітряних сил імені Івана Кожедуба О. М. Ольховський;

д-р пед. наук, проф., проф. кафедри управління фізичною культурою та спортом Запорізького національного технічного університету $B$. В. Приходько

Друкується за рішенням вченої ради Дніпропетровського національного університету залізничного транспорту імені академіка В. Лазаряна (протокол № 4 від 03.12.12)

\section{УДК 796.011:159. 923:37.032:378}

Теоретико-методологічні й організаційні основи психологічної і психофізичної підготовки студентів залізничних вищих навчальних закладів у процесі фізичного виховання [Текст]: монографія / В. В. Пічурін; Дніпропетр. нац. ун-т залізн. трансп. ім. акад. В. Лазаряна. - Дніпропетровськ, 2015. - 420 с.

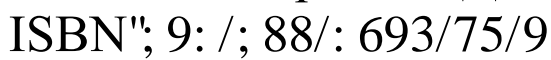

У монографії розглянуто питання пошуку теоретико-методологічних і організаційних основ психологічної і психофізичної підготовки студентів залізничних ВНЗ у процесі фізичного виховання. Проаналізовано філософське і психологічне підгрунтя для постановки питання про психологічну й психофізичну підготовку в процесі фізичного виховання, визначено іiї головну спрямованість і організаційні основи, наведено результати досліджень у цій сфері.

Для науковців та фахівців у сфері фізичної культури і спорту, психологів, студентів університетів фізичної культури та факультетів фізичного виховання, студентів психологічних факультетів.

Іл. 49. Табл. 46. Бібліогр.: 504 назви.

(C) Пічурін В. В., 2015

(C) Дніпропетр. нац. ун-т залізн. трансп. ім. акад. В. Лазаряна, редагування, оригінал-макет, 2015 


\section{В С Т У П}

Сьогодні життя безперервно ставить перед людиною все більш важкі завдання. У різних видах діяльності їй доводиться виконувати надзвичайно складні дії, що вимагають максимального психічного й фізичного напруження для успішного досягнення поставленої мети. Це стосується й діяльності сучасного інженера залізничного транспорту. Характерними для неї є висока відповідальність, велика суспільна значущість.

Високі вимоги до професійної діяльності інженера-залізничника, складність і великі витрати на його підготовку, у певних випадках екстремальність умов праці потребують, крім іншого, відповідної психологічної і психофізичної підготовленості. Тому загальновизнаним $є$ розгляд психологічної і психофізичної підготовки як обов'язкової складової в підготовці фахівця до професійної діяльності (особливо в разі ії виконання в надзвичайних умовах). Ця вимога передбачає необхідність формування у професійно значущому напрямку певних структурних компонентів особистості. Саме від них залежить результативність виконання професійних функцій. Відсутність уявлення про роль особистості в загальній професійній схемі призводить до того, що абсолютна більшість зусиль при підготовці інженерів спрямовується винятково на систему загальних та спеціальних знань. Формування інших компонентів структури особистості відбувається майже стихійно.

До сьогодні існує спрощена думка, відповідно до якої професійні знання є основою професійної підготовки, а інші сторони покликані обслуговувати їх освоєння. У той же час, звичними стають претензії до психологічної і психофізичної підготовки особистості фахівця (багато, наприклад, говориться про так званий людський фактор 
у зв'язку з аварійністю). Проте в загальній підготовці інженера як такій «місця» для психологічної і психофізичної підготовки немає. Вважається, що вона здійснюється в єдності з іншими сторонами навчання. Таким чином, спостерігається розрив між вимогами практики і реаліями підготовки інженера.

Психологи [133] наголошують сьогодні на необхідності удосконалення процесу підготовки фахівців у технічному вищому навчальному закладі. Одним із шляхів називають формування у студентів у процесі навчання психологічної готовності до професійної діяльності.

Низку важливих питань формування особистості i, зокрема, особистості професіонала досліджено в роботах К. О. АбульхановоїСлавської, Л. І. Анциферової, А. Г. Асмолова, Г. О. Балла, І. Д. Беха, М. Й. Боришевського, А. В. Брушлинського, М. С. Бургіна, В. П. Зінченко, А. К. Ковальова, Г. В. Ложкіна, С. Д. Максименка, В. О. Моляко, К. К. Платонова, С. Л. Рубінштейна, В. А. Семиченко, К. Чарнецкі, Н. В. Чепелевої та ін.

При розробці основ організації психологічної і психофізичної підготовки студентів у процесі фізичного виховання значний інтерес становлять роботи з визначення стратегії сучасної освіти (В. П. Андрущенко, І. А. Зязюн, В. Г. Кремень), роботи з теоретико-методичних засад фізичного виховання (Б. С. Вільчковський, Л. В. Волков, О. Д. Дубогай, М. Д. Зубалій, Т. Ю. Круцевич, О. С. Куц, Л. П. Сущенко, Б. М. Шиян та ін.).

Дослідженню питань психологічної готовності до професійної діяльності присвячено праці А. О. Авершина, Л. О. Махотнюк, В. А. Молотай, С. А. Мул, Т. Л. Панченко, Н. О. Прядко, В. А. Терещенко, О. В. Тюпа, Н. М. Хмель, О. В. Хуртенко, О. А. Черепехіної.

Проблемі використання фізичного виховання для формування в учнів такої характеристики особистості, як особистісна мобільність присвятив свою роботу А. О. Артюшенко.

Вплив спортивної спеціалізації на розвиток особистісних якостей вивчали А. В. Чесноков, С. М. Гордон, С. П. Ільїн, А. Р. Ротенберг.

Важливі для цього дослідження положення сформульовано в педагогічних і психолого-педагогічних концепціях зі сфери фізичної культури Є. П. Ільїна, П. Ф. Лесгафта, В. Л. Маріщука, Л. П. Матвеєва, А. Д. Новікова, А. Ц. Пуні, А. В. Родіонова, П. А. Рудика, Б. А. Ашмаріна, А. А. Горелова, В. А. Щеголева, Л. І. Лубишевої, 
В. В. Становова, В. Д. Чепіка, М. Я. Віленського, Т. Ю. Круцевич, Н. В. Москаленко.

Ми виходимо з того, що вагомий внесок у вирішення завдань психологічної і психофізичної підготовки майбутніх залізничників може зробити й така навчальна дисципліна, як фізичне виховання. Аналогічну позицію займають, очевидно, і російські фахівці, які серед актуальних напрямів і проблем наукових досліджень 3 фізичної культури у ВНЗ називають і такий напрям, як «Підготовка до професійної діяльності в рамках дисципліни «Фізична культура» [26].

Взагалі, у теоретичному контексті актуальними є дослідження, спрямовані на виявлення психологічних (і навіть психотерапевтичних) можливостей фізичного виховання. Наукових даних такого роду явно бракує. Фізкультурна і спортивна діяльність студентів під час занять, якщо іiі цілеспрямовано відповідно організувати, може бути ефективною у вищезгаданому плані. У той же час, залишається невизначеним питання про те, виходячи $з$ яких теоретичних засад можна взагалі ставити питання про використання фізичного виховання для психологічної і психофізичної підготовки майбутніх фахівців. Постає проблема теоретико-методологічного обгрунтування психологічної і психофізичної підготовки студентів. Не менш важливою є й розробка педагогічних основ для проведення цієї роботи. Спроба автора дати відповідь на них і складає зміст роботи.

Вихідними положеннями дослідження стали такі припущення:

1. Обгрунтування теоретико-методологічних і педагогічних засад психологічної і психофізичної підготовки студентів під час навчальних занять з фізичного виховання необхідно проводити на трьох рівнях: філософському, психологічному й технологічному. Такий підхід дає змогу системно розглянути проблему.

2. Для реалізації вищезгаданого припущення в дослідженні логічно розглянути такі питання, як психофізична проблема в історії науки, взаємовплив організму і психіки, уявлення про особистість людини в сучасній психології, фізичне виховання як засіб підготовки особистості до професійної праці, психологічна і психофізична специфіка роботи на залізничному транспорті, зміст, засоби й основи організації психологічної і психофізичної підготовки студентівзалізничників, особливості впливу фізкультурної і спортивної діяльності на складові психологічної і психофізичної підготовленості 
студентів, формування психологічної і психофізичної готовності студентів у процесі фізичного виховання.

Розробка теоретико-методологічних і організаційних засад психологічної і психофізичної підготовки студентів залізничних ВНЗ у процесі фізичного виховання створить необхідну теоретичну основу для розробки конкретних методик, педагогічних технологій, дасть змогу виробити чіткі критерії та вимоги до студентів у процесі навчання.

Метою дослідження є з'ясування теоретико-методологічних і педагогічних основ психологічної і психофізичної підготовки студентів-залізничників у процесі фізичного виховання, експериментальна перевірка ефективності запропонованого підходу.

Обрана мета зумовила такі завдання дослідження:

1. Дослідити накопичені в психології та інших науках дані про обгрунтованість постановки питання про психологічну й психофізичну підготовку особистості в процесі фізичного виховання.

2. Розкрити сутність психологічної і психофізичної підготовки студентів як складової навчальної дисципліни «Фізичне виховання».

3. Теоретично обгрунтувати основи психологічної і психофізичної підготовки студентів-залізничників у процесі фізичного виховання.

4. Емпірично дослідити особливості впливу видів фізкультурної і спортивної діяльності на складові психологічної і психофізичної готовності студентів-залізничників.

5. Емпірично дослідити питання формування психологічної і психофізичної готовності студентів-залізничників до професійної праці в процесі навчальних занять $з$ фізичного виховання.

Суть авторської концепції теоретико-методологічних і організаційних основ психологічної і психофізичної підготовки студентів полягає:

- у комплексному підході до фізичного виховання студентів вищих навчальних закладів, яке не зводиться лише до оволодіння руховими навичками й уміннями та розвитку фізичних якостей. Одночасно з вищезгаданими необхідно вирішувати освітні, виховні, оздоровчі та інші завдання, одним з яких, на думку автора, є формування психологічної і психофізичної підготовленості студента до майбутньої професійної діяльності;

- постановці питання про проведення психологічної і психофізичної підготовки студентів у процесі фізичного виховання, яке потре- 
бує наукового обгрунтування, і перш за все, виявлення іï теоретикометодологічних і організаційних основ;

- ствердженні того, що методологічне підгрунтя для постановки питання про психологічну й психофізичну підготовку особистості студента в процесі фізичного виховання виявляється в психології і філософії при розгляді таких питань, як психофізична проблема, взаємовплив організму і психіки людини, проблема особистості;

- визначенні основ психологічної і психофізичної підготовки студентів залізничних ВНЗ у процесі фізичного виховання, зокрема: iii спрямованості на майбутню професію, іiі сутності й структури, змісту, засобів;

- розкритті й розробці (для деяких складових) методів психологічної діагностики психологічної і психофізичної підготовленості студентів;

- констатації того, що в ході занять 3 навчальної дисципліни «Фізичне виховання» можна ефективно вирішувати завдання професійно орієнтованої психологічної і психофізичної підготовки студентів;

- констатації положення, що зміст діяльності навчальних секцій і навчальних груп у процесі занять 3 фізичного виховання є головним чинником, який визначає особливості психологічної і психофізичної підготовленості студентів.

\section{Головні гіпотези дослідження:}

1. Теоретико-методологічне підгрунтя для постановки питання про психологічну і психофізичну підготовку студентів у процесі фізичного виховання виявиться в дослідженнях психофізичної проблеми, питань взаємовпливу організму і психіки людини, психології особистості. Підходи до цих проблем, спроби їх вирішення, що сформувалися в психології, філософії, інших науках, утворюють необхідний базис.

2. У процесі навчальних занять з фізичного виховання у студентів-залізничників можна ефективно формувати складові їх психологічної і психофізичної готовності. Для цього у фізичному вихованні необхідно: ставити відповідні цілі, організовувати відповідну діяльність у процесі занять, використовувати відповідні засоби й методи діагностики. 
У ході досліджень:

- вперше виявлено теоретико-методологічне підгрунтя для вирішення питання про проведення спеціальної психологічної і психофізичної підготовки студентів у процесі фізичного виховання;

- вперше теоретично обгрунтовано сутність психологічної і психофізичної підготовки у фізичному вихованні студентів;

- вперше розроблено педагогічні основи психологічної і психофізичної підготовки студентів залізничних ВНЗ у процесі фізичного виховання;

- вперше обгрунтовано й емпірично підтверджено можливість ефективного формування психологічної і психофізичної готовності студентів-залізничників до професійної діяльності у процесі занять 3 навчальної дисципліни «Фізичне виховання»;

- розроблено психодіагностичний інструментарій для визначення рівня розвитку вольових якостей особистості;

- набули подальшого розвитку сучасні наукові уявлення про вплив фізкультурної і спортивної діяльності на формування низки складових структури особистості;

- поглиблено уявлення про зв'язок рівня суб'єктивного контролю особистості й агресивністю в спорті (на прикладі футболу);

- дістали подальшого розвитку погляди на вдосконалення контролю у фізичному вихованні студентів.

Таким чином, ситуація, що склалась в теорії фізичного виховання, i запит з боку практики зумовлюють теоретичну і практичну значущість дослідження проблеми психологічної і психофізичної підготовки студентів. 
РОЗДІЛ 1

\section{Сучасний стан розробки проблеми психологічної і психофізичної підготовки особистості до професійної праці}

\section{1. Психологічна і психофізична підготовка як об'єкт наукових досліджень}

У науковій літературі існує низка підходів до визначення поняття «психологічна підготовка». Його розглядають таким чином:

1. Психологічна підготовка персоналу - комплекс організаційних, інформаційних, освітніх та психологічних заходів, що здійснюється 3 метою забезпечення професійно-психологічної готовності персоналу до виконання професійних завдань, адаптації до умов професійної діяльності, запобігання професійній деформації, відхиленням у психоемоційних станах внаслідок дій умов професійної діяльності [302].

2. Психологічна підготовка - комплекс заходів психолого-педагогічного характеру, спрямованих на формування, підтримку та розвиток у працівників професійно важливих психологічних та моральноділових якостей, внутрішнього самоконтролю в конфліктних ситуаціях, комунікативної культури, психологічної готовності до професійної діяльності в екстремальних ситуаціях, позитивної мотивації до вибору безпечних технологій виконання службових завдань [254].

3. Психологічна підготовка - це комплекс заходів, спрямованих на формування та підтримку в працівників професійно важливих психологічних і морально-ділових якостей, внутрішнього самоконтролю під час конфліктних ситуацій, комунікативної культури, психологічної готовності до професійної діяльності в екстремальних ситуаціях, позитивної мотивації на дотримання правил особистої безпеки [151]. 
4. Психологічна підготовка - це наукова підготовка психіки військовослужбовців до стійкої практичної діяльності в складі підрозділу (частини) на полі бою в умовах сучасної війни [445].

5. Психологічна підготовка - процес формування, закріплення й активізації готовності особистості, колективу до певного виду діяльності або виконання завдання. Психологічна підготовка до виконання конкретного завдання - це вплив на особистість, групу 3 метою налаштування на його виконання і створення суб'єктивних умов для ефективного використання і прояву знань, навиків, умінь, здібностей, інших якостей у процесі майбутньої діяльності. Психологічна підготовка повинна відображати психологічну структуру майбутньої діяльності [14].

6. Психологічна підготовка - цілеспрямоване формування індивідуальних прийомів, які забезпечують оператору збереження заданих параметрів виконання діяльності в складних ситуаціях [125].

Як видно із наведених визначень, психологічна підготовка пов'язується: 3 комплексом різнопланових заходів спеціального психологічного спрямування; 3 процесом створення оптимального психологічного стану людини для виконання діяльності; із системою занять спеціалізованого психологічного спрямування; 3 педагогічним процесом виховання особистості спортсмена; з видом формування особистості до певної діяльності; з процесом формування готовності до певного виду діяльності; $з$ цілеспрямованим формуванням індивідуальних прийомів виконання діяльності. На нашу думку, усі визначення можна умовно об'єднати у три групи. До першої слід віднести визначення, у яких психологічна підготовка трактується як комплекс спеціалізованих заходів. Друга група - це визначення, у яких психологічна підготовка розглядається як процес формування готовності особистості до умов певної діяльності. Третя група визначень пов'язує психологічну підготовку з психологічним налаштуванням людини на виконання певної діяльності.

У науковій літературі використовується й поняття «психофізична підготовка». У результаті аналізу виявлена певна різниця в його розумінні. $€$ підходи, коли під психофізичною підготовкою розуміють, по суті, фізичну підготовку (у тому значенні, як іï завжди розглядали в теорії і методиці фізичного виховання і пов'язували з розвитком фізичних якостей людини). При цьому спритність розглядається як вищий ступінь психофізичної підготовленості людини. Таку позицію 
займає, наприклад, I. М. Туревський [395]. Близьким до вищезгаданого є підхід С. М. Борщова [55]. А. О. Сгоричев [132] поняття «психофізична підготовка» використовує для поєднання в одній системі підсистем фізичної і психологічної готовності. До них він включає такі складові: соматичне здоров'я, рухові здібності, професійні нахили, спеціальні професійні здібності, властивості нервової системи. Аналогічний підхід демонструє Л. Ф. Колокатова [166]. У деяких роботах [402] психофізична підготовка і професійно-прикладна фізична підготовка практично ототожнюються.

На нашу думку, у випадку, коли психологічна або психофізична підготовка реалізується в процесі фізичного виховання, доцільним буде їх поєднання в рамках одного блоку. Висуваючи таку пропозицію, ми виходили $з$ того, що фізкультурна діяльність є ефективною у плані як формування психологічних складових (наприклад, рис особистості), так і розвитку психофізичних якостей (наприклад, психомоторики). У такому випадку немає сенсу розривати ці види підготовки під час їх реалізації в ході навчальних занять з фізичного виховання. Доцільно також відповідно називати цей процес. Щоб відобразити обидві складові, ми й пропонуємо назву «психологічна і психофізична підготовка».

У цьому дослідженні психологічна і психофізична підготовка розглядається як частина (сторона) фізичного виховання студентів, спеціалізована (спрямована) стосовно психологічних і психофізичних особливостей їх майбутньої професійної діяльності. Результатом такої підготовки є психологічна і психофізична підготовленість.

Професії мають свою специфіку. Вони відрізняються в тому числі і за психологічними і психофізичними характеристиками, і умовами праці, а значить, висувають і різні вимоги до психологічної і психофізичної підготовленості спеціаліста. Це об’єктивно зумовлює профілювання процесу психологічної і психофізичної підготовки, робить необхідним реалізацію прикладного підходу до неї.

Психологічна і психофізична підготовка проводиться в різних сферах діяльності. Активно вона використовується, наприклад, у збройних силах (особливо в спеціальних підрозділах). Психофізичними вправами там називають такі вправи, які тренують психіку та одночасно людина вдосконалюється фізично. Вони являють собою комплекс дій, які виконуються в умовах підвищеної небезпеки і пов'язані зі значним фізичним і психічним напруженням. 
На фізичні показники в умовах бою великою мірою впливає психічний фактор. У повітряно-десантних військах проводилися такі випробування. Спочатку боєць стройовим кроком проходив по широкій дошці, що лежала на землі. Час проходження фіксувався. Потім боєць проходив по тій же дошці, але на висоті п'ять метрів. На висоті час, що був затрачений на проходження дошки, виявився набагато більшим: висота давила на психіку, і швидкість втрачалася. Страх перешкоджав швидкому виконанню вправи. Це підтвердили й інші випробування, коли бійці на тій же висоті виконували вправи на гнучкість, силу або стрибки. Їх результат був нижчим, ніж під час виконання вправ на землі. Усі ці випробування показали взаємозв'язок: чим сильніший боєць психічно, тим кращі в нього фізичні показники і навпаки. У роботі Л. П. Гримак [104] описано психологічну підготовку парашутистів.

Для того щоб активно впливати під час тренувань на психіку солдата, в умови виконання вправ обов'язково включають небезпеку для нього. 3 цієї причини на заняттях 3 фізичної підготовки (для тренування психіки) широко використовують вправи, виконання яких пов'язане з небезпекою і ризиком. Завдяки їм боєць навчається перемагати страх у найтяжчі для нього хвилини.

Усі вправи, усі тренування намагаються проводити так, щоб працювати на одну ціль: переконати людину, що вона сильніша від власного страху. У звичайній фізичній вправі можна змінити обставини й отримати вже психологічну або психофізичну складову.

Бійців навчають переборювати страх, заглушати інстинкт самозбереження. Це досягається роз'яснювальною роботою і цілеспрямованими тренуваннями.

В. В. Ягупов [445] наголошує, що сутність і зміст психологічної підготовки військовослужбовців визначають труднощі сучасного бою. Серед них він виділяє:

a) небезпеку (для життя людини);

б) раптовість;

в) дефіцит часу та інформації (суперечливість інформації);

г) небувале ускладнення управління військами;

д) дискомфорт.

Характер дії вищезгаданих чинників визначає зміст психологічної підготовки військовослужбовців. Називаються і основні якості, які необхідні для подолання труднощів бою. Такому психологічному 
фактору бою, як небезпека протиставляються такі якості особистості: сміливість, мужність, витримка, схильність до ризику; раптовості самовладання, витримка; дефіциту часу та інформації - ініціативність, винахідливість; небувалому ускладненню управління військами - відповідальність, рішучість, самостійність.

Серед основних компонентів психологічної готовності воїна називають мотиваційний, пізнавальний, емоційний, вольовий.

Психологічна підготовка військовослужбовців спрямовується на формування психічної стійкості та психологічної готовності. Це здійснюється в процесі військових занять і навчань в умовах, наближених до бойових. У збройних силах виділяють три види психологічної підготовки: загальну, спеціальну і цільову. У процесі загальної підготовки у військовослужбовців формується усвідомлення необхідності виконання свого конституційного обов'язку, об'єктивне уявлення про характер сучасної війни і засоби ії ведення, труднощі, які необхідно подолати для перемоги. Спеціальна психологічна підготовка враховує специфіку діяльності різних видів збройних сил, родів військ і бойової спеціальності. Цільова психологічна підготовка спрямована на психологічне забезпечення виконання конкретних бойових завдань.

Велика увага психологічній підготовці співробітників приділяється і в органах внутрішніх справ. Там її включено до структури службової підготовки особового складу наряду з функціональною, вогневою, фізичною та загальнопрофільною (медична підготовка, засоби зв'язку, спеціальна техніка, цивільна оборона). У свою чергу службова підготовка входить як складова до системи професійної підготовки і являє собою вид навчання, що охоплює систему підвищення професіоналізму працівників органів внутрішніх справ шляхом удосконалення спеціальних навичок з метою успішного виконання оперативно-службових завдань і функціональних обов'язків.

В органах внутрішніх справ психологічна підготовка особового складу здійснюється службою психологічного забезпечення оперативно-службової діяльності. Вона регламентується наказами міністерства внутрішніх справ [254-256]. У цих документах, зокрема, психологічна підготовка визначається як комплекс заходів психологопедагогічного характеру, спрямованих на формування, підтримку та розвиток у працівників професійно важливих психологічних та морально-ділових якостей, внутрішнього самоконтролю в конфліктних 
ситуаціях, комунікативної культури, психологічної готовності до професійної діяльності в екстремальних ситуаціях, позитивної мотивації до вибору безпечних технологій виконання службових завдань [254].

Психологічна підготовка особового складу здійснюється психологами на спеціальних заняттях, іiі зміст відображено у відповідних програмах та тематичних планах. Деякі аспекти психологічної підготовки включаються до практичних занять з функціональної, вогневої, фізичної та інших видів підготовки.

Перед психологічною підготовкою в органах внутрішніх справ ставиться ряд завдань, головним з яких є формування та підтримання мотивації до служби, профілактика негативних явищ і втрат серед персоналу, підготовка працівників до ефективного виконання окремих специфічних видів службової діяльності шляхом розвитку професійно значущих психологічних якостей, спеціальних знань і практичних навичок. Наслідком психологічної підготовки має стати готовність до службової діяльності як системна якість особистості фахівця.

Формами навчальних занять з психологічної підготовки (у системі службової підготовки) є лекції, інтерактивні заняття, рольові й ділові ігри, тренінги, тематичні практикуми та ін. Передбачається також наявність матеріально-технічної бази (відповідно до специфіки професійних завдань підрозділу).

Особливо великого значення психологічна підготовка набуває під час підготовки співробітників до дій в екстремальних умовах. Формування психологічної готовності до таких дій забезпечується за допомогою цілеспрямованого та систематизованого комплексу заходів, що здійснюється в межах психолого-педагогічного процесу в органах та підрозділах. Основними завданнями психологічної підготовки $є$ :

1) виховання почуття обов'язку, відповідальності;

2) забезпечення особового складу системою знань і уявлень про особливості та умови діяльності, їх вимоги до особистості;

3) формування у працівників умінь і навичок виконання службових обов'язків у напружених та складних умовах;

4) розвиток емоційно-вольової стійкості, здатності до ефективної саморегуляції в разі ускладнення ситуації; 
5) формування вмінь реально оцінювати рівень своєї підготовленості до виконання професійних завдань, прогнозувати результати діяльності, коригувати свої вчинки.

Психологічна підготовка здійснюється трьома етапами: 1) завчасне формування готовності до дій в екстремальних умовах; 2) безпосереднє формування готовності до дій в екстремальних умовах; 3) підтримання готовності в процесі виконання складного завдання. Завчасне формування готовності до дій у екстремальних ситуаціях полягає у формуванні у співробітників впевненості в собі та своїй підготовленості, у своїх колегах, цілеспрямованості, самостійності при прийнятті рішення, самовладання, вміння керувати своїми емоціями та ін. Безпосереднє формування готовності до дій в екстремальних умовах полягає в моделюванні умов майбутньої діяльності, обговоренні оптимальних дій та їх послідовності. Етап підтримання готовності в процесі виконання складного завдання пов'язаний 3 необхідністю збереження готовності в разі зміни ситуації, виникнення нових труднощів і перепон, до яких потрібно додатково пристосуватися.

Важливу роль психологічна підготовка відіграє і в професійній праці співробітників Державної прикордонної служби України. Підтвердженням цього $є$ наказ Адміністрації Державної прикордонної служби України від 14 квітня 2008 року № 318, яким затверджено інструкцію про порядок організації та проведення психопрофілактичної роботи з персоналом [302]. У цьому документі професійнопсихологічна готовність посадової особи органу Державної прикордонної служби України визначається як сукупність якостей і властивостей особистості, що зумовлює стан мобілізованості психіки, налаштованість на найбільш доцільні активні та рішучі дії в складних чи небезпечних для життя і здоров'я умовах виконання функціональних обов'язків.

Як головні завдання психопрофілактичної роботи визначено:

1. Моніторинг впливу факторів службової (професійної) діяльності, побутових, соціальних та інших чинників на психологічний стан та психіку посадових осіб, контроль психогігієнічних умов їх службової (професійної) діяльності.

2. Моніторинг психологічного стану персоналу під час виконання службових завдань з охорони державного кордону та в позаслужбовий час. 
3. Підготовку та надання рекомендацій керівництву органів та підрозділів щодо забезпечення оптимальних психологічних чинників оперативно-службової діяльності персоналу; контроль стану виконання рекомендацій керівництвом підрозділів Державної прикордонної служби України.

4. Виявлення осіб з ознаками соціально-психологічного неблагополуччя, соціально-психологічної та особистісної дезадаптації, професійної деформації, відхиленнями психоемоційних станів та таких, що потребують соціально-психологічної допомоги та вживання заходів вторинної психопрофілактики.

5. Надання психологічної та іншої спеціалізованої допомоги персоналу для запобігання професійній психологічній деформації посадових осіб, розвитку в них нервово-психічних та психосоматичних захворювань психогенного характеру, кризовим психологічним станам, що розвиваються внаслідок дії негативних факторів службової (професійної) діяльності, побутових, соціальних та інших факторів.

6. Розроблення та надання рекомендацій посадовим особам керівного складу органів Державної прикордонної служби щодо дотримання оптимальних норм службової діяльності, дозвілля та відпочинку особового складу.

7. Організація та впровадження заходів психологічної підготовки персоналу.

8. Запровадження в практику заходів, спрямованих на зміцнення психологічної сфери, морально-психологічного стану, професійнопсихологічної готовності посадових осіб до виконання службових завдань, забезпечення статутної поведінки особового складу.

9. Розвиток психологічної компетентності персоналу.

10. Психологічна просвіта персоналу, пропаганда психогігієнічних знань серед особового складу.

11. Упровадження та пропаганда здорового способу життя та психогігієни професійної діяльності персоналу.

Відповідно до інструкції основою для здійснення заходів психологічної профілактики в органі Державної прикордонної служби України є збирання, аналіз та оцінювання психологічної інформації про персонал органу. Первинна психопрофілактика є основною частиною психопрофілактичної роботи. Вона здійснюється начальниками органів (підрозділів); заступниками начальників органів (підрозділів) по роботі з особовим складом; іншими посадовими особами, які мають 
у підпорядкуванні персонал. Первинна психопрофілактика охоплює весь персонал Державної прикордонної служби України.

В інструкції визначено й основні функції суб'єктів психопрофілактичної роботи на етапі первинної психопрофілактики.

Вторинна психопрофілактика відповідно до інструкції здійснюється психологами та посадовими особами закладів (структурних підрозділів) охорони здоров’я Державної прикордонної служби України. Вона виконується з посадовими особами, які визначені такими, що потребують індивідуальної соціально-психологічної допомоги на підставі переліку ознак.

Грунтовною $є$ психологічна підготовка служб, підпорядкованих Міністерству України з питань надзвичайних ситуацій. У рамках цієї структури вона проводиться відповідно до інструкції з організації психологічного забезпечення службової діяльності аварійно-рятувальних служб, яку затверджено наказом міністерства від 23.02.2004 № 89 [151]. У цьому документі як головне завдання психологічної підготовки визначено зменшення кількості нещасних випадків 3 працівниками під час виконання службових обов'язків шляхом забезпечення психологічної готовності до їх виконання.

Завдання психологічної підготовки працівників вирішуються під час проходження служби на заняттях і навчаннях.

У документі вказується, що тактичні заняття на об'єктах і психологічних смугах, заняття з психологічної підготовки мають сприяти розвитку професійно необхідних якостей відчуття, сприйняття, уяви, пам'яті, мислення, адаптації до екстремальних умов навколишнього середовища та стрес-факторів, фізичному загартуванню працівників. Психологічні тренінги та лекційні заняття мають підвищувати рівень психологічної культури працівників, сприяти осмисленню внутрішніх психічних процесів та станів, навчати методам, прийомам регуляції психічних станів та професійно необхідним методам ефективного спілкування.

Зміст психологічної підготовки працівників визначається відповідними програмами та тематичними планами, що складаються підрозділами психологічного забезпечення разом з відповідальними за службову підготовку в підрозділах.

Проблема психологічної підготовки як особливий напрямок роботи досліджувалась і в психології спорту. А. В. Родіонов і Л. Г. Уляєва у своїй статті, яка присвячена історії розвитку психології спорту 
[322], зазначають, що ця проблема починає виділятись у 50-х роках. У цей період психологічна підготовка спортсмена розглядалась як комплексний педагогічний процес, який спрямований на всебічний розвиток вольових якостей спортсмена. У теоретичну розробку проблеми суттєвий внесок зробили А. Ц. Пуні [307] і П. А. Рудик [332, 333, 335], А. В. Родіонов [321], Брайент Дж. Кретті [57], Т. Т. Джамгаров [118], Є. П. Ільїн [146] та ін. На думку П. А. Рудика, предметом психологічної підготовки є цілеспрямоване вдосконалення психічних процесів, станів і особливостей особистості спортсмена.

У спорті психологічна підготовка розглядається як один із видів (сторін) підготовки спортсмена (наряду з фізичною, технічною, тактичною), який має таке саме значення для спортивного вдосконалення, як і інші складові. Виділяють два види психологічної підготовки спортсменів: загальну психологічну підготовку й спеціальну психологічну підготовку до участі в майбутніх конкретних змаганнях [319]. Загальна розглядається як усебічний розвиток у процесі систематичних тренувальних занять психічних функцій і якостей особистості, які необхідні спортсмену для успішної спортивної діяльності. Вона являє собою основу для спеціальної психологічної підготовки. Спеціальна психологічна підготовка спортсмена до змагань спирається на досягнутий рівень розвитку необхідних для спортивної діяльності психічних складових.

Встановлено велику кількість компонентів психічної структури спортсменів, які відіграють важливу роль у досягненні ними спортивної майстерності. У той же час, виявлено специфічні прояви одних і тих самих компонентів у спортсменів, що представляють різні види спорту. Як зазначає П. А. Рудик, спортивна діяльність потребує від спортсменів розвитку великого комплексу психічних процесів і станів, які пронизують собою всі сторони діяльності спортсмена під час тренувань і змагань, і при цьому розвитку не взагалі, а розвитку з урахуванням специфіки кожного виду спорту.

Як головні завдання загальної психологічної підготовки спортсменів виділяють:

1. Розвиток і доведення до високого рівня вдосконалення найбільш важливих для конкретного виду спорту психічних функцій (спеціалізованого сприйняття, мислення, уваги, швидкості реакції і т. ін.).

2. Розвиток здатності до прояву необхідних вольових зусиль. 
Спеціальна психологічна підготовка до участі в конкретних змаганнях обмежується завданнями, які ставляться перед спортсменом у цих змаганнях. Як правило, вона полягає в такому:

1. Усвідомлення особливостей і завдань майбутнього змагання.

2. Усвідомлення конкретних умов майбутнього змагання (час, місце, кліматичні умови і т. ін.) і підготовка до ефективних дій в цих умовах.

3. Усвідомлення сильних і слабких сторін суперника й підготовка до дій з урахуванням цих особливостей.

4. Формування активного прагнення до перемоги (установка на перемогу) в майбутньому змаганні.

5. Формування впевненості у своїх силах і можливості отримати перемогу в майбутньому змаганні.

6. Подолання негативних емоцій, які можуть бути пов'язані з участю у майбутніх змаганнях.

7. Формування готовності до прояву максимальних вольових напружень і вміння проявити їх в умовах майбутнього змагання.

Про надзвичайну важливість психологічної підготовки у спорті свідчать дані, наведені в роботі В. В. Смирнової [361]. Вона досліджувала динаміку особистісних характеристик спортсменів у процесі психологічного супроводу. Об'єктом дослідження були борці високої кваліфікації. Предметом дослідження обрано взаємозв'язок спортивно важливих особистісних якостей і результативності борців в умовах психологічного супроводу. В. В. Смирнова припустила, що результативність борців на змаганнях залежить не тільки від наявності стану психологічної готовності до конкретного змагання, але й від сформованості спортивно важливих якостей їх особистості, від загального рівня психологічної підготовленості спортсмена.

Автор наголошує на обов'язковому включенні до підготовки спортсменів високої кваліфікації психологічного супроводу. Враховуючи надзвичайну психологічну складність спортивної діяльності на цьому рівні, до структури психологічного супроводу вона обгрунтовано включає: загальну психологічну підготовку, спеціальну психологічну підготовку до конкретних змагань, оперативне психологічне втручання, психологічну підготовку до багаторічного тренувального процесу. Як показник ефективності психологічного супроводу пропонується розглядати психологічну підготовленість спортсмена в цілому. 
Серед складових психологічної підготовленості борців високої кваліфікації В. В. Смирнова називає:

1) спеціальні спортивно важливі якості особистості (виражену екстравертованість, нейротизм, високу стійкість до перешкод, «нормативну» агресію, високий самоконтроль, розвинені вольові якості);

2) виражену мотивацію до досягнення успіху;

3) психологічну стабільність (впевненість у собі, емоційне благополуччя, відсутність емоційних порушень);

4) здатність до саморегуляції (цілеспрямоване керування своїми почуттями, думками, діями й поведінкою).

В. В. Смирнова виявила, що для більш результативних борців характерними $\epsilon$ такі якості, як високий рівень розвитку стійкості до перешкод, вольових якостей, психологічного благополуччя й мотивації успіху. Характерними для них $є$ також низькі показники деструктивних форм агресивності (предметної агресії, емоційної і самоагресії) i тривожності. У низько результативних борців виявлено перевагу низьких показників стійкості до перешкод, вольових якостей, мотивації до досягнення успіху. Характерними для них $є$ також високі показники деструктивних форм агресивності, несприятливого психологічного стану, тривожності.

У ході експерименту В. В. Смирнова встановила, що особистісні складові психологічної підготовленості борців можуть розглядатись як детермінанти їх змагальної результативності й повинні складати змістовну основу психологічного супроводу борців високої кваліфікації.

Психолого-акмеологічну концепцію психологічної готовності спортсменів вищої кваліфікації силових єдиноборств розробив О. О. Бобрищєв [42]. Об'єктом дослідження стала психологічна готовність спортсменів силових єдиноборств. Предметом - психолого-акмеологічні особливості прояву, комплексної оцінки, прогнозування, екстреної корекції і формування психологічної готовності спортсменів силових єдиноборств вищої кваліфікації до змагальної діяльності в екстремальних ситуаціях.

Дослідник прийшов до висновку, що психологічна готовність спортсменів силових єдиноборств до змагальної діяльності в екстремальних ситуаціях повинна розглядатись як багатокомпонентне психолого-акмеологічне утворення й оперативний психічний стан, який проявляється в довгостроковій і оперативній формі. 
Було встановлено, що психологічна готовність спортсменів силових єдиноборств визначає ефективність їх змагальної діяльності в екстремальних ситуаціях і залежить від рівня сформованості мотиваційного, вольового, регуляторного, когнітивного й типологічного компонентів. Цілеспрямоване формування останніх у процесі психологічної підготовки суттєво впливає на успішність діяльності спортсменів у екстремальних ситуаціях.

О. О. Бобріщєв виявив тісний зв'язок психологічної готовності спортсменів силових єдиноборств вищої кваліфікації з досвідом участі в міжнародних змаганнях.

Автор встановив особливості прояву головних компонентів психологічної готовності спортсменів силових єдиноборств до змагальної діяльності в екстремальних ситуаціях. Так, у високо- і середньоуспішних спортсменів було зафіксовано домінування вольового, мотиваційного й типологічного компонентів. Менш вираженими були регуляторний і когнітивний компоненти. У спортсменів з низькою успішністю діяльності найбільш сформованими виявилися вольовий i типологічний компоненти. Рівень розвитку інших був суттєво нижчим.

У ході дослідження було також встановлено залежність психологічної готовності спортсменів-єдиноборців від особливостей їх особистості (особливостей копінг-поведінки, кар'єрних i ціннісних орієнтацій особистості, нервово-психічної стійкості, регуляції поведінки, особистісного адаптаційного потенціалу, сміливості, самоконтролю, когнітивних здібностей).

О. О. Бобріщєв встановив залежність високого рівня довгострокової психологічної готовності спортсменів до змагальної діяльності в екстремальних ситуаціях від таких якостей особистості, як асертивна стратегія копінг-поведінки, самоконтроль, нервово-психічна стійкість, високий рівень регуляції поведінки, високий рівень особистісного адаптаційного потенціалу, тривожність, гнучкість мислення, організаторські та комунікативні здібності, відповідальність, сміливість, низький рівень прояву патопсихологічних властивостей особистості й акцентуацій характеру, активність.

Дослідник виявив, що рівень психологічної готовності спортсменів можна підвищити шляхом застосування психологічного відбору, психологічного супроводу й корекції негативних психічних станів, 
кваліфікованою організацією психолого-педагогічного впливу тренерів.

А. М. Кочергін розглянув у своїй роботі питання інтеграції техніко-тактичної, фізичної і психологічної підготовки до рукопашного бою [176]. Він припустив, що для інтеграції техніко-тактичного та фізичного потенціалу і психологічної підготовки до рукопашного бою у військовослужбовців необхідна розробка психолого-педагогічних методик, спрямованих на підвищення в них порогу больових відчуттів, зменшення страху перед ними, а також на освоєння наступальної i агресивної тактики ведення рукопашної сутички. За задумом автора, це буде сприяти оптимальному збудженню перед сутичкою, самоконтролю, адекватному сприйняттю обставин і дій потенційного противника в рукопашній сутичці, розвитку сміливості й рішучості в діях.

У ході дослідження було виявлено, що психологічна підготовка займає ключове положення в комплексі проблем інтеграції складових підготовки до рукопашного бою. Без належного рівня психологічної підготовленості людина не може проявити в реальних умовах професійної діяльності свій фізичний і техніко-тактичний потенціал.

Автор прийшов до обгрунтованого висновку про те, що відсутність у структурі сучасних керівних документів з фізичної підготовки силових структур Росії конкретних методик для психологічної підготовки до рукопашного бою суттєво знижує якість підготовки особового складу.

А. М. Кочергін встановив, що для завчасної психологічної адаптації співробітників до стресових умов реальної рукопашної сутички необхідно забезпечити набуття досвіду психологічних і фізичних навантажень, больових відчуттів, що супроводжують сутичку, підвищити поріг больових відчуттів і зняти відчуття страху перед ними. Вирішення цього завдання забезпечує реалізацію в сутичці технікотактичної і фізичної підготовленості людини, знижує скованість.

Автор розробив і експериментально перевірив комплекс методик, у яких втілено вищезгаданий підхід. Зіфіксовано суттєво кращі результати експериментальної групи з виконання семи груп прийомів i в повноконтактних сутичках. Перевагу експериментальної групи зафіксовано і за показниками емоційної напруженості, пам'яті, уваги, самооцінки готовності до рукопашного бою.

На необхідність врахування в процесі психологічної підготовки спортсменів індивідуальних особливостей психологічного захисту 
особистості вказує В. В. Андреєв [12]. Об'єктом свого дослідження він обрав психологічний захист особистості, який виникає в умовах екстремальної діяльності спортсменів. Предметом - особливості психологічного захисту кваліфікованих спортсменів різних спортивних спеціалізацій і різного рівня спортивної майстерності.

Дослідник припустив, що особливості індивідуального психологічного захисту у кваліфікованих спортсменів різних спеціалізацій проявляються в специфічній роботі їх свідомості й підсвідомості, які формують у спортсменів особливе відчуття захищеності від деструктивних впливів змагального стресу й думок про програш або невдачу у спортивній діяльності.

У ході дослідження було встановлено, що на особливості прояву індивідуального психологічного захисту кваліфікованих спортсменів різних спеціалізацій суттєво впливають індивідуально-психологічні й спортивні фактори змагальної діяльності, які характеризуються як типовими, так і індивідуалізованими проявами видів і механізмів психічного захисту.

В. В. Андреєв виявив статеві розбіжності у використанні спортсменами різних видів психологічного захисту. Порівняно з жінками у чоловіків було зафіксовано більш структурований і більш виражений психологічний захист. На основі отриманих даних автор робить висновок про значущі статеві розбіжності в структурованості, інтенсивності й функціонуванні системи психологічного захисту у кваліфікованих спортсменів. Обгрунтовано звертається увага на необхідність врахування цих реалій у процесі психологічної підготовки до змагань. Автором встановлено й особливості зміни показників різних видів психологічного захисту, залежно від віку.

Досліджено також вплив рівня спортивної майстерності на особливості психологічного захисту спортсменів. Зі зростанням спортивної майстерності у спортсменів спостерігалося зниження використання психологічного захисту.

В. В. Андреєв виявив особливості психологічного захисту спортсменів, що представляли різні види спорту. У легкоатлетів головним видом захисту виявилося заперечення, у боксерів - проекція, у футболістів - регресія.

У психології спорту ставиться питання і про спеціальну психологічну підготовку до певних психологічних впливів. Так, необхідність спеціальної психологічної підготовки яхтсменів обгрунтовується 
в роботі У. В. Корнійко, яка присвячена вивченню психологічних змін особистості яхтсмена в процесі спортивної діяльності під впливом психотравмуючих факторів [171]. Об'єктом дослідження була особистість спортсмена, що зазнає впливу психотравмуючих факторів. Предметом - характер змін якостей у структурі особистості яхтсмена під впливом психотравмуючих факторів.

Автор встановила, що виникнення психотравмуючих ситуацій у спортивній діяльності зумовлене об'єктивними й суб'єктивними чинниками. До перших вона віднесла умови вітрилення, дії суперників, стан матеріальної частини. До других - особистісні якості, особливості стосунків з оточуючими.

За критеріями сили впливу психотравмуючих факторів і характеру змін особистості, які відбуваються, У. В. Корнійко виділила три підгрупи спортсменів. До першої вона віднесла спортсменів, які переживають вплив психотравмуючих факторів найбільш сильно. У цій групі нею виявлено зв'язок показників впливу психотравмуючих факторів з рівнем мотивації досягнення успіху, емоційної стійкості, неадекватністю самооцінки, домінантністю, сміливістю, рядом показників і форм агресії, емоційною виснаженістю. У цій групі спортсменів сила процесів збудження виявилася чинником, який визначає силу впливу психотравмуючих факторів. До другої підгрупи було віднесено спортсменів, які не так гостро переживають вплив психотравмуючих факторів. У цій групі було виявлено як негативні зміни особистості (зростання показників різних видів і форм агресії, зниження рівня інтернальності, зростання рівня психічного виснаження), так і позитивні (покращення якості уваги). До третьої (найменшої) підгрупи спортсменів було віднесено тих, хто адекватніше ніж попередні переживає вплив психотравмуючих факторів. У цій групі було виявлено зростання інтернальності у сфері досягнень, зниження реактивної тривожності, зростання швидкості переносу інформації у зорово-руховій системі. Ці зміни спричиняли покращення тренувальної та змагальної діяльності.

У. В. Корнійко виявила, що під впливом психотравмуючих факторів у висококваліфікованих яхтсменів змін зазнають якості, що належать до різних підструктур особистості. На рівні соціально-зумовлених якостей було зафіксовано зміни самооцінки, Я-концепції, рівня мотивації досягнення успіху, інтернальності у сфері досягнень і сфері невдач. На рівні психічних процесів - емоційної стійкості, рівня фру- 
строваності, рівня агресії, негативізму, роздратованості, аутоагресії. Під впливом психотравмуючих факторів було зафіксовано зниження фрустраційної толерантності.

У ході дослідження автор встановила, що для яхтсменів високої кваліфікації характер переживання психотравмуючих факторів зумовлюють вік, сила процесів збудження та гальмування, рівень інтелекту. Встановлено було і відмінності у характері впливу психотравмуючих факторів на спортсменів різної кваліфікації. Психологічні зміни у майстрів спорту міжнародного класу виявилися менш генералізованими порівняно з менш кваліфікованими яхтсменами. Як справедливо вважає автор, це спричиняє менший деструктивний вплив психотравмуючих факторів на їх особистість.

У. В. Корнійко розробила обгрунтовані рекомендації щодо змісту психологічного супроводу тренувальної та змагальної діяльності яхтсменів. Вони полягають у проведенні спеціальної завчасної психологічної підготовки до переживання впливу психотравмуючих факторів.

Спортивні психологи [322, 323] справедливо підкреслюють, що психологічна підготовка сама по собі не є окремою проблемою психології спорту, це загальна проблема психології як у теоретичному, так і в експериментальному і практичному плані.

Різні аспекти проблеми психологічної підготовки розглянули у своїх дослідженнях Т. В. Зобніна [140], 3. С. Акбієва [5], I. С. Скляренко [356], Н. А. Калугіна [155], Г. А. Мисіна [252], Л. З. Стуколова [380], Т. В. Маркелова [231], Т. Д. Василенко [68], Є. В. Соломатін [365], Є. В. Сіліч [350].

Результатом психологічної підготовки є відповідна готовність особистості. Проблема психологічної готовності до професійної праці також грунтовно досліджувалася науковцями. Як зазначає С. М. Янкевич [447], дослідження психологічної готовності проводилось у двох теоретико-методологічних площинах. Перша названа автором функціональною. Тут готовність розглядалась як необхідна умова успішності виконання професійних обов'язків. Друга отримала назву особистісної. В іiі рамках готовність досліджували як характеристику особистості. До неї відносили спеціальні та загальні здібності людини, потребу у професійному самовдосконаленні, комунікативні, професійні та інші вміння. Слід відзначити роботи П. П. Горностай [102], К. М. Дурай-Новакової [124], М. I. Дьяченко та 
Л. А. Кандибовича [126], Л. Н. Захарової [138], Е. П. Корабліної [167], С. Д. Максименка та О. М. Пелеха [224], В. О. Моляко та М. Л. Смульсон [248], Р. Д. Санжаєвої [339], Э. А. Фарапонтової [398] та ін.

С. М. Янкевич виконав у своїй роботі [447] ретельний аналіз підходів як вищезгаданих, так і інших авторів. На підставі цього він констатує, що майже всі вчені, які досліджували проблему готовності, вказують на наявність в її структурі мотивації, знань, комплексу професійно необхідних якостей (здібності, темперамент, характер, особливості психічних процесів). Готовність до діяльності розглядається як необхідна передумова професійної праці та як результат і наслідок професійної підготовки у навчальному закладі.

Дослідженню питань психологічної готовності до професійної діяльності присвячено також роботи А. О. Авершина [4], Л. О. Махотнюк [237], В. А. Молотай [247], С. А. Мул [251], Т. Л. Панченко [275], Н. О. Прядко [303], В. А. Терещенко [388], О. В. Тюптя [396], Н. М. Хмель [417], О. В. Хуртенко [421], О. А. Черепєхіної [428], Т. Г. Хащенко [414], 3. Г. Ханової [413], С. А. Масалова [232], I. Ю. Горєлова [100]. У них розкриваються важливі питання психологічної готовності до різних видів професійної праці. У той же час, не дослідженим залишається комплекс питань щодо використання фізичної культури для формування психологічної і психофізичної готовності до професійної діяльності. У цьому напрямку найбільший доробок створено науковцями, які вивчали використання фізичного виховання для вирішення питань психологічної підготовки військовослужбовців або працівників органів внутрішніх справ.

У наукових дослідженнях встановлено, що фізичні вправи є одним iз засобів активного впливу на психіку військовослужбовців (В. Л. Маріщук [228, 229]; Ю. П. Блажко [39]; В. А. Щоголев [440]; I. М. Свдокимов [127]; С. М. Ашкіназі та А. Н. Потапчук [20]; А. Г. Саракул [340], Ю. К. Дем'яненко [115], В. С. Хагай [410], Н. В. Краснов [181], Л. Ю. Федотов [401], Д. О. Петров [278], О. В. Пристав [298] та ін.). У той же час слід зазначити, що ще не склалося чітких уявлень про методику проведення психологічної підготовки в процесі занять фізичними вправами.

Засоби фізичної підготовки активно використовуються для вирішення завдань психологічної підготовки військовослужбовців підрозділів спеціального призначення. А. Г. Саракул дослідив питання 
психологічної підготовки особового складу підрозділів спеціального призначення шляхом використання фізичних вправ, які поєднувалися 3 прийомами психоемоційного самоуправління [340]. Встановлено залежність психологічної стійкості військовослужбовців (за умови психогенного впливу) від рівня їх фізичної підготовленості. Такий висновок зроблено автором на основі порівняння результатів військовослужбовців з високим і середнім рівнем фізичної підготовленості, які вони продемонстрували в ході подолання «стежки розвідника». Середні оцінки іiі подолання в цих групах після стрибка з тренажера відрізнялись несуттєво. Після реального стрибка з гелікоптера 3 подальшим подоланням «стежки розвідника» оцінка в обох групах суттєво знизилась, але в групі із середнім рівнем фізичної підготовки це зниження виявилось більшим, ніж у групі з високим рівнем фізичної підготовленості.

У ході дослідження автор перевірив також власну методику психологічної підготовки військовослужбовців підрозділів спеціального призначення, яка включала поєднання фізичних вправ 3 прийомами психоемоційного самоуправління в загальній системі фізичної і психологічної підготовки. Було встановлено, що багаторазове виконання фізичних вправ в умовах реальної небезпеки, фізичної втоми і психогенного впливу бойових подразнювачів (десантування, подолання «стежки розвідника»), які поєднані $з$ прийомами психоемоційного самоуправління, сприяє формуванню психологічної адаптації військовослужбовців до службово-бойової діяльності й виробленню певного способу поведінки, необхідного для успішних дій під час виконання спеціальних завдань. Про це свідчили результати експериментальної групи, які отримані після психогенного впливу (парашутний стрибок з бойовою викладкою) і в яких зафіксовано покращення вегетативних реакцій, уваги і координації рухів. Зросли також оцінки в стрільбі, яка виконувалася після приземлення з парашутом.

В. С. Хагай виконав роботу, у якій дослідив використання рукопашного бою як засобу формування психоемоційної стійкості військовослужбовців [410]. Дослідник обгрунтовано відносить до сильних сторін рукопашного бою як засобу психологічної підготовки такі його характеристики: можливість створення множини варіативних конфліктних ситуацій; безпосереднє зіткнення (обличчям до обличчя) з вірогідним противником; переживання відчуття небезпеки; активне протиборство противника, його агресивність; дефіцит часу на 
прийняття рішень; дефіцит інформації; непередбачуваність дій противника та ін. Вищезгадані характеристики, як справедливо зазначає автор, роблять рукопашний бій не тільки засобом формування необхідних навиків з виведення із строю противника, але й засобом формування психоемоційної стійкості у військовослужбовця, виховання в нього сміливості, рішучості й впевненості у власних силах.

У ході експерименту було встановлено ефективність авторської методики використання рукопашного бою як засобу розвитку психоемоційної стійкості військовослужбовців. Сутністю методики стало навчання курсантів прийомам рукопашного бою і формування психоемоційної стійкості за три етапи, яким відповідають певні організаційні форми підготовки курсантів. На першому етапі, який було названо навчальним, здійснювалося навчання техніці виконання бойових прийомів рукопашного бою, тренування з прискореного пересування, подолання перешкод. Для формування основ психоемоційної стійкості курсантів використовувались і поєдинки. На другому етапі, який було названо спортивним, вдосконалювалася техніка базових прийомів рукопашного бою, здатність подолання перешкод і здатність пересування на фоні попереднього фізичного навантаження, несприятливих погодних умов, використання засобів хімічного захисту, вивчалися нові прийоми і дії, що розширювали діапазон військово-прикладної рухової підготовленості. Під час третього етапу, який було названо тактичним, організовувалося комплексне застосування головних прийомів рукопашного бою в умовах воєнізованої (психоемоціональної) смуги перешкод (з подоланням природних і штучних перешкод), з прискореним пересуванням за різних погодних умов, зі створенням тактичних обставин бою з метанням гранат, стрільбою. Створювалися також екстремальні умови, які моделювали екстремальні умови бойових дій (вибухи вибухових пакетів, стрільба холостими патронами, горіння горючої суміші, димова завіса, колючий дріт, рогатки).

Дані, наведені в дослідженні В. С. Хагая, підтверджують ефективність комплексного використання прискореного пересування, подолання перешкод і рукопашного бою для формування психоемоційної стійкості й розвитку прикладних рухових навиків.

Проблему формування психологічної готовності до дій в екстремальних умовах у співробітників підрозділів спеціального призначення міністерства внутрішніх справ Російської Федерації засобами 
фізичної підготовки досліджував Д. О. Петров [278]. Він виявив, що поетапне комплексне застосування комп'ютерних, тренажерних, імітаційних і бойових методів впливу сприяє формуванню психологічної готовності співробітників підрозділів спеціального призначення до екстремальних умов службово-бойової діяльності.

У ході експерименту Д. О. Петров перевірив авторську програму фізичної підготовки співробітників, яка включала моделювання службово-бойової діяльності співробітників у комплексі з прискореним пересуванням, подоланням перешкод, відпрацюванням прийомів рукопашного бою, вогневою підготовкою. Його результати дозволяють зробити висновок про ефективність розробленої програми для формування психологічної адаптації співробітників до дії чинників професійної праці. Це засвідчують наведені автором результати експериментальної групи, які суттєво перевищують показники контрольної. При цьому перевищення зафіксовано за показниками і функціонального стану, і психічних властивостей особистості, і фізичної підготовленості, і морально-вольових якостей.

Грунтовне дослідження професійно-психологічної підготовки співробітників спеціальних підрозділів органів внутрішніх справ до дій в екстремальних умовах провів В. М. Смирнов [360]. Він виявив психологічну своєрідність діяльності співробітників спеціальних підрозділів органів внутрішніх справ, яку визначають: об'єкт (організовані, озброєні групи злочинців, терористи), предмет діяльності (проведення «силових» операцій), цілі (ліквідація терористичних, організованих, озброєних груп злочинців, припинення масових безладів), задачі («силова» підтримка оперативно-розшукових, слідчих заходів, звільнення заручників, боротьба з терористами), способи їх вирішення (застосування психологічного, фізичного примусу, нанесення відповідної до спротиву шкоди і знищення злочинців), умови виконання поставлених службово-бойових завдань (часові, інформаційні, силові обмеження, підвищена персональна відповідальність за життя заручників, оточуючих громадян), психологічні труднощі (фізичні, психологічні, психофізіологічні), часові параметри (тривалість виконання професійних завдань в умовах групової ізоляції).

Виходячи з психологічних особливостей професійної діяльності спецпідрозділів, В. М. Смирнов обгрунтовано запропонував проведення для цього контингенту особливого виду професійнопсихологічної підготовки - професійно-екстремально-психологічної 
підготовки. На думку автора, вона повинна бути спрямована на такі аспекти, як: адекватна екстремальним умовам оцінка поведінки, заходи психологічної протидії з боку призвідників і активних учасників масових безладів, «зниження напруги», освоєння прийомів і способів психологічного впливу співробітників на правопорушників, оволодіння вербальними командами при затриманні організованих злочинних груп і терористів, взаєморозуміння, взаємодія, взаємозамінність, підтримка, надання допомоги членам групи, регуляція бойових психічних станів при проведенні конртерористичних операцій; переважна орієнтація навчання на підготовку функціональних груп (відділення, оперативна група); формування надситуативної активності, підвищеної відповідальності за життя заручників і оточуючих людей, використання «екстремальності» як компонента навчання.

У ході дослідження було встановлено, що успіх професійної діяльності співробітників спецпідрозділів у екстремальних умовах залежить не тільки від сформованих професійно значущих якостей і характеристик, але й від знань, умінь і навиків регуляції бойових психічних станів. Дослідник визначив такі рівні регуляції: повна, підвищена «включеність» в екстремальні умови діяльності, причетність і «відстороненість» від екстремальних умов. Рівні повної і підвищеної «включеності» пов'язані з високою мірою ідентифікації співробітників з екстремальними умовами діяльності.

В. М. Смирнов встановив, що ефективність професійної екстремально-психологічної підготовки залежить від ії узгодження з комплексом службової, бойової і фізичної підготовки. Він пропонує також проводити іiі трьома етапами. На першому (попередньому) етапі реалізуються загальний і спеціальний розділи. Загальний розділ складають лекції і семінарські заняття, на яких здійснюється діагностика професійно важливих якостей співробітників, з'ясування цілей, завдань, змісту навчання, психологічних понять, освоєння знань, вивчення особливостей пізнавальних процесів, професійних психічних властивостей і станів. Спеціальний розділ складає психологічний практикум, до складу якого входять діагностика, осмислення й оцінка психологічних цінностей, загальних, спеціальних індивідуальних і групових професійних знань, умінь і навиків, екстремально-психологічних за своєю природою характеристик функціональних груп.

Другий етап - це етап безпосередньої професійної екстремальнопсихологічної підготовки. Він складається з двох розділів - передбо- 
йового і бойового. До змісту передбойового розділу входить діагностика, розвиток професійних якостей співробітників і характеристик функціональних груп (екстремально-психологічних за своєю природою), підвищення екстремально-психологічної стійкості, відпрацювання загальних і спеціальних умінь і навиків. Зміст бойового розділу складає екстремально-психологічний тренінг, до якого входять: діагностика, корекція психологічних цінностей співробітників, набуття професійних навиків адекватної психічної рефлексії відповідно до функціонального призначення, розвиток професійно-важливих якостей співробітників, психологічних характеристик функціональних груп, формування й розвиток надситуативної активності.

Третій етап названо етапом підготовки в умовах активного відпочинку. Він включає також два розділи - реабілітаційно-відновлювальний і націлений на підтримку екстремально-психологічної підготовленості співробітників. Завданням першого є відновлення працездатності співробітників і забезпечення їх готовності до засвоєння головних вправ. Завданням другого розділу цього етапу є підтримка досягнутого рівня підготовленості, високого рівня витривалості, психологічної стійкості, уваги, інтелекту, самоконтролю за діяльністю і проявом агресії.

У ході дослідження встановлено й ефективність додаткових нетрадиційних психотехнічних вправ, таких як «Спостереження за диханням», «Конфлікт без емоцій», «Загальна розповідь», «Загальний рисунок», «Реакція», «Уявна перемога», «Уявна дія». Автор рекомендує застосовувати їх для розвитку професійно важливих психологічних якостей (інтелект, реакція, увага, комунікативні здібності), регуляції бойових психічних станів, покращення психологічних характеристик функціональних груп (згуртованість, знання, уміння, навики взаєморозуміння, взаємодії, підтримки, надання взаємодопомоги).

За результатами дослідження В. М. Смирнов формулює критерії і показники екстремально-психологічної підготовленості. Для окремих співробітників це: обсяг професійних знань, умінь і навиків, рівень розвитку професійно важливих якостей, екстремально-психологічних за своєю природою, сформованість соціальних цінностей. Для функціональних груп це: задоволеність співробітників стосунками в колективі й діяльністю, надситуативна активність групи, групова екстремально-психологічна майстерність, професіоналізм групи. 
Цікаве дослідження проблеми формування й підтримки психічного стану курсантів військово-транспортного університету залізничних військ фізичними вправами й ментальним тренінгом провела О. В. Пристав [298]. Вона виявила, що в умовах навчання в університеті психічні стани курсантів динамічні, залежать від фізичної підготовленості, впливають на комплекс соціально значущих властивостей особистості, на успішність навчання й військово-професійної діяльності.

О. В. Пристав розробила й експериментально перевірила авторську технологію морально-психологічного забезпечення діяльності спеціалістів залізничних військ. Основою технології стало поєднання ментального тренінгу, тренувань 3 формування спеціальних навиків м'язової релаксації і виконання спеціальних дихальних вправ. Реалізація технології здійснювалася за рахунок використання частини часу, виділеного на самопідготовку.

За даними, які отримано в ході експериментальної роботи, встановлено, що програми ментального тренінгу недостатньо формують навик м'язової релаксації. Водночас продуктивність оволодіння методом саморегуляції суттєво залежить від уміння входити в стан м'язової релаксації.

Результати формувального експерименту показали, що в групі, де ментальний тренінг поєднувався 3 формуванням навиків м'язової релаксації, зафіксовано більш виражені позитивні зміни за такими показниками, як ступінь вираженості емоційно-психічної напруженості, оцінка відчуття впевненості в собі, протистояння розвитку м'язової скованості. Зафіксовано також більш суттєве зростання емоційної стійкості, а також таких показників, як організованість у службі й навчанні, пізнавальна активність, уміння протистояти нервовому стомленню, зберігати працездатність, витримку.

На підставі результатів дослідження О. В. Пристав робить обгрунтований висновок, що поєднання ментального тренінгу з попереднім проведенням фізичного тренування, спрямованого на забезпечення м'язової релаксації, дозволяє отримати більш високі показники позитивної динаміки психічного стану курсантів. Останне, у свою чергу, призводить до зростання ефективності навчальної і військово-професійної діяльності.

Засоби фізичної культури є ефективними і в плані формування соціально значущих соціально-психологічних характеристик у військо- 
вослужбовців. Це встановлено, наприклад, у дослідженні Ю. Ю. Андреєва [13]. Об'єктом його дослідження стали міжособистісні відносини серед курсантів військових навчальних закладів внутрішніх військ МВС Росії. Як предмет дослідження було обрано педагогічну технологію виховання позитивних міжособистісних відносин серед курсантів внутрішніх військ МВС Росії засобами фізичної культури.

Ю. Ю. Андреєвим зафіксовано, що високий рівень фізичної і спортивної підготовленості позитивно впливає на характер розвитку міжособистісних відносин. Встановлено також, що високий рівень фізичної підготовленості сприяє зростанню авторитету серед однокурсників, укріпленню особистого статусу й самовизначенню в колективі. Курсанти з високим рівнем спортивно-фізичної підготовленості були більш впевненими в собі й менш агресивними в міжособистісних відносинах.

У ході дослідження були встановлені найбільш ефективні для розвитку міжособистісних відносин різновиди фізкультурної діяльності. До їх числа віднесено: спортивні ігри, військово-прикладні види спорту, групові вправи у складі курсантських підрозділів.

Основою запропонованої Ю. Ю. Андреєвим педагогічної технології $\epsilon$ поетапне виховання позитивних міжособистісних відносин у процесі фізкультурної діяльності. На першому етапі передбачається використання фізкультурної діяльності за інтересами курсантів. На другому - проводяться спортивні й рухливі ігри. Третій етап технології полягає в застосуванні військово-прикладних видів спорту в складі підрозділів. Головною формою організації є навчальні заняття і спортивні заходи.

Ефективність запропонованої педагогічної технології підтвердили результати педагогічного експерименту. Про це свідчать наведені в роботі Ю. Ю. Андреєва дані експериментальної групи за такими показниками, як динаміка здатності до міжособистісної комунікації, особистісний статус, стійкість до конфліктів, уміння правильно будувати взаємовідносини з рівними й старшими за військовим званням, рівень готовності до правильного діалогу в умовах суперечки.

Використання засобів фізичної культури і спорту для управління розвитком соціально значущих якостей у студентів вивчав С. О. Семенов [345]. У ході виконання роботи досліджувались особливості розвитку соціально значущих якостей у студентів і виявлялися фактори, які впливають на їх формування в процесі фізкультурно- 
спортивної діяльності. Було встановлено, що найбільш важливими факторами, які впливають на характер розвитку соціально значущих якостей у студентів, $є$ :

- рівень професійної підготовленості викладачів фізичного виховання; наявність у студентів фізкультурно-спортивного досвіду;

- чітке обгрунтування педагогічних цілей і завдань виховання в процесі фізкультурно-спортивної діяльності;

- врахування індивідуально-психологічних особливостей студентів, їх особистісного розвитку, фізкультурних інтересів і запитів;

- рівень згуртованості студентського колективу і тенденції його розвитку; конфліктність у навчальній групі.

Поглиблене дослідження такого фактора, як наявність фізкультурно-спортивного досвіду в студентів показало його суттєвий вплив на розвиток соціально значущих якостей. Рівень прояву соціально значущих якостей вивчався 3 використанням експертних оцінок і самооцінки студентів. Отримані результати засвідчили, що за більшістю показників, які характеризують прояв соціально значущих якостей, перевагу мають студенти з більш високим рівнем фізичної підготовленості.

С. О. Семенов виявив і взаємозалежність соціальної активності й активності у фізкультурно-спортивній сфері у студентів. Було встановлено, що серед студентів, які постійно займаються фізичною культурою і спортом, активність у суспільній сфері більш висока. 3 іншого боку, соціально активні студенти проявляли більш високу активність і у фізкультурно-спортивній діяльності.

У ході дослідження було з'ясовано умови ефективного управління розвитком соціально значущих якостей. Використавши метод ранжування (умов), автор виявив найбільш важливі умови. До їх числа віднесено:

- вдосконалення підбору й навчання викладачів фізичного виховання;

- стимулювання зростання всебічного фізичного розвитку студентів;

- підбір найбільш ефективних засобів фізичної культури і спорту для розвитку соціально значущих якостей;

- всебічне методичне й матеріально-технічне забезпечення занять з фізичної культури; 
- формування здорового морально-психологічного клімату в процесі фізкультурно-оздоровчої діяльності студентів;

- узгодження зусиль усіх посадових осіб ВНЗ і кафедри фізичного виховання при вирішенні виховних завдань.

С. О. Семенов розробив і експериментально перевірив власну технологію управління розвитком соціально значущих якостей у студентів. Вона передбачала педагогічне коригування організації, змісту й методики проведення занять з фізичної культури для студентів. Характерною особливістю експериментальної програми стало те, що організація студентів і методика проведення з ними різних за формою занять 3 фізичної культури мали значну виховну спрямованість на формування соціально значущих якостей і укріплення міжособистісних взаємовідносин. Ефективність експериментальної технології було оцінено за такими групами показників, як: фізична підготовленість, функціональний стан, рівень розвитку соціально значущих якостей у студентів. По закінченні експериментальної роботи було зафіксовано позитивні зміни всіх цих показників. У той же час в експериментальній групі динаміка позитивних змін була більш суттєвою.

I. А. Бікмаєв досліджував проблему професійної психофізичної підготовки студентів спеціальності «Безпека життєдіяльності» у фізкультурних ВНЗ [34]. Він припустив, що методика професійної психофізичної підготовки студентів спеціальності «Безпека життєдіяльності», до змісту якої увійдуть засоби, які дозволять розвинути професійно важливі психофізичні якості і які будуть реалізовуватися в ситуаціях, що моделюють роботу в екстремальних умовах, дозволять сформувати оптимальний рівень психофізичної підготовленості майбутнього учителя з безпеки життєдіяльності. У ході перевірки припущення було виявлено головні професійно важливі якості вчителя з безпеки життєдіяльності: впевненість у собі, рішучість, емоційна стійкість, високий рівень розвитку переключення уваги, концентрація уваги, загальна витривалість, значний об'єм оперативної пам'яті, швидкісно-силові здібності, силова витривалість, просторова точність рухів, динамічна рівновага, статична рівновага, статична сила, швидкість цілісної рухової дії, часова точність рухів, силова точність рухів, швидкість простої рухової реакції, активна гнучкість.

У ході експериментальної роботи було перевірено ефективність авторської методики професійної психофізичної підготовки. Ї̈ї основу 
складали вправи й елементи з таких видів спорту, як легка атлетика, спортивні ігри, туризм, спортивне орієнтування, альпінізм, важка атлетика, гімнастика, плавання, боротьба, спеціальні психофізичні вправи, теоретична підготовка. До складу методики входили заняття в умовах прямої дії несприятливих факторів (до 10 \% від загального часу навчання).

I. А. Бікмаєв встановив, що найбільш ефективне відсоткове співвідношення засобів професійної психофізичної підготовки в експериментальній методиці складає: у першому півріччі (п'ятий семестр) - до 40 \%, у другому півріччі (шостий семестр) - до 55 \% від загального часу курсу «Фізкультурно-спортивне вдосконалення».

Експериментальна робота за авторською методикою протягом навчального року дозволила зафіксувати в студентів досягнення оптимального рівня розвитку професійних якостей учителя з безпеки життєдіяльності.

Роль фізичного виховання в підготовці студентів ВНЗ до майбутньої професійної діяльності вивчала О. О. Заплатіна [137]. Вона визначила й експериментально перевірила ефективність таких педагогічних умов підвищення ролі фізичного виховання для підготовки до професійної діяльності:

1) формування позитивного ставлення студентів ВНЗ до занять фізичною культурою і спортом у процесі диференціації навчальної діяльності;

2) вивчення і врахування сформованості професійно важливих якостей особистості студента в процесі навчальної і позанавчальної діяльності з фізичного виховання;

3) організація спільної фізкультурно-оздоровчої i спортивної діяльності викладачів і студентів ВНЗ. Було встановлено, що у випадку реалізації цих умов відбувається зростання професійно значущих показників у студентів.

Питання індивідуалізації психологічної підготовки юних спортсменів у складнокоординаційних видах спорту досліджувала О. В. Сiліч [350]. Для його вирішення вона запропонувала власну методику, яка розрахована на спортсменів 12-18 років. Рекомендується:

1) у багаторічній навчально-тренувальній і змагальній діяльності розглядати психологічну підготовку як обов'язковий компонент цілісного педагогічного процесу в єдності з іншими видами підготовки; 
2) у процесі вирішення загальних і часткових завдань враховувати специфіку виду спорту й модельні характеристики;

3) для розробки індивідуального плану і програми психологічної підготовки спортсмена використовувати результати комплексної оцінки спортивної успішності, яка враховує особливості діяльності в складнокоординаційних видах спорту і включає експертну оцінку суб'єктивних і об'єктивних компонентів діяльності.

Цікаве дослідження, пов'язане з колом питань, що розглядаються в цій роботі, провів О. А. Аляб'єв, який вивчав питання оцінки й розвитку емоційної стійкості у курсантів військового інституту фізичної культури [11]. Він припустив, що застосування стресора, яким був стрибок у воду із семиметрової вишки (за умови відсутності попереднього досвіду таких стрибків) і паралельне спостереження за зовнішнім проявом емоцій, вегетативними реакціями, тестування ряду психічних пізнавальних процесів дозволяють отримати надійну прогностичну інформацію про схильність до емоційної напруги. О. А. Аляб'єв також припустив, що контролюючи свою міміку, включаючи в підготовчу, основну й заключну частину занять м'язову релаксацію, дихальні вправи з подовженою фазою видиху, можна формувати спеціальні уміння з управління своїм психічним станом і подолання емоційного стресу. Використання вищезгаданих засобів, за задумом автора, приведе до розвитку в курсантів емоційної стійкості, що, у свою чергу, сприятиме зниженню в них агресивності.

Припущення автора підтверджуються даними, які отримано в процесі виконання експериментальної роботи. Підтверджено психодіагностичну цінність для виявлення схильності до прояву емоційної напруги тесту, що включав стрибок у воду із семиметрової вишки 3 оцінкою зовнішнього прояву емоцій і ряду психологічних і психофізіологічних параметрів. Встановлено, що важливою умовою під час виконання тесту є відсутність попереднього досвіду таких стрибків.

У ході дослідження О. А. Аляб'єв встановив психодіагностичну надійність виконання модифікованої проби Ромберга перед виконанням стрибка у воду із семиметрової вишки. Курсантам пропонувалося встановити на одній лінії носок однієї стопи й п'ятку іншої. Збереження рівноваги в такому положенні менше 15 с оцінювалось у 2 бали. За умови збереження рівноваги протягом 15 с з відкритими очима нараховувалося 3 бали. За умови збереження рівноваги ще протягом 15 c, але із заплющеними очима, ставилось 4 бали. У випадку, коли 
курсант зберігав рівновагу ще протягом 15 с із заплющеними очима й витягнутими вперед руками, ставилося 5 балів. Автором встановлено, що курсанти, які показували високі результати за цим тестом, мали високі оцінки й за результатами інших тестів на оцінку емоційної стійкості.

У дослідженні О. А. Аляб'єва виконано й експериментальну перевірку системи самоуправління психічним станом. Ї̈і зміст складало виконання прийомів м'язової релаксації, дихальних вправ з подовженою фазою видиху, методики самоконтролю за своїм психічним станом. В експериментальній групі було зафіксовано суттєве покращення таких показників: запобігання негативним мімічним реакціям, подолання скованості, оцінки координації рухів, оцінки за пробою Ромберга, показників частоти серцевих скорочень після впливу стресора, показників оперативної пам'яті через 8-10 хв після впливу стресора, показників переключення уваги (за червоно-чорнини таблицями) після впливу стресора.

Автором зафіксовано також зв'язок показників емоційної стійкості та агресивності в курсантів. Так, було виявлено, що курсанти, які отимали високі оцінки за показником емоційної стійкості, більшою мірою здатні оптимізувати свою особистісну агресивність. Встановлено, що підвищення емоційної стійкості сприяє зниженню загальної агресивності, дозволяє утримуватися від прояву деструктивної агресії.

\section{2. Професійна придатність фахівця і його психологічна та психофізична підготовленість}

Організація й проведення психологічної і психофізичної підготовки зі студентами потребує визначення головної спрямованості цієї роботи. На нашу думку, як орієнтир доцільно використовувати майбутню професію студента, або, більш конкретно, професійно значущі компоненти структури особистості майбутнього фахівця. Обгрунтовуючи саме такий підхід, ми виходимо 3 того, що вища школа $\epsilon$ школою професійною і навчально-виховний процес у ній повинен бути максимально зорієнтованим на підготовку фахівця. При такому під- 
ході першим логічним кроком буде визначення психологічної і психофізичної підготовленості особистості в контексті іiі професійної придатності.

Оцінка професійної діяльності (ії результативності та якості) проводиться з використанням таких понять, як ефективність, продуктивність праці. Властивість людини, яка полягає в ії можливості виконувати конкретну працю протягом заданого часу з необхідною ефективністю і якістю, називають працездатністю [48]. Її рівень і стійкість визначаються професійною підготовленістю людини, досвідом, фізіологічними й психологічними характеристиками. На динаміку працездатності впливають індивідуальні особливості людини, особливості змісту, засобів, умов організації діяльності.

Важливим показником ефективності професійної діяльності є надійність. Під цим терміном розуміють безпомилковість, точність і своєчасність виконання робочих дій у певних умовах. На професійну надійність впливає не тільки рівень підготовленості, але й стан функціональних систем організму і психіки. У зв'язку з цим було введено поняття функціональної надійності, яким позначають рівень розвитку функціональних систем організму і психіки, їх стійкість щодо впливу різноманітних чинників праці, адекватність їх реагування на умови і зміст діяльності. По суті, поняття функціональної надійності відображає характер енергетичної пристосованості людини до праці.

Цінність діяльності для людини пов'язують 3 можливістю самовираження, застосування своїх здібностей, з можливістю творчості [3]. Одним із показників професійної діяльності є задоволеність працею. Вона показує емоційне відображення людиною процесу і результату праці, матеріального забезпечення, соціального статусу.

Для дослідження трудової діяльності людини необхідний аналіз відповідності характеристик суб'єкта і об'єкта праці, їх придатності для виконання трудових завдань. У зв'язку з цим науковцями було запропоноване поняття «професійна придатність», яке відображає як різні індивідуальні особливості людини, які необхідні для успішного виконання трудової діяльності, так і характеристики об'єкта праці (зміст, засоби, умови організації діяльності) з точки зору їх відповідності можливостям людини (придатність праці для людини).

Професійна придатність людини визначається співвідношенням вимог професії до особистісних характеристик людини. Вона має свій 
об’єкт - систему «людина-професія» (певну категорію людей, вид діяльності); відображає стан, ступінь розвитку сукупності індивідуальних якостей людини (рис особистості, здібностей, мотивації, професійної підготовленості, фізичного стану й т. ін.). Професійна придатність є динамічною властивістю системи «людина-професія», оскільки відображає розвиток суб'єкта праці та мінливість об'єкта праці.

Дослідження професійної придатності ведеться за двома головними напрямками:

1) визначення придатності, іiї оцінка, контроль, експертиза;

2) формування придатності, розвиток професійно значущих якостей особистості на етапах професійного шляху (професійної підготовки, адаптації спеціалістів, реальної трудової діяльності).

Психологічні аспекти проблеми професійної придатності досліджували: Б. Г. Ананьєв, О. А. Абдулліна, В. А. Бодров, К. М. Гуревич, В. М. Дружинін, С. О. Климов, Б. В. Кулагіна, В. Л. Маріщук, Б. М. Теплов та інші. Системний аналіз проблеми зробив В. А. Бодров [46]. Він формулює такі положення, які розкривають эї зміст:

1. Професійна придатність визначається сукупністю індивідуальних особливостей людини, які впливають на успішність освоєння конкретної трудової діяльності та ефективність ії̈ виконання. Вона відображає реальний рівень розвитку професійно значущих якостей для конкретної діяльності, які формуються і проявляються на етапах життєвого і професійного шляху. До них належать якості, що відображають особливості трудового виховання і навчання, професійної підготовленості, структури особистості, стану здоров'я і фізіологічних функцій, фізичного розвитку, які визначаються вимогами профeciï.

2. Професійна придатність розглядається і як сукупність якостей людини, які визначають успішність формування придатності до конкретної діяльності (або видів діяльності), і як сукупність наявних професійних знань, навичок, умінь, психологічних, фізіологічних якостей і властивостей, що забезпечують якісне виконання професійних завдань. Вона формується як під впливом природних задатків людини, так і під впливом навчання, у процесі самої діяльності.

3. Процес формування професійної придатності проходить ряд етапів. Головними є: трудове виховання і навчання дитини, професійна орієнтація, професійний вибір, професійна підготовка, профе- 
сійна адаптація, професійна діяльність, професійна атестація, професійна реабілітація. Зміст кожного етапу специфічний з позицій цілей, методів, засобів, термінів реалізації.

4. Формування професійної придатності відбувається під впливом двох складових - індивідуальних особливостей людини (якостей, що визначають формування придатності до конкретної праці) і самої професійної діяльності.

5. Розвиток такої характеристики особистості, як професійна придатність відбувається одночасно у взаємозв'язку із загальним процесом психічного розвитку особистості.

6. У ході трудової професійної праці формуються не тільки окремі професійно орієнтовані психічні й фізіологічні функціональні системи людини, але й їі особистість (утворюється соціально-професійний тип особистості з певним ціннісними орієнтаціями, характером, стилем спілкування і т. ін.).

7. Професійну придатність можна розглядати не тільки як властивість суб'єкта діяльності, як характеристику його функціонального ресурсу і практичної готовності до діяльності, але і як міру реалізації можливостей організму і психіки, що виражається через результат діяльності.

8. Для визначення професійної придатності людини слід брати до уваги комплекс характеристик, які в сукупності визначають ії рівень. Головними $з$ них $є$ такі: професійна мотивація, загальна і професійна підготовленість (знання, навички й уміння, що необхідні для виконання типових і нештатних трудових завдань), рівень функціональної готовності організму до трудової діяльності (розвиток професійно значущих фізіологічних функцій аналізаторів і фізичних якостей сили, швидкості, витривалості, спритності, гнучкості), стан індивідуально-психологічних якостей особистості, які $\epsilon$ важливими для конкретної діяльності.

9. Професійна придатність залежить не тільки від сукупності професійно значущих якостей особистості, але й від ступеня їх прояву та характеру взаємозв'язку. Одні й ті самі професійні завдання можуть виконувати люди з різним поєднанням (індивідуальною своєрідністю) психічних властивостей і якостей, з використанням різних способів досягнення результату. Однак компенсуючі можливості індивідуального стилю обмежені. Не є безмежними також і можливості компенсації психічних процесів, професійно значущих для діяльності. 
10. У людини не може бути повної професійної придатності до того, поки вона практично не включилася в професійну підготовку й відповідну трудову діяльність. У той же час деякі необхідні складові придатності до професії можуть бути сформовані завчасно (ставлення до праці, дієздатність та ін.).

11. Рівні професійної придатності можуть бути виділені на основі оцінки потенційних передумов придатності (за результатами обстеження) і реальних проявів її в процесі трудової діяльності за конкретними показниками ефективності, надійності, безпеки. Так, перший рівень можна визначити як такий, що відповідає вимогам нормативної діяльності (максимальна ефективність і надійність професійної діяльності стосовно всього діапазону іiі можливих варіантів і умов виконання, включаючи екстремальні умови). Другий рівень - ефективне виконання типових штатних завдань діяльності в умовах, що виключають нештатні (аварії, поломки, відмови) і екстремальні (небезпека, висока відповідальність, інтенсивні зовнішні впливи) ситуації. Третій рівень - ефективне виконання окремих завдань професійної діяльності протягом певного відрізку часу.

12. Не кожна людина може оволодіти деякими професіями, навіть якщо має високий рівень професійної підготовки і мотивації. Професійна придатність до таких професій може бути сформована лише за наявності певного ступеня розвитку професійно значущих психофізичних якостей особистості.

Відомий російський фахівець Є. О. Климов [159] виділив 5 структурних компонентів професійної придатності. До них він відносить:

1. Громадянські якості (ставлення до суспільства, моральний облік).

2. Ставлення до праці, до професії, інтереси, схильність до даної сфери праці (професійно-трудова спрямованість особистості).

3. Дієздатність загальна (фізична і розумова). До неї Є. О. Климов відносить якості, які необхідні не в одному, а в дуже багатьох видах діяльності, наприклад: ширина і глибина розуму, самодисципліна, розвинений самоконтроль, ініціативність, активність.

4. Одиничні, часткові, спеціальні здібності, тобто якості, які дуже потрібні в окремих видах діяльності. Самі по собі вони не роблять людину професіоналом, але є необхідними в загальній системі професійної придатності.

5. Навички, уміння, досвід. 
Виділивши структуру професійної придатності, Є. О. Климов у той же час відкидає низку поширених упереджень. Перше з них це ідея про одиничність комплекту особистих якостей, який підходить для тієї чи іншої професії. Він закликає педагогів ставитись до своїх вихованців не як до якоїсь ідеалізованої копії когось, а як до людей, які повинні самовизначитись індивідуально й неповторно, оскільки своєрідними є внутрішні умови їх розвитку. Друге упередження полягає в тому, що професійну придатність вважають незмінною характеристикою людини й намагаються ії якомога раніше виявити. У зв'язку з цим С. О. Климов зазначає, що людина як суб'єкт праці й особистість розвивається, а їі придатність до діяльності формується в процесі самої діяльності. Наявними можуть бути тільки деякі якості, що є основою професійної придатності. Третє упередження - це думка, що властивість професійної придатності пов'язана виключно 3 працюючим суб'єктом, у той час як невідповідною може бути об'єктивна сторона праці (погана техніка, погана організація виробництва).

Професійна придатність людини є однією з категорій, що характеризують діяльність. Психологічні особливості професійної діяльності зумовлені регулюючим впливом не окремих психічних якостей і функцій, а їх сукупністю.

Сукупність психічних властивостей, якостей суб'єкта у своїй цілісності, єдності, організовану для виконання функцій конкретної діяльності, називають психологічною системою діяльності. Концепцію про сутність, структуру, функції, динаміку психологічної системи діяльності розробив В. Д. Шадріков [431, 433]. Психологічна система діяльності має такі головні складові: мотиви, цілі, програми й інформаційні основи діяльності, прийняття рішення, професійно значущі якості. Вона $є$ утворенням мінливим, таким, що розвивається, і специфічним у деяких своїх проявах для конкретної професійної діяльності. Одночасно структура іїі компонентів залишається, як правило, незмінною.

Недостатня сформованість окремих елементів психологічної системи діяльності, їх неадекватність особливостям і вимогам конкретної професійної діяльності можуть бути причиною зниження рівня професійної придатності.

У формуванні психологічної системи діяльності особливе місце належить підсистемі професійно значущих якостей особистості 
спеціаліста. Вони є тими внутрішніми психологічними характеристиками суб' єкта діяльності, у яких відображаються зовнішні специфічні впливи факторів конкретного трудового процесу і які виступають у формі професійних вимог до особистості.

Дослідженню проблеми розвитку окремих професійно значущих компонентів і їх структури в діяльності, а також формування підсистеми професійно значущих компонентів структури особистості присвячено роботи В. А. Бодрова [44, 45], В. Л. Маріщука [217], В. Д. Шадрікова [432], Є. О. Клімова [160], А. Б. Олова [270], Л. М. Мітіної [245] та ін. Основними результатами роботи стали отримані дані про розвиток окремих професійно значущих якостей у представників певних професій.

Індивідуально-психологічні передумови вибору професії у підлітковому і юнацькому віці вивчала у своїй роботі Н. О. Велумян [73]. Об'єктом дослідження були індивідуально-психологічні особливості старшокласників. Предметом - стійкі структури темпераменту, характерологічних і когнітивних властивостей старшокласників, які визначають навчальні й професійні переваги.

Встановлено, що між індивідуально-психологічними особливостями (темпераментом, характером, когнітивним стилем) та навчальними й професійними перевагами існують тісні взаємозв'язки. Школярі, які надавали перевагу тому чи іншому навчальному предмету, відрізнялися різними характеристиками темпераменту, характеру й когнітивного стилю.

Було виявлено, що вибір професійних категорій «людиналюдина» і «людина-художній образ» у підлітковому й ранньому юнацькому віці пов'язаний з певними навчальними перевагами.

А. С. Бисюк провела дослідження психологічних факторів успішності професійної діяльності інженерів-метрологів [64]. Вона виявила психологічні чинники, які впливають на успішність професійної діяльності інженерів-метрологів. Ці чинники А. С. Бисюк кваліфікувала як зовнішні та внутрішні. До зовнішніх віднесено організаційно-управлінську систему підприємства і психологічну безпеку організаційного середовища підприємства. До внутрішніх - індивідуально-психологічні особливості особистості.

Дослідниця встановила комплекс психологічних чинників, які впливають на успішність професійної діяльності інженерів-метрологів. До їх числа віднесено наявність у інженера-метролога таких 
рис особистості, як відповідальність, самоконтроль, дисциплінованість, емоційна стійкість, домінування, здатність до набуття статусу, товариськість, самоприйняття, незалежність, емпатія, соціалізація, відсутність або низький рівень прояву симптомів професійного «вигорання», сприйняття соціального середовища організації як психологічно безпечного, використання різнопланових стилів когнітивноповедінкових стратегій подолання.

У ході дослідження було виявлено, що поєднання конструктивноперетворюючих стратегій подолання, психологічна захищеність і наявність особистісних якостей, притаманних соціально-компетентній особистості (відповідальність, самоконтроль) суттєво впливають на успішність професійної діяльності інженерів-метрологів.

Цікаве дослідження питання взаємозв'язку інтегративних професійно важливих якостей і особистісних характеристик спеціалістів 3 різною ефективністю діяльності виконала С. В. Гуцикова [110]. Метою дослідження стало виявлення особливостей взаємозв'язку інтегративних професійно важливих якостей і особистісних характеристик співробітників служби охорони з різною ефективністю професійної діяльності. Об'єктом дослідження була професійна придатність співробітників служби охорони. Предметом - взаємозв'язок інтегративних професійно значущих якостей i особистісних характеристик співробітників служби охорони.

С. В. Гуцикова припустила, що спеціалісти з різною ефективністю діяльності характеризуються якісною своєрідністю взаємозв'язку їх інтегративних професійно значущих якостей і особистісних характеристик.

Дослідник ввела поняття домінантних особистісних характеристик. Це $\epsilon$ ті із особистісних характеристик людини, які вирізняються стійким взаємозв'язком 3 інтегративними професійно важливими якостями спеціалістів. Було встановлено, що домінантні особистісні характеристики співробітників служби охорони з різною ефективністю діяльності є різними.

С. В. Гуцикова виявила, що інтегративні професійно важливі якості ефективних співробітників служби охорони пов'язані зі сприятливими для діяльності домінантними особистісними характеристиками. До їх числа віднесено високу соціальну сміливість, виражену орієнтацію на групову думку, практичність поведінки, високий контроль бажань, домінантність, високий інтелект. Встановлено також, що 
в малоефективних співробітників служби охорони вираженими $є$ домінантні особистісні характеристики, які $\epsilon$ несприятливими для діяльності, зокрема м'якосердя, схильність до почуття провини, низька самооцінка.

На нашу думку, дослідження С. В. Гуцикової засвідчує важливість формування професійно значущих характеристик особистості в підготовці до професійної діяльності. Значною мірою це завдання може бути вирішено в процесі професійно орієнтованої психологічної і психофізичної підготовки.

Дослідження професійної придатності пілотів з позиції особистісно орієнтованої експертизи провела О. М. Сиваш [349]. Об'єктом дослідження стали пілоти з різним рівнем професійної кваліфікації i здоров'я. Предметом - взаємозв'язок властивостей особистості й психічних станів пілотів різних категорій з рівнем їх кваліфікації й станом здоров'я в процесі психологічної експертизи професійної придатності.

Дослідник припустила, що професійно важливі властивості й психічні стани пілотів пов'язані з такими чинниками, як:

a) суб'єктивна оцінка психологічного, фізичного й професійного статусу;

б) вік, стаж, кваліфікація і спеціалізація пілотів;

в) деякі нозологічні форми порушення стану здоров'я.

У ході дослідження було встановлено, що задоволеність роботою слід вважати суб'єктивним критерієм професійної придатності пілотів.

О. М. Сиваш виявила взаємозв'язок певних рис особистості пілотів, рівня їх задоволеності працею, самооцінки власного психологічного, фізичного й професійного статусу з показниками професійної кваліфікації. На підставі цього нею розроблено обгрунтовані рекомендації відносно доцільності використання вищезгаданих характеристик пілотів для діагностики й прогнозування професійної придатності.

Автор зафіксувала в пілотів з порушенням стану здоров'я більш виражені показники тривожності, емоційності, психічної напруженості, зниження відчуття компетентності. Усі вони є професійно значущими. Цей факт є важливим і для нашого дослідження, оскільки свідчить про взаємовплив організму й психіки людини. 
При визначенні професійної придатності особистості до низки професій, які пов'язані з високою відповідальністю за життя людей (наприклад, професії транспорту) або з ризиком для власного життя (наприклад, рятувальники, пожежники, бійці спеціальних підрозділів) важливо знати схильність людини до так званої неочевидно адаптованої активності. Термін введено для позначення неочевидних форм поведінки (суїцидальна поведінка, альтруїзм, поведінка, пов'язана з ризиком для життя або здоров'я).

О. В. Янихбаш провів дослідження взаємозв'язку ризикованої поведінки $з$ психологічними характеристиками особистості [448]. Метою дослідження стало виявлення психологічних характеристик і особливостей поведінки, які пов'язані зі здійсненням ризикованих вчинків. Предметом - психологічні характеристики, пов'язані з ризикованою поведінкою.

Автор припустив існування специфіки у вираженості й структурі психологічних характеристик і в поведінкових особливостях у групах, що різняться за досвідом здійснення ризикованих вчинків. Інше припущення полягало в тому, що серед психологічних характеристик особистості такий показник, як «загальний індекс пошуку відчуттів» $\epsilon$ найбільш вірогідним психологічним компонентом для прогнозування поведінки, пов'язаної з ризиком.

У ході дослідження було встановлено, що схильність до здійснення ризикованих вчинків характеризується специфікою особливостей поведінки й психологічних характеристик. У схильних до ризику людей О. В. Янихбаш виявив більшу емоційну стабільність, товариськість, прагнення до встановлення нових контактів 3 оточуючими і відкритість новому досвіду. Виявлено й відмінності в способах підвищення соціального статусу.

О. В. Янихбаш встановив можливість прогнозування ризикованої поведінки за психометричним показником «загальний індекс пошуку відчуттів». У дослідженні про це свідчили більш високі показники «загального індексу пошуку відчуттів» у індивідів, які займалися парашутним спортом, на відміну від тих, хто не здійснював стрибків 3 парашутом.

Автор також зазначає, що схильність до ризику пов'язана зі стратегіями сексуальної поведінки. У схильних до ризику індивідів було виявлено орієнтацію на встановлення короткострокових сексуальних 
відносин. У індивідів, які не схильні до ризику, виявлено орієнтацію на довгострокові відносини.

Психологічні особливості підготовки до різних видів професійної діяльності розглянули у своїх роботах А. С. Борисюк [54], О. I. Гура [106], О. С. Фальова [397], О. П. Федик [399], Н. М. Кульбіда [193]. Інші фахівці $[28,43,63,87,150,184,363,425,436]$ важливою проблемою психології професійної діяльності вважають вивчення процесу формування особистості професіонала. У цьому контексті викликає інтерес робота Ю. П. Поваренкова [290]. Він висуває припущення про існування трьох підструктур особистості професіонала. До першої підструктури віднесено ті якості (продуктивність, якість, надійність), що впливають на ефективність діяльності і відображають рівень професійної майстерності. Другу підструктуру утворюють ті якості особистості, що визначають професійну ідентичність особистості (мотиваційна сфера особистості професіонала). Критеріями тут $\epsilon$ задоволеність від праці, професійна самооцінка, самореалізованість. Третю підструктуру утворюють властивості особистості, що забезпечують саморегуляцію професійного становлення (професійна самосвідомість).

Аналіз питань професійної придатності та психологічної системи діяльності показує, що до їх структури необхідно віднести і психологічну та психофізичну підготовленість спеціаліста. Без ії достатнього розвитку важко уявити ефективну реалізацію в ході трудової діяльності інших якостей (особливо в екстремальних ситуаціях). Психологічна й психофізична підготовка спрямована на формування (розвиток) низки складових, що входять до структури компонентів професійної придатності особистості, виділених Є. О. Климовим.

Необхідність проведення у вищій школі спеціальної психологічної і психофізичної підготовки до конкретного виду професійної праці в сучасних умовах визначають багато чинників. Перший пов'язаний із специфічним впливом сучасної праці на людину. Її виконання супроводжується недостатньою руховою активністю, напруженим емоційним станом, несприятливим впливом навколишнього середовища та ін. Вплив цих чинників порушує процес природної фізіологічної адаптації людини й призводить до низки негативних наслідків для іiі здоров'я і працездатності. Другий чинник визначається зміною місця й функціональної ролі людини в сучасному виробничому процесі. Об'єктом трудових зусиль спеціаліста стає доцільне використання 
машин і автоматизованих систем. Суттєво підвищується відповідальність професіонала за результат праці. Сучасне виробництво висуває підвищені вимоги до таких психофізичних характеристик, як стійкість, вибірковість, переключення, розподілення уваги, швидкість і точність реакції. Організація і проведення цілеспрямованої психологічної та психофізичної підготовки студентів дає можливість моделювати різноманітні ситуації на фоні психофізичних навантажень. Третій чинник пов'язаний з необхідністю забезпечення високого рівня інтенсивності й продуктивності праці сучасного фахівця. Ці показники обмежені його психофізичними можливостями, але можуть бути покращені в процесі спеціалізованої підготовки. Четвертий чинник - необхідність забезпечення психологічної і психофізичної надійності майбутніх спеціалістів у процесі виконання професійних функцій. Якість підготовки спеціаліста значною мірою залежить не тільки від професійних знань, умінь і навиків, але й від психологічної та психофізичної підготовленості.

Загалом характерною ознакою сучасного виробництва є тенденція до постійного зростання вимог до освітніх, професійних, психологічних, психофізичних та багатьох інших характеристик особистості фахівця. Усе це вимагає їх відповідної підготовки у вищих навчальних закладах. Значний потенціал для психологічної і психофізичної підготовки майбутніх фахівців має фізична культура та спорт.

У наш час спортивну діяльність у психології обгрунтовано відносять до тієї сфери діяльності, для якої характерними є: надзвичайно висока динаміка зміни подій, у ряді випадків надмірне навантаження на психіку людини, яке впливає на якість виконання діяльності [18]. При цьому відзначається, що успіх у змаганнях визначають не тільки кількість і якість проведених спортсменом тренувань, але й рівень розвитку (сформованості) ряду психологічних складових, насамперед, емоційної стійкості. Змагальна діяльність (особливо в ігрових видах спорту) розглядається як емоціогенна ситуація підвищеної значущості. Ії̈ супроводжують дуже висока динамічність у зміні подій на майданчику, виникнення непередбачуваних ситуацій. Звертається увага на те, що учасники змагань повинні швидко реагувати та пристосовуватися до зміни умов діяльності. Крім того, вони перебувають під впливом почуття відповідальності за результат діяльності та під тиском емоційного навантаження з боку тренерів, вболівальників та суперників. І. Ф. Аршава обгрунтовано підкреслює, що досягнення 
успіху в такій діяльності залежить від здатності людини швидко адаптуватися до умов діяльності, від здатності сприймати ситуацію як виклик чи загрозу та від рівня стресозахисного потенціалу. Проведене нею експериментальне дослідження (із залученням висококваліфікованих спортсменів з настільного тенісу) підтвердило припущення про те, що такі характеристики особистості, як високий рівень адаптивності, толерантності до невизначеності мають безпосередній вплив на досягнення спортсменами високих результатів у постійно змінюваних емоціогенних ситуаціях спортивної діяльності підвищеної значущості. Сформовані в процесі такої спортивної діяльності характеристики особистості, безумовно, є професійно значущими для певних професій, у тому числі й професій залізничного транспорту. Психологи звертають увагу і на важливість спортивної діяльності для самореалізації особистості [347].

\section{3. Фізичне виховання як засіб підготовки особистості до професійної праці}

Використання засобів фізичного виховання для підготовки до трудової діяльності простежується з ранніх етапів розвитку людства. Як зазначає Л. Кун [194], людина стала людиною не тільки завдяки розвитку засобів праці, але й завдяки постійному вдосконаленню організму людини як головної виробничої сили.

Фізична культура являє собою вид людської діяльності, який здійснює різнобічний вплив на розвиток суспільства. Це стосується, зокрема, і суспільного виробництва, і формування особистості людини.

На необхідності використання фізичної культури для виховання гармонійно розвиненої особистості наголошував П. Ф. Лесгафт [206]. Він підкреслював і важливу роль фізичної культури для освоєння професії. Як на чинник, що сприяє як оволодінню, так і вдосконаленню в обраній професії, вказував на фізичну культуру В. В. Гориневський [101].

Важлива роль при підготовці населення до праці відводилася фізичній культурі в СРСР. Було створено комплекс ГПО, що виконував роль нормативної основи для визначення готовності людей до праці. У кінці 50-х років минулого століття остаточно формується специфі- 
чна сфера фізичної підготовки людини до праці, що реалізується в процесі фізичного виховання. Мова йде про професійно-прикладну фізичну підготовку. Цим терміном позначається спеціалізований педагогічний процес 3 переважним використанням форм, засобів і методів фізичного виховання, які оптимально забезпечують розвиток i вдосконалення функціональних i рухових можливостей людини, необхідних для конкретних видів трудової і військової діяльності.

Професійно-прикладну фізичну підготовку визначають як систему організаційно-педагогічних заходів, спрямованих на формування і вдосконалення професійно важливих якостей, навиків, умінь, знань особистості, які мають суттєве значення для іiї успішної праці за обраною спеціальністю [311, с. 20]. В. І. Ільїніч визначає професійноприкладну фізичну підготовку як спеціально спрямоване і вибіркове використання засобів фізичної культури і спорту для підготовки людини до певної професійної діяльності [402]. На думку Ю. О. Суворова і В. О. Платонової, професійно-прикладна фізична підготовка це педагогічно спрямований процес забезпечення спеціалізованої фізичної підготовленості до майбутньої професійної діяльності. Як зазначають автори, у своїй основі - це процес навчання, який збагачує індивідуальний фонд професійно корисних рухових умінь і навиків, виховання фізичних і безпосередньо пов'язаних з ними здібностей, від яких прямо або опосередковано залежить професійна дієздатність [381, с. 3]. На нашу думку, найбільш вдалим є саме це визначення.

Один 3 найбільш авторитетних фахівців у цій сфері Р. Т. Раєвський розглядає професійно-прикладну фізичну підготовку як підсистему формування спеціаліста, що має професійну спрямованість. На його думку, іiі забезпечують мета, завдання, принципи, які випливають із вимог до фізичної надійності й готовності до плідної роботи за спеціальністю [311, с. 21]. Цілі, завдання й принципи професійноприкладної фізичної підготовки знаходять своє відтворення в підборі відповідних засобів, методів, форм організації, контролі. Професійноприкладна фізична підготовка здійснюється відносно конкретної професії або спеціальності.

Результативність професійно-прикладної фізичної підготовки як засобу підготовки до професійної діяльності підтверджено в дослідженнях Р. Т. Раєвського (1969), В. А. Кабачкова (1970), Ю. В. Полухіна (1983), I. Г. Бондаренко (2009), В. О. Садовського (2012) та багатьох інших. Досліджувалася вона і 3 позицій підготовки до 
конкретних професій. Серед них: пілоти авіації, студенти художніх ВНЗ, монтажники дрібних деталей, спеціалісти сільського господарства, гірничої справи, будівельники, лікарі, моряки, геологи, музиканти, курсанти морських ВНЗ та ін. За всіма напрямками зафіксовано позитивний вплив професійно-прикладної фізичної підготовки на відповідну готовність до професійної праці.

Систему формування професійно-прикладної фізичної культури курсантів і слухачів ВНЗ МВС Росії розробив В. О. Овчінніков [267]. Він визначив мету формування професійно-прикладної фізичної культури у вищих навчальних закладах $\mathrm{MBC}$; якою $є$ професійноприкладна фізична культура курсантів; що являє собою персоніфікований комплекс здібностей людини, iї знань, умінь і навиків до творчої самоорганізації і управління розвитком своїх фізичних можливостей.

Дослідник запропонував модель системи формування професійноприкладної фізичної культури курсантів МBC, у якій фізичну підготовку в структурі навчального процесу прямо пов'язав з усіма дисциплінами службово-бойової підготовки (тактико-спеціальною підготовкою, вогневою, початковою професійною підготовкою і вступом до спеціальності, основами особистої безпеки співробітників органів внутрішніх справ). Навчальна дисципліна «Фізична підготовка» розглядається як визначальна в системі службово-бойової підготовки курсантів. На неї і покладається формування їх професійноприкладної фізичної культури.

В. О. Овчінніков до змісту професійно-прикладної фізичної підготовки курсантів включає блоки теоретичної, фізичної, технічної і практичної підготовки. Теоретичну підготовку передбачається здійснювати на лекційних і семінарських заняттях. Вона включає вісім головних тем. Фізична підготовка спрямована на розвиток координаційних та силових здібностей і витривалості. У iї рамках передбачається освоєння таких розділів, як прикладна гімнастика, подолання природних і штучних перешкод, загальна і спеціальна фізична підготовка, спортивні ігри, основи спортивної боротьби. Завданням технічної підготовки є освоєння техніки й тактики використання боротьби, які застосовуються для затримання правопорушників. Практична підготовка пов'язана із застосуванням набутих знань, рухових умінь і навиків на практиці (подолання спеціалізованої смуги перешкод, ве- 
дення поєдинку за правилами рукопашного бою, ведення вогневого поєдинку й т. ін.).

Автором розроблено й систему педагогічного контролю, яка включає вісім різновидів. Для кожного виду контролю розроблено специфічні тести.

В. О. Овчінніков експериментально перевірив ефективність розробленої системи. Курсанти експериментальних груп, у яких вона була застосована, показали суттєво вищі результати за показниками фізичної, технічної і практичної підготовленості.

Цікаве дослідження вдосконалення професійно-прикладної фізичної підготовки студентів юридичних спеціальностей ВНЗ на основі використання айкідо провів О. Г. Миронов [244]. Об'єктом дослідження була система професійно-прикладної фізичної підготовки студентів юридичних спеціальностей ВНЗ. Як предмет дослідження було обрано процес професійно-прикладної фізичної підготовки студентів юридичних спеціальностей на основі застосування айкідо в умовах вищої професійної освіти.

Дослідник з'ясував педагогічний потенціал айкідо як засобу професійно-прикладної фізичної підготовки студентів юридичних спеціальностей ВНЗ. Встановлено, що айкідо сприяє формуванню таких професійно значущих для юриста якостей: сміливість, рішучість, витримка, самовладання, психологічна стійкість, швидкість, витривалість, силові й швидкісно-силові якості, спритність, уміння знешкодити правопорушника.

О. Г. Миронов розробив авторську програму курсу «Професійноприкладна фізична підготовка студентів юридичних спеціальностей ВНЗ на основі використання айкідо», у якій окреслено його мету, завдання, зміст, технологію. Експериментальна перевірка підтвердила іiі ефективність. За результатами експерименту автором зафіксовано суттєве підвищення рівня професійно-прикладної фізичної підготовленості студентів-юристів.

М. С. Еммерт вивчала питання професійно-прикладної фізичної підготовки майбутніх спеціалістів 3 управління персоналом [442]. Об'єктом дослідження був процес їх фізичного виховання. Предметом дослідження стали структура, зміст і засоби розділу професійноприкладної підготовки у фізичному вихованні, які найбільш ефективно розвивають професійно значущі якості майбутніх спеціалістів з управління персоналом. 
Вивчення професіограми, результати власного спостереження за роботою цих фахівців дозволили автору встановити професійно значущі якості спеціаліста з управління персоналом. До їх числа вона віднесла: статичну й силову витривалість м'язів спини, преса й плечового поясу, функції уваги, пам'яті, логічне мислення, стресостійкість, комунікативні й організаторські здібності.

Виходячи 3 особливостей професійної діяльності спеціалістів з управління персоналом, М. С. Еммерт розробила методику професійно-прикладної фізичної підготовки для них. Її зміст склали модифіковані композиції дубль-степ аеробіки, рухливі ігри й прикладні вправи. Методика передбачає збільшення кількості годин на професійно-прикладну фізичну підготовку (до 45,7 \% від загальної кількості навчальних годин навчальної дисципліни «Фізична культура»). Структурно в методиці виділяють підготовчий, базовий і заключний періоди. Головним засобом підготовки є дубль-степ аеробіка. Рухливі ігри й прикладні вправи використовуються як додаткові засоби.

Методика професійно-прикладної фізичної підготовки майбутніх спеціалістів 3 управління персоналом була експериментально перевірена іiі автором. У результаті цієї роботи в експериментальній групі зафіксовано достовірні зміни показників сили і статичної витривалості м'язів спини, преса й плечового поясу. Спостерігалося в ній і достовірне зростання професійно важливих психічних якостей.

Дослідження питання індивідуалізації професійно-прикладної фізичної підготовки до діяльності, пов'язаної з ризиком для життя і здоров'я, провів Г. В. Руденко [330]. Об'єктом дослідження була адаптація студентів до діяльності, яка пов'язана з ризиком для життя і здоров'я, засобами професійно-прикладної фізичної підготовки. Предметом - індивідуалізація професійно-прикладної фізичної підготовки до діяльності, яка пов'язана з ризиком для життя і здоров'я.

Дослідник припустив, що професійно-прикладна фізична підготовка, зміст якої сформовано на основі зіставлення професіограм (у плані відповідності професійно важливих фізичних і психічних якостей), яка враховує індивідуальні психофізичні характеристики студента і в процесі проведення якої застосовується індивідуальний підхід, дозволить забезпечити підготовленість студента до професійної діяльності, пов'язаної з ризиком для життя і здоров'я. Він обгрунтовано ставить питання про те, що професійно-прикладна фізична підготовка повинна бути зорієнтована не на абстрактного студента, 
а на конкретного студента зі своїми індивідуальними особливостями. По суті, порушується питання індивідуалізованої професійноприкладної фізичної підготовки.

Автор встановив умови, за яких індивідуалізована професійноприкладна фізична підготовка може бути ефективною в плані підготовки студента до діяльності, пов'язаної з ризиком для життя і здоров'я. Ними $є$ :

- обов'язкове врахування в процесі підготовки індивідуальних психофізичних можливостей студента;

- індивідуальний підхід в процесі навчання. Окреслено й вимоги щодо змісту та методики такої підготовки, зокрема:

a) використання виду спорту, елементи спортограми якого близькі до елементів професіограми конкретної спеціальності;

б) регулювання навантаження в ході занять з урахуванням фізичних і психічних якостей та функціональних можливостей студента;

в) постійний контроль за станом студента на основі критеріїв професійної адаптації.

Г. В. Руденко запропонував критерії для оцінки рівня індивідуальної адаптації студентів до професійної діяльності, що пов'язана з ризиком для життя і здоров'я. При оцінці фізичних якостей пропонується використовувати тести з фізичної підготовки з курсу «Фізична культура» (виконуються згідно з графіком такого тестування), при оцінці психічних якостей тест для оцінки схильності до ризику (рекомендується проводити один раз на місяць). При оцінці функціональних показників пропонується оцінювати адаптаційний потенціал за Брехманом (рекомендується проводити перед кожним заняттям).

У ході дослідження було виявлено ряд професійно важливих якостей. Для спеціалістів гірничого профілю до них віднесено: загальну витривалість, силову витривалість, емоційну стійкість, логічність мислення, стійкість уваги, координацію рухів, точність рухів, швидкість реакції, стійкість до перешкод, довгострокову пам'ять, розподіл уваги, сенсомоторну реакцію, оперативну пам'ять. Для спеціалістів геологічного профілю виділено такі якості: координацію рухів, загальну витривалість, точність рухів, логічність мислення, оперативну пам'ять, розподіл уваги, силову витривалість, швидкість реакції, стійкість уваги, емоційну стійкість, стійкість до перешкод, довгострокову пам'ять. 
Експериментальна перевірка підтвердила ефективність запропонованої Г. В. Руденко індивідуалізованої професійно-прикладної фізичної підготовки для вирішення завдань, що розглядаються в роботі.

Н. Ю. Борейко провела дослідження педагогічних умов професійно-прикладної фізичної підготовки студентів вищих технічних навчальних закладів $[52,53]$. Об'єктом дослідження був процес професійно-прикладної фізичної підготовки студентів вищих технічних навчальних закладів. Предметом - педагогічні умови практичної організації професійно-прикладної фізичної підготовки студентів вищих технічних навчальних закладів.

Дослідник припустила, що процес професійно-прикладної фізичної підготовки студентів вищих технічних навчальних закладів буде ефективнішим, якщо реалізувати такі педагогічні умови:

а) забезпечення гуманних засад професійно-прикладної фізичної підготовки студентів вищих технічних навчальних закладів (застосування діалогового підходу, впровадження особистісно орієнтованої технології навчання);

б) формування професійно значущих мотивів у фізичній підготовці студентів вищих технічних навчальних закладів за допомогою синтезу традиційних та нетрадиційних засобів, методів, форм професійно-прикладної фізичної підготовки, а також валеології, гігієни, охорони праці, психології особистості.

Суттєвою особливістю роботи є виділення функцій професійноприкладної фізичної підготовки. До них віднесено: освітню, виховну, розвивальну, загальнокультурну, оздоровчу, компенсаторну, адаптаційну, профілактичну, діагностичну.

Н. Ю. Борейко експериментально перевірила висунуту гіпотезу щодо ефективності професійно-прикладної фізичної підготовки. У результаті цієї роботи встановлено, що реалізація зазначених педагогічних умов суттєво вплинула на зростання рівня сформованості складових професійно-прикладної фізичної підготовленості. В експериментальних групах також зафіксовано значне зростання професійних мотивів занять фізичною підготовкою.

Для нашого дослідження особливий інтерес становить робота В. О. Садовського [338], у якій розглянуто питання формування рухової готовності спеціалістів залізничного транспорту в умовах професійно орієнтованої системи фізичного виховання. Розглянемо її детальніше. Як об'єкт дослідження було обрано профільну фізичну під- 
готовку спеціалістів залізничного транспорту. Предметом дослідження стало формування рухової готовності студентів навчальних закладів залізничного транспорту до професійної діяльності.

В. О. Садовський виокремив найбільш важливі ознаки професійної рухової діяльності, а саме: типові трудові дії, структуру їх рухів і робочі пози; характерні й такі, що часто зустрічаються в процесі діяльності, рухові помилки, які призводять до професійних хвороб і травматизму; обсяг рухової активності, величина фізичного навантаження і його спрямованість; співвідношення професійно важливих фізичних якостей; головні професійні рухові уміння й навики; реєстр професійних захворювань і шкідливості виробництва; ділові й особистісні якості; галузеві, кліматичні, метеорологічні й санітарно-гігієнічні характеристики виробничих умов; фізична працездатність і адаптаційні характеристики в процесі виробничої діяльності.

Базуючись на ознаках професійної рухової діяльності залізничників, автор встановив, що процес фізичного виховання у навчальних закладах залізничного транспорту спрямований більшою мірою на загальний фізичний розвиток і менше на професійну рухову готовність до виконання майбутньої виробничої діяльності. Він обгрунтовано наголошує на необхідності розробки технологій профільної фізичної підготовки й окремих методик профільної рекреації, рухової реабілітації і виробничої фізичної культури як в період отримання професійної освіти, так і в ході трудової діяльності.

В. О. Садовським запропоновано власну модель професійно орієнтованої системи фізичного виховання, в основу якої покладено принцип профільної спрямованості фізичної підготовки студентів. Їх структуру складають чотири компоненти, які відображають специфіку підготовки спеціаліста в конкретній галузі виробництва. До їх числа включено:

1) галузевий компонент. Його складовими є:

- рівні освіти;

- матеріально-технічна база;

- людські ресурси;

- специфічна виробничо-рухова активність спеціаліста як системоутворююча основа для розробки програмно-змістовної технології профільної фізичної підготовки студентів;

2) структурно-функціональний компонент. До його складу входять: 
- неспеціальна фізкультурна освіта;

- профільна фізична підготовка;

- прикладні види спорту;

- профільна рухова рекреація і реабілітація;

- виробнича фізична культура;

3) організаційно-управлінський компонент;

4) оцінно-коригувальний компонент (включає оцінку рівня профорієнтації у фізкультурній освіті, рівня розвитку професійно важливих рухових здібностей, рівня сформованості професійних рухових умінь і навиків, рівня сформованості особистісних рис характеру спеціаліста галузі, рівня функціональної готовності).

У ході дослідження автор також розробив і експериментально перевірив технологію профільної фізичної підготовки студентів, що здобувають середню і вищу професійну освіту. Було встановлено ефективність технології за такими критеріями:

1) мотиваційним (ставлення студентів до занять фізичними вправами у професійній школі);

2) освітнім (знання 3 розділу «Професійно-прикладна фізична культура спеціаліста»);

3) інтегральним (сформованість рухової готовності студентівзалізничників до виробничої діяльності за п'ятьма факторами:

- психофізична готовність;

- загальна фізична готовність;

- статична і силова витривалість;

- функціональна готовність;

- професійно особистісні якості).

На нашу думку, дослідження В. О. Садовського є суттєвим внеском в розробку основ професійно-прикладної фізичної підготовки студентів-залізничників. У той же час необхідно наголосити, що професійно-прикладна фізична підготовка не єдиний шлях використання фізичного виховання для підготовки до професійної діяльності. Не менш важливими $є$ питання використання фізичного виховання для вирішення завдань психологічної і психофізичної підготовки майбутніх фахівців залізничної галузі.

А. А. Ребрина у своєму дослідженні [317] проаналізувала програмне забезпечення професійно-прикладної фізичної підготовки студентів вищих навчальних закладів. Провівши аналіз навчальних програм з фізичного виховання для студентів вищих навчальних закладів 
3 початку 20-х років двадцятого століття і по наш час, вона робить обгрунтований висновок про зростання у фізичному вихованні студентів ролі професійно-прикладної підготовки. На нашу думку, така тенденція не $\epsilon$ випадковою. Вона свідчить про розуміння важливості використання фізичного виховання студентів для підготовки до професійної праці.

Питання теоретико-методичного забезпечення фізичного виховання у вищих закладах освіти розглянула В. С. Білогур [38]. Вона звертає увагу на недостатнє науково-методичне обгрунтування теоретико-методичного забезпечення фізичного виховання у вищих навчальних закладах. Автор запропонувала структурно-функціональну модель теоретико-методичного забезпечення. Експериментальна перевірка моделі засвідчила зростання рівня знань студентів за теоретичними розділами програми з фізичного виховання.

Поділяючи думку дослідниці щодо теоретико-методичного забезпечення фізичного виховання студентів, слід вказати на необхідність посилення в його структурі розділу, пов'язаного з використання фізичної культури для підготовки до майбутньої професії.

У контексті питання, що розглядається, інтерес становить робота С. П. Козіброцького, який виконав історико-методологічний аналіз програмно-нормативних основ фізичного виховання студентів [163]. Об'єктом дослідження були програмно-нормативні засади фізичного виховання. Предметом - історико-методологічні аспекти розвитку програмно-нормативних основ фізичного виховання студентів у вищих навчальних закладах України.

Автор встановив відносну стабільність розвитку структури навчальних програм 3 фізичного виховання для студентів вищих навчальних закладів України. У той же час виявлено відмінності за змістом програмного матеріалу, метою, завданнями фізичного виховання, величиною навчального навантаження.

С. П. Козіброцький виділяє п'ять періодів у розвитку програмнонормативного забезпечення фізичного виховання студентів: період $20-x$ років, період $30-x$ років, період $40-50-x$ років, період $60-80-$ х років двадцятого століття та сучасний пострадянський період. Виявлено характерні особливості кожного періоду.

Узагальнюючи тенденції формування й укладання навчальних програм з фізичного виховання для студентів, автор обгрунтовано наголошує, що вони зараз повинні мати такі властивості: оздоровча 
спрямованість, врахування інтересів та уподобань учасників навчально-виховного процесу, відповідність регіональним традиціям, матеріальним, кліматичним та природним умовам, максимальне врахування майбутньої професії студентів. Останній аспект, на нашу думку, є особливо важливим.

Механізм підвищення тих функціональних можливостей організму, від яких залежить адаптація до специфічних умов праці, лежить в основі позитивного впливу професійно-прикладної фізичної підготовки. У даному випадку мова йде про перенесення ефекту тренованості. При цьому таке явище спостерігається як у випадку формування рухових навиків, так і у випадку розвитку фізичних якостей. Професійно-прикладна фізична підготовка суттєво впливає на готовність людини до конкретної професійної діяльності завдяки можливості ефективного перенесення попередньо розвинених у неї фізичних і психічних якостей та властивостей, формуванню навиків і здатності протистояти дії несприятливих факторів середовища [403].

У сфері фізичного виховання поняття «професійно-прикладна фізична підготовка» відоме давно. Опубліковано велику кількість праць, які присвячені цій проблематиці: [51, 66, 114, 129, 130, 131, $135,142,149,152,162,172,291,294,312,325,346,393,310,424,219$, 239 та ін.].

Багато дослідників (В. К. Бальсевич, Л. І. Лубишева, К. М. Гуревич, В. А. Кабачков, Л. П. Матвеєв та ін.) відзначають, що професійно-прикладна фізична підготовка дозволяє молодим спеціалістам 3 успіхом набувати навичок професійної діяльності. У той же час В. А. Кабачков, М. В. Мацкевич, М. І. Станкін та інші звертають увагу на той факт, що прямої залежності між зростанням фізичної підготовленості, з одного боку, і продуктивністю праці, з іншого, не спостерігається. Фізична підготовка виконує роль передумов успішної професійної діяльності й опосередковано проявляється в ній. Пряма залежність між зазначеними показниками простежується у випадку спрямованого розвитку фізичних і професійних якостей.

У наукових дослідженнях вивчались і можливості фізичного виховання в плані психічного розвитку. У цьому контексті інтерес викликає робота Ю. І. Родіна [320]. Об'єктом його дослідження став взаємозв'язок психічного і рухового розвитку дітей дошкільного віку. Предметом було обрано психічний розвиток дітей дошкільного віку в процесі навчання рухам. 
Автор припустив, що процес навчання рухам, спрямований на формування у свідомості дитини інтегрального психічного образу культурно детермінованих форм рухової поведінки, створює ресурс психічного розвитку дітей дошкільного віку.

Ю. І. Родін встановив, що для дитячого руху характерна єдність сенсомоторних процесів і вищих психічних функцій. На думку автоpa, дитячий рух пов'язаний зі знаково-символічною діяльністю дитини і являє собою більш високу, порівняно із сенсомоторним актом, форму рухової поведінки людини, яка є єдиною за своїм генезисом і психологічною структурою з вищими психічними функціями.

Було виявлено, що діяльнісне залучення дітей до загальнолюдського досвіду через навчання утворює стадію в розвитку вищих форм поведінки людини, стимулює психомоторний і загальний психічний розвиток дитини дошкільного віку.

У ході дослідження було також встановлено, що основу дитячого руху складає інтегральний психічний образ, що включає когнітивний, чуттєвий і емоційний компоненти. Саме він робить дитячий рух фактором розвитку психіки.

Ю. І. Родін у ході експерименту зафіксував взаємозв'язок психічного і рухового розвитку дітей дошкільного віку. Про це свідчили отримані дані щодо більш високого рівня статистичного зв'язку інтегральних показників розвитку основних рухів і психічних процесів у дітей експериментальної групи. Автор обгрунтовано стверджує, що спрямованість процесу навчання на формування узагальненого психічного образу руху з опорою на зовнішню і внутрішню мову сприяє інтеграції механізмів регуляції розумової і рухової активності, стимулює загальний психічний розвиток дитини.

Дослідник з'ясував і психолого-педагогічні умови, які сприяють психомоторному й психічному розвитку дітей дошкільного віку в процесі навчання рухам. До їх числа віднесено ігрове моделювання рухової поведінки дитини, усвідомлення інтегрального психічного образу руху, що вивчається, активне творення дитиною ідеальної форми руху, узагальнено-алгоритмічний підхід до вирішення рухових завдань.

I. В. Родін розробив програму «Азбука живого руху», яка спрямована на формування інтегрального психічного образу руху, що вивчається. Експериментальна перевірка показала її ефективність для психомоторного й загальнопсихічного розвитку дітей дошкільного віку. 
Цікаве дослідження використання фізичної культури для формування особистості дитини дошкільного віку виконала В. М. Шебеко [434]. Об'єктом дослідження була особистість дитини дошкільного віку. Предметом - педагогічна стратегія формування особистості дитини дошкільного віку засобами фізичної культури в системі дошкільної освіти.

Автор виявила взаємозв'язок показників розвитку особистості і фізичної підготовленості дітей в різні періоди дошкільного віку. Так, у дітей молодшого дошкільного віку було виявлено зв'язок показників творчої уяви та самооцінки з такими показниками фізичної підготовленості, як швидкість, швидкісно-силові здібності, спритність, витривалість. У дітей середнього дошкільного віку було зафіксовано взаємозв'язок показників самооцінки 3 показниками швидкості, швидкісно-силовими здібностями, спритністю і витривалістю. Зафіксовано також кореляцію між показниками творчості й фізичної підготовленості. Найбільшу кореляцію показників розвитку особистості й показників фізичної підготовленості В. М. Шебеко виявила у дітей старшого дошкільного віку. На підставі отриманих даних зроблено висновок про можливість розвитку особистості дитини дошкільного віку засобами фізичної культури починаючи з 4-річного віку.

Дослідник встановила і низку педагогічних умов, які сприяють формуванню особистості дитини дошкільного віку засобами фізичної культур, зокрема:

а) цілісне бачення дитини при проектуванні єдиного педагогічного процесу;

б) інтеграцію різних видів діяльності дітей;

в) варіативність освітнього простору;

г) наявність інформації про стан фізичної підготовленості й розвиток психіки в дітей;

д) врахування індивідуальних можливостей та інтересів дітей;

е) організацію процесу навчання з використанням підтримки й супроводу.

В. М. Шебеко розробила й експериментально перевірила ряд умов організації рухової діяльності дітей, які розвивають у них здатність до самооцінки. Серед них:

а) включення до діяльності дітей різних за складністю завдань (при цьому результати виконання повинні легко визначатися дітьми); 
б) педагогічну оцінку рухової діяльності дитини;

в) використання методів навчання, спрямованих на формування самоконтролю рухів.

Автор запропонувала технологію розвитку творчого потенціалу дітей дошкільного віку засобами фізичної культури. Її головною особливістю стала така побудова навчального процесу, у ході якого практикується використання відомих способів виконання рухів у різних ситуаціях, набуття вміння самостійно висувати рухові гіпотези та створювати нові рухові рішення. В. М. Шебеко виявила показник, які характеризують творчість дітей у руховій діяльності. Це:

a) захопленість руховою діяльністю;

б) оригінальність рухових рішень;

в) вдалий підбір рухів, які сприяють втіленню ігрового образу;

г) своєрідність комбінування відомих рухів;

д) поява нових елементів під час створення простих форм рухів.

В. М. Шебеко розробила авторську програму фізичного виховання, орієнтовану на особистісний розвиток дітей.

Теоретико-методичні засади формування гармонійно-розвиненої особистості дитини дошкільного віку в процесі фізичного виховання дослідила Н. С. Пангелова [274]. Автор встановила взаємозалежність між розвитком складових морфо-функціонального стану, фізичної підготовленості, компонентами інтелектуального й морального розвитку дітей 4-6 років. Було також виявлено статеві відмінності в темпах розвитку дітей.

Особливості впливу фізичного виховання на формування особистості учнів середнього шкільного віку досліджував О. І. Головченко [93]. Об'єктом вивчення було фізичне виховання учнів середнього шкільного віку. Предметом - вплив фізичного виховання на процес формування особистості учнів середнього шкільного віку.

У ході констатуючого експерименту дослідник виявив особливості психологічного профілю особистості учнів середнього шкільного віку. Було зафіксовано:

а) відхилення у функціональному стані окремих систем організму у $50,6 \%$ учнів;

б) дисгармонію фізичного розвитку у $31 \%$ учнів;

в) фізичну підготовленість на рівні «нижче за середній» у 62,7 \% учнів;

г) слабкий тип нервової системи у 50,3 \% учнів; 
д) низький рівень абстрактно-логічного мислення у 56,7 \% учнів;

е) помірну екстраверсію (14,1 бала);

ж)помірний рівень прояву нейротизму (9,8 бала) та ін.

Дослідник розробив методику оцінки психологічного профілю особистості учнів 11-15 років, яка спрямована на встановлення зони найближчого розвитку їх особистісних якостей.

O. І. Головченко встановив малу ефективність традиційних занять 3 фізичного виховання для розвитку параметрів психологічного профілю особистості. Для вирішення питання він розробив авторську програму сприяння розвитку особистісних якостей підлітків засобами фізичного виховання.

Автор виконав експериментальну перевірку ефективності розробленої програми. Після ії̈ впровадження зафіксовано суттєве зростання сумарного показника психологічного профілю особистості в учнів. На основі отриманих даних О. І. Головченко робить обгрунтований висновок про можливість і необхідність використання фізичного виховання для формування особистості підлітків середнього шкільного віку.

Дослідження використання фізкультурної діяльності для профілактики соціально-негативної поведінки підлітків провів С. В. Галіцин [85]. Метою дослідження стала розробка й експериментальне обгрунтування теоретико-методологічних положень і технологічного змісту педагогічної системи фізкультурної діяльності підлітків з різними формами соціально-негативної поведінки.

Автор встановив, що в основу розробки змісту педагогічної системи фізкультурної діяльності повинна бути покладена діагностика динаміки фізичних і соціально-психологічних показників школярів, кризових тенденцій у розвитку їх фізичних якостей і властивостей особистості.

У ході дослідження виявлено, що для більшості учнів, яких класифіковано як «успішних», фізкультурна діяльність $є$ однією із пріоритетних. Автор встановив, що найсуттєвіший внесок в «успішність» роблять показники, які характеризують рухову активність і рівень фізичної підготовленості.

С. В. Галіцин сформулював такі принципи педагогічної системи фізкультурної діяльності підлітків з різними формами соціальнонегативної поведінки:

а) психофізична єдність людини; 
б) використання культуровідповідного змісту фізкультурної діяльності;

в) диференціація підлітків на типологічні групи;

г) пріоритет фізкультурної освіти і колективних форм фізкультурної діяльності, що здійснюється в умовах культуро-відповідного середовища;

д) оптимізація фізкультурної діяльності;

е) прогнозування й моделювання показників психофізичного стану підлітків. Зазначені принципи автор розглядає як методологічну основу для побудови педагогічної системи.

Дослідник встановив умови, за яких фізична культура є ефективним засобом профілактики асоціальних форм поведінки. Це, зокрема:

а) реалізація культурної сутності фізичної культури;

б) спрямованість на всебічний і гармонійний розвиток особистості;

в) врахування психофізичного стану підлітків і пріоритетного виду їх діяльності;

г) диференціація підлітків на типологічні групи;

д) підбір відповідних видів фізкультурної діяльності;

е) випереджальна стратегія застосування фізичної культури відносно формування асоціальних форм поведінки.

С. В. Галіцин провів експериментальну перевірку ефективності педагогічної системи фізкультурної діяльності підлітків. В експериментальній групі, де роботу було організовано відповідно до пропозицій автора, зафіксовано суттєве покращення в підлітків психофізичного стану й сформованості різних форм соціально значущої поведінки.

3 точки зору нашого дослідження слід зауважити, що С. В. Галіцин, формулюючи принципи побудови авторської системи фізкультурної діяльності, називає принцип психофізичної єдності людини. На нашу думку, це не $є$ випадковим. Без визнання цього теоретичного положення важко пояснити виховний вплив фізкультурної діяльності. Заслуговують на увагу і отримані експериментальні дані щодо можливості використання фізкультурної діяльності для профілактики соціально-негативної поведінки підлітків.

Цікаве дослідження використання засобів фізичної культури для оптимізації соціальної адаптації студентів початкових курсів провів Р. М. Стасюк [376]. Об'єктом дослідження було обрано соціальну 
адаптацію студентів початкових курсів. Предметом став вплив засобів фізичної культури на соціальну адаптацію студентів початкових курсів.

Автор не випадково звертає увагу на недослідженість проблеми обгрунтування використання фізичної культури для фахової підготовки педагога. На нашу думку, це є актуальним і стосовно інших професій.

Дослідник розробив авторську програму оптимізації соціальної адаптації студентів засобами фізичної культури. До ії складу включено такі складові, як діагностика особистісних якостей студентів, розвиток і психолого-педагогічна корекція особистісних якостей студентів в процесі засвоєння програмного матеріалу з фізичного виховання, контроль за розв'язанням поставлених завдань і моніторинг динаміки особистісних якостей студентів.

Експериментальна перевірка ефективності програми підтвердила iï суттєвий вплив на ряд показників студентів. Так, було зафіксовано істотне зростання показників фізичного розвитку й фізичної підготовленості студентів. Найбільшою мірою покращилися показники спритності й витривалості.

Р. М. Стасюк справедливо відзначає, що існуюча програма з фізичного виховання суттєво не впливає на розвиток психофізичних якостей студентів. Реалізація авторської програми дозволила суттєво підвищити такі показники, як швидкість реакції, точність, вестибулярна стійкість, а також вольові якості студентів, повагу, взаємодопомогу. Зафіксовано також покращення показників самопочуття, активності, настрою, самооцінки, успішності навчання.

Після опрацювання робіт науковців постає питання про те, чим же відрізняється поняття «професійно-прикладна фізична підготовка» від поняття, яке пропонуємо ми - «психологічна і психофізична підготовка»? Як видно із наведених визначень і аналізу робіт, у першому випадку акцент зроблено переважно на прикладній (стосовно професіi) спрямованості насамперед фізичної підготовки фахівця. У другому - завдання ставиться інакше і полягає у формуванні професійно значущих психологічних і психофізичних складових. Для цього, насамперед, передбачається використання ефективних (щодо поставлених завдань) засобів фізичного виховання. Психологічна і психофізична підготовка розглядається нами як частина (сторона) фізичного виховання студентів, спеціалізована (спрямована) стосовно психоло- 
гічних і психофізичних особливостей майбутньої професійної діяльності. Результатом такої підготовки є психологічна й психофізична підготовленість. Передбачається комплексне вирішення традиційних для фізичного виховання і нових завдань в рамках викладання однієї дисципліни. Програма психологічної і психофізичної підготовки повинна складатися з урахуванням профілю ВНЗ, його кадрового потенціалу, існуючої навчальної бази та ін. Психологічна і психофізична підготовка доповнює загальну і спеціальну фізичну підготовку та професійно-прикладну фізичну підготовку у фізичному вихованні студентів.

Психологічна й психофізична підготовка, на нашу думку, може розглядатись і як один із шляхів для вирішення головного завдання, яке поставлено суспільством перед системою освіти на хвилі демократизації. Воно полягає у формуванні особистості людини, а не тільки і не стільки в тому, щоб дати їй певні знання й виробити в неї корисні навички та вміння. Проте реальні кроки з реалізації цього завдання поки що можна назвати недостатніми. Аналіз навчальновиховного процесу у вищій школі показує, що спрямований він, як i раніше, майже виключно на реалізацію завдань навчання (хоч і вони вирішуються далеко не на належному рівні). У той же час адекватності до професії за багатьма іншими компонентам структури особистості увага практично не приділяється. Продовжує ігноруватися той факт, що далеко не кожна людина може з успіхом займатися тією чи іншою трудовою діяльністю. Дослідженнями багатьох вчених доведено, що існують певні професійні вимоги до особистості спеціаліста. У зв'язку з цим нами було запропоновано ввести таку іiі характеристику, як професійна адекватність [283]. Вона відображає відповідність структурних компонентів особистості вимогам тієї професії, яку вона обрала. Професійна адекватність до праці - це імовірна характеристика особистості, що відображає не тільки можливості, але й прагнення людини досягти високих показників у професійній діяльності при відповідній підготовці й набутті досвіду.

Професійна адекватність - це складна параметрична властивість особистості спеціаліста, яка детермінується професією як параметром і може бути представлена в вигляді композиції більш простих компонентів. Формування професійної адекватності особистості студента повинно стати однією з головних цілей навчально-виховного процесу у вищих навчальних закладах. 
Психологічна й психофізична підготовка студентів-залізничників під час навчальних занять 3 фізичного виховання розглядається нами як одна із складових загальної підготовки фахівця у ВНЗ, що входить до змісту професійної освіти. У педагогіці професійна освіта за змістом поділяється на теоретичну й практичну підготовку. В. С. Ледньов [197] зазначає, що практична підготовка разом з теоретичною утворює основу всієї професійної освіти. У той же час він справедливо підкреслює, що практична професійна підготовка являє собою тільки один $з$ розділів усієї практичної освіти як частини освіти взагалі, бо практичний компонент має не тільки професійна освіта. На його думку, сутність професійної практичної підготовки визначається, по-перше, тим, що це одна 3 основних частин професійної освіти, по-друге, тим, що водночас це одна із головних частин практичної підготовки як цілісної системи, що має в освіті людини відносну автономність і свій базисний предмет - формування умінь у сферах діяльності, що освоюються людиною. Отже, завданням практичної частини професійної освіти $\epsilon$ формування у студентів системи навиків і вмінь, що дозволяють виконувати професійні функції.

Таким чином, сутність практичної підготовки напряму пов'язана 3 формуванням у студентів навичок і умінь. Для того щоб здійснювати професійну діяльність, не достатньо тільки знань. Потрібно ще навчитися виконувати цю діяльність, оволодіти відповідною системою умінь. Дійсно, можна добре знати будову тепловоза, можна вивчити алгоритм управління ним, але не вміти управляти ним. Уміння часто визначають як здатність людини виконувати деякий вид діяльності. Навик - це усталена здатність виконувати дії (як правило, без суттєвих затрат уваги).

Психологічна та психофізична підготовка у ВН3, насамперед, пов'язана 3 практичним розділом професійної освіти (до теоретичного розділу слід віднести завдання психологічної просвіти). Вона спрямована на розвиток тих передумов (задатків, структурних компонентів особистості), що являють собою фундамент для формування професійно необхідних навиків і умінь.

Сьогодні фізичне виховання розглядається як важливий компонент гуманітарного виховання, що спрямований на формування у молоді фізичного та морального здоров'я, удосконалення фізичної i психічної підготовки до ведення активного життя, професійної діяльності та захисту Батьківщини [116]. У рамках такого підходу 
$€$ потреба у новому змісті (на відміну від відомого, коли фізичне виховання зводилося до формування рухових умінь і навичок та розвитку фізичних якостей людини). Спробуємо проаналізувати можливі напрямки вдосконалення фізичного виховання у вищих навчальних закладах.

На нашу думку, важливим насамперед $є$ покращення підготовки самих викладачів фізичного виховання. Фахівці обгрунтовано звертають увагу на недостатній розвиток творчої активності у викладачів. Так, зокрема, підкреслюється той факт, що переважна більшість викладачів фізичного виховання, маючи непогану спортивно-практичну підготовку, по суті неграмотні в науково-методичному плані. Багато 3 них і хотіли б залучитися до науково-методичної роботи, але не знають, як це зробити.

Ситуація ускладнюється ще й тим, що праця викладача фізичного виховання стає все більш «необмеженою». Викладач фізичного виховання після академічних занять залишається для проведення занять у спортивних секціях, які в наш час взагалі не оплачуються; у вихідні й святкові дні дуже часто буває задіяним у проведенні різноманітних змагань. Необхідно включати до індивідуального плану роботи викладача фізичного виховання всі ті види роботи, які він виконує. Навчальне навантаження у викладачів фізичного виховання також не повинно відрізнятися від навантаження викладачів інших навчальних дисциплін (досить часто воно буває набагато більшим).

Суттєвого покращення потребує спортивно-масова робота у вищих навчальних закладах. У зв'язку зі значним зменшенням штату викладачів на кафедрах фізичного виховання відповідно зменшується кількість спортивно-масових заходів, які проводять ВН3, кількість видів спорту, що культивуються в них. Це унеможливлює врахування спортивних інтересів значної кількості студентів, обмежує можливості залучення їх до фізкультурної діяльності. На нашу думку, саме в розгортанні спортивно-масової роботи слід насамперед шукати резерви для збільшення рухової активності студентів.

Останнім часом серйозно загострилося питання проведення якісного медичного огляду студентів перед початком занять. Почастішали випадки, коли під час занять студентам, яких за результатами медичного огляду визнано здоровими, стає зле. Викладачі й кафедри фізичного виховання в цілому змушені реагувати на такі випадки зменшенням навантаження під час занять, відмовою від підготовки 
й складання студентами деяких контрольних нормативів (наприклад, на витривалість). На нашу думку, такий підхід не $\epsilon$ виходом із ситуації. Він, по суті, нівелює і так невеликі (зважаючи на кількість виділених для фізичного виховання навчальних годин) можливості фізичного виховання щодо розвитку фізичних якостей і укріплення здоров'я студентів (не слід забувати про залежність адаптаційних змін в організмі від навантаження). Медичний огляд необхідно проводити якісно, і здоровий студент у результаті повинен отримувати достатнє фізичне навантаження. У зв'язку з цим особливої актуалізації набуває реалізація диференційованого підходу в процесі фізичного виховання. Актуальними є й відповідні наукові дослідження. У цьому контексті слід відзначити роботу О. О. Малімона [225].

Потребує вдосконалення і зміст навчальної дисципліни «Фізичне виховання». У його структурі необхідно суттєво «підсилювати» професійну спрямованість. Як уже зазначалось у цій монографії, вища школа - школа професійна. Відповідним має бути в ній і фізичне виховання. Мова йде про перерозподіл навчальних годин на користь таких розділів, як професійно-прикладна фізична підготовка та психологічна й психофізична підготовка студентів (яка і обстоюється в дослідженні).

У сучасних наукових дослідженнях спостерігається стійка тенденція до вивчення можливостей використання фізичного виховання для вирішення різнопланових завдань. Так, А. О. Артюшенко виконав цікаве дослідження використання фізичного виховання для формування в учнів загальноосвітньої школи особистісної мобільності [16]. С. О. Сичов дослідив фізичне виховання з точки зору залучення студентів до цінностей фізичної культури [352]. В. Г. Вітун вивчав фізичне вихованя в контексті формування адаптаційного потенціалу студентів вищих навчальних закладів [77], а О. О. Іванова в контексті педагогічних умов ефективної реалізації адаптаційного потенціалу фізкультурно-спортивної діяльності студентів технічного ВНЗ [144]. О. П. Гонтарь розглянула фізичне виховання в плані розвитку фізичної культури особистості студента технічного ВН3 [97]. Організацію фізичного виховання студентів на основі розвитку суспільносамодіяльної форми фізкультурно-спортивної діяльності у ВНЗ вивчала Н. Л. Гусєва [109]. Цікаве дослідження використання засобів фізичної культури для вирішення завдань естетичного виховання студентів технічного ВНЗ провела О. Р. Кабірова [153]. С. Г. Матвеєв 
розглянув вплив фізичного розвитку курсантів на особистіснопрофесійне становлення майбутнього військового спеціаліста [235]. Використання засобів фізичної культури і спорту для формування психофізичної готовності до професійної діяльності майбутніх спеціалістів з організації і безпеки руху досліджувала О. М. Сергеєва [348]. А. Д. Соломко грунтовно дослідила використання засобів фізичного виховання для формування ігрових навиків і емоційно-перцептивної сфери у дітей 5-7 років з розладами аутистичного спектру [366]. Слід відзначити роботу В. Ю. Солонського, яка присвячена вивченню використання засобів фізичної культури для розвитку психологічних характеристик курсантів військового ВНЗ як суб'єктів навчальної діяльності [367] і роботу Н. О. Строгової, яка дослідила формування професійно значущих якостей особистості майбутніх спеціалістів з адаптивної фізичної культури [378, 379]. Викликає інтерес і робота К. Б. Тумарова, у якій розглянуто зміст і організацію особистісно-орієнтованого фізичного виховання студентів на основі міні-футболу [394]. У дослідженні Л. К. Солнцевої розглянуто питання впливу занять фізичними вправами на розвиток психічних функцій [364]. В. В. Фудімовим запропоновано технологію використання різних видів спорту для підвищення особистісно орієнтованої спрямованості тренувальних занять спортсменів [409]. Питанню виховання морально-вольових якостей підлітків в умовах шкільних спортивних клубів присвячено роботу Т. І. Чедової [426]. Д. С. Завірохін виконав дослідження виховання емоційної стійкості в ході занять кульовою стрільбою [134]. К. Ю. Акулова дослідила педагогічні умови формування у студентів готовності до самопізнання в процесі фізичного виховання [6]. В. Г. Тодорова провела цікаве дослідження емоційно-вольового образу «Я» студентів, що займаються різними видами фізичної культури [389]. У той же час досліджень, у яких вивчаються питання використання фізичного виховання для вирішення завдань психологічної і психофізичної підготовки студентів залізничних ВНЗ, нами не виявлено. 


\section{Висновки до розділу}

Інформацію цього розділу підсумуємо таким чином:

1. У науковій літературі феномен психологічної й психофізичної підготовки найчастіше пов'язується або з комплексом різнопланових заходів спеціального психологічного спрямування, або з процесом формування готовності особистості до умов певної діяльності, або 3 психологічним налаштуванням на виконання певної діяльності.

2. Психологічна й психофізична підготовка розглядається автором як частина (сторона) фізичного виховання студентів, спеціалізована (спрямована) стосовно психологічних і психофізичних особливостей їх майбутньої професійної діяльності.

3. Психологічна і психофізична підготовка $є$ важливою складовою підготовки до професійної діяльності. Найбільш широке практичне застосування вона знаходить сьогодні у збройних силах, органах внутрішніх справ, державній прикордонній службі України, міністерстві України з питань надзвичайних ситуацій.

4. Різні аспекти проблеми психологічної підготовки і психологічної готовності до праці були предметом багатьох досліджень. У той же час невирішеним залишається комплекс питань щодо використання фізичної культури для формування психологічної і психофізичної готовності до професійної діяльності. Найбільш значущими серед них $\epsilon$ необхідність теоретико-методологічного обгрунтування використання фізичної культури для формування психологічної і психофізичної готовності до праці. Справа в тому, що не виявленими є наукові підстави для того, щоб розглядати фізичну культуру як засіб формування професійно значущих психічних складових. Не дослідженим $є$ й актуальне питання формування психологічної і психофізичної підготовки студентів-залізничників у процесі фізичного виховання.

5. Науковцями, які досліджували трудову діяльність людей, введено поняття «професійна придатність». Воно відбиває відповідність (узгодженість) між собою вимог професії і особистісних характеристик людини. Психологічну й психофізичну підготовленість необхідно розглядати як підсистему загальної системи професійної придатності.

6. У фізичному вихованні студентів підготовка до майбутньої професійної діяльності є одним із головних завдань. Воно традиційно вирішується в рамках такого напрямку фізичного виховання, як про- 
фесійно-прикладна фізична підготовка. Опубліковано велику кількість робіт, які присвячено дослідженню їі різних аспектів. Головний акцент у них зроблено на прикладній (відносно професії) спрямованості насамперед фізичної підготовки фахівця. При підході, який обстоюємо ми (психологічна і психофізична підготовка), завдання ставиться інакше і полягає у формуванні професійно значущих психологічних і психофізичних складових. Кожен із названих видів підготовки має свої специфічні завдання і доповнює один одного в процесі фізичного виховання студентів. 
РОЗДІЛ 2

\section{Організація й методи дослідження проблеми психологічної і психофізичної підготовки студентів залізничних ВН3 у процесі фізичного виховання}

\section{1. Організація дослідження}

Дослідження було проведено в Дніпропетровському національному університеті залізничного транспорту ім. акад. В. Лазаряна 32000 по 2014 рік шістьма послідовними етапами.

На першому етапі (2000-2002 рік) було проаналізовано напрямки розвитку фізичного виховання студентів. На підставі цього було зроблено такі висновки:

1. Недостатньо вивченим є напрям використання фізичного виховання для формування складових психологічної організації людини.

2. Особливо актуальними для вищої школи є дослідження професійної спрямованості фізичного виховання.

Наступним об'єктом аналізу на цьому етапі стали роботи, присвячені дослідженню питань професійно-прикладної фізичної підготовки та психофізичної підготовки в процесі фізичного виховання. Було 3'ясовано зміст понять, напрямки, результати та перспективи досліджень.

Виконана робота дозволила сформулювати власний напрям дослідження - психологічна й психофізична підготовка студентів у процеci фізичного виховання. Було виявлено також, що теоретикометодологічні засади використання фізичного виховання для формування складових психічної організації людини є не з'ясованими. Одним з найбільш актуальних $\epsilon$ й питання розробки основ організації психологічної і психофізичної підготовки в процесі фізичного вихо- 
вання. Воно включає встановлення спрямованості, мети, змісту, структури, головних напрямків роботи, засобів та ін.

На другому етапі (2003-2005 рік) вивчалися теоретичні аспекти, пов'язані з методологічним обгрунтуванням постановки самого питання про проведення спеціальної (професійно-орієнтованої) психологічної і психофізичної підготовки в ході фізичного виховання студентів. Ми виходили з таких міркувань. Фізичне виховання пов'язане головним чином із впливом на організм людини. Психологічна й психофізична підготовка передбачає формування психічних і психофізичних складових. Чи $є$ в такому разі достатні наукові підстави для іiі проведення в процесі фізичного виховання?

Ставилися завдання:

1. Виявити коло проблем, які розроблялися в психології, філософiï, інших науках про людину і в яких можна знайти підстави для позитивної чи негативної відповіді на питання про можливість формування психологічних i психофізичних складових особистості в процесі фізичного виховання.

2. Виконати аналіз виявленого кола питань і зробити відповідні висновки.

За результатами другого етапу роботи необхідно було з'ясувати коло наукових проблем, результати дослідження яких можуть бути теоретико-методологічним підгрунтям для використання фізичного виховання в плані формування психологічних складових. Було встановлено, що до них належать: психофізична проблема, взаємовплив організму і психіки, дослідження особистості в психології. Аналіз наукової розробки цієї проблематики дав підстави зробити висновок про наукову обгрунтованість проведення психологічної і психофізичної підготовки студентів у процесі фізичного виховання.

Третій етап дослідження (2006-2007 рік) був спрямований на вивчення психологічної і психофізичної специфіки роботи на залізничному транспорті й можливостей формування відповідної готовності студентів у процесі фізичного виховання.

Вивчення психологічної і психофізичної специфіки професійної діяльності на залізничному транспорті здійснювалося на основі аналізу наукових праць зі сфери залізничної психології, професіограм. На цьому етапі ставилися завдання:

1. Виявити головні групи професій на залізничному транспорті та професійні функції для кожної з них. 
2. Виявити складові психологічної і психофізичної готовності фахівців, які необхідні для ефективного виконання професійних функцій.

3. Виявити загальні й спеціальні (що випливають із особливостей конкретної спеціальності) вимоги до психологічної і психофізичної підготовленості інженерів-залізничників.

Результати, отримані на цьому етапі роботи, використовувались як під час підбору засобів психологічної діагностики, так і в ході розробки основ організації психологічної і психофізичної підготовки студентів.

Головними завданнями четвертого етапу (2008-2009 рік) стали:

1. Розробка основ психологічної і психофізичної підготовки студентів залізничних ВНЗ (ії сутність, структура, зміст, засоби) у ході фізичного виховання.

2. Діагностика актуального стану психологічної і психофізичної підготовленості студентів.

Для їх розв'язання було вирішено:

- Побудувати теоретичну модель психологічної і психофізичної підготовленості особистості.

- Виділити й охарактеризувати головні напрямки психологічної і психофізичної підготовки студентів у процесі фізичного виховання.

- Охарактеризувати засоби психологічної і психофізичної підготовки студентів у процесі фізичного виховання.

- Охарактеризувати види спорту з позицій їх використання для вирішення завдань психологічної і психофізичної підготовки.

Рівень сформованості характеристик психологічної і психофізичної підготовленості визначався з використанням як відомих, так і розроблених автором психодіагностичних засобів. Психологічну діагностику пройшли 420 студентів, з них 345 - юнаки, 75 - дівчата.

П'ятий етап (2010-2011 рік) було присвячено дослідженню формування психологічної і психофізичної готовності студентів у процесі фізичного виховання (формуючий етап експерименту). У ході експерименту виявлявся можливий вплив розробленої автором психологічної і психофізичної підготовки на певні характеристики психологічної і психофізичної готовності студентів.

До початку експерименту як робочу гіпотезу було сформульовано припущення, що психологічна і психофізична підготовка студентів у процесі фізичного виховання буде сприяти формуванню у них від- 
повідної готовності до професійної праці. Під час планування експерименту, не знижуючи уваги до розв'язання традиційних завдань фізичного виховання студентів, передбачалося доповнити їх новими. Для вирішення останніх теоретичний розділ навчальної програми 3 фізичного виховання [242] було доповнено блоком психологічної просвіти, а практичний - блоком психологічної і психофізичної підготовки. Контрольні заходи також доповнювалися контролем психологічної і психофізичної підготовленості студентів.

Експериментальна робота проводилася протягом двох років (перший і другий курс навчання студентів). План-графік навчальних занять було розроблено до початку експерименту. При складанні конспектів занять викладачі були зорієнтовані на комплексне вирішення традиційних і нових завдань. Це передбачало, насамперед, активне застосування таких засобів, які були ефективними в обох планах. Насамперед, це стосувалось використання професійно значущих видів спорту та спеціальних фізичних вправ.

Завданнями експерименту були:

1. Оцінка вихідного і підсумкового рівня психологічної і психофізичної готовності студентів.

2. Перевірка дієвості запропонованих засобів психологічної і психофізичної підготовки.

3. Виявлення ефективності розроблених основ психологічної і психофізичної підготовки у формуванні психологічної і психофізичної підготовленості студентів до професійної праці (зокрема, рис особистості, уваги, вестибулярної стійкості та ін.).

Шостий етап (2012-2013 рік) був пов'язаний з теоретичним узагальненням отриманих результатів. Підготовлено монографію і ряд статей, у яких відображено головні результати дослідження.

\section{2. Характеристика методів дослідження}

Дослідження (і проведення) психологічної і психофізичної підготовки студентів під час навчальних занять з фізичного виховання потребувало виявлення наявності й міри прояву в конкретного студента тих чи інших складових його психічної структури. У психології прийняття кваліфікованого рішення про наявний психологічний стан 
людини в цілому або про їі певну (окремо взяту) складову називають психодіагностикою. Термін не є однозначним. Існує два його визначення. По-перше, психодіагностикою називають галузь психологічної науки, яка розробляє теорію, принципи та інструменти оцінки й вимірювання індивідуально-психологічних особливостей особистості [61, с.104]. По-друге, термін використовується для позначення специфічної сфери діяльності психолога, яка пов'язана з практичним встановленням психологічного діагнозу. У цій роботі термін буде використовуватися в другому значенні.

Під час вибору методик, які було використано в дослідженні, ми виходили з того, що психологічна й психофізична готовність особистості має структурні складові різного рівня. Відповідно до розробленої моделі у студентів діагностувався рівень розвитку таких складових, як професійно значущі риси особистості, особливості психічних процесів, психомоторика.

Психологічна діагностика рис (характеристик) особистості виконувалася з використанням таких методик, як розроблена автором таблиця для оцінки прояву якостей особистості студентів (дод. 1), розроблена автором таблиця для оцінки прояву вольових якостей особистості у студентів (дод. 4), тест Кеттелла (16 РF-опитувальник), шкала оцінки рівня реактивної і особистісної тривожності Ч. Спілбергера (дод. 5), опитувальник рівня суб'єктивного контролю, розроблений Є. Ф. Бажиним на основі шкали локусу контролю Д. Роттера (дод. 6), методика для психологічної діагностики копінг-механізмів Е. Heim, методика PCRS (Personal change readiness survey) в перекладі і адаптації Н. А. Бажанова і Г. Л. Бардієр.

У плані виявлення рівня розвитку пізнавальних процесів у студентів використовувалися: коректурна проба Бурдона (дод. 3) і тест Мюнстерберга (дод. 2).

Із психомоторних процесів виконувалася діагностика швидкості в діях та діагностика стійкості вестибулярних реакцій студентів. Як засоби діагностики застосовувалися спеціальні фізичні вправи.

Коротко охарактеризуємо використані методи діагностики.

Важливим в характеристиці особистості $є$ виявлення того, яким чином людина приймає рішення в різних життєвих ситуаціях. Одним із головних факторів, що впливають на цей процес, $\epsilon$ рівень суб'єктивного контролю. Це узагальнена характеристика особистості, яка має регулятивний вплив у різних сферах життєдіяльності людини. 
Відповідно до концепції локусу контролю (Д. Роттер) люди, які беруть відповідальність за події свого життя на себе, мають внутрішній (інтернальний) контроль. I навпаки, люди, які схильні перекладати відповідальність за всі події на зовнішні чинники (інших людей, випадок і т. ін.), мають зовнішній (екстернальний) контроль.

У психології розроблено метод дослідження рівня суб'єктивного контролю (дод. 6). Його зміст полягає в тому, що людині пропонують 44 твердження. На підставі відповідей можна зробити висновок про те, який рівень суб'єктивного контролю в цієї людини. 3 кожним із тверджень людина повинна виразити свою згоду або незгоду. Максимальна кількість балів, які можна отримати в тесті рівня розвитку суб'єктивного контролю, дорівнює 44.

Вважається, що особи, які отримали від 33 до 44 балів, здатні взяти на себе відповідальність за те, що відбувається з ними і з іншими залежними від них людьми. Люди, що отримали від 12 до 32 балів, мають середній рівень розвиненості суб'єктивного контролю і майже настільки ж часто в житті беруть на себе відповідальність, скільки покладають іiі на інших людей, тим самим знімаючи особисто із себе відповідальність за те, що відбувається. Ті, чий сумарний показник в балах за цією методикою виявився 11 і нижче, характеризуються тим, що в більшості випадків знімають із себе відповідальність за події і перекладають іiї на обставини чи на інших людей, тобто не мають належної відповідальності.

Оцінка психологічної і психофізичної підготовленості майбутнього залізничника передбачає оцінку такої характеристики особистості, як тривожність, яка суттєвою мірою визначає і їі емоційну стійкість. 3 цією метою для психодіагностики використано шкалу оцінки рівня реактивної і особистісної тривожності (Ч. Спілбергер).

Це надійний і інформативний засіб самооцінки реактивної і особистісної тривожності. Його розробником є Ч. Спілбергер. Адаптацію провів Ю. Л. Ханін (див. дод. 5). Шкала самооцінки складається 3 двох частин. Перші 20 тверджень оцінюють реактивну тривожність (РТ), другі 20 тверджень (з 21 по 40) - особистісну (ОT).

Показники реактивної (РТ) і особистісної (ОТ) тривожності обчислюються за формулами:

$$
\mathrm{PT}=\sum_{1}-\sum_{2}+35
$$


де $\Sigma_{1}$ - сума закреслених цифр на бланку за пунктами шкали $3,4,6$, $7,9,12,13,14,17,18$

$\Sigma_{2}$ - сума інших закреслених цифр (пункти 1, 2, 5, 8, 10, 11, 15, $16,19,20)$;

$$
\mathrm{OT}=\Sigma_{1}-\Sigma_{2}+35
$$

де $\Sigma_{1}$ - сума закреслених цифр на бланку за пунктами шкали 22, 23, $24,25,28,29,31,32,34,35,37,38,40$;

$\Sigma_{2}$ - сума інших цифр за пунктами $21,26,27,30,33,36,39$.

При інтерпретації результат оцінювався так: до 30 - низька тривожність; 31-45 - помірна тривожність; 46 і більше - висока тривожність.

До методик психологічної діагностики, які дають змогу оцінити особистість за низкою взаємопов'язаних характеристик, належить особистісний опитувальник Р. Кеттелла, який також було використано в дослідженні. Він призначений для виміру 16 факторів особистості і являє собою реалізацію підходу до ії дослідження на основі теоpiï рис особистості. Опитувальник дає змогу діагностувати риси особистості, які Р. Кеттелл називав конституційними факторами. Метою опитувальника $\epsilon$ оцінка рівня розвитку таких якостей особистості, що складають 16 факторів:

1. А Афектотімія (сердечність, доброта) - Сизотімія (обособленість, відчуженість).

2. В Високий інтелект (розумний) - Низький інтелект (нерозумний).

3. С Сила «Я» (емоційна стійкість) - Слабість «Я» (емоційна нестійкість).

4. E Домінантність (наполегливість, напористість) - Конформність (покірність, залежність).

5. F Сургенсія (безпечність) - Десургенсія (стурбованість).

6. G Сила «Зверх Я» (висока совість) - Слабкість «Зверх Я» (недобросовісність).

7. Н Пармія (сміливість) - Тректія (нерішучість).

8. I Премсія (м'якосердечність, ніжність) - Харрія (суворість, жорстокість).

9. L Протенсія (недовірливість) - Алаксія (довірливість). 
10. М Аутія (мрійливість) - Праксернія (практичність).

11. $\mathbf{N}$ Проникливість, розважливість - Наївність, простота.

12. О Гіпотімія (схильність до почуття провини) - Гіпертімія (самовпевненість).

13. Q1 Радикалізм (гнучкість) - Консерватизм (ригідність).

14. Q2 Самодостатність (самостійність) - Соціабельність (залежність від групи).

15. Q3 Контроль бажань (високий самоконтроль) - Імпульсивність (низький самоконтроль поведінки).

16. Q4 Фрустрируваність (напруженість) - Нефрустрируваність (розслабленість).

Крім цього, виявляється фактор «адекватність самооцінки».

Скорочений варіант опитувальника, який було використано в дослідженні, містить 105 запитань. Час обстеження - від 20 до 50 хв.

Відповіді заносилися на спеціальний аркуш, а потім 3 допомогою спеціального ключа виконувався підрахунок балів. Отримані бали переводилися в стени (бали) за спеціальною таблицею Р. Кеттелла. Групування результатів також виконувалося відповідно до таблиці Р. Кеттелла і передбачало низькі, середні й високі стени.

В експериментальній роботі зі студентами діагностувалася і така характеристика особистості як толерантність до невизначеності. Ï̈ діагностика проводилась за методикою PCRS (Personal change readiness survey) в адаптації Н. А. Бажанова і Г. Л. Бардієр. Про методику відомо, що вона особливо ефективна при розгляді стресових ситуацій, які пов'язані з інноваціями.

Методика спрямована на оцінку таких діагностичних конструктів: пристрасність (розглядається як енергійність, невтомність, підвищений життєвий тонус), винахідливість (розглядається як уміння знаходити вихід із складних ситуацій, звертатися до нових джерел для вирішення нових проблем), оптимізм (розглядається як великі надії, віра в успіх, небажання орієнтуватись на гірший розвиток подій, намагання зосередитись не на проблемах, а на можливості їх вирішення), сміливість, підприємливість (трактується як потяг до нового, невідомого, відмова від перевіреного і надійного), адаптивність (розглядається як уміння змінювати свої плани і рішення, перебудовуватись у нових ситуаціях, не наполягати на своєму, якщо цього вимагає ситуація), упевненість (розглядається як віра в себе, у свої позитивні якості і свої сили, у те, що все є можливим, варто тільки 
захотіти), толерантність до двозначності (розглядається як спокійне ставлення до відсутності зрозумілих відповідей, самовладання в ситуаціях, коли незрозумілою $є$ сутність того, що відбувається, або незрозумілим $\epsilon$ кінець справи, коли невизначеними $\epsilon$ цілі й очікування, коли розпочата справа залишається незавершеною).

Підраховувалася кількість балів по кожній із 7 шкал. Сума від 21 бала і нижче розглядалась як низький рівень розвитку властивості, яка оцінювалась. Сума, яка була в діапазоні від 22 до 26 балів, оцінювалась як середній рівень розвитку властивості. Сума від 27 балів і вище оцінювалась як високий рівень розвитку властивості.

У цій роботі діагностувалися також копінг-стратегії студентів. У психології базовими копінг-статегіями вважаються: стратегія «вирішення проблем», стратегія «пошуку соціальної підтримки» і стратегія «уникання». Першу класифікують як активну поведінкову стратегію, застосовуючи яку людина використовує особистісні ресурси для пошуку можливих способів вирішення проблем. Друга також розглядається як активна поведінкова стратегія, за якої для вирішення проблеми людина звертається за допомогою до оточуючих iï людей (сім’ї, друзів та ін.). Третю стратегію відносять до поведінкової стратегії, при застосуванні якої людина прагне уникати контакту 3 оточуючими, намагається витіснити необхідність розв'язання проблеми. Вважається, що найбільш ефективним є ситуативне використання всіх 3 стратегій.

Методику вивчення копінг-статегій розробив Е. Неim, адаптацію проведено під керівництвом Л. І. Вассермана. Всього методика дозволяє дослідити 26 варіантів копінгу. Виділяються когнітивні, емоційні й поведінкові копінг-статегії. До когнітивних стратегій віднесено такі: ігнорування, смиренність, дисимуляція, збереження самовладання, проблемний аналіз, відносність, релігіозність, розгубленість, надання сенсу, встановлення власної цінності. Серед емоційних стратегій виокремлено такі, як: протест, емоційна розрядка, придушення емоцій, оптимізм, пасивна кооперація, покірність, самозвинувачення, агресивність. До поведінкових віднесено такі: відволікання, альтруїзм, активне уникнення, компенсація, конструктивна активність, відступ, співробітництво, звернення.

Усі названі стратегії, у свою чергу, було також розподілено на 3 групи: адаптивні варіанти копінг-поведінки, неадаптивні варіанти копінг-поведінки і відносно-адаптивні варіанти копінг-поведінки. 
У ході дослідженні структурних компонентів особистості студентів навчальних секцій легкої атлетики і футболу дані стосовно рівня сформованості у студентів факторів особистості (за Р. Кеттеллом) отримували 3 допомогою експертних оцінок. Експертами були люди, які добре знають студента (викладачі, що тривалий час проводили заняття в групі студента, куратор та ін.). Для того щоб зробити роботу експертів більш продуктивною, нами була розроблена спеціальна таблиця, у якій реєструвалася міра прояву якостей особистості студента (дод. 1). У ній експертам пропонувалось оцінити за п'ятибальною шкалою міру прояву запропонованих рис особистості у студентів.

Одним із важливих завдань психологічної і психофізичної підготовки студентів-залізничників є формування у них вольових якостей особистості. Їх психологічна діагностика виконувалася 3 допомогою експертних оцінок. Експертами були куратор, викладачі та інші люди, що добре знають студента. Нами було розроблено спеціальну таблицю для оцінки прояву вольових якостей особистості у студентів (дод. 4). У ній експертам пропонувалось оцінити за десятибальною шкалою міру прояву ряду вольових якостей у студентів.

До пізнавальних процесів, розвиток яких цілеспрямовано досліджувався у процесі психологічної і психофізичної підготовки студентів-залізничників, належать різноманітні характеристики уваги.

Вибірковість уваги визначалася 3 допомогою методики Мюнстерберга (дод. 2), яку можна використовувати як в групі, так і індивідуально. Студенти отримували таку інструкцію: «Серед буквеного тексту є слова. Ваше завдання, переглядаючи рядок за рядком, якомога швидше знайти ці слова. Знайдені слова підкреслюйте. Час виконання завдання 2 хв».

Оцінці підлягали кількість виділених слів і кількість помилок (пропущені й неправильно виділені слова). Отримані результати групувалися за п'ятибальною шкалою. В один бал оцінювалося знайдення від 0 до 5 слів. Два бали нараховувалися за знайдення від 6 до 10 слів. За 11-15 слів надавалося три бали. Чотири - призначались за знайдення від 16 до 20 слів. У п'ять балів оцінювався результат від 21 до 25 слів.

При діагностиці концентрації і стійкості уваги у студентів використовувалась коректурна проба Бурдона (дод. 3). Методика проведення була такою. Протягом 10 хв студенти на спеціальному бланку (дод. 3) букву К в кожному рядку підкреслювали, а букву И - 
закреслювали. За сигналом «хвилина» вони ставили вертикальну риску в тому місці бланку, де їх зупинив сигнал. Обробка даних виконувалася за спеціальною формулою. Підрахунок проводився по кожній хвилині. Потім визначався результат за 10 хв.

Результати групувалися за 9-бальною шкалою, запропонованою В. Л. Маріщуком [240, с. 155]. Продуктивність роботи від 800 до 999 знаків оцінювалася в один бал, від 1000 до 1200 знаків - у два бали, від 1201 до 1350 - у три бали, від 1351 до 1500 знаків - у чотири бали, від 1501 до 1700 - у п’ять балів, від 1701 до 1850 - у шість балів, від 1851 до 2000 - у сім балів, від 2001 до 2150 - у вісім балів. Дев'ять балів надавалось за результат у діапазоні 2151-2 300 знаків.

3 допомогою цієї методики можна оцінити також розподіл і переключення уваги. Для цього перед тими, хто виконує роботу, ставиться більш складне завдання. Працюючи 15 хв, потрібно:

1) протягом першої хвилини відшуковувати, підкреслювати або закреслювати дві різні букви;

2) протягом другої хвилини те саме виконують 3 двома іншими буквами;

3) протягом третьої - знову виконується завдання 3 першими двома буквами і так далі, до кінця 15 хв.

Таким чином, у процесі роботи тому, хто її виконує, доводиться постійно розподіляти увагу між двома буквами i, крім цього, через кожну хвилину переключати эï на пошук двох інших букв.

Оцінка психофізичної підготовленості студентів включала визначення рівня розвитку психомоторних процесів. 3 цією метою в роботі використовувалися спеціальні фізичні вправи. Ці вправи не потребують спеціального обладнання і можуть ефективно застосовуватися в психодіагностичних цілях під час занять 3 фізичного виховання. Наведемо ряд вправ, які були використані для дослідження психомоторних процесів.

Вправа для оиінки швидкості в діях «удари баскетбольним м'ячем в коло». Ставилося завдання виконати якомога швидше 20 кидків м'яча в стіну (у коло діаметром 50 см з відстані 2 м). Кидки мимо кола не зараховувались. Результат більший за 21 с вважався низьким.

Вправи для очінки вестибулярних реакцій:

1. Біг на 25 м $з$ одночасним виконанням 5 поворотів. Біг виконувався в коридорі шириною 150 см. Спочатку проводився звичайний біг, потім пробігання з поворотами. Враховувалося збільшення часу 
пробігання і кількість виходів 3 коридору. Результат вважався відмінним в тому випадку, якщо час збільшувався не більше ніж на 3 с i не було допущено жодного виходу з коридору. При збільшенні часу більше ніж на 5 с або при двох випадках виходу з коридору спостерігалися підвищені вестибуло-соматичні реакції.

2. Стійкість після перекидань. Студенти виконували 5 перекидань вперед за 10 с. Здатність впевнено зберігати основну стійку після виконання перекидань оцінювалась як «відмінно», за наявності нестійкості із сходженням 3 місця до одного кроку - «добре», два або три кроки - «задовільно». При більш значному відхиленні або падінні оцінка «незадовільно». У цій вправі після перекидань можуть також застосовуватись підскоки на місці. Показником відмінної стійкості вважалося відхилення від фінішної лінії вперед на 20 см, доброї 40 см, задовільної - 60 см і незадовільної - більш значне відхилення.

Оцінка теоретичного рівня з розділу психологічна і психофізична підготовка здійснювалась відповідно до положення про заліки з фізичного виховання [292]. Теоретична підготовленість з розділу психологічної підготовки перевірялась і оцінювалась за результатами відповіді студента по білету, що містив два запитання. Відповіді були усними або письмовими.

Статистична обробка результатів діагностики виконувалася з використанням загальноприйнятих методів [91, 258], які розроблені в Excel для ПК, а також за допомогою пакету статистичних програм SPSS 10,0 for Windows. Визначались: середнє арифметичне, медіана, мода, стандартне відхилення.

Під час вивчення особливостей формування вольових якостей особистості й рівня розвитку уваги студентів статистичну обробку отриманих даних проведено 3 використанням $U$-критерію МанаУїтні.

Для статистичної обробки емпіричних даних щодо впливу рівня контролю особистості на агресивність у футболі використано коефіцієнт рангової кореляції Спірмена.

У ході експериментального дослідження впливу психологічної і психофізичної підготовки на особистісну тривожність студентів для статистичної обробки емпіричних даних використано $t$-критерій Стьюдента для залежних вибірок. Цей самий критерій було використано для обробки емпіричних даних, отриманих у ході дослідження розвитку вестибулярної стійкості, формування професійно значущих 
рис особистості, формування складових толерантності до невизначеності в процесі психологічної і психофізичної підготовки.

Обробку емпіричних даних, отриманих у ході експериментального дослідження розвитку концентрації і стійкості уваги в процесі психологічної і психофізичної підготовки студентів, виконано з використанням $T$-критерію Вілкоксона. 


\section{Теоретико-методологічне обгрунтування психологічної і психофізичної підготовки особистості в процесі фізичного виховання}

3.1. Психофізична проблема як методологічне підгрунтя для постановки питання про психологічну й психофізичну підготовку у фізичному вихованні

Вихідними положеннями дослідження стали такі припущення:

1. Теоретико-методологічну основу психологічної і психофізичної підготовки студентів під час навчальних занять з фізичного виховання необхідно виявляти на філософському й психологічному рівні.

2. Виходячи з того що фізичне виховання безпосередньо пов'язане із впливом на організм людини, а психологічна й психофізична підготовка спрямована головним чином на психічні складові, необхідно виконати аналіз тих філософських і психологічних питань, які прямо пов'язані з предметом дослідження, а саме: психофізична проблема в історії науки, взаємовплив організму та психіки, уявлення про особистість у сучасній психології.

Психофізична проблема в науковій літературі розглядається в широкому і вузькому сенсі. У першому випадку її трактують як питання про відношення психічних і фізичних явищ. У другому - як питання про співвідношення між психічними й фізіологічними процесами. Грунтовно психофізична проблема почала розроблятись у філософії 17 століття. Було два підходи до іiі розуміння. Р. Декарт запропонував варіант вирішення психофізичної проблеми з позицій психофізичної взаємодії. За Декартом, живе тіло є свого роду машиною, тоді як свідомість (мислення, воля), будучи відмінною від тіла субстанцією, з одного боку, відчуває його вплив (при відчуттях, афектах і т. д.), 
з іншого - здатна впливати на нього (наприклад, при вольовому зусиллі).

Г. Лейбніц для вирішення психофізичної проблеми запропонував ідею психофізичного паралелізму. На відміну від попереднього підходу, тут відхилялася взаємодія і стверджувався принцип паралельного перебігу психічних і фізичних процесів. Цей підхід був дуже поширений у 19 столітті. У той же час, 3 позицій дарвінівського вчення, психіку слід було розуміти як активний чинник регуляції життєвих процесів. Ця вимога отримала відгук у новому варіанті психофізичної взаємодії, яку запропонував У. Джемс [119]. Виступивши проти асоціанізму, він розробив, на противагу йому, свою концепцію «потоку свідомості» - цілісних та індивідуальних психічних станів, які безперервно змінюють один одного і відображають фізіологічні процеси в організмі. Джемс висунув на перший план принцип активності психічного життя і перевагу в ньому волі й інтересу. Психіка, за Джемсом, має життєву, «функціональну» цінність, являючи собою знаряддя біологічного виживання індивіду.

Ще одна спроба поєднати психіку й тіло і розглянути організм як єдине ціле відома під назвою організмічного підходу. Його добре ілюструють у своїй роботі К. Холл і Г. Ліндсей [418]. Представником цього напрямку є Курт Гольдштейн [470, 471]. На основі власних спостережень і досліджень він прийшов до висновку, що для того щоб зрозуміти функціонування будь-якої складової організму, потрібно відкрити загальні закони функціонування всього організму. Психіка і тіло являють собою єдність. I фізіологічні, і психологічні чинники здійснюють вплив у межах всього організму.

Висловлюються і думки, що питання взаємодії тіла і розуму $\epsilon$ принципово кібернетичним [37]. Вирішити проблему вважається можливим тільки «функціональним методом опису», який відкидає будь-які «причинно-наслідкові зв'язки». При цьому підході психофізичну проблему розглядають як метафізичну, таку, що не перевіряється з допомогою досвіду.

Сподівання на те, що буде з'ясовано питання, чому психофізична проблема не є можливою для розв'язання, висловив В. Франкл [407, c. 50]. Свій аналіз він починає посиланням на онтологію М. Гартмана і антропологію М. Шелера. Вони виділяють різні рівні або пласти: тілесний, душевний і духовний. 3 кожним рівнем співвідноситься певна наука: 3 тілесним - біологія, з душевним - психологія і т. д. Саме 
із відмінності цих рівнів бере початок «плюралізм наук». А де ж «єдність людини», цікавиться В. Франкл і визначає людину як єдність всупереч багатогранності. На його думку, є антропологічна єдність, незважаючи на онтологічні відмінності, на відмінність між різними формами буття. «Відмітною ознакою людського буття є співіснування в ньому антропологічної єдності і онтологічних різниць, єдиного людського способу буття і різних форм буття у яких він виявляється. Коротше, людське буття це «Unitas multiplex», виражаючись словами Фоми Аквінського. Воно не охоплюється ні плюралізмом, ні монізмом ...» [407, с. 48] (Переклад тут і далі мій. - В. П.). Далі В. Франкл викладає своє розуміння людини з позицій димензіональної онтології [469]. «Людина також, якщо в неї редукувати специфічний людський вимір і спроектувати його на площини біології і психології, відбивається в них так, що ці проекції суперечать одна одній. Адже проекція в біологічний вимір знаходить соматичні явища, тоді як проекція в психологічний вимір знаходить явища психічні. У світлі димензіональної онтології ця суперечливість не ставить під сумнів єдність людини - як факт незбігу круга і прямокутника не суперечить тому, що це дві проекції одного й того ж циліндра. Але будемо пам'ятати: безглуздо шукати єдність людського способу буття, що переборює багатоманітність різних форм буття, а також розв'язання таких суперечностей, як антиномія душі і тіла, у тих площинах, на які ми проектуємо людину. Знайти іiі можна лише у вищому вимірі специфічно людських проявів» [407, с. 50].

Ідею психофізичної єдності людини покладено в основу такого напрямку сучасної психології, як психоаналіз. У світлі цієї теорії людина розглядається як єдине психофізіологічне ціле. Базуючись на цьому припущенні, пояснюється те, як неусвідомлені уявлення можуть впливати на найелементарніші фізіологічні функції.

У вітчизняній психології аналіз психофізичної проблеми виконав С. Л. Рубінштейн [328]. Він прийшов до висновку, що це найважча і найгостріша з усіх проблем, які стояли перед людьми, вважав іiі такою, що не має рішення. С. Л. Рубінштейн сформулював низку вимог, які мають важливе філософське значення. У них наголошується на необхідності не виводити психічне як ідеальне за межі матеріального світу, не допускати відокремлення ідеального від матеріального й дуалістичного протиставлення одного іншому. У цьому контексті Я. А. Пономарьов [295] звертає увагу на те, що до постановки 
психофізичної проблеми приводить попереднє усвідомлення якісної відмінності психічного від матеріального.

Аналізуючи психофізичну проблему, не можна не згадати так званий психосоматичний підхід у медицині. Його докладно описують у своїй роботі Ф. Александер і Ш. Селесник [7]. Автори звертають увагу на те, що головний принцип сучасного психосоматичного підходу полягає в тому, що особистість і організм утворюють єдине ціле, а до проблем людини слід підходити з позиції взаємодії психологічних і соматичних аспектів.

У рамках психосоматичного підходу в медицині фахівці виділяють три напрямки: тілесно-психологічні теорії особистості, теорії конфліктів, схеми, у яких робляться спроби зіставити тілесні й психологічні властивості. Представниками підходу є Е. Данбар [463466,], Г. Бергман [453], А. Йорес [480] та ін.

Питання взаємодії психічного, фізичного, соціального в людині грунтовно розглядається і в такому розділі психологічних знань, як психологія розвитку [187, 454, 461, 485, 497, 499, 502-504]. Поняттям «розвиток» позначено зміни, які з часом відбуваються в будові тіла, мисленні або поведінці людини внаслідок біологічних процесів, що проходять в організмі, та впливу навколишнього середовища [187, с. 15]. Фахівці у сфері психології розвитку підкреслюють, що розвиток людини зумовлений взаємодією біологічного, психічного і соціального. Звертається увага й на те, що середовище, яке оточує людину, саме складається 3 множини конкретних середовищ, які постійно взаємодіють між собою і впливають на розвиток через цю взаємодію [187, с. 16].

Дослідники, що працюють у сфері психології розвитку, виділяють три сфери, у яких цей розвиток відбувається: фізичну, когнітивну і психосоціальну [187, с. 17]. До фізичної сфери відносять такі фізичні характеристики, як розмір і форма тіла і органів, зміна структури мозку, сенсорні можливості й моторні (рухові) навички. До когнітивної сфери - усі розумові здібності й психічні процеси. Психосоціальну сферу утворюють властивості особистості та соціальні навички, властивий кожному індивідуальний стиль поведінки й емоційного реагування [187, с. 17]. Розвиток людини в цих трьох сферах відбувається одночасно й взаємопов'язано. Зазначається, що між різними сферами розвитку людини існує складна взаємодія. Розвиток являє собою не послідовність окремих, не узгоджених між собою змін, 
а має цілісний, системний характер, внаслідок чого зміни в одній сфері тягнуть за собою зміни в іншій $[187$, с. 18].

Таким чином, дослідження у сфері психології розвитку також засвідчують складну взаємодію фізичних, психічних і соціальних параметрів у становленні особистості людини.

Спроби теоретичного аналізу психофізичної проблематики робляться і з боку психотерапії. Насамперед це стосується такого ії напрямку, як тілесно орієнтована психотерапія. Загальний аналіз підходу виконано в [306, 331]. Тілесно орієнтовану психотерапію утворює група методів психотерапії, яка орієнтована на вивчення тіла, усвідомлення пацієнтом тілесних відчуттів, на дослідження того, як потреби, бажання й почуття проявляються в різних тілесних станах, на навчання реалістичним способам усунення дисфункцій у цій сфері. Є багато різновидів тілесно орієнтованої психотерапії (біоенергетичний аналіз А. Лоуена [213-215], структурна інтеграція I. Рольфа, метод М. Фельденкрейса, первинна терапія А. Янова та ін.), проте всі вони пов'язані з роботами В. Райха [314]. Райх вважав, що механізми психологічного захисту й пов'язана 3 ними захисна поведінка сприяють формуванню «м'язового панциру» (або «панциру характеру»), який проявляється в напруженні різних груп м'язів, утрудненому диханні та ін. Протистояти психологічним захисним механізмам можна шляхом модифікації тілесного стану й впливу на напружену область.

Структуру м'язового панциру, за Райхом, утворюють 7 головних захисних сегментів, що складаються 3 м'язів і органів відповідних функцій. Ці сегменти утворюють ряд із семи горизонтальних кіл, що розташовані під прямим кутом до хребта. Головні сегменти панциру розміщені в області очей, рота, шиї, грудей, діафрагми, живота, тазу.

Терапія при цьому підході полягає в «розпуску» панциру в кожному сегменті, починаючи з очей і закінчуючи тазом. Сегменти вважаються відносно незалежними й такими, з якими можна працювати окремо. Для розпуску панциру використовують три типи засобів:

a) накопичення в тілі енергії за допомогою глибокого дихання;

б) прямий вплив на хронічні м'язові затистиснення за допомогою надавлювання, пощипування і т. ін.;

в) відкритий розгляд разом з пацієнтом опору й емоційних обмежень, які виявляються при цьому.

Із вітчизняних робіт, що продовжують цей напрямок, слід виділити монографію О. Е. Газарової [82]. Свій аналіз автор починає 
3 констатації того, що процеси взаємодії тіла і психіки, як правило, зараз не піддаються сумніву. Але глибину й наслідки цієї взаємодії мало хто може оцінити, за винятком психотерапевтів тілесно орієнтованого напрямку. Проте в літературі все частіше почав траплятися термін тілесність, який швидко поширився не тільки серед психотерапевтів вищезгаданого напрямку. Незважаючи на це, саме поняття «тілесність» не сформульовано й різні автори вкладають в нього різний сенс. На думку О. С. Газарової вивчення тілесності можливе тільки на межі багатьох наук і галузей знань про людину: біології, психології, фізіології, анатомії, антропології, соціології, фізики, хімії, історії, медицини, філософії, культурології, релігієзнавства та ін. Вона висловлює думку, що сферою таких міждисциплінарних досліджень могла б стати психологія тілесності - наука про душевнотілесну відповідність (конгруентність). Предметом вивчення психології тілесності повинні стати конгруентні психологічні, біологічні й смислові аспекти тілесності. Психологія тілесності досліджуватиме механізми формування, загальні закономірності існування й особливості цих аспектів.

Наступним кроком О. Е. Газарової $є$ порівняння значення тілесного досвіду в житті тварин, стародавньої і сучасної людини. Вона приходить до висновку, що на відміну від доцільної фізіології паттернів поведінки тварин і стародавніх людей, у фізіології поведінки сучасної людини можливі парадоксальні поєднання. Наприклад, сильне хвилювання, що переживається тілесно із стриманим диханням, жестами, мімікою і поведінкою в цілому.

Далі наголошується, що сформований за мільйони років властивий тілу принцип природної доцільності порушується під тиском уявлень і соціальних установок людини. Людина підпорядковується особистісній доцільності, і характерні психосоматичні паттерни виконують певну роль у контексті цієї доцільності (роль захисту особистості). Навіть в умовах безпеки людина не може дозволити собі прояви щирості й спонтанності. Це, на думку Газарової, тривожний знак. У зв’язку з непотрібністю тіло забуло природні реакції. Проте тілесний досвід і тілесна рефлексія являють собою додаткову «модальність» самопізнання, модальність, не менш важливу, ніж усі інші. «Знаки» цієї «модальності» значно впливають на психічні процеси. Тіло й тілесні процеси - своєрідний інформаційний канал. Міміка, рухи тіла, жести, м'язові затиски можуть без слів дуже багато розповісти про особисті- 
сні проблеми людини. Одночасно вони є і каналом впливу на особистість людини (особливо у випадках когнітивних, вербальних «блокувань» і захистів).

Такі спроби теоретичного осмислення психотерапевтичної практики збагачують психологію. Очевидно на їх користь висловився і відомий російський психолог С. О. Климов. Він вважає, що в роботі практикуючих психологів народжується цінне життєздатне істинне знання, відповідно до якого повинно змінюватись і обличчя тієї психології, яка вважає себе академічною. Це можна зрозуміти як внутрішньосистемне, внутрішньопрофесійне застосування, упровадження одних психологічних напрямків в інші $[158$, с. 11].

Підбиваючи підсумок аналізу теоретичних підходів до розуміння психофізичної проблеми, взаємодії психічного і фізичного, можна зробити висновок про те, що в сучасній психології загальновизнаним $\epsilon$ положення про взаємовплив організму і психіки людини.

Висновки, зроблені в ході аналізу психофізичної проблеми, потребують більш наочної демонстрації. У зв'язку з цим, наступним логічним кроком буде вирішення питання взаємовпливу організму людини та їі психіки.

\section{2. Взасмовплив організму і психіки людини як теоретична основа використання фізичного виховання для вирішення завдань психологічної і психофізичної підготовки}

Взаємовплив організму і психіки людини вивчався різними науковими напрямками, починаючи 3 філософського і закінчуючи біохімічним.

Звернення до проблематики фізичного в людині є одним із напрямків пошуку сучасної філософської думки. Сьогодні можна констатувати концептуальну відкритість щодо проблеми людського тіла та визнання його одним із найсуттєвіших чинників людського буття. Першою у вітчизняній філософії систематичною працею з цієї проблематики є робота О. Гомілко [96]. Автор звертає увагу на хибність стереотипу розуміння тілесності, який «відкидає» $\dddot{1 i}$ у суто природний світ. Підкреслюється, що розгляд процесу самовизначення людини 
робить проблемним цей стереотип і кінець кінцем спростовує його. Людина має тіло не лише за натуральну передумову власного буття. Тілесність є основою сутнісних, ключових самоідентифікацій людини. Висувається і обгрунтовується теза про те, що плоть є не менш важливим конститутивним чинником особистості, аніж розум, воля або соціальне середовище. Автор звертає увагу, що ця теза може здатися надто сильною тільки у випадку коли ототожнюється плоть із абстрактним тілом, винесеним за межі екзистенціального досвіду особи. Така абстракція плоті не має людського буттєвого сенсу. «Справжнє місце тілесності у людському бутті та ії онтологічне значення визначається не абстрактною ідеєю тіла, а колом тих можливостей існування, котрі виникають завдяки тілесності людини і мають іiі за передумову. Культурний і екзистенціальний сенс тілесності в самовизначенні людини розкривається лише через коло тих буттєвих подій, послідовність яких складає процес самовизначення, а ареною яких є людська плоть» [96, с. 232]. Ці складові процесу самовизначення, через які конституюється особистість і щодо яких тілесність $\epsilon$ визначальною (і вирішальною) умовою їх можливості, О. Гомілко називає антропологічними подіями.

Головні антропологічні події людського життя зумовлені наявністю в людини тіла. Саме тілесність $є$ умовою їх можливості. Людина входить у них, стає їх учасником та переживає їх наслідки (і сама стає їх наслідком) передусім завдяки тому, що вона $\epsilon$ тілесною істотою. Інші, досить різноманітні значення цих подій, які зустрічаються в культурі, є нашаруваннями над цим (тілесним) первинним онтологічним сенсом.

Розвиваючи далі свій підхід, О. Гомілко підкреслює, що «... між антропологічним (соматико-вітальним) та культурним змістом людського буття загалом не існує відношень взаємоопозиції, взаємовиключення та протиставлення. Абсолютизація протиставлення антропологічного (вітального) та культурного значень подій є надуманою хоча б тому, що все, що залучається до людського світу, залучається 3 допомогою артикуляції культурного поля й існує лише в такому культурно-артикульованому вигляді. А тому, суто «вітальний» зміст явища може визначатися лише суто умовно» [96, с. 234].

Як головні антропологічні події людського буття О. Гомілко називає: народження, дитинство, вік, стать, хворобу, старість, смерть. На iii думку, аналіз цих феноменів, через які й здійснюється антропологі- 
чна самоідентифікація особистості, дає відповідь на запитання, як можлива і якою є людська особистість, якщо людина має плоть, тобто $€$ тілесною істотою. У контексті цього питання тілесність із категорії натуральних даностей переходить до кола метафізичних сутностей. Вона постає не як емпірична «обставина» людського життя, а як його сутнісна передумова - умова можливості бути й самовизначатись як особистість.

Завершуючи свій аналіз, О. Гомілко робить такий висновок: «Людина, маючи тілесність за свою сутнісну ознаку, можлива як особистість через особливість та унікальність своєї плоті, котра тут народжується, так зростає і так трансформується, тоді досягає зрілості, занепадає та вмирає. Через головні антропологічні події - народження, стать, вік, хворобу, смерть тощо - відбувається інтеграція тілесності як у життєвий світ особистості, так і в культурну реальність» $[96$, c. 250$]$.

Вплив тілесності на психічні складові особистості досліджували А. Ю. Рождественський [324], А. В. Старовойтов [374], Л. В. Кочкіна [177]. Цікаве дослідження впливу тілесності на суб'єктивну картину життєвого шляху особистості виконала Т. Д. Василенко [66]. Вона емпірично дослідила взаємозв'язки тілесності й суб'єктивної картини життєвого шляху особистості в таких ситуаціях:

1) ситуації хронічного соматичного захворювання (на прикладі захворювань гастроентерологічного й кардіологічного профілю);

2) ситуації онкологічного захворювання гінекологічного профілю і при гінекологічному захворюванні;

3) ситуації наявності тілесного досвіду безплідності;

4) ситуації переживання тілесного досвіду першої вагітності (вивчено процес прийняття ролі матері й структура суб'єктивної картини життєвого шляху у вагітних жінок при різних термінах першої вагітності);

5) ситуації типу переживання першої вагітності в процесі прийняття соціальної ролі матері;

6) ситуації відновлення репродуктивної функції;

7) ситуації деформації репродуктивної функції.

У ході цієї роботи було встановлено, що тілесний досвід хронічного соматичного захворювання супроводжується трансформацією структури суб'єктивної картини життєвого шляху особистості. Хворі цього профілю оцінювали свій настрій як негативний, меншою мірою 
орієнтований на майбутнє. Спостерігалося фаталістичне відношення до сьогодення. Переважали негативні оцінки минулого, теперішнього і майбутнього. Зафіксовано зниження параметрів осмислення життя.

Було встановлено, що тілесний досвід онкологічного захворювання також супроводжувався зменшенням насиченості подіями, перевагою негативних подій, пов'язаних зі здоров'ям. Зафіксовано різке звуження соціальних контактів і пасивний рівень соціальної взаємодії. Тілесний досвід онкологічного захворювання супроводжувався блокуванням рефлексивних процесів і зниженням вираженості життєвих прагнень.

У пацієнтів 3 тілесним досвідом гінекологічного захворювання Т. Д. Василенко не зафіксувала суттєвих відмінностей у структурі суб'єктивної картини життєвого шляху порівняно зі здоровими.

У паціснтів 3 тілесним досвідом безплідності було зафіксовано блокування процесів смислової переробки життєвого досвіду і трансформацію суб'єктивної картини життєвого шляху жінки. Минуле i майбутнє сприймаються як безглузді етапи життєвого шляху, що не несуть у собі позитивних смислів.

Т. В. Василенко встановила, що переживання і усвідомлення тілесного досвіду першої вагітності супроводжується, в плані життєвого шляху, прийняттям ролі матері й типом переживання вагітності (адекватним, тривожним і ігноруючим). Тип переживання вагітності через зміну ідентичності особистості в конкретній життєвій ситуації впливає на структуру суб'єктивної картини життєвого шляху особистості.

У пацієнтів з тілесним досвідом деформації репродуктивної функції було виявлено трансформацію часових і смислових аспектів суб' єктивної картини життєвого шляху (зниження цілеспрямованості і негативне усвідомлення минулого досвіду, незбалансованість часової перспективи). Зафіксовано низьку міру задоволеності сімейними стосунками і перевагу тенденції до домінування у міжособистісних відносинах. Прийняття соціальної ролі матері мало суперечливий характер.

Дослідження Т. В. Василенко підтверджує іï думку про те, що особистість як носій психосоматичної єдності переживає і усвідомлює тілесний досвід як життєву ситуацію і інтегрує його в суб'єктивну картину життєвого шляху. Цей факт важливий і для нашого дослі- 
дження, оскільки певною мірою підтверджує єдність психічного і фізичного в структурі особистості людини.

Дані щодо взаємовпливу тілесного і психічного отримано в психології і при дослідженні проблеми сприйняття і оцінки індивідуаль-

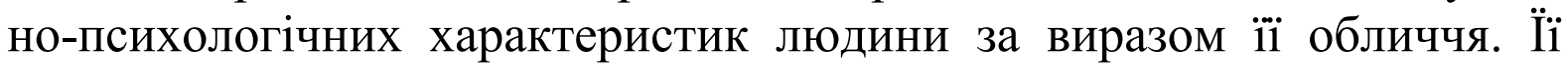
розробляли О. О. Бодальов, В. А. Барабанщиков, D. Berry, E. Rosenberg та ін. Вивченими $є$ питання, що стосуються сприйняття і оцінки рис особистості, особливостей характеру, темпераменту, емоційних проявів та ін. Однією 3 останніх робіт цього напрямку є праця I. М. Майніної [221]. Об'єктом дослідження стало сприйняття особистості людини за виразом її обличчя. Як предмет дослідження було обрано оцінку «глибинних» індивідуально-психологічних характеристик незнайомої людини за фотозображенням іiї обличчя.

I. М. Майніна припустила, що сторонні спостерігачі здатні адекватно оцінювати «глибинні» індивідуально-психологічні особливості незнайомої людини за виразом іiї обличчя. Інше припущення полягало в тому, що «глибинні» індивідуально-психологічні характеристики людини оцінюються спостерігачами менш точно ніж, «поверхові».

У ході дослідження було встановлено, що сприйняття спостерігачами «глибинних» і «поверхових» характеристик людини відрізняється. «Глибинні» індивідуально-психологічні характеристики оцінюються менш точно, ніж «поверхові». Основою для оцінки «поверхових» характеристик є Я-концепція, а «глибинних» характеристик власний комунікативний досвід людини.

I. М. Майніна виявила певну статеву залежність оцінки «поверхових» характеристик. Такі риси, як рівень самоповаги, задоволеність собою краще розпізнавалися за фотозображенням жіночих облич. Впевненість у собі, рівень самоконтролю, незалежність від зовнішніх обставин краще ідинтифікувалися за фотозображеннями чоловічих облич. Окрім цього, жінки краще за чоловіків розпізнавали такі характеристики, як рівень самоповаги, задоволеності собою, вольові якості.

Було встановлено і факт здатності спостерігачів розрізняти рівень екзистенційної наповненості особистості незнайомої людини за фотозображенням ії обличчя. При цьому спостерігачі з низьким і середнім рівнем екзистенційної наповненості більш точно оцінювали «поверхові» характеристики. Спостерігачі ж із високим рівнем однаково точно оцінювали i «поверхові», i «глибинні» характеристики. 
Дослідник виявила також вибірковість оцінки «глибинних» і «поверхових» характеристик людини. Із «глибинних» характеристик найбільш точно спостерігачами розпізнавалася здатність людини орієнтуватись у власному внутрішньому світі, із «поверхових» - впевненість у собі, незалежність, достатній самоконтроль.

У контексті нашого дослідження важливим $\epsilon$ те, що вивчення в психології проблеми сприйняття й оцінки індивідуально-психологічних характеристик людини за виразом її обличчя дає підстави для ствердження факту певного впливу психічного (характеристик особистості) на фізичне (обличчя людини). Це свідчить на користь методологічної обгрунтованості постановки питання про психологічну й психофізичну підготовку в процесі фізичного виховання.

Проблема конституції, типу тілобудови як проблема людини в цілому глибоко цікавила ще лікарів старого світу. $\mathcal{C}$ підстави вважати, що конституційні типи відповідають темпераментам і конституція являє собою щось на зразок одягу для темпераменту. Психотерапевти стверджують, що конституція перебуває в гармонії з психікою людини і вказує їм на істинне, природжене покликання того чи іншого індивіда, дозволяючи вже при швидкому огляді дізнатися надзвичайно багато про нього [86, с. 26].

У науці (окрім психології) дослідження психічних явищ ведеться за такими головними напрямками: мікробіологічним, біохімічним, генетичним, нейрохірургічним, орієнтованим на нервову систему, шокової терапії, психохірургічним, психофармакологічним.

Спостерігається і зворотний процес - вплив психологічних параметрів на фізичні характеристики людини. Фізичні реакції на суб'єктивний стан особистості фіксуються на різних рівнях структури організму: фізіологічному, нейроанатомічному, нейрохімічному. Проілюструємо це на прикладі таких суб'єктивних відчуттів, як емоції. Прояви емоцій фіксують за такими фізичними показниками, як міміка, жести, рівень тонічного напруження м'язів, голос, зміна опору шкіри, частоти серцевих скорочень, кров'яного тиску, розширення і звуження судин, зміна температури шкіри, гормонального та хімічного складу крові, зміни біотоків головного мозку.

Фізіологи, медики спостерігають й інші впливи на психіку різних фізичних складових. Серед них можна назвати: зміну електричної активності миндалини, ушкодження або стимулювання певних відділів мозку. Сучасні дані вказують також на чітку залежність наших на- 
строїв і переживань від біохімічного складу внутрішнього середовища мозку.

Фізичне виховання також передбачає розуміння взаємовпливу організму і психіки $[147,286]$.

Виконаний аналіз взаємовпливу організму і психіки людини дає підстави констатувати їх взаємну залежність і взаємний вплив. Це $\epsilon$ важливим фактичним матеріалом для обгрунтування питання про психологічну й психофізичну підготовку особистості в процесі фізичного виховання.

\section{3. Психологія особистості як методологічний базис психологічної і психофізичної підготовки особистості у фізичному вихованні}

Зараз іде активне переосмислення перспектив фізичної культури. Це проявляється, зокрема, у розробці нових програм з фізичного виховання, у яких акцент зміщується в бік впливу на внутрішні спонукальні сили щодо занять фізичною культурою, розробці нових концепцій, педагогічних технологій та ін. Дослідники звертають увагу на багатоплановість фізичного виховання, його здатність ефективно вирішувати не тільки традиційні, але й інші, не менш важливі завдання. Головне 3 них - сформувати особистість людини. Фахівці обгрунтовано ставлять питання про підвищення освітнього і виховного потенціалу фізичного виховання у формуванні особистості сучасного спеціаліста $[75,216,217,300]$. Викладач фізичного виховання, як і педагог будь-якого іншого профілю, повинен бути добре обізнаним з усіма сторонами і характеристиками особистості, зі способами іiі формування і розвитку. Повною мірою це стосується і вирішення завдання психологічної і психофізичної підготовки студентів під час навчального процесу з фізичного виховання у ВНЗ, оскільки вона прямо пов'язана з впливом на структурні компоненти особистості.

У теоретичному плані психологічна й психофізична готовність розглядається в дослідженні як характеристика (компонент структури) особистості людини. У зв'язку 3 цим, важливий теоретикометодологічний базис для iї дослідження становить така галузь психології, як психологія особистості. Дослідження в цій сфері 
$\epsilon$ фундаментальними для вивчення питань психологічної і психофізичної підготовки особистості до професійної діяльності. У контексті поставлених завдань проаналізуємо їх.

У психології загальновизнаним є факт того, що адекватної теорії особистості ще не створено. Як наслідок, серед психологів відсутній єдиний погляд не тільки на теорію особистості, але й на саме її визначення. У $30-\mathrm{x}$ роках минулого століття психолог Г. Олпорт нарахував десятки визначень особистості. Така ж різноманітність визначень може бути виявлена і в більш сучасних дослідженнях $[59,111$, $205,242,319,384,422,450]$. Їх найхарактернішою ознакою (порівняно з більш ранніми роботами) є акцент на складності й унікальності організації особистості (на противагу небагатьом визначенням, що свідчать просто про комплекс властивостей). Особистість розглядається також як динамічне і пластичне утворення. Стабільність, стійкість поєднані в психологічній організації особистості з гнучкістю, збагаченням сфери іiї потенцій, з компенсаторними резервами, з багатоваріантністю шляхів перебудови, взаємозаміни, взаємодоповнення компонентів структури.

Деякі дослідники вважають, що смислові відтінки, що вносяться кожним новим визначенням особистості, дають можливість краще висвітлити й краще зрозуміти явище. 3 цього погляду, особистість слід розглядати з різних позицій. Загальна ідея полягає в тому, що будь-який психологічний феномен, у тому числі й особистість, можна вивчати або конструювати, базуючись на різних передумовах. Стверджується, що жодне визначення не може дати вичерпного уявлення про особистість, але кожне з них описує певні сторони явища. Використання множини різноманітних визначень розширює і поглиблює наше розуміння особистості. Такий підхід Дж. Келлі назвав конструктивним альтернативізмом.

У вітчизняній психології теж відзначають складність ситуації. Так, Г. О. Балл [24] підкреслює, що зміст категорії відзначається завеликим ступенем нечіткості й суперечливості. Аналогічно оцінюють ситуацію і інші дослідники [222, 223, 305, 491]. Для покращення стану робляться спроби систематизувати підходи до проблеми. Г. О. Балл обгрунтовано пропонує розмежовувати розуміння поняття особистості в психології й інших галузях знання (філософії, культурологіï). Він звертає увагу на те, що у філософії, характеризуючи особистість, по суті виводять ії за межі психологічної науки, підкрес- 
люють іï трансцендентність будь-якому поняттю. Г. О. Балл пропонує розмежовувати психологічні й інші трактування особистості (відмітною ознакою психологічного підходу є концентрація уваги на дослідженні закономірностей і механізмів розвитку особистості як цілісності).

Далі Г. О. Балл окреслює своє бачення власне психологічного розуміння особистості й визначає особистість як системну якість людського індивіда, яка забезпечує його здатність бути відносно автономним та індивідуально своєрідним суб'єктом культури.

Із усіх визначень особистості вдалим, на наш погляд, $є$ і те, що було дане Г. Олпортом і в якому особистість розглядається як прижиттєво сформована, індивідуально своєрідна сукупність психофізіологічних систем - рис особистості, якими визначаються своєрідні для цієї людини мислення й поведінка.

Нерідко відбувається змішування понять особистості й моделі особистості. Наприклад, у роботі [408] під особистістю розуміють сукупність психологічних властивостей, які характеризують кожну окрему людину. У дійсності це певна модель особистості. Зауважимо, що фундаментальний аналіз поняття особистості зробив В. В. Давидов [111].

Аналіз проблеми особистості в психології був би не повним без розгляду таких питань, як структура і динаміка особистості. Структура особистості була предметом багатьох досліджень. Цим займалися такі відомі психологи, як С. Л. Рубінштейн, О. М. Леонтьєв, Б. М. Теплов, Б. Г. Ананьєв, Ж. Піаже і багато інших. Існуючі структурні моделі особистості дуже різноманітні, і більшість із них багатоаспектні. Це відображає реальний факт складності й різнобічності особистості людини як об'єкта вивчення. Дослідження особистості, розробка іiі адекватної моделі - дуже складне питання. Про це свідчить, наприклад, те, що до сих пір немає повної класифікації типів особистості, хоча в психології вже існує низка підходів до цього [199, 344, 351]. Із числа вітчизняних концепцій структури особистості можна виділити концепції А. Г. Ковальова [161], К. К. Платонова [287], Н. І. Непомнящої [269], М. С. Кагана [154], В. С. Ледньова [197], Д. О. Леонтьєва [204], М. С. Бургіна [58, 59]. Порівняльний аналіз більшості з них подає у своїй роботі В. С. Ледньов [197], тенденції дослідження аналізуються в [439]. Ми ж охарактеризуємо підхід М. С. Бургіна, 
який, на нашу думку, є найбільш інформативним з позиції поставлених у цій роботі завдань.

М. С. Бургін $[58,59]$ запропонував ієрархічну екстенсивно-кільцеву модель. Модель включає психологічне ядро, що утворює кільце, а також розширену послідовність підсистем, що дають загальну картину особистості (від іiї внутрішнього змісту до його зовнішнього вираження і сприйняття). У ній поєднуються як психологічні, так і соціальні аспекти особистості. Така модель особистості входить як підструктура в модель індивіда.

Усі компоненти екстенсивно-кільцевої моделі пов'язані між собою. Наприклад, взаємозв'язок між спрямованістю, відношеннями й моральними рисами особистості є основою для виділення в деяких моделях особистості цих компонентів як підструктури більш високого рівня ієрархії. Ця підструктура формується, головним чином, шляхом виховання, хоча і навчання суттєво впливає на неї.

До розглянутих компонентів дуже близькі і світогляд, і переконання, i бажання, i інтереси, і прагнення, i схильності, і ідеали особистості. Вони самі утворюють складні структури, які мають спільні елементи, що іноді частково або повністю входять в іншу структуру. Усі ці підструктури - деякі більше (світогляд або переконання), деякі менше (схильності або прагнення) - залежать не тільки від того, як вихована людина, але й від iї знань. Науковий світогляд неможливий без достатньо високого рівня знань, загальної культури людини.

Знання, навики, уміння, звички - взагалі увесь досвід людини виділяються в окрему підструктуру особистості, що формується в процесі навчання, але під значним впливом біологічних властивостей індивіда.

Екстенсивно-кільцева модель особистості людини має ієрархічну структуру і включає інші моделі особистості. У цій структурі виділяються різні рівні підструктур особистості - від найглибших, що стосуються головних характеристик психіки людини, i до зовнішніх, у яких особистість проявляється і які багато в чому пов'язані із соціальною сутністю людини.

Перший рівень моделі особистості включає такі компоненти: темперамент, який через емоціональність пов'язаний 3 мотиваційною сферою; ця сфера через спонукання пов'язана з характером людини, який, у свою чергу, шляхом саморегуляції (волі) з'єднується зі здібностями; здібності через уяву і пам'ять пов'язані з інтелектом, який, 
у свою чергу, через структури активності поєднується з темпераментом. Таким чином, ці глибинні системи психічної організації людини утворюють за своїми зв'язками кільце. На них, як на фундаменті, формуються і розвиваються інші характеристики особистості.

Другий рівень структури особистості, що охоплює перший рівень, утворюють знання, навики, уміння, звички, весь досвід людини.

На цьому рівні, як на фундаменті, розташовується наступний (третій) рівень структури особистості, що включає спрямованість, світогляд, інтереси, схильності, моральні риси, цінності та інші установки.

На четвертому рівні, фундамент якого складають перші три, розташовуються ставлення людини до навколишнього світу, до себе, до діяльності. У певному сенсі система відносин найбільш повно характеризує особистість. У ній відображаються всі більш глибокі структури особистості. Вона має не тільки психологічні, але й соціальні аспекти, оскільки система особистісних ставлень включена і тим самим невід'ємно пов'язана із системою соціальних стосунків. У зв'язку з цим не випадково деякі вчені (наприклад, Д. А. Леонтьєв [204]) зводять особистість повністю до системи ставлень (відношень). На наш погляд, ці уявлення неповні й у структурі особистості існують і більш глибокі, і більш високі рівні.

На п'ятому рівні розташовано діяльність людини і їі спілкування. Саме в них проявляються всі ті відносини, які окреслені на попередньому рівні структури. Для усіх попередніх шарів особливо важливо, як вони проявляються в діяльності і спілкуванні. Уся підготовка, наприклад, студента залізничного ВНЗ спрямована, у першу чергу, на досягнення ним більшої майстерності в професійній діяльності. Однак без формування міцного фундаменту, який утворюють перші чотири рівні, не можна розраховувати не тільки на досягнення високих показників у роботі інженера, але й на здобуття ним достатнього професіоналізму.

Нарешті, шостий рівень моделі особистості утворює сприйняття людини іншими людьми. Без цього компонента неможливо повністю охарактеризувати особистість як соціальну істоту. Цей аспект через діяльність і спілкування доповнює систему ставлень (відношень) самої людини, яка без цього залишається однобокою, даючи уявлення тільки про внутрішні показники якостей особистості.

Дослідники виділяють чотири головних підходи у вивченні особистості: біологічний, експериментальний, соціальний і психометрич- 
ний. У рамках біологічного підходу вивчення особистості здійснюється 3 погляду раннього набутого досвіду, генетичних фундацій і еволюційного розвитку. Прихильники експериментального підходу за основу вивчення особистості обирають дослідження процесів сприйняття, навчання і вищої нервової діяльності. Їх розуміння дає можливість 3'ясувати те, як конкретні події впливають на подальшу поведінку індивіда через вплив на структуру його особистості. При соціальному підході вивчається соціальне оточення індивіда і його вплив на розвиток особистості: вплив соціальних ролей, культури в цілому. Психометричний підхід демонструє дослідження особистості, що відображають внутрішню структуру властивостей особистості. Вимір властивостей особистості грунтується на спостереженнях за поведінкою індивіда, на самозвітах, непрямій оцінці характеристик.

Теоретикам і практикам фізичного виховання потрібно виходити 3 того, що особистість є синтезом усіх характеристик індивіда в унікальну структуру, яка визначається і змінюється внаслідок адаптації до середовища, яке постійно змінюється.

В. А. Богданов [42] вважає, що найбільш глибока суперечність у сфері теорії особистості полягає в такому. 3 одного боку, існують і розвиваються уявлення про структуру особистості, елементами якої $\epsilon$ так звані риси або властивості особистості, що відображають об'єктивну стійкість у поведінці людей та іiї нормативну соціальну оцінку. У рамках цього підходу розроблено багато психодіагностичних методик, здійснено теоретичні узагальнення щодо психології людей. Представники ж іншого методологічного напряму називають вищезгаданий підхід колекціонерським, таким, що зводить високе поняття особистості до суми якостей. В. А. Богданов констатує, що така ідейна несумісність сприймається як полярність природознавчого й ортодоксально-гуманітарного підходів. Вона існувала на всіх етапах розвитку знань про людину і $є$ виразом двох загальнонаукових традицій, які відомі з античних часів.

Особливості бачення світу в прихильників обох підходів відбиваються на особливостях постановки проблем структури, поведінки й розвитку особистості. Природознавчий підхід практикує причинне бачення світу, ортодоксально-гуманітарний - цільове.

Далі В. А. Богданов звертає увагу на те, що першою причинною концепцією світу було вчення Демокріта про атоми, вічні й незмінні першоелементи всього існуючого. На його думку, такий елемента- 
ристський варіант детермінізму упізнається у вченнях про хромосоми в генетиці, про віруси в медицині і т. ін. Такий же варіант пояснювальної схеми використовується і в роздумах про структуру особистості, яку зводять до сукупності ії властивостей. Суть явища при даному підході вважають похідною від природи іiі частин і їх внутрішніх зв'язків.

Ортодоксально-гуманітарний підхід демонструє відмову від зведення явища до першоелементів, концентрує увагу на якісних змінах, переходах об'єкта із стану в стан, які не змінюють, однак, втіленої в ньому мети. Останню визначають відносини об'єкта серед подібних до нього або відносини серед множини його власних станів. Головною характеристикою досліджуваного предмета тут є неперервність змін, що відбуваються в ньому (а звідси, і послідовність подій, що впливають на нього). Прихильники культурологічного (на відміну від наукового) знання схильні вважати, що поведінку особистості в принципі не можна передбачити, передбачити можна тільки масові соціальні процеси.

Підбиваючи підсумок, В. А. Богданов робить важливий висновок про необхідність і перспективність синтезу вищезгаданих шляхів пізнання, що доповнюють один одного, коли мова йде про складні об’єкти.

Фахівці зазначають, що в сучасній психології відбувається поступовий перехід від структурно-агрегатного опису особистості до аналізу їі динаміки як цілісної системи, що постійно змінюється і розвивається [15]. Цю тенденцію необхідно враховувати й педагогампрактикам, які працюють у сфері виховання (у тому числі й фізичного). Знання особливостей динаміки особистості - основа педагогічно ефективного впливу на неї. У психології особистості виділяють два класи понять, що відображають різні форми динаміки. Перший утворюють поняття психологічних новоутворень особистості (формування нових суб'єктивних відношень, позицій, рис особистості, нової системи цінностей, нового сенсу життя). Цей клас понять вказує на «стійкі» зміни особистості. Другий клас понять віддзеркалює «рухливі» зміни в психологічній організації особистості. Ці поняття відображають «функціонування» особистості в межах іiї сформованої організації. Сюди входять:

1) актуалізація і дезактуалізація вже вироблених психологічних механізмів, операцій, знань і умінь; 
2) зміна установок;

3) підвищення або зниження психічної напруги, інтелектуальних зусиль;

4) зміна психічних станів і т. ін.

Перший клас понять показує стійкі зміни особистості, у яких тим чи іншим чином трансформуються компоненти структури особистості, iii характеристики. Таку динаміку логічно буде назвати характеристичною, або глибинною. Сам процес зміни особистості може бути представлений траєкторією точки (або певної області, коли характеристики особистості розглядаються як нечіткі властивості) в просторі характеристик особистості.

Другий клас понять дозволяє подати поточні (теперішні) зміни стану людини. Таку динаміку логічно буде назвати функціональною, або поверхневою. Стани можуть бути як складними (наприклад, радість, горе, образа, вдячність, захоплення і т. ін.), так і простими (наприклад, актуалізація знань, підвищення інтелектуальної напруги i т. ін.). Такі процеси можуть бути представлені траєкторією точки (або певної області у випадку нечітких показників) у просторі психічних станів людини.

Між двома формами динаміки особистості людини існують тісні зв'язки. 3 одного боку, поверхова динаміка безпосередньо впливає на глибинну (зміна характеристик особистості відбувається під впливом функціонування цієї особистості). 3 іншого боку, функціонування особистості залежить від ії характеристик, що виробляються глибинними динамічними процесами.

Таким чином, повна динаміка особистості містить три складові: характеристичну, функціональну динаміку та взаємозв'язки між ними. Така структура повної динаміки може бути представлена математичною конструкцією іменованої множини [60]. При цьому взаємозв'язки між двома динаміками можна розглядати як цілком задані (i тим самим у даний момент статичні) і як процесуальні, тобто такі, що розвиваються в часі. У першому випадку як модель повної динаміки отримуємо іменовану множину 3 теоретико-множинним відношенням іменування. У другому відношення іменування буде процедурним.

Виконаний аналіз показує, що існуючі в психології особистості уявлення про цей феномен, про його психологічні, соціальні, біологічні та інші витоки також дають достатне теоретичне підгрунтя для 
постановки питання про психологічну й психофізичну підготовку в процесі фізичного виховання. Окрім цього, базуючись на сучасних уявленнях про структуру особистості, є можливість побудувати модель їі психологічної і психофізичної готовності.

На нашу думку, використання наукового доробку, отриманого у сфері психології особистості, дає можливість:

1) цілеспрямовано організувати навчально-виховний процес, орієнтований на формування психологічної і психофізичної готовності до праці;

2) виробити чіткі критерії та вимоги до студентів у процесі психологічної і психофізичної підготовки;

3) розробити ефективний зміст навчальної роботи студентів;

4) створити точні методи оцінювання професійно значущих характеристик особистості;

5) розробити ефективні засоби і методики їх формування у сфері фізичної культури та спорту.

\section{Висновки до розділу}

1. Теоретико-методологічний підхід до розуміння проблеми психологічної і психофізичної підготовки особистості студента в процесі фізичного виховання пов'язаний з аналізом таких фундаментальних питань, як психофізична проблема, взаємовплив організму і психіки, проблема особистості людини в психології.

2. У сучасній філософії і психології психофізична проблема розглядається в широкому сенсі як питання про відношення психічних явищ до фізичних, а в більш вузькому - як питання про співвідношення між психічними і фізіологічними процесами.

3. Варіанти вирішення психофізичної проблеми пропонували: Р. Декарт, Г. Лейбніц, У. Джемс, К. Гольдштейн, В. Франкл, С. Л. Рубінштейн, 3. Фрейд, представники психосоматичного підходу в медицині. Питання взаємодії психічного і фізичного розглядається i в такому розділі психологічних знань, як психологія розвитку. $€$ спроби теоретичного аналізу психофізичної проблеми і з боку психотерапії.

4. Серед психологів визнається залежність психіки від тіла. 
5. Характерною ознакою сучасної філософської думки є те, що одним із напрямків пошуку є звернення до проблеми фізичного в людині. Тіло людини визнається як один із найсуттєвіших чинників людського буття. При цьому підкреслюється хибність стереотипу розуміння тілесності, який відносить эї в суто природний світ. Звертається увага на те, що місце тілесності в людському бутті визначається не абстрактною ідеєю тіла, а колом тих можливостей існування, котрі виникають завдяки тілесності людини й мають ії за передумову.

6. Ряд вчень Сходу і Заходу звертають увагу на взаємозалежність організму і психіки людей. Насмперед це стосується типу тілобудови й темпераменту людей.

7. Психологічні чинники суттєво впливають на фізичні характеристики людини. Фізичні реакції організму на суб'єктивний стан особистості фіксуються на різних рівнях структури організму: фізіологічному, нейроанатомічному, нейрохімічному.

8. Існуючі в психології особистості уявлення про цей феномен, про його психологічні, соціальні, біологічні та інші витоки дають достатнє теоретичне підгрунтя для постановки питання про психологічну й психофізичну підготовку в процесі фізичного виховання. Окрім цього, базуючись на сучасних уявленнях про структуру особистості, є можливість побудувати модель психологічної і психофізичної готовності до професійної праці, розробити основи організації психологічної і психофізичної підготовки студентів.

9. Аналіз виконаних у розділі досліджень психофізичної проблеми, взаємовпливу організму і психіки людини, психології особистості дає підстави зробити важливі для фізичного виховання висновки:

- впливаючи на організм, можна формувати деякі психічні складові;

- впливаючи на психіку, можна змінювати перебіг деяких фізіологічних процесів у організмі. 
РОЗДІЛ 4

\section{Основи організації \\ психологічної і психофізичної підготовки \\ студентів залізничних ВНЗ \\ у процесі фізичного виховання}

\section{1. Психологічна й психофізична специфіка роботи на залізничному транспорті}

Залізничний транспорт є тією галуззю народного господарства, у якій особливо гостро відчувається роль і значення так званого людського фактора. Відповідно актуальними для нього $є$ і наукові дослідженя, пов'язані 3 цією проблематикою. Рівень роботи об'єктів транспорту, їх економічна ефективність, збереження вантажів, життя людей і багато іншого залежить від рівня професійності працівників залізничного транспорту.

Практичне значення якості підготовки фахівців у цій сфері зростає в міру зростання технічної оснащеності залізничного транспорту, підвищення швидкості руху поїздів, упровадження сучасних засобів управління і контролю. Саме це спрямовує пошук науковців того чи іншого профілю на вирішення проблем, які пов'язані з підготовкою залізничних кадрів. Зауважимо, що розуміння важливості цього питання існує давно. Досить сказати, що до 1936 року на всіх великих залізницях СРСР функціонували психологічні лабораторії. У наш час дослідження проблем залізничної психології ведеться 3 порівняно обмеженого кола тем: діагностика професійної придатності, професійний відбір, психологічні причини виникнення небезпечних ситуацій, реабілітація кадрів і т. ін. [79, 81, 164, 198, 262-264, 400, 405]. Особливо слід виділити праці А. Л. Сиркіної [382] і Т. А. Павлової [272]. 
А. Л. Сиркіна досліджувала ціннісно-смислову компоненту професійної мотивації спеціалістів локомотивних бригад. Вона виявила взаємозв'язок між професійно значущими особистісними особливостями цих спеціалістів (емоційна стійкість, високий вольовий самоконтроль, тривожність, напруженість, товариськість, нонконформізм, оптимістичність, соціальна інтроверсія) і показниками ціннісно-смислової сфери їх особистості.

Автор встановила і суттєві якісні розбіжності змісту ціннісно-смислової сфери залежно від рівня професійної успішності спеціалістів локомотивних бригад. Для найбільш успішних спеціалістів характерними є наявність і вираженість у категоріальній системі свідомості таких конструктів, як «професіоналізм», «професія машиніст» (належність до професії), «любов до своєї роботи», «акуратність».

Т. А. Павлова виконала дослідження питання формування професійно важливих якостей провідників пасажирських вагонів у процесі їх діяльності [261]. Об'єктом дослідження були професійно важливі якості провідників пасажирських вагонів, предметом дослідження психологічні умови й особливості формування професійно важливих якостей провідників пасажирських вагонів у процесі їх діяльності.

Автор припустила, що доповнення професійної діяльності провідника активними методами спрямованого формування професійно важливих якостей забезпечить розвиток особистісного потенціалу, що визначає успішність діяльності.

Т. А. Павлова виділила головні професійно важливі якості провідників пасажирських вагонів, а саме: силу і рухливість нервової системи, здатність виявляти зміни характеристик зовнішнього середовища, швидкість реакції, сприйняття тексту, мовні властивості, довгострокову й логічну пам'ять, відповідальність, емоційно-вольову стійкість, комунікативність, здатність регулювати поведінку, компромісність. Вказані якості автор розглядає як основу еталона професійної діяльності провідника пасажирських вагонів. До них вона також додає ще одну інтегральну характеристику, яку класифікує як готовність провідника до коректної взаємодії з пасажирами.

У ході дослідження було також перевірено ефективність розробленої Т. А. Павловою програми навчального ситуативного психологічного тренінгу. Він був спрямований на формування професійно важливих якостей провідників пасажирських вагонів. Результати ви- 
конаної роботи свідчать про підвищення рівня професійної діяльності провідників.

У той же час недостатньо дослідженими залишаються питання психологічної і психофізичної готовності фахівців до роботи на залізничному транспорті. Так, не вивчалися питання використання в зазначеному контексті фізичного виховання і спорту.

На залізничному транспорті є багато професій, які пов'язані з рухом поїздів. Головні з них пов'язані з управлінням рухомим складом залізниць і з організацією руху поїздів.

Основним завданням машиніста (тепловоза, електровоза) є безаварійне водіння поїздів, проведення маневрових робіт, виконання графіка руху поїздів та інших норм експлуатаційної роботи.

Професійними функціями машиніста $є$ :

1. Виконання вимог правил технічної експлуатації електровоза (тепловоза).

2. Забезпечення безаварійного водіння поїздів і проведення маневрових робіт.

3. Забезпечення стійкого і якісного виконання графіка руху поїздів та інших норм експлуатаційної роботи.

4. Використання засобів поїзного та маневрового радіозв'язку.

5. Виявлення й усунення несправностей рухомого складу.

6. Приймання і здача рухомого складу.

7. Контроль за діями помічника машиніста.

При управлінні рухомим складом фахівець перебуває в ситуації, коли потрібно керувати роботою двох самостійних систем, кожна 3 яких має свої канали зворотного зв'язку і свої специфічні об'єкти управління. В одній системі об'єктом управління є рухомий склад (тепловоз, електровоз). Так, машиніст сприймає інформацію про стан колії, сигналів, простору навколо залізниці і т. д. Обсяг інформування такого роду досить великий. Підрахунок подразнювачів, що діють на машиніста за період одного рейсу, показав, що загальна сума їх складає від 8 до 10 тисяч. 3 них тільки $10 \%$ виявляються виробничоважливими (світлофори, переїзди, обмежувачі швидкості і т. д.), інші у будь-який момент можуть ними стати.

Необхідна для діяльності машиніста безперервна зорова оцінка різних ділянок шляху часто здійснюється у вкрай несприятливих умовах: вночі, у туманну або дощову погоду і т. д. Така оцінка залежить перш за все від того, наскільки правильно вміє машиніст порівнювати 
різні просторові величини в нормальних умовах. Вона формується в процесі виробничого навчання, але $\epsilon$ й інші ефективні засоби іiї вироблення (у тому числі й ті, що належать до сфери фізичного виховання і психофізичної підготовки). Особливого значення вищезгадана неперервна оцінка набуває у випадках необхідності екстреного гальмування.

Другим об'єктом управління в діяльності машиніста є енергосистема локомотива. Інформація щодо ії роботи сприймається машиністом за показаннями приладів, через шум працюючої машини, вібрацію корпусу локомотива і т. ін. Регулююча дія тут передається прямо (через відповідні важелі) або опосередковано (через помічника машиніста).

Помічник машиніста електровоза (тепловоза) забезпечує безпечний рух поїздів під час залізничних перевезень пасажирів і вантажів. Він виконує доручення машиніста щодо догляду за локомотивом та його технічного обслуговування. У разі виявлення несправностей локомотива - вживає необхідні заходи з їх усунення. Він контролює роботу обладнання з безпеки та радіозв'язку.

У роботі помічника машиніста необхідні достатнє здоров'я, фізична сила й витривалість, висока гострота слуху й зору, швидка реакція, розвинений окомір (лінійний, площинний, об'ємний), здатність розподіляти і швидко переключати увагу, гарна зорова пам'ять.

Робота з організації руху поїздів пов'язана з виконанням функцій поїзного диспетчера або чергового по станції. Їх трудові операції суттєво відрізняються від роботи машиніста. Трудові дії останнього включають в себе, поряд зі сприйняттям, суттєвий фізичний компонент і $є$ просторовими. На відміну від цього, дії організатора руху поїздів являють собою сукупність психічних актів. Різниця між ними полягає в засобах здійснення діяльності, у характері інформації, що отримується, і способах іiі отримання.

I диспетчер, і машиніст «ведуть» поїзд, але якщо машиніст здійснює цю операцію, використовуючи зорову, слухову, вібраційну інформацію, оперує різними важелями управління, то диспетчер вирішує завдання з усунення всіх чинників, які перешкоджають руху поїзда. До операцій диспетчера входять деякі фізичні дії, однак ця фізична частина операції не є суттєвою для організації руху. Вона являє собою лише завершення якогось більш чи менш складного психічного процесу (процесів). 
Черговий по залізничній станції організовує роботу із забезпечення прийняття, відправлення, пропуску поїздів, маневрову роботу на станції, забезпечує виконання графіка руху поїздів, маневрової роботи і змінного плану роботи станції, керує стрілками і сигналами, готує маршрути прийняття, відправлення, пропуску поїздів і маневрів.

Головними професійними функціями цього спеціаліста є:

1. Ведення поїзної та іншої документації.

2. Виконання графіка руху поїздів і маневрів на станції.

3. Виконання операцій з приготування маршрутів прийняття, відправлення і пропуску поїздів і маневрових пересувань.

4. Використання в ході роботи комп'ютерів та іншої техніки для отримання і введення оперативної інформації.

5. Контроль правильності закріплення поїздів і вагонів на станційній колії гальмівними пристроями.

6. Контроль правильності підготовки маршрутів за показниками приладів управління.

7. Забезпечення безпечного руху поїздів.

8. Забезпечення виконання змінного плану роботи станції, наказів, розпоряджень і вказівок профільного міністерства, залізниці, відділення залізниці стосовно організації руху поїздів і маневрової роботи, безпеки руху, правил охорони праці й безпеки життєдіяльності.

9. Оперативне планування й керівництво роботою станції.

10. Керівництво роботою складачів поїздів та машиністів маневрових локомотивів у районі обслуговування.

11. Оформлення й видача попередження й дозволу на рух поїздів.

12. Оцінка обставин і керівництво рухом поїздів на станції.

13. Подання поїздів на технічний і комерційний огляд, контроль їх готовності.

14. Прийняття оптимальних рішень щодо організації руху поїздів, маневрової роботи і процесу перевезень з урахуванням ситуації, що склалась.

15. Участь у здійсненні вантажних і пасажирських перевезень.

Спостереження за роботою машиніста дозволили встановити, що однією з необхідних умов його праці повинна бути стійкість до монотонних впливів (висока концентрація і стійкість уваги). Для чергового по станції або поїзного диспетчера ця якість необхідна набагато менше. Зате він повинен володіти здатністю швидко змінювати один 
план дій на інший, приймати рішення в складних обставинах (високі показники переключення, об'єму, вибірковості уваги).

Слюсар з ремонту рухомого складу ремонтує локомотиви й вагони. Він визначає якість деталей, усуває дефекти складання. Під час ремонту - виконує заміну несправних деталей, регулює і випробовує складені й відремонтовані вузли.

Цей спеціаліст повинен мати достатню фізичну силу й витривалість, мати гарний зір і слух. Йому потрібна добра рухливість і точність кистей рук і пальців рук, точний окомір (лінійний і об'ємний), розвинена просторова уява, гарна пам'ять.

Слюсар-електрик 3 ремонту електрообладнання рухомого складу здійснює технічне обслуговування й ремонт електрообладнання електровозів, забезпечуючи їх безаварійну роботу. Його головними професійними функціями є: виконання електромонтажних робіт; виявлення й усунення неполадок електрообладнання, що обслуговується; здійснення підготовки електрообладнання до роботи в зимових і літніх умовах; розбирання і збирання, комплектація і ремонт електричних вузлів, апаратів, систем сигналізації, комутації, електрозахисту, розподільчих та захисних пристроїв, арматури електроосвітлення; розбирання і збирання електродвигунів; знімання і встановлення електричних машин, електричної апаратури, засобів автоматики та ін.; читання креслень і монтажних схем.

Електромонтер пристроїв сигналізації, централізації і блокування забезпечує безаварійну роботу й безпечну експлуатацію пристроїв сигналізації, централізації і блокування на залізницях, здійснює їх технічне обслуговування й ремонт. Головними професійними функціями $є$ : огляд пристроїв сигналізації, централізації і блокування; виконання поточного ремонту пристроїв; виявлення й усунення причин окремих несправностей пристроїв сигналізації, централізації і блокування; забезпечення утримання пристроїв сигналізації, централізації і блокування в суворій відповідності із затвердженими нормами й допусками, вимогами посадових і спеціальних інструкцій; здійснення технічного обслуговування, ремонту, монтажу і регулювання світлофорів, маршрутних і світлових дороговказів, стрілочних електроприладів і контрольних замків, стрілочних переводів, кабельних мереж електричної централізації пристроїв автоблокування, автоматичної поїздної сигналізації; заміна (разом 3 електромеханіком) приладів i окремих пристроїв електричної і диспетчерської централізації, 
напівавтоматики й автоматичного блокування, автоматики сортувальних гірок; читання електричних схем і креслень.

Професійна діяльність інженера на залізничному транспорті також потребує достатнього розвитку певних психологічних і психофізичних характеристик. Багато з них, зокрема достатній рівень розвитку об'єму, розподілу, концентрації та стійкості уваги, оперативного мислення, оперативної та довгострокової пам'яті, емоційної стійкості $\epsilon$ важливими для фахівців усіх інженерних професій на залізниці.

Окрім загальних, існують і спеціальні вимоги до психологічної і психофізичної підготовленості інженерів-залізничників, які випливають 3 особливостей конкретної спеціальності. Наведемо деякі приклади.

Спеціальності «Локомотиви та тепловозне господарство», «Вагони та вагонне господарство». Інженери цієї спеціальності в основному забезпечують технічну експлуатацію і ремонт тепловозів у депо та на заводах. Специфічні вимоги до підготовленості інженерів цього профілю визначаються необхідністю самому добре знати тепловоз чи вагон будь-якої марки, у потрібний момент вміти випробувати його, за необхідності організувати ремонтні роботи. Для цих спеціалістів важливі добрий стан зору, органів слуху, вестибулярного апарату, правильність та швидкість простих і складних реакцій на швидку зміну обставин, добра узгодженість і точність рухів рук та ніг, висока амплітуда рухів у суглобах. Важливе значення мають також здібність визначити відстань і швидкість руху на око, глибинний зір, об'єм, розподіл уваги на значну кількість об'єктів, вміння швидко і правильно приймати рішення у різних варіативних критичних ситуаціях, здатність зосереджуватися на довгий час, сприйнятливість до інформації, зібраність, впевненість.

Спечіальності «Електричний транспорт», «Електричні системи електропостачання», “Електромеханічні системи автоматизації та електропривід». Інженерам-електрикам часто доводиться разом 3 робітниками і техніками брати участь у ремонті й випробуваннях складного електрообладнання. Ця робота характеризується сприйняттям та переробкою великого об'єму зорової та слухової інформації, великою кількістю найрізноманітніших рухів, вимушеними позами стоячи, сидячи, навприсядки. Відрізняє іiї і значна емоційна напруженість. Інженер тут повинен мати добрий зір, добре сприйняття кольору, відмінний слух, який дозволятиме йому при випробуваннях 
електричних вузлів і апаратів виявляти за характером шуму їх несправності. Важливо також мати добрий вестибулярний апарат, який би забезпечував високу координацію і точність рухів рук. Чимале значення має і статична витривалість м`язів рук, спини та ніг. Невід’ємними якостями інженера цього профілю повинні бути спритність, швидка реакція. Окрім того, робота з обладнанням, яке перебуває під напругою, вимагає від людини великої уваги, зосередженості, сміливості, великої точності рухів рук.

Спеціальність «Мости і транспортні тунелі». Ця спеціальність висуває високі вимоги до психофізичних здібностей людини. Ефективність трудової діяльності тут залежить від високої вестибулярної стійкості в специфічних умовах, розвиненої сили й силової витривалості, сміливості, а також загартованості щодо різких перепадів атмосферних факторів. Важливі уміння плавати, надати допомогу потопаючому, використовувати різні плавзасоби.

Спеціальність «Організачія перевезень і управління на залізничному транспорті». Специфіка роботи спеціалістів цього профілю описана вище. Інженери спеціальності часто працюють диспетчерами залізничного транспорту. Ця робота висуває надзвичайно високі вимоги до таких характеристик уваги спеціаліста, як інтенсивність, об'єм, розподіл, переключення.

Підсумовуючи, зазначимо, що професії залізничного транспорту (як і інші професії) мають свою психологічну й психофізичну специфіку, отже, висувають і свої специфічні вимоги до підготовки фахівця. Це робить необхідним здійснення професійно орієнтованої психологічної і психофізичної підготовки під час навчання у вищому навчальному закладі.

\section{2. Зміст, засоби й основи організації психологічної і психофізичної підготовки студентів-залізничників}

Досліджуючи проблеми психологічної і психофізичної підготовки студентів-залізничників, ми виходили 3 діяльнісного розуміння формування психіки людини, продемонстрованого в роботах [2, 139, 201-203, 211, 329] та ін. Враховувались і результати сучасних дослі- 
джень методологічних проблем психології [21, 22, 69, 170, 233, 241, $243,369,404,444,489]$. Було вивчено також роботи, у яких розглянуто питання організації навчання $[112,180,406,446]$. Важливу роль відіграли і результати досліджень 3 теорії і методики фізичного виховання [76, 80, 236, 268, 271, 362, 373, 386, 387, 419, 427, 441].

Метою психологічної й психофізичної підготовки студентів-залізничників під час навчальних занять 3 фізичного виховання $є$ сприяння підвищенню ефективності професійного навчання й досягнення високої та стійкої працездатності при виконанні професійних функцій. Професійно необхідні компоненти структури особистості, навички та уміння, як відомо, формуються й удосконалюються насамперед у процесі навчання обраній спеціальності, а також у процесі самої праці. Але оволодіння робочими операціями відбувається значно швидше, якщо поєднувати процес професійного навчання зі спеціальною психологічною і психофізичною підготовкою. Недостатньо розвинена психологічна й психофізична готовність досить часто гальмує оволодіння професійною майстерністю.

У той же час необхідно підкреслити, що психологічна й психофізична підготовка не може замінити загальну й спеціальну фізичну підготовку, які є основою системи фізичного виховання. Важливим фактором забезпечення всебічної підготовки до виробничої праці є широка загальна і спеціальна фізична підготовка. Різнобічне й спеціальне виховання фізичних здібностей і систематичне збагачення фонду рухових навиків і умінь продовжує залишатися важливим завданням, не відміняється введенням психологічної і психофізичної підготовки.

Головними факторами, які визначають зміст психологічної і психофізичної підготовки студентів-залізничників, є:

1. Домінування розумової праці під час виконання професійних функцій.

2. Велика відповідальність за безпеку людей та збереження вантажів і пов'язане з цим психоемоційне перевантаження.

3. Високі специфічні (професійні) вимоги до різноманітних компонентів структури особистості фахівця.

4. Необхідність знання основ психології ефективного керування виробничим колективом.

Головним завданням, яке ставиться перед психологічною і психофізичною підготовкою студентів, є формування їх відповідної готов- 
ності до професійної праці. У зв'язку з цим логічним є питання про побудову моделі психологічної і психофізичної готовності фахівця. У цій роботі вихідним положенням дослідження психологічної і психофізичної готовності студента до професійної діяльності є іiї розгляд як певної підструктури особистості людини. Як наслідок, для побудови моделі психологічної і психофізичної готовності особистості необхідно орієнтуватися на ту чи іншу модель особистості. Найбільш відповідною, на думку автора, буде екстенсивно-кільцева модель особистості М. С. Бургіна $[58,59]$, яка вже описувалася в цій роботі. Грунтуючись на ній, $є$ можливість побудувати модель психологічної і психофізичної підготовленості особистості. Головною особливістю моделі є ïi ієрархічність. Основу моделі складають професійно значущі риси особистості, мотивація професійної діяльності та емоційна стійкість особистості. Ці компоненти найбільшою мірою визначають, насамперед, психологічну готовність до праці. Над ними розташована система знань стосовно структури психіки людини, можливостей регулювання власних емоцій і взаємовідносин з оточуючими. Вона також дуже важлива для психологічної готовності до праці. Наступний рівень складають особливості окремих психічних процесів (увага, відчуття, сприйняття, пам'ять, мислення, уява). Ці складові характеризують головним чином психофізичну сторону готовності до праці. Наступний рівень психофізичної готовності складає психомоторика людини. Схематично модель наведено на рис. 1. Структуризація психологічної і психофізичної готовності особистості сприяє розробці ефективних методів їі формування, дає можливість здійснювати педагогічний вплив більш цілеспрямовано.

Психомоторика фахівия

Особливості психічних проиесів

(увага, відчуття, сприйняття, пам'ять, мислення, уява)

Система знань стосовно структури психіки людини, можливостей регулювання власних емочій і взаємовідносин з оточуючими

Професійно значущі риси особистості, мотиваиія професійної діяльності, емоиійна стійкість

Рис. 1. Структура психологічної і психофізичної готовності фахівця 
Виходячи зі структури психологічної і психофізичної готовності фахівця психологічну й психофізичну підготовку студентів у процесі фізичного виховання можна умовно розділити на дві складові. Перша - це психологічна підготовка. До неї слід віднести формування професійно значущих рис особистості та емоційної стійкості, професійно значущої мотивації щодо професійної діяльності, роботу з оволодіння студентами системою професійно значущих психологічних знань. Друга складова - це психофізична підготовка. Вона включає роботу 3 розвитку в професійно значущому напрямку психічних процесів і психомоторики майбутнього фахівця.

Спрямованість психологічної і психофізичної підготовки інженерів-залізничників визначається головним чином вимогами, які висуваються до їх психологічної і психофізичної підготовленості, і можливістю реалізації цих вимог у процесі занять.

У роботі зі студентами-залізничниками можна виділити 4 головних напрямки психологічної і психофізичної підготовки, що складають іï структуру:

1) психологічна просвіта студентів;

2) навчання навичкам психічної саморегуляції, формування емоційної стійкості, профілактика засобами фізичного виховання невротичної поведінки у схильних до цього студентів;

3) розвиток психомоторики майбутнього фахівця, використання рухової активності для профілактики негативних впливів на психіку та зняття агресивності у студентів;

4) формування професійно значущих структурних компонентів особистості.

У рамках першого напрямку вирішуються завдання психологічної просвіти студентів-залізничників. Слід зазначити, що сьогодні в психології $є$ велика кількість наукових напрямків, які $є$ дуже корисні в плані вирішення цих завдань. Тільки в теорії особистості достатньо буде назвати психодинамічний, его-психологію, диспозиційний, біхевіоральний, соціально-когнітивний, когнітивний, гуманістичний, феноменологічний та інші напрямки. Зрозуміло, що ознайомити студентів з цим масивом, та ще й у рамках викладання навчальної дисципліни «Фізичне виховання», просто не реально. На нашу думку, оптимальним вибором тут може бути вивчення студентами основ структурного і трансакційного аналізу відомого американського психіатра Еріка Берна [29-31]. Він містить такі складові: 
1) структурний аналіз (аналіз структури особистості);

2) аналіз трансакцій (вербальних і невербальних взаємодій між людьми);

3) аналіз психологічних ігор (прихованих трансакцій, які приводять до бажаного результату (виграшу));

4) аналіз сценарію (індивідуального життєвого сценарію, відповідно до якого людина неусвідомлено діє).

Ще однією складовою психологічної просвіти студентів-залізничників $\epsilon$ їх ознайомлення 3 так званими копінг-стратегіями. Справа в тому, що результативність діяльності інженера-залізничника в екстремальних ситуаціях залежить від сформованості в нього ефективних стратегій копінг-поведінки. Назва «копінг» походить від англійського «соре», що означає «переборювати». У психології копінг пов'язується 3 психологічним подоланням стресу. Поняття було введене для опису усвідомлених стратегій подолання стресу [196].

У психології головними видами копінг-стратегій називають: стратегії «вирішення проблем», стратегії пошуку «соціальної підтримки», стратегії «уникання» [67]. Про перший випадок мова йде в разі застосування людиною особистісних ресурсів для пошуку результативних шляхів вирішення проблем. При другому - людина у важкій ситуації звертається за допомогою до оточуючих. У третьому випадку наявним є витіснення важкої ситуації зі свідомості. Доцільним вважається використання в різних ситуаціях різних поведінкових стратегій.

В іншій класифікації (С. Карвер та ін.) копінг-стратегії розподіляють так:

1) безпосередньо спрямовані на вирішення проблемної ситуації;

2) ті, що можуть сприяти адаптації людини до стресу, але не пов'язані з активним копінгом;

3) ті, що не належать до адаптивних стратегій, але в деяких випадках можуть допомогти в адаптації до стресу.

До перших стратегій відносять:

- активний копінг (активні дії з усунення джерела стресу);

- планування (планування своїх дій відносно проблемної ситуації, що склалася);

- пошук активної соціальної підтримки (пошук допомоги, поради у свого соціального оточення); 
- позитивне тлумачення та зростання (оцінка ситуації з погляду іiі позитивних сторін і ставлення до неї як до одного $з$ епізодів свого життєвого досвіду);

- прийняття (визнання реальності ситуації).

До стратегій другого роду включають:

- пошук емоційної соціальної підтримки (пошук співчуття та розуміння від оточуючих);

- придушення конкуруючої діяльності (зниження активності відносно інших справ і проблем і повне зосередження на джерелі стресу);

- заборона (очікування сприятливіших умов для вирішення ситуації).

До стратегій третьої групи включають:

- фокусування на емоціях і їх вираженні (емоційне реагування в стресовій ситуації);

- заперечення (заперечення стресової події);

- ментальне відчуження (психологічне відвернення від джерела стресу через розваги та ін.);

- поведінкове відчуження (відмова від вирішення ситуації). Знання студентами-залізничниками різних видів поведінки в стресових ситуаціях допоможе їм більш раціонально й ефективно діяти в разі їх виникнення.

На важливості вирішення вищезгаданого завдання наголошується і в дослідженні Б. Б. Величковського [72]. Об'єктом вивчення були способи адаптації людини до життєвих труднощів і напружених умов діяльності. Предметом - специфіка суб'єктивного відображення скрутних ситуацій і доступних ресурсів їх подолання у осіб з різним рівнем індивідуальної стійкості до стресу.

Дослідник прийшов до висновку, що індивідуальна стійкість до стресу являє собою системну динамічну характеристику, яка відображає здатність людини до успішного подолання труднощів. Відмітною ознакою високої стійкості до стресу є подолання гострого і хронічного стресу без негативних наслідків для психічного і фізичного здоров'я.

У ході дослідження було встановлено, що діагностика рівня індивідуальної стійкості до стресу повинна включати оцінку індивідуально-особистісних властивостей i їх взаємодій, що характеризують 
особливості індивідуальних способів подолання труднощів на основі суб'єктивного образу стресогенної ситуації.

Б. Б. Величковський розробив схему багатовимірної оцінки індивідуальної стійкості до стресу. До її складу він включив диспозиційні і ситуативні оцінки когнітивно-афективних комплексів тривоги, депресії і гніву, а також показники міри виснаження функціональних ресурсів забезпечення діяльності. Експериментальна перевірка багатовимірної оцінки стійкості до стресу підтвердила іiі діагностичну ефективність.

Автор також встановив, що висока індивідуальна стійкість до стресу нейтралізує вплив психологічних стрес-факторів, які виникають в особистому житті й професійному середовищі людини. Він виявив і психологічні механізми, які підвищують ефективність поведінки подолання. До них віднесено високу позитивну емоційну гранулярність і зниження суб'єктивно сприйманої напруженості діяльності у випадку ускладнення умов іiї виконання.

Цікаве дослідження особистісних факторів емоційної дезадаптації студентів виконала М. В. Москова [250]. Об'єктом дослідження були особистісні фактори емоційної дезадаптації студентів. Предметом перфекціонізм і ворожість як фактори емоційної дезадаптації студентів. Метою роботи стало вивчення взаємозв'язку перфекціонізму й ворожості з показниками емоційної дезадаптації студентів.

У студентів ВНЗ автор виявила високий рівень емоційної дезадаптації. Він проявлявся, зокрема, у симптомах депресії, тривоги, інтенсивному повсякденному стресі. При цьому у студентів першого курсу було зафіксовано більш високі суїцидальні показники й показники інтерперсонального стресу. У студентів третього курсу - більш високі показники академічного стресу.

М. В. Москова виявила в студентів 3 високим рівнем перфекціонізму достовірно вищі показники емоційної дезадаптації (порівняно зі студентами з помірним і низьким рівнем перфекціонізму). У цієї категорії студентів було виявлено й достовірно більш високі (порівняно зі студентами з помірним і низьким рівнем перфекціонізму) показники різних форм подолання стресу.

У ході дослідження встановлено, що для студентів з високим рівнем ворожості характерними є більш високі показники емоційної дезадаптації (порівняно зі студентами з помірним і низьким рівнем ворожості). 
М. В. Москова зафіксувала достовірну позитивну кореляцію перфекціонізму 3 такими характеристиками особистості, як нейротизм і відкритість досвіду. Достовірна негативна кореляція перфекціонізму була зафіксована 3 такою характеристикою, як доброзичливість. Що стосується ворожості, то тут було зафіксовано достовірну негативну iї кореляцію зі свідомістю. Для студентів з високим рівнем ворожості характерним був брак самоорганізації й відповідальності та недостатня добросовісність.

На нашу думку, дані, наведені в дослідженні М. В. Москової, є ще одним свідченням на користь необхідності проведення психологічної і психофізичної підготовки студентів вищих навчальних закладів.

Тематика лекцій для розділу психологічної просвіти така:

1. Теорії особистості людини в сучасній психології (компоненти, критерії оцінки, головні положення стосовно природи людини) 4 год.

2. Структурний аналіз за Е. Берном (структура особистості за Е. Берном) - 2 год.

3. Функція особистості (реакція на стимули, потік зміщення, кордони «Я», проблема «себе істинного», зісковзування в стани «Я», критерії станів «Я») - 2 год.

4. Аналіз трансакцій -2 год.

5. Аналіз ігор - 2 год.

6. Аналіз взаємовідношень - 2 год.

7. Копінг-стратегії поведінки в стресових ситуаціях - 2 год.

Другою надзвичайно важливою професійно значущою складовою психологічної і психофізичної підготовки студентів-залізничників $\epsilon$ навчання навичкам психічної саморегуляції, формування емоційної стійкості особистості майбутнього фахівця та профілактика невротичної поведінки (засобами фізичного виховання) у схильних до цього студентів. Саме вони в багатьох випадках можуть визначати ефективність діяльності майбутнього залізничника. Це пояснюється складністю і відповідальністю, які супроводжують виконання професійних функцій на залізниці. Існує ще низка чинників, які вимагають звернути серйозну увагу на формування емоційної стійкості майбутніх фахівців. Серед них можна назвати збільшення стресогенності сучасного суспільства, неухильне зростання в людей психічних розладів, пов'язаних з тривогою і депресією, поширення антисоціальної поведінки. У зв'язку з цим сьогодні фахівці констатують значне зростання 
досліджень емоційної сфери людей в зарубіжній психології [273]. Такі дослідження проводяться і в Україні та Росії $[1,11,70,173,208$, $236,318,372$ та ін.]. Не можна ігнорувати й факт надзвичайного зростання психологічних (і насамперед емоційних) навантажень на людину в сучасному світі. Як зазначають психологи [357], стала типовою для життя і діяльності людини необхідність приймати відповідальні рішення в ситуаціях 3 невизначеністю, яка пов'язана 3 дефіцитом або надлишком вхідної інформації. Це, зокрема, є характерним для більшості видів складної професійної діяльності, якими є й інженерні спеціальності залізничного транспорту. Сьогодні ставиться питання про формування стресостійкості особистості, яка суттєво впливає на професійну діяльність в екстремальних умовах, забезпечує збереження працездатності та здоров'я [74, 83, 174]. Активно досліджується і питання формування емоційної стійкості майбутніх педагогів [94, 336, 337]. У вирішенні зазначеної проблеми треба використовувати весь можливий комплекс засобів, у тому числі й засоби фізичного виховання. Такий погляд, очевидно, відстоює й відомий дослідник Ю. Л. Ханін, який вивчав питання управління емоційним станом студентів засобами фізичного виховання [412].

У психології емоціями прийнято називати сильні психічні стани, які зазвичай пов'язані зі збудженням або високим рівнем енергії [175, с. 1020]. Емоції розділяють на позитивні й негативні. Найбільш впливовою (незважаючи на аргументовану критику) теорією емоцій продовжує залишатися концепція Джемса-Ланге. Відповідно до неї емоції складаються з тілесних змін і психічних переживань. Психічне переживання, специфічне для емоцій, на їхній погляд, є наслідком тілесних змін. Емоції розглядаються як наслідок органічних змін, які виникають у тілі людини, що реагує на об'єкт, який викликає збудження. Саме емоційне переживання складається із трьох фаз:

1) сприйняття об'єкта, який приводить до збудження;

2) зовнішній прояв емоцій (плач, втеча і т. ін.);

3) психічний вплив, або власне емоція (гнів, страх і т. ін.).

У психології виділяють три види прояву емоцій: як реакція, як стан і як риса особистості. Підгрунтям для такого розподілу стала тривалість існування емоцій. У той же час розподіл емоційних проявів не означає, що вищезгадані сторони не можуть бути взаємопов'язані. Навпаки припускається їх взаємозумовленість. Це дозволяє 
на основі знання особливостей одного 3 проявів емоцій робити висновки про особливості інших.

У психології цікаві дослідження емоційної сфери людей виконуються і в рамках проблеми регуляції емоцій. Під нею розуміють комплекс психічних процесів, які підсилюють, послаблюють або підтримують на одному рівні інтенсивність емоційних реакцій людини [462]. Аналіз цих досліджень зробив М. А. Падун [262]. Він пропонує розділяти регуляцію емоцій на такі складові:

1) регуляція емоцій як процес, що відображає розгортання регуляторних зусиль у часі;

2) регуляція емоцій як властивість, що пов'язана з індивідуальними відмінностями в способах регуляції, які використовуються.

У рамках дослідження регуляції емоцій як процесу виявлено:

1. Емоційні реакції $є$ наслідком суб'єктивної оцінки емоційно значущого стимулу [488].

2. Послідовність розгортання емоційної реакції складають: ситуація, увага, оцінка, реакція.

3. Ситуація, що викликає емоційну реакцію, може бути і зовнішньою, і внутрішньою [472].

4. Дослідники [479] класифікують стратегії регуляції емоцій на такі, що передують реакції, і такі, що фокусовані на реакції. Перші пов'язані з регулюванням емоцій до того моменту, коли емоційна реакція виникла. Другі використовуються у випадках, коли емоційне реагування вже почалося. До стратегій, що передують реакції, належать:

- вибір ситуації (коли людина включається в одні ситуації і уникає інших з метою регуляції емоційного стану);

- модифікація ситуації (коли є можливість повністю або частково змінити обставини, що піддаються контролю людини);

- розподіл уваги (вибір тих сторін ситуації, на які слід звертати увагу);

- когнітивні зміни (переоцінка значення ситуації).

До сфокусованих на реакції стратегій відносять зміну емоційної реакції. Як спосіб зміни використовуються: релаксація, фізичні вправи, медикаменти, емоціонально-експресивна поведінка, придушування експресії емоцій. 
У рамках дослідження регуляції емоцій як властивості виявлено:

1. Використання стратегії переоцінки емоційної реакції негативно пов'язане з нейротизмом у людей, а використання стратегії придушування негативно корелює з екстраверсією [473].

2. Використання стратегії придушування емоцій значуще корелює 3 неаутентичністю (розходженням внутрішнього стану людини 3 тим, що вона демонструє у своїй поведінці).

Аналіз використання поняття «емоційна стійкість» у науковій літературі показує, що в його розумінні існують суттєві розбіжності. Так, одні автори (П. Фрес, Є. А. Мілерян, О. А. Чернікова та ін.) емоційну стійкість розуміють як емоційну стабільність, стійкість певного емоційного стану. За такого підходу емоційна стійкість зводиться до відсутності реагування на емоціогенні ситуації. Інші фахівці (В. М. Писаренко) вбачають в емоційній стійкості переважання у людини позитивних емоцій. В. Л. Маріщук трактує емоційну стійкість як здатність долати стан надмірного емоційного збудження в ході виконання складної діяльності. Для Л. М. Аболіна емоційна стійкість тотожна стійкості продуктивності діяльності, що виконується в напружених умовах. Деякі науковці критерієм емоційної стійкості називають ефективність діяльності в емоціогенній ситуації (О. А. Сиротін, В. М. Смирнов, А. І. Трохачов). Емоційну стійкість також пов'язують зі здатністю до контролю над проявом емоцій (Я. Рейковський, Ю. Н. Кулюткін, Г. С. Сухобська, Н. А. Амінов). К. К. Платонов у структурі емоційної стійкості виділяє емоційно-вольову, емоційно-моторну й емоційно-сенсорну стійкість. М. I. Дьяченко i В. А. Пономаренко ще більше розширюють зміст поняття, трактуючи його як властивість особистості й психічний стан, що забезпечують доцільну поведінку в екстремальних ситуаціях.

Питання оптимізації емоційної стійкості особистості студента через навчальну діяльність вивчав В. Р. Сари-Гузель [341]. Метою дослідження стало з'ясування психологічних особливостей формування емоційної стійкості особистості студента через навчальну діяльність і виявлення умов іiі оптимізації. Об'єктом вивчення була навчальна діяльність як засіб розвитку емоційної стійкості. Предметом - формування емоційної стійкості особистості студента і іï оптимізація в умовах цілеспрямованого психологічного впливу.

Дослідник встановив, що на успішність навчальної діяльності студентів суттєво впливає високий рівень емоційної стійкості особисто- 
сті. Розвиток цієї якості особистості в студентів відбувається стихійно і не є об'єктом цілеспрямованої систематичної роботи педагогів.

У ході експериментальної роботи автор виявив, що для студентів з усталено низьким рівнем емоційної стійкості властивим $є$ загальне зниження інструментальної діяльності, спрямованої як на досягнення успіху, так і на уникання неуспіху. Це призводить до зниження в них сили мотивації. На противагу їм, студенти, що мали більш високий рівень емоційної стійкості, мали й більш високий рівень очікування успіху й характеризувалися вищим рівнем позитивного емоційного стану.

В. Р. Сари-Гузель зафіксував у студентів з усталено низьким рівнем емоційної стійкості виражену ситуативну тривожність на фоні високої особистісної тривожності. У студентів, які показали низьку ефективність у процесі напруженої діяльності під час екзаменів, було зафіксовано виражену екстернальність у сфері досягнень.

Автор встановив, що проявами емоційної стійкості під час виконання напруженої діяльності $\epsilon$ : очікування невдачі, переживання невпевненості в собі, блокування інструментальної діяльності, спрямованої на досягнення успіху, зниження сили мотивації.

У ході виконання роботи В. Р. Сари-Гузель виявив, що зниження емоційної стійкості як стану характеризується зростанням ситуативної тривожності, але не викликає змін особистісної тривожності у студентів.

Глибокий аналіз підходів до розуміння природи емоційної стійкості людини виконала в своїй роботі І. Ф. Аршава [19]. Вона звертає увагу на те, що при всіх підходах загальна схема розкриття сутності емоційної стійкості відбувається через оцінку рівня складності умов професійної діяльності щодо визначення іiі ефективності (як ознаки емоційної стійкості). Це призводить до того, що операційна напруженість, яка в багатьох випадках забезпечує ефективну діяльність, може помилково розглядатись як емоційна стійкість. І. Ф. Аршава пропонує розглядати емоційну стійкість та емоційну вразливість за критерієм їх значущості для успішності врівноваження суб'єкта із змінюваним середовищем, спрямованого на збереження або відтворення гомеостазу. Показниками емоційної стійкості при такому підході $\epsilon$ асиміляційна й акомодаційна активність. Основною формою їх виявлення буде збереження гомеостазу. Показниками ж емоційної 
вразливості будуть ускладнення в урівноваженні із змінами середовища. Формою їх виявлення є зміна функціонального стану.

У своїй роботі ми будемо використовувати поняття «емоційна стійкість» у тому сенсі, як його розуміють Б. А. Душков, А. В. Корольов і Б. А. Смирнов [119]. Цим поняттям вони позначають здатність людини до збереження стійкості психічних і психомоторних процесів, до підтримання професійної ефективності в умовах впливу емоціогенних чинників.

Емоційна стійкість має певну мінливість. Несприятливий функціональний стан, недостатня підготовленість до діяльності тощо можуть іiі знижувати. 3 іншого боку, суттєво підвищити ії можуть висока професійна підготовка, до складу якої входить спеціально організована психологічна й психофізична підготовка, адаптація до можливих емоціогенних чинників, відчуття впевненості у своїх силах.

Фахівці виділяють також емоційну стійкість під час певної професійної діяльності, яка сформувалася внаслідок гарної підготовки до неї. Можна, наприклад, говорити про емоційну стійкість диспетчера, водія і т. ін. Види емоційної стійкості можуть демонструвати взаємний перенос, але можуть його й не мати. Вважається також, що всі вони залежать від певного загального рівня емоційної стійкості, який характерний для особистості в найбільш загальних рисах.

Емоційна стійкість проявляється в разі настання емоційної напруги. Чим нижче рівень емоційної стійкості, тим більш швидко настає емоційна напруга. За Г. Сельє першою фазою реакції людини на емоційну напругу є реакція тривоги (людина реагує на напругу входженням у стан тривоги). Проявами тривоги на фізіологічному рівні $\epsilon$ прискорення серцебиття і дихання, підвищення артеріального тиску, зростання загальної збудженості, зниження порогу чутливості, на психологічному рівні - напруга, стурбованість, нервозність, відчуття невизначеності й загроза невдачі, неспроможність прийняти рішення та ін. Водночас, як показують дослідження, залежність між станом тривоги й результативністю діяльності далеко не однозначна. Про це, зокрема, свідчать і результати досліджень у сфері психології спорту. Тут завжди приділяли увагу можливості покращення спортивних результатів через контроль рівня тривожності спортсменів до і під час змагань. Склалася низка підходів щодо управління тривожністю спортсменів. Їх у своїй роботі аналізують У. П. Морган і К. А. Сліксон [249]. Перший вони називають «теорією спонукання». Вона спи- 
рається на дослідження [478] і обгрунтовує точку зору, відповідно до якої зростання збудження призводить до покращення результативності діяльності. У той же час дослідження $[474,475,495]$ дають підстави для сумніву в правильності постулату теорії спонукання.

Другий підхід (теорія перевернутого U) базується на думці про те, що результати спортсмена покращуються в міру зростання збудження, але тільки до певної межі, після проходження якої зростання збудження призводить до зниження результатів. Критикуючи цей підхід, ряд дослідників $[486,490]$ роблять акцент на тому, що абсолютні значення рівня збудження (які є основними для цієї теорії) менш важливі, ніж динаміка цих рівнів і методи, які застосовує спортсмен для контролю ситуативної тривоги. У той же час теорія $є$ досить популярною.

В основі третього підходу лежить концепція порогу (парадоксального дистанційного ефекту) [496]. Вона, як і попередня, пов'язує зростання результату залежно від зростання збудження до певного рівня i його погіршення після досягнення цього рівня. Але, на відміну від неї, тут мова йде не про певний інтервал для оптимального рівня збудження, а про його певне (дискретне) значення.

Четвертий підхід - це так звана теорія релаксації. Вона побудована на припущенні про те, що стан спокою позитивно впливає на показ спортсменом бажаних результатів на змаганнях. Загальна схема тут протилежна тій, що характерна для теорії спонукання. Зусилля спрямовуються на розслаблення, зменшення напруженості спортсмена. Деякі дослідження [476] заперечують постулати цієї теорії.

П'ятий підхід представлений теорією оптимального збудження, яка сформувалася на роботах Ю. Л. Ханіна [476]. Її зміст зводиться до такого. Припускається, що в кожної людини є своя «зона оптимального функціонування». Якщо рівень збудження перебуває в межах цієї зони, то ефективність діяльності людини буде найвищою. Відповідно до цієї теорії одні спортсмени зможуть показати свої найкращі результати під час найвищого збудження, другі - під час розслаблення, треті - за умови помірного рівня збудження.

У. П. Морган та К. А. Єліксон приводять також результати власних досліджень впливу фізичних вправ на тривожність. Так, ними було виявлено [494], що ситуативна тривожність збільшується відразу після фізичного навантаження, але суттєво знижується по закінченні короткого проміжку часу (як фізичне навантаження використо- 
вувався біг протягом 45 хв). У пізніших дослідженнях [467] було підтверджено гіпотезу про те, що до суттєвого зниження ситуативної тривожності приводять фізичні вправи 3 певним (досить високим) порогом інтенсивності. У той же час $є$ й дані [501], які свідчать про те, що фізична активність не є більш ефективною для зниження тривожності, ніж, наприклад, відпочинок у тиші. Відмінність полягає в тому, що вплив фізичних вправ зберігається більш тривалий проміжок часу, ніж після відпочинку [500].

За даними [493], від 10 до 30 \% пацієнтів, які звертаються до терапевтів, мають неврози, що пов'язані з тривожністю. Ці люди страждають від синдромів, які характеризуються нездатністю протистояти стресам.

На нашу думку, більш ефективним напрямком використання засобів фізичної культури для зменшення рівня тривожності в студентів $\epsilon$ не просте використання будь-якої фізичної активності (яка скоріше призводить до «відволікань», а не до зменшення чутливості до стресу), а їх залучення до занять тими видами спорту, які підвищать впевненість у власних силах. Для чоловіків це єдиноборства, атлетизм, для жінок - художня та спортивна гімнастика, аеробіка і т. ін.

Цей напрямок психологічної і психофізичної підготовки студентів повинен бути спрямований, у тому числі, і на використанні іiі для профілактики і психотерапії неврозів. Як зазначають психіатри [86, с. 38], невроз - це психозахисне пристосування до реальності не впевненої в собі людини, яке спричинене психологічною травматизацією і проявляється в трьох формах: «капітуляції, відказу» (неврастенія), «надзахист» (невроз нав'язливих станів) і «індивідуальної» реакції, «втечі у хворобу» (невроз істерії).

Фахівці вважають, що шлях у невроз починається 3 виникнення почуття невпевненості в собі. Цьому сприяє низька адаптивність низькі природжені психофізичні дані, наявність психофізичного дефекту й соціальні фактори: неправильне виховання, несприятливі умови життя, невдачі й досвід несприятливого впливу осіб, що оточують індивіда, конфлікти з іншими [86, с. 38].

Таким чином, спеціалісти вважають, що в патогенезі неврозів як його обов'язкові складові наявні насамперед почуття невпевненості в собі й психологічний захист. Головним у психотерапії неврозів вони називають подолання відчуття невпевненості [86, с. 42]. 
Впевненість у собі розглядається також як необхідна умова існування особистості як суб'єкта активності, здатного до самостійного вибору цілей [301]. Л. О. Глушко [92] виконав порівняльний аналіз розуміння поняття впевненості в працях вітчизняних і зарубіжних психологів. Автор констатує існування різних поглядів щодо розуміння поняття і визначає такі чотири головних напрямки дослідження:

1) впевненість у собі як риса особистості;

2) впевненість у правильності власних суджень;

3) впевненість як перевага процесів збудження над процесами гальмування;

4) впевненість у собі як психічний стан.

Л. О. Глушко наводить і власний погляд на природу впевненості в собі, розглядаючи їі як властивість особистості, «ядром якої є позитивна оцінка індивідом власних навичок та здібностей як достатніх для досягнення значущих для нього цілей та задоволення його потреб. Важливим при формуванні впевненості в собі є не стільки об'єктивний життєвий успіх, статус тощо, скільки суб'єктивна позитивна оцінка результатів власних дій та оцінки, що надходять з боку значущих людей» [92, с. 97].

Іншим конструктивним методом переборення відчуття невпевненості, що може результативно використовуватися в межах психологічної і психофізичної підготовки, є компенсація. $Є$ люди з такими фізичними або іншими вадами, які неможливо усунути. Вони повинні мати достатню компенсацію в тому, що в них може бути розвинено добре. Однією зі сфер, де доцільно вести пошук для такої компенсації, є фізична культура і спорт. Яскравий приклад цього - параолімпійський рух, завдяки якому багато людей у світі знайшли сенс у своєму житті. У рамках психологічної і психофізичної підготовки таким людям можна надати допомогу в плані пошуку шляхів ефективної адаптації до занять спортом.

Виконаний аналіз свідчить на користь необхідності й важливості включення до структури психологічної і психофізичної підготовки студентів роботи з профілактики невротичної поведінки у схильних до неї студентів. Її зміст спрямований на подолання (зменшення) тривожності, в основі якої лежить відчуття неспроможності особистості. Тривожність являє собою індивідуальну психологічну особливість, яка проявляється в схильності людини до частих і інтенсивних 
переживань стану тривоги та в низькому порозі його виникнення. У психології вона розглядається як особистісне утворення і як властивість темпераменту, зумовлена слабкістю нервових процесів.

У рамках проведення психологічної і психофізичної підготовки студентів доцільною є така послідовність в роботі. На початку навчального року виконують психологічну діагностику тривожності. 3 цією метою може бути використана шкала «прояву тривожності» $[49$, с. 32], яка являє собою особистісний опитувальник, що призначений для виміру прояву тривожності (див. дод. 4). Після обробки матеріалів психологічної діагностики студентів, у яких виявлено дуже високі й високі показники тривожності, зараховують до окремих навчальних груп навчальної секції фізичного виховання або фізичної реабілітації. Робота в цих групах будується навколо подолання почуття неспроможності, яке викликає тривогу. Ставиться завдання набути й закріпити якості, що сприяють адаптації людини.

Як зазначають психотерапевти [86, с. 43], ефективними в цьому плані $є$ і засоби фізичного виховання. Насамперед (для чоловіків) це стосується занять єдиноборствами (боротьба, бокс, карате, айкідо i т. ін.) і атлетизмом (важка атлетика, пауерліфтинг і т. ін.). Саме до занять цими видами спорту (на вибір) необхідно залучати студентів з високими показниками тривожності.

Ефективним у плані профілактики невротичної поведінки є також використання вправ для формування навиків саморегуляції психічного стану (сахаджа-йога, аутогенне тренування тощо). Вони можуть поєднуватись із заняттями вищезгаданими видами спорту.

У кінці семестру знову виконується діагностика тривожності в студентів. Отримані дані використовуються для коректування навчально-виховного процесу на перспективу.

Третій аспект психологічної і психофізичної підготовки студентів, який реалізовується в рамках викладання фізичного виховання, пов'язаний з розвитком психомоторики майбутнього фахівця та з використанням механізму профілактичного і лікувального впливу рухової діяльності на психіку людини (виникнення в головному мозку під час скорочення м'язів нового осередку збудження). Останній аспект пояснимо детальніше.

Енергія, приплив сил, приємні емоції, які мимоволі відчуває людина, виконуючи фізичну роботу, підсилюють потенціал «м'язового осередку збудження». Імпульси від цієї ділянки поширюються на су- 
сідні відділи кори головного мозку і пригнічують застійні осередки збудження, що пов'язані з негативними емоціями. При цьому неприємні, гнітючі думки непомітно зникають і на зміну тривожному, напруженому стану приходить відчуття бадьорості, а в корі головного мозку і внутрішніх органах відбуваються відновлювальні процеси. Усе це поряд 3 покращенням кровообігу, посиленням постачання органів і тканин поживними речовинами і киснем сприяє нормалізації діяльності як нервової системи, так і організму в цілому.

У свій час I. М. Сеченов показав, що найбільш сприятливими і продуктивними для людини $є$ такі види і режими роботи, при виконанні яких відбувається зміна навантаження, зміна груп працюючих м'язів. Він експериментально довів, що працездатність відновлюється швидше і повніше не під час пасивного відпочинку, а коли виконується спеціально організована робота іншими, не втомленими частинами тіла. Саме цей, зафіксований I. М. Сеченовим феномен активного відпочинку лежить в основі усіх рекомендацій щодо широкого застосування засобів фізичної культури для підтримання й відновлення розумової і фізичної працездатності.

Повною мірою це стосується і використання психологічної і психофізичної підготовки в процесі навчальних занять 3 фізичного виховання як важливої умови результативної професійної діяльності інженерів-залізничників. Їх праця - праця в основному розумова. Досвід показує, що при такій роботі суттєві результати можуть бути отримані лише за умови тривалої і наполегливої зосередженості на розв'язанні завдання. За таких обставин знаходити резерви для відпочинку й відновлення слід не в зниженні розумових зусиль, а в активному відпочинку. Завданням психологічної і психофізичної підготовки в даному контексті є підбір найбільш ефективних засобів фізичної культури і спорту з урахуванням індивідуальних психологічних особливостей студентів.

Робота м'язів стимулює велику кількість нервових імпульсів, що надходять до головного мозку й збагачують його безліччю відчуттів. Тим самим мозок підтримується в нормальному робочому стані. У період напруженої розумової праці в людей часто спостерігається зосереджений вираз обличчя, стиснуті губи. Це відбувається тому, що імпульси, які надходять від напружених м'язів до центральної нервової системи, стимулюють діяльність головного мозку, допомагають йому підтримувати потрібний тонус. 
Виконання діяльності, яка не потребує фізичних зусиль і точно координованих рухів, часто супроводжується напруженням м'язів шиї, плечового поясу, обличчя, мовного апарату. Це пояснюється тим, що їх активність тісно пов'язана з функціонуванням нервових центрів, які керують проявом уваги, емоцій, мови.

Тривала робота призводить до втоми тіла й нервової системи. Внаслідок цього компенсаторне напруження поширюється на ті групи м'язів, які безпосередньо не стосуються роботи, що виконується. Наприклад, якщо людина швидко і довго пише (студент на лекціях), напруження поступово зміщується від пальців до м'язів плеча і плечового поясу. Таким чином нервова система намагається активізувати кору головного мозку, підтримує працездатність. Якщо це відбувається достатньо довго і монотонно, то мозок звикає до подразнювачів і починається процес гальмування. Внаслідок цього працездатність знижується. Кора головного мозку більше не може переробляти нервове збудження, воно розподіляється по всіх м'язах, які стають джерелом монотонних імпульсів. Для того щоб зняти нервове збудження і звільнити м'язи від зайвого напруження, необхідні рухи.

Тонус і працездатність головного мозку може підтримуватися протягом тривалих проміжків часу у випадку, коли скорочення і напруження різних груп м'язів ритмічно чергується з подальшим розтягненням і розслабленням. Такий режим рухів характерний для ходьби, бігу, пересування на лижах, ковзанах і багатьох інших рухів, які виконуються ритмічно і з помірною інтенсивністю.

Важливу роль відіграє і стан м'язової системи, яка допомагає нервовій системі справлятися 3 інтелектуальними навантаженнями. Не буде перебільшенням сказати, що для успішної розумової праці потрібен не тільки тренований мозок, але й треноване тіло. Ця теза підтверджується науковими даними про те, що стійкість і активність пам'яті, уваги, сприйняття суттєво залежать від рівня фізичної підготовленості людини.

Оптимально підібране м'язове навантаження підвищує загальний емоційний тонус, створює позитивний настрій, що служить сприятливим фоном для розумової діяльності. Фізичні вправи ніколи не сприймаються організмом людини як щось нав'язане ззовні, вони $\epsilon$ природними для людини. У сучасних умовах сильні м'язи $є$ тим резервом, який допоможе людині протистояти величезному натиску 
нервових і психоемоційних перевантажень, зберегти здоров'я і високу працездатність.

Для реалізації третьої складової психофізичної підготовки в університеті необхідно довести режим рухової активності студентів до 8-10 год на тиждень (як і передбачено навчальною програмою 3 фізичного виховання). Реалізація цього завдання можлива за таких умов:

1. Формування у студентів потреби в систематичних заняттях фізичною культурою і спортом.

2. Наявності якісної, різнопрофільної спортивної бази в університеті.

3. Проведення обов'язкових навчальних занять 3 фізичного виховання в обсязі 4 навчальних годин на тиждень протягом всього періоду навчання студентів (за винятком останнього семестру).

4. Організація роботи в позанавчальний час великої кількості різноманітних спортивних секцій з вільним доступом для студентів.

5. Проведення в позанавчальний час різноманітних (враховуючи інтереси студентів) спортивно-масових заходів.

До цього ж напрямку доцільно віднести використання спорту, фізичного виховання, психофізичної підготовки для зняття агресивності. Заняття спортом дають вихід агресивності спортсмена завдяки створенню можливості контрольованого й спрямованого емоційного реагування. Специфікою спорту є те, що спортивні норми й правила змушують учасників суворо контролювати свої дії і емоції в певних ситуаціях. Спортсмени повинні бути терплячими, вчитися поводити себе належним чином. Як форма соціальної організації спорт вимагає від спортсменів пасивного стримування. Він сприяє збереженню психічного здоров'я і душевної рівноваги. При цьому є можливість дати вихід природній агресивності й прагненню до суперництва.

Четвертий аспект пов'язаний з формуванням в рамках навчальновиховного процесу 3 фізичного виховання професійно значущих структурних компонентів особистості. Практично при вивченні всіх навчальних дисциплін робота будується так, щоб передати учням або студентам необхідний обсяг знань. Але в структурі особистості крім знань $\epsilon$ ще багато компонентів, які необхідно цілеспрямовано формувати. Саме психологічна й психофізична підготовка має суттєвий потенціал для вироблення таких структурних компонентів особистості, як професійно значущі риси особистості, відчуття, різні характерис- 
тики уваги й багато інших. Пояснимо цю думку на такому прикладі. Для багатьох професій надзвичайно важливими є такі характеристики уваги, як інтенсивність, об'єм, розподіл, переключення та ін. Жодна навчальна дисципліна їх спеціально не розвиває. Але давайте подивимося на спортивні ігри. На спортивному майданчику гравець виконує «роботу», яка $\epsilon$ дуже ефективною в плані розвитку вищезгаданих характеристик уваги. В умовах браку часу гравець, наприклад, повинен обрати спосіб приймання м'яча, оцінити розташування партнерів по команді, розташування гравців суперника і прийняти максимально ефективне для конкретної ігрової ситуації рішення. Таких прикладів багато. Точніше кажучи, той процес, що проходить на заняттях 3 фізичного виховання, уже треба називати психофізичною підготовкою. Ïї роль в наш час буде постійно зростати.

Робота 3 формування професійно значущих структурних компонентів особистості студентів-залізничників має ряд етапів. Так, на першому виявляється рівень сформованості професійно значущих компонентів (відповідно до обраної спеціальності).

Наступний етап - підбір виду рухової активності, у ході якої можна ефективно формувати необхідні складові. Так, для спеціальності «Мости і транспортні тунелі» професійно значущими видами рухової активності будуть: гімнастика, акробатика, плавання, веслувальний спорт, водне поло. Для спеціальностей «Вагони та вагонне господарство», «Тепловози та тепловозне господарство» професійно значущими $є$ гімнастика, спортивні ігри. Студентів, які навчаються за спеціальністю «Електричний транспорт», важливо залучити до занять спортивними іграми (волейбол, баскетбол, настільний теніс), легкою атлетикою. Для студентів спеціальності «Організація перевезень i управління на залізничному транспорті» професійно значущими $\epsilon$ заняття спортивними іграми (волейбол, футбол, футзал, баскетбол, гандбол, водне поло та ін.).

Третій етап передбачає залучення студентів до систематичних занять професійно значущим видом спорту. Доцільним і ефективним на цьому етапі є також використання під час занять з фізичного виховання психотренувальних засобів з розвитку професійно значущих структурних компонентів, спеціальних фізичних вправ та інших засобів психологічної і психофізичної підготовки. Так, для розвитку тих чи інших характеристик уваги можна використовувати відповідний тестовий матеріал. 
На четвертому - виконується діагностика рівня сформованості структурних компонентів, які вдосконалювалися, коректується, в разі необхідності, їх зміст, форма, методи. Він, як правило, збігається із закінченням семестру.

Головним засобом психологічної і психофізичної підготовки студентів, яка обстоюється в цій роботі, є фізичні вправи. Це пов'язано 3 тим, що зазначена підготовка реалізується в рамках фізичного виховання студентів, і з тим, що фізичні вправи впливають не тільки на м'язи людини, але й чинять різнобічний вплив на весь іiі організм і психіку. При виконанні фізичних вправ у організмі й психіці людини відбувається цілий ряд фізіологічних, психічних, біохімічних та інших процесів, які викликають відповідні зміни.

У теорії і методиці фізичного виховання ретельно описано такі питання, як: зміст і форма фізичних вправ, техніка фізичних вправ, класифікація фізичних вправ та ін. Так, як зазначає Т. Ю. Круцевич [387, с. 73], нині відомо понад 300 класифікацій фізичних вправ. Найбільш поширеними є:

1. Класифікація вправ за переважною цільовою спрямованістю їх використання.

2. Класифікація вправ за їх переважною дією на розвиток окремих якостей (здатностей) людини.

3. Класифікація вправ за їх переважним проявом певних рухових навичок і умінь.

4. Класифікація вправ за структурою рухів. У цьому випадку вправи поділяються на циклічні, ациклічні та змішані.

5. Класифікація вправ, побудована за переважним впливом на розвиток окремих м'язових груп.

6. Класифікація вправ за особливостями роботи м язів.

7. Класифікація вправ за відмінністю механізмів енергозабезпечення м'язової діяльності, що беруть участь у роботі.

8. Класифікація вправ за інтенсивністю роботи.

У будь-якій класифікації фізичних вправ мається на увазі, що кожна $з$ них здійснює певний вплив на людину, який залежить від особливостей змісту й форми даної вправи. У той же час такий авторитетний спеціаліст, як Л. П. Матвеєв [385, с. 84] обгрунтовано зазначає: «Фактично, однак, конкретний ефект фізичної вправи визначається і низкою умов її виконання. Інакше кажучи, реальний характер дії фізичної вправи залежить не лише від притаманних їй властивостей, 
але й від того, хто виконує, як вона виконується, під чиїм керівництвом і в якій обстановці проводяться заняття. Зокрема, одні й ті самі фізичні вправи, що належать до однієї й тієї ж класифікаційної групи, можуть давати суттєво різний ефект залежно від особливостей контингенту осіб, які займаються (індивідуальні, вікові, статеві, стан здоров’я, рівень фізичної підготовки), режиму життя, сумарного денного завантаження, відпочинку й умов побуту, а також особливостей зовнішніх умов занять (метеорологічних, географічних умов, стану обладнання, інвентарю, гігієни місць занять і т. ін.)».

Саме умови виконання фізичних вправ є важливим фактором, що перетворює їх із засобу фізичного виховання у засіб психологічної і психофізичної підготовки.

Підбір засобів психологічної і психофізичної підготовки студентів-залізничників виконувався 3 урахуванням особливостей майбутньої професійної діяльності. Їх можна розділити на блоки таким чином:

1. Блок психологічної просвіти.

2. Професійно значущі види спорту.

3. Психотренувальні засоби для розвитку характеристик уваги.

4. Спеціальні фізичні вправи для розвитку психомоторики.

5. Вправи для освоєння навиків саморегуляції психічного стану й зменшення наслідків стресу (аутогенне тренування, медитація, сахаджа-йога).

6. Спортивні змагання з професійно значущих видів спорту.

Як засіб психологічної просвіти студентів-залізничників усіх спеціальностей пропонується вивчення основ структурного й трансакційного аналізу відомого американського психіатра Еріка Берна. Ця концепція порівняно проста, легко засвоюється студентами. Одночасно вона достатньою мірою вирішує перше завдання психологічної і психофізичної підготовки. У цьому контексті доречно буде навести думку відомого українського дослідника Г. О. Балла щодо простоти і складності в побудові психологічних концепцій [23]. Він звертає увагу на те, що, з одного боку, обгрунтованими є претензії до них стосовно неправомірності спрощення уявлень про таке надскладне явище як, людська психіка. 3 іншого - відзначає факт простоти ідей і наукових моделей, які найістотніше вплинули на розвиток психологічної науки і практики. Наводячи приклад таких ідей, Г. О. Балл згадує і підхід Е. Берна. Він наголошує на тому, що попри величезну 
складність досліджуваного об'єкта (людської психіки), саме прості ідеї стають найкориснішими в його пізнанні (з огляду на легкість засвоєння). Головна вимога до цих простих ідей полягає в тому, що вони повинні відобразити істотні речі в об'єкті, який вивчається. Тільки за цієї умови вони будуть корисними.

Кожен вид спорту акцентовано розвиває певні не тільки фізичні, але й психічні складові. Якщо характер розвитку цих складових збігається $з$ тим, який необхідний у тій чи іншій професійній діяльності, такі види спорту прийнято називати професійно-прикладними. Підбір таких видів спорту для конкретної спеціальності, зокрема залізничної, і їх використання під час занять 3 фізичного виховання сприяє формуванню професійно значущих якостей, які визначають успішність професійної діяльності.

До психотренувальних належать засоби, з допомогою яких можна розвивати (і діагностувати) ті чи інші психологічні властивості. Наприклад, коректурна проба Бурдона (див. дод. 3) є засобом психологічної діагностики концентрації і стійкості уваги. У той же час, iï можна використовувати й для розвитку вищезгаданих характеристик уваги, пропонуючи студентам відповідні завдання під час занять. 3 допомогою цієї методики можна оцінити й розвивати також розподіл і переключення уваги. Для цього перед тими, хто виконує роботу, ставиться більш складне завдання. Працюючи 15 хв, потрібно:

1) протягом першої хвилини відшукувати, підкреслювати або закреслювати дві різні літери;

2) протягом другої хвилини те саме робиться 3 двома іншими літерами;

3) протягом третьої знову виконується завдання з першими двома літерами і так далі, до кінця 15-ї хв.

Таким чином, у процесі роботи тому, хто її виконує, доводиться постійно розподіляти увагу між двома літерами i, крім цього, через кожну хвилину переключати ï на пошук двох інших. Існує декілька варіантів коректурної проби, які доцільно використовувати під час занять.

Аналогічні засоби можна використовувати і для розвитку інших психічних характеристик. Так, для розвитку об'єму уваги це може бути тахістоскоп, для розвитку концентрації уваги - тест «переплутані лінії». Для розвитку розподілення й переключення уваги доцільно використовувати методику «відшукування чисел 3 переключенням 
уваги за червоно-чорними таблицями». Прикладів можна навести багато. Детальний опис та інструкції щодо застосування цієї групи засобів можна знайти в літературі, яка присвячена методикам психологічної діагностики $[47,49,62,191,200,230,240,261,266,297,313$, 435 та ін.].

До засобів, які певною мірою можуть розв'язати завдання профілактики невротичної поведінки студентів, на нашу думку, слід віднести ті види спорту, які допоможуть їм підняти впевненість у собі. Для студентів-юнаків це атлетизм, боротьба, бокс, кікбоксинг, карате, айкідо і т. ін., для дівчат - художня і спортивна гімнастика, танці.

Ефективними засобами психологічної і психофізичної підготовки студентів також є спеціальні фізичні вправи. Так, з їх допомогою можна оцінювати або розвивати розподіл і переключення уваги студентів. Їх прикладами можуть бути:

1. «Заборонений рух». Під час виконання низки рухів поточним способом завчасно домовляються не виконувати один або два рухи (наприклад, руки на пояс і нахил вперед). Хто помиляється і виконує «заборонений» рух услід за викладачем, робить крок уперед, при наступній помилці - ще крок і т. д. У кінці виконання вправи відмічають неуважних студентів.

2. «Роби навпаки». Під час виконання загальнорозвиваючих вправ за методикою «роби за мною» студенти повинні робити вправи дзеркальним способом, тобто якщо викладач піднімає праву руку, студенти - ліву, викладач виконує нахил вліво, студенти - вправо і т. д.

3. «Роби як я». Викладач на місці або рухаючись швидко виконує низку послідовних вправ, студенти повторюють їх і слідкують один за одним, визначаючи, хто робить помилки, хто повільно переключається від однієї вправи до іншої.

4. «Виконай точні рухи». Студенти розміщуються у двох шеренгах обличчям до обличчя. Подається команда, що включає 3-4 дії (наприклад: «Ліву руку вгору, праву в бік, крок вперед і крок вправо»). Студенти почергово визначають точність виконання команд. Більш складний варіант, коли всі виконують команду одночасно і контролюють один одного.

5. «Слідкуй за командою». Виконується комплекс фізичних вправ за підрозділами. Кожен рух виконується за командою «роби - раз, роби два» і т. д. Умовою $\epsilon$ пропускати рухи, якщо в команді пропущене слово «роби». 
5. «Роби навпаки». Дається завдання під час якої-небудь вправи виконувати всі рухи протилежно поданим командам (у протилежну сторону). Наприклад, за командою «Ліву руку вгору» треба підняти праву руку.

6. Різні вправи на узгодження рухів. Наприклад: поплескування по голові лівою рукою і виконання одночасно рухів вгору і вниз по животі правою; виконання зустрічних кругових рухів руками одночасно в протилежні боки; виконання різноманітних загальнорозвиваючих вправ з узгодженням рухів руками з кроком на місці і в русі.

7. Вправи на узгодження рухів на гімнастичній лаві. «Раз» - ліва нога на лаві, права рука на поясі; «два» - стрибком змінити положення ніг, ліву руку на пояс; «три» - стрибком змінити положення ніг, праву руку до плеча; «чотири» - стрибком змінити положення ніг, ліву руку до плеча і т. д.

8. «Оббігай перешкоди за завданням». Студенти шикуються у дві шеренги. Подається команда, яка визначає правила оббігання перешкод (гімнастичних снарядів, стояків і т. ін.). Наприклад: «В обхід по залу за годинниковою стрілкою оббігти лівий стояк перекладини правим колом, виконати три перекидання вперед на матах, пройти всередині брусів, підлізти під коня, оббігти стояк лівим плечем уперед, стати в стрій. Перша шеренга виконує завдання, друга - контролює правильність виконання» (по закінченні - зміна).

9. Оббігання стояків за різними сигналами. На баскетбольному майданчику розставляються в лінію три стояки через 6 м. Перебуваючи під щитом на лицьовій лінії, за командою «Марш» студент починає бігти і оббігає стояки по ходу і зворотно (виходить 5 стояків). Кількість кіл біля кожного стояка і напрямок оббігання визначає викладач сигналами прапорців у лівій і правій руці (кількість прапорців означає кількість оббігань, напрямок кіл залежить від того, у якій руці прапорці: ліва рука - ліве коло, права рука - праве коло). Якщо при цьому викладач подає сигнали свистком, то кількість оббігань визначається кількістю свистків, а прапорці в лівій або правій руці означають тільки, яким колом повинен бігти студент. Усього виконується 8 оббігань стояків. Реєструється загальний час оббігання стояків, кількість помилок, штрафний час за помилки (оббігання в протилежний бік - 2 с, пропуск кола -4 c, зайве коло не штрафується). Нормативні оцінки за цю вправу: «відмінно» - 26,5 с, «добре»-26,6-28,2 с, «задовільно» - 28,3-29,9 с, «незадовільно» - 32 с і більше. 
10. Ведення м'яча навколо стояків за сигналами. На баскетбольному майданчику розставлено два стояки: перший на відстані 5 м від лінії старту, другий - через 5 м по ходу. Студент повинен, перебуваючи на лицьовій лінії, за командою «Марш» добігти до протилежного щита, взяти м'яч і повести його баскетбольним способом до стояків. При підході до першого стояка за 2-3 м він отримує команду від викладача, який піднімає певну кількість прапорців у лівій або правій руці, що означає напрямок оббігання і кількість кіл. Сума всіх кіл навколо стояків - 4. Реєструється загальний час виконання завдання, кількість помилок, штрафний час за помилки. Нормативні оцінки за вправу: «відмінно» - 25,3 с, «добре» - 25,4-28,1 с, «задовільно» 28,2-30,9 с, «незадовільно» - 31 с і більше.

11. Естафета 3 акробатикою. Укладаються два ряди по 3-4 мати. Перед кожним матом студентам подаються сигнали (свистком або прапорцем), які вказують, скільки і яких перекидань необхідно виконати на кожному маті.

12. Рух по гімнастичній лаві з м'ячем. Студенту пропонується пройти по рейках двох перевернутих лав, що поставлені одна за одною, вперед і назад і голосно вимовляти числа за таблицею множення на 6 при проходженні в один бік і на 7 при поверненні. Під кожний рахунок таблиці необхідно також виконувати одне перекидання баскетбольного м'яча із руки в руку. Відстань між кистями рук близько 1 м. Реєструється час проходження вперед і назад, за кожну помилку в таблиці множення і втрату рівноваги додається по секунді. Нормативні оцінки за вправу: «відмінно» - 13 с, «добре» - 13,1-15,0 с, «задовільно» - 15,1-17 с, «незадовільно» - 17,1 с і більше.

Аналогічні засоби підбираються й для розвитку інших складових психологічної і психофізичної готовності студентів. Насамперед це стосується розвитку в студентів психомоторики (вестибулярна стійкість, швидкість у діях і т. ін.).

Важливу роль у психологічній і психофізичній підготовці студентів відіграють засоби для освоєння навиків саморегуляції психічного стану й зниження наслідків стресу (аутогенне тренування, сахаджайога).

У плані розвитку в студентів механізмів адаптації до стресових ситуацій, підняття загального рівня стресостійкості, важливо використовувати такий засіб фізичного виховання, як спортивні змагання. 
У зв'язку з цим спортивні змагання було також включено до числа засобів психологічної і психофізичної підготовки.

До засобів відновлення працездатності студентів після напруженої розумової праці слід віднести фізичні вправи. Їх підбір виконується з урахуванням інтересів студентів.

Розробляючи основи формування складових психологічної і психофізичної готовності студентів-залізничників, ми виходили зі специфіки конкретної залізничної професії. Для цього було вивчено професіограми й кваліфікаційні характеристики основних інженерних професій працівників залізничного транспорту [120]. Відповідно до їх змісту, здійснювався підбір засобів психологічної і психофізичної підготовки студентів факультету, який готує цих спеціалістів.

Як уже зазначалось у даній роботі, однією з головних на залізниці $\epsilon$ спеціальність «Організація перевезень і управління на залізничному транспорті». Спеціалісти цього профілю виконують роботу диспетчера на залізниці. Домінуючими видами діяльності для цієї професії є:

- регулювання руху поїздів;

- убезпечення руху поїздів;

- зменшення або збільшення часу зупинки поїздів на окремих пунктах;

- зміна черговості й пунктів беззупинного схрещення і обгону поїздів;

- створення умов для беззупинкового схрещення поїздів;

- контроль за дотриманням правил руху;

- отримання відомостей про проходження поїздів по станціях певної дільниці від чергового по станції;

- отримання інформації від машиністів локомотивів поїздів, що рухаються (по радіозв'язку);

- контроль за графіком виконаного руху поїздів і коригування за ним планового графіку;

- контроль за відтворенням на дисплеї поїзної ситуації;

- контроль за готовністю маршрутів, відкриттям сигналів, зайнятістю станційних колій, ділянок наближення і віддалення;

- відкриття вхідних і вихідних світлофорів;

- встановлення маршрутів прийняття і відправлення поїздів на проміжних станціях;

- контроль за роботою системи «автодиспетчер»;

- прийняття інформації про несправності, екстремальні ситуації; 
- видача розпоряджень про подальші дії машиніста у випадку несправності поїзда або в екстремальній ситуації;

- контроль за роботою станції і виконанням завдань 3 навантаження та розвантаження вагонів, формуванням поїздів.

До якостей, які сприяють успішному виконанню професійної діяльності диспетчера на залізниці, належать: швидка реакція, оперативність, образне мислення (здатність подумки відтворювати складні обставини на дільниці), концентрація уваги (здатність протягом тривалого часу займатися певним видом діяльності), високий рівень стійкості уваги, гарна моторна пам'ять (на дії), гарна координація пальців, аналітичне мислення, гострий зір, гарний слух, чітка дикція, здатність швидко приймати рішення, здатність прогнозувати, високий рівень розвитку пам'яті (короткострокової, слухової), емоційна стійкість, витривалість, психічна врівноваженість, ретельність, пунктуальність, відповідальність, спостережливість, оперативність (швидка реакція в екстрених ситуаціях), організованість, зібраність, винахідливість.

Серед якостей, які перешкоджають ефективному виконанню професійної діяльності, можна виділити: безвідповідальність, нечітку дикцію, емоційну нестійкість, ригідність мислення, неуважність, відсутність спостережливості, тривожність, неакуратність, швидку стомлюваність, неквапливість.

Виходячи із специфіки роботи диспетчера на залізниці, до числа засобів психологічної і психофізичної підготовки в процесі фізичного виховання було включено:

1. Блок психологічної просвіти (описаний вище).

2. Професійно значущі види спорту. Серед них спортивні ігри (баскетбол, волейбол, гандбол, футбол, футзал), легку атлетику (біг на середні й довгі дистанції), плавання (на середні й довгі дистанції), шахи.

3. Психотренувальні засоби для розвитку характеристик уваги.

4. Спеціальні фізичні вправи для розвитку психомоторики (швидкість простої і складної рухової реакції, швидкість у діях та ін.).

5. Вправи для здобуття навиків саморегуляції психічного стану й зниження наслідків стресу (аутогенне тренування);

6. Спортивні змагання з професійно значущих видів спорту.

Як головний засіб психологічної і психофізичної підготовки нами розглядалися заняття професійно значущими видами спорту, і насам- 
перед - спортивними іграми. Ми виходили 3 того, що професійна діяльність залізничного диспетчера і діяльність спортсмена-ігровика близькі за своїми психологічними характеристиками. Внаслідок цього відбудеться ефект позитивного перенесення розвинених в ігровій діяльності психічних складових у професійну діяльність диспетчера.

Детальніше пояснимо цю думку на прикладі футболу. Як діяльність цю гру характеризують:

1. Колективний характер діяльності, необхідність взаємодії з партнерами.

2. Підпорядкованість ігрового амплуа, вимог до дій окремого гравця загальнокомандним завданням.

3. Складність дій футболістів.

4. Необхідність єдиноборства в тісному контакті із суперником.

5. Чергування успіхів і невдач.

6. Залежність успішної діяльності команди від узгодженості партнерів між собою, чіткого розподілу ігрових функцій, взаємозамінюваності й взаємовиручки на полі та ін.

Заняття футболом $є$ ефективним засобом розвитку багатьох психологічних і психофізичних складових, зокрема:

- процеси сприйняття («відчуття м’яча», «відчуття часу», «відчуття простору»);

- уваги (об’єм, інтенсивність, розподіл, переключення, вибірковість, концентрація і стійкість);

- спостережливості, уміння швидко і правильно орієнтуватись у складній ігровій ситуації;

- пам'яті і уяви, які проявляються в здатності запам'ятати особливості ігрових дій і в умінні в деталях уявити можливі ситуації очікуваного змагання;

- тактичного мислення, здатності швидко і правильно оцінювати ігровий момент, приймати ефективне рішення і контролювати свої діï;

- здатності керувати своїми емоціями в процесі ігрової діяльності та ін.

Порівнявши особливості діяльності у футболі з особливостями професійної діяльності залізничного диспетчера, можна зробити такий висновок. Футбол є професійно значущим видом спорту для цієї професії, тобто таким, який розвиває професійно значущі якості цього фахівця. 
Діяльність в таких ігрових видах спорту, як волейбол, баскетбол, гандбол, футзал $є$ психологічно дуже схожою з футболом, тому ці види спорту теж $є$ професійно значущими для диспетчерів на залізниці.

Легка атлетика, плавання (біг і плавання на середні та довгі дистанції) $є$ ефективним засобом формування абсолютної більшості вольових якостей особистості - наполегливості, стійкості, самостійності, цілеспрямованості, дисциплінованості, витримки, енергійності, терпеливості та ін. Оскільки для залізничного диспетчера розвиток цих якостей $є$ важливим, то вищезгадані види спорту теж повинні розглядатись як професійно значущі для нього.

Професійно значущим для залізничного диспетчера $\epsilon$ i такий вид спорту, як шахи. Заняття цим видом забезпечують вироблення навиків граничного напруження нервової діяльності, гарний стан центральної нервової системи, розвивають концентрацію і стійкість уваги, емоційну стійкість, витримку і самовладання, терпіння.

Окремо слід відзначити такий засіб психологічної і психофізичної підготовки, як змагання з професійно значущих видів спорту. Під час змагальної діяльності людина часто перебуває в екстремальних (стресових) ситуаціях. Внаслідок цього накопичується певний досвід адаптації до таких ситуацій, підвищується потенціал стресостійкості особистості. Це також позитивно впливає на виконання професійної діяльності залізничного диспетчера.

Інші наведені вище блоки засобів психологічної і психофізичної підготовки використовуються для спрямованого впливу на окремі складові готовності. Так, психотренувальні засоби доцільно використовувати для розвитку характеристик уваги. Вони будуть підсилювати вплив спортивних ігор на ровиток цієї складової. Спеціальні фізичні вправи - це ефективний засіб розвитку психомоторики майбутніх залізничників. Вони також будуть доповнювати вплив на цю складову професійно значущих видів спорту. Використання в процесі занять 3 фізичного виховання вправ на розиток саморегуляції спрямоване на навчання студентів керуванню своїм психічним станом. Це також важлива складова психологічної і психофізичної підготовки. Вона в практичному плані доповнює блок психологічної просвіти.

До числа головних спеціальностей залізничного транспорту слід віднести і «Вагони та вагонне господарство» та «Локомотиви та локомотивне господарство». Ці фахівці часто займають посаду інженера $з$ приймання локомотивів (вагонів) у депо. До завдань і обов'язків 
цього спеціаліста входить здійснення приймання всіх відремонтованих деповським, капітальним ремонтом локомотивів і вагонів. Він контролює якість капітального і поточного видів ремонту і технічних обслуговувань вагонів, локомотивів, електросекцій та дизель-поїздів, а також окремих їх вузлів; відповідність випробувальних стендів, контрольно-вимірювальних приладів, вимірювального інструменту, спеціальних шаблонів, дефектоскопів та іншого обладнання паспортним характеристикам і технічним умовам; виконання правил та iнструкцій з ремонту вагонів, локомотивів і моторвагонного рухомого складу, їх вузлів і деталей. Цей фахівець оглядає комісійно два рази на рік (весною та восени) локомотиви, вагони й моторвагонний рухомий склад. У разі наявності несправностей, нестійкості роботи обладнання, виключених пристроїв або апаратів, а також відхилень від норм допустимих розмірів вузлів і деталей забороняє випуск локомотивів, вагонів та моторвагонного рухомого складу. Він перевіряє технологічну підготовку й метрологічне забезпечення ремонтних дільниць, відділень та цехів, у разі порушень призупиняє ремонт або технічне обслуговування тягового рухомого складу, вузлів та агрегатів; аналізує якість капітального і поточного ремонтів локомотивів, вагонів та моторвагонного рухомого складу (за результатами аналізу відмов вузлів і обладнання локомотивів, вагонів та моторвагонного рухомого складу розробляє пропозиції щодо їх зменшення); контролює виконання обов'язкового обсягу робіт, що передбачений правилами та технологією ремонту, інструкціями, вказівками, а також затвердженим технологічним процесом; контролює якість відремонтованих локомотивів, вагонів та моторвагонного рухомого складу; бере участь в інженерній роботі депо, в обкатуванні локомотивів, вагонів і моторвагонного рухомого складу, у розслідуванні випадків псувань, несправностей, відчеплень і непланового ремонту локомотивів, вагонів і моторвагонного рухомого складу, у підготовці технічних заходів, що спрямовані на поліпшення якості ремонту й утримання технічних засобів; оформляє встановленим порядком відповідні повідомлення, акти, облікові форми й книги ремонту локомотивів, моторвагонного рухомого складу, вагонів; контролює своєчасне подання претензій; подає квартальні, місячні письмові звіти про роботу згідно з колом обов'язків; організовує свою роботу з урахуванням правил внутрішнього трудового розпорядку. 
До якостей, які сприяють успішному виконанню професійної діяльності інженера 3 приймання локомотивів (вагонів) у депо, слід віднести: уважність, спостережливість, кмітливість, пильність, обачливість, терпеливість, спритність, акуратність, сумлінність, психічну врівноваженість, ретельність, пунктуальність, відповідальність, спостережливість, організованість, зібраність, впевненість, вестибулярну стійкість, вибірковість уваги, концентрацію і стійкість уваги, розвинене технічне мислення, гарну моторну пам'ять, гострий зір, гарний слух, добре розвинену координацію рухів, гарне зорове сприйняття (вміння визначити несправність «на око»).

Якостями, які перешкоджають ефективному виконанню професійної діяльності, є: безвідповідальність, халатність, неуважність, нерозвинене технічне мислення, відсутність спостережливості, неакуратність, вестибулярна нестійкість.

Виходячи зі специфіки роботи інженера 3 приймання локомотивів (вагонів) у депо, до числа засобів психологічної і психофізичної підготовки в процесі фізичного виховання включено такі блоки:

1. Блок психологічної просвіти.

2. Професійно значущі види спорту: професійно-прикладна гімнастика, спортивні ігри (баскетбол, волейбол, гандбол, футбол, футзал), легка атлетика, шахи.

3. Психотренувальні засоби для розвитку характеристик уваги.

4. Спеціальні фізичні вправи для розвитку психомоторики (швидкість простої і складної рухової реакції, вестибулярна стійкість, швидкість у діях).

5. Вправи для здобуття навиків саморегуляції психічного стану й зменшення наслідків стресу (аутогене тренування).

6. Спортивні змагання з професійно значущих видів спорту.

Головним засобом психологічної і психофізичної підготовки для цих фахівців також є професійно значущі види спорту. Доцільність використання (і для розв'язання яких завдань) спортивних ігор і легкої атлетики вже обгрунтовувалась, тому зупинимося докладніше на професійно-прикладній гімнастиці. Її професійна значущість пов'язана $з$ тим, що вона спрямована на вдосконалення здібностей людини, від яких значною мірою залежить успіх в оволодінні професією. Для професійної діяльності інженера з приймання локомотивів (вагонів) у депо важливе значення має така характеристика, як вестибулярна стійкість. Елементи професійно-прикладної гімнастики є ефективним 
засобом їі розвитку. Насамперед це стосується виконання вправ на збереження рівноваги, на лазання і перелізання, вправ на гімнастичних снарядах (гімнастичній стінці, лаві, канатах, колоді).

Використання спеціальних фізичних вправ також планувалось з урахуванням специфіки майбутньої професійної діяльності студентів. Якщо порівнювати із спеціальністю залізничного диспетчера, то для майбутніх інженерів 3 приймання локомотивів (вагонів) у депо, окрім вправ для розвитку простої і складної рухової реакції та швидкості у діях, використовувалися вправи для розвитку вестибулярної стійкості.

Блоки психологічної просвіти, вправи для здобуття навиків саморегуляції психічного стану використовувалися такі самі, як і для спеціальністі «Організація перевезень і управління на залізничному транспорті».

Основними на залізничному транспорті $є$ також спеціальності «Електричний транспорт» $\mathrm{i}$ «Електромеханічні системи автоматизації та електропривід». Фахівці цього профілю на залізниці займають посаду електромеханіка. Він забезпечує справний стан, безаварійну та надійну роботу пристроїв і обладнання, що обслуговується, правильну їх експлуатацію, своєчасний якісний ремонт і модернізацію відповідно до інструкцій з технічного обслуговування, затверджених креслень та схем, чинних технічних умов і норм; вивчає умови роботи пристроїв, виявляє причини передчасного спрацювання, вживає заходів щодо запобігання їм та їх усунення; інструктує працівників, що користуються цими пристроями, щодо правил їх експлуатації; керує роботою електромонтерів, контролює якість робіт, що виконуються, дотримання технології, правил охорони праці, виробничої санітарії і пожежної безпеки; бере участь в ліквідації несправностей у роботі пристроїв, їх ремонті, монтажі та регулюванні, електротехнічних вимірюваннях і випробуваннях; забезпечує робочі місця матеріалами, сировиною, запасними частинами, вимірювальними приладами, засобами захисту, інструментом, пристроями, технічною документацією; освоює і впроваджує прогресивні методи технічного обслуговування, ремонту, монтажу та інших робіт закріпленого типу пристроїв; бере участь в розробленні заходів з підвищення надійності, якості роботи закріплених технічних засобів, в освоєнні і модернізації діючих пристроїв; у складанні замовлень на матеріали, запасні частини, інструмент і забезпечує їх економне і раціональне витрачання; у розсліду- 
ванні причин пошкоджень обладнання і розробленні заходів до запобігання аварій і виробничого травматизму, у проведенні оглядів стану колії, стрілочних переводів, пристроїв сигналізації, централізації, блокування; бере участь у проведенні технічного навчання, у тому числі з працівниками суміжних служб (служби перевезень, колії, локомотивної) згідно з колом питань за профілем роботи.

До якостей, які сприяють успішному виконанню професійної діяльності електромеханіка, належать: розвинене технічне мислення, організаторські й комунікативні здібності, добрий зір, добре кольоросприйняття, відмінний слух (дозволить при випробуваннях електричних узлів і апаратів виявляти за характером шуму їх несправності), вестибулярна стійкість, спритність, швидка реакція, добра довгочасна пам'ять, розвинені вибірковість, концентрація і стійкість, переключення уваги, зосередженість, сміливість, гарна координація пальців, емоційна стійкість, витривалість, психічна врівноваженість, ретельність, пунктуальність, відповідальність, спостережливість, оперативність, організованість, зібраність.

Ефективному виконанню професійної діяльності перешкоджають: безвідповідальність, неуважність, емоційна нестійкість, відсутність спостережливості, тривожність, неакуратність, поганий зір та кольоросприйняття, поганий слух.

Відштовхуючись від специфіки роботи електромеханіка, до числа засобів психологічної і психофізичної підготовки студентів в процесі фізичного виховання було включено такі блоки:

1. Блок психологічної просвіти.

2. Професійно значущі види спорту: спортивні ігри (баскетбол, волейбол, гандбол, футбол, футзал), професійно-прикладна гімнастика, акробатика, легка атлетика, шахи.

3. Психотренувальні засоби для розвитку характеристик уваги (описані вище).

4. Спеціальні фізичні вправи для розвитку психомоторики (швидкість простої і складної рухової реакції, вестибулярна стійкість, швидкість у діях).

5. Вправи для здобуття навиків саморегуляції психічного стану й зменшення наслідків стресу (аутогенне тренування).

6. Спортивні змагання з професійно значущих видів спорту.

Фахівці спеціальності «Залізничні споруди та колійне господарство» працюють на залізниці інженерами $з$ під’їздних колій. Завдання 
і обов'язки цього спеціаліста такі. Він організовує підготовку матеріалів, що необхідні для укладання та переукладання договорів залізниць 3 підприємствами, організаціями та установами на подавання, прибирання вагонів і експлуатацію під'їзних колій; контролює виконання залізничними станціями, підприємствами, організаціями та установами умов договорів на експлуатацію під'їзних колій і на подавання та прибирання вагонів, Статуту залізниць України, Правил перевезень вантажів, а також інших положень та інструкцій у частині, що стосується експлуатації під’їзних колій; вживає заходів щодо повного використання місткості та вантажності вагонів; контролює розроблені підприємствами організаційно-технічні заходи 3 питань зниження простою вагонів і розвитку під'їзних колій; організовує і проводить обстеження під'їзних колій для укладання або переукладання договорів згідно з планом, а також у разі виявлення змін, що виникли в технічному оснащенні на під'їзни коліях. Бере участь у роботі комісій з розроблення єдиних технологічних процесів роботи під'їзних колій. Інструктує працівників станцій та підприємств, організацій і установ з питань виконання умов договору щодо експлуатації під'їзних колій, подавання й прибирання вагонів, Статуту залізниць України, Правил перевезень вантажів, положень та інструкцій в частині, що стосується експлуатації під’їзних колій; щомісячно готує матеріали й контролює правильність даних 3 питань простою вагонів на під'їзних коліях, що передаються в обчислювальні центри за встановленою формою, та аналізує їх; бере участь у розгляді розбіжностей у договорах на експлуатацію під'їзни колій і на подавання, прибирання вагонів, підготовку матеріалів зі спірних питань для передавання їх у арбітражні суди, розгляді справ у арбітражних судах згідно з дорученням залізниці; виконує аналіз використання вагонів та під'їзних колій, вивчає причини невиконання встановлених норм простою вагонів і готує пропозиції щодо їх усунення; вивчає, узагальнює і готує пропозиції з поширення передових методів роботи станцій і під’їзних колій з питань поліпшення використання вагонів і скорочення їх простою на під'їзних коліях. Бере участь у розгляді пропозицій з розвитку і технічного оснащення залізничного господарства.

Якостями, які сприяють успішному виконанню інженером 3 під’їзних колій професійної діяльності, є: аналітичне мислення, психічна 
врівноваженість, ретельність, відповідальність, організованість, зібраність, витривалість, концентрація і стійкість уваги.

Перешкоджають успішному виконанню професійної діяльності такі якості, як: безвідповідальність, неуважність, неакуратність, швидка стомлюваність.

Враховуючи специфіку професійної праці інженера 3 під'їзних колій, до блоків психологічної і психофізичної підготовки студентів було включено такі компоненти:

1. Блок психологічної просвіти.

2. Професійно значущі види спорту: спортивне орієнтування, туризм, кросова підготовка, спортивні ігри (баскетбол, волейбол, гандбол, футбол), шахи.

3. Психотренувальні засоби для розвитку характеристик уваги (описані вище).

4. Спеціальні фізичні вправи для розвитку психомоторики.

5. Вправи для освоєння навиків саморегуляції психічного стану й зменшення наслідків стресу (аутогенне тренування).

6. Спортивні змагання з професійно значущих видів спорту.

Важливою для залізничної галузі є й така спеціальність, як «Мости і транспортні тунелі». Спеціалісти цього профілю займають посади інженера-будівельника і працюють на будівництві мостів і транспортних тунелів.

До обов'язків інженера-будівельника (мостовика) входять:

1. Здійснення виробничо-технологічної, організаційно-управлінської, проектно-конструкторської і дослідницької діяльності.

2. Вивчення і аналіз техніко-економічної інформації, пов'язаної 3 проектуванням і будівництвом мостів.

3. Виконання технологічних розрахунків, їх узагальнення і систематизація.

4. Виконання робіт з нормування праці, будівельних кошторисів.

5. Розробка і впровадження методичної, нормативної і технічної документації.

6. Здійснення нагляду і контролю за якістю будівельних матеріалів і конструкцій, експлуатацією обладнання, дотриманням встановлених вимог, чинних правил і стандартів.

7. Керівництво здійсненням будівельних, монтажних і пусконалагоджувальних робіт. 
8. Контроль за дотриманням робітниками правил охорони праці, безпеки життєдіяльності, протипожежного захисту.

Підвищені вимоги до психологічної і психофізичної підготовленості інженера-будівельника (мостовика) вносять такі чинники, як:

- робота на висоті;

- небезпека потрапляння у воду (під воду);

- підвищена відповідальність за життя і здоров'я робітників;

- необхідність утримувати в пам'яті великий обсяг інформації довідкового характеру;

- наявність специфічних умов праці (робота на повітрі в несприятливих умовах, будівельний пил, шум).

До якостей, які сприяють успішному виконанню професійної діяльності інженера-будівельника (мостовика), належать: емоційна стійкість, технічне мислення, просторова уява, гарна довгострокова і оперативна пам'ять, гарний окомір, розвинені концентрація, стійкість, розподіл, вибірковість уваги, особиста організованість, самостійність, організаторські здібності, ініціативність, відповідальність, вестибулярна стійкість, сміливість.

Перешкоджають ефективному виконанню професійної діяльності: емоційна нестійкість, безвідповідальність, неуважність, тривожність, вестибулярна нестійкість.

Відштовхуючись від специфіки роботи інженера-будівельника (мостовика), до психологічної і психофізичної підготовки студентів у процесі фізичного виховання було включено блоки засобів 3 таким змістом:

1. Блок психологічної просвіти.

2. Професійно значущі види спорту: спортивна й прикладна гімнастика, акробатика, прикладне плавання, веслування, спортивні ігри (баскетбол, волейбол, гандбол, футбол, футзал), легка атлетика, шахи.

3. Психотренувальні засоби для розвитку характеристик уваги (описані вище).

4. Спеціальні фізичні вправи для розвитку психомоторики (швидкості простої і складної рухової реакції, вестибулярної стійкості, швидкості у діях).

5. Вправи для освоєння навиків саморегуляції психічного стану й зменшення наслідків стресу (аутогенне тренування).

6. Спортивні змагання з професійно значущих видів спорту. 
Визначення специфіки психологічної і психофізичної підготовки студентів-залізничників конкретної спеціальності $€$ важливий, але не останній етап в іiі організації. Наступним кроком стало залучення студентів до такої діяльності в рамках психологічної і психофізичної підготовки, яка б враховувала їх індивідуальні особливості (реальний рівень розвитку складових психологічної і психофізичної готовності до майбутньої професії). Для цього на початку першого семестру виконувалася психологічна діагностика основних показників психологічної і психофізичної готовності студентів до обраної ними спеціальності. Так, для спеціальності «Організація перевезень і управління на залізничному транспорті» це було визначення таких характеристик, як особистісна тривожність, концентрація, стійкість, вибірковість уваги, швидкість простої і складної рухової реакції, швидкість у діях, вольові та інші професійно значущі якості особистості. На підставі діагностики вказаних характеристик визначався оптимальний для конкретного студента зміст психологічної і психофізичної підготовки. Якщо, наприклад, у студента було виявлено високі показники рівня розвитку концентрації і стійкості уваги, але одночасно й недостатньо розвинені вольові якості особистості, то із числа професійно значущих для цієї спеціальності видів спорту для нього обирали легку атлетику, а не один із видів спортивних ігор. Таким чином студент залучався до ефективної для розвитку вольових якостей діяльності під час занять професійно значущим видом спорту. Розвивати характеристики уваги він міг у процесі занять, до структури яких (відповідно до плану-графіку) входило використання або спеціальних фізичних вправ, або спеціальних психотренувальних засобів для розвитку уваги, або на заняттях, на яких планувалося проведення спортивних змагань зі спортивних ігор.

Суттєвою особливістю запропонованого підходу до організації психологічної і психофізичної підготовки в процесі фізичного виховання $є$ те, що вплив професійно значущого виду спорту доповнюється (збалансовується) використанням інших змістовних блоків.

Якщо в студента виявлялися високі показники особистісної тривожності (що, як видно із професіограми залізничного диспетчера, перешкоджає ефективному виконанню професійної діяльності), то його направляли в окрему групу, у якій професійно значущими видами спорту були атлетизм, пауерліфтинг, важка атлетика, єдиноборства і т. ін. Ці види сприяли підвищенню впевненості студента в собі. 
Інші важливі для майбутньої професії складові психологічної і психофізичної готовності він розвивав під час навчальних занять, до структури яких входили й інші блоки засобів (спеціальні фізичні вправи, психотренувальні засоби, вправи для формування навиків саморегуляції психічного стану, спортивні змагання).

Для спеціальності «Мости і транспортні тунелі» виконувалася вихідна діагностика таких характеристик, як особистісна тривожність, вестибулярна стійкість, концентрація, стійкість, вибірковість, розподіл уваги, рівень розвитку вольових якостей. Оцінювались уміння плавати та веслувати. Якщо в результаті вихідної діагностики у студента виявлявся низький показник вестибулярної стійкості, то професійно значущим видом спорту для нього обирали спортивну гімнастику або акробатику. Інші складові розвивалися завдяки використанню в ході занять засобів з інших блоків.

У випадку коли в студента-мостовика виявлялася достатньо розвинена вестибулярна стійкість, але він погано плавав, йому як професійно значущий вид спорту обирали плавання. У процесі занять він не тільки вчився гарно плавати, але й освоював його прикладні види, навчався надавати першу допомогу постраждалим на воді та ін. Інші важливі для майбутньої професії складові психологічної й психофізичної готовності вдосконалювались у ході занять, на яких було заплановано (відповідно до плану-графіку навчальних занять) використання інших змістовних блоків підготовки.

Аналогічно підбиралися засоби психологічної і психофізичної підготовки й для студентів-залізничників інших спеціальностей.

Ефективність педагогічної діяльності багато в чому залежить від врахування психологічних особливостей вихованців [304]. Повною мірою це стосується і психологічної, і психофізичної підготовки студентів. Студентський період життя людини збігається з початком періоду ранньої дорослості, який якісно відмінний (у плані детермінації) від попередніх етапів онтогенезу людини. Як зазначають фахівці [187, с. 648], зміни мислення й поведінки особистості тут тільки незначною мірою зумовлені хронологічним віком або специфічними змінами в організмі (що характерно для попередніх етапів). Визначальною мірою вони залежать від особистих, соціальних й культурних чинників. Соціальні орієнтири й культурні запити студентів можуть підтримувати, розширяти або підривати сформовані в юнацькі роки форми поведінки, вимагаючи освоєння нових. Студент 
опиняється перед необхідністю вибору й вирішення багатьох проблем. Критерієм зрілості якраз і $є$ його здатність реагувати на зміни й пристосовуватися до нових умов.

Теоретики, які працюють у сфері теорії розвитку [187, с. 649], звертають увагу на те, що в цей період вже не існує таких фізичних орієнтирів, як пубертат, таких чітко окреслених стадій когнітивного розвитку, як стадія конкретних операцій, за якими можна точно визначити, коли закінчується одна стадія розвитку й починається інша. На цій стадії хід розвитку людини розпізнають, спираючись на соціальні орієнтири, які визначаються культурою, на ролі й відносини, які входять до складу циклів сімейного життя і кар'єри.

Формування особистості в студентський період визначається особливо великою кількістю соціальних, психологічних, біологічних та організаційно-педагогічних чинників. Крім того, сама особистість у цей період являє собою виключно динамічне утворення. У процесі iii розвитку зростає цілісність, інтегративність психічної організації, посилюється взаємозв'язок різних характеристик, які сформувались як реакції людини на власні якості.

Т. В. Алексеєва [9] підкреслює, що студентський період це в основному період ранньої і зрілої юності або початку дорослості в житті людини. Соціальну ситуацію розвитку тут визначає початок дорослості, який загострює питання життєвого самовизначення. Характерними $\epsilon$ інтенсифікація самопізнання й психологічна спрямованість у майбутнє. Вона звертає увагу на те, що на відміну від ранньої юності (коли відбувається первинний вибір життєвого шляху) в студентський період починається початок руху з оволодіння обраною професією і засвоєння нових соціальних ролей. Автор відзначає, що характерним $\epsilon$ й те, що студенти в одних ситуаціях можуть діяти як дорослі, а в інших - ні. Властивим є також намагання завжди проявити самостійність у виборі й прийнятті рішень. У той же час вибір може бути імпульсивним, а рішення - змінюватися досить часто.

Т. В. Алексєєва відзначає, що основні труднощі свого життя студенти пов'язують 3 появою нової відповідальності. Вона також звертає увагу на те, що останнім часом з об'єктивних причин серед студентів зростає роль навчально-професійної діяльності як провідного виду діяльності студентів. Значення спілкування й розваг відповідно знижується. Сама навчально-професійна діяльність студентів, як за- 
значає автор, поєднує в собі ознаки як власне навчальної, так і трудової.

У працях, присвячених дослідженню мотиваційної сфери особистості в юнацькому віці $[10,99]$, показано, що мотиви професійного самовизначення посідають центральне місце у взаємовідносинах іiі з навколишнім світом, актуалізують світоглядні аспекти їі духовного життя, стимулюють пошуки життєвого покликання. У психологічній літературі поняттям «професійне самовизначення особистості» визначають найістотнішу особливість розвитку й соціального дозрівання людини. Професійне самовизначення залишається актуальним для молодої людини й у період іï навчання у ВНЗ. Великого значення тут набуває формування конкретної професійної спрямованості особистості спеціаліста.

Результати досліджень свідчать про те, що основною характеристикою розвитку особистості спеціаліста в умовах ВНЗ є формування суспільно й професійно ціннісної мотивації діяльності, безпосередньо пов'язаної з його самовизначенням. Виділено три домінуючих мотиваційних компоненти. Це, по-перше, мотиви морально-світоглядного самовизначення. Цим мотиваційним компонентом професійного становлення визначається життєва активність молодого спеціаліста. Другим мотиваційним компонентом є бажання досягти професійної майстерності й компетентності, самоствердитися у творчій професійній діяльності. В основі розвитку цих мотивів лежить усвідомлення студентом себе як суб'єкта професійної діяльності. Це надає особливого змісту всім мотивам навчання та науково-пізнавальним інтересам. Третім мотиваційним компонентом становлення особистості спеціаліста є професійна самооцінка - усвідомлення людиною своїх професійних можливостей. Адекватність професійної самооцінки це основа реалістичного рівня домагань студента в досягненні певного професійного статусу.

Дослідження особливостей функціонування та розвитку згаданих вище мотиваційних компонентів професійного самовизначення студентів дало можливість науковцям [10] визначити чотири типи ставлення їх до процесу навчання й оволодіння спеціальністю. Ці типи розрізняються за особливостями функціонування та рівнем розвитку мотивів професійного самовизначення, а також за особливостями психологічної та соціальної адаптації до професії в період професійно спрямованого навчання у ВНЗ. 
Перший мотиваційний тип відзначається гармонійністю та високим рівнем розвитку трьох основних мотиваційних компонентів морально-світоглядного самовизначення, прагнення досягти професійної компетентності, мотивів, пов'язаних із самооцінкою професійної адекватності. Це оптимальний тип мотивації професійного самовизначення.

Другий тип мотивації характеризується деякою розбіжністю у розвитку провідних мотиваційних компонентів. Передусім це виявляється в недостатній визначеності професійних інтересів студентів, дещо заниженою чи завищеною їх самооцінкою власної професійної адекватності. Студенти цього мотиваційного типу переживають декілька криз у професійному самоствердженні, які здебільшого припадають на початок другого та випускного курсів. Досить часто структура мотивації діяльності студентів характеризується перетворенням у ході навчання другого мотиваційного типу професійного самовизначення у перший, а інколи й у третій.

Що ж до третього мотиваційного типу, то тут переважають мотиви, які зумовлюють егоцентричну спрямованість особистості. Характерна риса представників цього типу - утилітарне ставлення до професії, прагнення задовольнити свої, головним чином побутові, потреби. Професія розглядається ними як засіб досягнення по-своєму зрозумілого матеріального та духовного комфорту. Їхні пізнавальні та професійні інтереси недостатньо визначені, тим часом як академічна успішність може бути високою. Самооцінка професійної відповідності в таких студентів завищена.

До четвертого мотиваційного типу належить та частина студентів, які обрали професію без достатньо глибокого усвідомлення ії вимог, своїх можливостей щодо оволодіння нею. Ці студенти ще не зайняли чіткої життєвої позиції. Професійні інтереси студентів такого типу не сформовані, життєві перспективи не пов'язані з обраною спеціальністю, професійні самооцінки є низькими. Суттєва частина 3 них або залишають ВНЗ самі, або змушені це зробити через неуспішність.

Вказані вище психологічні особливості студентів необхідно враховувати як на стадії планування, так і на стадії реалізації психологічної і психофізичної підготовки.

Оскільки психологічна й психофізична підготовка студентів, що вивчається в роботі, реалізується в процесі фізичного виховання, наступним питанням дослідження став розгляд того, як така підготовка може бути адаптована до структури фізичного виховання. 


\section{3. Психологічна й психофізична підготовка студентів-залізничників у структурі фізичного виховання}

У наш час поняття «фізичне виховання» трактується ширше і глибше порівняно $з$ тим періодом, коли його зміст зводився до оволодіння руховими навичками й уміннями та до розвитку фізичних якостей людини. Воно розглядається як складова освіти й виховання, педагогічний, навчально-виховний процес, предмет (навчальна дисципліна), спрямований на оволодіння знаннями, уміннями й навичками щодо управління фізичним розвитком людини, різновидами рухової активності, з метою навчання й виховання особистості в дусі відповідального ставлення до власного здоров'я і здоров'я оточення [293]. Фахівець із Молдови С. Данаіл обгрунтовано звертає увагу на можливість фізичної культури генерувати основні види людської діяльності. Він підкреслює універсальність і одночасно унікальність фізичної культури як педагогічної системи [113]. Т. Ю. Круцевич [387] виділяє в теорії фізичного виховання три напрямки: соціологічний, педагогічний та біологічний. У рамках першого розглядається питання ролі та місця фізичного виховання в житті людини та суспільства, співвідношення фізичного виховання з навчанням, вихованням та трудовою діяльністю, перспективи розвитку. Педагогічний напрямок пов'язаний з вивченням загальних закономірностей управління процесом фізичного виховання та його різновидами (професійно-прикладна фізична культура, рекреація, реабілітація). Біологічний напрямок концентрує увагу на дослідженні впливу рухової активності на процес життєдіяльності організму людини, його адаптації до рухової активності. Таке поєднання дозволяє розвивати, вдосконалювати фізичне виховання, ефективно реагувати на потреби життя. Саме в такому контексті ми розглядаємо питання психологічної і психофізичної підготовки студентів у ході викладання навчальної дисципліни «Фізичне виховання» у ВНЗ. Це допоможе якісніше підготувати до роботи майбутнього професіонала. Вища школа - школа професійна. Саме тому всі навчальні дисципліни, які викладаються, повинні повною мірою реалізовувати свої можливості для підготовки спеціаліста. Не є винятком і фізичне виховання. Перед дисципліною ставиться 
мета сприяти підготовці гармонійно розвинених висококваліфікованих фахівців.

Досягнення поставленої мети значною мірою залежить від змісту програми, яка реалізується. Навчальна програма для вищих навчальних закладів України III-IV рівнів акредитації [253] визначає стандарт фізичного виховання, відповідний мінімальний рівень обов'язкової фізкультурної освіти для студентів, що навчаються у вищих навчальних закладах і отримують кваліфікацію «молодший спеціаліст», «бакалавр». Вона є складовою стандарту вищої освіти, що гарантує держава.

Спираючись на навчальний план та базову навчальну програму 3 фізичного виховання, ВНЗ розробляють свої робочі навчальні програми $з$ цієї дисципліни. Вони конкретизують і доповнюють зміст базової фізкультурної освіти, враховуючи свою специфіку.

Відповідно до навчального плану навчальну дисципліну «Фізичне виховання» віднесено до блоку соціально-гуманітарних та економічних дисциплін. До обов'язкового мінімуму їх змісту на рівні підготовки бакалавра входить і положення про те, що бакалавр повинен розуміти роль фізичної культури і здорового способу життя, а також володіти системою практичних умінь і навичок, які забезпечують зміцнення здоров'я, розвиток психофізичних здатностей та якостей. По суті, тут прямо вказується на необхідність проведення психофізичної підготовки студентів під час викладання навчальної дисципліни «Фізичне виховання». Таким чином, зазначена проблема має важливе як теоретичне, так і практичне значення, але, незважаючи на це, $\epsilon$ недостатньо розробленою.

У навчальній програмі для ВНЗ вказано дві головні форми роботи зі студентами. Перша пов'язана 3 проведенням обов'язкових навчальних занять 3 фізичного виховання і спрямована на вирішення освітніх, виховних і оздоровчих завдань (з пріоритетом освітніх). Друга форма - це заняття у позанавчальний час (оздоровче й спортивне тренування, спортивні змагання, туристичні походи тощо). Використання різних форм і видів фізичного виховання повинно забезпечити 8-10 год на тиждень рухової активності студентів.

Розв'язання завдань, поставлених перед фізичним вихованням студентів, відповідно до програми забезпечується за допомогою двох взаємозалежних змістовних дидактичних компонентів: обов'язкового базового, що формує основи фізичної культури особистості фахівця 
відповідного рівня освіти, й елективного, що спирається на базовий і доповнює його з урахуванням професійної фізичної підготовки, індивідуальних інтересів, потреб, стану здоров'я. Навчальний матеріал кожного з компонентів реалізується через такі розділи: теоретична підготовка, методична підготовка, фізична підготовка, контроль. Завданням теоретичного розділу програми $\epsilon$ формування у студентів системи знань у сфері фізичної культури. Основне завдання методичної підготовки - освоїти методику визначення та індивідуального дозування рівня фізичних навантажень під час занять фізичними вправами, набути досвід використання фізкультурно-спортивної діяльності для досягнення поставлених життєвих і професійних цілей. Практичний розділ пов'язаний з безпосередньо фізичною підготовкою студентів.

Відповідно до положення про організацію фізичного виховання й масового спорту у вищих навчальних закладах [293], у ВН3 для проведення навчальних занять створюються навчальні групи навчальних секцій фізичного виховання, спортивного виховання й фізичної реабілітації. Розподіл проводиться на початку навчального року 3 урахуванням статі, стану здоров'я, фізичного розвитку, фізичної і спортивної підготовленості. Зміст роботи в кожній з перелічених вище навчальних секцій має свою специфіку. На нашу думку, ії необхідно доповнити тією чи іншою за змістом психологічною і психофізичною підготовкою. Остання повинна бути спрямована головним чином на підготовку до професійної діяльності.

Формою підсумкового контролю у фізичному вихованні студентів $€$ диференційований залік. У ході проведення контрольних заходів перевіряється засвоєння студентами навчальної програми відповідного року навчання за розділами теоретичної, методичної і фізичної підготовки. На нашу думку, цей розділ також необхідно доповнити контролем психологічної і психофізичної складової.

Запропоноване нами поєднання завдань фізичного виховання студентів і їх психологічної та психофізичної підготовки узгоджується також 3 державними вимогами до системи фізичного виховання дітей, учнівської і студентської молоді [116]. У документі зазначено, що фізичне виховання дітей і молоді України є важливим компонентом гуманітарного виховання, спрямоване на формування у них фізичного та морального здоров'я, удосконалення фізичної і психічної підготовки до ведення активного способу життя, професійної діяль- 
ності та захисту Батьківщини. На нашу думку, зазначене в документі поєднання фізичної і психічної підготовки в рамках фізичного виховання $є$ обгрунтованим, орієнтує на комплексний підхід під час його організації. Насамперед це стосується фізичного виховання студентів вищих навчальних закладів, у яких ведеться професійна підготовка і які повинні формувати в тому числі й професійно значущі структурні компоненти психічної організації майбутнього спеціаліста.

Одним із головних напрямків вдосконалення викладання фізичного виховання як навчальної дисципліни у вищих навчальних закладах $\epsilon$ вдосконалення його професійної спрямованості. Ця проблема досліджувалась науковцями за різними напрямками $[51,128,165,207$, 276, 291 та ін.]. Встановлено, що існуюча система фізичного виховання не забезпечує повною мірою психофізичну готовність випускників ВНЗ до життєдіяльності й професійної праці та потребує подальшого вдосконалення. Наголошується на особливій актуальності досліджень, спрямованих на вирішення проблем вдосконалення професійної спрямованості фізичного виховання студентів.

Метою психологічної та психофізичної підготовки студентівзалізничників $\epsilon$ формування психологічної та психофізичної готовності до продуктивної професійної праці. Її досягнення передбачає вирішення таких завдань, які визначаються специфікою майбутньої професійної діяльності. До них належать:

1. Формування у студентів системи знань стосовно структури психіки людини, можливостей регулювання власних емоцій і відносин 3 оточуючими.

2. Формування професійно значущих структурних компонентів особистості студента.

3. Розвиток характеристик уваги у студентів.

4. Навчання навикам психічної саморегуляції, формування емоційної стійкості студентів, профілактика засобами фізичної культури і спорту невротичної поведінки у схильних до цього студентів.

5. Розвиток психомоторики майбутнього фахівця, використання рухової активності для профілактики негативних впливів на психіку та зняття агресивності у студентів.

Робота з вирішення завдань психологічної і психофізичної підготовки студентів повинна плануватись у поєднанні із завданнями фізичного виховання. Їх достатнім співвідношенням для спеціальностей залізничного транспорту буде пропорція 1 до 3. 
Складові психологічної і психофізичної підготовленості студентів підлягають контролю. Підготовленість з розділу психологічна і психофізична підготовка оцінюється окремо і входить як складова до загальної оцінки з дисципліни «Фізичне виховання».

Організація роботи з психологічної і психофізичної підготовки серед студентів-залізничників передбачає проведення відповідної спеціалізованої підготовки як у навчальний, так і в позанавчальний час. Що стосується організації роботи під час навчальних занять, то тут вона будується відповідно до робочої навчальної програми з дисципліни «Фізичне виховання», яку складає кафедра фізичного виховання на основі Навчальної програми для вищих навчальних закладів України III-IV рівнів акредитації [253]. Робоча програма складається 3 урахуванням психологічної і психофізичної специфіки майбутньої професійної діяльності студентів факультету (напряму підготовки, спеціальності).

Поглиблену психологічну й психофізичну підготовку студентів необхідно забезпечити, створюючи в структурі навчальної секції фізичного виховання спеціалізовані навчальні групи психологічної і психофізичної підготовки. Аналогічно в рамках навчальної секції спортивного виховання доцільно створювати навчальні групи з професійно значущих видів спорту.

Студентам, яких за станом здоров'я віднесено до навчальної секції фізичної реабілітації, пропонуються доступні для засвоєння частини психологічної і психофізичної підготовки.

Навчальні заняття з психологічної і психофізичної підготовки студентів проводяться в теоретичній і практичній формі. Теоретичні заняття спрямовані головним чином на вирішення завдань психологічної просвіти.

Робота $з$ психологічної і психофізичної підготовки, яка організовується в позанавчальний час, доповнює ту, що проводиться під час навчальних занять (як практичних, так і теоретичних). Форми іiї організації можуть бути такі:

1. Самостійна теоретична підготовка (самопідготовка, написання реферату та ін.).

2. Заняття професійно значущими видами спорту під керівництвом тренера.

3. Самостійні практичні заняття (з використанням як засобів фізичного виховання, так і психотренувальних засобів). 
4. Спортивні й спортивно-масові заходи (змагання 3 професійно значущих видів спорту).

Викладачі кафедри фізичного виховання оцінюють рівень засвоєння теоретичного й практичного розділів психологічної і психофізичної підготовки. При цьому вони орієнтуються на спеціальні вимоги й нормативи, що розроблені кафедрою для кожного факультету (напряму підготовки, спеціальності). Так, рівень розвитку вестибулярної стійкості оцінюється в студентів спеціальностей «Мости і транспортні тунелі», «Електричний транспорт», «Електромеханічні системи автоматизації та електропривід», «Рухомий склад та спеціальна техніка залізничного транспорту».

Затверджені кафедрою фізичного виховання залікові вимоги 3 розділу психологічної і психофізичної підготовки є обов'язковими для студентів. Вони входять як окрема складова до залікових вимог 3 навчальної дисципліни «Фізичне виховання». Студенти, яких за станом здоров'я віднесено до навчальної секції фізичної реабілітації, виконують ті вимоги психологічної і психофізичної підготовки, які $€$ доступними для них.

У фізичному виховання студентів існує низка проблем у сфері контролю. Детальніше зупинимося на них. Контроль (від фр. controle) має декілька значень. У дидактиці його розуміють як нагляд, спостереження і перевірку успішності учнів (чи студентів). Контроль - більш широке поняття, ніж перевірка. Спостереження за студентом під час занять, вивчення продуктів навчальної і практичної діяльності, перевірка знань, навичок і вмінь студентів $є$ засобами контролю. Облік успішності передбачає фіксацію результатів контролю у вигляді оцінного судження або числового бала з метою аналізу стану навчально-виховного процесу за певний період, його причин і прийняття рішень про необхідність удосконалення практичних занять та інших форм організації навчання і їх методики.

Не буде перебільшенням сказати, що педагогічна майстерність викладача великою мірою визначається тим, як він володіє методами оцінювання студента, його навчальної діяльності, навчальної ситуації, результатів навчальної діяльності і т. д.

Педагогічна оцінка - це висновок відносно студента чи учня про характер його навчальної праці і її відповідність нормам навчальної діяльності. 
У фізичному вихованні завдяки контролю фіксуються дані про фізичний стан, техніко-тактичну підготовленість та кількісні досягнення тих, хто займається. Крім цього, перевіряється ефективність засобів, методів і організаційних форм, які застосовуються, з'ясовується характер ускладнень у навчальному процесі. Ці дані дозволяють точніше планувати й коректувати навчально-виховний процес, тим самим сприяючи покращенню його якості.

У педагогіці проблему контролю за навчальною діяльністю студентів досліджували С. О. Скидан [354], М. І. Сметанський [359], В. С. Сосонко [368], І. М. Гулідов [105], Н. В. Ізотова [145], М. Л. Романова [327] та ін.

Метою дослідження автора, результати якого відображено в [282], стало виявлення проблем контролю у фізичному вихованні студентів.

Завданнями дослідження були:

1. Здійснення аналізу системи контролю у фізичному вихованні студентів і виявлення існуючих недоліків.

2. Узагальнення та групування недоліків контролю (з метою організації цілеспрямованої роботи з їх усунення).

Головними методами дослідження були теоретичний аналіз і узагальнення літературних даних, спостереження за оцінювальною діяльністю викладачів у ситуаціях контролю.

При всьому розмаїтті форм навчання і педагогічних закладів, що виникають в наш час, головним, як і раніше, залишаються завдання навчання і виховання учнів чи студентів і контроль за цими процесами. Велике поширення феномена оцінки в навчально-виховному процесі школи і ВНЗ стало причиною того, що оцінювання викладачем (або учителем) результатів навчальної діяльності підопічних і самооцінювання виділились у самостійний напрям [195]. У сучасних дослідженнях контроль знань розглядається і як важливий чинник самовизначення студентів [192]. Проблема оцінювання й оцінки в різних своїх аспектах отримала відображення в працях вітчизняних і зарубіжних психологів і педагогів (Б. Г. Ананьєв, Ю. К. Бабанський, П. П. Блонський, Дж. Брунер, Л. І. Божович, Л. С. Виготський, І. Я. Лернер, В. С. Мерлін, С. Л. Рубінштейн, Г. І. Щукіна, Д. Б. Ельконін та ін.). Серед робіт, що присвячені питанням контролю у фізичному вихованні, слід виділити праці Т. Ю. Круцевич $[185,186]$, Є. Я. Бондаревського [50], Г. А. Вайник [65], М. Д. Зубалія [117]. 
Відповідно до теорії навчальної діяльності [260, с. 240], оцінювальна діяльність породжує потребу учня чи учителя отримувати інформацію про те, відповідає чи ні якість знань і умінь учня з предмету вимогам програми. Метою оцінювальної діяльності є, таким чином, контроль успішності тих, хто навчається, і формування у них адекватної самооцінки. У тих, хто навчається, у ході навчальновиховного процесу формується установка на оцінку своїх можливостей - одного із головних компонентів самооцінки. Предметом оцінювальної діяльності (який збігається 3 предметом навчально-пізнавальної діяльності) є система знань і умінь студента чи учня. Наслідком акта оцінювання викладачем (або вчителем) результатів навчальної діяльності підопічного є оцінка.

Аналіз педагогічної літератури, особистий педагогічний досвід автора та численні спостереження дозволяють виявити, узагальнити та згрупувати недоліки контролю у системі фізичного виховання ВНЗ. Насамперед звертає на себе увагу суперечність методологічного характеру. Зміст дисципліни в різних категорій студентів (навчальні секції фізичного виховання, спортивного виховання, фізичної реабілітації) різний, контрольні заходи в них теж різні, у той же час наприкінці семестру всім виставляється диференційований залік з дисципліни «Фізичне виховання». Таку ситуацію важко навіть уявити при вивченні будь-якої іншої дисципліни. Наприклад, коли при вивченні математики одного студента оцінювали б за знання вищої математики, іншого за знання таблиці множення, а потім обом виставляли отримані бали за знання вищої математики.

Безумовно, фізичне виховання має свою специфіку. Однією із іï складових $\epsilon$ те, що велику групу студентів за результатами медичного огляду відносять до спеціальної медичної групи або звільняють від практичних занять. Це закономірно і не викликає заперечень. Хвора людина не може виконувати те фізичне навантаження, яке виконує здорова. Але в такому випадку логічно було б змінити назву дисципліни, яку вона вивчає. Ця назва повинна відображати зміст роботи, що виконується. У ВНЗ, на наш погляд, могли б бути такі: «Оздоровче виховання», «Фізичне виховання в секції фізичної реабілітації», «Фізична реабілітація» і т. ін.

Математики, до речі, діють саме так. Вони прийшли до висновку, що для деяких економічних спеціальностей вивчення дисципліни «Вища математика» в повному обсязі не є доцільним. Після цього бу- 
ло проведено відповідні скорочення, але автоматично змінили і назву дисципліни. Її назвали «Математика для економістів». У цій ситуації все зрозуміло. Вивчав студент вищу математику - це одне, вивчав математику для економістів - це інше. У фізичному ж вихованні такої диференціації, на жаль, немає. Хворий студент, який відвідував заняття у спеціальній медичній групі, і студент-спортсмен із відділення спортивного виховання можуть отримати, наприклад, оцінку «відмінно» з однієї і тієї ж дисципліни «Фізичне виховання». По суті, відбувається нівелювання педагогічної вимоги про єдність вимог в процесі контролю.

Друга група - це недоліки контролю загальнопедагогічного та дидактичного характеру. Вони спричиняють порушення принципів та функцій контролю і безпосередньо впливають на виявлення повноти і глибини засвоєння студентами навчального матеріалу. До цих недоліків належать необ'єктивність оцінки, контроль другорядних знань, використання завдань, які потребують репродуктивних відповідей, відсутність детального дидактичного аналізу помилок і прогалин у підготовці, затримка роботи над помилками і прогалинами після контрольних заходів, відсутність диференційованої роботи зі студентами за результатами контролю.

Третя група - недоліки методичного характеру. До них належать:

- недостатня теоретична та методична підготовка викладачів (перш за все молодих);

- не визначаються базові знання та вміння з теоретичної та методичної підготовки, які необхідно контролювати;

- не завжди правильно визначаються викладачами місце та час контролю;

- викладачі не знають або не дотримуються умов виконання вправ при складанні студентами контрольних нормативів 3 фізичної підготовки;

- різний підхід викладачів до визначення значущості виявлених недоліків;

- відсутність коментування оцінки та систематичних спостережень за ліквідацією прогалин у підготовці студентів з урахуванням результатів перевірки.

Четверту групу складають недоліки виховного характеру, які негативно впливають на особистість студента. До них належать: систематичне завищення або заниження оцінки; суб'єктивний характер 
висловлених викладачем оцінювальних суджень; антипедагогічні дії батьків з метою стимулювання студента до навчання.

До п'ятої групи слід віднести недоліки психологічного характеру. Вони лежать в основі необ'єктивної оцінки.

Особливості психологї викладача. Під час контролю та оцінки зважає на репутацію студента, особисте ставлення до нього; рівень групи («сильна» чи «слабка»); несумлінний під час контролю, виявляє лібералізм або надмірну суворість; не має розподіленої уваги або вона недостатньо сформована; схильний до позитивних або негативних емоційних проявів та суджень.

Особливості психологї студента. Під час контрольних заходів може не показувати своєї фактичної підготовки. Це є результатом виявлення студентом недовір'я викладачу щодо справедливого оцінювання рівня підготовки, завищення вимог викладача, хвилювання під час складання.

Висновки дослідження:

1. Завдання навчання і виховання студентів та контроль за цими процесами продовжують залишатися головними в роботі закладів освіти.

2. Контроль у фізичному вихованні студентів має ряд проблем різного рівня, які умовно можна класифікувати як методологічні, загальнопедагогічні та дидактичні, методичні, виховні, психологічні.

3. Запропонована класифікація проблем контролю допоможе викладачам організувати цілеспрямовану роботу з їх позитивного вирішення під час організації роботи з проведення психологічної і психофізичної підготовки майбутніх фахівців.

Широкий простір для моделювання ситуацій, у яких можуть ефективно вирішуватися завдання психологічної і психофізичної підготовки студентів-залізничників, надають заняття з плавання, гімнастики, спортивних ігор, легкої атлетики, важкої атлетики, єдиноборств. Так, для розвитку такої професійно значущої для деяких залізничних професій якості, як вестибулярна стійкість ефективними є гімнастичні вправи. Їх приклади подано в [88].

Вправи на рівновагу, вправи $з$ лазання й перелізання, переповзання, подолання перешкод можна використовувати для забезпечення психологічної і психофізичної підготовленості таких залізничних спеціальностей, як «Мости i транспортні тунелі», «Електричний транспорт», «Електромеханічні системи автоматизації та електропри- 
від», «Вагони та вагонне господарство», «Локомотиви та локомотивне господарство», «Підйомно-транспортні, будівельні, дорожні, меліоративні машини і обладнання», «Залізничні споруди та колійне господарство», «Промислове і цивільне будівництво».

Вправи на рівновагу можна виконувати як на підлозі, так і на підвищеній опорі (гімнастичній лаві, гімнастичній колоді). Необхідною умовою збереження рівноваги $є$ розташування центру ваги над площиною опори. Чим більша площина опори й нижче центр ваги, тим стійкіша рівновага. Вправи на рівновагу виконуються як на місці, так i в русі. Прикладами вправ на місці є різноманітні стійки (на носках, на п’ятах, на одній нозі), рухи руками, ногами, тулубом за зменшеної опори (різноманітні повороти як на одній, так і на двох ногах, повороти стрибком, присідання на одній і двох ногах). Крім цього, на підвищеній опорі можна виконувати різноманітні переходи із більш низького положення в більш високе і навпаки (у тому числі і в положення лежачи). Прикладами вправ у русі є всі різновиди ходьби (звичайна, приставним кроком, ходьба спиною вперед, із заплющеними очима, з нахилом або поворотом голови), пересування бігом і танцювальними кроками. Більшу частину вправ цієї групи складає ходьба 3 додатковими рухами руками й тулубом, із зупинками, нахилами, поворотами і т. ін. Використовуються також вправи з ходьби з подоланням перешкод, перенесенням вантажу, із розходженням удвох i пересуванням у змішаній опорі. Перешкодами під час виконання вправ на колоді можуть бути скакалки, палки, набивні м'ячі тощо. Вправи з пересування зі змішаною опорою можуть являти собою пересування в упорі стоячи на колінах, в упорі присівши, пересування вбік в упорі сидячи.

Вправи $з$ лазання й перелізання є також ефективним засобом розвитку координаційних здібностей студентів, їх спритності, сміливості. Лазання можна виконувати в змішаному висі й у висі на одних руках. На заняттях з гімнастики використовуються вправи з лазання на гімнастичній стінці (лазання вгору, вниз, пересування в сторони 3 почерговим перехватом руками і переступанням ногами; те саме, але з одночасним перехватом руками; пересування стрибками вгору, вниз і в сторони; лазання спиною до стінки) і лазання по канату (лазання у висі на зігнутих руках, лазання в три прийоми, лазання у два прийоми, лазання із зупинками). 
Найбільш складним видом лазання є групове. Воно потребує високої психологічної і фізичної підготовленості студентів і надійного обладнання. Виконується воно на гімнастичній драбині у вертикальному або в нахиленому положеннях, на канаті або жердині. Лазання поєднується $з$ перенесенням товариша або з перелізанням. На драбині й канаті можна проводити лазання з партнером, що сидить на спині або плечах.

Що стосується перелізань, то їх виконують у висі (з канату на канат, $з$ драбини на драбину), в упорі та із вису в упор і назад. Так, на нахиленій або горизонтальній драбині виконуються перелізання 3 верхнього боку на нижній і назад (ногами вперед, головою вперед, переворотами в упор, підійманням силою, опусканням вперед із упору і т. д.).

Одним із головних напрямів вдосконалення викладання фізичного виховання як навчальної дисципліни у вищих навчальних закладах $\epsilon$ теоретичне і практичне вирішення комплексу питань, які пов'язані 3 організацією роботи зі студентами, яких за станом здоров'я віднесено до навчальної секції фізичної реабілітації. До цієї секції включають студентів, котрі мають відхилення у стані здоров'я тимчасового чи постійного характеру, які не $\epsilon$ перешкодою для занять 3 фізичного виховання, але потребують обмеження фізичних навантажень. Серед засобів фізичного виховання цих студентів використовуються: загартовування, фізичні вправи (релаксаційні, ідеомоторні, дихальні, ритмопластичні, на координацію, у рівновазі, коригувальні), ігри (народні, спортивні), самомасаж. У той же час, актуальним $\epsilon$ дослідження використання ряду інших засобів у роботі зі студентами навчальної секції фізичної реабілітації. Це може підвищити мотивацію до занять, зробить можливим вирішення в рамках вивчення навчальної дисципліни «Фізичне виховання» інших важливих завдань.

Фахівці [387, 385] виділяють такі завдання, що стоять перед фізичним вихованням цієї категорії студентів:

- виробити у студентів позитивне ставлення до подолання відхилень у стані здоров'я;

- надати знання про причини захворювань і відставання у фізичному розвитку, властивості хворого й ослабленого організму, про оздоровчі засоби й методи, способи самоконтролю; 
- сформувати у студентів стійку звичку до загартовування й систематичних фізичних вправ;

- підібрати й застосувати найраціональніші індивідуальні засоби й методи фізичного виховання, які відповідають рівню фізичного розвитку й фізичній підготовленості;

- забезпечити необхідний рівень рухової активності, котра відповідає загальним та індивідуальним вимогам за тривалістю, інтенсивністю, спрямованістю фізичних вправ;

- суворо дотримуватися методичних рекомендацій, не використовувати протипоказані засоби фізичного виховання;

- уникати перевантажень, забезпечити профілактику травм;

- забезпечити раціональний відпочинок і відновлення оптимального функціонального стану й працездатності.

У той же час фізичне виховання має суттєвий потенціал для підготовки студента до майбутньої професії. У багатьох роботах підкреслюється необхідність реалізації у ВНЗ професійно спрямованого фізичного виховання [132, 165, 172, 280, 312, 402] та ін. Науковцями [51, 66, 346 та ін.] запропоновано варіанти такого фізичного виховання для ряду професій, але орієнтовані вони в основному на студентів навчальних секцій фізичного і спортивного виховання. Виникає питання про зміст, засоби, форми, методи професійно спрямованого фізичного виховання студентів навчальної секції фізичної реабілітації.

Останнім часом спостерігається стійка тенденція до збільшення розмаїття форм і засобів фізкультурно-оздоровчої діяльності та зростання інтересу до нетрадиційних (для нашої країни) форм фізичної культури. Східні оздоровчі системи - це цілісні комплекси соціокультури Сходу, що поєднують функції оздоровлення, лікування, освіти та тренування. Великий інтерес серед оздоровчих систем викликає йога, яка об'єднує в єдиний комплекс енергетичні, психічні та фізіологічні ресурси людини і спрямовує їх на активну адаптацію до навколишнього соціального й природнього середовища. В останнє десятиріччя широкої популярності набула сахаджа-йога. Більш ніж у 100 країнах світу численні прибічники цього напрямку демонструють його лікувальний та перетворювальний ефект.

Дослідження впливу системи сахаджа-йоги на оздоровлення людини були проведені в Індії (лікарями Рай, Сетхі, Сінг, 1994) та в Роciї (на базі Державної академії фізичної культури ім. П. Ф. Лесгафта (м. Санкт-Петербург) у період з 1993 по 2003 р.). 
Під керівництвом автора проведено дослідження можливостей використання сахаджа-йоги для вирішення завдань психологічної і психофізичної підготовки студентів-залізничників, які відвідували навчальні заняття з фізичного виховання в навчальній секції фізичної реабілітації. У дослідженні брали участь 30 студенток Дніпропетровського національного університету залізничного транспорту ім. акад. В. Лазаряна. Вік учасників дослідження 17-19 років. Метою дослідження стало виявлення можливостей використання сахаджа-йоги для формування у професійно значущому напрямку деяких складових професійно-спрямованої психологічної і психофізичної підготовки студентів-залізничників. Завданнями цього напрямку досліджень були:

1. Проаналізувати й виявити елементи системи сахаджа-йога, які можуть бути використані для вирішення завдань психологічної і психофізичної підготовки студентів-залізничників.

2. Перевірити ефективність використання елементів сахаджа-йога у формуванні складових психологічної і психофізичної підготовки студентів-залізничників.

Оздоровча система сахаджа-йога інтегрує всі види йоги, застосовуючи у своїй практиці медитацію, фізичні вправи - асани, дихальні вправи - пранаяму, природні фактори природи для очищення і загартування фізичного тіла і його енергоінформаційної структури. Система включає в себе такі складові:

1. Формування особистої відповідальності за стан власного здоров'я.

2. Навчання здоровому способу життя (свідома відмова від шкідливих звичок, оптимізація фізичних і психічних навантажень).

3. Навчання управлінню своїм станом і зниженню явищ стресу.

4. Розвиток моральності як основи здоров'я і сім'ї.

5. Застосування методик саморелаксації, що базуються на принципах добра й миру, які дають можливість позитивної трансформації особистості та сімейних відносин.

Виявлено позитивний вплив застосування оздоровчої системи сахаджа-йога як засобу психофізичної рекреації на нормалізацію психоемоційного напруження, підвищення рівня саморегуляції фізичного стану, розвиток деяких особистісних якостей. Так, 10-15-хвилинна медитація при напрузі і втомі давала рекреаційний ефект, рівний декільком годинам повноцінного сну. Було виявлено, що після кількох 
тижнів практики медитації за методикою сахаджа-йоги змінюється низка фізіологічних параметрів, які пов'язані з активацією парасимпатичної нервової системи. Багаторічні спостереження показали, що стресові ситуації не тільки легко переносяться практикуючими, але й дають можливість запобігати небажаним наслідкам стресу.

Методика комплексного відновлення здоров'я людини сахаджайога 2003 року внесена в каталог-довідник Міністерства охорони здоров’я РФ «Діагностичні та оздоровчі технології відновлювальної медицини».

Основними засобами програми психологічної і психофізичної підготовки студентів навчальної секції фізичної реабілітації за методикою сахаджа-йоги були медитація та фізичні вправи йоги (асани).

Для вдосконалення фізичного стану головна увага приділялася належному догляду за хребтом. Нервова система є провідником енергоінформаційних імпульсів, які координують роботу всіх систем і органів. Одним із ефективних методів підтримки хребта в задовільному стані є виконання його простих скручувань. Для відновлення і розвитку гнучкості хребта на заняттях використовувалась вправа йоги «Крокодил» (за А. Рааб).

Медитація в сахаджа-йозі - це повна відсутність думок при повній свідомості. Слово «медитація» на санскриті звучить як «дхьяна», що іноді перекладається як «зосередження». У Китаї це слово трансформувалось в «чань», а в Японії в «дзен». Медитація в сахаджа-йозі не $\epsilon$ видом самонавіювання, трансу, втрати свідомості або чогось подібного. Під час такої медитації неможливо споглядати видіння, світло, чути голоси та інше, що відволікає від реальності. У процесі медитації сахаджа-йог повністю усвідомлює себе (своє місцезнаходження, загальний стан і т. ін.). Суб'єктивно результати сахаджамедитації переживаються як «легкість», «розслаблення», «безтурботний спокій», «прояснення» свідомості, встановлення радісно-комфортного відчуття у всьому організмі, відчуття бадьорості.

Медитація зі студентами проводилася на початку та в кінці заняття. В основній частині використовувалися вправи для розвитку фізичних якостей, вправи на відновлення, розвиток гнучкості хребта.

Перед початком впровадження програми та в ході занять були прочитані лекції. Їх метою було зорієнтувати студентів на необхідність самопізнання та самовдосконалення, розвиток своїх внутрішніх здібностей, розкриття життєвого потенціалу. 
Використання зазначених вище елементів сахаджа-йоги позитивно вплинуло на ряд складових, що відіграють важливу роль у структурі психологічної і психофізичної підготовленості студентів-залізничників. Так:

1. Змінилося ставлення студентів до занять 3 фізичного виховання. Це проявилось, зокрема, у суттєвому покращенні відвідування занять, зростанні інтересу до них.

2. Студенти здобули початкові знання з використання прийомів діагностики та саморегуляції свого психоемоційного стану.

3. Студенти почали розуміти необхідність всебічного підходу до оздоровлення, до його фізичних, психічних і соціальні складових.

4. Змінилося на краще ставлення і правильне сприйняття студентами самих себе і навколишнього світу.

5. Опитування показало, що заняття із сахаджа-йоги суттєво вплинули на покращення емоційної стійкості студентів.

Дослідження дозволило зробити такі висновки:

1. Ефективними засобами психологічної і психофізичної підготовки студентів-залізничників, які відвідують навчалні заняття в секції фізичної реабілітації, є такі складові східної системи сахаджа-йога, як медитація та фізичні вправи йоги (асани).

2. Вказані вище елементи можуть бути використані в практиці фізичного виховання як ефективний засіб психологічної та психофізичної підготовки.

\section{4. Діагностика актуального стану психологічної і психофізичної підготовленості студентів-залізничників}

Наступним кроком дослідження стало виявлення реального рівня психологічної і психофізичної підготовленості студентів. Мета цього етапу - з'ясувати рівень розвитку низки характеристик студентів-залізничників, які впливають на їх психологічну й психофізичну підготовленість. Головні завдання:

1. Виявити рівень ситуативної і особистісної тривожності студентів та рівень їх суб'єктивного контролю. 
2. Встановити рівень розвитку вибірковості та концентрації і стійкості уваги в студентів.

3. Встановити рівень розвитку сенсомоторних процесів у студентів (швидкість у діях, стійкість вестибулярних реакцій).

У дослідженні брали участь 420 студентів ДНУЗТ ім. акад. В. А. Лазаряна. 3 них 345 - юнаки і 75 - дівчата. Усі студенти навчалися на першому курсі факультетів «Мости і тунелі», «Електрифікація залізниць», «Механічний», «Управління процесами перевезень», «Організація будівництва доріг та експлуатація колії», «Промислове та цивільне будівництво», «Економіка та менеджмент на транспорті», «Технічна кібернетика». Вік учасників дослідження складав $17-18$ років.

Діагностика показників психологічної і психофізичної підготовленості виконувалася 3 використанням таких засобів. При діагностиці ситуативної й особистісної тривожності в студентів застосовувалася шкала оцінки рівня ситуативної й особистісної тривожності Ч. Спілбергера в адаптації Ю. Л. Ханіна. Рівень суб'єктивного контролю вимірювався 3 допомогою опитувальника рівня суб'єктивного контролю Є. Ф. Бажина, розробленого на основі шкали локусу контролю Дж. Роттера. Вибірковість уваги у студентів визначалась із застосуванням тесту Мюнстерберга, а такі ії характеристики, як концентрація і стійкість - з допомогою коректурної проби Бурдона. Оцінка сенсомоторних процесів проводилась 3 використанням спеціальних фізичних вправ [240, с. 203]. Так, для оцінки швидкості в діях студенти виконували кидки баскетбольного м'яча в коло. Ставилося завдання виконати якомога швидше 20 кидків м'яча в стіну (у коло діаметром 50 см) з відстані два метри. Результат, більший за 21 с, вважався низьким. Стійкість вестибулярних реакцій оцінювалася за допомогою таких вправ, як біг на 25 м з одночасним виконанням п'яти поворотів (обертів на $360^{\circ}$ ) та стійкість після виконання перекидань. Перша вправа полягала у виконанні бігу в коридорі шириною 150 см. Спочатку студенти виконували звичайне пробігання, а потім - пробігання з поворотами. Враховувалося збільшення часу пробігання й кількість виходів із коридору. Результат вважався відмінним у тому випадку, якщо час пробігання збільшувався не більше ніж на три секунди i не було допущено жодного виходу із коридору. При збільшенні часу більш ніж на 5 с або у випадку двох виходів із коридору фіксувалася підвищена вестибуло-соматична реакція. Під час другої вправи 
студенти виконували 5 перекидань вперед за 10 с. Здатність впевнено зберігати основну стійку після виконання перекидань оцінювалась оцінкою «відмінно». За наявності нестійкості зі сходженням 3 місця до одного кроку ставилась оцінка «добре», до двох кроків - «задовільно», при більш значних відхиленнях або зниженні - «незадовільно».

За показником ситуативної тривожності отримано такі результати (табл. 1).

Таблиия 1

Рівень ситуативної тривожності студентів $(n=420)$

\begin{tabular}{l|c|c|c|c}
\hline \multirow{2}{*}{\begin{tabular}{c} 
Рівень ситуативної \\
\multicolumn{1}{c|}{ тривожності }
\end{tabular}} & \multicolumn{2}{|c}{ Юнаки } & \multicolumn{2}{c}{ Дівчата } \\
\cline { 2 - 5 } & Кількість & $\%$ & Кількість & $\%$ \\
\hline Низький & 314 & 91 & 43 & 57 \\
Середній & 31 & 9 & 32 & 43 \\
Високий & 0 & 0 & 0 & 0
\end{tabular}

Статистичні показники вибірки хлопців такі:

1. Середнє арифметичне - 21 бал.

2. Медіана - 21 бал.

3. Мода - 22 бали.

4. Стандартне відхилення - 6,56 бали.

Статистичні показники вибірки дівчат такі:

1. Середнє арифметичне - 26 балів.

2. Медіана - 25, 5 бала.

3. Мода - 32 бали.

4. Стандартне відхилення - 11, 25 бала.

За критерієм особистісної тривожності розподіл відбувся, як показано в табл. 2.

Таблиця 2

Рівень особистісної тривожності студентів $(n=420)$

\begin{tabular}{l|c|c|c|c}
\hline \multirow{2}{*}{$\begin{array}{c}\text { Рівень ситуативної } \\
\text { тривожності }\end{array}$} & \multicolumn{2}{|c|}{ Юнаки } & \multicolumn{2}{c}{ Дівчата } \\
\cline { 2 - 5 } \multicolumn{1}{c|}{} & Кількість & $\%$ & Кількість & $\%$ \\
\hline Низький & 41 & 12 & 0 & 0
\end{tabular}


Закінчення табл. 2

\begin{tabular}{l|c|c|c|c}
\hline \multirow{2}{*}{\begin{tabular}{c} 
Рівень ситуативної \\
\multicolumn{1}{c|}{ тривожності }
\end{tabular}} & \multicolumn{2}{|c|}{ Юнаки } & \multicolumn{2}{c}{ Дівчата } \\
\cline { 2 - 5 } & Кількість & $\%$ & Кількість & $\%$ \\
\hline Середній & 255 & 74 & 38 & 51 \\
Високий & 49 & 14 & 37 & 49
\end{tabular}

Статистичні показники вибірки хлопців такі:

1. Середнє арифметичне - 37 балів.

2. Медіана -36 балів.

3. Мода - 35 балів.

4. Стандартне відхилення - 11,25 бала.

Статистичні показники вибірки дівчат такі:

1. Середнє арифметичне - 45,64 бали.

2. Медіана - 46 балів.

3. Мода - 61 бал.

4. Стандартне відхилення - 10,07 бала.

Діагностика рівня суб'єктивного контролю дала змогу виявити такі результати (табл. 3).

Таблиця 3

Рівень суб’'сктивного контролю студентів $(n=420)$

\begin{tabular}{l|c|c|c|c}
\hline \multirow{2}{*}{$\begin{array}{c}\text { Рівень ситуативної } \\
\text { тривожності }\end{array}$} & \multicolumn{2}{|c|}{ Юнаки } & \multicolumn{2}{c}{ Дівчата } \\
\cline { 2 - 5 } & Кількість & $\%$ & Кількість & $\%$ \\
\hline Низький & 0 & 0 & 0 & 0 \\
Середній & 273 & 79 & 61 & 81 \\
Високий & 72 & 21 & 14 & 19
\end{tabular}

Статистичні показники вибірки хлопців такі:

1. Середнє арифметичне - 28,1 бала.

2. Медіана - 29 балів.

3. Мода - 30 балів.

4. Стандартне відхилення - 5,3 бала.

Статистичні показники вибірки дівчат становлять:

1. Середнє арифметичне $-27,7$ бали.

2. Медіана - 27 балів. 
3. Мода - 27 балів.

4. Стандартне відхилення - 4,75 бала.

Дослідження вибірковості уваги у студентів показало таку ситуацію (табл. 4).

Таблиияя 4

Вибірковість уваги студентів $(n=420)$

\begin{tabular}{c|c|c|c|c}
\hline \multirow{2}{*}{ Бали } & \multicolumn{2}{|c|}{ Юнаки } & \multicolumn{2}{c}{ Дівчата } \\
\cline { 1 - 5 } & Кількість & $\%$ & Кількість & $\%$ \\
\hline 1 & 3 & 1 & 0 & 0 \\
3 & 31 & 9 & 0 & 0 \\
4 & 83 & 24 & 2 & 3 \\
5 & 138 & 40 & 30 & 40 \\
& 90 & 26 & 43 & 57
\end{tabular}

Статистичні показники вибірки хлопців за цим показником такі:

1. Середнє арифметичне - 17 слів.

2. Медіана - 18 слів.

3. Мода - 16 слів.

4. Стандартне відхилення - 5 слів.

Статистичні показники вибірки дівчат такі:

1. Середне арифметичне - 20,7 слова.

2. Медіана - 21 слово.

3. Мода - 22 слова.

4. Стандартне відхилення - 3 слова.

Результати діагностики рівня розвитку концентрації і стійкості уваги у студентів наведено в табл. 5.

Таблицяя 5

Концентрація і стійкість уваги студентів $(n=420)$, бали

\begin{tabular}{c|c|c|c|c|c|c|c|c|c}
\hline Бали & 1 & 2 & 3 & 4 & 5 & 6 & 7 & 8 & 9 \\
\hline & \multicolumn{1}{c}{ Юнаки } \\
Кількість & 52 & 76 & 83 & 48 & 35 & 34 & 7 & 10 & 0 \\
$\%$ & 15 & 22 & 24 & 14 & 10 & 10 & 2 & 3 & 0
\end{tabular}


Закінчення табл. 5

\begin{tabular}{c|c|c|c|c|c|c|c|c|c}
\hline Бали & 1 & 2 & 3 & 4 & 5 & 6 & 7 & 8 & 9 \\
\hline \multirow{2}{*}{ Кількість } & 0 & 4 & 4 & 19 & 26 & 4 & 18 & 0 & 0 \\
$\%$ & 0 & 5 & 5 & 25 & 35 & 5 & 25 & 0 & 0
\end{tabular}

Статистичні показники вибірки хлопців такі:

1. Середне арифметичне - 1320 знаків.

2. Медіана - 1281 знак.

3. Мода - 1226 знаків.

4. Стандартне відхилення - 304 знаки.

Статистичні показники вибірки дівчат такі:

1. Середнє арифметичне - 1600 знаків.

2. Медіана - 1562 знаки.

3. Мода - 1508 знаків.

4. Стандартне відхилення - 234 знаки.

Діагностика рівня розвитку деяких сенсомоторних процесів у студентів дозволила встановити таке (табл. 6).

Таблицуя 6

Швидкість у діях студентів $(n=345)$

\begin{tabular}{l|c|c}
\hline \multicolumn{1}{c|}{ Рівень прояву } & Кількість & $\%$ \\
\hline Низький & 169 & 49 \\
Достатній & 176 & 51
\end{tabular}

Статистичні показники вибірки такі:

1. Середнє арифметичне - 23,6 c.

2. Медіана - 21 с.

3. Мода -19 с.

4. Стандартне відхилення - 7,41 с.

Дослідження стійкості вестибулярних реакцій (за результатами бігу на 25 м з одночасним виконанням п'яти поворотів) продемонструвало такі результати (табл. 7). 
Стійкість вестибулярних реакцій студентів за результатами виконання бігу на 25 м з одночасним виконанням 5 поворотів $(n=345)$

\begin{tabular}{l|c|c}
\hline \multicolumn{1}{c|}{ Рівень прояву } & Кількість & $\%$ \\
\hline Відмінний & 124 & 36 \\
Підвищені вестибулярні реакції & 221 & 64
\end{tabular}

Діагностика стійкості вестибулярних реакцій за результатами 5 перекидань вперед за 10 секунд дозволила зафіксувати таку тенденцію (табл. 8).

Таблиия 8

Стійкість вестибулярних реакцій студентів за результатами виконання 5 перекидань вперед за 10 с $(n=345)$

\begin{tabular}{c|c|c|c|c}
\hline Бали & 5 & 4 & 3 & 2 \\
\hline Кількість & 24 & 86 & 62 & 173 \\
$\%$ & 7 & 25 & 18 & 50
\end{tabular}

Статистичні показники вибірки такі:

1. Середнє арифметичне - 2,96 бали;

2. Медіана - 3 бали;

3. Мода - 2 бали;

4. Стандартне відхилення - 1,03 бала.

Дані, отримані в дослідженні стосовно ситуативної (реактивної) тривожності студентів, показують, що фізичне виховання не викликає в них відчуття тривоги. Абсолютна більшість студентів (як юнаків, так і дівчат) продемонструвала низький рівень цього показника. Це дає підстави констатувати певне позитивне налаштування на фізкультурну діяльність, не сприйняття ії як стресогенної. Така ситуація $\epsilon$ сприятливою для вирішення завдань психологічної і психофізичної підготовки в процесі навчальних занять з фізичного виховання. Мова йде, насамперед, про подолання властивого для деяких студентів відчуття невпевненості в собі, про підвищення рівня психологічної просвіти.

Показники особистісної тривожності не були такими однозначними, як у випадку ситуативної. Незважаючи на те що 86 \% юнаків 
продемонстрували низький і помірний рівень особистісної тривоги, у 14 \% виявлено високий. Це досить значна група, яка потребує проведення спеціальної профілактичної роботи в процесі психологічної і психофізичної підготовки. На нашу думку, підвищити рівень впевненості в собі і таким чином позитивно вплинути на високий рівень особистісної тривожності у цих студентів можуть заняття єдиноборствами, атлетизмом і т. ін. Таких студентів доцільно об'єднувати в окремі навчальні групи й проводити з ними відповідну роботу.

У дівчат (порівняно 3 юнаками) показники особистісної тривожності виявилися набагато вищими. Високі показники зафіксовано у 49 \% студенток, низькі - взагалі не зафіксовано. Для пояснення ситуації необхідні спеціальні психологічні дослідження. У рамках же психологічної і психофізичної підготовки студенток із високими показниками особистісної тривожності необхідно залучати до занять, які будуть сприяти підвищенню впевненості у собі. Це може бути художня або спортивна гімнастика, аеробіка, танці, сахаджа-йога. Таких студенток також доцільно об'єднувати у окремі навчальні групи.

Важливою узагальненою характеристикою особистості, яка суттєво впливає на формування міжособистісних відносин і способи розв'язання кризових (у тому числі й виробничих) ситуацій, $є$ рівень суб'єктивного контролю. Відповідно до концепції локусу контролю (Дж. Роттер) особи, які беруть відповідальність за події, що відбуваються в їх житті, на себе (пояснюють їх своєю поведінкою, рисами особистості, здібностями) мають внутрішній (інфернальний) контроль. Особи ж, які налаштовані приписувати відповідальність за події зовнішнім чинникам (іншим людям, випадку і т. ін.), мають зовнішній (екстернальний) контроль.

Враховуючи відповідальність, яку несе сучасний інженер-залізничник за збереження життя і здоров'я пасажирів, за збереження вантажів, нами було виконано вивчення рівня суб'єктивного контролю у студентів-залізничників. Результати, наведені в табл. 3, показують таке. $21 \%$ юнаків та $19 \%$ дівчат мають високий рівень суб'єктивного контролю. Це люди, які здатні взяти на себе відповідальність за те, що відбувається $з$ ними та іншими (залежними від них) людьми. Середній рівень суб'єктивного контролю виявлено у 79 \% юнаків та у 81 \% дівчат. Вважається, що такі люди однаковою мірою як беруть відповідальність на себе, так і перекладають іiї на інших людей. Низький рівень суб'єктивного контролю в студентів нами не виявлений. 
Такі люди у більшості випадків знімають із себе відповідальність за те, що відбувається, і перекладають їі на обставини або інших людей. По суті, вони не володіють необхідною відповідальністю.

Виявлені тенденції дають підстави припустити, що абсолютна більшість абітуріснтів залізничних ВНЗ усвідомлюють, що професії залізничного транспорту покладають на людину велику особисту відповідальність. Ті з них, хто не готовий до цього, до залізничних вишів не вступають.

Для низки професій залізничного транспорту (організація перевезень і управління на залізничному транспорті, електричний транспорт, рухомий склад та спеціальна техніка залізничного транспорту) винятково важливе значення має достатній розвиток різноманітних характеристик уваги. У роботі наведено дані стосовно розвитку вибірковості (див. табл. 4) та концентрації і стійкості (див. табл. 5) уваги студентів-залізничників. Стосовно вибірковості уваги виявлено, що у 66 \% юнаків розвиток цієї характеристики знаходиться на рівні 4 і 5 балів (за 5-бальною шкалою). На рівні 3 балів виконали роботу $24 \%$ студентів. $10 \%$ показали незадовільні результати (на рівні 2 і 1 балу). Показники вибірковості уваги у дівчат виявилися суттєво вищими. $97 \%$ \% них виконали завдання на 5 або 4 бали.

Вибірковість уваги людини характеризує іï здатність вибрати із множини сигналів тільки деякі із них. Вона пов'язана з можливістю успішного налаштування (за наявності перешкод) на сприйняття інформації, яка стосується усвідомленої цілі. Отримані дані показують, що дві третини студентів мають цю характеристику добре розвиненою (оцінки на рівні 5 і 4 балів). У той же час у третини студентів вибірковість уваги розвинена недостатньо (оцінки на рівні 1, 2 і 3 балів). Ця частина студентів потребує спеціальної психофізичної підготовки з їі розвитку.

Слід відзначити суттєво вищі показники вибірковості уваги у дівчат порівняно з юнаками. Тут також було б доречним спеціальне психологічне дослідження.

Стійкість уваги розглядається в психології як здатність суб'єкта не відхилятися від спрямованості психічної активності й зберігати зосередженість на об'єкті уваги. Концентрація уваги передбачає визначення здатності суб'єкта зберігати зосередженість на об'єкті уваги при наявності перешкод. Стійкість і концентрація уваги фахівця залізничного транспорту напряму пов'язана 3 такими питаннями його 
професійної праці, як безаварійність роботи, зниження травматизму, підвищення продуктивності праці та ін.

Аналіз даних, отриманих у ході дослідження концентрації і стійкості уваги студентів (див. табл. 5), показує, що ця характеристика $\epsilon$ недостатньо розвиненою у студентів. Результати на рівні від 1 до 4 балів (за 9-бальною шкалою) показали 75 \% студентів. На рівні 7 і 8 балів завдання виконали тільки $5 \%$. На рівні ж 9 балів не зафіксовано жодного результату. У дівчат, як видно із таблиці, показники суттєво кращі, але й вони не можуть вважатися достатніми, враховуючи їх велику професійну значущість. На нашу думку, необхідна спеціальна, цілеспрямована психофізична підготовка з розвитку концентрації і стійкості уваги у студентів залізничних ВНЗ.

Невід'ємною складовою трудової діяльності людини є активність iii психомоторики. Спеціальності залізничного транспорту також висувають високі вимоги до рівня розвитку сенсомоторних процесів фахівця. Враховуючи це, у даній роботі було виконано дослідження таких характеристик, як швидкість у діях і стійкість вестибулярних реакцій. У дослідженні цих характеристик брали участь тільки юнаки. Відносно швидкості в діях було виявлено, що 49 \% студентів мають низький рівень розвитку цього показника. Вони потребують організованої роботи щодо його покращення. Це позитивно вплине на їх професійну придатність.

Стійкість вестибулярних реакцій студентів визначалася в даному дослідженні за результатами виконання таких фізичних вправ: 1) біг на 25 м $з$ одночасним виконанням п'яти поворотів (обертів на $360^{\circ}$ ); 2) п'яти перекидань вперед за 10 с. Виконання першої вправи показало, що для 64 \% студентів характерними є підвищені вестибулярні реакції (див. табл. 7). Такі люди, в разі виникнення відповідних впливів на організм, не зможуть ефективно виконувати професійні функції. Оцінка студентів за результатами виконання другої вправи дала аналогічну картину (див. табл. 8). 50 \% студентів показали незадовільні результати, 18 \% - задовільні, і тільки 32 \% виконали вправу добре або відмінно.

Важлива роль у розвитку сенсомоторних процесів людини належить фізичній культурі та спорту. На нашу думку, отримані в дослідженні результати пояснюються сьогоднішніми реаліями викладання фізичної культури в школах. 3 ряду об'єктивних і суб'єктивних причин (відсутність задовільної матеріальної бази й спортивного 
інвентарю, низький рівень проведення медичних оглядів школярів, збільшення кількості нещасних випадків під час навчальних занять, інертність багатьох учителів фізичної культури та ін.) шкільна фізична культура не може реалізувати свій значний потенціал щодо забезпечення високого рівня фізичного й психічного розвитку школярів. Вирішити це завдання (у рамках своїх можливостей) покликане фізичне виховання вищої школи.

\section{Висновки до розділу}

1. Залізничний транспорт є однією зі сфер народного господарства, для яких важливою є спеціалізована психологічна й психофізична підготовка фахівців.

2. Інженер-залізничник повинен мати високий рівень розвитку низки психологічних і психофізичних характеристик.

3. Окрім загальних, існують і спеціальні вимоги до психологічної і психофізичної підготовленості інженерів-залізничників, які випливають із особливостей конкретної спеціальності.

4. Метою психологічної і психофізичної підготовки студентівзалізничників є сприяння підвищенню ефективності професійної підготовки.

5. Психологічна й психофізична підготовка не заміняе загальну і спеціальну фізичну підготовку, які є основою фізичного виховання студентів.

6. Спрямованість психологічної й психофізичної підготовки майбутніх інженерів-залізничників визначається вимогами до їх психологічної і психофізичної підготовленості й можливістю реалізації цих вимог у процесі занять.

7. Автор виділяє 4 головних напрямки психологічної і психофізичної підготовки студентів-залізничників під час навчальних занять 3 фізичного виховання:

1) психологічна просвіта студентів;

2) навчання навичкам психічної саморегуляції, формування емоційної стійкості, профілактика засобами фізичного виховання невротичної поведінки у схильних до цього студентів; 
3) розвиток психомоторики майбутнього фахівця, використання рухової активності для профілактики негативних впливів на психіку та зняття агресивності у студентів;

4) формування професійно значущих структурних компонентів особистості.

8. Необхідність проведення у ВНЗ спеціальної психологічної і психофізичної підготовки визначають такі чинники, як:

a) специфічний вплив сучасної праці на людину;

б) зміна місця й функціональної ролі людини в сучасному виробничому процесі;

в) необхідність забезпечення високого рівня інтенсивності й продуктивності праці сучасного фахівця;

г) необхідність забезпечення психологічної і психофізичної надійності майбутніх спеціалістів у процесі виконання професійних функцій.

9. Сучасний підхід до розуміння фізичного виховання студентів розглядає його як складову освіти і виховання, у ході якої вирішується широкий спектр завдань. Це повною мірою стосується і проведення психологічної і психофізичної підготовки студентів.

10. Робота 3 вирішення завдань психологічної і психофізичної підготовки студентів планується в поєднанні з традиційними завданнями фізичного виховання студентів.

11. Головними факторами, які визначають зміст психологічної і психофізичної підготовки студентів-залізничників, є:

а) домінування розумової праці під час виконання професійних функцій;

б) велика відповідальність за безпеку людей та збереження вантажів і пов'язане $з$ цим психоемоційне перенавантаження;

в) високі специфічні (професійні) вимоги до різноманітних компонентів структури особистості фахівця;

г) необхідність знання основ психології ефективного керування виробничим колективом.

12. Підбір засобів психологічної і психофізичної підготовки студентів-залізничників виконується 3 врахуванням особливостей майбутньої професійної діяльності.

13. Фізичні вправи розглядаються автором як головний засіб психологічної і психофізичної підготовки. 
14. Ефективними засобами психологічної і психофізичної підготовки студентів-залізничників, які відвідують навчальні заняття в секції фізичної реабілітації, є такі складові східної системи сахаджайога, як медитація та фізичні вправи йоги (асани).

15. Контроль у фізичному вихованні студентів має ряд проблем різного рівня, які умовно можна класифікувати як методологічні, загальнопедагогічні та дидактичні, методичні, виховні, психологічні.

16. Аналіз результатів діагностики ряду характеристик психологічної і психофізичної підготовленості студентів-залізничників показує їх відповідну непідготовленість.

17. Студенти-залізничники потребують спеціальної цілеспрямованої психологічної і психофізичної підготовки в ході навчальних занять 3 фізичного виховання. 
РОЗДІЛ 5

\section{Особливості впливу \\ фізкультурної і спортивної діяльності \\ на складові психологічної і психофізичної \\ готовності студентів}

Одним із завдань, які вирішувалися в ході виконання роботи, було дослідження впливу фізкультурної і спортивної діяльності на складові психологічної і психофізичної готовності студентів-залізничників. У зв'язку з цим в першій частині експериментальної роботи нами було вивчено особливості впливу ряду видів фізкультурної активності студентів під час навчальних занять 3 фізичного виховання на формування в них ряду компонентів психологічної і психофізичної підготовленості. Ці компоненти належать до таких підструктур, як риси особистості студента й пізнавальні процеси.

У ході дослідження особливостей формування особистості виконано:

1. Вивчення специфіки структурних компонентів особистості студентів, які під час навчальних занять з фізичного виховання займались легкою атлетикою або футболом.

2. Дослідження особливостей розвитку вольових якостей у студентів, що займались легкою атлетикою, футболом і спортивною гімнастикою.

3. Дослідження впливу рівня суб'єктивного контролю студентів на прояви агресивності у футболі.

Що стосується пізнавальних процесів, то тут досліджено особливості розвитку низки характеристик уваги в студентів. 


\section{1. Специфіка структурних компонентів особистості студентів навчальних секцій легкої атлетики і футболу}

У наш час досить поширеною $є$ концепція виділення особливостей особистості в представників різних видів спорту і в рамках конкретного виду спорту - різного рівня майстерності спортсменів. Однак серед дослідників повної одностайності з цього питання поки немає.

У своїй роботі ми виходили з припущення, що у студентів-спортсменів, представників різних видів спорту, є як тотожності, так і відмінності характеристик особистості [281].

Як статистична нульова гіпотеза було припущення про те, що різниця між показниками рівня прояву чинників особистості в студентів-спортсменів, які спеціалізувались з футболу, і у студентів-спортсменів, які спеціалізувались з легкої атлетики, значуще не відрізняється від нуля.

Альтернативною статистичною гіпотезою було припущення про те, що різниця між показниками рівня прояву чинників особистості в студентів-спортсменів, які спеціалізувалися з футболу, і у студентів-спортсменів, які спеціалізувалися з легкої атлетики, значуще відрізняється від нуля.

Для перевірки цього припущення було експериментально досліджено показники прояву якостей особистості у студентів-спортсменів, представників таких видів спорту, як футбол і легка атлетика. Зокрема, було емпірично перевірено, чи збігаються прояви якостей особистості студентів-спортсменів із вищезгаданих груп. Використовувався метод експертних оцінок. Як експерти були задіяні тренери студентів-спортсменів.

Для того щоб зробити роботу експертів більш продуктивною, нами була розроблена спеціальна таблиця, у якій реєструвалася міра прояву якостей особистості студента-спортсмена. Для створення таблиці (див. дод. 1) було використано 16 чинників особистості, виділених Р. Кеттелом [62, с. 158]. Експертам пропонувалось оцінити за п’ятибальною шкалою (від 1 до 5) міру вираженості факторів особистості в студентів. Завдання дослідження вимагали визначення рівня прояву кожної із запропонованих якостей особистості. При цьому враховувалися їх кількісні та якісні показники. Критерії прояву 
передбачали високий (позитивний полюс), низький (негативний полюс) і середній рівень прояву запропонованих для оцінки характеристик особистості.

В експериментальному дослідженні брали участь 50 студентівспортсменів ДНУЗТ ім. акад. В. Лазаряна, спортивна спеціалізація яких футбол (25 чоловіків) і легка атлетика (25 чоловіків). Результати зведені, узагальнені й наведені в табл. 9.

Таблиия 9

Рівні прояву чинників особистості у студентів-спортсменів

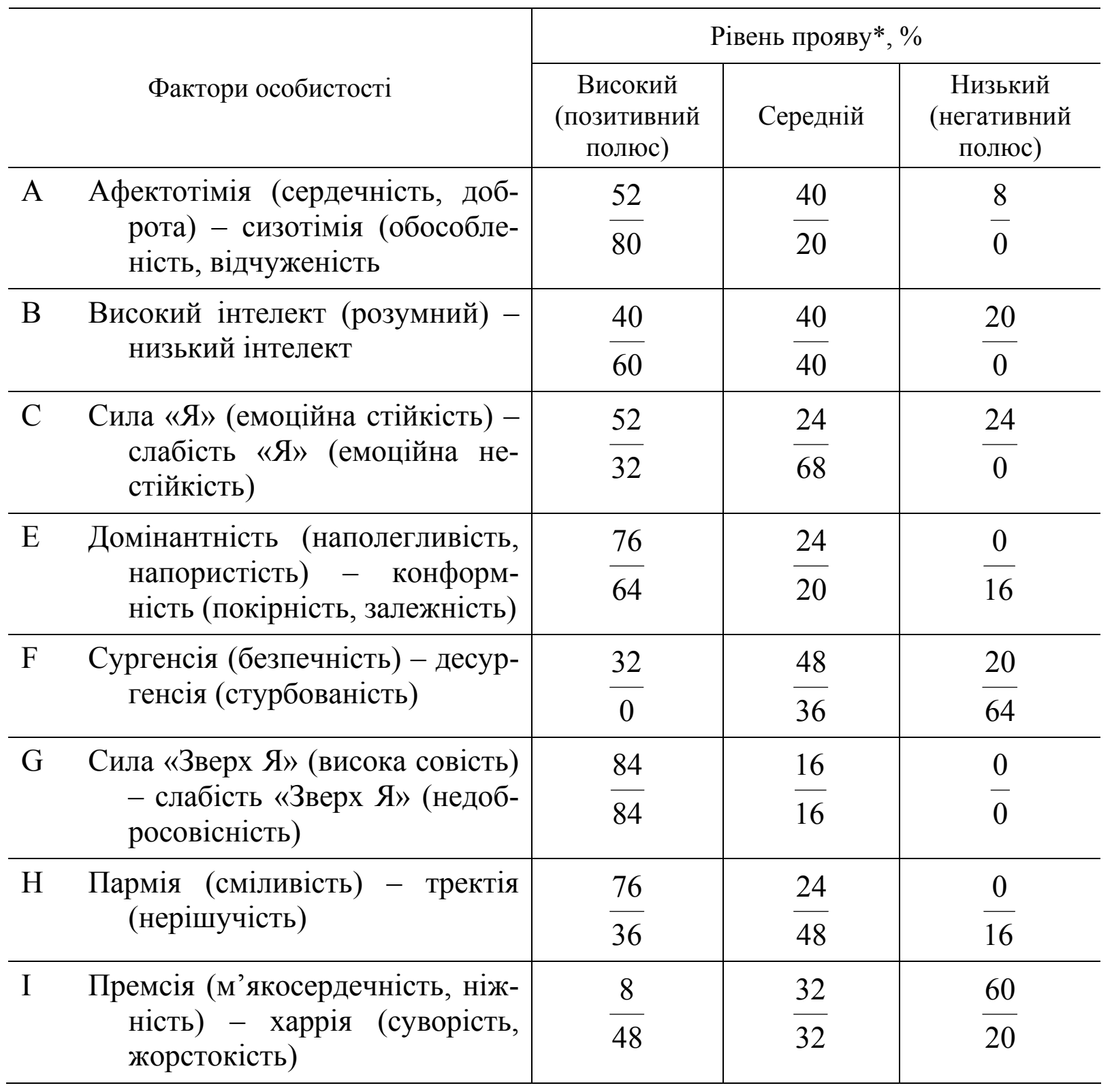


Закінчення табл. 9

\begin{tabular}{|c|c|c|c|c|}
\hline \multirow{2}{*}{\multicolumn{2}{|c|}{ Фактори особистості }} & \multicolumn{3}{|c|}{ Рівень прояву*, \% } \\
\hline & & Високий & & \\
\hline \multirow[t]{2}{*}{$\mathrm{L}$} & \multirow{2}{*}{$\begin{array}{c}\text { Протенсія (недовірливість) - } \\
\text { алаксія (довірливість) }\end{array}$} & 16 & 16 & 68 \\
\hline & & 0 & 52 & 48 \\
\hline \multirow[t]{2}{*}{ M } & \multirow{2}{*}{$\begin{array}{l}\text { Аутія (мрійливість) - праксернія } \\
\text { (практичність) }\end{array}$} & 0 & 16 & 84 \\
\hline & & 0 & 24 & 76 \\
\hline \multirow[t]{2}{*}{$\mathrm{N}$} & \multirow{2}{*}{$\begin{array}{l}\text { Проникливість, розважливість - } \\
\text { наївність, простота }\end{array}$} & 84 & 16 & 0 \\
\hline & & 68 & 32 & $\overline{0}$ \\
\hline \multirow[t]{2}{*}{$\mathrm{O}$} & \multirow{2}{*}{$\begin{array}{l}\text { Гіпотімія (схильність до почут- } \\
\text { тя провини) - гіпертімія (са- } \\
\text { мовпевненість) }\end{array}$} & 4 & 24 & 72 \\
\hline & & 0 & 68 & 32 \\
\hline \multirow[t]{2}{*}{ Q1 } & \multirow{2}{*}{$\begin{array}{l}\text { Радикалізм (гнучкість) - консе- } \\
\text { рватизм (ригідність) }\end{array}$} & 48 & 48 & 4 \\
\hline & & 48 & 52 & 0 \\
\hline \multirow[t]{2}{*}{ Q2 } & \multirow{2}{*}{$\begin{array}{l}\text { Самодостатність (самостійність) } \\
\text { - соціабельність (залежність } \\
\text { від групи) }\end{array}$} & 60 & 28 & 12 \\
\hline & & 64 & 36 & 0 \\
\hline \multirow[t]{2}{*}{ Q3 } & \multirow{2}{*}{$\begin{array}{l}\text { Контроль бажань (високий са- } \\
\text { моконтроль поведінки) - iм- } \\
\text { пульсивність (низький само- } \\
\text { контроль поведінки) }\end{array}$} & 60 & 16 & 24 \\
\hline & & 84 & 16 & 0 \\
\hline & \multirow{2}{*}{$\begin{array}{l}\text { Фрустрованість (напруженість) } \\
\text { - нефрустрованість (розслаб- } \\
\text { леність) }\end{array}$} & 8 & 48 & 44 \\
\hline & & $\overline{0}$ & $\overline{84}$ & $\overline{16}$ \\
\hline
\end{tabular}

Примітка. * У чисельнику - спеціалізація футбол, у знаменнику - спеціалізація легка атлетика.

Статистичну обробку даних було виконано 3 використанням $U$-критерію Манна-Уїтні.

За результатами виконаної роботи було встановлено таке. Існують статистично значущі відмінності показників рівня прояву чинників особистості у студентів-спортсменів, які спеціалізувалися з футболу, і у студентів-спортсменів, які спеціалізувалися з легкої атлетики, за такими чинниками, як «афектотімія - сизотімія», «високий інтелект низький інтелект», «домінантність - конформність», «сургенсія - де- 
сургенсія», «пармія - тректія», «премсія - харрія», «протенсія - алаксія», «гіпотімія - гіпертімія», «контроль бажань - імпульсивність». Так, за таким чинником, як «афектотімія (сердечність, доброта) - сизотімія (обособленість, відчуженість)» $U$ емпіричне склало 189 (критичне значення $p \leq 0,01=192)$. Середнє арифметичне показників за фактором у студентів-спортсменів, які займались футболом, становить 3,6 ; у студентів-спортсменів, які займались легкою атлетикою, 4,36. Медіана за фактором у студентів-футболістів складала 4, у студентів-легкоатлетів - 5. Показник моди за фактором у студентівфутболістів складав 3. Цей же показник у студентів-легкоатлетів становить 5. Стандартне відхилення у групі студентів-футболістів становило 1,11, у легкоатлетів - 0,81. Суттєво вищі показники за фактором виявлено у студентів, які займалися легкою атлетикою. Графічно показники зображено на рис. 2.

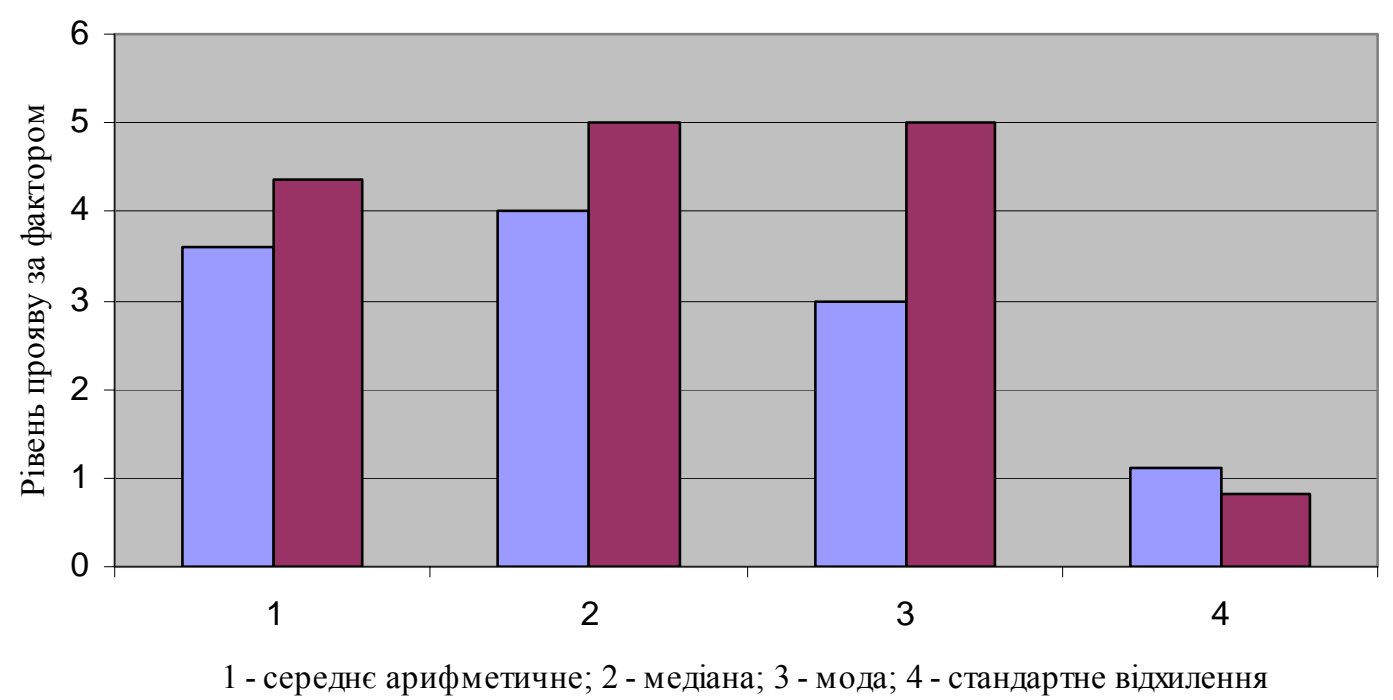

Рис. 2. Статистичні показники студентів-футболістів ( і студентів-легкоатлетів ( $\mathbf{\square})$ за фактором «афектотімія (сердечність, доброта) - сизотімія (обособленість, відчуженість)»

За фактором «високий інтелект - низький інтелект» $U$ емпіричне склало 210 (критичне значення $p \leq 0,05=227$ ). Середнє арифметичне показників за фактором у студентів-спортсменів, які займались футболом, становить 3,28; у студентів-спортсменів, які займались легкою атлетикою, - 3,96. Медіана по групі студентів-футболістів складала 3, студентів-легкоатлетів - 4. Показник моди у групі студентів-футболістів складав 3, у легкоатлетів - також 3. Стандартне 
відхилення в групі студентів-футболістів складало 1,13, у студентівлегкоатлетів - 0,88. Суттєво вищими за фактором є показники студентів-легкоатлетів. Графічно показники наведено на рис. 3.

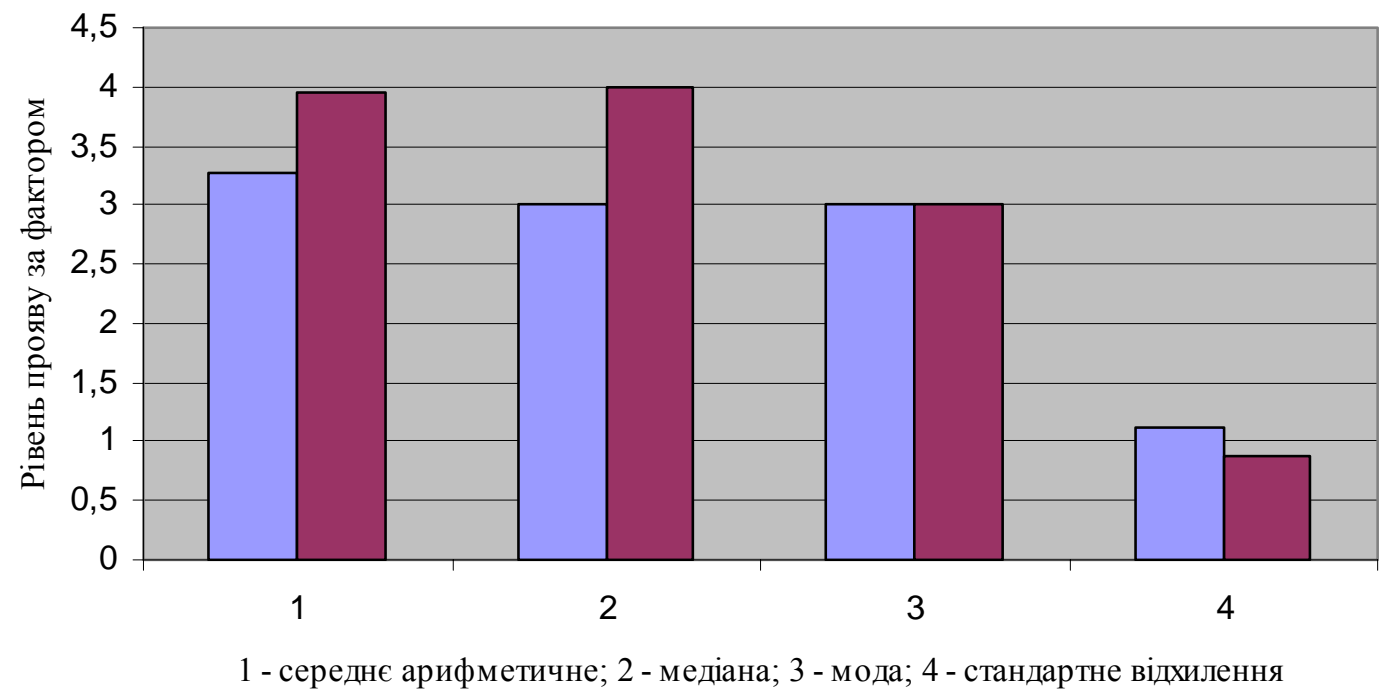

Рис. 3. Статистичні показники студентів-футболістів ( і студентів-легкоатлетів ( $($ ) за фактором «високий інтелект - низький інтелект»

За фактором «домінантність (наполегливість, напористість) конформність (покірність, залежність)» $U$ емпіричне склало 214,5 (критичне значення $p \leq 0,05=227$ ). Середнє арифметичне показників за фактором у студентів-спортсменів, які займались футболом, становить 4,24; студентів-спортсменів, які займались легкою атлетикою, 3,6. Медіана за фактором у обох групах складала 4. Показник моди в групі студентів-футболістів складав 5, у легкоатлетів - 4. Стандартне відхилення по групі студентів-футболістів було 0,83, студентівлегкоатлетів - 1,15. Суттєво вищими за фактором $\epsilon$ показники студентів-футболістів. Графічно показники зображено на рис. 4.

За фактором «сургенсія (безпечність) - десургенсія (стурбованість)» $U$ емпіричне склало 144,5 (критичне значення $p \leq 0,01=192$ ). Середнє арифметичне показників за фактором у студентів-спортсменів, які займались футболом, було 3,28; студентів-спортсменів, які займались легкою атлетикою, - 2,32. Медіана по групі студентівфутболістів становила 3 , студентів-легкоатлетів - 2. Показник моди по групі студентів-футболістів був 3 , легкоатлетів - 2. Стандартне відхилення в групі студентів-футболістів складало 1,1 , у студентів- 
легкоатлетів - 0,55. Суттєво вищі показники за фактором виявлено у студентів, які займалися футболом. Графічно показники наведено на рис. 5.

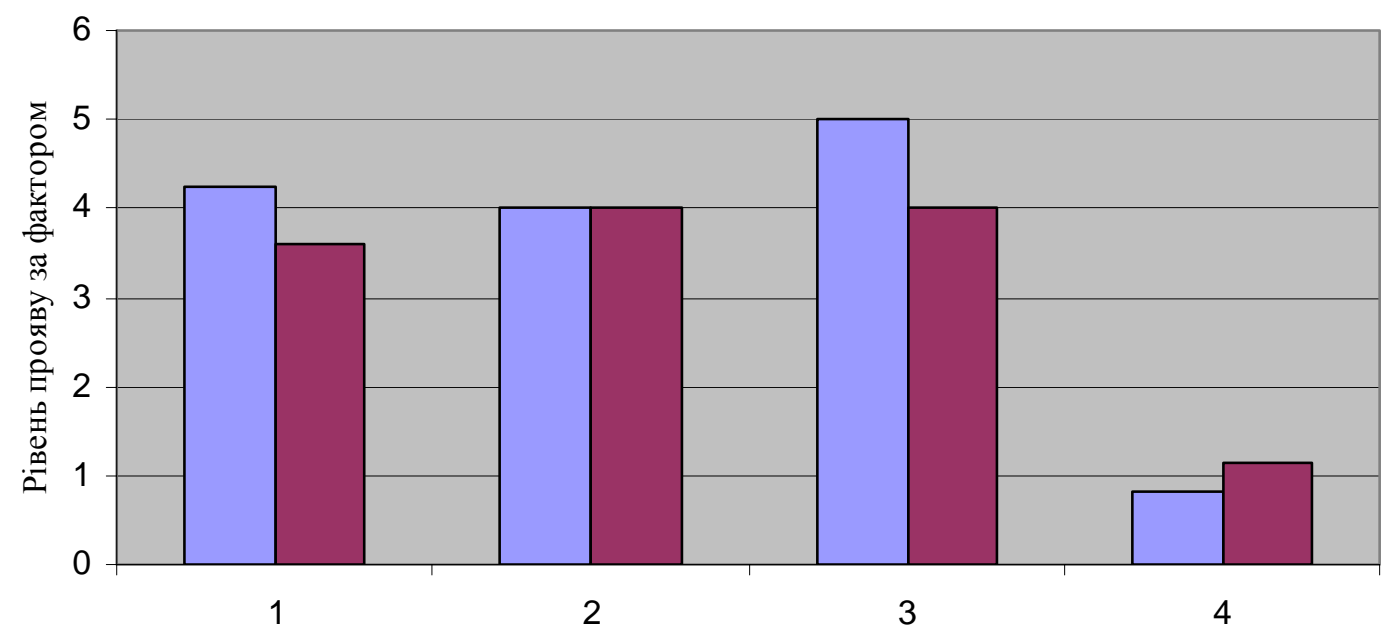

1 - середнє арифметичне; 2 - медіана; 3 - мода; 4 - стандартне відхилення

Рис. 4. Статистичні показники студентів-футболістів (-) і студентів-легкоатлетів (ש) за фактором «домінантність (наполегливість, напористість) - конформність (покірність, залежність)»

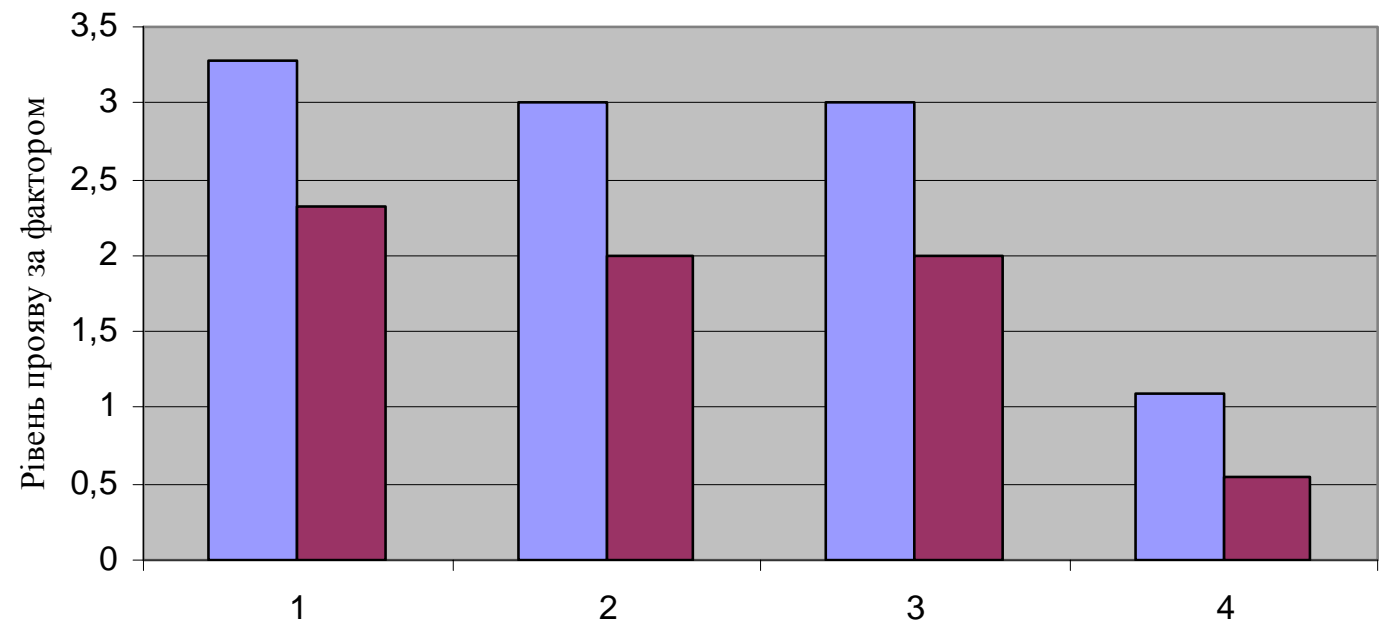

1 - середнє арифметичне; 2 - медіана; 3 - мода; 4 - стандартне відхилення

Рис. 5. Статистичні показники студентів-футболістів (-) і студентів-легкоатлетів ( (безпечність) - десургенсія (стурбованість)» 
За фактором «пармія (сміливість) - тректія (нерішучість)» $U$ емпіричне склало 173,5 (критичне значення $p \leq 0,01=192$ ). Середнє арифметичне показників за фактором у студентів-спортсменів, які займались футболом, склало 4,2; студентів-спортсменів, які займались легкою атлетикою, - 3,4. Медіана за фактором по групі студентів-футболістів становила 4, легкоатлетів - 3. Показник моди по групі студентів-футболістів був 5, для студентів-легкоатлетів - 3. Стандартне відхилення по групі студентів-футболістів було 0,81, легкоатлетів - 1. Суттєво вищі показники за фактором виявлено в студентів, які займалися футболом. Графічно показники наведено на рис. 6.

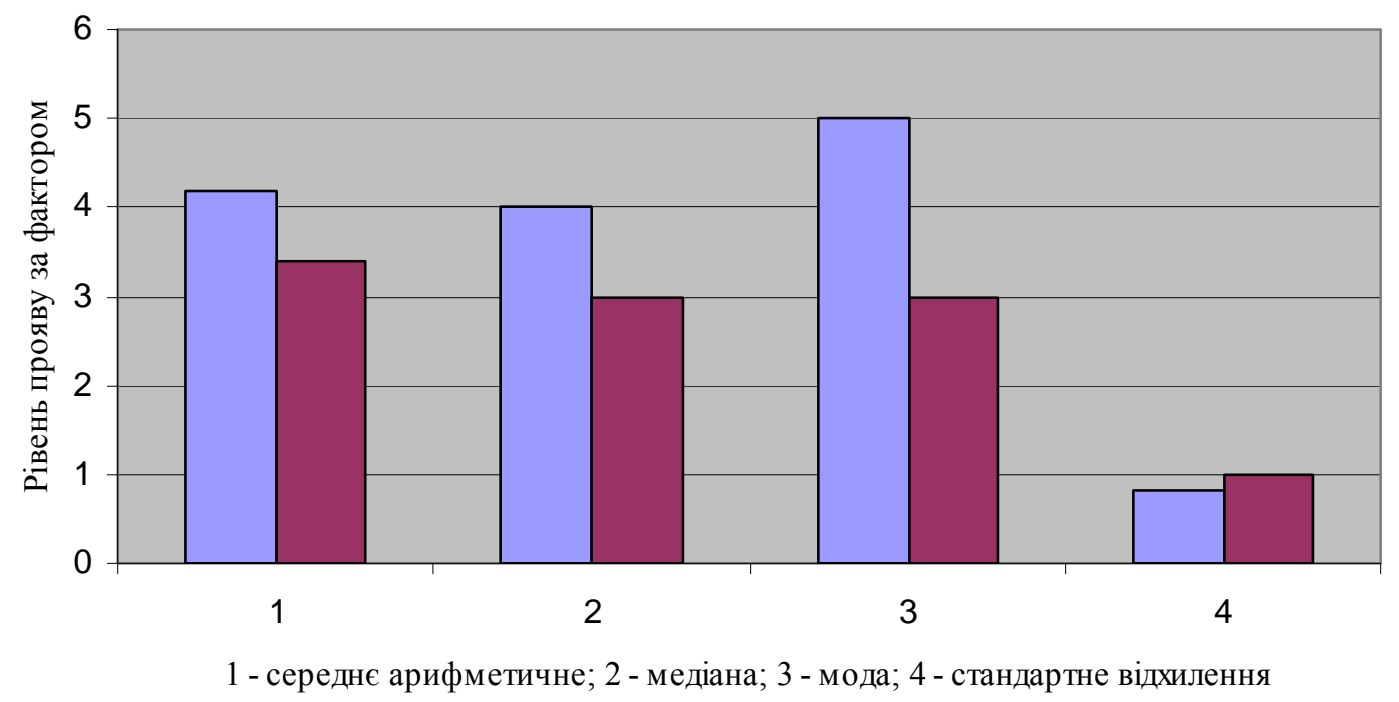

Рис. 6. Статистичні показники студентів-футболістів ( і студентів-легкоатлетів ( $\square$ ) за фактором «пармія (сміливість) - тректія (нерішучість)»

За фактором «премсія (м'якосердечність, ніжність) - харрія (суворість, жорстокість)» $U$ емпіричне склало 156,5 (критичне значення $p \leq 0,01=192$ ). Середнє арифметичне показників за фактором у студентів-спортсменів, які займалися футболом, склало 2,36; студентівспортсменів, які займались легкою атлетикою, - 3,28. Медіана по групі студентів-футболістів становила 2, студентів-легкоатлетів - 3 . Показник моди по групі студентів-футболістів був 2, легкоатлетів - 4 . Стандартне відхилення у групі студентів-футболістів складало 0,95, студентів-легкоатлетів - 1,06. Суттєво вищими є показники студентів-легкоатлетів. Графічно показники наведено на рис. 7. 


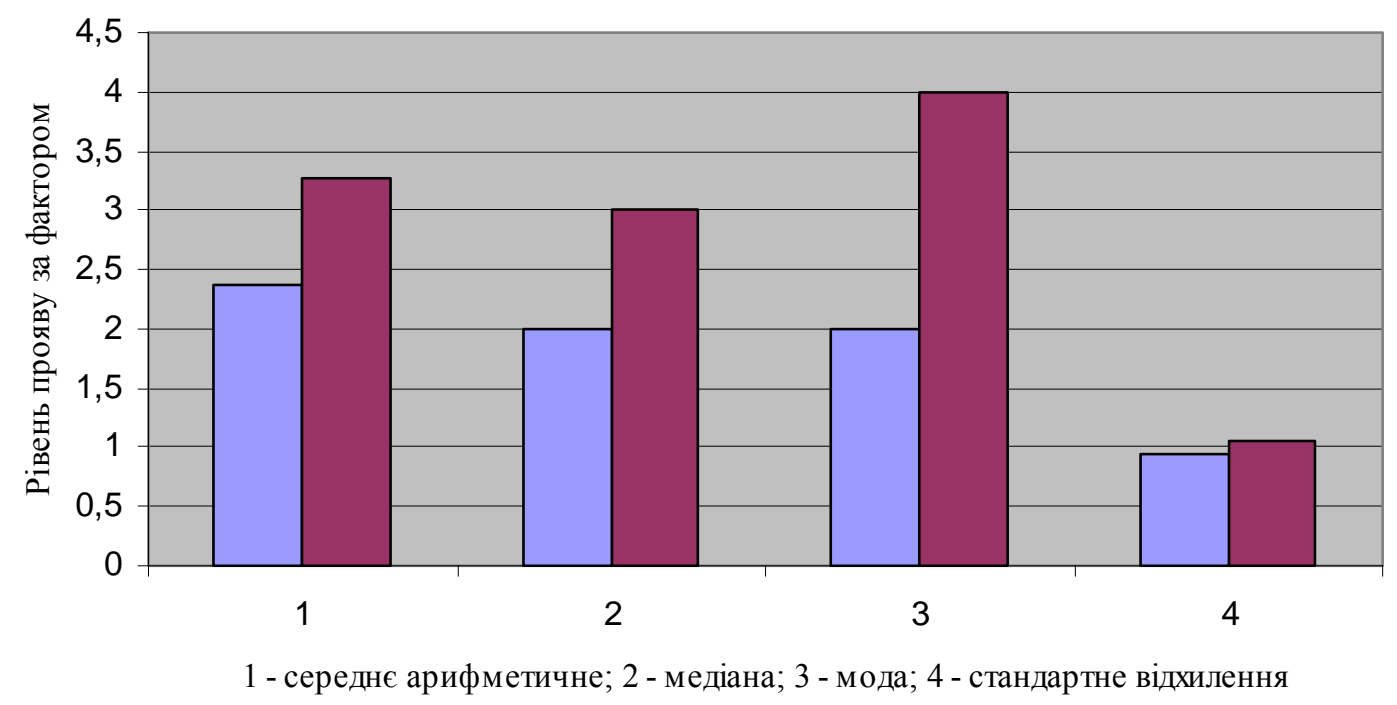

Рис. 7. Статистичні показники студентів-футболістів (-) і студентів-легкоатлетів ( $\boldsymbol{(})$ за фактором «премсія (м'якосердечність, ніжність) - харрія (суворість, жорстокість)»

За фактором «протенсія (недовірливість) - алаксія (довірливість)» $U$ емпіричне становило 224,5 (критичне значення $p \leq 0,05=227$ ). Середнє арифметичне показників у студентів-спортсменів, які займались футболом, складало 2,08; студентів-спортсменів, які займались легкою атлетикою, - 2,48. Медіана за фактором по групі студентівфутболістів становила 2, студентів-легкоатлетів - 3. Показник моди по групі студентів-футболістів складав 1 , для легкоатлетів - 3. Стандартне відхилення в групі студентів-футболістів було 1,11, студентівлегкоатлетів - 0,58. Суттєво вищі показники за фактором виявлено у студентів, які займалися легкою атлетикою. Графічно показники наведено на рис. 8.

За фактором «гіпотімія (схильність до почуття провини) - гіпертімія (самовпевненість)» $U$ емпіричне склало 164 (критичне значення $p \leq 0,01=192$ ). Середнє арифметичне показників за фактором у студентів-спортсменів, які займалися футболом, становить 2; студентівспортсменів, які займались легкою атлетикою, - 2,68. Медіана за фактором по групі студентів-футболістів становила 2, студентівлегкоатлетів - 3. Показник моди по групі студентів-футболістів складав 2, для легкоатлетів - 3. Стандартне відхилення у групі студентівфутболістів складало 0,86; студентів-легкоатлетів - 0,47. Суттєво вищими $є$ показники студентів-легкоатлетів. Графічно показники зображено на рис. 9. 


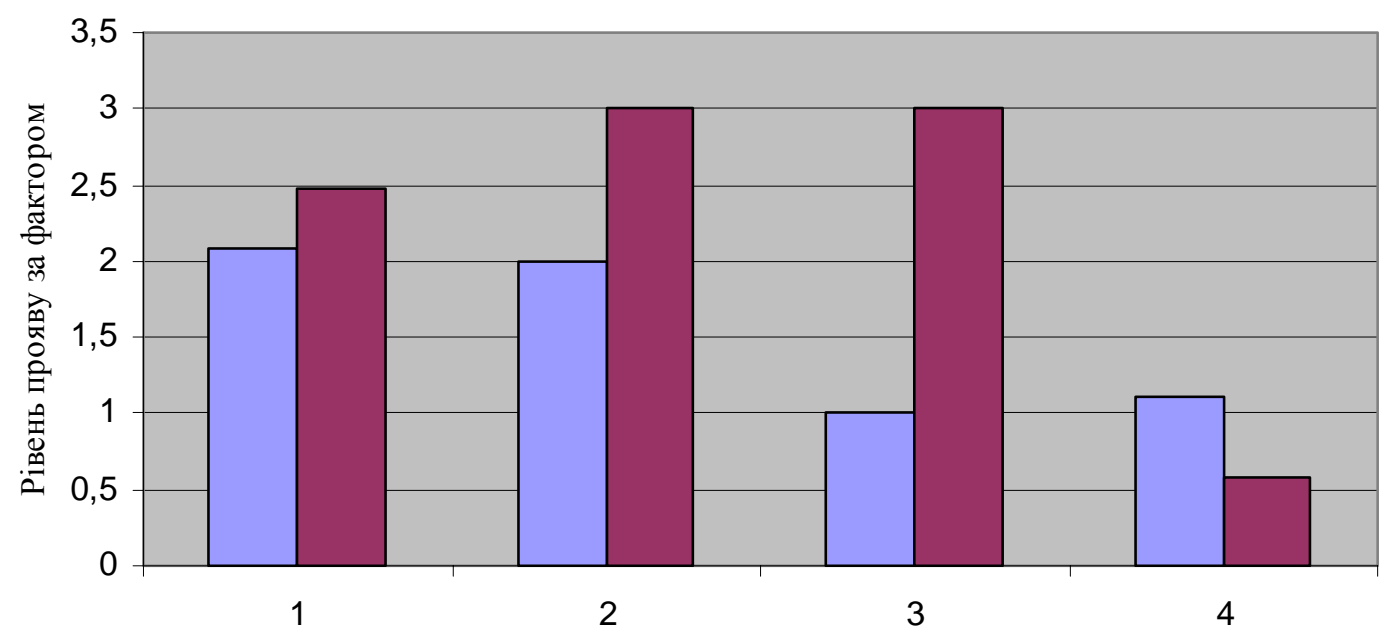

1 - середнє арифметичне; 2 - медіана; 3 - мода; 4 - стандартне відхилення

Рис. 8. Статистичні показники студентів-футболістів ( і студентів-легкоатлетів ( $\mathbf{(})$ за фактором «протенсія (недовірливість) - алаксія (довірливість)»

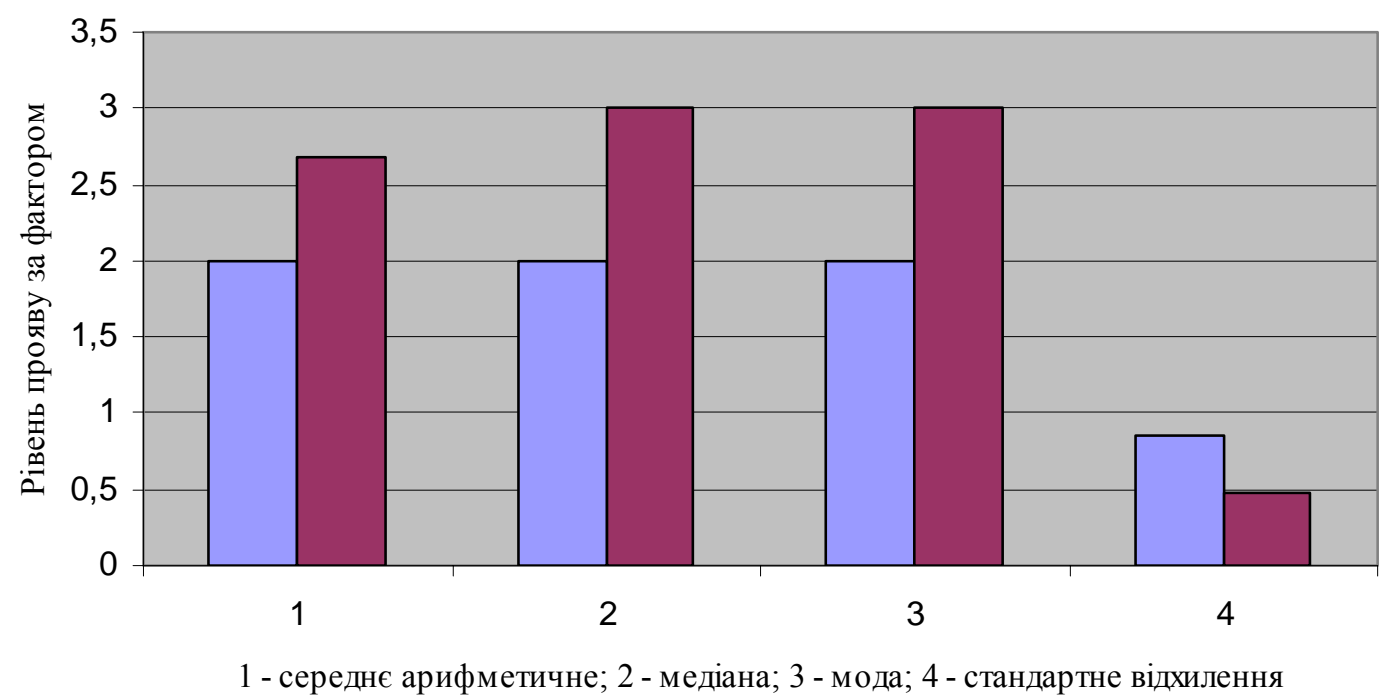

Рис. 9. Статистичні показники студентів-футболістів ( і студентів-легкоатлетів ( $($ ) за фактором «гіпотімія (схильність до почуття провини) - гіпертімія (самовпевненість)»

За фактором «контроль бажань (високий самоконтроль поведінки) - імпульсивність (низький самоконтроль поведінки)» $U$ емпіричне склало 207,5 (критичне значення $p \leq 0,05=227$ ). Середнє арифметичне показників за фактором у студентів-спортсменів, які займались футболом, становить 3,48 ; студентів-спортсменів, які займались лег- 
кою атлетикою, $-4,16$. Медіана за фактором по обох групах становила 4. Показник моди також однаковий для обох груп і становить 4. Стандартне відхилення у групі студентів-футболістів складало 1,12, легкоатлетів - 0,68. Суттєво вищими є показники студентів-легкоатлетів. Графічно показники наведено на рис. 10.

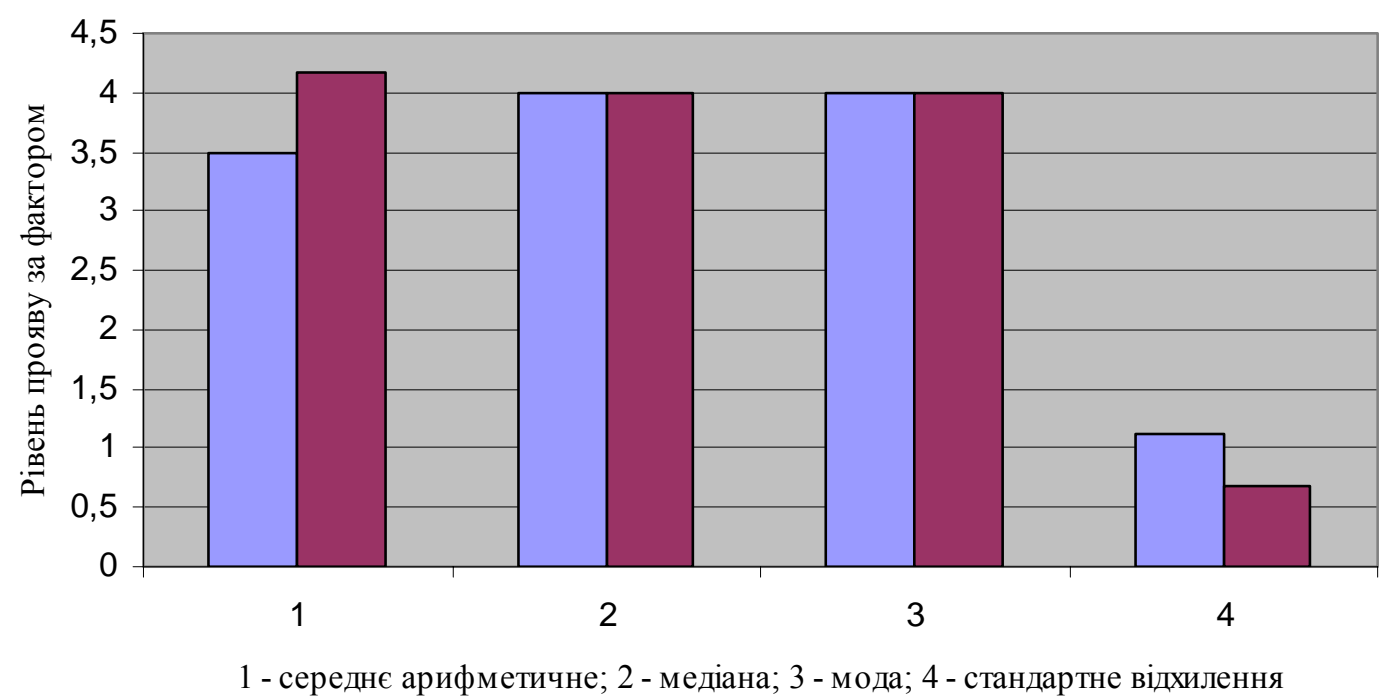

Рис. 10. Статистичні показники студентів-футболістів (

і студентів-легкоатлетів ( $\boldsymbol{(})$ за фактором «контроль бажань (високий самоконтроль поведінки) - імпульсивність (низький самоконтроль поведінки)»

За факторами «сила Я (емоційна стійкість) - слабкість Я (емоційна нестійкість)», «сила "Зверх Я"» (висока совість) - слабкість "Зверх Я"» (недобросовісність)», «аутія (мрійливість) - праксернія (практичність)», «проникливість, розважливість - наївність, простота», «радикалізм (гнучкість) - консерватизм (ригідність)», «самодостатність (самостійність) - соціабельність (залежність від групи)», «фрустрованість (напруженість) - нефрустрованість (розслабленість)» отримано емпіричні значення $U$, які розташовані в зоні незначущості.

У ході експериментальної роботи було зафіксовано й інші цікаві факти. Деякі зі студентів-спортсменів, що потрапили до вибірки, демонстрували суттєве відхилення від загальної тенденції сформованості таких чинників, як «домінантність - конформність», «сила "Зверх Я" - слабість "Зверх Я"», «премсія - харрія», «аутія - праксернія», «гіпотімія - гіпертімія». Їх показники були суттєво нижчими або вищими. У той же час, на рівні їх спортивної майстерності це негативно 
не позначилося. Спостереження показало, що вони компенсують бажані, але недостатньо сформовані в них якості іншими.

Результати, отримані в ході дослідження, дають підстави стверджувати, що експериментальна гіпотеза підтвердилась. У студентівспортсменів, які займались такими видами спорту, як футбол і легка атлетика, виявлено:

1. Тотожності у рівні розвитку за такими факторами особистості, як «емоційна стійкість - емоційна нестійкість», «висока совість недобросовісність», «мрійливість - практичність», «проникливість, розважливість - наївність, простота», «радикалізм - консерватизм», «самодостатність - соціабельність», «фрустрованість - нефрустрованість».

2. Відмінності в рівні розвитку за такими факторами, як «афектотімія - сизотімія», «високий інтелект - низький інтелект», «домінантність - конформність», «сургенсія - десургенсія», «пармія - тректія», «премсія - харрія», «протенсія - алаксія», «гіпотімія - гіпертімія», «контроль бажань - імпульсивність».

\section{2. Особливості формування вольових якостей особистості студентів навчальних секцій футболу, спортивної гімнастики, легкої атлетики}

Одним із головних завдань психологічної і психофізичної підготовки студентів-залізничників $\epsilon$ формування професійно значущих структурних компонентів особистості майбутнього інженера. Повною мірою це стосується і розвитку вольових якостей - цілеспрямованості, дисциплінованості, витримки, наполегливості, самовладання, стійкості, ініціативності, самостійності, рішучості, сміливості, енергійності, терпеливості. Важко уявити собі ефективного керівника в залізничній галузі, у якого не були б розвинені достатньою мірою ці якості.

В. М. Шляпніков виконав аналіз досліджень вольової регуляції в сучасній зарубіжній психології [437]. Він показує, що інтерес до цієї проблематики коливався. Так, починаючи з 30-х років двадцятого століття поняття волі майже на 50 років втратило свою привабливість для дослідників. Але починаючи з 80 -х років того ж століття ситуація 
змінюється. Цьому сприяв той факт, що без поняття волі стало неможливо пояснити цілеспрямовану поведінку людини в реальних життєвих ситуаціях. Питання волі вивчають такі дослідники, як Р. П. Багоцці [451], Ю. Куль [483], Х. Хекхаузен [415, 416], І. Д. Бех [33], В. І. Селіванов [343], Є. П. Ільїн [148] та ін. Воля розглядається в рамках питання про прийняття рішення і його реалізацію.

Підбиваючи підсумок свого аналізу, В. М. Шляпніков робить такі висновки:

1. У сучасній зарубіжній психології зростає інтерес до проблеми волі.

2. Зростання інтересу спричинено тим, що пояснити механізм складної цілеспрямованої поведінки людини в реальних життєвих ситуаціях за допомогою тільки мотиваційної складової важко.

3. У ході реалізації намірів і дій воля $є$ одним із головних механізмів, що забезпечує інтегральну роботу різних психічних процесів.

4. Вольова регуляція дії являє собою складний процес, у ході якого взаємодіють такі складові особистості, як мотиви, наміри, стратегії самореалізації, соціальні установки.

У ході досліджень виявлено, що вольова регуляція $є$ необхідною умовою успіху в різних видах діяльності [141, 342, 449, 481, 482, 484, 492]. У той же час iï психологічні механізми ще недостатньо вивчені.

Відомий російський дослідник проблеми волі В. А. Іванніков [143, с. 9] виділяє два підходи в розумінні цього феномену. Перший пов'язує волю з проблемою самодетермінації. У його рамках сформувались свої два підходи - «мотиваційний» і «вільного вибору». Другий - це регуляційний підхід. Він тлумачить волю у зв'язку з проблемою саморегуляції.

У свою чергу, у рамках мотиваційного підходу В. А. Іванніков виділяє три види розуміння природи волі. Перший вид зводить волю до початку мотивації дії (бажання, прагнення, афекту). Другий вид виділяє волю як самостійну силу непсихічної або психічної природи, яка не зводиться до інших складових і сама у свою чергу визначає інші психічні процеси. Третій розглядає волю як здатність до спонукання до дій, які містять подолання труднощів і пов'язана 3 мотивацією, але не збігається з нею.

Підсумовуючи свій аналіз мотиваційного підходу, В. А. Іванніков підкреслює, що з цієї позиції воля розглядається як здатність до ініціювання дій або до підсилення спонукання до дій при їх дефіциті 
внаслідок зовнішніх або внутрішніх перешкод, відсутності актуально переживаного бажання до дій, наявності конкуруючих мотивів відносно дії, яка виконується, і т. ін.

Підхід вільного вибору розглядає волю або як самостійну силу, або як функціонування пізнавальних процесів.

У психології виділяють чотири типи критеріїв волі. Вважається, що ії прояви є:

1. У вольових діях.

2. У виборі мотивів і цілей.

3. У регуляції внутрішніх станів людини, іiі дій і психічних процесів.

4. У вольових якостях особистості.

У контексті поставлених у даній роботі завдань найбільший інтерес викликають вольові якості особистості, тому зупинимось на них детальніше. До цісї групи, як правило, відносять: наполегливість, самовладання, стійкість, ініціативність, самостійність, рішучість, сміливість, цілеспрямованість, дисциплінованість, витримку, енергійність, терпеливість та інші. У той же час існують певні труднощі в оцінці розвитку волі в людини. Встановлено, що окремі вольові якості не завжди пов'язані між собою (наявність одного не передбачає наявності інших). Це спричиняє певну невизначеність в оцінці розвитку волі в людини, яка проявляє у своїй поведінці, наприклад, тільки одну вольову якість (та й ту не в усіх видах діяльності). Ще одна трудність пов'язана 3 тим, що для розвитку вольових якостей необхідним $є$ формування багатьох інших характеристик особистості (наприклад, почуття впевненості в собі, адекватний рівень самооцінки), без яких неможливі вольові якості. Необхідною $є$ і наявність відповідних мотивів, знань, навиків і умінь людини. Наступна трудність полягає в тому, що прояв вольових якостей, який людина демонструє, не завжди свідчить про прояв волі. Наполегливість, наприклад, може бути наслідком наявності сильного мотиву, або може бути пов'язаною із впевненістю у своїх силах, або демонструватись 3 метою уникнення низької самооцінки [416, 468]. Загалом, можна констатувати, що робити однозначні висновки про розвиток волі у конкретної людини, яка проявляє у своїй діяльності і поведінці вольові якості, не завжди можна.

В. А. Іванніков [143, с.79] виділяе чотири функції волі:

1. Ініціація і здійснення вольової дії. 
2. Вибір дії в разі наявності конфлікту цілей і мотивів.

3. Регуляція різних параметрів дій.

4. Регуляція станів і організація психічних процесів.

Як головний механізм вольової регуляції найчастіше називають вольове зусилля. Ще один механізм, що виділяється, це цілеспрямована зміна сенсу дій [143, с. 87].

3 точки зору поставлених у даній роботі завдань інтерес викликає ще одна робота В. М. Шляпнікова, яка присвячена дослідженню ролі вольової регуляції в процесі професійної адаптації молодих спеціалістів [438]. Автор виходить 3 того, що прикладом життєвої ситуації, яка вимагає від особистості прояву волі, є освоєння нею нового виду діяльності, і таким іiі видом для молодого спеціаліста є діяльність професійна. Молодий спеціаліст, починаючи свою професійну діяльність на виробництві, потрапляе в таку соціальну ситуацію розвитку, у якій він вперше починає відігравати роль суб'єкта праці. Суть професійної адаптації молодого спеціаліста і полягає, насамперед, у його пристосуванні до цих (нових для нього) умов. Він приймає на себе такі складові професійної діяльності, як іiі завдання, предмет, засоби, способи і ціннісні орієнтації. У молодого спеціаліста, який починає адаптацію до професії, ще не сформовані достатньою мірою необхідні знання й навички, професійно значущі якості особистості й мотиви та ін. Усе це вимагає від нього вольових проявів для виконання трудової діяльності.

У ході цієї роботи В. М. Шляпніковим було експериментально вивчено такі питання:

1) динаміка стану вольової регуляції в процесі професійної адаптації молодих спеціалістів;

2) успішність професійної адаптації і стан вольової регуляції молодих спеціалістів;

3) індивідуальні особливості вольової регуляції й успішність професійної адаптації.

Отримані в ході дослідження цих питань дані дали підстави автору констатувати таке:

1. Воля відіграє важливу роль у процесі освоєння нових видів діяльності (особливо на початкових етапах цього процесу).

2. Люди, які мають більш розвинену вольову регуляцію, більш успішно адаптуються до нової діяльності. 
3. Вольова регуляція може стати суттєвим психологічним ресурсом підвищення ефективності освоєння нових видів діяльності. Це відбувається в тих випадках, коли людина сприймає діяльність як особистісно значущу і свідомо приймає рішення застосувати вольову регуляцію для вирішення завдань, що стоять перед нею.

4. У міру освоєння діяльності або втрати інтересу до неї, роль волі в регулюванні діяльності зменшується.

Дослідження волі проводилось і в спортивній діяльності. Було розроблено низку прийомів розвитку вольових якостей, способи вольової регуляції дій у складних умовах, встановлено зв'язок ефективності вольової регуляції з технічною, фізичною і тактичною підготовкою, з емоційною стійкістю спортсменів та інші [289, 308, 334, 443].

Подальше вивчення волі в спортивній діяльності пов'язане 3 дослідженням психологічної підготовки спортсменів, головне місце в якій займала вольова підготовка. ÏÏ розділяли на загальну й спеціальну. Розвиток здатності до подолання перешкод (зовнішніх і внутрішніх) розглядався як загальний розвиток волі. У свою чергу розвиток необхідних вольових якостей спортсмена, представника певного виду спорту, класифікувався як спеціальний розвиток волі [309]. Було встановлено, що ефективність вольової регуляції залежить від мотивації, моральних принципів, установок спортсмена.

Виконано й прикладні дослідження вольової регуляції дій. Так, було виявлено структуру вольових якостей спортсменів, представників різних видів спорту. У гімнастів вольові якості (у міру їх важливості для спортсменів) було розподілено в такій послідовності: витримка і самовладання, сміливість і рішучість і т. д. У бігунів на довгі дистанції: наполегливість і завзятість, витримка і самовладання і т. д. У стрибунів з трампліну на лижах: сміливість і рішучість, витримка і самовладання, наполегливість і завзятість і т. д.

У подальших дослідженнях було встановлено, що різні види перешкод потребують відповідних їм засобів подолання. Одні - ефективних інтелектуальних рішень, другі - фізичної підготовленості, треті - технічної підготовленості, четверті були пов'язані з необхідністю подолання небажаних емоційних реакцій і станів, п'яті вимагали вольової мобілізації. Це дозволило зробити висновок, що успішність діяльності залежить не стільки від волі, скільки від інших видів підготовки спортсмена, від його емоційної стійкості та інших чинників (Б. Б. Коссов, П. А. Рудик, О. А. Чернікова, Б. А. Вяткін). Було 
встановлено також, що навіть сама ефективність вольового регулювання залежить від вищезгаданих чинників. У свою чергу ефективність дій виявилася залежною від міри розвитку вольових якостей (Ю. П. Мальцев).

Ефективність вольової регуляції значною мірою визначають емоційні стани як внутрішні перешкоди дій. У зв'язку з цим увага дослідників у сфері психології спорту почала поступово переходити на пошук засобів і методів довільного регулювання емоційних станів та умов, що забезпечують емоційну стійкість спортсмена. Дослідження емоційної регуляції спортивної діяльності поступово виділилось в самостійний напрямок. Увага дослідників до вольової проблематики суттєво зменшилась.

Серед досліджень, у яких розглядається формування волі в процесі фізкультурної діяльності, слід відзначити роботу М. М. Платонова [288]. Питання ж розвитку вольових якостей у студентів на заняттях з фізичного виховання $\epsilon$ недостатньо вивченими у спеціальних дослідженнях.

Метою даного дослідження стало вивчення особливостей формування вольових якостей особистості студентів-залізничників під час навчальних занять з фізичного виховання у ряді навчальних груп навчальних секцій спортивного й фізичного виховання.

Завданнями дослідження були:

1. Вивчення особливостей прояву вольових рис особистості у студентів навчальних секцій спортивного й фізичного виховання.

2. Дослідження ефективності використання занять футболом, спортивною гімнастикою, легкою атлетикою для формування вольових якостей особистості студента в ході навчального процесу з фізичного виховання.

Експериментальною гіпотезою дослідження стало припущення про те, що в процесі фізкультурної діяльності, під час навчальних занять $з$ фізичного виховання, найбільш ефективною для формування вольових якостей особистості студентів є діяльність, яка пов'язана:

1) з використанням великої за обсягом одноманітної роботи (біг на довгі та середні дистанції);

2) з використанням координаційно-складних вправ (заняття спортивною гімнастикою).

Як незалежна змінна розглядався зміст навчальної діяльності студентів, до складу якого входили заняття бігом на довгі та середні 
дистанції, спортивною гімнастикою, заняття футболом. Залежною змінною були показники рівня сформованості ряду вольових якостей особистості в студентів.

Як статистична нульова гіпотеза було припущення про те, що різниця між показниками рівня сформованості вольових якостей особистості студентів навчальної секції спортивного виховання, які займались легкою атлетикою, спортивною гімнастикою, футболом, і показники студентів з навчальної секції фізичного виховання значуще не відрізняються від нуля.

Альтернативною статистичною гіпотезою було припущення про те, що різниця між показниками рівня сформованості вольових якостей особистості в студентів навчальної секції спортивного виховання, які займались легкою атлетикою, спортивною гімнастикою, футболом, і в студентів навчальної секції фізичного виховання значуще відрізняється від нуля.

Для перевірки припущення було організовано діагностику рівня сформованості вольових якостей особистості у студентів різних навчальних секцій, які відвідували навчальні заняття з фізичного виховання. В експериментальній частині роботи було емпірично перевірено, чи є статистично значущі відмінності в рівні прояву ряду вольових якостей особистості у студентів.

У дослідженні брали участь 120 студентів (чоловіки 18-20 років) Дніпропетровського національного університету залізничного транспорту. Контрольну групу склали 30 студентів, які не займалися спортом і відвідували навчальні заняття 3 фізичного виховання (4 навчальних години на тиждень) у навчальних групах секції фізичного виховання. Експериментальну групу склали 90 студентів, які відвідували навчальні заняття з фізичного виховання у навчальних групах секції спортивного виховання (по 30 чоловік із навчальних груп футболу, спортивної гімнастики й легкої атлетики). До експериментальної групи з легкої атлетики було зараховано студентів, які спеціалізувалися з бігу на довгі та середні дистанції. Усі студенти, які брали участь у дослідженні, відвідували навчальні заняття з фізичного виховання в університеті протягом двох років.

Головними методами дослідження були: теоретичний аналіз, метод експертних оцінок, спостереження. Статистична обробка даних виконана $з$ допомогою $U$-критерію Манна-Уїтні. 
Експертами були викладачі, які працювали зі студентами, що взяли участь у дослідженні. Для того щоб зробити роботу експертів більш продуктивною, нами була розроблена спеціальна таблиця, у якій реєструвалася міра прояву вольових якостей особистості студентів. Для створення таблиці були використані 12 рис (якостей) особистості, які в психології класифікують як вольові. Експертам пропонувалось оцінити за десятибальною шкалою (від 0 до 10) міру прояву зазначених рис у студентів.

Окремо порівнювалися результати експериментальних груп (футболу, спортивної гімнастики, легкої атлетики) з результатами контрольної (студенти, які займались у навчальній секції фізичного виховання). У кожній з груп, що порівнювались, було по 30 студентів (табл. 10).

Таблиия 10

Результати виявлення статистично значущої відмінності

в рівні прояву вольових якостей особистості студентів експериментальних і контрольної груп $(n=120)$

\begin{tabular}{|c|c|c|c|c|c|c|c|c|c|c|c|c|}
\hline \multirow[b]{2}{*}{$\begin{array}{c}\text { Групи } \\
\text { навчальної секцї } \\
\text { спортивного } \\
\text { виховання }\end{array}$} & \multicolumn{12}{|c|}{ Вольові якості } \\
\hline & 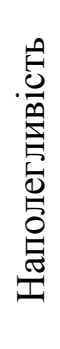 & 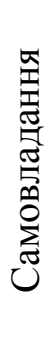 & U & 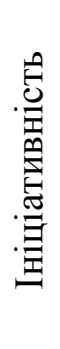 & 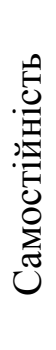 & 兽 & . & 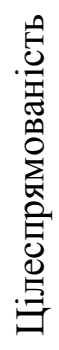 & 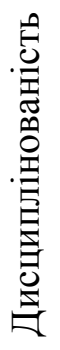 & 莺 & 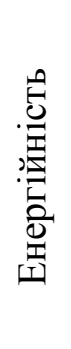 & 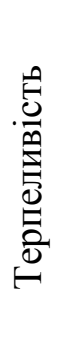 \\
\hline Футбол & + & - & - & + & - & + & + & - & - & - & - & - \\
\hline $\begin{array}{l}\text { Спортивна гімнас- } \\
\text { тика }\end{array}$ & + & - & + & + & - & + & + & + & + & - & + & - \\
\hline Легка атлетика & + & - & + & + & + & + & + & + & + & + & + & + \\
\hline
\end{tabular}

Порівняння показників студентів з експериментальної групи, які займалися футболом, і показників студентів контрольної групи дало такі результати. Існують статистично значущі відмінності рівня сформованості вольових якостей у групах за такими якостями, як наполегливість, ініціативність, рішучість, сміливість. Так, при оцінці такої якості, як наполегливість, було встановлено, що в експериментальній 
групі середнє арифметичне показників становить 7,9, медіана - 8, мода -8 ; стандартне відхилення - 1,42. У контрольній групі середнє арифметичне склало 6,5, медіана - 6, мода - 6; стандартне відхилення - 1,38. Графічно ці дані зображено на рис. 11 . Вторинну статистичну обробку отриманих даних зроблено 3 використанням $U$-критерію Манна-Уїтні. $U$ емпіричне склало 218,5 (критичне значення $p \leq 0,01=292$ ). Отримане емпіричне значення $U$ розташоване в зоні значущості. Суттєво вищими є показники експериментальної групи студентів, які займалися футболом. На підставі цього відхилено нульову гіпотезу стосовно рівня сформованості наполегливості в цих групах і підтверджено правильність альтернативної.

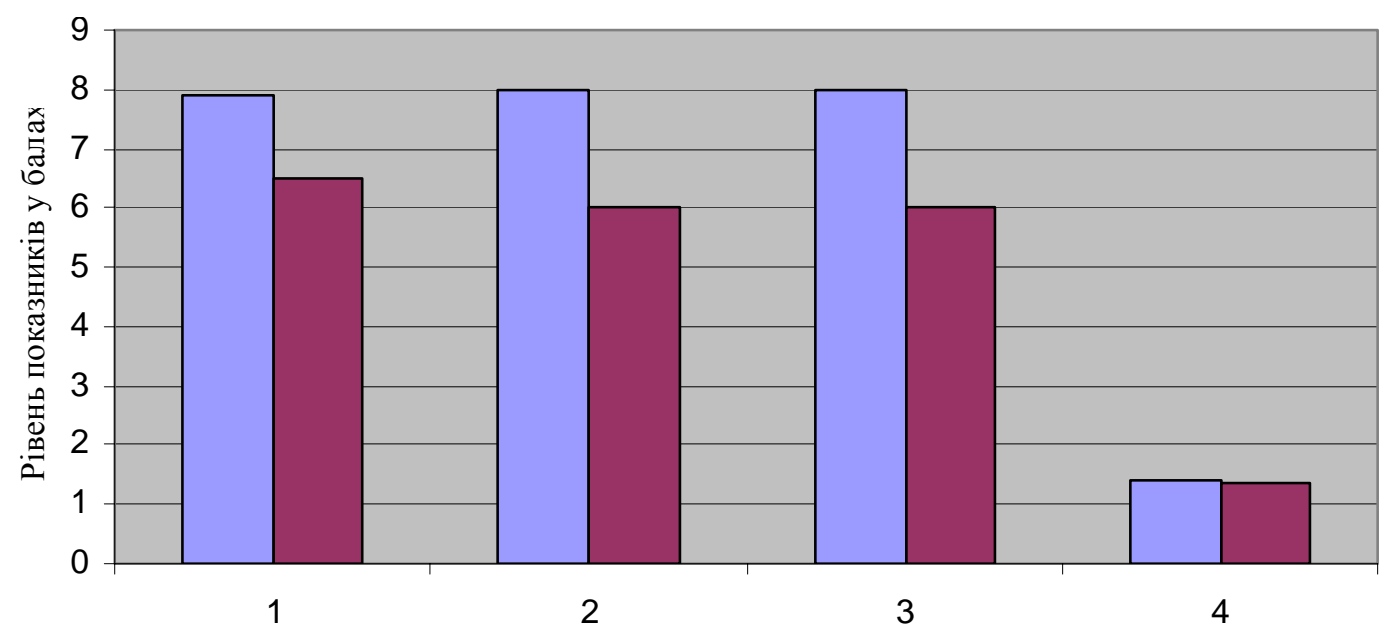

1 - середнє арифметичне; 2 - медіана; 3 - мода; 4 - стандартне відхилення

Рис. 11. Статистичні показники рівня сформованості наполегливості студентів експериментальної групи, які займалися футболом, $(\square)$ і контрольної ( ()

Під час оцінювання вищезгаданих груп за такою якістю, як ініціативність зафіксовано таке. В експериментальній групі середнє арифметичне склало 7, медіана - 7, мода - 7; стандартне відхилення 1,36. У контрольній групі середнє арифметичне склало 6,2, медіана 6, мода - 6; стандартне відхилення - 1,35. Графічно ці дані наведено на рис. 12. Виконавши вторинну статистичну обробку даних з використанням $U$-критерію Манна-Уїтні, було встановлено, що $U$ емпіричне становить 318 (критичне значення $p \leq 0,05=338$ ). Статистично значуще вищими $є$ показники експериментальної групи студентів. На підставі цього відхилено нульову гіпотезу стосовно рівня сформо- 
ваності ініціативності в цих групах і підтверджено правильність альтернативної.

За якістю «рішучість» в експериментальній групі середнє арифметичне показників склало 7,66, медіана - 8, мода - 8; стандартне відхилення - 1,21. У контрольній групі середнє арифметичне становило 6,3 , медіана -6 , мода -7 ; стандартне відхилення - 0,98. Графічно результати зображено на рис. 13. Вторинна статистична обробка отриманих даних з використанням $U$-критерію Манна-Уїтні показала, що $U$ емпіричне становить 178,5 (критичне значення $p \leq 0,01=292$ ). Статистично значуще вищими є показники експериментальної групи. На підставі цього відхилено нульову гіпотезу стосовно рівня сформованості рішучості в цих групах і підтверджено правильність альтернативної.

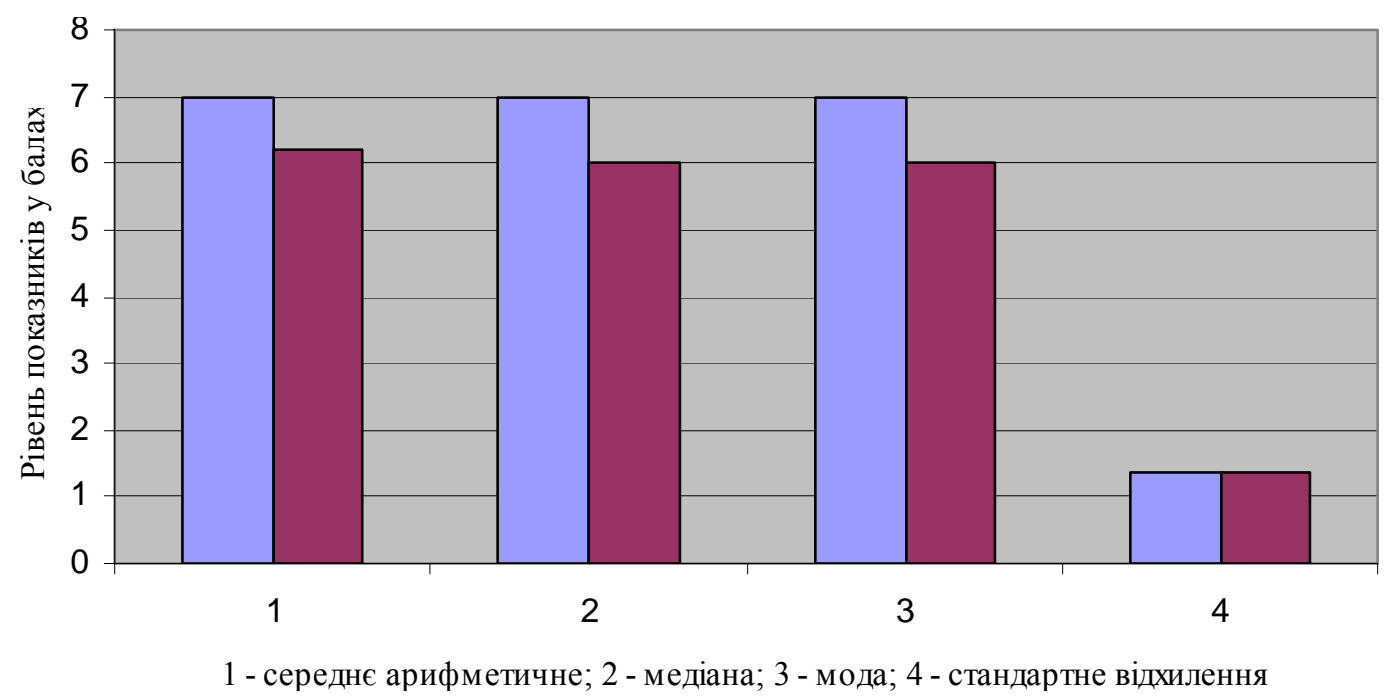

Рис. 12. Статистичні показники рівня сформованості ініціативності у студентів експериментальної групи, які займалися футболом,

$$
(\boxminus) \text { і контрольної (曰) }
$$

За якістю «сміливість» в експериментальній групі студентів-футболістів середнє арифметичне показників склало 7,9, медіана - 8, мода - 8; стандартне відхилення - 1,32. У контрольній групі середнє арифметичне склало 6,6 , медіана -7 , мода -7 ; стандартне відхилення - 1 (рис. 14). При статистичній обробці отриманих даних з використанням $U$-критерію Манна-Уїтні встановлено, що $U$ емпіричне складає 197,5 (критичне значення $p \leq 0,01=292$ ). Статистично значуще вищими є показники експериментальної групи. На підставі цього 
відхилено нульову гіпотезу стосовно рівня сформованості сміливості в цих групах і підтверджено правильність альтернативної.

За такими вольовими якостями, як самовладання, стійкість, самостійність, цілеспрямованість, дисциплінованість, витримка, енергійність, терпеливість статистично значущих відмінностей у рівні їх прояву в студентів експериментальної групи, які займались футболом, і в студентів контрольної не виявлено.

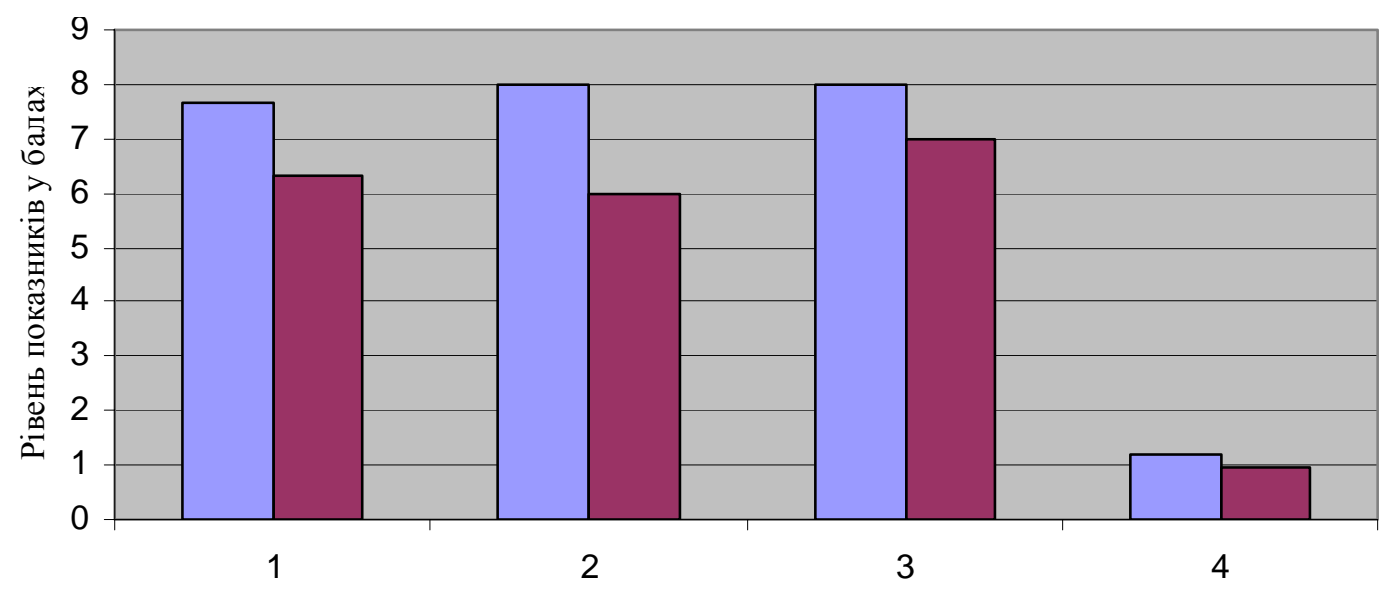

1 - середнє арифметичне; 2 - медіана; 3 - мода; 4 - стандартне відхилення

Рис. 13. Статистичні показники рівня сформованості рішучості у студентів експериментальної групи, які займалися футболом, $(\square)$ і контрольної (曰)

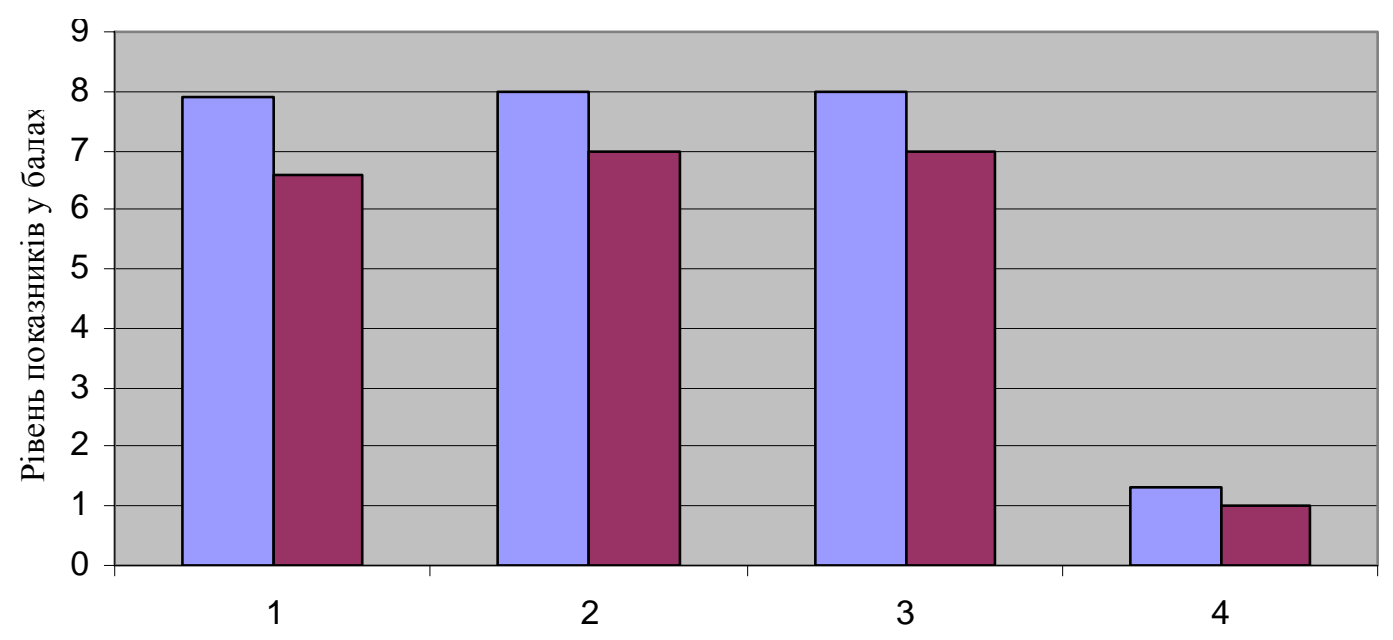

1 - середнє арифметичне; 2 - медіана; 3 - мода; 4 - стандартне відхилення

Рис. 14. Статистичні показники рівня сформованості сміливості у студентів експериментальної групи, які займалися футболом,

$$
(\square) \text { і контрольної (曰) }
$$


Порівнюючи показники студентів експериментальної групи, які займалися легкою атлетикою, і показники студентів контрольної групи, встановлено таке. Існують статистично значущі відмінності рівня сформованості вольових якостей у зазначених групах за такими якостями, як наполегливість, стійкість, ініціативність, самостійність, рішучість, сміливість, цілеспрямованість, дисциплінованість, витримка, енергійність, терпеливість. Так, оцінюючи в цих групах таку якість, як наполегливість, було встановлено, що в експериментальній групі студентів середнє арифметичне показників становить 8,53, медіана 9 , мода - 9; стандартне відхилення - 1,1. У контрольній групі середнє арифметичне склало 6,5 , медіана -6 , мода -6 ; стандартне відхилення - 1,38. Графічно результати зображено на рис. 15 . Вторинну статистичну обробку отриманих даних було виконано з використанням $U$ критерію Манна-Уїтні. $U$ емпіричне склало 123 (критичне значення $p \leq 0,01=292$ ). Отримане емпіричне значення $U$ розташоване в зоні значущості. Суттєво вищими є показники експериментальної групи студентів, які займалися легкою атлетикою (бігом на середні та довгі дистанції). На підставі цього відхилено нульову гіпотезу стосовно рівня сформованості наполегливості в цих групах і підтверджено правильність альтернативної.

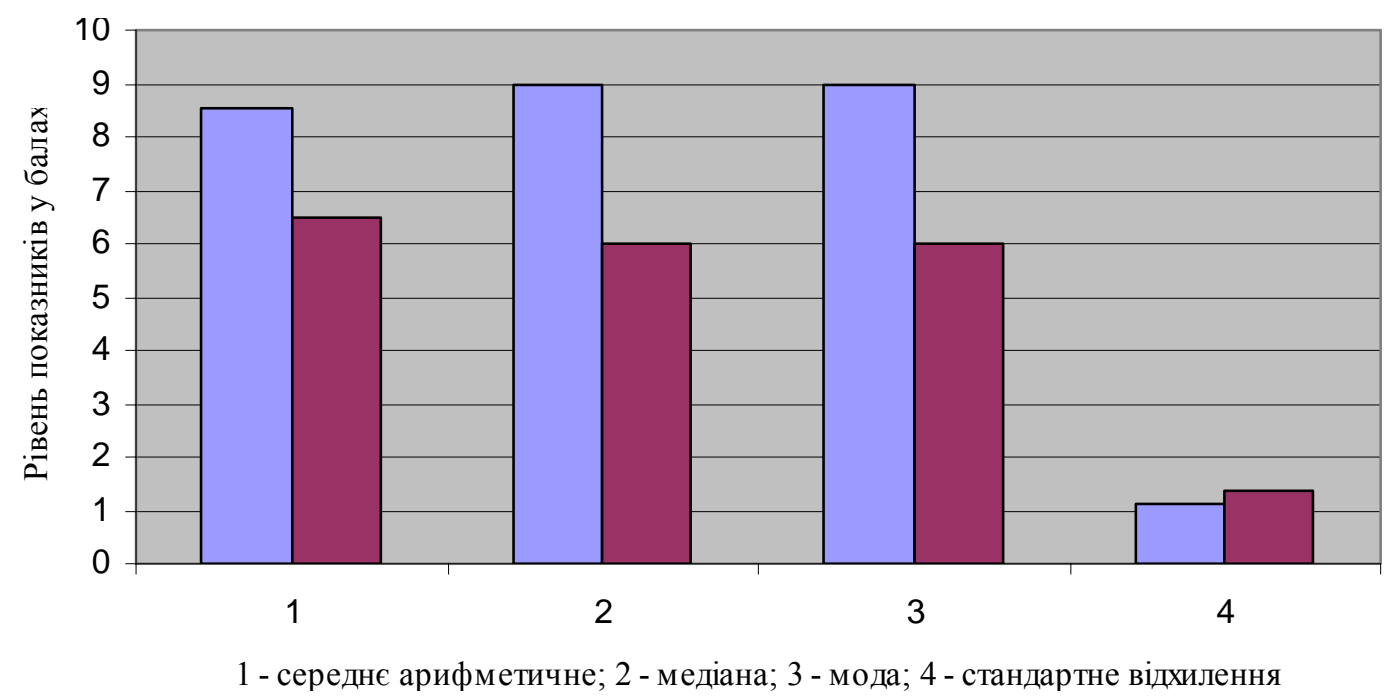

Рис. 15. Статистичні показники рівня сформованості наполегливості у студентів експериментальної групи, які займалися легкою атлетикою, $(\square)$ і контрольної ( $(\mathbf{)}$ 
За такою вольовою якістю, як стійкість в експериментальній групі середнє арифметичне показників склало 7,93, медіана -8 , мода -8 ; стандартне відхилення - 1,01. У контрольній групі середнє арифметичне склало 6,86, медіана - 7, мода - 7; стандартне відхилення 1,22 . Графічно результати подано на рис. 16. Виконавши вторинну статистичну обробку даних 3 використанням $U$-критерію МаннаУїтні, було встановлено, що $U$ емпіричне становить 240 (критичне значення $p \leq 0,01=292$ ). Отримане емпіричне значення $U$ розташоване в зоні значущості. Суттєво вищими є показники експериментальної групи студентів, які займалися легкою атлетикою (бігом на середні та довгі дистанції). На підставі цього відхилено нульову гіпотезу стосовно рівня сформованості стійкості в цих групах і підтверджено правильність альтернативної.

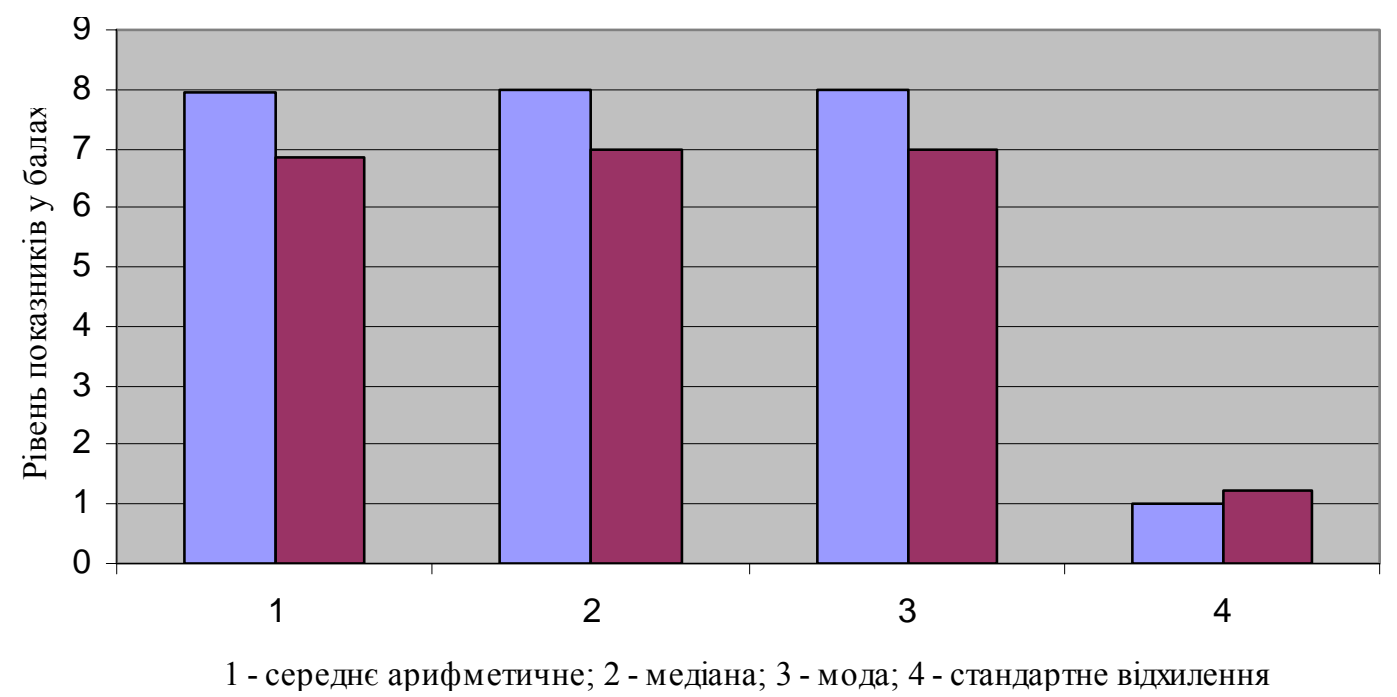

Рис. 16. Статистичні показники рівня сформованості стійкості у студентів експериментальної групи, які займалися легкою атлетикою, $(\square)$ і контрольної ( $\square)$

За якістю «ініціативність» в експериментальній групі середнє арифметичне показників склало 8,13, медіана - 8, мода - 8; стандартне відхилення - 0,97. У контрольній групі середнє арифметичне склало 6,2, медіана - 6, мода - 6; стандартне відхилення - 1,35. Графічно результати зображено на рис. 17. При статистичній обробці отриманих даних з використанням $U$-критерію Манна-Уїтні встановлено, що $U$ емпіричне складає 123 (критичне значення $p \leq 0,01=292$ ). Статистично значуще вищими $є$ показники експериментальної групи. 
На підставі цього відхилено нульову гіпотезу стосовно рівня сформованості ініціативності в цих групах і підтверджено правильність альтернативної.

За якістю «самостійність» в експериментальній групі середнє арифметичне показників становило 8,66, медіана - 9, мода - 10; стандартне відхилення - 1,42. У контрольній групі середнє арифметичне склало 7, медіана - 7, мода - 8; стандартне відхилення - 1,5. Графічно результати зображено на рис. 18. При статистичній обробці отриманих даних 3 використанням $U$-критерію Манна-Уїтні встановлено, що $U$ емпіричне складає 190 (критичне значення $p \leq 0,01=292$ ). Статистично значуще вищими є показники експериментальної групи. На підставі цього відхилено нульову гіпотезу стосовно рівня сформованості самостійності в цих групах і підтверджено правильність альтернативної.

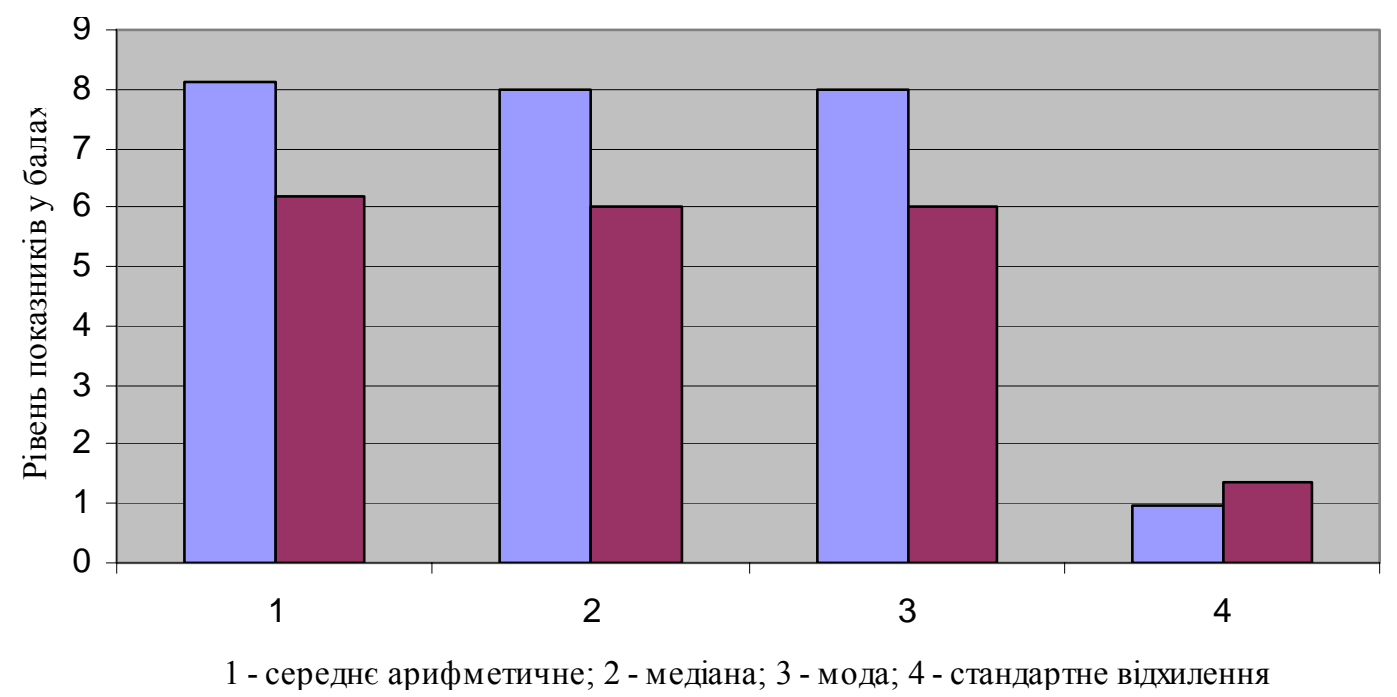

Рис. 17. Статистичні показники рівня сформованості ініціативності у студентів експериментальної групи, які займалися легкою атлетикою, $(\square)$ і контрольної ( $(\mathbf{)}$

За такою вольовою якістю, як рішучість було встановлено, що в експериментальній групі студентів-легкоатлетів середнє арифметичне показників становило 8,13, медіана - 8, мода - 8; стандартне відхилення $-1,27$. У контрольній групі середнє арифметичне становило 6,3, медіана - 6, мода - 7; стандартне відхилення - 0,98. Графічно результати зображено на рис. 19. При статистичній обробці отриманих даних з використанням $U$-критерію Манна-Уїтні встановлено, що $U$ 
емпіричне складає 122 (критичне значення $p \leq 0,01=292$ ). Статистично значуще вищими є показники експериментальної групи. На підставі цього відхилено нульову гіпотезу стосовно рівня сформованості рішучості в цих групах і підтверджено правильність альтернативної.

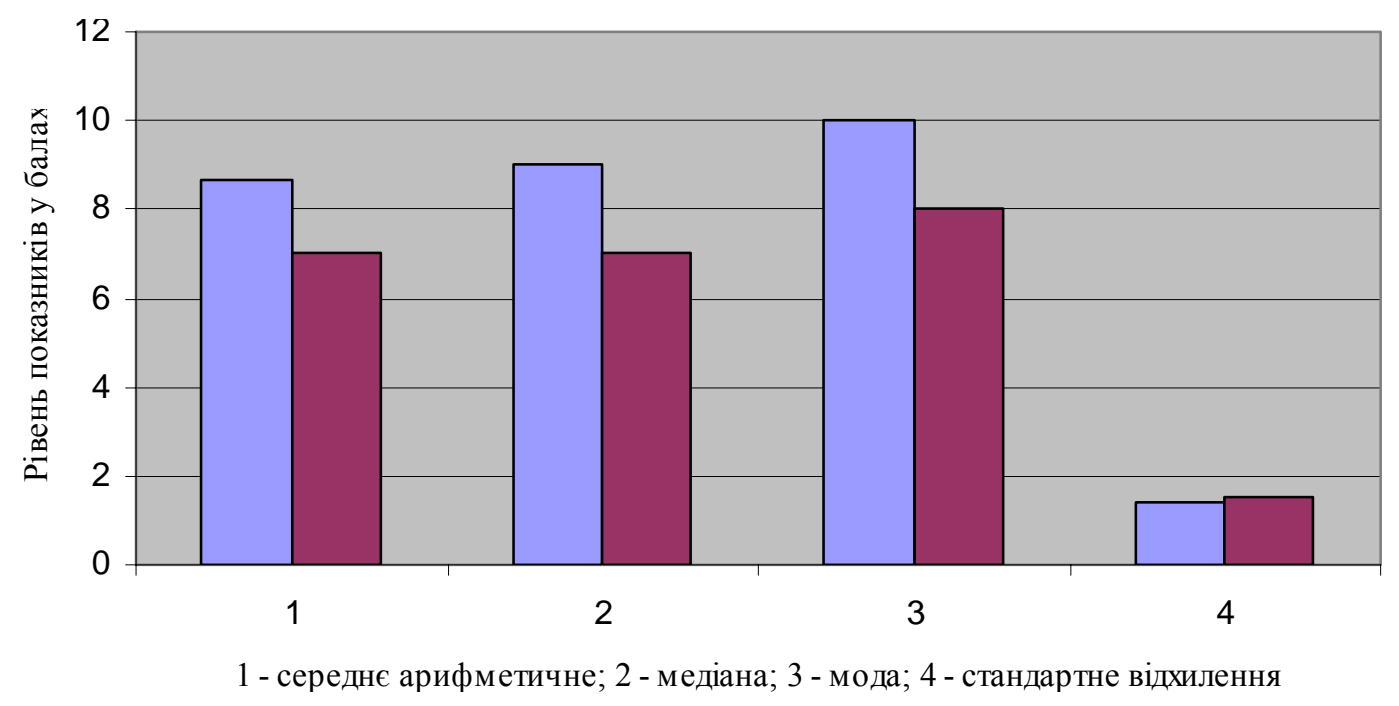

Рис. 18. Статистичні показники рівня сформованості самостійності у студентів експериментальної групи, які займалися легкою атлетикою, $(\square)$ і контрольної ( $\square)$

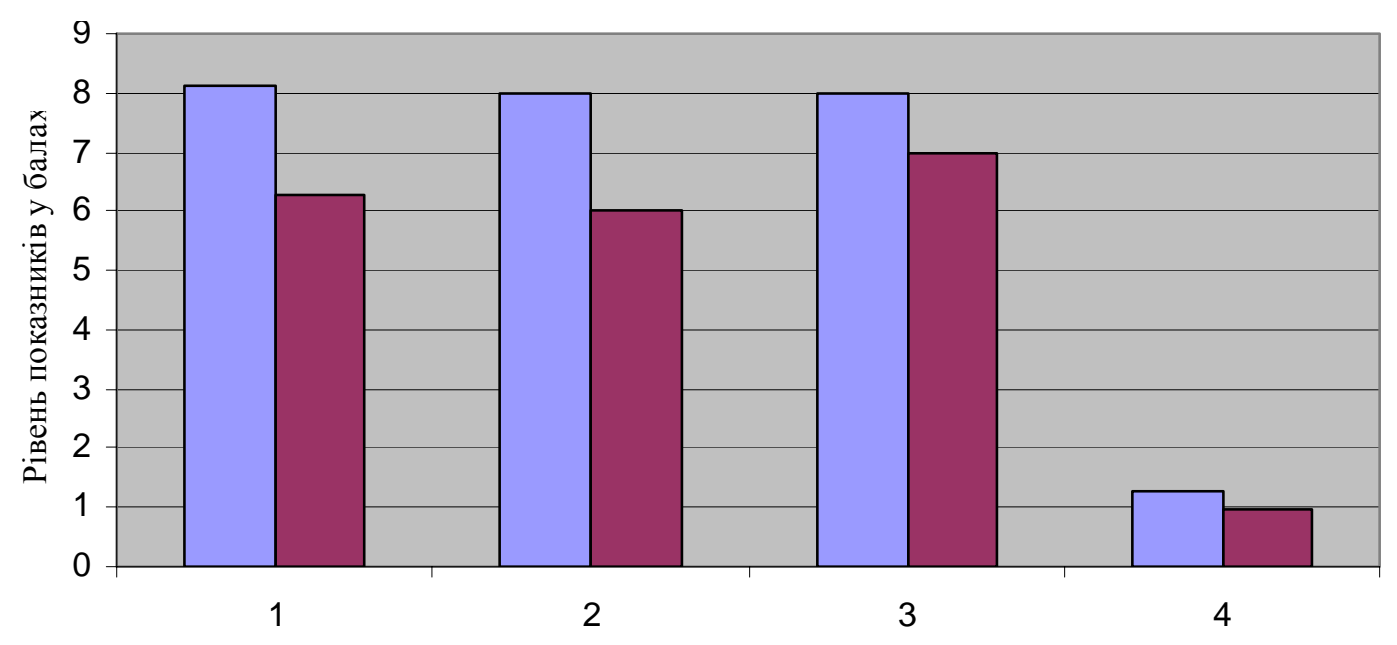

1 - середнє арифметичне; 2 - медіана; 3 - мода; 4 - стандартне відхилення

Рис. 19. Статистичні показники рівня сформованості рішучості у студентів експериментальної групи, які займалися легкою атлетикою, $(\square)$ і контрольної ( () 
За такою якістю, як сміливість в експериментальній групі студентів-легкоатлетів середнє арифметичне показників складало 7,86, медіана -8 , мода -8 ; стандартне відхилення - 1,1. У контрольній групі середнє арифметичне становило 6,6 , медіана - 7, мода - 7; стандартне відхилення - 1. Графічно результати зображено на рис. 20. При статистичній обробці отриманих даних 3 використанням $U$-критерію Манна-Уїтні встановлено, що $U$ емпіричне складає 189 (критичне значення $p \leq 0,01=292$ ). Статистично значуще вищими є показники експериментальної групи. На підставі цього відхилено нульову гіпотезу стосовно рівня сформованості сміливості в цих групах і підтверджено правильність альтернативної.

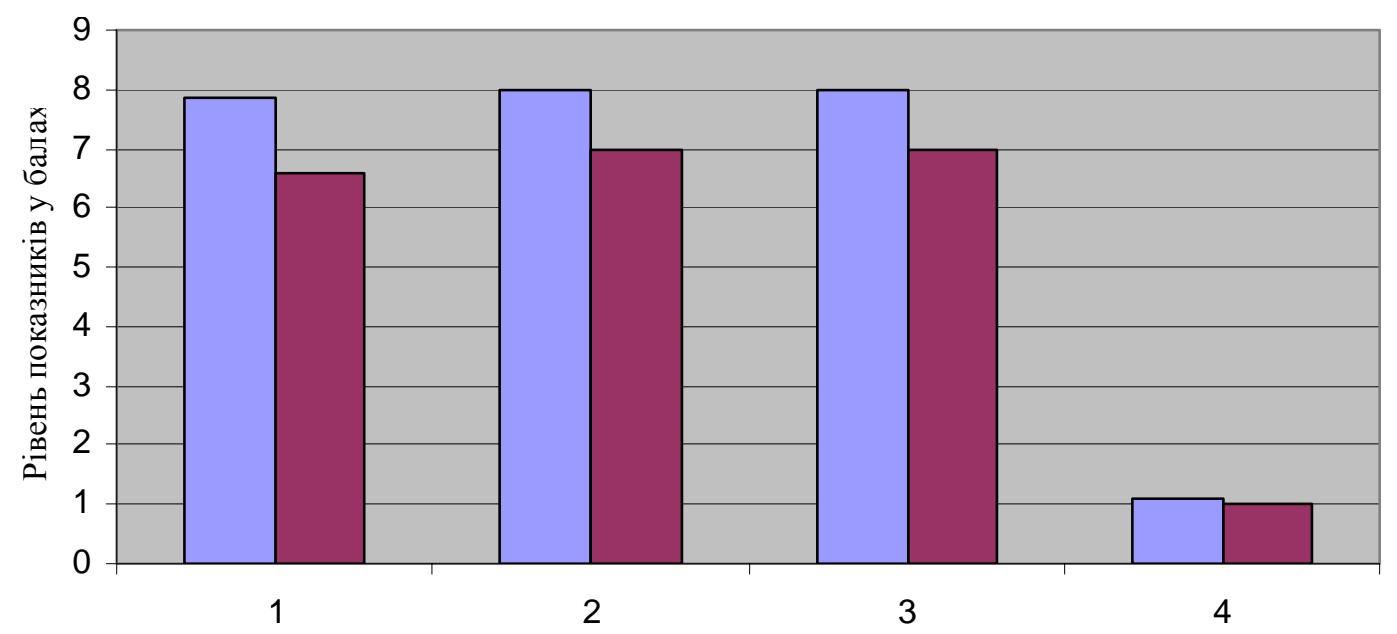

1 - середнє арифметичне; 2 - медіана; 3 - мода; 4 - стандартне відхилення

Рис. 20. Статистичні показники рівня сформованості сміливості у студентів експериментальної групи, які займалися легкою атлетикою, $(\square)$ і контрольної $(\square)$

За якістю «цілеспрямованість» в експериментальній групі студентів-легкоатлетів середнє арифметичне показників становило 8,53, медіана - 9, мода - 9; стандартне відхилення - 0,97. У контрольній групі середнє арифметичне склало 6,8, медіана - 7, мода - 8; стандартне відхилення - 1,66. Графічно результати наведено на рис. 21 . При статистичній обробці отриманих даних 3 використанням $U$-критерію Манна-Уїтні встановлено, що $U$ емпіричне складає 185 (критичне значення $p \leq 0,01=292$ ). Статистично значуще вищими $є$ показники експериментальної групи. На підставі цього відхилено нульову 
гіпотезу стосовно рівня сформованості цілеспрямованості в цих групах і підтверджено правильність альтернативної.

За якістю «дисциплінованість» в експериментальній групі студентів-легкоатлетів середнє арифметичне показників склало 8,2, медіана - 9, мода - 9; стандартне відхилення - 1,44. У контрольній групі середнє арифметичне становило 6,83, медіана - 7, мода - 8; стандартне відхилення - 1,7. Графічно результати наведено на рис. 22. Статистична обробка отриманих даних 3 використанням $U$-критерію МаннаУїтні показала, що $U$ емпіричне складало 243 (критичне значення $p \leq 0,01=292$ ). Статистично значуще вищими виявилися показники експериментальної групи. На підставі цього відхилено нульову гіпотезу стосовно рівня сформованості дисциплінованості в цих групах і підтверджено правильність альтернативної.

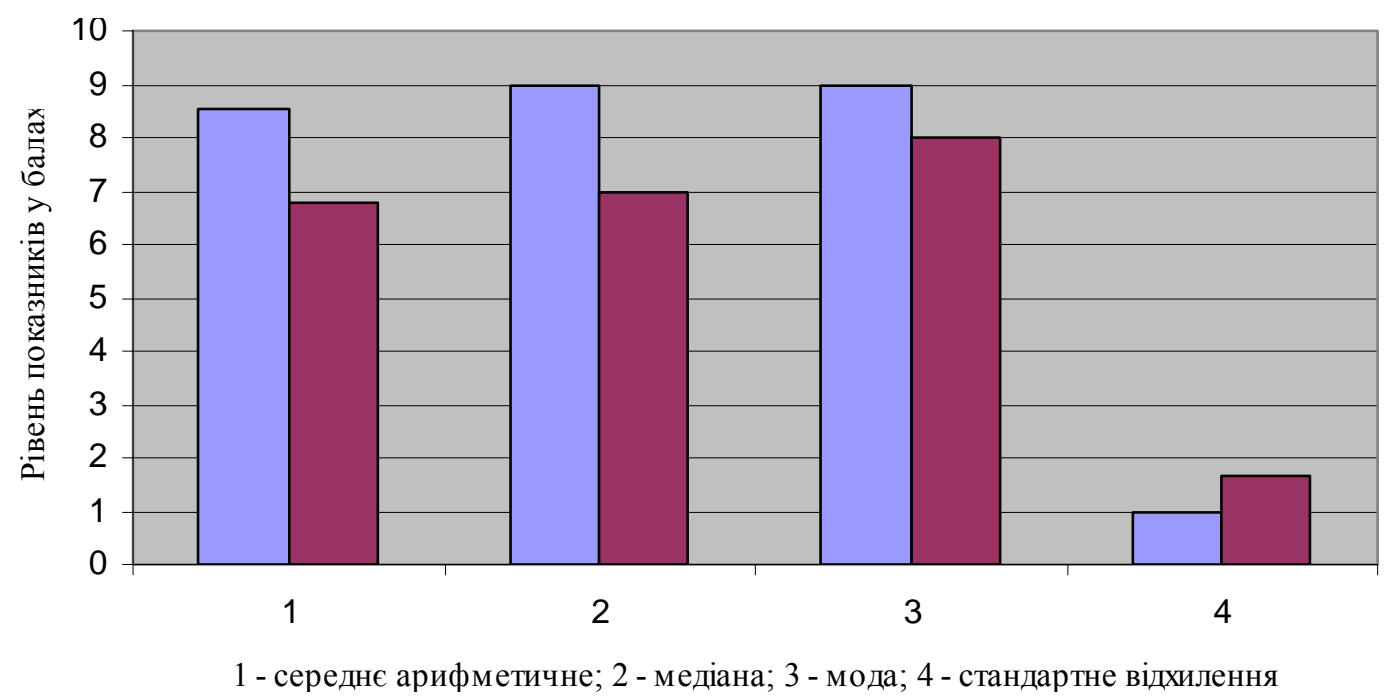

Рис. 21. Статистичні показники рівня сформованості цілеспрямованості у студентів експериментальної групи, які займалися легкою атлетикою, $(\square)$ і контрольної ( ()

За якістю «витримка» було встановлено, що в експериментальній групі студентів-легкоатлетів середнє арифметичне показників становило 7,93, медіана - 8, мода - 8; стандартне відхилення - 0,86. У контрольній групі середнє арифметичне складало 6,7, медіана - 7, мода 8; стандартне відхилення - 1,48. Графічно результати зображено на рис. 23. Статистична обробка отриманих даних з використанням $U$ критерію Манна-Уїтні показала, що $U$ емпіричне складає 235 (критичне значення $p \leq 0,01=292)$. Статистично значуще вищими були 
показники експериментальної групи. На підставі цього відхилено нульову гіпотезу стововно рівня сформованості витримки в цих групах і підтверджено правильність альтернативної.

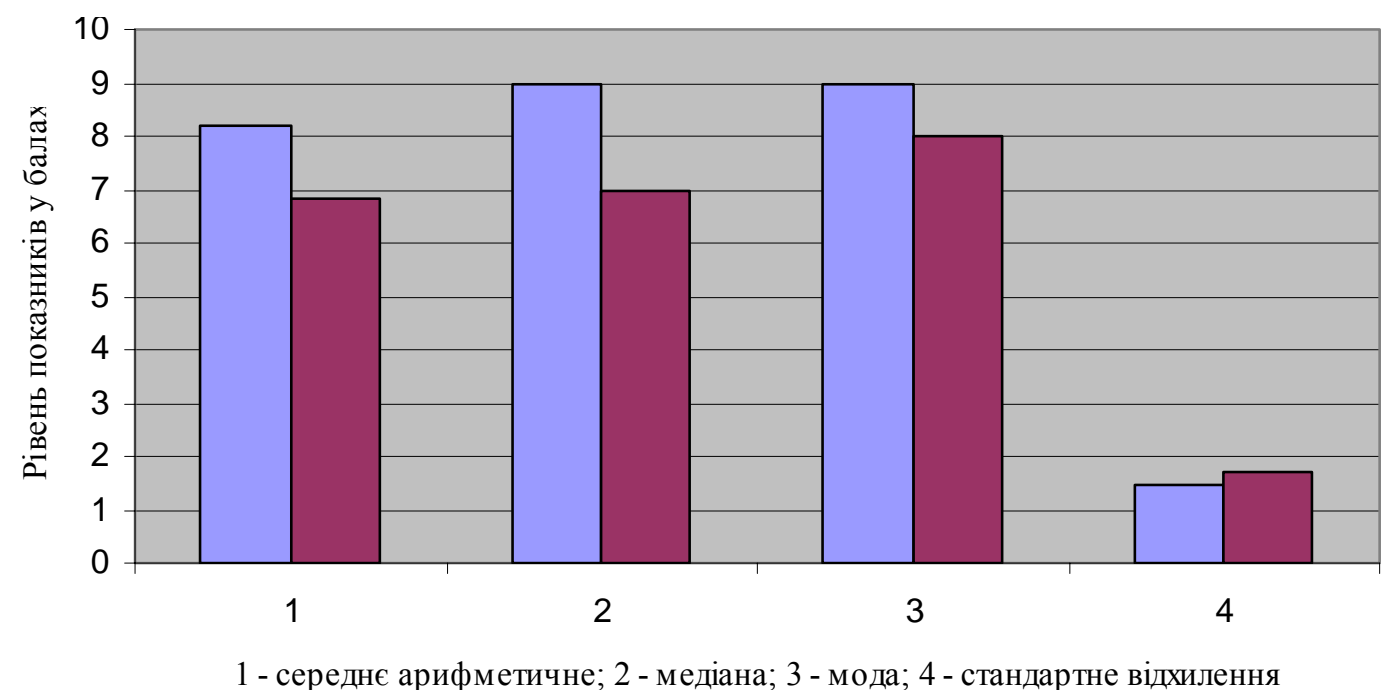

Рис. 22. Статистичні показники рівня сформованості дисциплінованості у студентів експериментальної групи, які займалися легкою атлетикою, $(\square)$ і контрольної ( $\square)$

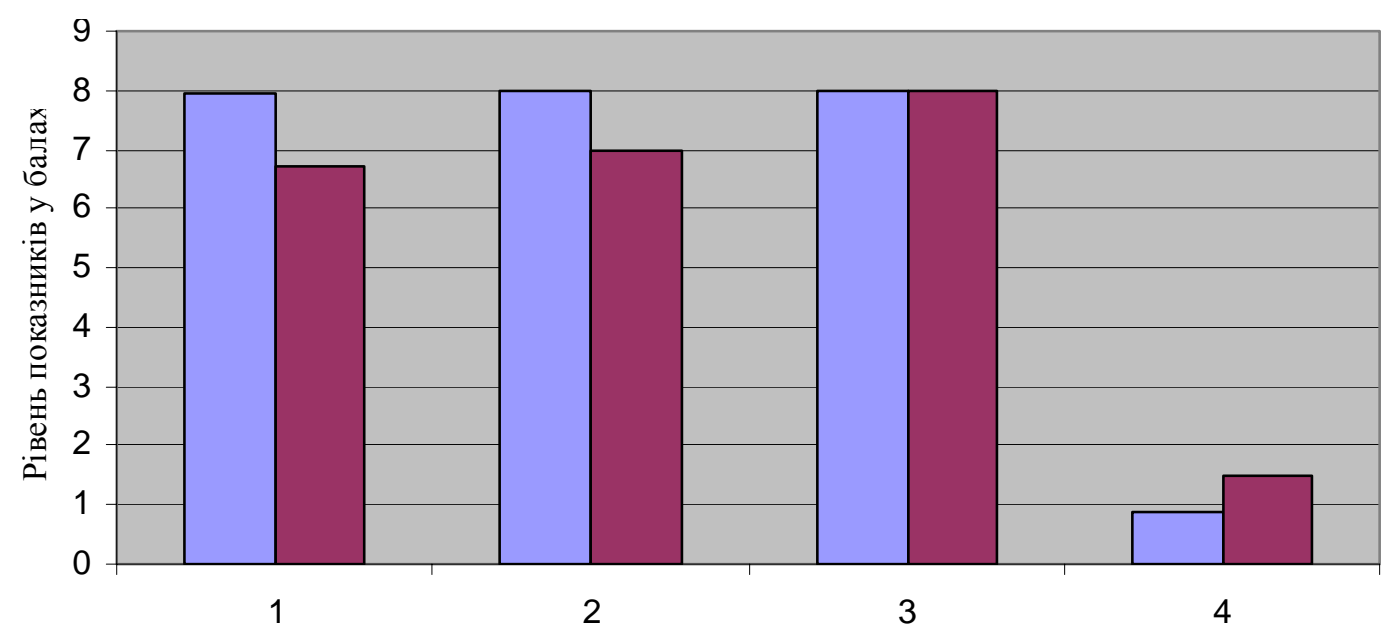

1 - середнє арифметичне; 2 - медіана; 3 - мода; 4 - стандартне відхилення

Рис. 23. Статистичні показники рівня сформованості витримки у студентів експериментальної групи, які займалися легкою атлетикою, $(\square)$ і контрольної (匚)

За якістю «енергійність» встановлено, що в експериментальній групі студентів-легкоатлетів середнє арифметичне показників 
складало 7,66, медіана - 8, мода - 8; стандартне відхилення - 0,8. У контрольній групі середнє арифметичне було 6,43, медіана $-6,5$, мода -7 ; стандартне відхилення - 1,27. Графічно результати наведено на рис. 24. Статистична обробка отриманих даних з використанням $U$-критерію Манна-Уїтні показала, що $U$ емпіричне складає 195 (критичне значення $p \leq 0,01=292$ ). Статистично значуще вищими були показники експериментальної групи. На підставі цього відхилено нульову гіпотезу стосовно рівня сформованості енергійності в цих групах і підтверджено правильність альтернативної.

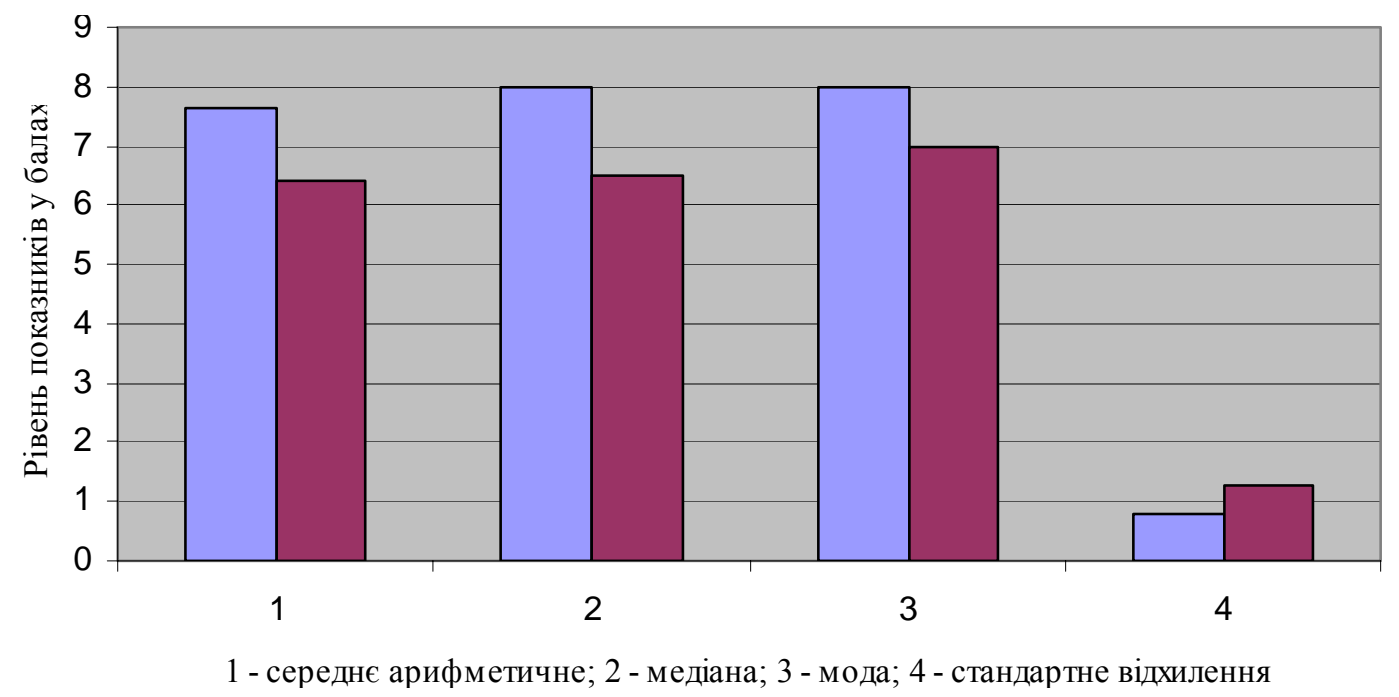

Рис. 24. Статистичні показники рівня сформованості енергійності у студентів експериментальної групи, які займалися легкою атлетикою, $(\square)$ і контрольної ( ()

За якістю «терпеливість» було встановлено, що в експериментальній групі студентів-легкоатлетів середнє арифметичне показників становило 7,93, медіана - 8, мода - 9; стандартне відхилення - 0,94. У контрольній групі середнє арифметичне становило 6,83, медіана 7 , мода -8 ; стандартне відхилення - 1,31. Графічно результати зображено на рис. 25. При статистичній обробці отриманих даних 3 використанням $U$-критерію Манна-Уїтні встановлено, що $U$ емпіричне складає 336 (критичне значення $p \leq 0,05=338$ ). На підставі цього відхилено нульову гіпотезу стосовно рівня сформованості терпеливості в цих групах і підтверджено правильність альтернативної.

За такою вольовою якістю особистості, як «самовладання» статистично значущих відмінностей у рівні прояву в студентів експеримен- 
тальної групи, які займалися легкою атлетикою, і студентів контрольної групи не виявлено.

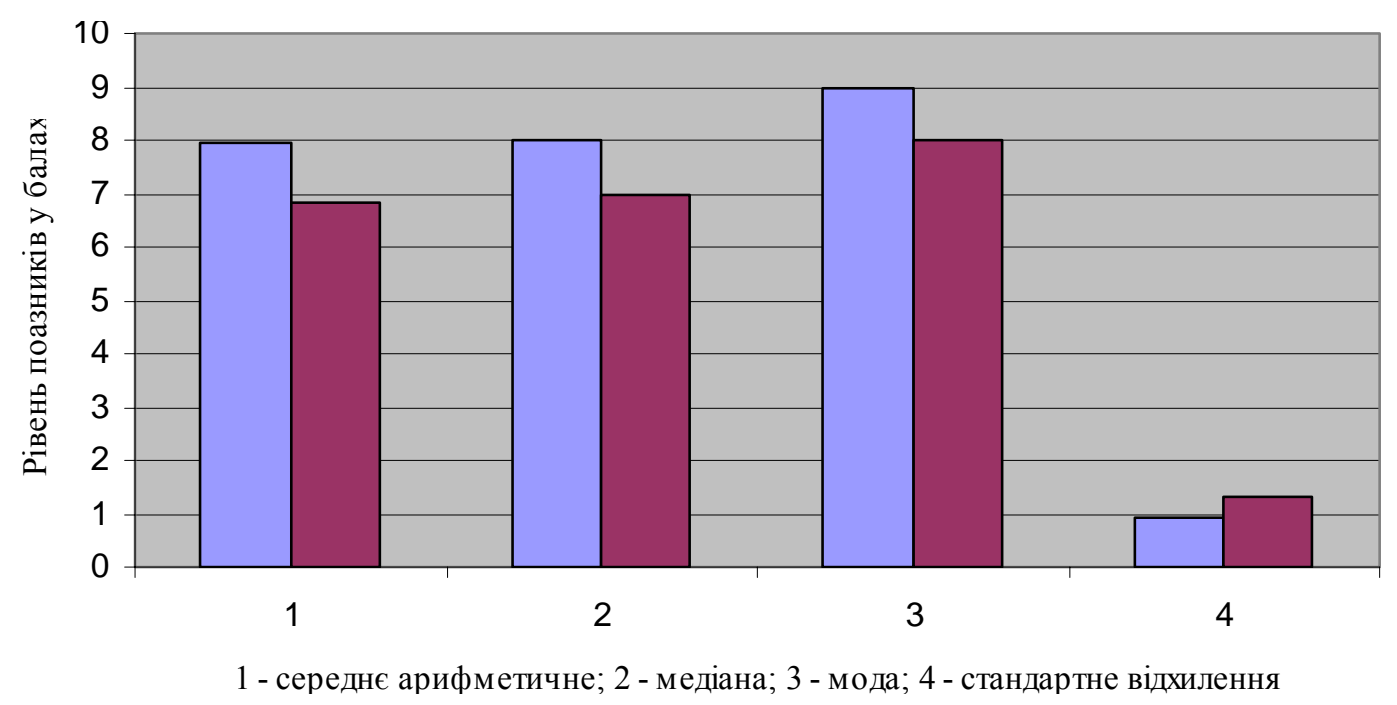

Рис. 25. Статистичні показники рівня сформованості терпеливості у студентів експериментальної групи, які займалися легкою атлетикою, $(\square)$ і контрольної ( ()

3 порівняння показників студентів експериментальної групи, які займалися спортивною гімнастикою, і студентів контрольної групи встановлено таке. Існують статистично значущі відмінності рівня сформованості вольових якостей у цих групах за такими якостями, як наполегливість, стійкість, ініціативність, рішучість, сміливість, цілеспрямованість, дисциплінованість, енергійність. Так, при оцінці такої якості, як наполегливість, було встановлено, що в експериментальній групі середнє арифметичне показників становить 8,06, медіана - 8, мода -8 ; стандартне відхилення - 1,08. У контрольній групі середнє арифметичне складало 6,5, медіана - 6, мода - 6; стандартне відхилення - 1,38. Графічно результати зображено на рис. 26. Вторинну статистичну обробку отриманих даних було проведено з використанням $U$-критерію Манна-Уїтні. $U$ емпіричне становило 173 (критичне значення $p \leq 0,01=292$ ). Отримане емпіричне значення $U$ розташоване в зоні значущості. Суттєво вищими є показники студентів експериментальної групи, які займалися спортивною гімнастикою. На підставі цього відхилено нульову гіпотезу стосовно рівня сформованості наполегливості в цих групах і підтверджено правильність альтернативної. 
За якістю «ініціативність» було встановлено, що в експериментальній групі студентів-гімнастів середне арифметичне показників становило 7,73, медіана - 8, мода - 7; стандартне відхилення - 1,63. У контрольній групі середнє арифметичне складало 6,2, медіана - 6, мода - 6; стандартне відхилення - 1,35 (рис. 27). При статистичній обробці отриманих даних з використанням $U$-критерію Манна-Уїтні встановлено, що $U$ емпіричне складає 225 (критичне значення $p \leq 0,01=292$ ). Отримане емпіричне значення $U$ розташоване в зоні значущості. Статистично значуще вищими є показники експериментальної групи. На підставі цього відхилено нульову гіпотезу стосовно рівня сформованості ініціативності в цих групах і підтверджено правильність альтернативної.

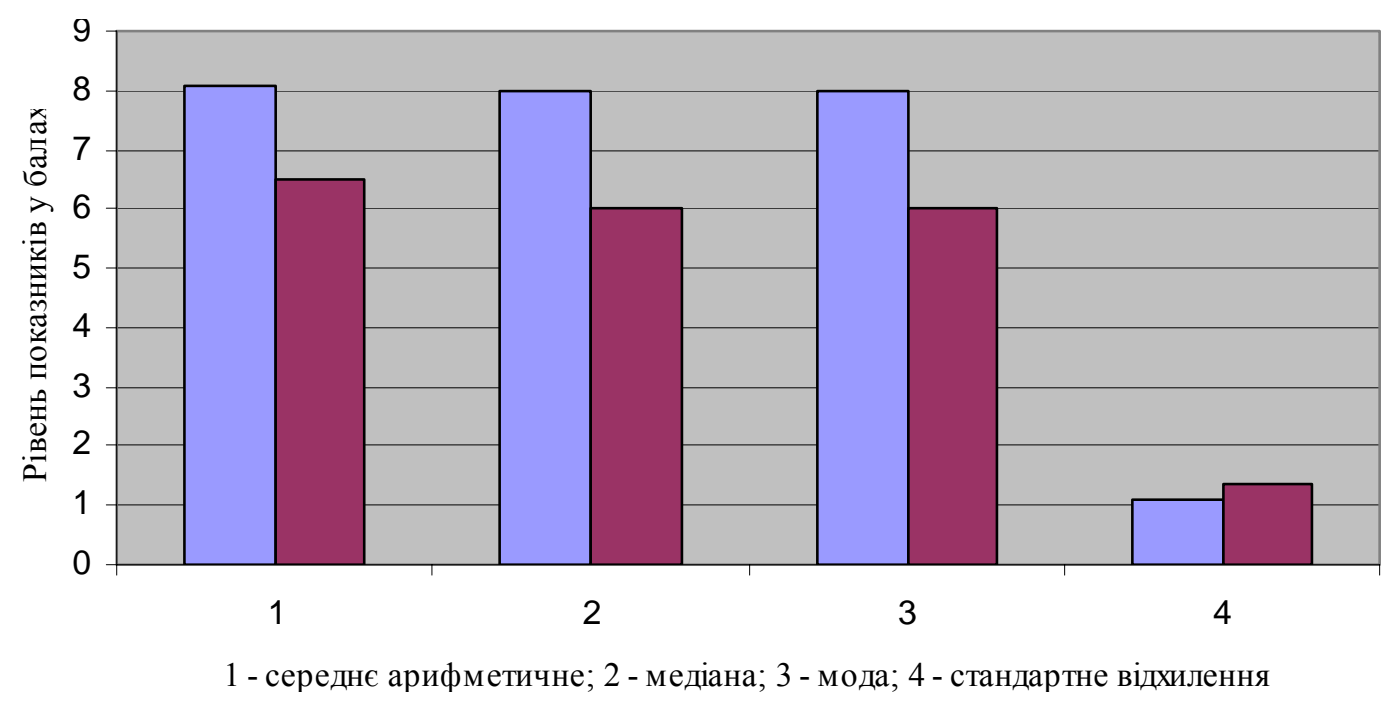

Рис. 26. Статистичні показники рівня сформованості наполегливості у студентів експериментальної групи, які займалися спортивною гімнастикою, $(\square)$ і контрольної (曰)

За якістю «стійкість» встановлено, що в експериментальній групі студентів-гімнастів середнє арифметичне показників складало 8,33, медіана -8 , мода -7 ; стандартне відхилення - 1,21. У контрольній групі середнє арифметичне становило 6,86, медіана - 7, мода - 7; стандартне відхилення - 1,22 (рис. 28). При статистичній обробці отриманих даних 3 використанням $U$-критерію Манна-Уїтні було встановлено, що $U$ емпіричне складає 201 (критичне значення $p \leq 0,01=292$ ). Отримане емпіричне значення $U$ розташоване в зоні значущості. Статистично значуще вищими $є$ показники експеримен- 
тальної групи. На підставі цього відхилено нульову гіпотезу стосовно рівня сформованості стійкості в цих групах і підтверджено правильність альтернативної.

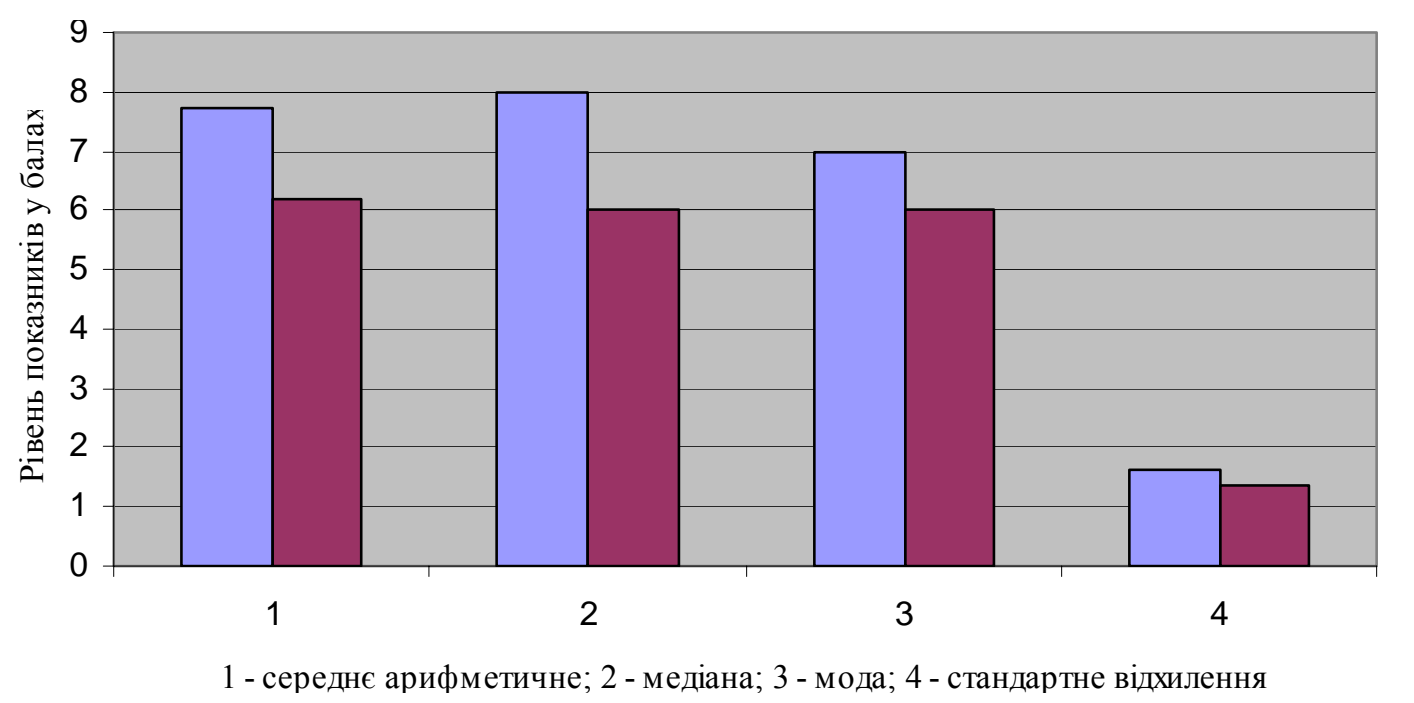

Рис. 27. Статистичні показники рівня сформованості ініціативності у студентів експериментальної групи, які займались спортивною гімнастикою, $(\square)$ і контрольної ( ()

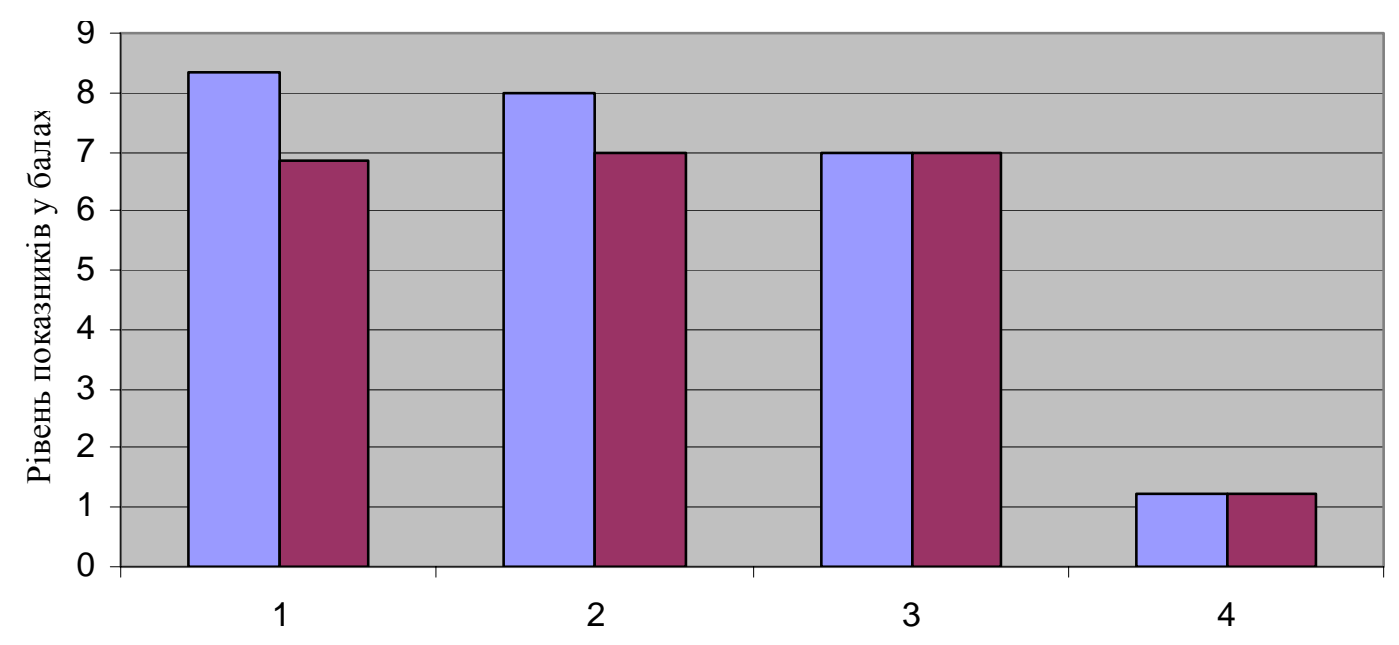

1 - середнє арифметичне; 2 - медіана; 3 - мода; 4 - стандартне відхилення

Рис. 28. Статистичні показники рівня сформованості стійкості у студентів експериментальної групи, які займалися спортивною гімнастикою, $(\square)$ і контрольної ( $\square)$

За якістю «рішучість» в експериментальній групі студентівгімнастів середнє арифметичне показників складало 7,86, медіана -8 , 
мода - 8; стандартне відхилення - 0,97. У контрольній групі середнє арифметичне склало 6,3, медіана - 6, мода - 7; стандартне відхилення - 0,98 (рис. 29). При статистичній обробці отриманих даних 3 використанням $U$-критерію Манна-Уїтні встановлено, що $U$ емпіричне складає 117 (критичне значення $p \leq 0,01=292$ ). Отримане емпіричне значення $U$ розташоване в зоні значущості. Статистично значуще вищими $є$ показники експериментальної групи. На підставі цього відхилено нульову гіпотезу стосовно рівня сформованості рішучості в цих групах і підтверджено правильність альтернативної.

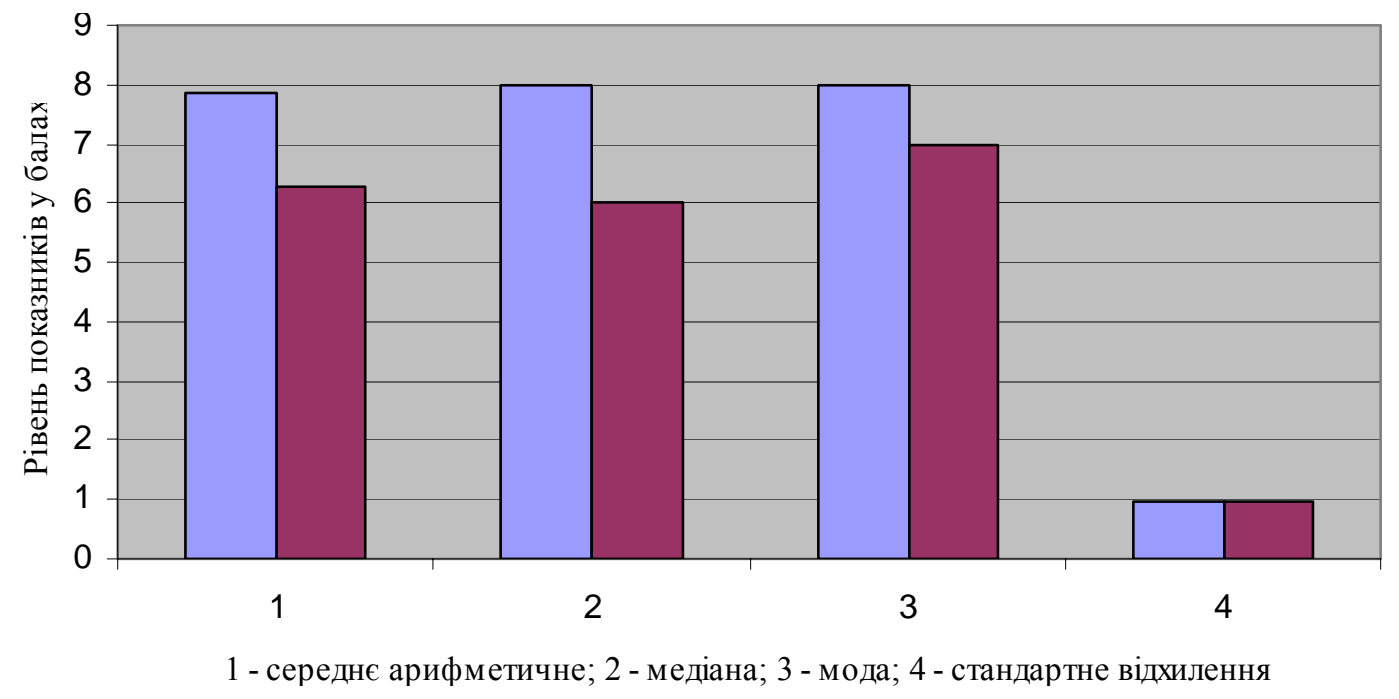

Рис. 29. Статистичні показники рівня сформованості рішучості у студентів експериментальної групи, які займались спортивною гімнастикою, $(\square)$ і контрольної ( $($ )

За якістю «сміливість» в експериментальній групі студентівгімнастів середнє арифметичне показників становило 8,13, медіана 8 , мода - 8; стандартне відхилення - 1,04. У контрольній групі середнє арифметичне було 6,6, медіана - 7, мода - 7; стандартне відхилення - 1. Графічно результати подано на рис. 30. При статистичній обробці отриманих даних 3 використанням $U$-критерію Манна-Уїтні встановлено, що $U$ емпіричне складає 136 (критичне значення $p \leq 0,01=292$ ). Отримане емпіричне значення $U$ розташоване в зоні значущості. Статистично значуще вищими $є$ показники експериментальної групи. На підставі цього відхилено нульову гіпотезу стосовно рівня сформованості сміливості в цих групах і підтверджено правильність альтернативної. 
За якістю «цілеспрямованість» в експериментальній групі студентів-гімнастів середне арифметичне показників склало 8,26, медіана 8 , мода - 8; стандартне відхилення - 1,36. У контрольній групі середнє арифметичне було 6,8, медіана - 7, мода - 8; стандартне відхилення - 1,66. Графічно результати зображено на рис. 31 . При статистичній обробці отриманих даних 3 використанням $U$-критерію МаннаУїтні встановлено, що $U$ емпіричне склало 241 (критичне значення $p \leq 0,01=292$ ). Отримане емпіричне значення $U$ розташоване в зоні значущості. Статистично значуще вищими є показники експериментальної групи. На підставі цього відхилено нульову гіпотезу стосовно рівня сформованості цілеспрямованості в цих групах і підтверджено правильність альтернативної.

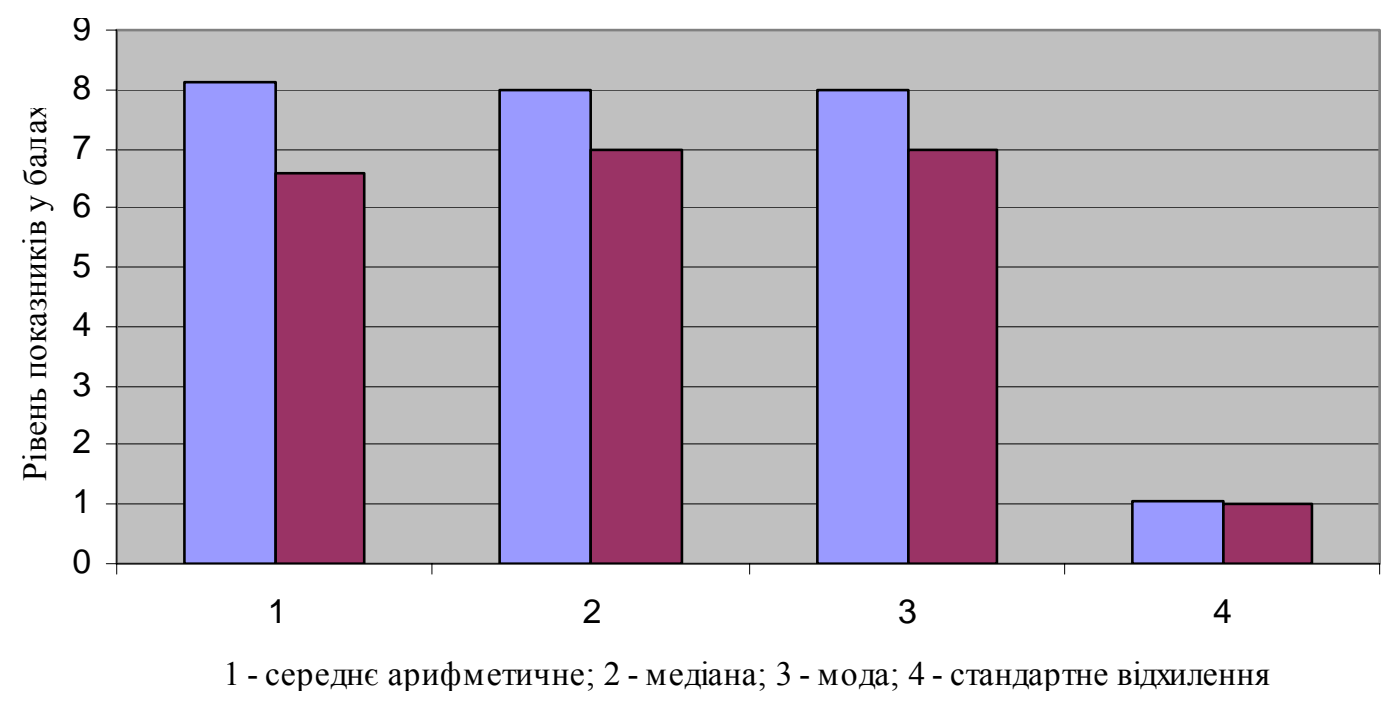

Рис. 30. Статистичні показники рівня сформованості сміливості у студентів експериментальної групи, які займалися спортивною гімнастикою, $(\square)$ і контрольної ( ()

За вольовою якістю «дисциплінованість» в експериментальній групі студентів-гімнастів середнє арифметичне показників становило 8,33 , медіана - 8, мода - 10; стандартне відхилення - 1,56. У контрольній групі середнє арифметичне складало 6,83, медіана - 7, мода 8; стандартне відхилення - 1,7. Графічно результати зображено на рис. 32. При статистичній обробці отриманих даних з використанням $U$-критерію Манна-Уїтні встановлено, що $U$ емпіричне склало 239 (критичне значення $p \leq 0,01=292$ ). Отримане емпіричне значення $U$ розташоване в зоні значущості. Статистично значуще вищими 
є показники експериментальної групи. На підставі цього відхилено нульову гіпотезу стосовно рівня сформованості дисциплінованості в цих групах і підтверджено правильність альтернативної.

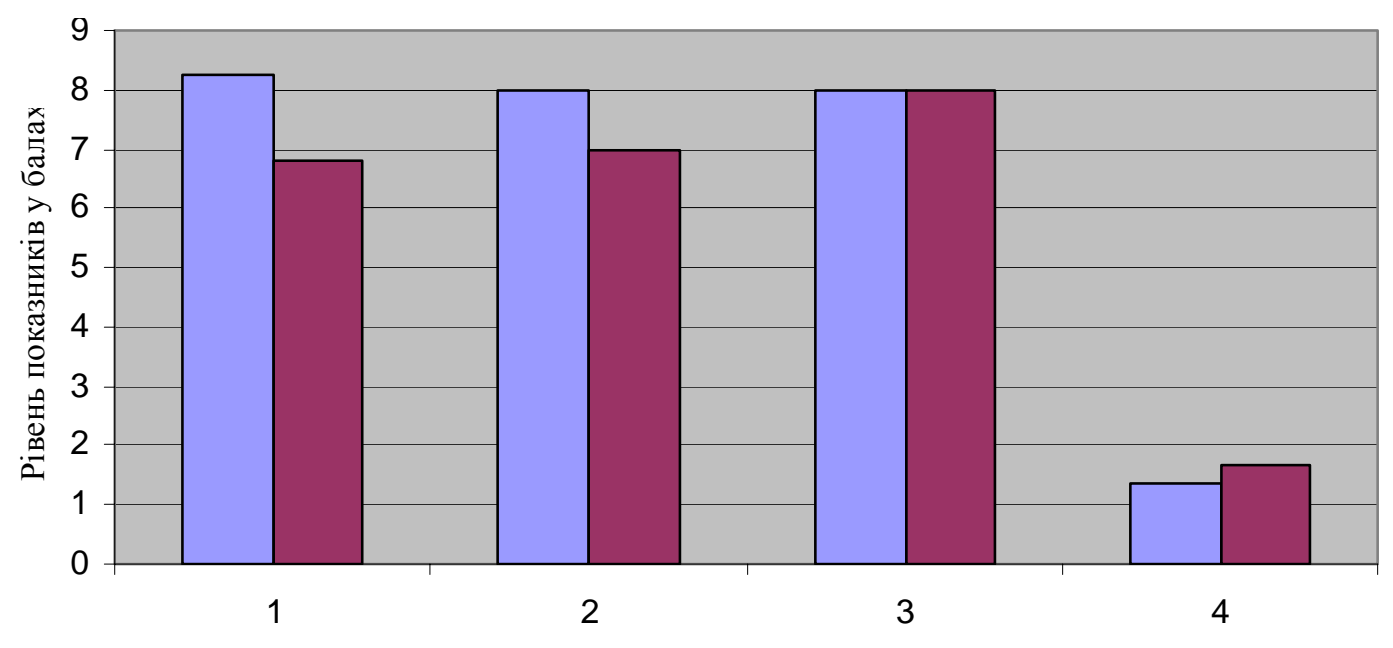

1 - середнє арифметичне; 2 - медіана; 3 - мода; 4 - стандартне відхилення

Рис. 31. Статистичні показники рівня сформованості цілеспрямованості у студентів експериментальної групи, які займалися спортивною гімнастикою, $(\square)$ і контрольної (曰)

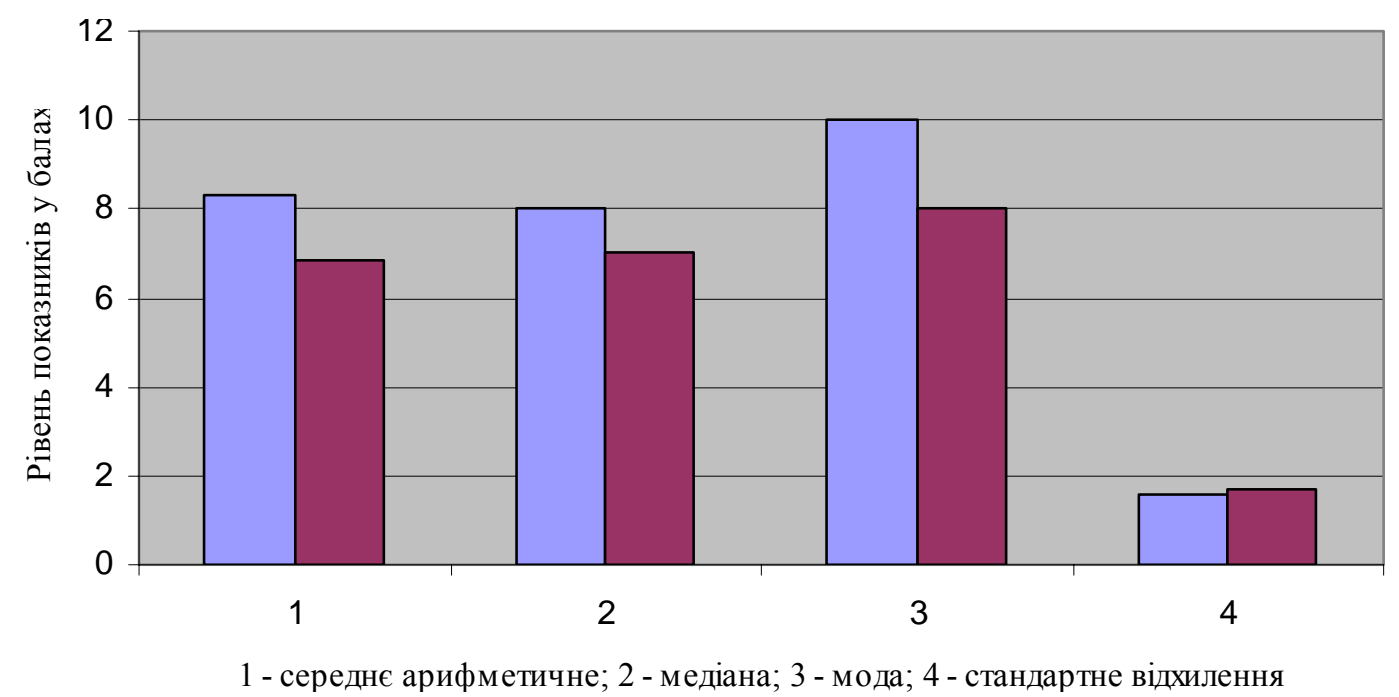

Рис. 32. Статистичні показники рівня сформованості дисциплінованості у студентів експериментальної групи, які займалися спортивною гімнастикою, $(\square)$ і контрольної ( $\square)$

За вольовою якістю «енергійність» в експериментальній групі студентів-гімнастів середнє арифметичне показників склало 8, медіа- 
на -8 , мода -8 ; стандартне відхилення $-1,27$. У контрольній групі середнє арифметичне становило 6,43 , медіана $-6,5$, мода - 7; стандартне відхилення - 1,27. Графічно результати зображено на рис. 33. При статистичній обробці отриманих даних з використанням $U$ критерію Манна-Уїтні встановлено, що $U$ емпіричне склало 180 (критичне значення $p \leq 0,01=292$ ). Отримане емпіричне значення $U$ розташоване в зоні значущості. Статистично значуще вищими $є$ показники експериментальної групи. На підставі цього відхилено нульову гіпотезу стосовно рівня сформованості енергійності в цих групах і підтверджено правильність альтернативної.

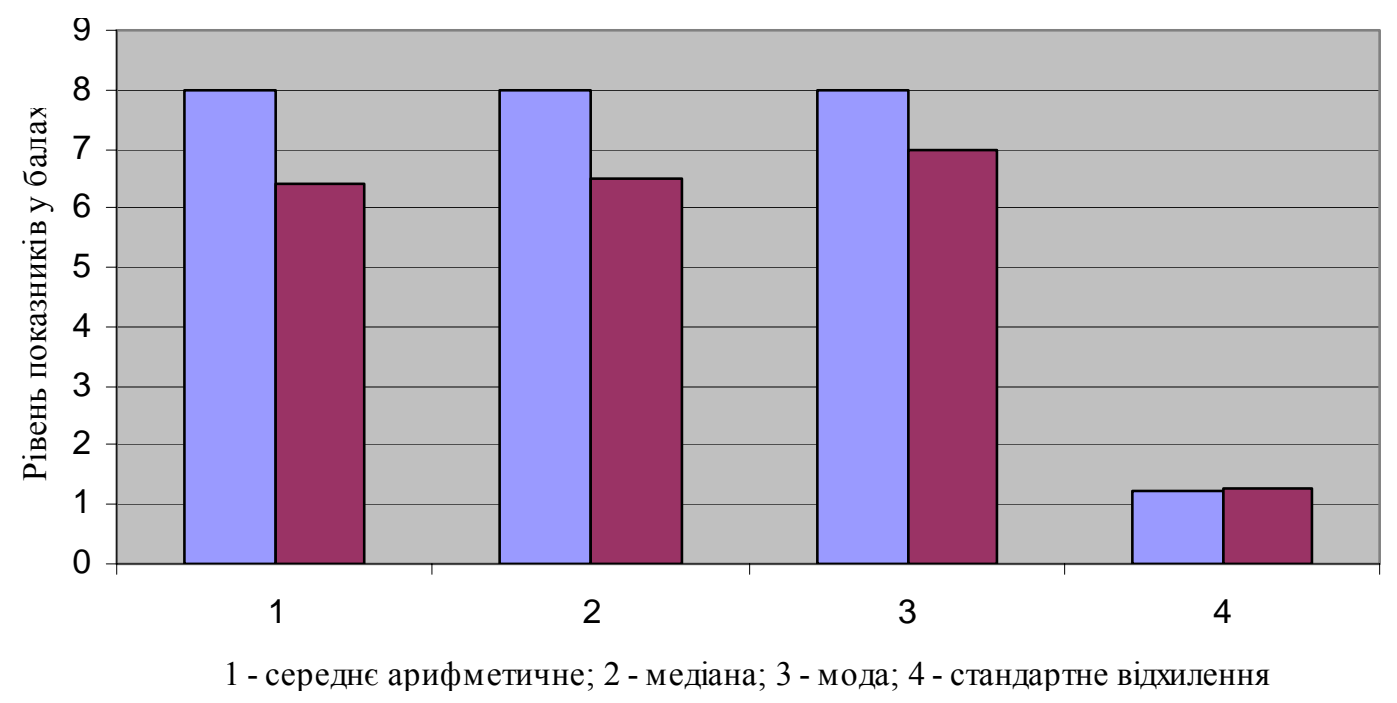

Рис. 33. Статистичні показники рівня сформованості енергійності у студентів експериментальної групи, які займалися спортивною гімнастикою,

$$
(\square) \text { і контрольної (ロ) }
$$

За такими вольовими якостями особистості, як самовладання, самостійність, витримка, терпеливість статистично значущих відмінностей у рівні їх прояву у студентів експериментальної групи, які займалися спортивною гімнастикою і студентів контрольної групи не виявлено.

Здобуті дані дозволяють констатувати наявність позитивного впливу занять футболом, спортивною гімнастикою і легкою атлетикою на формування вольових якостей особистості студентів. Рівень прояву цих якостей в експериментальних групах був суттєво (статистично значуще) вищим порівняно 3 контрольною. Однак це твердження не є абсолютним. Зафіксовано суттєві відмінності впливу 
занять футболом, спортивною гімнастикою і легкою атлетикою на ті чи інші вольові якості особистості. Аналіз отриманих даних показує, що всі три види спорту здійснюють суттєвий позитивний вплив на формування наполегливості, ініціативності, рішучості, сміливості. У той же час жоден 3 них не впливає на формування самовладання особистості.

У рамках мотиваційного розуміння природи волі в психології існує уявлення про волю як здатність до свідомого навмисного подолання перешкод. На нашу думку, кількість, специфіка і величина зовнішніх і внутрішніх перешкод, які доводиться долати особистості під час занять футболом, спортивною гімнастикою або легкою атлетикою, визначальною мірою впливають на формування іiі вольових якостей.

Отримані в ході дослідження дані дозволяють зробити такі висновки:

1. Заняття легкою атлетикою і спортивною гімнастикою є ефективним засобом формування більшості вольових якостей особистості студента під час навчальних занять 3 фізичного виховання.

2. Заняття футболом ефективно впливають на формування таких вольових якостей, як наполегливість, ініціативність, рішучість, сміливість.

3. Заняття такими видами спорту, як футбол, спортивна гімнастика і легка атлетика суттєво не впливають на формування самовладання особистості у студентів.

\section{3. Особливості розвитку уваги студентів у процесі занять футболом}

Одним з найбільш важливих питань, що пов'язані з встановленням рівня психофізичної підготовки особистості спеціаліста того чи іншого профілю, є питання про визначення такого показника цього рівня, у якому б, як у фокусі, відбивалися по можливості всі зміни, які відбулися на даний момент в іiі психофізичній організації. На нашу думку, таким критерієм може бути якість показників уваги людини. Аналогічні підходи в психології вже траплялися. Так, М. І. Яновський, 
запропонував використовувати прояви уваги як інтегральний показник особливостей функціонування психіки.

Сучасне виробництво висуває особливо високі вимоги до таких характеристик уваги інженера, як вибірковість, концентрація, стійкість. Спостереження за роботою спеціалістів залізничного транспорту показують, що успіх у роботі багато в чому залежить від якості їх уваги (для деяких же спеціальностей це надзвичайно важливо). Увага вдосконалюється в міру зростання професійної майстерності, потребує тривалих зусиль.

Адекватність до професії визначається багатьма структурними компонентами особистості. У зв'язку з цим і було запропоновано таку характеристику особистості, як эї професійна адекватність [283]. Повною мірою це стосується і розвитку різноманітних характеристик уваги майбутнього спеціаліста.

Метою дослідження стало вивчення особливостей розвитку вибірковості, концентрації і стійкості уваги у студентів на заняттях з фізичного виховання.

Завданнями дослідження визначено такі:

1. Вивчення особливостей вибірковості, концентрації і стійкості уваги у студентів різних навчальних секцій.

2. Встановлення впливу професійного навчання й фізкультурної діяльності на динаміку розвитку вищезгаданих характеристик уваги у студентів.

3. Дослідження ефективності використання занять футболом для розвитку вибірковості, концентрації і стійкості уваги у студентів.

4. Встановлення можливого зв'язку між показниками уваги студентів і рівнем їх психофізичної підготовленості.

У психології проблему уваги досліджували такі авторитетні спеціалісти, як: Т. Рібо, Д. М. Узнадзе, П. Я. Гальперін, Л. С. Виготський, О. М. Леонтьєв, Е. Б. Тітченер. У наш час ії вивченням займаються науковці різного профілю, зокрема слід відзначити роботи Ю. Б. Гіппенрейтер [89], І. М. Баранова-Крилова [25], Ю. П. Корнілова [169], Л. П. Кузми [189], Н. О. Пахомової [277], О. В. Литвиненко [209] та ін. Увагу розглядають як спрямованість і зосередженість психічної діяльності людини. При цьому під спрямованістю розуміють вибірковий характер активності, а під зосередженістю - заглиблення в дану діяльність. 
Регулююча функція уваги проявляється досить чітко. Це дало підстави для класифікації іiї видів залежно від рівнів психічної регуляції. Така класифікація передбачає розподіл уваги на мимовільну, довільну і післядовільну. Якщо спрямованість і зосередженість мимовільні, то говорять про мимовільну увагу. Вона зумовлена як фізичними характеристиками стимулу (інтенсивністю, контрастністю, довготою, несподіваністю і т. ін.), так і значущістю його для людини. Якщо спрямованість і зосередженість уваги людини пов'язані зі свідомо поставленою метою, то говорять про довільну увагу. Поряд 3 цими двома видами уваги розрізняють і третій - післядовільну. У цьому випадку свідоме виконання якого-небудь завдання супроводжується поглинанням (захопленням) особистості даною діяльністю і не вимагає вольових зусиль.

До головних характеристик уваги відносять об'єм, вибірковість, стійкість, концентрацію, розподіл і переключення. Усі характеристики уваги являють собою функціональну єдність, i їх розподіл $є$ умовним.

Дослідженням особливостей уваги у спортсменів займалися такі науковці, як В. А. Гавриленко, Ф. Генов, В. М. Дьячков, Л. С. Нерсесян, В. К. Петрович та інші. Встановлено особливості уваги в представників різних видів спорту. У той же час питання розвитку уваги у студентів на заняттях з фізичного виховання недостатньо вивчено в спеціальних дослідженнях.

Експериментальною гіпотезою дослідження стало припущення про те, що заняття футболом у навчальній секції спортивного виховання здійснюють суттєвий позитивний вплив на формування у студентів таких характеристик уваги, як вибірковість, концентрація і стійкість.

Незалежною змінною був зміст навчальної діяльності студентів, до складу якого входили заняття футболом. Залежною змінною стали показники рівня розвитку вибірковості уваги та концентрації і стійкості уваги у студентів.

Як статистична нульова гіпотеза приймалося припущення про те, що різниця між показниками рівня розвитку вибірковості та концентрації і стійкості уваги у студентів навчальної секції спортивного виховання, які займалися футболом, і студентів навчальної секції фізичного виховання значуще не відрізняється від нуля. Альтернативною статистичною гіпотезою було припущення про те, що різниця між 
показниками рівня розвитку вибірковості та концентрації і стійкості уваги у студентів навчальної секції спортивного виховання, які займалися футболом, і студентів навчальної секції фізичного виховання значуще відрізняється від нуля.

У дослідженні брали участь 60 студентів (чоловіки 18-20 років). Контрольну групу склали 30 студентів (по 15 чоловік) з факультетів «Технічна кібернетика» і «Механічний», які не займалися спортивними іграми в університеті (віднесені за станом здоров'я до основної чи підготовчої медичної груп) і відвідували заняття з фізичного виховання (4 навчальних години на тиждень) у навчальних групах секції фізичного виховання. Експериментальну склали також 30 студентів факультетів «Технічна кібернетика» і «Механічний» (по 15 чоловік), яких за станом здоров'я віднесено до основної медичної групи і які 2 роки займалися в університеті футболом (4 навчальних години на тиждень) у навчальних групах секції спортивного виховання.

Діагностика вибірковості уваги у студентів проводилася 3 допомогою тесту Мюнстерберга. Діагностика концентрації і стійкості - 3 використанням коректурної проби Бурдона (завдання виконувалося протягом 10 хв). Статистична обробка даних виконана 3 допомогою $U$-критерію Манна-Уїтні.

Здобуті дані (рис. 34) дозволяють зробити висновок про позитивний вплив занять футболом на вибірковість уваги студентів. В експериментальній групі середнє арифметичне показників вибірковості уваги склало 19,8, медіана - 21, показник моди - 18; стандартне відхилення - 3,9. У контрольній групі ці статистичні показники були такими: середнє арифметичне - 16,4, медіана - 16,5, мода - 12; стандартне відхилення - 4,4. Вторинну статистичну обробку отриманих даних здійснено з використанням $U$-критерію Манна-Уїтні. $U$ емпіричне склало 258,5 (критичне значення $p \leq 0,01=292$ ). Отримане емпіричне значення $U$ розташоване в зоні значущості. Отже, суттєво вищими є показники експериментальної групи. На підставі цього відхилено нульову гіпотезу стосовно цих груп і підтверджено правильність альтернативної. Це свідчить про суттєвий позитивний вплив занять футболом на розвиток вибірковості уваги у студентів.

У цьому дослідженні нами також перевірявся можливий вплив професійної підготовки на факультеті на розвиток вибірковості уваги у студентів. Для цього було зроблено порівняння таких підгруп студентів: 
a) підгрупу студентів механічного факультету з експериментальної групи (займалися футболом) 3 підгрупою студентів факультету технічної кібернетики 3 контрольної групи (відвідували заняття з фізичного виховання в навчальній секції фізичного виховання);

б) підгрупу студентів факультету технічної кібернетики з експериментальної групи (займалися футболом) з підгрупою студентів механічного факультету 3 контрольної групи (відвідували заняття з фізичного виховання в навчальній секції фізичного виховання);

в) підгрупу студентів факультету технічної кібернетики 3 експериментальної групи (займалися футболом) з підгрупою студентів факультету технічної кібернетики з контрольної групи;

г) підгрупу студентів механічного факультету з експериментальної групи (займалися футболом) 3 підгрупою студентів механічного факультету з контрольної групи;

д) підгрупу студентів механічного факультету з експериментальної групи (займалися футболом) з підгрупою студентів факультету технічної кібернетики з експериментальної групи (займалися футболом);

е) підгрупу студентів механічного факультету з контрольної групи 3 підгрупою студентів факультету технічної кібернетики з контрольної групи.

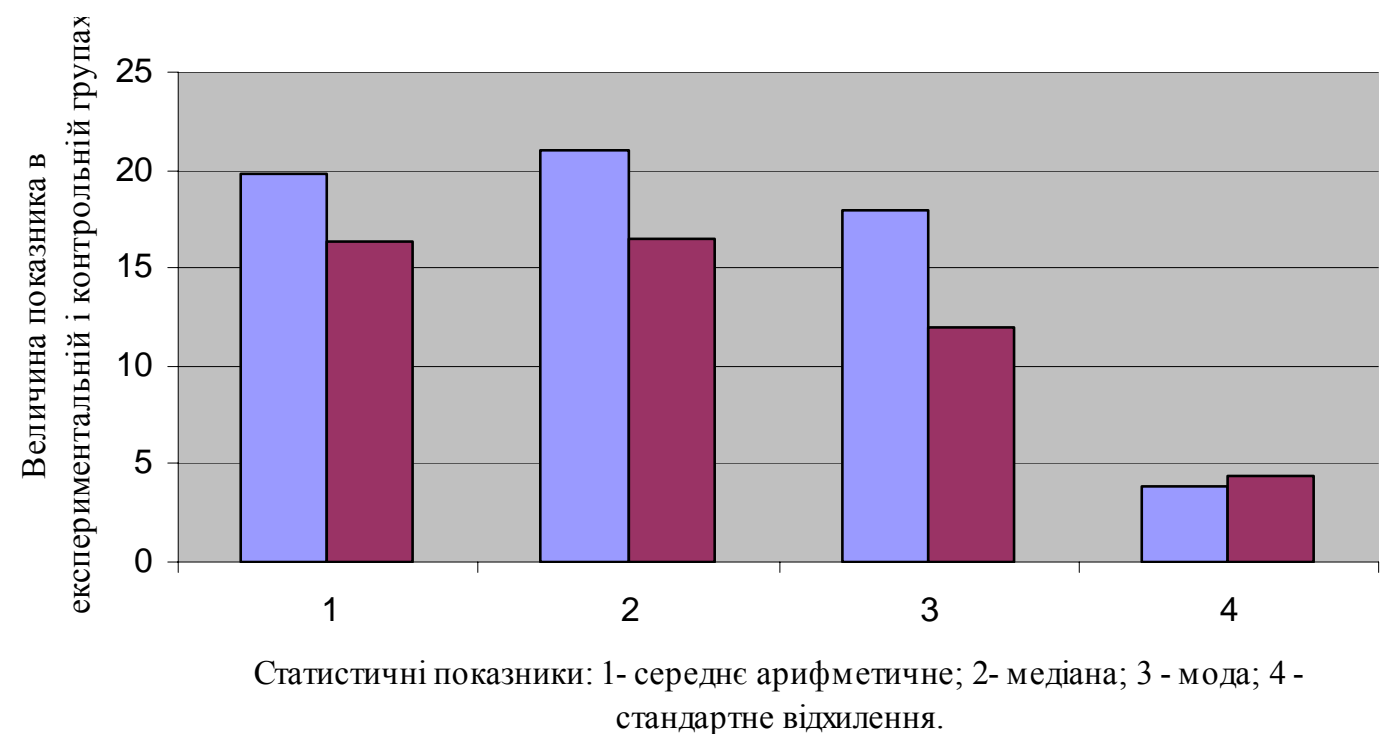

Рис. 34. Статистичні показники вибірковості уваги у студентів експериментальної ( $\square)$ і контрольної груп $(\square)(n=60)$ 
При порівнянні студентів механічного факультету, які входили до складу експериментальної групи (займалися футболом), зі студентами факультету технічної кібернетики, які входили до складу контрольної групи, встановлено таке (рис. 35). В експериментальній підгрупі студентів-механіків середнє арифметичне показників рівня вибірковості уваги складало 18,86 , медіана - 19, мода - 18; стандартне відхилення - 3,87. У контрольній групі студентів факультету технічної кібернетики середнє арифметичне становило 18, медіана - 19, мода - 19; стандартне відхилення - 3,8. При статистичній обробці даних вказаних підгруп студентів 3 використанням $U$-критерію МаннаУїтні було встановлено, що $U$ емпіричне складає 106 (критичне значення $p \leq 0,05=72$ ). Отримане емпіричне значення розташоване в зоні незначущості. Констатуємо правильність нульової гіпотези стосовно цих підгруп студентів. На нашу думку, отримані дані свідчать про суттєвий вплив професійної підготовки на факультеті технічної кібернетики на розвиток вибірковості уваги студентів. Він співмірний із впливом занять футболом на розвиток вибірковості уваги в студентів механічного факультету.

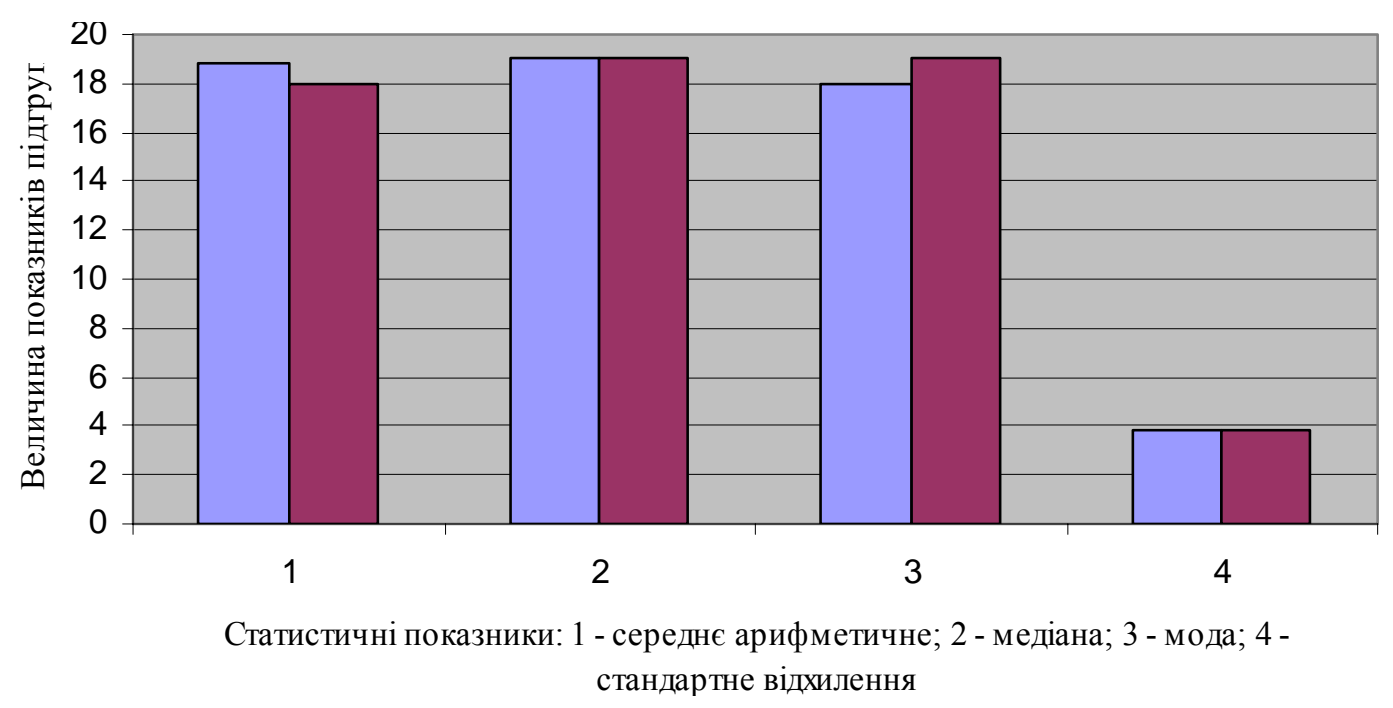

Рис. 35. Статистичні показники вибірковості уваги студентів експериментальної підгрупи механічного факультету (־) і студентів контрольної підгрупи факультету ТК $(\boldsymbol{\square})(n=30)$

При порівнянні показників вибірковості уваги студентів експериментальної підгрупи факультету технічної кібернетики (займалися футболом) і показників студентів контрольної підгрупи механічного 
факультету зафіксовано таке (рис. 36). В експериментальній підгрупі студентів факультету технічної кібернетики середнє арифметичне показників рівня вибірковості уваги склало 20,8, медіана - 22, мода 23; стандартне відхилення - 3,87. У контрольній підгрупі студентівмеханіків середнє арифметичне показників вибірковості уваги становило 14,8 , медіана - 14, мода - 14; стандартне відхилення - 4,53. При статистичній обробці даних вказаних підгруп студентів 3 використанням $U$-критерію Манна-Уїтні встановлено, що $U$ емпіричне складає 35,5 (критичне значення $p \leq 0,01=56$ ). Отримане емпіричне значення розташоване в зоні значущості. Суттєво вищими є показники експериментальної підгрупи. На підставі цього відхилено нульову гіпотезу стосовно цих підгруп і підтверджено правильність альтернативної. Це свідчить про суттєвий позитивний вплив занять футболом на розвиток уваги у студентів експериментальної підгрупи.

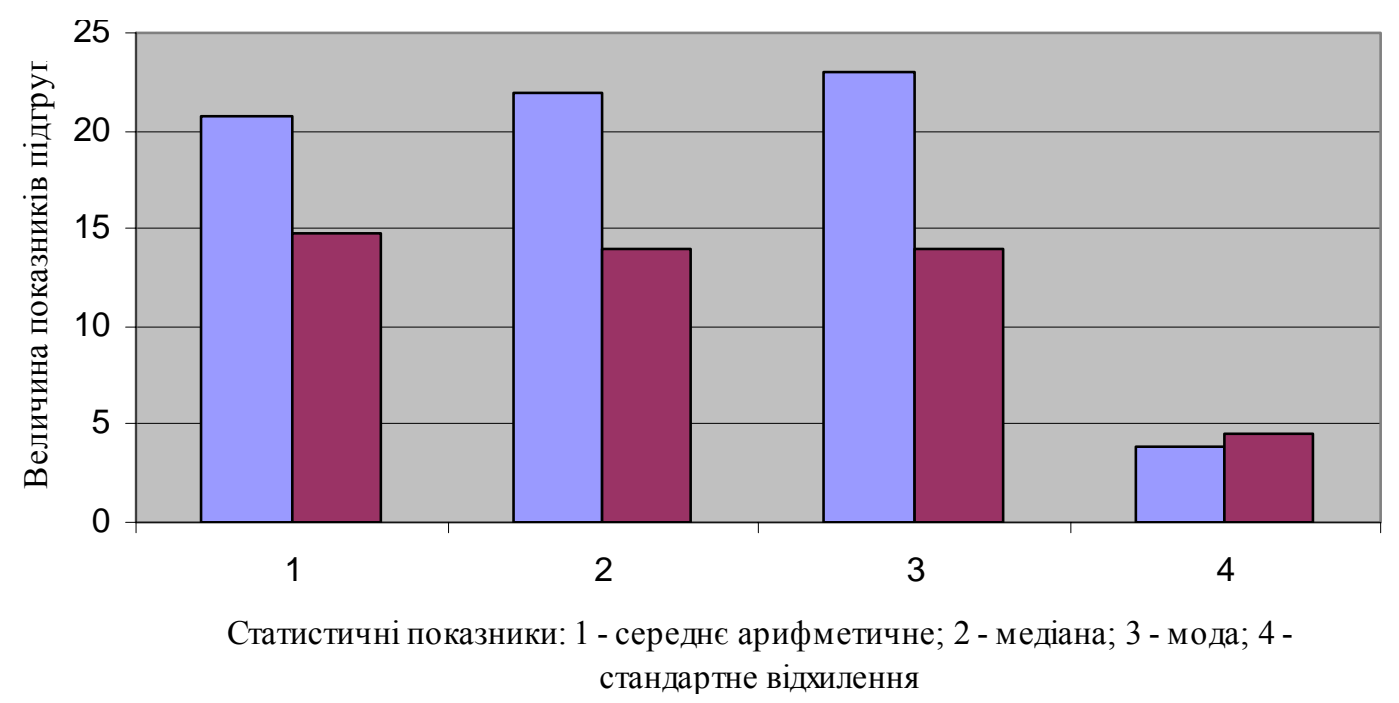

Рис. 36. Статистичні показники вибірковості уваги студентів експериментальної підгрупи з факультету ТК $(\square)$ і контрольної підгрупи з механічного факультету $(\square)(n=30)$

При порівнянні показників вибірковості уваги студентів експериментальної підгрупи з факультету технічної кібернетики з показниками студентів контрольної групи 3 того ж факультету виявлено таке (рис. 37). В експериментальній підгрупі з цього факультету середнє арифметичне показників рівня вибірковості уваги складало 20,8, медіана - 22, мода - 23; стандартне відхилення - 3,87. У контрольній підгрупі студентів 3 факультету технічної кібернетики середнє ариф- 
метичне показників вибірковості уваги становило 18, медіана - 19 , мода - 19; стандартне відхилення - 3,8. При статистичній обробці даних цих підгруп студентів з використанням $U$-критерію Манна-Уїтні встановлено, що $U$ емпіричне складає 63 (критичне значення $p \leq 0,01=72$ ). Суттєво вищими виявилися показники студентів експериментальної підгрупи факультету. На підставі цього відхиляємо нульову гіпотезу стосовно цих підгруп і підтверджуємо правильність альтернативної. Це свідчить про суттєвий позитивний вплив занять футболом на розвиток вибірковості уваги у студентів.

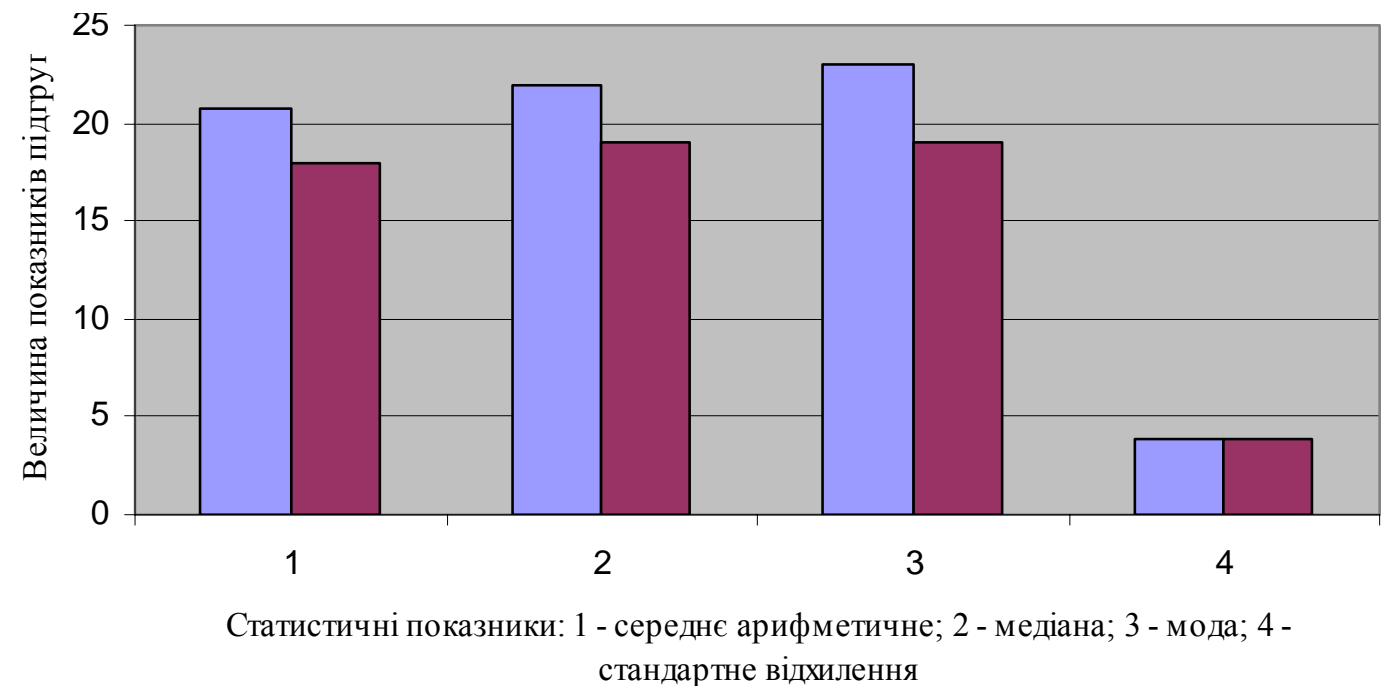

Рис. 37. Статистичні показники вибірковості уваги студентів факультету ТК з експериментальної ( $\square)$ і контрольної підгруп $(\square)(n=30)$

Порівняння показників вибірковості уваги студентів експериментальної підгрупи з механічного факультету з показниками студентів контрольної підгрупи з механічного факультету дозволило встановити таке (рис. 38). В експериментальній підгрупі з цього факультету середне арифметичне показників рівня вибірковості уваги становило 18,86 , медіана - 19, мода - 18; стандартне відхилення - 3,87. У контрольній підгрупі студентів-механіків середнє арифметичне показників вибірковості уваги становило 14,8, медіана - 14, мода - 14; стандартне відхилення - 4,53. При статистичній обробці даних цих підгруп студентів 3 використанням $U$-критерію Манна-Уїтні встановлено, що $U$ емпіричне складає 54 (критичне значення $p \leq 0,01=56$ ). Отримане емпіричне значення розташоване в зоні значущості. 
Суттєво вищими $є$ показники студентів експериментальної підгрупи механічного факультету. На підставі цього відхилено нульову гіпотезу стосовно цих підгруп і підтверджено правильність альтернативної. Вказаний факт свідчить про суттєвий позитивний вплив занять футболом на розвиток вибірковості уваги в студентів.

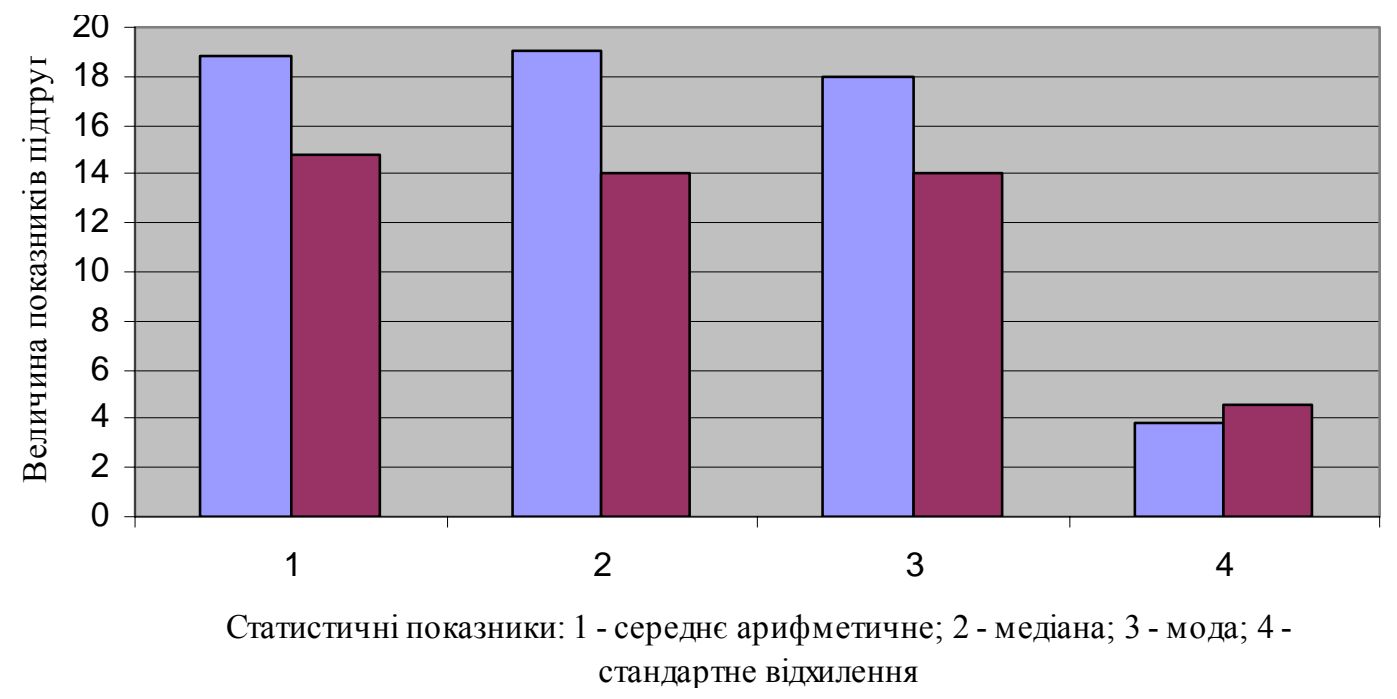

Рис. 38. Статистичні показники вибірковості уваги студентів експериментальної ( () і контрольної ( () підгруп з механічного факультету $(n=30)$

Порівняння показників вибірковості уваги студентів експериментальної підгрупи 3 механічного факультету з показниками студентів експериментальної підгрупи з факультету технічної кібернетики показало таке (рис. 39). В експериментальній підгрупі 3 механічного факультету середнє арифметичне показників вибірковості уваги складало 18,86 , медіана - 19, мода - 18; стандартне відхилення $-3,87$. В експериментальній підгрупі студентів з факультету технічної кібернетики середнє арифметичне показників вибірковості уваги складало 20,8 , медіана - 22, мода - 23; стандартне відхилення - 3,87 . У ході статистичної обробки даних цих підгруп студентів 3 використанням $U$-критерію Манна-Уїтні встановлено, що $U$ емпіричне становить 78 (критичне значення $p \leq 0,01=72$ ). Отримане емпіричне значення $U$ розташоване в зоні незначущості. Констатуємо правильність нульової гіпотези стосовно цих підгруп студентів. Наведені статистичні показники свідчать про суттєвий позитивний вплив занять футболом на розвиток у студентів вибірковості уваги. Позитивний вплив цих 
занять може певною мірою компенсувати й порівняно слабший вплив на її розвиток професійної підготовки на факультеті. Останнє видно з показників експериментальної підгрупи з механічного факультету.

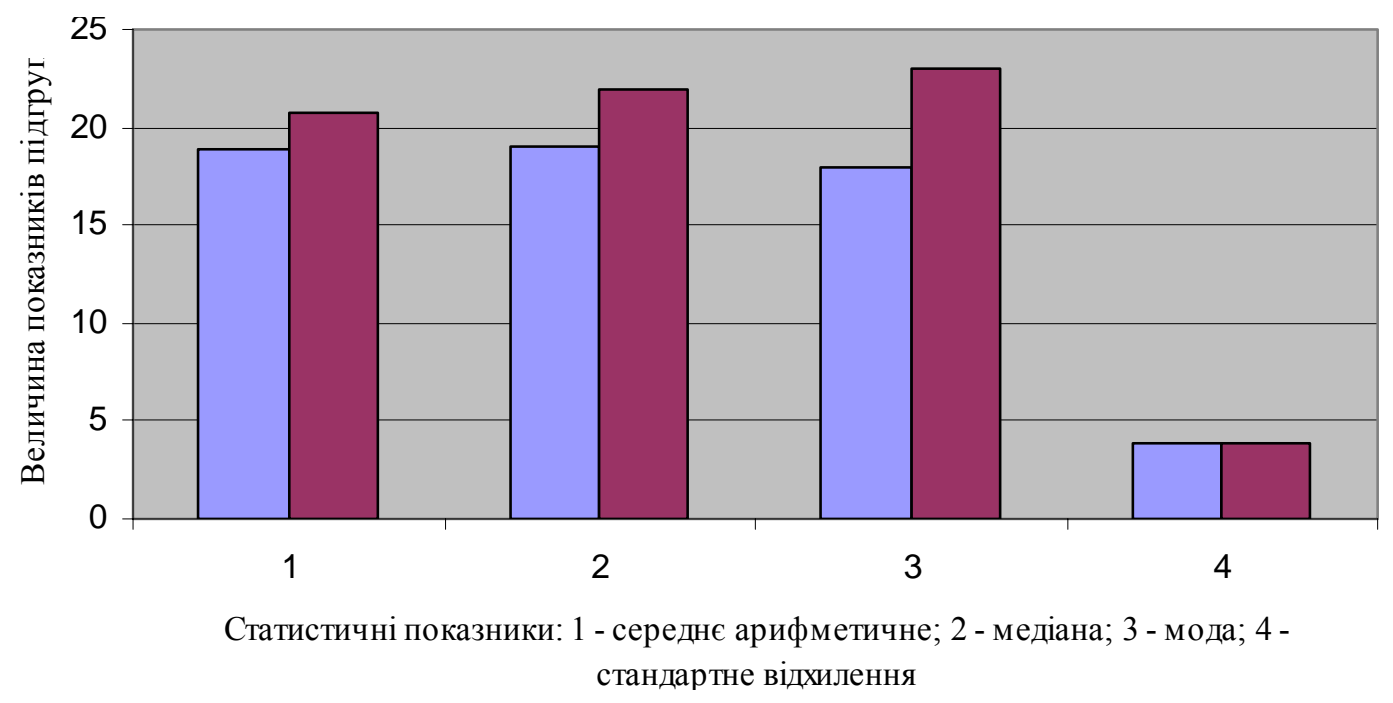

Рис. 39. Статистичні показники вибірковості уваги студентів експериментальної підгрупи з механічного факультету ( () і експериментальної підгрупи з факультету ТК $(\boldsymbol{\square})(n=30)$

При порівнянні показників вибірковості уваги студентів контрольної підгрупи з механічного факультету і з факультету технічної кібернетики встановлено таке (рис. 40).

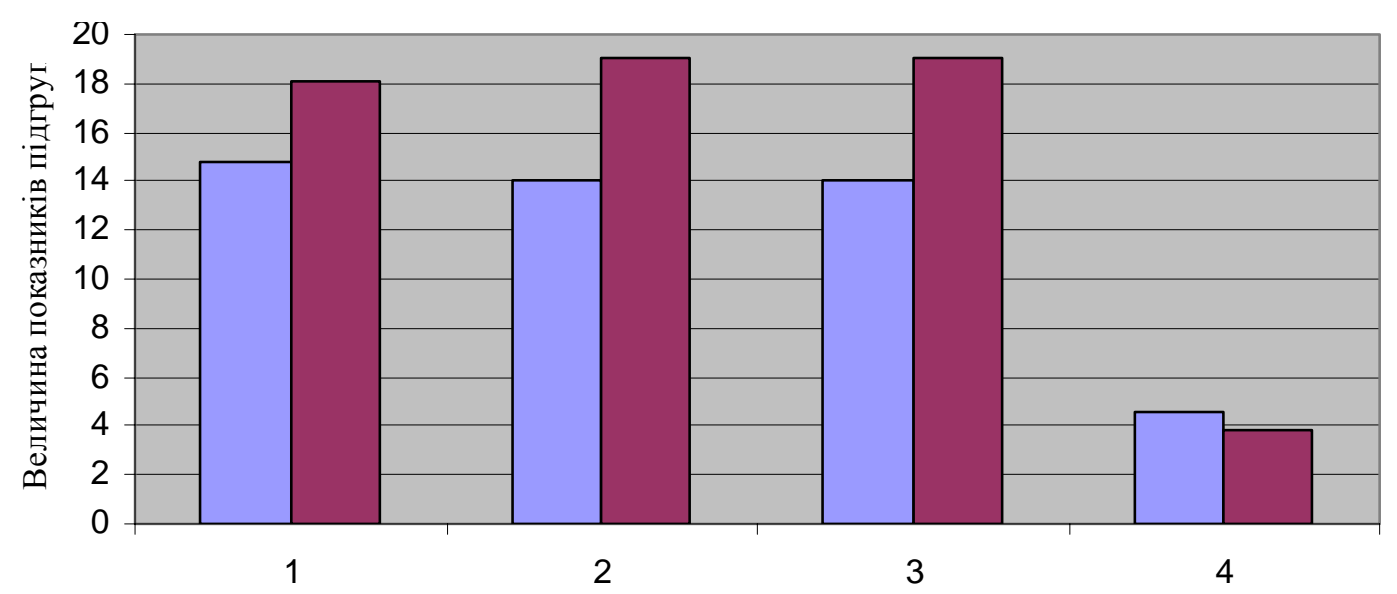

Статистичні показники: 1 - середнє арифметичне; 2 - медіана; 3 - мода; 4 стандартне відхилення

Рис. 40. Статистичні показники вибірковості уваги студентів контрольних підгруп з механічного факультету ( і факультету ТК ( ()$(n=30)$ 
У контрольній підгрупі з механічного факультету середнє арифметичне показників вибірковості уваги становило 14,8, медіана - 14, мода - 14; стандартне відхилення - 4,53. У контрольній підгрупі 3 факультету технічної кібернетики середнє арифметичне показників вибірковості уваги становило 18,06 , медіана - 19, мода - 19; стандартне відхилення - 3,8. При статистичній обробці даних цих підгруп студентів з використанням $U$-критерію Манна-Уїтні встановлено, що $U$ емпіричне складає 67 (критичне значення $p \leq 0,01=72$ ). Суттєво вищими виявилися показники студентів контрольної групи з факультету технічної кібернетики. На підставі цього відхилено нульову гіпотезу стосовно цих підгруп і підтверджено правильність альтернативної. Вказаний факт свідчить про суттєво більший позитивний вплив професійної підготовки на факультеті технічної кібернетики, порівняно з механічним факультетом, на розвиток вибірковості уваги в студентів.

У процесі дослідження концентрації і стійкості уваги студентів виявлено таке (рис. 41).

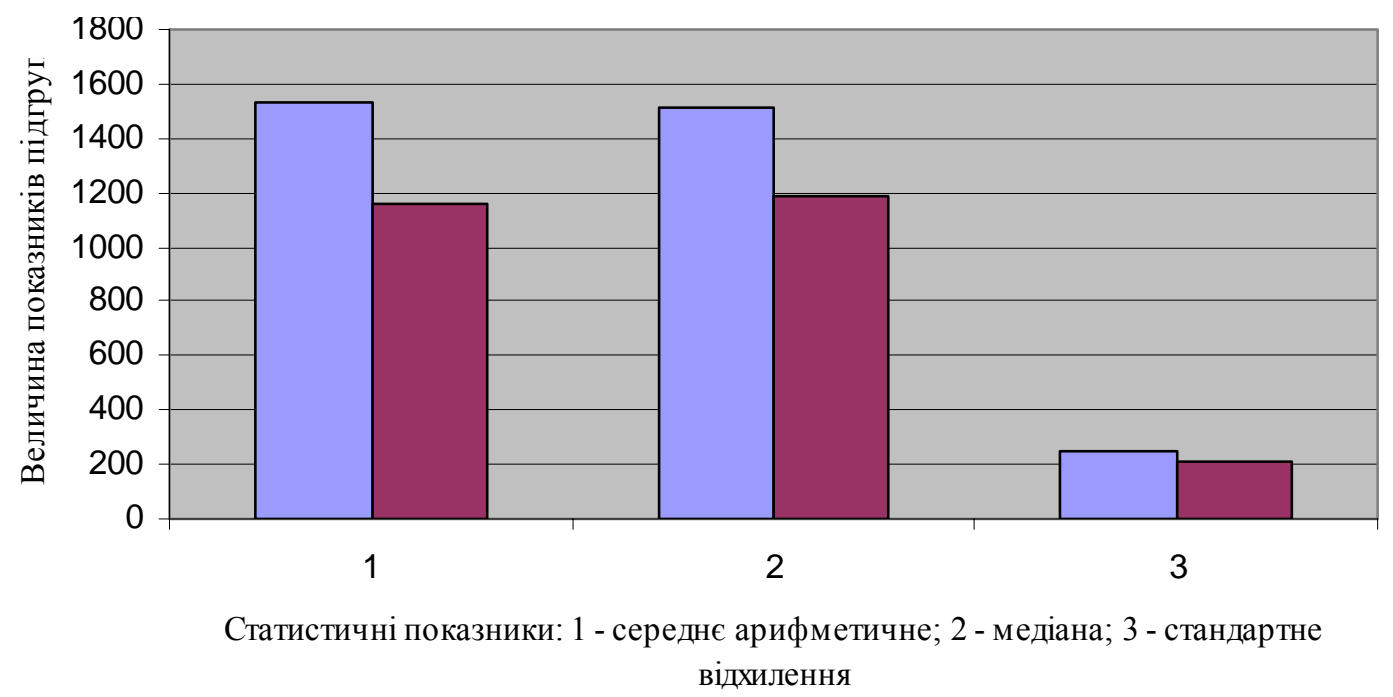

Рис. 41. Статистичні показники концентрації і стійкості уваги студентів експериментальної ( $($ ) і контрольної $(\square)$ груп $(n=60)$

В експериментальній групі середнє арифметичне показників концентрації і стійкості уваги становило 1532 , медіана - 1514,5 ; стандартне відхилення - 253,12. У контрольній групі середнє арифметичне складало 1160,23, медіана - 1190; стандартне відхилення - 213,36. Вторинну статистичну обробку отриманих даних, як і при дослі- 
дженні вибірковості уваги, було проведено 3 використанням $U$ критерію Манна-Уїтні. $U$ емпіричне склало 101 (критичне значення $p \leq 0,01=292$ ). Отримане емпіричне значення $U$ розташоване в зоні значущості. Суттєво вищими є показники експериментальної групи. На підставі цього відхиляємо нульову гіпотезу стосовно цих груп студентів і підтверджуємо правильність альтернативної. Зафіксовані дані свідчать про суттєвий позитивний вплив занять футболом на розвиток у студентів концентрації і стійкості уваги.

Як і при дослідженні вибірковості уваги, під час вивчення концентрації і стійкості уваги порівнювалися показники вищезгаданих груп і підгруп студентів. За задумом, це давало можливість виявити вплив професійної підготовки на факультеті на розвиток концентрації і стійкості уваги у студентів.

Так, при порівнянні показників концентрації і стійкості уваги студентів експериментальної підгрупи 3 механічного факультету 3 показниками експериментальної підгрупи з факультету технічної кібернетики встановлено таке (рис. 42).

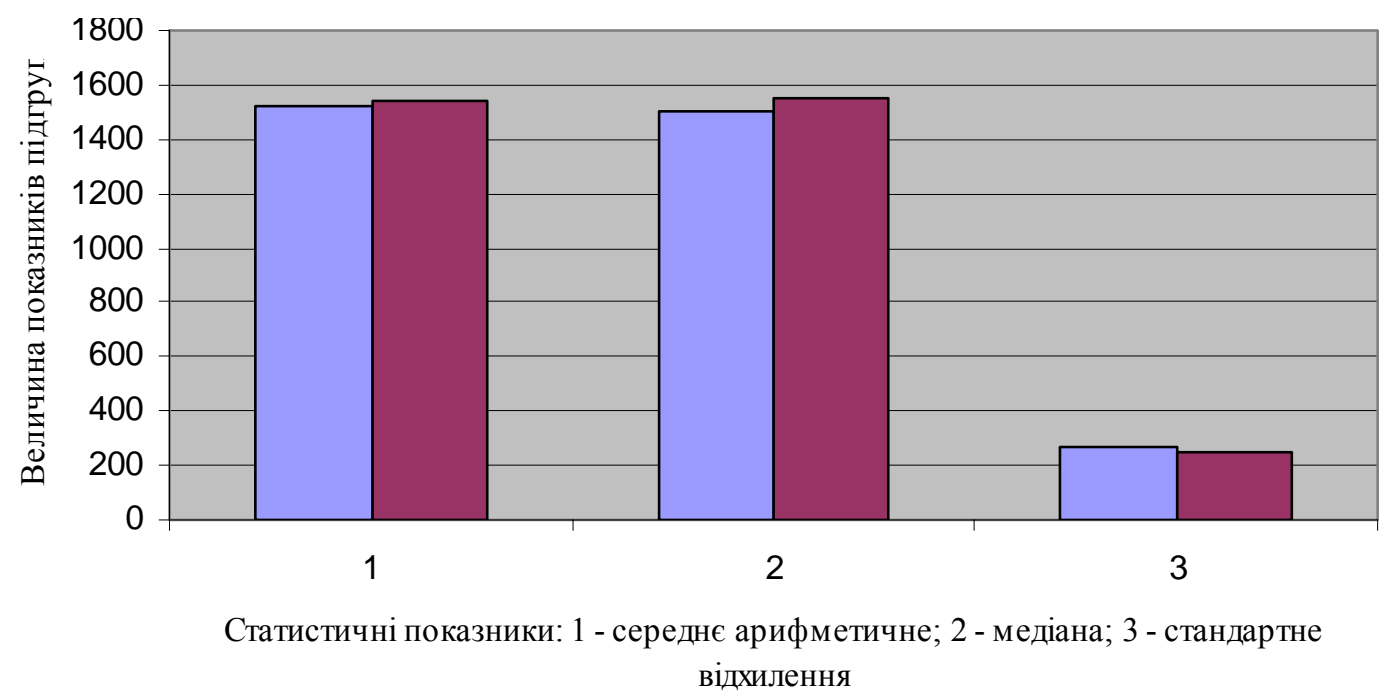

Рис. 42. Статистичні показники концентрації і стійкості уваги студентів експериментальних підгруп з механічного факультету (-) і факультету ТК $(\square)(n=30)$

В експериментальній підгрупі студентів-механіків середнє арифметичне показників концентрації і стійкості уваги становить 1518,33, медіана - 1504; стандартне відхилення - 265,95. В експериментальній підгрупі студентів факультету технічної кібернетики середнє 
арифметичне показників концентрації і стійкості уваги складало 1545,8 , медіана - 1550; стандартне відхилення - 248,15. При статистичній обробці даних цих підгруп студентів 3 використанням $U$ критерію Манна-Уїтні встановлено, що $U$ емпіричне складає 104 (критичне значення $p \leq 0,01=72$ ). Отримане емпіричне значення $U$ розташоване в зоні незначущості. Констатуємо правильність нульової гіпотези стосовно цих підгруп студентів. Наведені статистичні показники є досить високими й свідчать про суттєвий позитивний вплив занять футболом на розвиток концентрації і стійкості уваги в студентів обох факультетів.

Порівняння показників концентрації і стійкості уваги студентів контрольної підгрупи з факультету технічної кібернетики і показників студентів контрольної групи з механічного факультету показало таке (рис. 43).

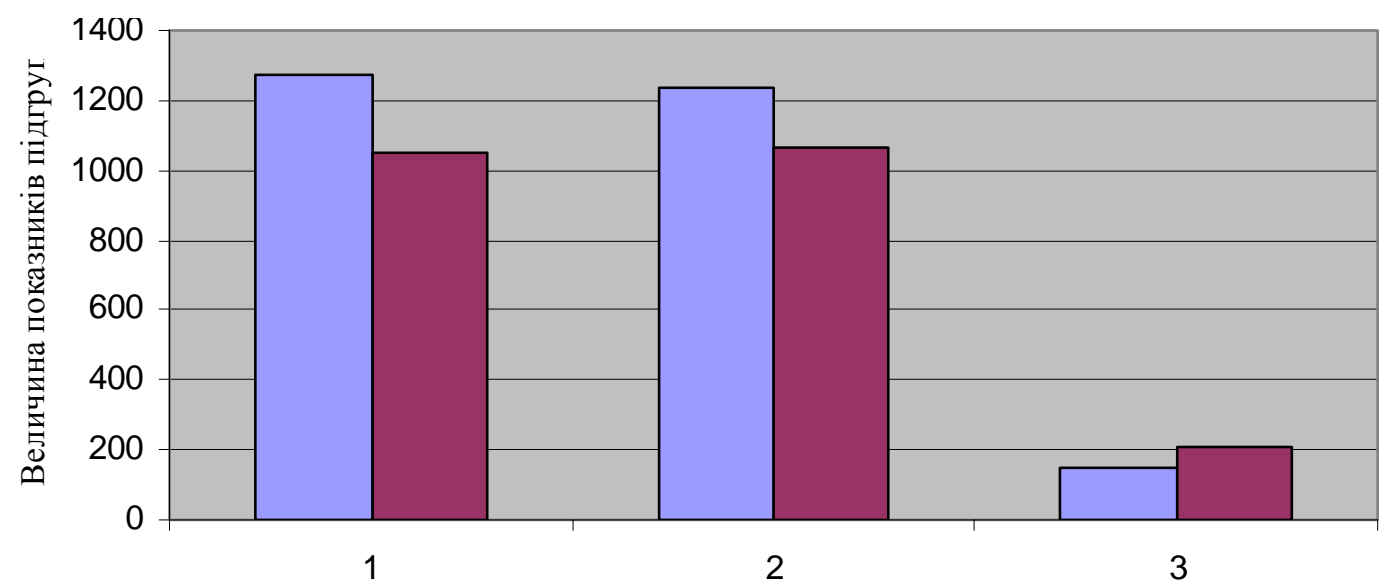

Статистичні показники: 1 - середнє арифметичне; 2 - медіана; 3 - стандартне відхилення

Рис. 43. Статистичні показники концентрації і стійкості уваги студентів контрольних підгруп з факультету ТК ( і механічного факультету $(\square)(n=30)$

У контрольній підгрупі з факультету технічної кібернетики середнє арифметичне показників концентрації і стійкості уваги складало 1273,26 , медіана - 1239 ; стандартне відхилення - 150,45. У контрольній підгрупі з механічного факультету середнє арифметичне показників концентрації і стійкості уваги складало 1047,2, медіана 1062 ; стандартне відхилення - 210,43. У ході статистичної обробки даних цих підгруп студентів 3 використанням $U$-критерію Манна- 
Уїтні встановлено, що $U$ емпіричне складає 43 (критичне значення $p \leq 0,01=56$ ). Отримане емпіричне значення $U$ розташоване в зоні значущості. Суттєво вищими є показники студентів контрольної підгрупи з факультету технічної кібернетики. На підставі цього відхилено нульову гіпотезу стосовно цих підгруп і підтверджено правильність альтернативної. Наведені статистичні дані свідчать про суттєво більший позитивний вплив професійної підготовки на факультеті технічної кібернетики (порівняно з механічним факультетом) на розвиток концентрації і стійкості уваги в студентів.

Результати порівняння показників концентрації і стійкості уваги студентів експериментальної підгрупи з механічного факультету і показників студентів контрольної групи з факультету технічної кібернетики такі (рис. 44).

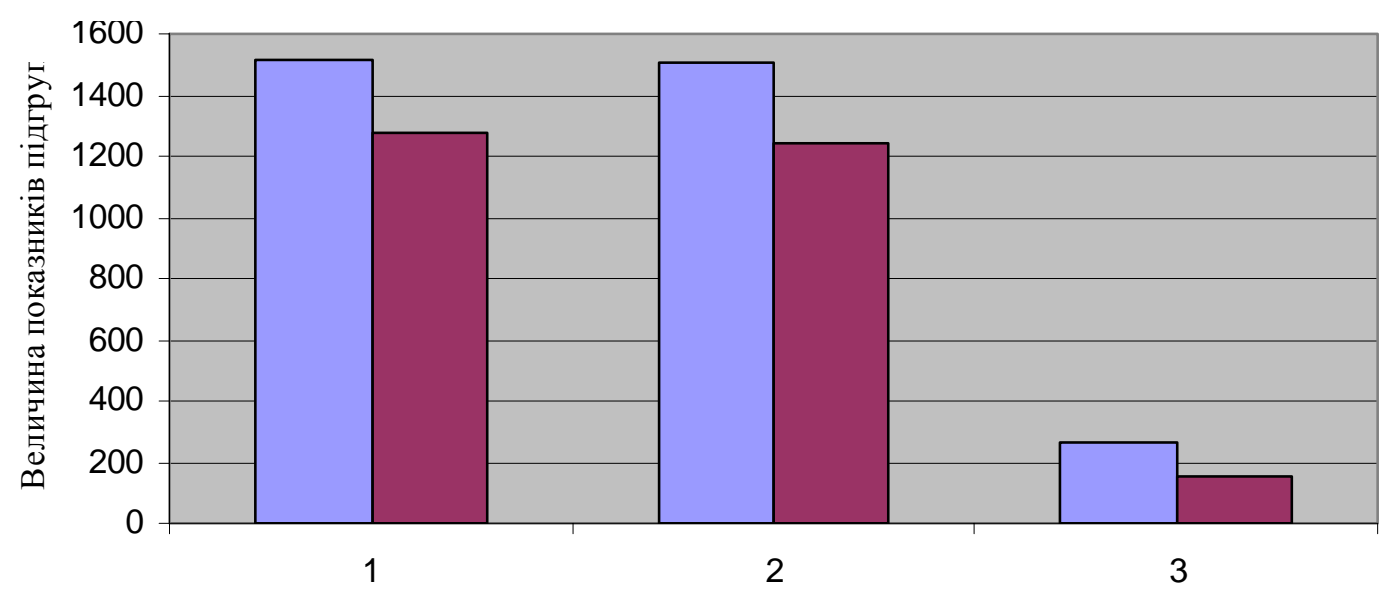

Статистичні показники: 1 - середнє арифметичне; 2 - медіана; 3 - стандартне відхилення

Рис. 44. Статистичні показники концентрації і стійкості уваги студентів експериментальної підгрупи з механічного факультету (-) і контрольної підгрупи з факультету ТК $(\square)(n=30)$

В експериментальній підгрупі студентів-механіків середнє арифметичне показників концентрації і стійкості уваги становило 1518,33, медіана - 1504; стандартне відхилення - 265,95. У контрольній підгрупі з факультету технічної кібернетики середнє арифметичне показників концентрації і стійкості уваги становило 1273,26 , медіана - 1239 ; стандартне відхилення - 150,45. При статистичній обробці даних цих підгруп студентів 3 використанням $U$ критерію Манна-Уїтні встановлено, що $U$ емпіричне склало 48 
(критичне значення $p \leq 0,01=56$ ). Отримане емпіричне значення $U$ розташоване в зоні значущості. Суттєво вищими є показники студентів експериментальної підгрупи з механічного факультету. На підставі цього відхилено нульову гіпотезу стосовно цих підгруп і підтверджено правильність альтернативної. Наведені дані свідчать про суттєвий позитивний вплив занять футболом на розвиток концентрації і стійкості уваги в студентів експериментальної підгрупи з механічного факультету.

При порівнянні показників концентрації і стійкості уваги студентів експериментальної підгрупи з факультету технічної кібернетики і показників студентів контрольної групи з механічного факультету було встановлено таке (рис. 45).

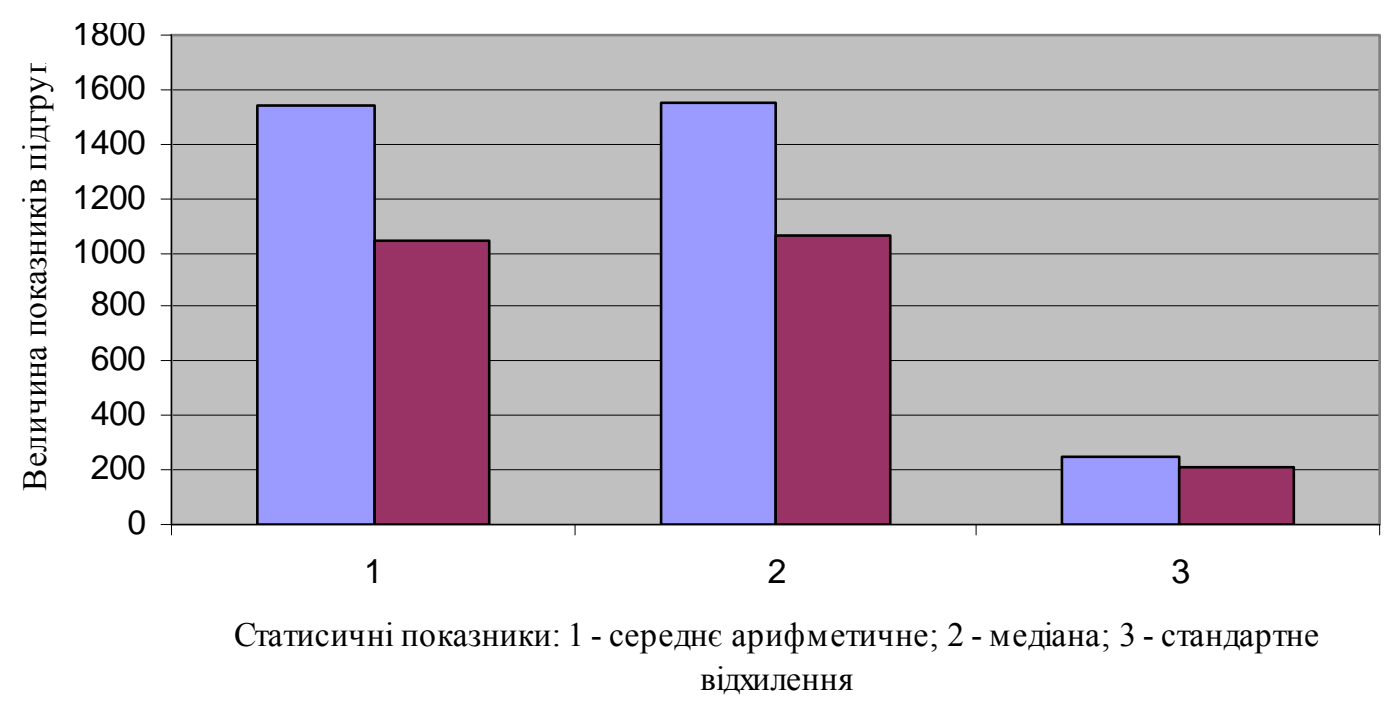

Рис. 45. Статистичні показники концентрації і стійкості уваги студентів експериментальної підгрупи з факультету ТК $(\square)$ і контрольної підгрупи з механічного факультету $(\boldsymbol{(})(n=30)$

В експериментальній підгрупі студентів 3 факультету технічної кібернетики середне арифметичне показників концентрації і стійкості уваги складало 1545,8 , медіана - 1550 ; стандартне відхилення 248,15 . У контрольній підгрупі 3 механічного факультету середнє арифметичне показників концентрації і стійкості уваги становило 1047,2 , медіана - 1062 ; стандартне відхилення - 210,43. У ході статистичної обробки даних цих підгруп студентів з використанням $U$ критерію Манна-Уїтні встановлено, що $U$ емпіричне складає 8 (критичне значення $p \leq 0,01=56)$. Отримане емпіричне значення $U$ роз- 
ташоване в зоні значущості. Суттєво вищими є показники студентів експериментальної підгрупи 3 механічного факультету. На підставі цього відхилено нульову гіпотезу стосовно цих підгруп і підтверджено правильність альтернативної. Наведені дані свідчать про суттєвий позитивний вплив занять футболом на розвиток концентрації і стійкості уваги в студентів експериментальної підгрупи з факультету технічної кібернетики.

Порівняння показників концентрації і стійкості уваги студентів експериментальної підгрупи з факультету технічної кібернетики з показниками контрольної підгрупи з цього ж факультету показало таке (рис. 46).

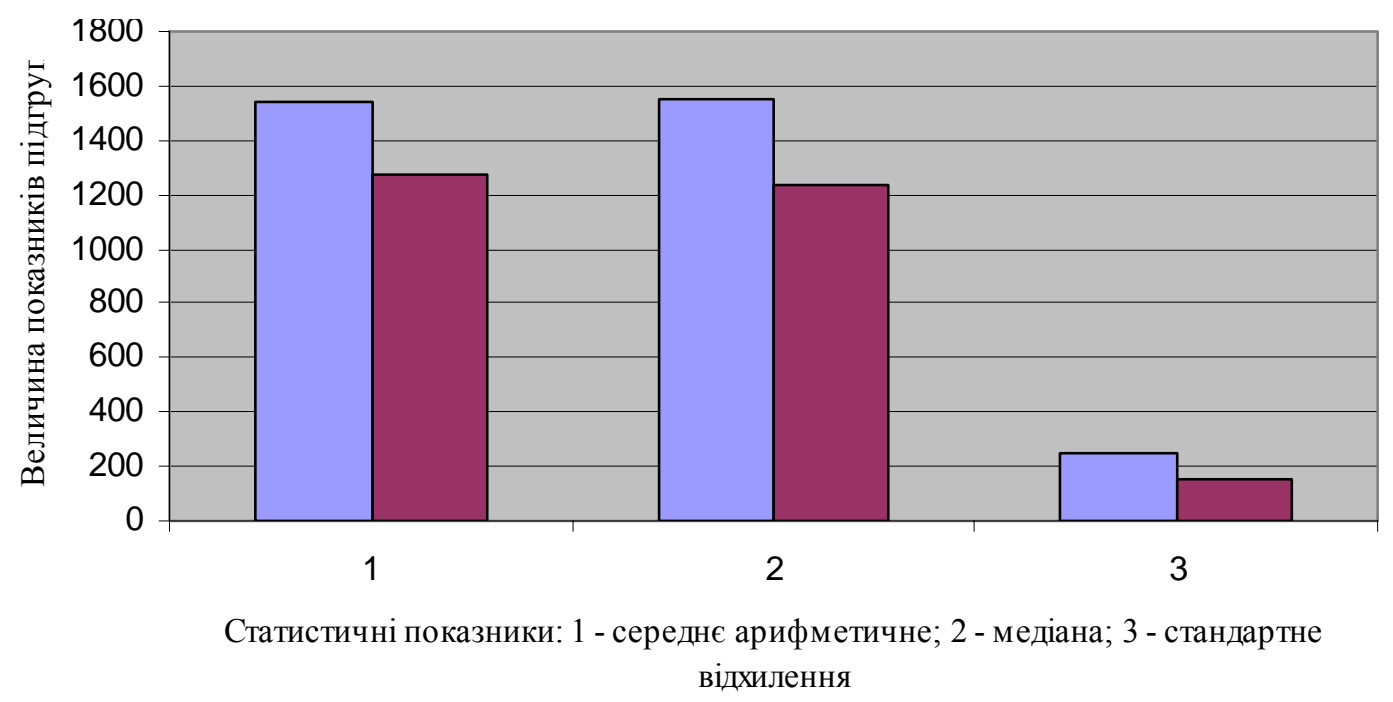

Рис. 46. Статистичні показники концентрації і стійкості уваги студентів експериментальної (-) і контрольної підгруп ( з факультету ТК $(n=30)$

В експериментальній підгрупі студентів 3 факультету технічної кібернетики середнє арифметичне показників концентрації і стійкості уваги становило 1545,8 , медіана - 1550 ; стандартне відхилення 248,15 . У контрольній підгрупі з факультету технічної кібернетики середнє арифметичне показників концентрації і стійкості уваги становило 1273,26, медіана - 1239; стандартне відхилення - 150,45. При статистичній обробці даних цих підгруп студентів 3 використанням $U$-критерію Манна-Уїтні встановлено, що $U$ емпіричне становило 32 (критичне значення $p \leq 0,01=56$ ). Отримане емпіричне значення $U$ розташоване в зоні значущості. Суттєво вищими є показники 
студентів експериментальної підгрупи з факультету технічної кібернетики. На підставі цього відхилено нульову гіпотезу стосовно цих підгруп і підтверджено правильність альтернативної. Отримані дані свідчать про суттєвий позитивний вплив занять футболом на розвиток концентрації і стійкості уваги у студентів експериментальної підгрупи з факультету технічної кібернетики.

При порівнянні показників концентрації і стійкості уваги студентів експериментальної підгрупи з механічного факультету з показниками контрольної підгрупи 3 цього ж факультету встановлено таке (рис. 47).

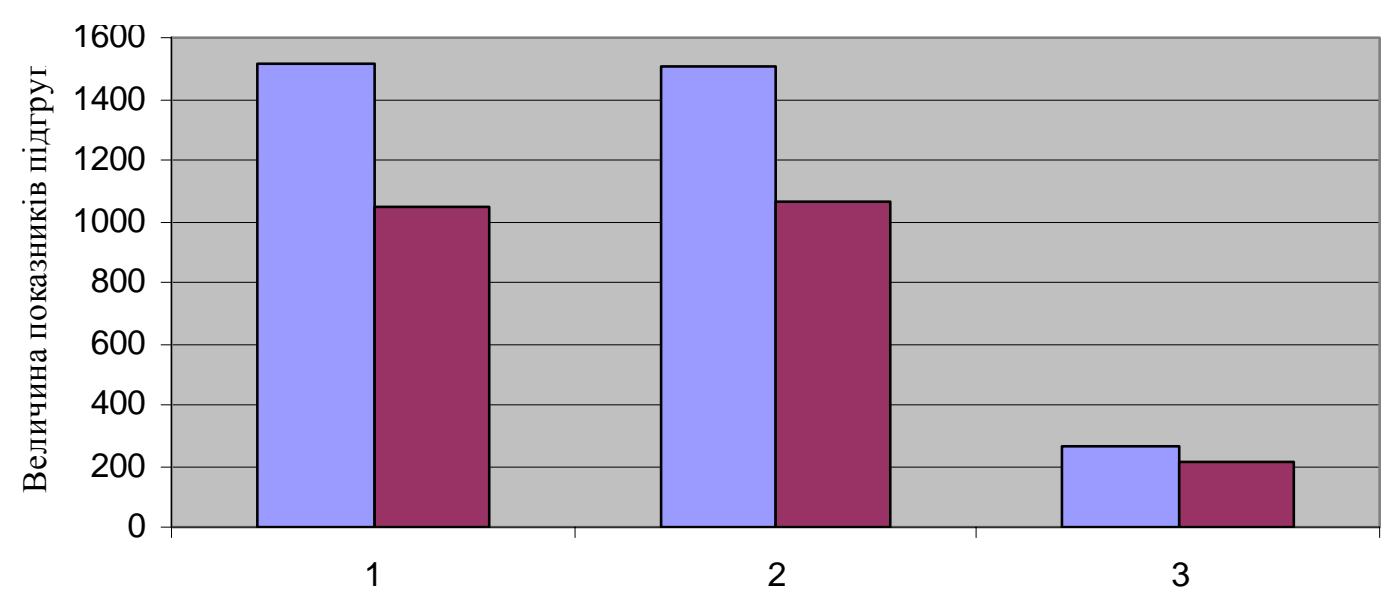

Статистичні показники: 1 - середнє арифметичне; 2 - медіана; 3 - стандартне відхилення

Рис. 47. Статистичні показники концентрації і стійкості уваги студентів експериментальної ( () і контрольної ( () підгруп 3 механічного факультету $(n=30)$

В експериментальній підгрупі з механічного факультету середнє арифметичне показників концентрації і стійкості уваги становило 1518,33 , медіана - 1504; стандартне відхилення - 265,95. У контрольній підгрупі з механічного факультету середнє арифметичне показників концентрації і стійкості уваги складало 1047,2, медіана 1062 ; стандартне відхилення - 210,43. У ході статистичної обробки даних цих підгруп студентів 3 використанням $U$-критерію МаннаУїтні встановлено, що $U$ емпіричне складає 13 (критичне значення $p \leq 0,01=56$ ). Отримане емпіричне значення $U$ розташоване в зоні значущості. Суттєво вищими виявилися показники студентів експериментальної підгрупи з механічного факультету. На підставі цього 
відхилено нульову гіпотезу стосовно цих підгруп і підтверджено правильність альтернативної. Отримані дані свідчать про суттєвий позитивний вплив занять футболом на розвиток концентрації і стійкості уваги у студентів експериментальної підгрупи з механічного факультету.

У своїй експериментальній гіпотезі ми припустили, що заняття футболом під час навчальних занять 3 фізичного виховання здійснюють суттєвий позитивний вплив на формування у студентів таких характеристик уваги, як вибірковість та концентрація і стійкість. Для перевірки гіпотези було проведено дослідження, у якому взяли участь дві групи студентів - експериментальна і контрольна.

Дані, отримані в ході дослідження стосовно розвитку в студентів вибірковості уваги, показали, що заняття футболом здійснюють суттєвий позитивний вплив на цей процес. Про це свідчать, зокрема, статистичні показники, отримані в ході порівняння результатів експериментальної і контрольної груп, експериментальної підгрупи з факультету технічної кібернетики (займалися футболом) i контрольної підгрупи з механічного факультету, експериментальної і контрольної підгруп з факультету технічної кібернетики, експериментальної і контрольної підгруп з механічного факультету, експериментальних підгруп з механічного факультету і факультету технічної кібернетики.

При порівнянні експериментальної підгрупи студентів 3 механічного факультету і контрольної підгрупи студентів 3 факультету технічної кібернетики статистично значущої відмінності в рівні результатів не виявлено. На нашу думку, це пов'язано з більшим (порівняно 3 механічним факультетом) впливом професійної підготовки на факультеті технічної кібернетики на розвиток вибірковості уваги. В. Д. Шадріков [431, 433] розробив концепцію про психологічну систему діяльності. Поняття відображає сукупність психічних властивостей, якостей особистості, яка у своїй цілісності організована для виконання функцій конкретної діяльності. Аналіз психологічної системи діяльності спеціальностей факультету технічної кібернетики і механічного показує, що вибірковість уваги набагато більш значуща для перших. Включаючись до такої діяльності, студент відповідно розвивається.

У той же час деякі студенти механічного факультету мали дуже високі показники вибірковості уваги. На нашу думку, таке 
«відхилення» від основної тенденції пояснюється їх відповідними природними задатками і заняттями футболом.

Крім цього, аналіз отриманих даних показав більш високі показники вибірковості уваги в студентів-футболістів, які краще технічно підготовлені, більш креативні стосовно своїх дій під час гри. Це пояснюється, на нашу думку, тим, що технічні гравці менше концентрують увагу на виконанні технічних прийомів і більшою мірою зосереджені на аналізі постійно змінних ігрових ситуацій. Спостереження свідчать про те, що часто розвиток різних характеристик уваги у футболіста починається тільки після того, як гравець освоїв певний «набір» технічних прийомів і може концентрувати увагу на інших складових гри.

При порівнянні контрольних підгруп виявлено статистично значуще вищі показники вибірковості уваги у студентів факультету технічної кібернетики. Як і в попередньому випадку, ми пояснюємо це порівняно більшим впливом професійної підготовки на цьому факультеті на розвиток вибірковості уваги.

Статистично значущі відмінності результатів вибірковості уваги не отримано і при порівнянні експериментальних підгруп студентів 3 механічного факультету і факультету технічної кібернетики. У той же час рівень показаних результатів є достаньо високим. На нашу думку, він спричинений заняттями футболом.

Дані, отримані в дослідженні стосовно розвитку в студентів концентрації і стійкості уваги, показали, що заняття футболом позитивно впливають на розвиток цих характеристик. Це підтверджують статистичні показники, отримані при порівнянні результатів експериментальної і контрольної груп, експериментальних підгруп з механічного факультету і факультету технічної кібернетики, експериментальної підгрупи з механічного факультету і контрольної підгрупи з факультету технічної кібернетики, експериментальної підгрупи з факультету технічної кібернетики і контрольної підгрупи 3 механічного факультету, експериментальної і контрольної підгруп з факультету технічної кібернетики, експериментальної і контрольної підгрупи 3 механічного факультету.

Статистично значущої відмінності результатів концентрації і стійкості уваги не отримано при порівнянні експериментальних підгруп студентів з факультету технічної кібернетики і механічного. У той же 
час, як і у випадку вибірковості уваги, рівень показників є достатньо високим. Ми пояснюємо це заняттями футболом.

При порівнянні контрольних підгруп з факультету технічної кібернетики і механічного виявлено суттєво вищі показники у студентів факультету технічної кібернетики. Ми пов'язуємо це з порівняно більшим впливом професійної підготовки на цьому факультеті на розвиток концентрації і стійкості уваги в студентів.

Формулюючи головні висновки дослідження відзначаємо:

1. Заняття футболом $є$ ефективним засобом розвитку вибірковості та концентрації і стійкості уваги в студентів.

2. Професійна підготовка на факультеті технічної кібернетики здійснює статистично значуще більший позитивний вплив, порівняно 3 механічним факультетом, на розвиток вибірковості та концентрації і стійкості уваги в студентів.

\section{4. Рівень контролю особистості та його вплив на агресивність у футболі}

У попередніх параграфах розділу розглянуто вплив фізкультурної і спортивної діяльності на складові психологічної і психофізичної структури особистості студентів. Постає питання про зворотний зв'язок. Тобто, чи впливають складові психічної структури студентів на особливості їх фізкультурної або спортивної діяльності? У пошуках відповіді нами було вивчено вплив такої характеристики особистості студента, як рівень суб'єктивного контролю, на прояви агресивності у футболі [279].

У психології агресія розглядається як складне явище, зумовлене безліччю причин, важко прогнозоване й часто таке, що не піддається контролю [175, с.10]. Агресія, у якій би формі вона не проявлялася, являє собою поведінку, спрямовану на заподіяння шкоди або збитку іншій живій істоті, що не бажає такого до собе ставлення [32, с.26]. Існує декілька по-різному спрямованих теорій, кожна з яких дає своє бачення сутності й джерел агресії.

Результати вивчення проблеми агресивності відображено в роботах $[32,41,84,95,121,178,179,183,212,220,238,257,259,265,316$, 392] та ін. Звертається увага на труднощі, які зумовлюють ситуацію. 
До їх числа належать:

1. Труднощі, спричинені специфікою галузей дослідження (психологія, соціологія, біологія, нейрофізіологія, психіатрія та ін.).

2. Труднощі, які пов'язані зі складністю узагальнення в одному визначенні розмаїття дій, в яких виявляється агресія (вбивства, нанесення тілесних ушкоджень, образи, сварки і т. ін.).

3. Труднощі, які пов'язані з вивченням дослідниками різних «сторін» агресії (як психічного стану, як властивості особистості, як поведінкового прояву, як об'єкта потреби).

Є. В. Тополов [390] виділяє такі основні види агресії:

1) фізична, активна, пряма;

2) фізична, активна, непряма;

3) фізична, пасивна, пряма;

4) фізична, пасивна, непряма;

5) вербальна, активна, пряма;

6) вербальна, активна, непряма;

7) вербальна, пасивна, пряма;

8) вербальна, пасивна, непряма.

Основними типами агресії в психології називають «емоційну (ворожу) агресію» (коли метою є завдання нанесення жертві страждань або інших збитків) та «інструментальну агресію» (коли агресію використовують як засіб для досягнення грошей, соціального статусу тощо) $[121,257]$. Інший підхід [183] пропонує типологію агресивності за такими критеріями, як:

1) модальність реакції (вербальна, фізична);

2) якість реакції (дія, бездіяльність);

3) безпосередність (безпосередність, опосередкованість);

4) можливість спостерігати (відкритість, прихованість);

5) підбурювання (неспровокованість, мстивість);

6) цілеспрямованість (ворожа, інструментальна);

7) вид спричиненої шкоди (фізична, психологічна);

8) тривалість наслідків (короткотермінові, тривалі);

9) соціальні одиниці, що задіяні (індивідуальна, групова).

Фахівці у сфері психології агресії $[41,121,257]$ наголошують на необхідності розрізнення понять агресії і агресивності. Перше поняття використовують, коли мова йде про агресивну поведінку або дії. Друге - коли говорять про агресивність як рису (властивість) особистості, яка відображає готовність людини до агресивних дій. Підкрес- 
люється факт того, що не всі агресивні дії спричинені агресивністю особистості, як і агресивність особистості не завжди призводить до агресивних дій.

Агресивність особистості в психології не завжди оцінюють негативно. Звертається увага на те, що наявність певного рівня агресивності допомагає людині в соціальній адаптації і подоланні життєвих перешкод [39, 246].

Грунтовний аналіз психологічних теорій агресії здійснили у своїх роботах Є. В. Тополов [391] та О. Є. Мойсеєва [246]. Є. В. Тополов аналізує і низку чинників, які в психології пов'язують 3 агресивною поведінкою людини. До них, зокрема, відносять:

1. Недоліки сімейного виховання.

2. Ситуативні фактори:

- вплив кліматичних умов;

- вплив культурних чинників;

- підвищений шум;

- вороже соціальне середовище;

- наявна температура навколишнього середовища;

- біль, стресова ситуація;

- спостереження за моделями агресивної поведінки інших у реальному житті, кіно та на телебаченні;

- оцінка іншими людьми;

- очікування помсти за власні агресивні дії;

- велике скупчення людей;

- неприємний запах та тіснота в приміщенні;

- зазіхання на особистий простір;

- дія певної дози алкоголю;

- сексуальне збудження;

- дискомфорт.

3. Особистісні чинники:

- підвищена ворожість та подразливість;

- підвищений рівень тривожності та депресії;

- негативна ефективність;

- перевищена, неадекватна самооцінка, неадекватний рівень домагань;

- підвищена емоційна реактивність та нестабільність;

- особливості мотиваційної сфери;

- низький рівень розвитку інтелекту; 
- антисоціальна спрямованість особистості, порушення функцій соціальної взаємодії, заздрісність;

- схильність приписувати оточуючим агресивні наміри.

4. Гендерні чинники.

5. Біологічні чинники (хромосомні аномалії, що викликають поведінкові й психічні розлади).

6. Соціальні чинники (тривале перебування у стресогенному середовищі).

Називаються і чинники, які стримують прояв агресивності:

1. Можливість покарання за агресію.

2. Любов.

3. Дружні стосунки.

4. Окремі риси особистості (поміркованість, толерантність, завбачливість, безконфліктність, високий самоконтроль).

Проблему співвідношення агресивної поведінки та ціннісних орієнтацій особистості досліджувала 3. В. Спринська [370]. Як об'єкт дослідження було обрано психологічні особливості особистостей 3 різними проявами агресивної поведінки. Предметом - показники агресивної поведінки, ціннісних орієнтацій та їх співвідношення.

Дослідник припустила, що міра значущості термінальних цінностей та сфер людського існування, що представлені в житті людини, пов'язана з певними показниками агресивної поведінки, за допомогою яких особистість реалізує свої бажання та прагнення.

Автор виявила у осіб з високим рівнем індексу агресивності вираженість таких якостей особистості, як домінантність, егоцентричність, авторитарність, самовпевненість, низький рівень суб'єктивного контролю, високий рівень завуальованої та відвертої жорстокості, агресивну стратегію психологічного захисту суб'єктивної реальності, високий рівень негативної комунікативної установки та зниженої комунікативної толерантності.

У осіб з високим індексом ворожості було зафіксовано вираженість депресивності, невротичності, нетовариськості, погану адаптацію до оточення, низький рівень суб'єктивного контролю. Як засіб вирішення конфліктної ситуації ці люди часто обирають агресію або уникання.

У осіб з обома високими індексами (агресивності й ворожості) 3. В. Спринська зафіксувала підвищений рівень психопатизації. Для цих людей характерною є імпульсивна поведінка та агресивне став- 
лення до соціального оточення, виражене прагнення домінувати, емоційна нестійкість, невпевненість у собі, нетовариськість. У них було виявлено достатньо високий рівень суб'єктивного контролю. Як стратегію захисту вони використовують виключно агресію.

У студентів з низьким рівнем індексу ворожості автор виявила такі якості, як недовірливість, схильність до афективних реагувань, збудливість, фрустрованість, невпевненість у собі, часті зміни настрою та недостатню регуляцію поведінки. Ці люди схильні уникати неприємних подій у житті.

3. В. Спринська виявила також залежність індивідуально-психологічних відмінностей у проявах агресивної поведінки від характеру й своєрідності поєднань компонентів, які входять до її складу. Було встановлено, що міра прояву таких показників, як індекс агресивності, індекс ворожості та їх поєднання (з високим чи низьким рівнем) пов'язана 3 певними ціннісними орієнтаціями та адаптивними й комунікативними характеристиками людей.

У своїй роботі ми виходили 3 того, що ключову роль у розвитку агресивності відіграють особистісні особливості, що відбивають характерні риси й нахили конкретної особистості, яка проявляє агресію, або, як їх ще іноді називають, індивідуальні детермінанти агресії. Під цим терміном у психології мають на увазі передумови для виникнення й розвитку агресії, зосереджені в основному в стійких рисах характеру й нахилах потенційних агресорів. До таких характеристик належить і рівень суб'єктивного контролю (локус контролю). Це поняття запропоноване американським психологом Д. Роттером для позначення схильності людини приписувати відповідальність за результати своєї діяльності зовнішнім силам (екстернальний, зовнішній локус контролю) або власним здібностям і зусиллям (інтернальний, внутрішній локус контролю).

Експериментальною гіпотезою дослідження стало припущення про те, що рівень суб' єктивного контролю особистості є чинником, що стосується агресії студентів-футболістів під час гри.

Як незалежна змінна були показники рівня розвитку суб'єктивного контролю студентів-футболістів. Залежною змінною розглядалися прояви агресивності під час футбольних матчів, за які гравці отримували червоні або жовті картки.

Статистичною нульовою гіпотезою було припущення, що кореляція між показниками рівня суб'єктивного контролю студентів- 
футболістів і рівнем їх агресивності під час гри значуще не відрізняється від нуля (є випадковою).

Альтернативною статистичною гіпотезою було припущення про те, що кореляція між показниками рівня суб'єктивного контролю студентів-футболістів і рівнем їх агресивності значуще відрізняється від нуля (не є випадковою).

У ході експерименту у 30 студентів-футболістів ДНУЗТ ім. акад. В. Лазаряна діагностувався рівень суб'єктивного контролю. 3 цією метою використовувався опитувальник рівня суб' єктивного контролю, який розроблений Є. Ф. Бажиним на основі шкали локусу контролю Д. Роттера (див. дод. 6). Наступним етапом була емпірична перевірка кореляції отриманих у ході опитування результатів з реальними фактами прояву агресивності в грі на різноманітних змаганнях 3 футболу та міні-футболу (враховувалася кількість червоних і жовтих карток, що отримали гравці за грубу гру проти суперника у 20 ігpax). Використано коефіцієнт рангової кореляції Спірмена [88].

За результатами роботи було встановлено, що експериментальну групу студентів-футболістів характеризували такі статистичні показники. За чинником «рівень суб'єктивного контролю» середнє арифметичне показників складало 27,36 бала, медіана - 27, мода - 34; стандартне відхилення - 5,67. Графічно результати зображено на рис. 48 . За чинником «рівень агресивності» середнє арифметичне показників складало 5,16, медіана - 5, мода - 5, стандартне відхилення - 2,53. Графічно результати наведено на рис. 49.

Вторинну статистичну обробку отриманих даних було проведено 3 використанням коефіцієнта рангової кореляції Спірмена. Отриманий результат $r_{s}$ становив 0,595 (критичним значенням для цієї вибірки на рівні статистичної значущості $0,01 € 0,47)$. Отже, кореляція між показниками рівня суб'єктивного контролю студентів-футболістів і показниками рівня їх агресивності під час гри є статистично значущою. На підставі цього відхилено нульову гіпотезу й підтверджено правильність альтернативної.

Дані, отримані в ході дослідження, дозволяють стверджувати, що рівень агресивності у студентів-футболістів 3 низьким рівнем суб'єктивного контролю помірний. Такі гравці рідко отримують жовті, а тим більше червоні картки. Їх агресивність збільшується несуттєво навіть за умови грубої гри проти них з боку суперника. Інша тенденція спостерігається у студентів-футболістів з високим рівнем суб'єк- 
тивного контролю. Вони, відчуваючи на собі прояви агресивності 3 боку суперника, самі стають агресивнішими. Серед цієї категорії гравців багато таких, які, програючи єдиноборство, часто використовують грубу гру.

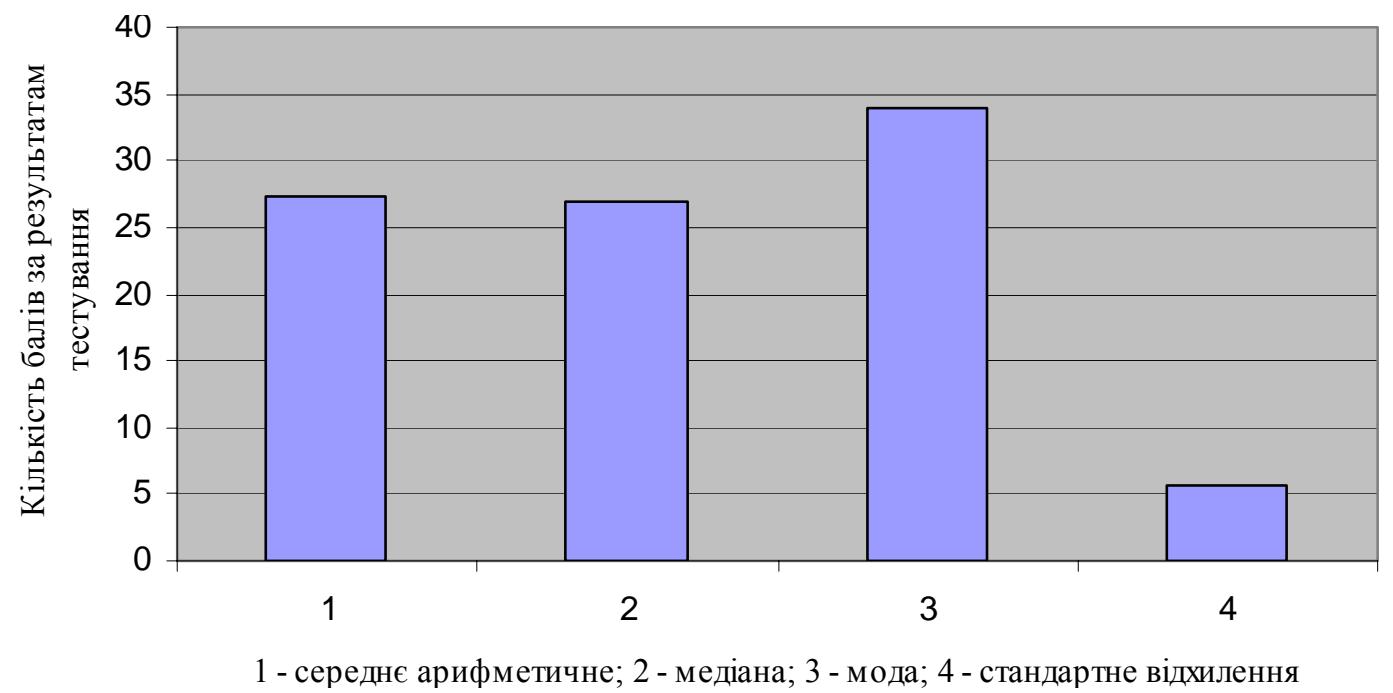

Рис. 48. Статистичні показники рівня суб'єктивного контролю у студентів-футболістів

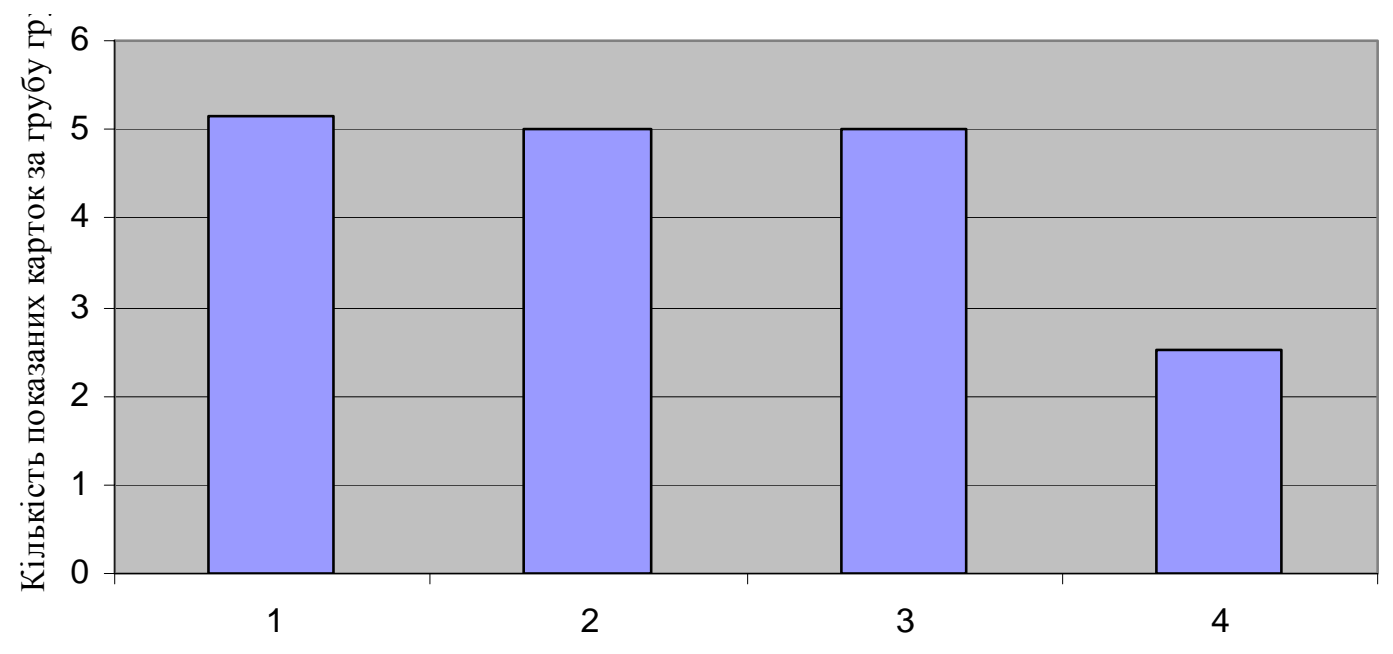

1 - середнє арифметичне; 2 - медіана; 3 - мода; 4 - стандартне відхилення

Рис. 49. Статистичні показники агресивних дій проти суперника студентів-футболістів

Отримані дані дозволяють зробити висновок, що рівень суб'єктивного контролю є чинником, який стосується агресії студентівфутболістів у багатьох ситуаціях гри у футбол. 


\section{Висновки до розділу}

Головними висновками розділу є такі твердження:

1. У студентів-спортсменів (представників таких видів спорту, як легка атлетика і футбол) є як тотожності, так і відмінності характеристик особистості.

2. Фізкультурна діяльність в таких видах спорту, як легка атлетика і спортивна гімнастика $\epsilon$ ефективним засобом формування багатьох вольових якостей особистості.

3. Заняття футболом - ефективний засіб розвитку вибірковості та концентрації і стійкості уваги у студентів.

4. Локус (рівень) контролю особистості студента є чинником, що стосується до фактів прояву агресивності у футболі.

5. Проведені й описані в п'ятому розділі дослідження були спрямовані на виявлення потенційних можливостей деяких видів фізкультурної і спортивної діяльності у формуванні складових психологічної і психофізичної структури студентів. Отримані дані дають підстави зробити висновок про доцільність використання зазначених засобів для вирішення завдань з формування (розвитку) компонентів їх психологічної і психофізичної готовності. Результати, отримані на цьому етапі дослідження, було враховано під час формувального експерименту. Насамперед це стосується підбору професійно значущих видів фізкультурної і спортивної діяльності студентів у процесі фізичного виховання. 
РОЗДІЛ 6

\section{Формування професійно значущих рис особистості студентів у процесі психологічної і психофізичної підготовки (експериментальне дослідження)}

\section{1. Процедура й основні характеристики формувального експериментального дослідження психологічної і психофізичної підготовки студентів}

Суть авторського підходу до організації психологічної і психофізичної підготовки в процесі фізичного виховання полягає в цілеспрямованому залученні студентів до участі в спеціально організованій діяльності. Передбачається, що в процесі іï виконання у студента буде сформовано (у професійно значущому для залізничного транспорту напрямку) необхідний рівень розвитку складових психологічної і психофізичної готовності. Ми виходили з того, що фізична культура і спорт є однією з небагатьох сфер життєдіяльності сучасного студента, у яких може бути змодельовано ситуації активного впливу на їх професійно значущі психологічні й психофізичні складові.

Одним із завдань дослідження стало вивчення можливості формування психологічної й психофізичної готовності студентів-залізничників саме в процесі фізичного виховання. Роботу було організовано за три етапи: підготовчий, основний, узагальнюючий.

На першому етапі викладачів фізичного виховання було ознайомлено з результатами діагностики складових психологічної і психофізичної підготовленості студентів, з робочою програмою дисципліни «Фізичне виховання», яка включала відповідний розділ, 3 планомграфіком навчальних занять (він також включав розділ з психологічної і психофізичної підготовки). Під час основного етапу було 
проведено підготовку викладачів фізичного виховання до роботи з експериментальними навчальними групами й організовано заплановану навчальну діяльність студентів. На етапі узагальнення було виконано підсумкову діагностику складових психологічної і психофізичної готовності студентів і зроблено висновки щодо результатів формувального експерименту.

У формуючому експериментальному дослідженні брали участь 376 студентів Дніпропетровського національного університету залізничного транспорту ім. акад. В. Лазаряна, 3 них 316 - юнаки і 60 дівчата. Студенти навчалися на таких факультетах, як «Мости і тунелі», «Електрифікація залізниць», «Механічний», «Управління процесами перевезень», «Організація будівництва доріг та експлуатація колії», «Промислове та цивільне будівництво», «Економіка та менеджмент на транспорті», «Технічна кібернетика». Вік учасників дослідження складав 17-19 років.

Експериментальною гіпотезою дослідження стало таке припущення. У процесі спеціально організованої психологічної і психофізичної підготовки під час навчальних занять 3 фізичного виховання в студентів можна ефективно формувати складові психологічної й психофізичної готовності до професійної праці. Для цього у фізичному вихованні необхідно ставити відповідні цілі й використовувати відповідні засоби формування та методи діагностики.

Як незалежна змінна використано такий параметр, як зміст розроблених автором основ психологічної і психофізичної підготовки студентів-залізничників. Залежною змінною були показники рівня сформованості (розвитку) у студентів визначених складових психологічної і психофізичної готовності до праці.

Як статистична нульова гіпотеза приймалося припущення про те, що показники сформованості (розвитку) психологічної і психофізичної готовності студентів експериментальних і контрольних груп не відрізняються один від одного.

Альтернативною статистичною гіпотезою було припущення про те, що показники сформованості психологічної і психофізичної готовності студентів експериментальних і контрольних груп є різними.

Наступним етапом статистичної обробки стало отримання фактичних даних про події, щодо яких було сформовано нулову гіпотезу, і визначення вірогідності того, що результат міг бути отриманим у випадку, коли нульова гіпотеза є правильною. 
Експериментальним планом дослідження обрано план для двох груп з попереднім і підсумковим тестуванням [122, с. 114].

На початку дослідження у студентів, які брали участь в експерименті, було продіагностовано обрані показники психологічної і психофізичної підготовленості. На підставі даних діагностики було сформовано експериментальні й контрольні групи. Головним завданням при цьому було вирівняти їх таким чином, щоб вони статистично значуще не відрізнялись одна від одної за мірою прояву показників психологічної і психофізичної готовності. Експериментальні й контрольні групи формувалися також з урахуванням того, щоб до їх складу входили студенти одного факультету (бажано навіть однієї спеціальності).

Після проведення вищезгаданої організаційної роботи студентів експериментальних груп було залучено до навчальних занять 3 фізичного виховання, які включали вивчення розроблених автором основ психологічної і психофізичної підготовки студентів-залізничників. Студенти контрольних груп вивчали курс фізичного виховання відповідно до навчальної програми для вищих навчальних закладів.

Експеримент тривав протягом чотирьох семестрів (перший і другий курс навчання в університеті). По його завершенні було повторно продіагностовано показники психологічної і психофізичної підготовленості студентів.

Описану процедуру експериментального дослідження застосовували для вивчення процесу формування (розвитку) ряду конкретних складових психологічної і психофізичної підготовленості студентівзалізничників.

Задум проведення формувального експерименту поставив перед нами завдання вибору конкретних складових психологічної і психофізичної підготовленості, які будуть об’єктами педагогічного впливу. Справа в тому, що психологічна й психофізична підготовленість, будучи підструктурою загальної структури особистості, сама є складним утворенням ряду компонентів іії загальної структури, що перебувають на різних рівнях організації. Виходячи із запропонованої в цій роботі моделі (див. рис. 1) можна побачити, що кожен рівень структури психологічної і психофізичної готовності складається із множини компонентів. Це стосується і професійно значущих рис особистості, i пізнавальних процесів, і психомоторики. Експериментально дослідити процес формування такої кількості складових, та ще 
й у рамках одного дослідження просто не реально. Необхідно було обрати коло конкретних компонентів, які й стануть об'єктом дослідження. Постало питання про критерій відбору компонентів для дослідження. Таким критерієм, виходячи із теми дослідження, було вирішено прийняти рівень значущості для професійної праці на залізниці.

Виходячи 3 таких міркувань, було вирішено обрати для проведення формувального експерименту по одному або по два компоненти 3 кожного рівня структури психологічної і психофізичної готовності. Так, на рівні професійно значущих рис особистості зупинилися на таких характеристиках, як фактори особистості за Р. Кеттеллом, копінгстратегії, толерантність до невизначеності, особистісна тривожність. Ми пов'язували останню характеристику особистості із впливом на таку важливу для залізничників складову професійної придатності, як емоційна стійкість. Окрім того, для деяких залізничних професій тривожність $є$ якістю, яка перешкоджає ефективній професійній діяльності. На рівні пізнавальних процесів було вирішено зупинити свій вибір на таких характеристиках уваги, як концентрація і стійкість та вибірковість. Вони надзвичайно важливі для професійної праці на залізниці. Насамперед це стосується спеціальностей, що пов'язані з організацією руху поїздів. На рівні психомоторики було обрано таку характеристику, як вестибулярна стійкість. Вона також дуже важлива, зокрема для таких спеціальностей залізничного транспорту, як «Мости і транспортні тунелі», «Локомотиви і локомотивне господарство», «Вагони i вагонне господарство», «Електричний транспорт».

\section{2. Формування професійно значущих рис особистості студентів у процесі психологічної і психофізичної підготовки}

Фізична культура і спорт є однією з небагатьох сфер життєдіяльності студента, у яких може ефективно вирішуватися завдання формування його особистості. У той же час спеціальних досліджень, спрямованих на вивчення питання використання фізичної культури для формування особистості, вкрай мало. У цьому контексті слід від- 
значити роботи В. М. Шебеко [434], О. І. Головченко [93], А. О. Артюшенко [16], О. П. Гонтарь [97], О. Р. Кабірової [153], С. Г. Матвеєва [235], В. Ю. Солонського [367], К. Б. Тумарова [394], Т. І. Чедової [426], Д. С. Завірохіна [134]. Не вивченим є питання особливостей формування особистості студентів, які займаються в навчальних секціях фізичного, спортивного виховання, фізичної реабілітації. Не розробленими залишаються і шляхи вдосконалення (перебудови) фізичного виховання в плані ефективного впливу на формування особистості студента.

У цій частині дослідження було поставлено за мету перевірити такі припущення:

1. Навчальні заняття в навчальній секції спортивного виховання суттєво впливають на формування особистості студентів, що визначається специфікою спортивної діяльності (виду спорту).

2. Навчальні заняття в навчальній секції фізичного виховання суттєво не впливають на формування особистості студентів.

3. Реалізація в процесі навчальних занять 3 фізичного виховання розроблених автором основ психологічної і психофізичної підготовки студентів-залізничників суттєво позитивно впливає на формування ряду професійно значущих факторів (за Р. Кеттеллом) особистості студентів навчальних секцій спортивного і фізичного виховання.

Незалежною змінною було використання в ході навчальних занять з фізичного виховання складових психологічної і психофізичної підготовки студентів-залізничників, що розроблено автором.

Як залежна змінна розглядалися показники рівня сформованості 17 факторів особистості (за Р. Кеттеллом).

Статистичною нульовою гіпотезою приймалося припущення про те, що зсув між показниками факторів особистості у студентів експериментальних i контрольних груп у початковому і кінцевому зрізі значуще не відрізняється від нуля.

Альтернативною статистичною гіпотезою було припущення про те, що зсув між показниками факторів особистості в студентів експериментальних і контрольних груп у початковому й кінцевому зрізі значуще відрізняється від нуля.

Для статистичної обробки отриманих даних використано $t$-критерій Стьюдента для залежних вибірок.

У дослідженні взяли участь 132 студенти Дніпропетровського національного університету залізничного транспорту ім. акад. 
В. Лазаряна. Вік учасників дослідження складав 17-20 років. Вибірку було сформовано таким чином. У навчальній секції спортивного виховання для участі в експерименті було сформовано одну експериментальну й одну контрольну групу студентів (юнаків), які займалися такими видами спорту, як футбол, легка атлетика, важка атлетика, плавання, спортивна гімнастика. Рівень спортивної кваліфікації третій, другий, перший розряд. Кількість осіб у кожній з груп - 33 . У навчальній секції фізичного виховання було сформовано одну експериментальну й одну контрольну групу студентів по 33 особи (юнаки) в кожній.

Студентів експериментальної групи 3 навчальної секції спортивного виховання було залучено до навчальних занять 3 фізичного виховання, які включали, крім іншого, вивчення основ психологічної і психофізичної підготовки студентів-залізничників. Заняття містили:

1. Вивчення теоретичного матеріалу, включеного до розділу психологічної просвіти (див. підрозд. 4.2).

2. Заняття обраним видом спорту.

3. Заняття з використанням психотренувальних засобів для розвитку характеристик уваги (коректурна проба Бурдона, тест «переплутані лінії», методика «відшукування чисел з переключенням уваги за червоно-чорними таблицями»).

4. Заняття з використанням спеціальних фізичних вправ для розвитку психомоторики студентів.

5. Участь у спортивних змаганнях з обраного виду спорту.

6. Вправи для розвитку навиків саморегуляції психічного стану (аутогенне тренування).

У ході навчальних занять вирішувались і традиційні завдання фізичного виховання студентів цієї навчальної секції.

Студенти контрольної групи навчальної секції спортивного виховання вивчали курс фізичного виховання відповідно до навчальної програми для вищих навчальних закладів [253] для цієї категорії студентів.

Навчальні заняття 3 фізичного виховання в експериментальній групі навчальної секції спортивного виховання мали таку структуру. Підготовча частина заняття складала 10 хв. Головна частина - 75 хв. 3 них 25 хв відводилося для вирішення традиційних завдань фізичного виховання студентів 3 формування в них рухових навичок та умінь і розвитку фізичних якостей. 20 хв у структурі заняття відводилося 
або на виконання студентами спеціальних фізичних вправ, або на роботу 3 психотренувальними засобами 3 розвитку характеристик уваги, або на виконання вправ для розвитку навиків саморегуляції психічного стану. У структурі конкретного заняття використовувався тільки один із 3 названих блоків засобів. 30 хв основної частини заняття виділялося для вдосконалення в обраному виді спорту. Заключна частина заняття складала 5 хв.

Студентів експериментальної групи з навчальної секції фізичного виховання було залучено до навчальних занять з фізичного виховання, які включали вивчення основ психологічної і психофізичної підготовки студентів-залізничників. Заняття містили:

1. Вивченя теоретичного матеріалу, включеного до розділу психологічної просвіти (див. підрозд. 4.2).

2. Заняття $з$ використанням психотренувальних засобів для розвитку характеристик уваги.

3. Заняття з використанням спеціальних фізичних вправ для розвитку психомоторики (швидкості простої і складної рухової реакції, швидкості в діях, вестибулярної стійкості).

4. Заняття професійно значущими (для обраної спеціальності) видами спорту.

5. Участь у спортивних змаганнях з професійно значущих видів спорту.

6. Вправи для розвитку навиків саморегуляції психічного стану (аутогенне тренування).

У ході навчальних занять у цій групі паралельно проводилась і робота 3 вирішення традиційних завдань фізичного виховання щодо формування рухових навичок, умінь та розвитку фізичних якостей студентів.

Студенти контрольної групи навчальної секції фізичного виховання вивчали курс фізичного виховання відповідно до навчальної програми для вищих навчальних закладів для цієї категорії студентів.

Навчальні заняття 3 фізичного виховання в експериментальній групі навчальної секції фізичного виховання мали структуру, аналогічну структурі, яка була використана в ході занять з фізичного виховання в експериментальній групі навчальної секції спортивного виховання, за винятком такого. Тут замість виду спорту, обраного як об'єкт для спортивного вдосконалення, використовувалися 
професійно значущі (для обраної спеціальності) види спорту. Аналогічно було організовано й спортивні змагання.

Психологічна діагностика факторів особистості у студентів виконувалася з використанням тесту Кеттелла. Оцінка рівня розвитку факторів особистості студентів здійснювалась відповідно до таблиці переводу очок в стени за методикою Р. Кеттелла.

Студенти експериментальних і контрольних груп відвідували навчальні заняття з фізичного виховання в обсязі 4 навчальних години на тиждень протягом першого і другого років навчання у ВНЗ.

Показники експериментальної та контрольної груп навчальної секції фізичного виховання до початку семестру були близькими (табл. 11).

Табличя 11

Рівень розвитку факторів особистості студентів експериментальної/контрольної груп навчальної секції фізичного виховання до початку експерименту $(n=33)$

\begin{tabular}{|c|c|c|c|c|c|c|}
\hline \multirow{2}{*}{$\begin{array}{c}\text { Фактори особистості } \\
\text { за Р. Кеттеллом }\end{array}$} & \multicolumn{2}{|c|}{ Низький рівень } & \multicolumn{2}{|c|}{ Середній рівень } & \multicolumn{2}{|c|}{ Високий рівень } \\
\hline & Кількість & $\%$ & Кількість & $\%$ & Кількість & $\%$ \\
\hline $\begin{array}{l}\text { 1. Замкнутість - то- } \\
\text { вариськість }\end{array}$ & $13 / 14$ & $41 / 43$ & $11 / 11$ & $32 / 33$ & $9 / 8$ & $27 / 24$ \\
\hline 2. Інтелект & $14 / 13$ & $44 / 40$ & $9 / 10$ & $27 / 30$ & $10 / 10$ & $29 / 30$ \\
\hline $\begin{array}{l}\text { 3. Емоційна нестій- } \\
\text { кість }\end{array}$ & $11 / 10$ & $33 / 30$ & $10 / 11$ & $30 / 33$ & $12 / 12$ & $37 / 37$ \\
\hline $\begin{array}{l}\text { 4. Підпорядкова- } \\
\text { ність - домінант- } \\
\text { ність }\end{array}$ & $9 / 8$ & $27 / 24$ & $16 / 18$ & $49 / 55$ & $8 / 7$ & $24 / 21$ \\
\hline $\begin{array}{l}\text { 5. Стриманість - } \\
\text { експресивність }\end{array}$ & $5 / 6$ & $15 / 18$ & $15 / 18$ & $46 / 55$ & $13 / 9$ & $39 / 27$ \\
\hline $\begin{array}{l}\text { 6. Схильність до по- } \\
\text { чуттів - висока } \\
\text { нормативність } \\
\text { поведінки }\end{array}$ & $3 / 4$ & $9 / 12$ & $10 / 8$ & $30 / 24$ & $20 / 21$ & $61 / 64$ \\
\hline $\begin{array}{l}\text { 7. Несміливсть - } \\
\text { сміливість }\end{array}$ & $4 / 3$ & $12 / 9$ & $15 / 17$ & $46 / 52$ & $14 / 13$ & $42 / 39$ \\
\hline $\begin{array}{l}\text { 8. Жорсткість - чут- } \\
\text { ливість }\end{array}$ & $18 / 16$ & $55 / 49$ & $13 / 14$ & $39 / 42$ & $2 / 3$ & $6 / 9$ \\
\hline
\end{tabular}


Закінчення табл. 11

\begin{tabular}{|c|c|c|c|c|c|c|}
\hline \multirow{2}{*}{$\begin{array}{c}\text { Фактори особистості } \\
\text { за Р. Кеттеллом }\end{array}$} & \multicolumn{2}{|c|}{ Низький рівень } & \multicolumn{2}{|c|}{ Середній рівень } & \multicolumn{2}{|c|}{ Високий рівень } \\
\hline & Кількість & $\%$ & Кількість & $\%$ & Кількість & $\%$ \\
\hline $\begin{array}{l}\text { 9. Довірливість - пі- } \\
\text { дозрілість }\end{array}$ & $3 / 2$ & $9 / 6$ & $11 / 13$ & $33 / 39$ & $19 / 18$ & $58 / 55$ \\
\hline $\begin{array}{l}\text { 10. Практичність - } \\
\text { розвинена уява }\end{array}$ & $8 / 8$ & $24 / 24$ & $17 / 16$ & $52 / 49$ & $8 / 9$ & $24 / 27$ \\
\hline $\begin{array}{l}\text { 11. Прямолінійність } \\
\text { - дипломатич- } \\
\text { ність }\end{array}$ & $8 / 7$ & $24 / 21$ & $17 / 16$ & $52 / 49$ & $8 / 10$ & $24 / 30$ \\
\hline $\begin{array}{l}\text { 12. Впевненість } \\
\text { у собі - тривож- } \\
\text { ність }\end{array}$ & $4 / 6$ & $12 / 18$ & $9 / 11$ & $27 / 33$ & $20 / 16$ & $61 / 49$ \\
\hline $\begin{array}{l}\text { 13. Консерватизм - } \\
\text { радикалізм }\end{array}$ & $10 / 9$ & $30 / 27$ & $10 / 12$ & $30 / 36,5$ & $13 / 12$ & $40 / 36,5$ \\
\hline $\begin{array}{l}\text { 14. Конформізм - } \\
\text { нонконформізм }\end{array}$ & $8 / 7$ & $24 / 21$ & $15 / 17$ & $46 / 52$ & $10 / 9$ & $30 / 27$ \\
\hline $\begin{array}{l}\text { 15. Низький само- } \\
\text { контроль - висо- } \\
\text { кий самоконт- } \\
\text { роль }\end{array}$ & $4 / 4$ & $12 / 12$ & $17 / 18$ & $52 / 55$ & $12 / 11$ & $36 / 33$ \\
\hline $\begin{array}{l}\text { 16. Розслабленість - } \\
\text { напруженість }\end{array}$ & $8 / 9$ & $24 / 27$ & $22 / 20$ & $67 / 61$ & $3 / 4$ & $9 / 12$ \\
\hline $\begin{array}{l}\text { MD. Адекватність } \\
\text { самооцінки }\end{array}$ & $2 / 3$ & $6 / 9$ & $16 / 18$ & $49 / 55$ & $15 / 12$ & $45 / 36$ \\
\hline
\end{tabular}

Як видно з таблиці, за фактором «замкнутість - товариськість» низький рівень прояву було зафіксовано у 13 студентів експериментальної і 14 студентів контрольної групи, що склало відповідно 41 і 43 \%. Такі люди характеризуються нетовариськістю, замкнутістю, байдужістю, зайвою строгістю в оцінці людей. Вони скептично налаштовані, холодні в ставленні до оточуючих, люблять бути на самоті. Високий рівень фактора зафіксовано у 9 студентів експериментальної і 8 студентів контрольної груп, що склало відповідно 27 і 24 \%. Це, як правило, люди відкриті й добродушні. Для них властивою $є$ природність і невимушеність у поведінці, уважність, доброта, сердечність у відносинах. Вони охоче працюють з людьми, активні 
в усуненні конфліктів, довірливі, не бояться критики, відчувають яскраві емоції, жваво відгукуються на будь-які події. Середній рівень розвитку фактора виявлено у 11 студентів експериментальної і у 11 студентів контрольної груп, що склало $32 \%$.

За фактором «інтелект» низькі показники виявлено у 14 студентів експериментальної (44 \%) і у 13 студентів контрольної (40 \%) груп. Для таких людей властивою $є$ конкретність і деяка ригідність мислення. Високі показники зафіксовано у 10 студентів експериментальної і у 10 студентів контрольної груп, що склало по 30 \%. Для таких людей характерною є абстрактність мислення, кмітливість, здатність швидко навчатися. Середні показники за фактором «інтелект» зафіксовано у 9 студентів експериментальної (27 \%) і у 10 студентів контрольної (30 \%) груп.

За фактором «емоційна нестійкість» низький рівень зафіксовано у 11 студентів експериментальної (33\%) і 10 студентів контрольної (30 \%) груп. Для таких людей характерною $є$ низька толерантність до фрустрації, мінливість інтересів, дратівливість, стомлюваність, невротичні симптоми, іпохондрія. Високі показники виявлено у 12 студентів експериментальної (37 \%) і у 12 студентів контрольної (37 \%) груп. Для цієї категорії характерними є витримка, працездатність, емоційна зрілість, реалістичне налаштування, здатність наслідувати вимоги групи, постійність інтересів, відсутність нервового стомлення. Середні показники виявлено у 10 студентів експериментальної (30 \%) і в 11 студентів контрольної (33 \%) груп.

За фактором «підпорядкованість - домінантність» низький рівень прояву виявлено в 9 студентів експериментальної (27\%) і 8 студентів контрольної (24 \%) груп. Для таких людей властивими $є$ сором'язливість; схильність поступатися дорогою іншим, брати провину на себе, тривожитися про свої можливі помилки; залежність; тактовність; покірливість; шанобливість. Високі показники зафіксовано у 8 студентів експериментальної (24\%) і у 7 студентів контрольної (21 \%) груп. Для цієї категорії характерними є владність; незалежність; невизнання влади й тиску з боку; самовпевненість; впертість, незалежність у судженнях і поведінці, схильність вважати свій спосіб мислення законом для себе і оточуючих, у конфліктах звинувачувати інших, до авторитарного стилю керівництва; конфліктність; норовливість. Середні показники виявлені в 16 студентів експериментальної (49 \%) і у 18 студентів контрольної (55 \%) груп. 
За фактором «стриманість - експресивність» низький рівень прояву зафіксовано у 5 студентів (15\%) експериментальної і 6 студентів контрольної (18 \%) груп. Для цієї категорії характерною є розсудливість, обережність, розважливість, мовчазливість, схильність все ускладнювати, стурбованість, песимістичність у сприйнятті дійсності, турбота про майбутнє, очікування невдач. Високі показники виявлено в 13 студентів експериментальної (39\%) і 9 студентів контрольної (27 \%) груп. Для них характерними $є$ життєрадісність, імпульсивність, безтурботність, веселість, говірливість, рухливість, енергійність. Соціальні контакти для таких людей є емоційно значущими. Середні показники зафіксовано в 15 студентів експериментальної (46 \%) і у 18 студентів контрольної (55 \%) груп.

За фактором «схильність до почуттів - висока нормативність поведінки» низький рівень прояву зафіксовано в 3 студентів експериментальної (9 \%) і 4 студентів контрольної (12 \%) груп. За таких показників люди схильні до непостійності, впливу випадку або обставин. Вони, зазвичай, не роблять зусиль 3 виконання групових вимог і норм, характеризуються безпринципністю, неорганізованістю, безвідповідальністю, гнучкими установками стосовно соціальних норм. Високі показники виявлено у 20 студентів експериментальної (61\%) і 21 студента контрольної (64 \%) груп. Для цієї категорії характерними є усвідомлене дотримання норм і правил поведінки, наполегливість у досягненні мети, точність, відповідальність, ділова спрямованість. Середні показники зафіксовано у 10 студентів експериментальної (29 \%) і 8 студентів контрольної (24\%) групи.

За фактором «несміливість - сміливість» низький рівень прояву виявлено в 4 студентів експериментальної (12\%) і 3 студентів контрольної (9 \%) груп. Для таких людей характерна сором'язливість, невпевненість у своїх силах, стриманість, прагнення перебувати в тіні, підвищена чутливість до загрози. Високий рівень прояву зафіксовано в 14 студентів експериментальної (42 \%) і 13 студентів контрольної (39 \%) груп. Такі люди, зазвичай, соціально сміливі, активні, готові мати справу з незнайомими обставинами й людьми. Вони схильні до ризику, тримаються вільно, розкуто. Середній рівень розвитку виявлено в 15 студентів експериментальної (46 \%) і 17 студентів контрольної (52\%) груп.

За фактором «жорсткість - чутливість» низький рівень прояву було зафіксовано у 18 студентів експериментальної (55 \%) 
і у 16 студентів контрольної (49 \%) груп. Для цієї категорії людей характерними є мужність, самовпевненість, розсудливість, реалістичність суджень, практичність, жорсткість, суворість, черствість у ставленні до оточуючих. Високі показники виявлено у 2 студентів експериментальної (6 \%) і 3 студентів контрольної (9 \%) груп. Їм властива м'якість, залежність, схильність до романтизму, артистичність натури, художність у сприйнятті світу, здатність до симпатії, співчуття, співпереживання та розуміння інших людей. Середній рівень прояву виявлено у 13 студентів експериментальної (39\%) і у 14 студентів контрольної (42\%) груп.

За фактором «довірливість - підозрілість» високий рівень прояву виявлено в 3 студентів експериментальної (9\%) і у 2 студентів контрольної (6 \%) груп. Таким людям властиві відвертість, довірливість, доброзичливість у ставленні до інших людей, терпимість, уживчивість, відсутність заздрості. Вони легко знаходять спільну мову з людьми й добре працюють у колективі. Високий рівень зафіксовано в 19 студентів експериментальної (58 \%) і 18 студентів контрольної (55\%) груп. Для цієї категорії людей властиві ревнивість, заздрісність, підозрілість, зарозумілість. Їх інтереси звернені до самих себе. Вони обережні у своїх вчинках, егоцентричні. Середні показники виявлено в 11 студентів експериментальної (33\%) і 13 студентів контрольної (39 \%) груп.

За фактором «практичність - розвинена уява» низький рівень прояву було встановлено у 8 студентів експериментальної (24 \%) і 8 студентів контрольної (24 \%) груп. Для цієї категорії людей характерними є практичність, сумління, орієнтація на зовнішню реальність, наслідування загальноприйнятих норм, певна обмеженість, зайва уважність до дрібниць. Високі показники діагностовано у 8 студентів експериментальної (24 \%) і у 10 студентів контрольної (30 \%) груп. Для таких людей властиві розвинена уява, орієнтування на свій внутрішній світ, високий творчий потенціал. Середні показники зафіксовано в 17 студентів експериментальної (52 \%) і 16 студентів контрольної (49 \%) груп. Для них властивими є середні характеристики за фактором.

За фактором «прямолінійність - дипломатичність» низький рівень прояву діагностовано у 8 студентів експериментальної (24 \%) і 7 студентів контрольної (21\%) груп. Таким людям властива прямолінійність, наївність, природність, безпосередність поведінки. Високі по- 
казники виявлено у 8 студентів експериментальної (24\%) і 10 студентів контрольної (30 \%) груп. Їх можна охарактеризувати як ощадливих, проникливих. Характерним є також розумний і сентиментальний підхід до подій і оточуючих людей. Середні показники зафіксовано в 17 студентів експериментальної (52 \%) і 16 студентів контрольної (49 \%) груп. Для них властивими є середні характеристики за фактором.

За фактором «впевненість у собі - тривожність» низький рівень прояву зафіксовано у 4 студентів експериментальної (12 \%) і 6 студентів контрольної (18 \%) груп. Такі люди, зазвичай, проявляють безтурботність, холоднокровність, спокій, впевненість у собі. Високі показники було діагностовано у 20 студентів (61\%) експериментальної і 16 студентів контрольної (49\%) груп. Для цієї категорії властиві тривожність, депресивність, ранимість, вразливість. Середні показники виявлено в 9 студентів експериментальної (27\%) і 11 студентів контрольної (33\%) груп.

За фактором «консерватизм - радикалізм» низький рівень прояву було виявлено в 10 студентів експериментальної (30 \%) і 9 студентів контрольної (27\%) груп. Для них властивими $€$ консервативність, стійкість відносно традиційних труднощів. Вони, як правило, знають, у що повинні вірити, i, незважаючи на неспроможність якихось принципів, не шукають нових, із сумнівом ставляться до нових ідей, схильні до моралізації. Ці люди противляться змінам і не цікавляться аналітичними й інтелектуальними міркуваннями. Високі показники було діагностовано у 13 студентів експериментальної (40 \%) і 12 студентів контрольної (36,5 \%) груп. Для цієї категорії людей характерними є критична налаштованість, наявність інтелектуальних інтересів, аналітичність мислення, прагнення бути добре поінформованим. Вони схильні до експериментування, спокійно сприймають нові погляди та зміни, не довіряють авторитетам, на віру нічого не приймають. Середній рівень прояву встановлено в 10 студентів експериментальної (30 \%) і 12 студентів контрольної (36,5 \%) груп.

За фактором «конформізм - нонконформізм» низький рівень прояву було діагностовано у 8 студентів експериментальної (24 \%) і у 7 студентів контрольної (21 \%) груп. Такі люди залежні від групи, наслідують громадську думку, віддають перевагу тому, щоб і працювати і приймати рішення разом з іншими людьми, орієнтуються на соціальне схвалення. У них часто відсутня ініціатива прийняття 
рішень. Високий рівень прояву зафіксовано у 10 студентів експериментальної (30 \%) і 9 студентів контрольної (27 \%) груп. Для цієї категорії людей властивим $є$ намагання приймати власні рішення, незалежність, прагнення самим приймати рішення і самим діяти, свій життєвий шлях вони обирають самі. Маючи власну думку, вони часто не прагнуть нав'язувати ії оточуючим. Схвалення і підтримки людей вони не потребують. Середній рівень прояву виявлено в 15 студентів експериментальної (46 \%) і 17 студентів контрольної (52 \%) груп. Для них властивими $є$ середні характеристики за фактором.

За фактором «низький самоконтроль - високий самоконтроль» низький рівень прояву встановлено в 4 студентів експериментальної (12\%) і 4 студентів контрольної (12\%) груп. Для них властивими $\epsilon$ недисциплінованість, внутрішня конфліктність уявлень про себе, відсутність турботи про виконання соціальних вимог. Високі показники було діагностовано у 12 студентів експериментальної (36 \%) і 11 студентів контрольної (33 \%) груп. Для цієї категорії людей характерним є розвинений самоконтроль, точність виконання соціальних вимог. Вони тримають своє уявлення про себе, добре контролюють свої емоції й поведінку, доводять справу до кінця. Їм притаманна цілеспрямованість та інтегрованість особистості. Середній рівень прояву виявлено в 17 студентів експериментальної (52 \%) і 18 студентів контрольної (55 \%) груп.

За фактором «розслабленість - напруженість» низький рівень прояву було зафіксовано у 8 студентів експериментальної (24 \%) i 9 студентів контрольної (27\%) груп. Таким людям притаманні розслабленість, млявість, спокій, низька мотивація, лінощі, зайва задоволеність. Високі показники виявлено у 3 студентів експериментальної (9 \%) і 4 студентів контрольної (12 \%) груп. Для них властивими $\epsilon$ напруженість, фрустрованість, наявність збудження і занепокоєння. Для цієї категорії людей стан фрустрації, у якому вони перебувають, являє собою результат підвищеної мотивації. Для них притаманним $\epsilon$ активне незадовільнення прагнень. Середні показники встановлено у 22 студентів експериментальної (67\%) і 20 студентів контрольної (61 \%) груп. Для них властивими є середні характеристики за фактором.

За фактором «адекватність самооцінки» низький рівень прояву діагностовано у 2 студентів експериментальної (6 \%) і 3 студентів контрольної (9 \%) груп. Високі показники виявлено у 15 студентів 
експериментальної (45 \%) і у 12 студентів контрольної (36 \%) груп. Середній рівень прояву був зафіксований в 16 студентів експериментальної (49 \%) і у 18 студентів контрольної (55 \%) груп. Чим вищою $\epsilon$ оцінка за фактором, тим більше для людини властиве намагання завищувати свої можливості й переоцінювати себе.

Показники контрольної групи навчальної секції спортивного виховання до початку семестру були близькими до показників експериментальної (табл. 12).

Таблиия 12

Рівень розвитку факторів особистості студентів експериментальної/контрольної груп навчальної секції спортивного виховання до початку експерименту $(n=33)$

\begin{tabular}{|c|c|c|c|c|c|c|}
\hline \multirow{2}{*}{$\begin{array}{c}\text { Фактори особистості } \\
\text { за Р. Кеттеллом }\end{array}$} & \multicolumn{2}{|c|}{ Низький рівень } & \multicolumn{2}{|c|}{ Середній рівень } & \multicolumn{2}{|c|}{ Високий рівень } \\
\hline & Кількість & $\%$ & Кількість & $\%$ & Кількість & $\%$ \\
\hline $\begin{array}{l}\text { 1. Замкнутість - то- } \\
\text { вариськість }\end{array}$ & $7 / 8$ & $21 / 24$ & $13 / 14$ & $39,5 / 43$ & $13 / 11$ & $39,5 / 33$ \\
\hline 2. Інтелект & $18 / 17$ & $55 / 52$ & $5 / 6$ & $15 / 18$ & $10 / 10$ & $30 / 30$ \\
\hline $\begin{array}{l}\text { 3. Емоційна нестій- } \\
\text { кість }\end{array}$ & $3 / 3$ & $9 / 9$ & $13 / 12$ & $39 / 36$ & $17 / 18$ & $52 / 55$ \\
\hline $\begin{array}{l}\text { 4. Підпорядкова- } \\
\text { ність - домінант- } \\
\text { ність }\end{array}$ & $9 / 8$ & $27 / 24$ & $16 / 16$ & $49 / 49$ & $8 / 9$ & $24 / 27$ \\
\hline $\begin{array}{l}\text { 5. Стриманість - } \\
\text { експресивність }\end{array}$ & $4 / 5$ & $12 / 15$ & $18 / 16$ & $55 / 49$ & $11 / 12$ & $33 / 36$ \\
\hline $\begin{array}{l}\text { 6. Схильність до по- } \\
\text { чуттів - висока } \\
\text { нормативність } \\
\text { поведінки }\end{array}$ & $2 / 1$ & $6 / 3$ & $10 / 12$ & $30 / 36$ & $21 / 20$ & $64 / 61$ \\
\hline $\begin{array}{l}\text { 7. Несміливсть - } \\
\text { сміливість }\end{array}$ & $2 / 2$ & $6 / 6$ & $12 / 10$ & $36 / 30$ & $19 / 21$ & $58 / 64$ \\
\hline $\begin{array}{l}\text { 8. Жорсткість - чут- } \\
\text { ливість }\end{array}$ & $25 / 26$ & $76 / 79$ & $7 / 5$ & $21 / 15$ & $1 / 2$ & $3 / 6$ \\
\hline $\begin{array}{l}\text { 9. Довірливість - пі- } \\
\text { дозрілість }\end{array}$ & $5 / 6$ & $15 / 18$ & $16 / 16$ & $49 / 49$ & $12 / 11$ & $36 / 33$ \\
\hline $\begin{array}{c}\text { 10. Практичність - } \\
\text { розвинена уява }\end{array}$ & $7 / 8$ & $21 / 24$ & $15 / 15$ & $46 / 46$ & $11 / 10$ & $33 / 30$ \\
\hline
\end{tabular}


Закінчення табл. 12

\begin{tabular}{|c|c|c|c|c|c|c|}
\hline \multirow{2}{*}{$\begin{array}{c}\text { Фактори особистості } \\
\text { за Р. Кеттеллом }\end{array}$} & \multicolumn{2}{|c|}{ Низький рівень } & \multicolumn{2}{|c|}{ Середній рівень } & \multicolumn{2}{|c|}{ Високий рівень } \\
\hline & Кількість & $\%$ & Кількість & $\%$ & Кількість & $\%$ \\
\hline $\begin{array}{l}\text { 11. Прямолінійність } \\
\text { - дипломатич- } \\
\text { ність }\end{array}$ & $4 / 4$ & $12 / 12$ & $19 / 18$ & $58 / 55$ & $10 / 11$ & $30 / 33$ \\
\hline $\begin{array}{l}\text { 12. Впевненість } \\
\text { у собі - тривож- } \\
\text { ність }\end{array}$ & $4 / 5$ & $12 / 15$ & $16 / 14$ & $49 / 42,5$ & $13 / 14$ & $39 / 42,5$ \\
\hline $\begin{array}{l}\text { 13. Консерватизм - } \\
\text { радикалізм }\end{array}$ & $9 / 10$ & $27 / 30$ & $16 / 15$ & $49 / 46$ & $8 / 8$ & $24 / 24$ \\
\hline $\begin{array}{l}\text { 14. Конформізм - } \\
\text { нонконформізм }\end{array}$ & $3 / 2$ & $9 / 6$ & $22 / 24$ & $67 / 73$ & $8 / 7$ & $24 / 21$ \\
\hline $\begin{array}{l}\text { 15. Низький само- } \\
\text { контроль - висо- } \\
\text { кий самоконт- } \\
\text { роль }\end{array}$ & $5 / 6$ & $15 / 18$ & $11 / 12$ & $33 / 36$ & $17 / 15$ & $52 / 46$ \\
\hline $\begin{array}{l}\text { 16. Розслабленість - } \\
\text { напруженість }\end{array}$ & $9 / 8$ & $27 / 24$ & $21 / 21$ & $64 / 64$ & $3 / 4$ & $9 / 12$ \\
\hline $\begin{array}{l}\text { MD. Адекватність } \\
\text { самооцінки }\end{array}$ & $6 / 5$ & $18 / 15$ & $13 / 15$ & $39 / 46$ & $14 / 13$ & $43 / 39$ \\
\hline
\end{tabular}

Наступним етапом дослідження стало виявлення можливого впливу занять спортом на формування особистості студентів. 3 цією метою було виконано статистичну обробку даних експериментальної групи навчальної секції фізичного виховання (див. табл. 11) і даних експериментальної групи навчальної секції спортивного виховання (див. табл. 12). Ми виходили 3 того, що оскільки суттєвою особливістю навчальних занять 3 фізичного виховання у навчальній секції спортивного виховання є спортивна діяльність, а в навчальній секції фізичного виховання - заняття фізичною культурою, то відмінності в рівні прояву факторів особистості в студентів цих навчальних секцій можуть бути спричинені саме заняттями спортом.

Як статистична нульова гіпотеза приймалося припущення про те, що різниця між показниками рівня прояву факторів особистості в студентів навчальних секцій фізичного виховання й спортивного виховання значуще не відрізняються від нуля. 
Альтернативною статистичною гіпотезою було припущення про те, що різниця між показниками рівня прояву факторів особистості в студентів навчальних секцій фізичного виховання і спортивного виховання значуще відрізняється від нуля.

Статистичну обробку даних було виконано 3 використанням $U$ критерію Манна-Уїтні.

У цій частині дослідження взяли участь 66 студентів Дніпропетровського національного університету залізничного транспорту ім. акад. В. А. Лазаряна. Це були чоловіки віком від 17 до 20 років. 33 з них відвідували навчальні заняття з фізичного виховання в навчальній секції фізичного виховання і 33 у навчальній секції спортивного виховання. У вибірку до навчальної секції спортивного виховання було включено студентів, які займались такими видами спорту, як: легка атлетика (7 студентів), плавання (7 студентів), футбол (8 студентів), важка атлетика (6 студентів), спортивна гімнастика (5 студентів). Рівень їх спортивної кваліфікації був від 3-го розряду до майстра спорту.

За результатами виконаної роботи було встановлено таке. Існують статистично значущі відмінності показників рівня прояву факторів особистості в студентів навчальних секцій фізичного виховання i спортивного виховання за такими факторами, як «емоційна нестійкість», «несміливість - сміливість», «довірливість - підозрілість». Так, за фактором «емоційна нестійкість» $U$ емпіричне склало 390,5 (критичне значення $p \leq 0,05=415$ ). Середнє арифметичне показників за фактором у студентів навчальної секції фізичного виховання становить 5,03 стена, навчальної секції спортивного виховання - 6,15 стена. Медіана за фактором становить 5 і 7 стенів відповідно. Показник моди за фактором становить 7 стенів для студентів навчальної секції фізичного виховання і 8 стенів для студентів навчальної секції спортивного виховання. Стандартне відхилення за фактором - 2,39 стена (для студентів навчальної секції фізичного виховання) і 2,1 стена (для студентів навчальної секції спортивного виховання). Суттєво вищими $є$ показники емоційної стійкості у студентів навчальної секції спортивного виховання.

За фактором «несміливість - сміливість» $U$ емпіричне склало 396,5 (критичне значення $p \leq 0,05=415$ ). Середнє арифметичне показників за фактором у студентів навчальної секції фізичного виховання становить 5,46 стена, навчальної секції спортивного виховання 
- 6,45 стена. Медіана за фактором становить 5 стенів і 7 стенів відповідно. Показник моди за фактором становить 5 стенів для студентів навчальної секції фізичного виховання і 7 стенів для студентів навчальної секції спортивного виховання. Стандартне відхилення за фактором - 2,27 стена (для студентів навчальної секції фізичного виховання) i 1,82 стена (для студентів навчальної секції спортивного виховання). Суттєво вищими є показники за фактором студентів навчальної секції спортивного виховання.

За фактором «довірливість - підозрілість» $U$ емпіричне склало 388 (критичне значення $p \leq 0,05=415$ ). Середне арифметичне показників за фактором у студентів навчальної секції фізичного виховання становить 6,54 стена, навчальної секції спортивного виховання - 5,39. Медіана за фактором становить 7 і 5 стенів відповідно. Показник моди за фактором становить 5 стенів для студентів обох секцій. Стандартне відхилення за фактором - 2,35 стена (для студентів навчальної секції фізичного виховання) і 2,37 стена (для студентів навчальної секції спортивного виховання).

За такими факторами, як «замкнутість - товариськість», «інтелект», «підпорядкованість - домінантність», «стриманість - експресивність», «схильність до почуттів - висока нормативність поведінки», «жорсткість - чутливість», «практичність - розвинена уява», «прямолінійність - дипломатичність», «впевненість в собі - тривожність», «консерватизм - радикалізм», «конформізм - нонконформізм», «низький самоконтроль - високий самоконтроль», «розслабленість - напруженість», «адекватність самооцінки», отримано емпіричні значення $U$, які розташовані в зоні незначущості.

Наступним етапом дослідження стало виявлення специфіки впливу конкретного виду спорту на особистість студента. Для цього було виконано статистичну обробку даних експериментальної групи навчальної секції фізичного виховання й частини даних навчальної секції спортивного виховання, до якої входили тільки студенти, які займалися конкретним видом спорту (легка атлетика, плавання, футбол, важка атлетика, спортивна гімнастика). Статистичну обробку даних було виконано з використанням $U$-критерію Манна-Уїтні.

Результати цієї роботи такі. Існують статистично значущі відмінності показників рівня прояву факторів особистості в студентів навчальних секцій фізичного виховання і студентів навчальної секції спортивного виховання, які займалися легкою атлетикою за такими 
факторами, як «емоційна нестійкість», «схильність до почуттів - висока нормативність поведінки», «практичність - розвинена уява». Так, за фактором «емоційна нестійкість» $U$ емпіричне склало 39,5 (критичне значення $p \leq 0,01=49$ ). Середнє арифметичне показників за фактором у студентів навчальної секції фізичного виховання становив 5,03 стена, студентів навчальної секції спортивного виховання, які займалися легкою атлетикою, - 7,85 стена. Медіана за фактором становила 5 і 8 стенів відповідно. Показник моди за фактором становив 7 стенів у студентів навчальної секції фізичного виховання і 10 стенів у студентів-легкоатлетів. Стандартне відхилення за фактором становить 2,39 стена у студентів навчальної секції фізичного виховання і 1,77 стена у студентів-легкоатлетів. Суттєво вищими є показники студентів, що займалися легкою атлетикою.

За фактором «схильність до почуттів - висока нормативність поведінки» $U$ емпіричне склало 65,5 (критичне значення $p \leq 0,05=68$ ). Середнє арифметичне показників за фактором у студентів навчальної секції фізичного виховання становить 6,51 стена, студентів навчальної секції спортивного виховання, які займались легкою атлетикою, 8 стенів. Медіана за фактором становила 7 і 9 стенів відповідно. Показник моди за фактором був 8 стенів у студентів навчальної секції фізичного виховання і 10 стенів у студентів-легкоатлетів. Стандартне відхилення за фактором складало 2 стени у студентів навчальної секції фізичного виховання і 2,51 стена у студентів-легкоатлетів. Суттєво вищими є показники студентів-легкоатлетів.

За фактором «практичність - розвинена уява» $U$ емпіричне склало 58,5 (критичне значення $p \leq 0,05=68$ ). Середнє арифметичне показників за фактором у студентів навчальної секції фізичного виховання становить 4,81 стена, у студентів-легкоатлетів - 6,14 стена. Медіана за фактором становила 5 і 7 стенів відповідно. Показник моди за фактором був 7 стенів у студентів навчальної секції фізичного виховання і 7 стенів у студентів-легкоатлетів. Стандартне відхилення за фактором склало 1,89 стена у студентів навчальної секції фізичного виховання і 2,26 стена у студентів-легкоатлетів. Суттєво вищими є показники студентів-легкоатлетів. Для них характерними є середні стени за фактором. Для студентів навчальної секції фізичного виховання низькі стени.

За такими факторами, як «замкнутість - товариськість», «інтелект», «підпорядкованість - домінантність», «стриманість - 
експресивність», «несміливість - сміливість», «жорсткість - чутливість», «довірливість - підозрілість», «прямолінійність - дипломатичність», «впевненість у собі - тривожність», «консерватизм - радикалізм», «конформізм - нонконформізм», «низький самоконтроль високий самоконтроль», «розслабленість - напруженість», «адекватність самооцінки» отримано емпіричні значення $U$, які розташовані в зоні незначущості.

Зафіксовано статистично значущі відмінності показників рівня прояву за фактором «низький самоконтроль - високий самоконтроль» в студентів навчальних секцій фізичного виховання і спортивного виховання (займалися плаванням). $U$ емпіричне склало 65 (критичне значення $p \leq 0,05=68$ ). Середнє арифметичне показників за фактором у студентів навчальної секції фізичного виховання становить 5,87 стена, у студентів-пловців - 4 стени. Медіана за фактором становила 6 і 3 стени відповідно. Показник моди за фактором складав 5 стенів у студентів навчальної секції фізичного виховання і 3 стени у студентів-пловців. Стандартне відхилення за фактором склало 2,21 стена у студентів навчальної секції фізичного виховання і 2,38 стена у студентів-пловців). Суттєво вищими є показники студентів навчальної секції фізичного виховання. За іншими факторами отримано емпіричні значення $U$, які розташовані в зоні незначущості.

При порівнянні показників студентів навчальних секцій фізичного виховання і спортивного виховання, які займалися футболом, за всіма 17 факторами особистості отримано емпіричні значення $U$, які розташовані в зоні незначущості.

Порівняння показників студентів навчальної секції фізичного виховання і показників студентів навчальної секції спортивного виховання, які займалися важкою атлетикою, дозволило встановити статистично значущу відмінність за такими факторами, як «замкнутість - товариськість», «підпорядкованість - домінантність», «консерватизм - радикалізм», «адекватність самооцінки». Так, за фактором «замкнутість - товариськість» $U$ емпіричне склало 40 (критичне значення $p \leq 0,05=56$ ). Середнє арифметичне показників за фактором у студентів навчальної секції фізичного виховання становило 4,33 стена, у студентів навчальної секції спортивного виховання, які займалися важкою атлетикою, становило 7 стенів. Медіана за фактором становила 5 стенів у студентів навчальної секції фізичного виховання і 7,5 стена в студентів-важкоатлетів. Показник моди за факто- 
ром був 5 стенів у студентів навчальної секції фізичного виховання і 8 стенів у студентів-важкоатлетів. Стандартне відхилення за фактором складало 2,41 і 1,54 стена відповідно. Суттєво вищими виявилися показники важкоатлетів.

За фактором «підпорядкованість - домінантність» $U$ емпіричне склало 53,5 (критичне значення $p \leq 0,05=56$ ). Середнє арифметичне показників за фактором у студентів навчальної секції фізичного виховання становило 4,75 стена, у студентів навчальної секції спортивного виховання, які займалися важкою атлетикою, - 6,5 стена. Медіана за фактором становила 5 стенів у студентів навчальної секції фізичного виховання і 6,5 стена у студентів-важкоатлетів. Показник моди за фактором був 5 стенів у студентів навчальної секції фізичного виховання і 7 стенів у студентів-важкоатлетів. Стандартне відхилення за фактором складало 2,06 і 1,51 стена відповідно. Суттєво вищими $\epsilon$ показники студентів-важкоатлетів.

За фактором «консерватизм - радикалізм» $U$ емпіричне склало 37 (критичне значення $p \leq 0,05=56$ ). Середнє арифметичне показників за фактором у студентів навчальної секції фізичного виховання було 5,6 стена, у студентів навчальної секції спортивного виховання, які займалися важкою атлетикою, - 3,16 стена. Медіана за фактором становила 6 стенів у студентів навчальної секції фізичного виховання і 3,5 стена у студентів-важкоатлетів. Показник моди за фактором був 3 стени у студентів навчальної секції фізичного виховання і 5 стенів у студентів-важкоатлетів. Стандартне відхилення за фактором складало 2,14 стена і 2,04 стена відповідно. Суттєво вищими виявилися показники студентів навчальної секції фізичного виховання. Показники студентів-важкоатлетів були від 5 стенів і нижче.

За фактором «адекватність самооцінки» $\mathrm{U}$ емпіричне склало 40,5 (критичне значення $p \leq 0,05=56$ ). Середне арифметичне показників за фактором у студентів навчальної секції фізичного виховання складало 6 стенів, у студентів навчальної секції спортивного виховання, які займались важкою атлетикою, $-8,16$ стена. Медіана за фактором у студентів навчальної секції фізичного виховання була 6 стенів, а у групі студентів-важкоатлетів - 8 стенів. Показник моди за фактором становив 7 стенів у студентів навчальної секції фізичного виховання і 10 стенів у групі студентів-важкоатлетів. Стандартне відхилення за фактором складало 1,95 і 1,72 стена відповідно. Суттєво 
вищими є показники студентів-важкоатлетів. Переважна більшість із них мала високі стени за фактором.

За іншими факторами отримано емпіричні значення $U$, які розташовані в зоні незначущості.

Зафіксовано статистично значущі відмінності показників студентів навчальної секції фізичного виховання і студентів навчальної секції спортивного виховання, які займалися спортивною гімнастикою, за такими факторами, як «інтелект», «довірливість - підозрілість», «конформізм - нонконформізм». Так, за фактором «інтелект» $U$ емпіричне склало 25 (критичне значення $p \leq 0,01=28$ ). Середнє арифметичне показників за фактором у студентів навчальної секції фізичного виховання складало 4,27 стена, у студентів навчальної секції спортивного виховання, які займались спортивною гімнастикою, 7,2 стена. Медіана за фактором у групі студентів навчальної секції фізичного виховання була 5 стенів, у групі студентів-гімнастів 7 стенів. Показник моди за фактором становив 1 стен у групі студентів навчальної секції фізичного виховання і 7 стенів у групі студентів-гімнастів. Стандартне відхилення за фактором складало 2,47 i 0,44 стена відповідно. Суттєво вищими виявилися показники студентів-гімнастів.

За фактором «довірливість - підозрілість» $U$ емпіричне склало 23,5 (критичне значення $p \leq 0,01=28$ ). Середнє арифметичне показників за фактором у студентів навчальної секції фізичного виховання складало 6,54 стена, студентів навчальної секції спортивного виховання, які займались спортивною гімнастикою, - 3 стени. Медіана за фактором у групі студентів навчальної секції фізичного виховання становила 7 стенів, студентів-гімнастів - 2 стени. Показник моди за фактором був 5 стенів у групі студентів навчальної секції фізичного виховання і 1 стен у групі студентів-гімнастів. Стандартне відхилення за фактором складало 2,35 і 2,54 стена відповідно. Суттєво вищими $є$ показники студентів навчальної секції фізичного виховання.

За фактором «конформізм - нонконформізм» $U$ емпіричне склало 36 (критичне значення $p \leq 0,05=43$ ). Середнє арифметичне показників за фактором у студентів навчальної секції фізичного виховання становило 5,42 стена, у студентів навчальної секції спортивного виховання, які займалися спортивною гімнастикою, - 3,4 стена. Медіана за фактором у групі студентів 3 навчальної секції фізичного виховання була 6 стенів, у групі студентів-гімнастів - 4 стени. Показник 
моди за фактором становив 6 стенів у групі студентів навчальної секції фізичного виховання і 5 стенів у групі студентів-гімнастів. Стандартне відхилення за фактором складало 2,39 і 1,81 стена відповідно. Суттєво вищими виявилися показники студентів навчальної секції фізичного виховання.

За іншими факторами отримано емпіричні значення $U$, які розташовані в зоні незначущості.

Плануючи дослідження питання про вплив занять спортом на формування особистості студентів, нами було висунуто статистичні гіпотези, виконано статистичну обробку даних експериментальної групи навчальної секції фізичного виховання і даних експериментальної групи навчальної секції спортивного виховання. Для проведення цієї роботи використано $U$-критерій Манна-Уїтні. Встановлено таке:

1. Студентів навчальної секції спортивного виховання характеризують статистично значуще вищі показники за факторами «емоційна нестійкість» і «несміливість - сміливість». Ці характеристики особистості (особливо перша) є надзвичайно важливими для професійної праці на залізничному транспорті. Можна рекомендувати заняття в навчальній секції спортивного виховання для формування емоційної стійкості студентів-залізничників.

2. Студентів навчальної секції фізичного виховання характеризують статистично значуще вищі показники за фактором «довірливість - підозрілість». Можна рекомендувати заняття в навчальній секції спортивного виховання для формування у студентів таких соціально значущих якостей, як відвертість, довірливість, доброзичливість у ставленні до інших, терпимість, товариськість, відсутність заздрості, здатність жити в злагоді з оточуючими й добре працювати в колективі.

3. Студентів навчальної секції спортивного виховання, які займаються легкою атлетикою, характеризують статистично значуще вищі показники за факторами «емоційна нестійкість», «схильність до почуттів - висока нормативність поведінки», «практичність - розвинена уява». Можна рекомендувати заняття легкою атлетикою для формування у студентів емоційної стійкості, усвідомленого дотримання норм і правил поведінки, наполегливості в досягненні мети, точності, відповідальності, ділової спрямованості, розвитку уяви й творчого потенціалу особистості. 
4. Студентів навчальної секції спортивного виховання, які займалися плаванням, характеризують суттєво нижчі показники за фактором «низький самоконтроль - високий самоконтроль». При цьому характерним $є$ перевага середніх стенів за фактором. Такі студенти більшою мірою (порівняно зі студентами навчальної секції фізичного виховання) схильні до недисциплінованості, внутрішньої конфліктності уявлень про себе. У них менше розвинений самоконтроль, точність виконання соціальних вимог, контроль своїх емоцій і поведінки, доведення справи до кінця.

5. Студенти навчальної секції спортивного виховання, які займалися футболом, не мають статистично значущих відмінностей у рівні прояву факторів особистості порівняно зі студентами навчальної секції фізичного виховання.

6. Студентів навчальної секції спортивного виховання, які займаються важкою атлетикою, характеризують статистично значуще вищі показники за факторами «замкнутість - товариськість», «підпорядкованість - домінантність», «адекватність самооцінки». Студентівважкоатлетів при цьому характеризують статистично значуще нижчі показники рівня прояву за фактором «консерватизм - радикалізм». Можна рекомендувати заняття важкою атлетикою для формування у студентів таких якостей, як відкритість, товариськість, природність в поведінці, уважність, доброта, активність в усуненні конфліктів, відсутність боязні щодо критики. Заняття важкою атлетикою сприяють також розвитку в студентів впевненості в собі, незалежності в судженнях і поведінці. При цьому такі заняття формують і схильність завищувати свої можливості й переоцінювати себе, консерватизм, схильність до моралізації й повчань.

7. Студентів навчальної секції спортивного виховання, які займаються спортивною гімнастикою, характеризують статистично значуще вищі показники за факторами «інтелект» і статистично значуще нижчі показники за факторами «довірливість - підозрілість» та «конформізм - нонконформізм». При цьому за фактором «інтелект» виявлено перевагу в студентів-гімнастів високих стенів, а за факторами «довірливість - підозрілість» та «конформізм - нонконформізм» низьких. Можна рекомендувати заняття спортивною гімнастикою для формування в студентів таких якостей, як абстрактність мислення, кмітливість, відвертість, довірливість, доброзичливість у ставленні до інших, терпимість, відсутність заздрості, здатність жити в злагоді 
3 оточуючими і добре працювати в колективі. При цьому заняття спортивною гімнастикою сприяють формуванню і таких якостей, як залежність від групи, наслідування суспільної думки, орієнтація на соціальне схвалення, відсутність ініціативи в прийнятті рішень.

Виявлені відмінності прояву якостей особистості у студентів навчальних секцій фізичного й спортивного виховання, на нашу думку, пояснюються специфічним впливом спорту як виду діяльності. Властивими для нього $є$ змагальний характер діяльності, максимальне напруження фізичних і психічних можливостей людини, необхідність корекції режиму життя. Вказана специфіка суттєво впливає на формування як організму, так і психіки спортсмена. Для спортсменів притаманними є: вдосконалені фізіологічні функції організму, високий рівень працездатності, високий рівень розвитку умінь і навиків та фізичних якостей (сила, швидкість, витривалість, спритність, гнучкість), високий рівень розвитку відчуттів, сприйняття, уваги, оперативного мислення, великий досвід переживання різноманітних емоційних станів і відчуттів, здатність управляти своїм емоційним станом, розвинені вольові якості особистості, здатність до правильної оцінки дій інших людей і своїх власних дій, вміння прогнозувати їх ефективність та ін. Характерною особливістю спорту $є$ те, що це такий вид діяльності, який потребує подолання труднощів. Саме це визначальною мірою впливає на формування особистості.

Плануючи формувальний експеримент, ми виходили 3 того, що аналіз професіоргам залізничних професій, наведений у четвертому розділі, показує, що найбільшу професійну значущість для студентівзалізничників має формування в них (у плані підсилення) таких факторів особистості, як «емоційна стійкість», «висока нормативність поведінки», «впевненість у собі», «високий самоконтроль», «адекватність самооцінки». У зв'язку з цим формування в професійно значущому напрямку вищезгаданих факторів було головним завданням блоку формування професійно значущих рис особистості, що входив до загальної структури психологічної і психофізичної підготовки студентів-залізничників (див. рис. 1). Для вирішення цього завдання було здійснено таке. Педагогічний вплив 3 формування емоційної стійкості студентів включав:

- участь у спортивних змаганнях 3 професійно значущих видів спорту; 
- виконання вправ з формування навиків саморегуляції власного психічного стану;

- вивчення основ психологічної просвіти.

Участь у спортивних змаганнях, за задумом, забезпечувала набуття студентами досвіду адаптації до емоційно-забарвленої (а в ряді випадків стресогенної) діяльності. У ході виконання вправ 3 формування навиків саморегуляції психічного стану студенти навчалися практичним прийомам регуляції власного емоційного стану i, у разі необхідності, могли використовувати їх у стресогенних ситуаціях. У процесі вивчення основ психологічної просвіти студенти здобували необхідні знання стосовно структури й механізмів функціонування психіки людей, використання копінг-статегій, набували розуміння того, що і з якою метою вони роблять у ході занять.

Педагогічний вплив 3 формування у студентів високої нормативності поведінки й високого самоконтролю передбачав:

- залучення студентів до занять професійно значущими видами спорту (залежно від спеціальності);

- виконання спеціальних фізичних вправ з розвитку характеристик уваги;

- вивчення основ психологічної просвіти;

- участь у спортивних змаганнях 3 професійно значущих видів спорту.

Заняття професійно значущими видами спорту й участь у спортивних змаганнях, за задумом, були тією діяльністю, у ході якої студенти розвивали здатність до дотримання норм і правил поведінки, наполегливість у досягненні мети, точність, відповідальність. Серйозні тренування, а тим більше участь у змаганнях, важко уявити без прояву особистістю цих якостей. У ході виконання спеціальних фізичних вправ для розвитку уваги й роботи з психотренувальними засобами з розвитку характеристик уваги студенти формували й таку важливу для фактору характеристику, як уважність як рису особистості.

Для формування у студентів такого фактору особистості, як впевненість у собі в процесі занять було використано:

- заняття пауерліфтингом (силове триборство);

- участь у спортивних змаганнях з пауерліфтингу;

- виконання вправ з формування навиків саморегуляції психічного стану (аутогенне тренування);

- вивчення основ психологічної просвіти. 
Для підвищення у студентів показників за фактором «адекватність самооцінки» передбачалося:

- розширення досвіду участі в спортивних змаганнях різного рівня (у ході яких студенти могли оцінити реальний рівень своєї підготовленості);

- вивчення основ психологічної просвіти (у ході якої вони здобували знання, які давали їм змогу об'єктивно оцінити ряд компонентів своєї психологічної структури).

Повторний зріз було проведено наприкінці четвертого семестру. Експериментальну й контрольну групи начальної секції фізичного виховання тепер характеризували показники, наведені у табл. 13, а експериментальну й контрольну групи навчальної секції спортивного виховання - показники, наведені в табл. 14.

Таблиия 13

Рівень розвитку факторів особистості студентів експериментальної/контрольної груп навчальної секції фізичного виховання по закінченні експерименту $(n=33)$

\begin{tabular}{|c|c|c|c|c|c|c|}
\hline \multirow{2}{*}{$\begin{array}{c}\text { Фактори особистості } \\
\text { за Р. Кеттеллом }\end{array}$} & \multicolumn{2}{|c|}{ Низький рівень } & \multicolumn{2}{|c|}{ Середній рівень } & \multicolumn{2}{|c|}{ Високий рівень } \\
\hline & Кількість & $\%$ & Кількість & $\%$ & Кількість & $\%$ \\
\hline $\begin{array}{l}\text { 1. Замкнутість - то- } \\
\text { вариськість }\end{array}$ & $14 / 13$ & $43 / 40$ & $11 / 11$ & $33 / 33$ & $8 / 9$ & $24 / 27$ \\
\hline 2. Інтелект & $12 / 13$ & $36,5 / 40$ & $12 / 9$ & $36,5 / 27$ & $9 / 11$ & $27 / 33$ \\
\hline $\begin{array}{l}\text { 3. Емоційна нестій- } \\
\text { кість }\end{array}$ & $8 / 10$ & $24 / 30$ & $14 / 12$ & $43 / 37$ & $11 / 11$ & $33 / 33$ \\
\hline $\begin{array}{l}\text { 4. Підпорядкова- } \\
\text { ність - домінант- } \\
\text { ність }\end{array}$ & $8 / 6$ & $24 / 18$ & $20 / 20$ & $61 / 61$ & $5 / 7$ & $15 / 21$ \\
\hline $\begin{array}{l}\text { 5. Стриманість - } \\
\text { експресивність }\end{array}$ & $7 / 7$ & $21 / 21$ & $14 / 19$ & $43 / 58$ & $12 / 7$ & $36 / 21$ \\
\hline $\begin{array}{l}\text { 6. Схильність до по- } \\
\text { чуттів - висока } \\
\text { нормативність } \\
\text { поведінки }\end{array}$ & $2 / 3$ & $6 / 9$ & $10 / 9$ & $30 / 27$ & $21 / 21$ & $64 / 64$ \\
\hline $\begin{array}{l}\text { 7. Несміливсть - } \\
\text { сміливість }\end{array}$ & $7 / 2$ & $21 / 6$ & $15 / 17$ & $46 / 52$ & $11 / 14$ & $33 / 42$ \\
\hline
\end{tabular}


Закінчення табл. 13

\begin{tabular}{|c|c|c|c|c|c|c|}
\hline \multirow{2}{*}{$\begin{array}{c}\text { Фактори особистості } \\
\text { за Р. Кеттеллом }\end{array}$} & \multicolumn{2}{|c|}{ Низький рівень } & \multicolumn{2}{|c|}{ Середній рівень } & \multicolumn{2}{|c|}{ Високий рівень } \\
\hline & Кількість & $\%$ & Кількість & $\%$ & Кількість & $\%$ \\
\hline $\begin{array}{l}\text { 8. Жорсткість - чут- } \\
\text { ливість }\end{array}$ & $17 / 16$ & $52 / 49$ & $13 / 13$ & $39 / 39$ & $3 / 4$ & $9 / 12$ \\
\hline $\begin{array}{l}\text { 9. Довірливість - пі- } \\
\text { дозрілість }\end{array}$ & $4 / 2$ & $12 / 6$ & $11 / 15$ & $33 / 45$ & $18 / 16$ & $55 / 49$ \\
\hline $\begin{array}{c}\text { 10. Практичність - } \\
\text { розвинена уява }\end{array}$ & $10 / 8$ & $30 / 24$ & $16 / 17$ & $49 / 52$ & $7 / 8$ & $21 / 24$ \\
\hline $\begin{array}{l}\text { 11. Прямолінійність } \\
\text { - дипломатич- } \\
\text { ність }\end{array}$ & $7 / 6$ & $21 / 18$ & $19 / 15$ & $58 / 46$ & $7 / 12$ & $21 / 36$ \\
\hline $\begin{array}{l}\text { 12. Впевненість } \\
\text { у собі - тривож- } \\
\text { ність }\end{array}$ & $4 / 6$ & $12 / 18$ & $10 / 11$ & $30 / 33$ & $19 / 16$ & $58 / 49$ \\
\hline $\begin{array}{l}\text { 13. Консерватизм - } \\
\text { радикалізм }\end{array}$ & $9 / 8$ & $27 / 24$ & $11 / 13$ & $33 / 40$ & $13 / 12$ & $40 / 36$ \\
\hline $\begin{array}{l}\text { 14. Конформізм - } \\
\text { нонконформізм }\end{array}$ & $8 / 8$ & $24 / 24$ & $17 / 17$ & $52 / 52$ & $8 / 8$ & $24 / 24$ \\
\hline $\begin{array}{l}\text { 15. Низький само- } \\
\text { контроль - висо- } \\
\text { кий самоконт- } \\
\text { роль }\end{array}$ & $4 / 4$ & $12 / 12$ & $14 / 17$ & $42 / 52$ & $15 / 12$ & $46 / 36$ \\
\hline $\begin{array}{l}\text { 16. Розслабленість - } \\
\text { напруженість }\end{array}$ & $10 / 10$ & $30 / 30$ & $19 / 20$ & $58 / 61$ & $4 / 3$ & $12 / 9$ \\
\hline $\begin{array}{l}\text { MD. Адекватність } \\
\text { самооцінки }\end{array}$ & $2 / 3$ & $6 / 9$ & $21 / 17$ & $64 / 52$ & $10 / 13$ & $30 / 39$ \\
\hline
\end{tabular}


Рівень розвитку факторів особистості студентів експериментальної/контрольної груп навчальної секції спортивного виховання по закінченні експерименту $(n=33)$

\begin{tabular}{|c|c|c|c|c|c|c|}
\hline \multirow{2}{*}{$\begin{array}{c}\text { Фактори особистості } \\
\text { за Р. Кеттеллом }\end{array}$} & \multicolumn{2}{|c|}{ Низький рівень } & \multicolumn{2}{|c|}{ Середній рівень } & \multicolumn{2}{|c|}{ Високий рівень } \\
\hline & Кількість & $\%$ & Кількість & $\%$ & Кількість & $\%$ \\
\hline $\begin{array}{l}\text { 1. Замкнутість - то- } \\
\text { вариськість }\end{array}$ & $5 / 7$ & $15 / 21$ & $16 / 15$ & $49 / 46$ & $12 / 11$ & $36 / 33$ \\
\hline 2. Інтелект & $17 / 15$ & $52 / 46$ & $7 / 8$ & $21 / 24$ & $9 / 10$ & $27 / 30$ \\
\hline $\begin{array}{l}\text { 3. Емоційна нестій- } \\
\text { кість }\end{array}$ & $2 / 3$ & $6 / 9$ & $13 / 13$ & $39 / 39$ & $18 / 17$ & $55 / 52$ \\
\hline $\begin{array}{l}\text { 4. Підпорядкова- } \\
\text { ність - домінант- } \\
\text { ність }\end{array}$ & $10 / 7$ & $30 / 21$ & $15 / 16$ & $46 / 49$ & $8 / 10$ & $24 / 30$ \\
\hline $\begin{array}{l}\text { 5. Стриманість - } \\
\text { експресивність }\end{array}$ & $6 / 5$ & $18 / 15$ & $15 / 14$ & $46 / 42,5$ & $12 / 14$ & $36 / 42,5$ \\
\hline $\begin{array}{l}\text { 6. Схильність до по- } \\
\text { чуттів - висока } \\
\text { нормативність } \\
\text { поведінки }\end{array}$ & $0 / 1$ & $0 / 3$ & $11 / 11$ & $33 / 33$ & $22 / 21$ & $67 / 64$ \\
\hline $\begin{array}{l}\text { 7. Несміливсть - } \\
\text { сміливість }\end{array}$ & $2 / 1$ & $6 / 3$ & $15 / 11$ & $45 / 33$ & $16 / 21$ & $49 / 64$ \\
\hline $\begin{array}{l}\text { 8. Жорсткість - чут- } \\
\text { ливість }\end{array}$ & $23 / 26$ & $70 / 79$ & $8 / 6$ & $24 / 18$ & $2 / 1$ & $6 / 3$ \\
\hline $\begin{array}{l}\text { 9. Довірливість - пі- } \\
\text { дозрілість }\end{array}$ & $6 / 7$ & $18 / 21$ & $17 / 16$ & $52 / 49$ & $10 / 10$ & $30 / 30$ \\
\hline $\begin{array}{c}\text { 10. Практичність - } \\
\text { розвинена уява }\end{array}$ & $8 / 7$ & $24 / 21$ & $16 / 16$ & $49 / 49$ & $9 / 10$ & $27 / 30$ \\
\hline $\begin{array}{l}\text { 11. Прямолінійність } \\
\text { - дипломатич- } \\
\text { ність }\end{array}$ & $5 / 4$ & $15 / 12$ & $16 / 16$ & $49 / 49$ & $12 / 13$ & $36 / 39$ \\
\hline $\begin{array}{l}\text { 12. Впевненість } \\
\text { У собі - тривож- } \\
\text { ність }\end{array}$ & $4 / 6$ & $12 / 18$ & $17 / 14$ & $52 / 43$ & $12 / 13$ & $36 / 39$ \\
\hline $\begin{array}{l}\text { 13. Консерватизм - } \\
\text { радикалізм }\end{array}$ & $8 / 9$ & $24 / 27$ & $19 / 17$ & $58 / 52$ & $6 / 7$ & $18 / 21$ \\
\hline
\end{tabular}


Закінчення табл. 14

\begin{tabular}{|c|c|c|c|c|c|c|}
\hline \multirow{2}{*}{$\begin{array}{c}\text { Фактори особистості } \\
\text { за Р. Кеттеллом }\end{array}$} & \multicolumn{2}{|c|}{ Низький рівень } & \multicolumn{2}{|c|}{ Середній рівень } & \multicolumn{2}{|c|}{ Високий рівень } \\
\hline & Кількість & $\%$ & Кількість & $\%$ & Кількість & $\%$ \\
\hline $\begin{array}{l}\text { 14. Конформізм - } \\
\text { нонконформізм }\end{array}$ & $5 / 2$ & $15 / 6$ & $20 / 23$ & $61 / 70$ & $8 / 8$ & $24 / 24$ \\
\hline $\begin{array}{l}\text { 15. Низький само- } \\
\text { контроль - висо- } \\
\text { кий самоконт- } \\
\text { роль }\end{array}$ & $2 / 6$ & $6 / 18$ & $14 / 11$ & $42 / 33$ & $17 / 16$ & $52 / 49$ \\
\hline $\begin{array}{l}\text { 16. Розслабленість - } \\
\text { напруженість }\end{array}$ & $10 / 9$ & $30 / 27$ & $20 / 20$ & $61 / 61$ & $3 / 4$ & $9 / 12$ \\
\hline $\begin{array}{l}\text { MD. Адекватність } \\
\text { самооцінки }\end{array}$ & $6 / 4$ & $18 / 12$ & $14 / 16$ & $43 / 49$ & $13 / 13$ & $39 / 39$ \\
\hline
\end{tabular}

Порівняння даних, отриманих у ході експерименту в експериментальній і контрольній (див. табл. 11 і 13) групах навчальної секції фізичного виховання, експериментальній і контрольній (див. табл. 12 i 14) групах навчальної секції спортивного виховання показує таке.

За факторами «замкнутість - товариськість», «інтелект», «підпорядкованість - домінантність», «стриманість - експресивність», «несміливість - сміливість», «жорсткість - чутливість», «довірливість - підозрілість», «практичність - розвинена уява», «прямолінійність дипломатичність», «консерватизм - радикалізм», «конформізм - нонконформізм», «розслабленість - напруженість» у жодній із 4 груп студентів не відбулося статистично значущих змін у рівні їх розвитку.

За фактором «емоційна нестійкість - емоційна стійкість» виявлено статистично значущі зміни показників розвитку в студентів експериментальних груп і не виявлено таких у студентів контрольних груп. Так, в експериментальній групі навчальної секції фізичного виховання середнє арифметичне показників студентів до початку експерименту складало 5,03, а по його закінченні - 5,18, що свідчить про суттєве зростання. У той же час у контрольній групі навчальної секції фізичного виховання зафіксовано дуже незначний зсув цього показника в сторону збільшення. Так, до початку експерименту середнє арифметичне показників студентів у цій групі складало 5,06, а по йо- 
го закінченні - 5,09. Зміна статистичних показників у групах секції фізичного виховання наведена в табл. 15.

Таблиия 15

Статистичні показники експериментальної і контрольної груп навчальної секції фізичного виховання до і після експерименту за фактором «емоційна нестійкість - емоційна стійкість»

\begin{tabular}{|c|c|c|c|c|}
\hline \multirow[b]{2}{*}{ Показник } & \multicolumn{2}{|c|}{ Експериментальна група } & \multicolumn{2}{|c|}{ Контрольна група } \\
\hline & $\begin{array}{c}\text { До } \\
\text { експерименту }\end{array}$ & $\begin{array}{c}\text { Після } \\
\text { експерименту }\end{array}$ & $\begin{array}{c}\text { До } \\
\text { експерименту }\end{array}$ & $\begin{array}{c}\text { Після } \\
\text { експерименту }\end{array}$ \\
\hline $\begin{array}{l}\text { Середнє арифмети- } \\
\text { чне }\end{array}$ & 5,03 & 5,18 & 5,06 & 5,09 \\
\hline Медіана & 5 & 5 & 5 & 5 \\
\hline Мода & 7 & 7 & 7 & 2 \\
\hline $\begin{array}{c}\text { Стандартне відхи- } \\
\text { лення }\end{array}$ & 2,39 & 2,28 & 2,51 & 2,42 \\
\hline
\end{tabular}

Динаміку змін за фактором добре видно і за змінами, які відбулись у групах в ході експерименту в загальній кількості й процентному співвідношенні студентів за інтервалами групування. Так, в експериментальній групі навчальної секції фізичного виховання до початку експерименту низький рівень за фактором емоційної стійкості було зафіксовано у 11 студентів, що складало 33 \%. По закінченні експерименту таких студентів залишилось 8 (24 \%). Зменшення чисельності відбулося за рахунок виходу на більш високий рівень 3 студентів, що свідчить про суттєве покращення. У контрольній групі до початку експерименту низькі показники за фактором емоційної стійкості демонстрували 10 студентів (30 \%). Після закінчення експерименту таких студентів залишилось 10 (30 \%). Кількісних змін у групі на цьому рівні не відбулося.

Результати середнього рівня за фактором емоційної стійкості в експериментальній групі навчальної секції фізичного виховання до початку експерименту було зафіксовано у 10 студентів, що склало 30 \%. По закінченні експерименту таких студентів стало 14, що склало 43 \%. Збільшення відбулось за рахунок виходу на цей рівень із більш низького 3 студентів і опускання на цей рівень (із більш високого) 1 студента. Констатуємо суттєве покращення на цьому рівні в експериментальній групі. У контрольній групі навчальної секції 
фізичного виховання до початку експерименту середні показники за фактором було виявлено у 11 студентів, що складало 33 \%. По закінченні експерименту студентів з такими показниками було виявлено 12, що склало 37 \%. Збільшення відбулось за рахунок опускання на цей рівень (із більш високого) 1 студента.

Високий рівень результатів за фактором до початку експерименту в експериментальній групі навчальної секції фізичного виховання було зафіксовано у 12 студентів, що склало 37 \%. По закінченні експерименту таких студентів виявилось 11 , що склало $33 \%$. Констатуємо невелике погіршення кількісного результату на цьому рівні в експериментальній групі. В контрольній групі навчальної секції фізичного виховання до початку експерименту високі результати за фактором показували 12 студентів, що становило 37 \%. По закінченні експерименту студентів 3 такими показниками стало 11 (33 \%). Констатуємо несуттєве погіршення результату на цьому рівні.

Зміна статистичних показників до та по закінченні експерименту в групах секції спортивного виховання показана в табл. 16.

Табличя 16

Статистичні показники експериментальної і контрольної груп навчальної секції спортивного виховання до і після експерименту за фактором «емоційна нестійкість - емоційна стійкість»

\begin{tabular}{|c|c|c|c|c|}
\hline \multirow[b]{2}{*}{ Показник } & \multicolumn{2}{|c|}{ Експериментальна група } & \multicolumn{2}{|c|}{ Контрольна група } \\
\hline & $\begin{array}{c}\text { До } \\
\text { експерименту }\end{array}$ & $\begin{array}{c}\text { Після } \\
\text { експерименту }\end{array}$ & $\begin{array}{c}\text { До } \\
\text { експерименту }\end{array}$ & $\begin{array}{c}\text { Після } \\
\text { експерименту }\end{array}$ \\
\hline $\begin{array}{l}\text { Середнє арифмети- } \\
\text { чне }\end{array}$ & 6,15 & 6,36 & 6,21 & 6,3 \\
\hline Медіана & 7 & 7 & 7 & 7 \\
\hline Мода & 8 & 8 & 7 & 5 \\
\hline $\begin{array}{c}\text { Стандартне } \text { відхи- } \\
\text { лення }\end{array}$ & 2,1 & 1.93 & 1,83 & 1,75 \\
\hline
\end{tabular}

В експериментальній групі навчальної секції спортивного виховання до початку експерименту низький рівень за фактором емоційної стійкості було виявлено у 3 студентів, що склало $9 \%$. По закінченні експерименту таких студентів стало 2 , що склало $6 \%$. Зменшення чисельності відбулось за рахунок виходу на більш високий 
рівень 1 студента. У контрольній групі навчальної секції спортивного виховання до початку експерименту низькі показники за фактором було зафіксовано у 3 студентів, що становило $9 \%$. По закінченні експерименту таких студентів виявилося також 3, що становило $9 \%$. Кількісних змін на цьому рівні в контрольній групі не відбулося.

Результати середнього рівня за фактором емоційної стійкості в експериментальній групі навчальної секції спортивного виховання до початку експерименту було зафіксовано у 13 студентів, що склало 39 \%. По закінченні експерименту таких студентів виявилося також 13 (39\%). Один студент піднявся на цей рівень 3 більш низького і один піднявся 3 цього рівня на більш високий. У контрольній групі навчальної секції спортивного виховання до початку експерименту результати середнього рівня продемонстрували 12 студентів, що складало $36 \%$. По закінченні експерименту результатів цього рівня виявлено також 12 (37\%). Кількісних змін на цьому рівні в контрольній групі не виявлено.

Високий рівень результатів за фактором емоційної стійкості в експериментальній групі навчальної секції спортивного виховання до початку експерименту виявлено у 17 студентів (52 \%). По закінченні експерименту таких студентів стало 18, що склало 55 \%. Констатуємо кількісне покращення на цьому рівні в експериментальній групі. В контрольній групі навчальної секції спортивного виховання до початку експерименту високі показники за фактором зафіксовано у 18 студентів (55\%). По закінченні експерименту таких студентів виявилось 17 , що склало 52 \%. Констатуємо несуттєве погіршення кількісного результату на цьому рівні в контрольній групі.

Вторинну статистичну обробку отриманих даних виконано з використанням $t$-критерію Стьюдента для залежних вибірок. У результаті цієї роботи встановлено таке. Для експериментальної групи навчальної секції фізичного виховання $t$ емпіричне становить 3 . Критичне значення $t$ на рівні статистичної значущості 0,01 становить 2,74 . Отже, отримане емпіричне значення розташоване в зоні значущості. На підставі цього відхилено нульову гіпотезу стосовно експериментальної групи навчальної секції фізичного виховання і підтверджено правильність альтернативної.

Для контрольної групи навчальної секції фізичного виховання $t$ емпіричне склало 0,2 . Критичне значення $t$ на рівні статистичної значущості 0,05 становить 2,04. Отримане емпіричне значення 
розташоване в зоні незначущості. На підставі цього зроблено висновок про правильність нульової гіпотези стосовно контрольної групи навчальної секції фізичного виховання.

Для експериментальної групи навчальної секції спортивного виховання $t$ емпіричне становить 2,4 . Критичне значення $t$ на рівні статистичної значущості 0,05 становить 2,04. Отримане емпіричне значення стало підставою для відхилення нульової гіпотези стосовно експериментальної групи навчальної секції спортивного виховання і підтвердження правильності альтернативної.

Для контрольної групи навчальної секції спортивного виховання $t$ емпіричне становить 1 . Критичне значення $t$ на рівні статистичної значущості 0,05 становить 2,04. Отримане емпіричне значення розташоване в зоні незначущості. На підставі цього зроблено висновок про правильність нульової гіпотези стосовно контрольної групи навчальної секції спортивного виховання.

Дані, отримані в ході експерименту стосовно формування особистості студентів за фактором емоційної стійкості, показують, що традиційні заняття з фізичного виховання, які проводились у контрольних групах навчальних секцій фізичного і спортивного виховання, статистично значуще не впливають на цей процес. Про це свідчить той факт, що в студентів контрольних груп, які в них навчались протягом 2 років, не відбулося статистично значущого зростання показників за фактором. На нашу думку, у контрольній групі навчальної секції фізичного виховання це пояснюється відсутністю у іiі роботі ефективної для формування емоційної стійкості навчальної діяльності. У контрольній групі навчальної секції спортивного виховання причини інші. В іiі роботі була використана ефективна для розвитку емоційної стійкості діяльність - спортивні змагання. Але її виявилось недостатньо для того, щоб у студентів протягом 2 років відбулися статистично значущі зсуви. Очевидно, потрібно більше часу для досягнення позитивної динаміки.

Статистично значуще зростання показників емоційної стійкості у студентів експериментальних груп ми пояснюємо реалізацією у їх роботі основ психологічної і психофізичної підготовки, у ході якої забезпечувалося:

а) набуття студентами досвіду участі в стресогенній діяльності (завдяки участі у спортивних змаганнях); 
б) освоєння студентами навиків саморегуляції психічного стану (завдяки включенню до структури ряду занять аутогенного тренування);

в) набуття знань відносно можливості використання копінгстратегій у емоціогенних ситуаціях (завдяки включенню до програми занять блоку психологічної просвіти, у яких відображено ці питання).

На нашу думку, саме це визначило суттєве зростання емоційної стійкості у студентів експериментальних груп.

У той же час, виявлено й відмінності динаміки показників емоційної стійкості у студентів експериментальних груп. В експериментальній групі навчальної секції фізичного виховання зафіксовано більш суттєве зростання показників за фактором ( $t$ емпіричне склало 3) порівняно з експериментальною групою навчальної секції спортивного виховання ( $t$ емпіричне склало 2,4$)$. При цьому вихідний рівень показників емоційної стійкості в експериментальній групі навчальної секції спортивного виховання був суттєво вищим. Середнє арифметичне показників у ній до початку експерименту складало 6,15. В експериментальній групі навчальної секції фізичного виховання середнє арифметичне показників до початку експерименту складало 5,03.

На нашу думку, виявлені реалії пояснюються силою впливу на фактор емоційної стійкості особистості такого чинника, як набуття досвіду участі у стресогенній діяльності під час спортивних змагань. У студентів експериментальної групи навчальної секції фізичного виховання досвіду участі в змаганнях до початку експерименту не було. Його набуття цими студентами в ході експерименту здійснило порівняно більший вплив на їх емоційну стійкість, ніж у студентів експериментальної групи з навчальної секції спортивного виховання, які мали такий досвід. Це пояснюється тим, що, на нашу думку, набуття досвіду участі в спортивних змаганнях на початковому етапі спортивної кар'єри більш суттєво впливає на формування емоційної стійкості особистості, ніж на наступних етапах. Для більш суттєвого впливу на зростання рівня емоційної стійкості на цих етапах необхідно застосовувати в ході занять додаткові (ефективні у цьому плані) засоби. Це й було реалізовано в ході навчального процесу в експериментальній групі навчальної секції спортивного виховання завдяки включенню до нього блоку психологічної і психофізичної підготовки. Окрім сказаного, слід враховувати, що рівень «стресогенності» 
спортивних змагань $є$ різним (та ще й різним для різних людей). Відповідною $\epsilon$ і сила впливу на особистість і межі ії адаптації до цих впливів. Участь у одних змаганнях може сприяти набуттю досвіду участі в стресогенній діяльності, а в інших - суттєво не впливати на цей процес.

На користь правильності такого припущення свідчать дані, отримані в контрольних групах навчальних секцій фізичного виховання і спортивного виховання. Так, вихідний рівень за фактором емоційної стійкості у студентів контрольної групи навчальної секції спортивного виховання був суттєво вищим порівняно зі студентами контрольної групи навчальної секції фізичного виховання (середнє арифметичне показників складало відповідно 6,21 і 5,06). У студентів, які входили до першої групи, через специфіку ії комплектування, був досвід участі у спортивних змаганнях. Студенти другої групи такого досвіду не мали. Вихідну різницю показників доцільно пояснити впливом саме цього чинника. По закінченні експерименту середнє арифметичне показників студентів у навчальній секції спортивного виховання складало 6,3 , а у студентів 3 навчальної секції фізичного виховання 5,09 . Порівняно краща динаміка (хоч і не статистично значуща) була зафіксована у студентів навчальної секції спортивного виховання. Ці студенти в ході експерименту брали участь у спортивних змаганнях. Студенти контрольної групи навчальної секції фізичного виховання в ході експерименту досвіду участі у спортивних змаганнях не набували. Різницю в рівні динаміки показників студентів цих груп також доцільно пояснити наявністю (у першому випадку) і відсутністю (у другому випадку) спортивних змагань у їх навчальній діяльності.

У той же час в контрольній групі навчальної секції спортивного виховання не застосовувалися ті засоби психологічної і психофізичної підготовки, які було використано (окрім участі у спортивних змаганнях) в навчальній діяльності експериментальної групи навчальної секції фізичного виховання. Досвід участі в спортивних змаганнях мали студенти обох груп. Статистично значущі зміни показників за фактором емоційної стійкості виявлено тільки в студентів експериментальної групи. Різницю в динаміці показників у студентів цих груп доцільно пояснити впливом чинника психологічної і психофізичної підготовки, який був задіяний у навчальній діяльності експериментальної групи. Ми припускаємо, що в контрольній групі навчальної секції спортивного виховання теж відбулися б статистично зна- 
чущі зміни в динаміці розвитку емоційної стійкості під впливом розширення досвіду участі у спортивних змаганнях, але для цього потрібен був би більш тривалий час ніж той, який був визначений у експерименті.

За фактором «схильність до почуттів - висока нормативність поведінки» також виявлено статистично значущі зміни показників у студентів двох експериментальних груп. У контрольних групах таких змін не зафіксовано. Зміни статистичних показників за цим фактором наведені в табл. 17.

Таблиия 17

Статистичні показники експериментальної і контрольної груп навчальної секції фізичного виховання до і після експерименту за фактором «схильність до почуттів - висока нормативність поведінки»

\begin{tabular}{|c|c|c|c|c|}
\hline \multirow[b]{2}{*}{ Показник } & \multicolumn{2}{|c|}{ Експериментальна група } & \multicolumn{2}{|c|}{ Контрольна група } \\
\hline & $\begin{array}{c}\text { До } \\
\text { експерименту }\end{array}$ & $\begin{array}{c}\text { Після } \\
\text { експерименту }\end{array}$ & $\begin{array}{c}\text { До } \\
\text { експерименту }\end{array}$ & $\begin{array}{c}\text { Після } \\
\text { експерименту }\end{array}$ \\
\hline $\begin{array}{l}\text { Середнє арифмети- } \\
\text { чне }\end{array}$ & 6,51 & 6,69 & 6,6 & 6,69 \\
\hline Медіана & 7 & 7 & 7 & 7 \\
\hline Мода & 8 & 8 & 7 & 7 \\
\hline $\begin{array}{c}\text { Стандартне } \text { відхи- } \\
\text { лення }\end{array}$ & 2 & 1,79 & 2,3 & 2,05 \\
\hline
\end{tabular}

За інтервалами групування в ході експерименту в групах відбулися такі зміни. В експериментальній групі до початку експерименту низький рівень показників за фактором «схильність до почуттів - висока нормативність поведінки» було зафіксовано в 3 студентів, що складало 9 \%. По закінченні експерименту таких студентів залишилось 2 , що становило $6 \%$. Зменшення чисельності відбулось за рахунок виходу на більш високий рівень 1 студента. У контрольній групі до початку експерименту низькі показники за фактором показали 4 студенти (12\%), після закінчення експерименту такі показники виявлено у 3 студентів (9 \%). Зменшення чисельності також відбулось за рахунок виходу на більш високий рівень 1 студента.

Результати середнього рівня за фактором «схильність до почуттів - висока нормативність поведінки» в експериментальній групі навчальної секції фізичного виховання до початку експерименту було 
виявлено в 10 студентів, що складало 30 \%. По закінченні експерименту таких студентів було також 10 (30 \%). При цьому один студент піднявся на цей рівень із більш низького, а один піднявся з цього рівня на більш високий. У контрольній групі навчальної секції фізичного виховання до початку експерименту середні показники за фактором було виявлено у 8 студентів (24\%). По закінченні експерименту студентів з такими показниками було виявлено 9, що склало $27 \%$. Збільшення чисельності відбулось за рахунок виходу на цей рівень (із більш низького) одного студента.

Високий рівень результатів за фактором до початку експерименту в експериментальній групі навчальної секції фізичного виховання було зафіксовано у 20 студентів, що складало 61 \%. По закінченні експерименту таких студентів стало 21 , що склало 64 \%. Збільшення чисельності відбулось за рахунок виходу на цей рівень (із більш низького) одного студента. У контрольній групі навчальної секції фізичного виховання до початку експерименту високі результати за фактором показав 21 студент (64 \%). По закінченні експерименту студентів 3 такими показниками було виявлено також 21 (64 \%). Кількісних змін у групі на цьому рівні не відбулось.

Статистичні показники для навчальної секції спортивного виховання наведено в табл. 18.

Табличяя 18

Статистичні показники експериментальної і контрольної груп навчальної секції спортивного виховання до і після експерименту за фактором «схильність до почуттів - висока нормативність поведінки»

\begin{tabular}{|c|c|c|c|c|}
\hline \multirow[b]{2}{*}{ Показник } & \multicolumn{2}{|c|}{ Експериментальна група } & \multicolumn{2}{|c|}{ Контрольна група } \\
\hline & $\begin{array}{c}\text { До } \\
\text { експерименту }\end{array}$ & $\begin{array}{c}\text { Після } \\
\text { експерименту }\end{array}$ & $\begin{array}{c}\text { До } \\
\text { експерименту }\end{array}$ & $\begin{array}{c}\text { Після } \\
\text { експерименту }\end{array}$ \\
\hline $\begin{array}{l}\text { Середнє арифмети- } \\
\text { чне }\end{array}$ & 7 & 7,21 & 6,93 & 7 \\
\hline Медіана & 8 & 8 & 7 & 7 \\
\hline Мода & 8 & 8 & 7 & 8 \\
\hline $\begin{array}{c}\text { Стандартне } \text { відхи- } \\
\text { лення }\end{array}$ & 2,15 & 1.86 & 2,03 & 1,88 \\
\hline
\end{tabular}

В експериментальній групі навчальної секції спортивного виховання до початку експерименту низький рівень показників за факто- 
ром «схильність до почуттів - висока нормативність поведінки» було виявлено у 2 студентів (6 \%). По закінченні експерименту таких студентів не виявлено. Відбувся вихід на більш високий рівень 2 студентів. У контрольній групі навчальної секції спортивного виховання до початку експерименту низькі показники за фактором було зафіксовано у 1 студента (3\%). По закінченні експерименту кількість таких студентів не змінилась. Кількісних змін на цьому рівні в контрольній групі не відбулось.

Результати середнього рівня за фактором в експериментальній групі навчальної секції спортивного виховання до початку експерименту було зафіксовано у 10 студентів (30\%). По закінченні експерименту таких студентів виявилось 11 (33\%). Двоє студентів піднялися на цей рівень із більш низького і один студент піднявся 3 цього рівня на більш високий. У контрольній групі навчальної секції спортивного виховання до початку експерименту результати середнього рівня продемонстрували 12 студентів (36 \%). По закінченні експерименту результатів цього рівня виявилось 9 (27 \%). Троє студентів піднялися 3 цього рівня на більш високий.

Високий рівень результатів за фактором «схильність до почуттів висока нормативність поведінки» в експериментальній групі навчальної секції спортивного виховання до початку експерименту виявлено у 21 студента (64\%). По закінченні експерименту таких студентів стало 22 (67\%). Констатуємо кількісне покращення на цьому рівні. У контрольній групі навчальної секції спортивного виховання до початку експерименту високі показники за фатором було зафіксовано у 20 студентів (61\%). По закінченні експерименту таких студентів виявилось 21 (64\%). Констатуємо кількісне покращення на цьому рівні.

Вторинну статистичну обробку отриманих даних проведено 3 використанням $t$-критерію Стьюдента для залежних вибірок. Встановлено таке. Для експериментальної групи навчальної секції фізичного виховання $t$ емпіричне становить 2,3 . Критичним значенням $t$ на рівні статистичної значущості 0,05 є 2,04. Отримане емпіричне значення дає підстави для відхилення нульової гіпотези стосовно експериментальної групи навчальної секції фізичного виховання і підтвердження правильності альтернативної.

Для контрольної групи навчальної секції фізичного виховання $t$ емпіричне становить 0,7 . Критичне значення $t$ на рівні статистичної 
значущості 0,05 становить 2,04. Отримане емпіричне значення розташоване в зоні незначущості. На підставі цього зроблено висновок про правильність нульової гіпотези стосовно контрольної групи навчальної секції фізичного виховання.

Для експериментальної групи навчальної секції спортивного виховання $t$ емпіричне становить 3 . Критичне значення $t$ на рівні статистичної значущості 0,01 становить 2,74. Отримане емпіричне значення розташоване в зоні значущості. На підставі цього відхилено нульову гіпотезу стосовно експериментальної групи навчальної секції спортивного виховання й підтверджено правильність альтернативної.

Для контрольної групи навчальної секції спортивного виховання $t$ емпіричне становить 0,4 . Критичне значення $t$ на рівні статистичної значущості 0,05 становить 2,04. Отримане емпіричне значення розташоване в зоні незначущості. На підставі цього зроблено висновок про правильність нульової гіпотези стосовно контрольної групи навчальної секції спортивного виховання.

Результати формувального експерименту, які наведено вище, показують, що традиційні заняття з фізичного виховання (проводились у 2 контрольних групах) не мають статистично значущого впливу на формування особистості за фактором «схильність до почуттів - висока нормативність поведінки». Ми пояснюємо це відсутністю в структурі таких занять ефективної для розвитку цього фактора навчальної діяльності студентів, відсутністю її планування і організації.

Статистично значуще зростання показників за фактором «схильність до почуттів - висока нормативність поведінки» в 2 експериментальних групах пояснюється включенням до змісту їх навчальної діяльності основ психологічної і психофізичної підготовки. Позитивний вплив на формування особистості студентів за фактором «схильність до почуттів - висока нормативність поведінки» визначило використання в навчальній діяльності цих груп таких складових психологічної і психофізичної підготовки як:

а) освоєння навиків саморегуляції психічного стану (аутогенне тренування), у ході якого у студентів вдосконалювалася здатність управляти своїм емоційним станом і відповідно підвищувати нормативність своєї поведінки;

б) постійні заняття професійно значущими видами спорту (у ході яких студентам доводилося підпорядковувати свою поведінку під 
правила змагань і інтереси своєї команди, у них формувалися необхідні для високої нормативності поведінки особистості вольові якості);

в) участь у спортивних змаганнях 3 професійно значущих видів спорту (розширювала особистий досвід нормативної поведінки особистості під час переживання нею різних емоційних станів і почуттів).

Виявлено також і відмінності динаміки показників особистості за фактором «схильність до почуттів - висока нормативність поведінки». В експериментальній групі з навчальної секції спортивного виховання зафіксовано більш суттєве зростання показників ( $t$ емпіричне склало 3) порівняно з експериментальною групою з навчальної секції фізичного виховання ( $t$ емпіричне склало 2,3 ). На нашу думку, це пояснюється, $з$ одного боку, суттєво більшим досвідом занять спортом i, як наслідок, вищою нормативністю поведінки у студентів експериментальної групи навчальної секції спортивного виховання (середнє арифметичне показників до початку експерименту становило 7) порівняно зі студентами експериментальної групи навчальної секції фізичного виховання (середнє арифметичне показників до початку експерименту становило 6,51). Отже, набуття досвіду занять спортом, яке відбулось в ході експерименту в студентів обох груп, у студентів експериментальної групи з навчальної секції спортивного виховання проходило на більш високому рівні, що й вплинуло більше на особистість цих студентів за фактором «схильність до почуттів - висока нормативність поведінки». 3 іншого боку, відмінність отриманого результату в цих групах пояснюється більш якісним освоєнням навиків саморегуляції психічного стану, яке показали студенти експериментальної групи з навчальної секції спортивного виховання порівняно зі студентами з експериментальної групи навчальної секції фізичного виховання. Це допомагає їм більшою мірою «регулювати» нормативність власної поведінки.

Статистично значущі зміни у студентів двох експериментальних груп виявлено і за фактором «впевненість в собі - тривожність». У студентів, які входили до складу двох контрольних груп таких змін не виявлено. Статистичні показники за цим фактором для студентів навчальної секції фізичного виховання наведено в табл. 19. 
Статистичні показники експериментальної і контрольної груп навчальної секції фізичного виховання до і після експерименту за фактором «впевненість у собі - тривожність»

\begin{tabular}{|c|c|c|c|c|}
\hline \multirow[b]{2}{*}{ Показник } & \multicolumn{2}{|c|}{ Експериментальна група } & \multicolumn{2}{|c|}{ Контрольна група } \\
\hline & $\begin{array}{c}\text { До } \\
\text { експерименту }\end{array}$ & $\begin{array}{c}\text { Після } \\
\text { експерименту }\end{array}$ & $\begin{array}{c}\text { До } \\
\text { експерименту }\end{array}$ & $\begin{array}{c}\text { Після } \\
\text { експерименту }\end{array}$ \\
\hline $\begin{array}{l}\text { Середнє арифмети- } \\
\text { чне }\end{array}$ & 6,48 & 6,33 & 6,39 & 6,3 \\
\hline Медіана & 7 & 7 & 6 & 6 \\
\hline Мода & 7 & 7 & 10 & 6 \\
\hline $\begin{array}{c}\text { Стандартне } \text { відхи- } \\
\text { лення }\end{array}$ & 2,38 & 2,25 & 2,64 & 2,56 \\
\hline
\end{tabular}

За інтервалами групування динаміка змін за фактором «впевненість у собі - тривожність» мала такий вигляд. В експериментальній групі навчальної секції фізичного виховання до початку експерименту низький рівень показників за фактором було зафіксовано у 4 студентів, що склало 12 \%. По закінченні експерименту таких студентів залишилось також 4 (12\%). Кількісних змін у групі на цьому рівні не відбулось. У контрольній групі навчальної секції фізичного виховання до початку експерименту низький рівень показників за фактором виявлено у 6 студентів, що склало 18 \%. По закінченні експерименту таких студентів було також 6 (18 \%). Кількісних змін у групі на цьому рівні не відбулось.

Результати середнього рівня за фактором в експериментальній групі навчальної секції фізичного виховання до початку експерименту було зафіксовано у 9 студентів, що склало $27 \%$. По закінченні експерименту таких студентів стало 10 (30 \%). Збільшення чисельності відбулось за рахунок опускання на цей рівень (із більш високого) одного студента. Констатуємо покращення в групі кількісного результату на цьому рівні. У контрольній групі навчальної секції фізичного виховання до початку експерименту середні показники за фактором зафіксовано у 11 студентів, що склало 33 \%. По закінченні експерименту показник не змінився. Кількісних змін у групі на цьому рівні не відбулось. 
Високий рівень показників за фактором «впевненість у собі - тривожність» до початку експерименту в експериментальній групі навчальної секції фізичного виховання виявлено у 20 студентів, що склало 61 \%. По закінченні експерименту таких студентів стало 19 (58 \%). Зменшення чисельності відбулося за рахунок опускання 3 цього рівня на нижчий одного студента. У контрольній групі навчальної секції фізичного виховання до початку експерименту високі результати за фактором було виявлено у 16 студентів, що склало 49 \%. По закінченні експерименту студентів 3 такими показниками було також 16 (49 \%). Кількісних змін у групі на цьому рівні не відбулось.

Статистичні показники за фактором «впевненість у собі - тривожність» для навчальної секції спортивного виховання наведено в табл. 20.

Табличя 20

Статистичні показники експериментальної і контрольної груп навчальної секції спортивного виховання до і після експерименту за фактором «впевненість у собі - тривожність»

\begin{tabular}{l|c|c|c|c}
\hline \multirow{2}{*}{ Показник } & \multicolumn{2}{|c|}{ Експериментальна група } & \multicolumn{2}{c}{ Контрольна група } \\
\cline { 2 - 5 } & $\begin{array}{c}\text { До } \\
\text { експерименту }\end{array}$ & $\begin{array}{c}\text { Після } \\
\text { експерименту }\end{array}$ & $\begin{array}{c}\text { До } \\
\text { експерименту }\end{array}$ & $\begin{array}{c}\text { Після } \\
\text { експерименту }\end{array}$ \\
\hline $\begin{array}{l}\text { Середнє арифмети- } \\
\text { чне }\end{array}$ & 6,48 & 6,27 & 6,42 & 6,36 \\
$\begin{array}{l}\text { Медіана } \\
\text { Мода }\end{array}$ & 6 & 6 & 6 & 6 \\
$\begin{array}{l}\text { Стандартне відхи- } \\
\text { лення }\end{array}$ & 2,26 & 6 & 6 & 6 \\
\end{tabular}

За інтервалами групування динаміка змін за фактором «впевненість у собі - тривожність» була такою. В експериментальній групі навчальної секції спортивного виховання до початку і по закінченні експерименту низький рівень за фактором зафіксовано у 4 студентів, що склало $12 \%$. Кількісних змін у групі на цьому рівні не відбулось. У контрольній групі навчальної секції спортивного виховання до початку експерименту низькі показники за фактором було зафіксовано у 5 студентів, що склало 15 \%. По закінченні експерименту таких 
студентів було 6 (18 \%). Збільшення чисельності відбулося за рахунок зміщення на цей рівень із більш високого одного студента.

Результати середнього рівня за фактором в експериментальній групі навчальної секції спортивного виховання до початку експерименту було зафіксовано у 16 студентів, що склало 49 \%. По закінченні експерименту 17 студентів продемонстрували результати на середньому рівні, що становило 52 \%. Збільшення чисельності студентів відбулося за рахунок зміщення на цей рівень із більш високого одного студента. У контрольній групі навчальної секції спортивного виховання до початку експерименту результати середнього рівня за фактором показали 14 студентів, що склало 42,5 \%. По закінченні експерименту результатів на цьому рівні в групі зафіксовано також 14 (43 \%). Кількісних змін у групі на цьому рівні не відбулося.

Високий рівень результатів за фактором «впевненість у собі - тривожність» в експериментальній групі навчальної секції спортивного виховання до початку експерименту зафіксовано у 13 студентів, що склало 39 \%. По закінченні експерименту 12 студентів показали результати на цьому рівні, що склало 36 \%. Зменшення чисельності відбулося за рахунок опускання з цього рівня на нижчий одного студента. У контрольній групі навчальної секції спортивного виховання до початку експерименту високі показники за фактором зафіксовано у 14 студентів (42,5\%). По закінченні експерименту таких студентів було 13 (39 \%). Зменшення чисельності відбулось за рахунок опускання з цього рівня на нижчий одного студента.

Вторинну статистичну обробку отриманих за фактором «впевненість у собі - тривожність» даних виконано з використанням $t$-критерію Стьюдента для залежних вибірок. Встановлено, що для експериментальної групи навчальної секції фізичного виховання $t$ емпіричне становить 2,5 . Критичним значенням $t$ на рівні статистичної значущості 0,05 є 2,04. Отримане емпіричне значення дало підстави для відхилення нульової гіпотези стосовно експериментальної групи навчальної секції фізичного виховання й підтвердження правильності альтернативної.

Для контрольної групи навчальної секції фізичного виховання $t$ емпіричне становить 0,3 . Критичним значенням $t$ на рівні статистичної значущості $0,05 € 2,04$. Отримане емпіричне значення розташоване в зоні незначущості. На підставі цього зроблено висновок про 
правильність нульової гіпотези стосовно контрольної групи 3 навчальної секції фізичного виховання.

Для експериментальної групи навчальної секції спортивного виховання $t$ емпіричне становить 2,7 . Критичне значення $t$ на рівні статистичної значущості 0,05 становить 2,04. Отримане емпіричне значення дає підстави для відхилення нульової гіпотези стосовно експериментальної групи навчальної секції спортивного виховання й підтвердження правильності альтернативної.

Для контрольної групи навчальної секції спортивного виховання $t$ емпіричне становить 0,5 . Критичним значенням $t$ на рівні статистичної значущості $0,05 \in 2,04$. Отримане емпіричне значення розташоване в зоні незначущості. На підставі цього зроблено висновок про правильність нульової гіпотези стосовно контрольної групи навчальної секції спортивного виховання.

Дані, отримані в ході експерименту щодо формування особистості студентів за фактором «впевненість у собі - тривожність», свідчать про неефективність традиційних занять 3 фізичного виховання для вирішення цього завдання. Про це, зокрема, можна судити за тим фактом, що в студентів двох контрольних груп, де такі заняття проводилися протягом 2 років, не відбулося статистично значущого зниження показників за фактором.

На відміну від контрольних, у експериментальних групах статистично значуще зниження показників за фактором «впевненість у собі - тривожність» виявлено. На нашу думку, це відбулось завдяки доповненню навчальної діяльності студентів під час навчальних занять 3 фізичного виховання блоком психологічної і психофізичної підготовки. Насамперед це стосується таких його складових, як виконання вправ для розвитку навиків саморегуляції психічного стану, вивчення розділу психологічної просвіти (у ході якого студентами було засвоєно низку копінг-статегій для вироблення доцільної поведінки в стресових ситуаціях), заняття професійно значущими видами спорту, участь у спортивних змаганнях з професійно значущих видів спорту.

Звертає на себе увагу близька за величиною динаміка змін в експериментальних групах ( $t$ емпіричне в експериментальній групі навчальної секції фізичного виховання становить 2,5 а в експериментальній групі навчальної секції спортивного виховання - 2,7). Ми пояснюємо це вирішальним впливом на формування особистості за фактором «впевненість у собі - тривожність» таких чинників, як 
виконання вправ для розвитку навиків саморегуляції психічного стану й вивчення розділу психологічної просвіти. Вони однаковою мірою були новими для студентів обох експериментальних груп, у той час як досвід занять спортом у студентів експериментальної групи навчальної секції спортивного виховання був значно більшим.

У студентів двох експериментальних груп у ході експерименту виявлено також статистично значущі зміни за фактором «низький самоконтроль - високий самоконтроль». У студентів двох контрольних груп таких значущих змін не зафіксовано (табл. 21, 22).

Таблиця 21

Статистичні показники експериментальної і контрольної груп навчальної секції фізичного виховання до і після експерименту за фактором «низький самоконтроль - високий самоконтроль»

\begin{tabular}{|c|c|c|c|c|}
\hline \multirow[b]{2}{*}{ Показник } & \multicolumn{2}{|c|}{ Експериментальна група } & \multicolumn{2}{|c|}{ Контрольна група } \\
\hline & $\begin{array}{c}\text { До } \\
\text { експерименту }\end{array}$ & $\begin{array}{c}\text { Після } \\
\text { експерименту }\end{array}$ & $\begin{array}{c}\text { До } \\
\text { експерименту }\end{array}$ & $\begin{array}{c}\text { Після } \\
\text { експерименту }\end{array}$ \\
\hline $\begin{array}{l}\text { Середнє арифмети- } \\
\text { чне }\end{array}$ & 5,87 & 6,15 & 5,81 & 5,87 \\
\hline Медіана & 6 & 6 & 6 & 6 \\
\hline Мода & 5 & 7 & 4 & 4 \\
\hline $\begin{array}{c}\text { Стандартне } \text { відхи- } \\
\text { лення }\end{array}$ & 2,21 & 2,12 & 2,45 & 2,3 \\
\hline
\end{tabular}

За інтервалами групування динаміка змін за фактором «низький самоконтроль - високий самоконтроль» була такою. В експериментальній групі навчальної секції фізичного виховання до початку експерименту низький рівень показників за фактором зафіксовано у 4 студентів, що склало $12 \%$. По закінченні експерименту таких студентів було також 4 (12\%). Кількісних змін у групі на цьому рівні не відбулося. Для контрольної групи маємо точно такі ж результати.

Результати середнього рівня за фактором в експериментальній грцпі навчальної секції фізичного виховання до початку експерименту було виявлено у 17 студентів, що склало 52 \%. По закінченні експерименту таких студентів стало 14 (42\%). Зменшення чисельності відбулось за рахунок переходу з цього рівня на більш високий 3 студентів. У контрольній групі навчальної секції фізичного виховання до 
початку експерименту середні показники за фактором показали 18 студентів, що склало 55 \%. По закінченні експерименту таких студентів стало 17 (52 \%). Зменшення чисельності відбулось за рахунок виходу з цього рівня на більш високий одного студента.

Високий рівень показників за фактором до початку експерименту в експериментальній групі навчальної секції фізичного виховання зафіксовано у 12 студентів, що склало 36 \%. По закінченні експерименту таких студентів стало 15, або 46 \%. Збільшення чисельності на цьому рівні відбулось за рахунок зміщення на цей рівень 3 більш низького 3 студентів. У контрольній групі навчальної секції фізичного виховання до початку експерименту високі результати за фактором зафіксовано у 11 студентів, що склало $33 \%$. По закінченні експерименту таких студентів стало 12 (36 \%). Збільшення чисельності в групі на цьому рівні відбулося за рахунок зміщення на цей рівень із більш низького одного студента.

Таблиия 22

Статистичні показники експериментальної і контрольної груп навчальної секції спортивного виховання до і після експерименту за фактором «низький самоконтроль - високий самоконтроль»

\begin{tabular}{|c|c|c|c|c|}
\hline \multirow{2}{*}{ Показник } & \multicolumn{2}{|c|}{ Експериментальна група } & \multicolumn{2}{|c|}{ Контрольна група } \\
\hline & $\begin{array}{c}\text { До } \\
\text { експерименту }\end{array}$ & $\begin{array}{c}\text { Після } \\
\text { експерименту }\end{array}$ & $\begin{array}{c}\text { До } \\
\text { експерименту }\end{array}$ & $\begin{array}{c}\text { Після } \\
\text { експерименту }\end{array}$ \\
\hline $\begin{array}{l}\text { Середнє арифмети- } \\
\text { чне }\end{array}$ & 6,36 & 6,69 & 6,39 & 6,45 \\
\hline Медіана & 7 & 7 & 6 & 6 \\
\hline Мода & 6 & 6 & 6 & 6 \\
\hline $\begin{array}{l}\text { Стандартне відхи- } \\
\text { лення }\end{array}$ & 2,3 & 1,82 & 2,46 & 2,42 \\
\hline
\end{tabular}

За інтервалами групування розподіл студентів навчальної секції спортивного виховання такий. В експериментальній групі низький рівень показників за фактором перед початком експерименту виявлено у 5 студентів (15\%). По закінченні експерименту таких студентів стало 2 (6 \%). Зменшення чисельності відбулося за рахунок зміщення 3 цього рівня на більш високий 3 студентів. У контрольній групі навчальної секції спортивного виховання до початку експерименту 
низький рівень показників за фактором було зафіксовано у 6 студентів (18\%). По закінченні експерименту кількість студентів на цьому рівні не змінилася.

Середній рівень результатів за фактором в експериментальній групі навчальної секції спортивного виховання до початку експерименту було зафіксовано у 11 студентів, що склало 33 \%. По закінченні експерименту таких студентів стало 14 (42\%). Збільшення чисельності відбулося за рахунок переходу на цей рівень із більш низького 3 студентів. У контрольній групі навчальної секції спортивного виховання до початку експерименту результати середнього рівня за фактором показали 12 студентів, що склало 36 \%. По закінченні експерименту результатів на цьому рівні в групі стало 11 (33\%). Зменшення чисельності відбулося за рахунок переходу з цього рівня на більш високий одного студента.

Високий рівень результатів за фактором «низький самоконтроль високий самоконтроль» в експериментальній групі навчальної секції спортивного виховання як до початку експерименту, так і по його закінченні було зафіксовано у 17 студентів, що склало 52 \%. Кількісних змін у групі на цьому рівні не відбулося. У контрольній групі навчальної секції спортивного виховання до початку експерименту високі показники за фактором виявлено у 15 студентів, що склало $46 \%$. По закінченні експерименту таких студентів стало 16 (49 \%). Збільшення чисельності відбулось за рахунок переходу на цей рівень із більш низького одного студента.

Вторинну статистичну обробку даних, отриманих у дослідженні за фактором «низький самоконтроль - високий самоконтроль», виконано 3 використанням $t$-критерію Стьюдента для залежних вибірок. Встановлено, що для експериментальної групи навчальної секції фізичного виховання $t$ емпіричне становить 3,4 . Критичним значенням $t$ на рівні статистичної значущості $0,01 \in 2,74$. Отримане емпіричне значення розташоване в зоні значущості. На підставі цього відхилено нульову гіпотезу стосовно експериментальної групи навчальної секції фізичного виховання й підтверджено правильність альтернативної.

Для контрольної групи навчальної секції фізичного виховання $t$ емпіричне становить 0,8 . Критичним значенням $t$ на рівні статистичної значущості 0,05 є 2,04 . Отримане емпіричне значення розташоване в зоні незначущості. На підставі цього зроблено висновок про 
правильність нульової гіпотези стосовно контрольної групи навчальної секції фізичного виховання.

Для експериментальної групи навчальної секції спортивного виховання $t$ емпіричне становить 2,8 . Критичним значенням $t$ на рівні статистичної значущості $0,01 \in 2,74$. Отримане емпіричне значення розташоване в зоні значущості. На підставі цього відхилено нульову гіпотезу стосовно експериментальної групи навчальної секції спортивного виховання й підтверджено правильність альтернативної.

Для контрольної групи навчальної секції спортивного виховання $t$ емпіричне становить 1,5 . Критичним значенням $t$ на рівні статистичної значущості $0,05 \in 2,04$. Отримане емпіричне значення розташоване в зоні незначущості. На підставі цього зроблено висновок про правильність нульової гіпотези стосовно контрольної групи навчальної секції спортивного виховання.

Аналіз результатів експерименту стосовно формування особистості студентів за фактором «низький самоконтроль - високий самоконтроль» показує, що традиційні заняття, як і у вищеописаних випадках за іншими факторами, статистично значуще не впливають на цей процес. Підтвердженням цього є статистичні дані, отримані в ході експерименту у двох контрольних групах, де проводились такі заняття. Водночас, у ході експерименту отримано й дані про ефективність використання навчальних занять 3 фізичного виховання для формування особистості студентів за фактором «низький самоконтроль - високий самоконтроль» за умови реалізації в ході навчального процесу основ психологічної і психофізичної підготовки. Це підтверджують статистичні дані двох експериментальних групах, де таку підготовку зі студентами було проведено. Ми пояснюємо це позитивним впливом на формування особистості за фактором таких складових психологічної і психофізичної підготовки як:

a) використання вправ для формування навиків саморегуляції психічного стану;

б) участь у спортивних змаганнях з професійно значущих видів спорту;

в) вивчення теоретичного матеріалу, включеного до розділу психологічної просвіти.

За фактором «адекватність самооцінки» також виявлено статистично значущі зміни показників у студентів двох експериментальних груп (табл. 23, 24). 
Статистичні показники експериментальної і контрольної груп навчальної секції фізичного виховання до і після експерименту за фактором «адекватність самооцінки»

\begin{tabular}{|c|c|c|c|c|}
\hline \multirow[b]{2}{*}{ Показник } & \multicolumn{2}{|c|}{ Експериментальна група } & \multicolumn{2}{|c|}{ Контрольна група } \\
\hline & $\begin{array}{c}\text { До } \\
\text { експерименту }\end{array}$ & $\begin{array}{c}\text { Після } \\
\text { експерименту }\end{array}$ & $\begin{array}{c}\text { До } \\
\text { експерименту }\end{array}$ & $\begin{array}{c}\text { Після } \\
\text { експерименту }\end{array}$ \\
\hline $\begin{array}{l}\text { Середнє арифмети- } \\
\text { чне }\end{array}$ & 6 & 5,66 & 5,54 & 5,57 \\
\hline Медіана & 6 & 5 & 5 & 5 \\
\hline Мода & 7 & 5 & 4 & 4 \\
\hline $\begin{array}{c}\text { Стандартне } \text { відхи- } \\
\text { лення }\end{array}$ & 1,95 & 1,99 & 1,96 & 2,06 \\
\hline
\end{tabular}

За інтервалами групування динаміка змін за фактором «адекватність самооцінки» у студентів навчальної секції фізичного виховання відбувалася таким чином. В експериментальній групі до початку експерименту низький рівень показників за фактором виявлено у 2 студентів (6 \%). По закінченні експерименту кількісних змін у групі на цьому рівні не відбулось. У контрольній групі навчальної секції фізичного виховання до початку експерименту низький рівень показників за фактором виявлено у 3 студентів, що склало 9 \%. По закінченні експерименту таких студентів було також 3 (9\%).

Результати середнього рівня за фактором в експериментальній групі навчальної секції фізичного виховання до початку експерименту зафіксовано у 16 студентів, що склало 49 \%. По закінченні експерименту таких студентів стало 21 (64 \%). Збільшення чисельності відбулося за рахунок зміщення на цей рівень з більш високого 5 студентів. У контрольній групі навчальної секції фізичного виховання до початку експерименту середні показники за фактором було виявлено у 18 студентів, що склало 55 \%. По закінченні експерименту таких студентів стало 17 (52 \%). Зменшення чисельності відбулося за рахунок виходу з цього рівня на більш високий одного студента.

Високий рівень показників за фактором до початку експерименту в експериментальній групі навчальної секції фізичного виховання було встановлено у 15 студентів, що склало 45 \%. По закінченні експерименту таких студентів стало 10 (30 \%). Зменшення чисельності 
в групі на цьому рівні відбулося за рахунок зміщення з цього рівня на більш низький 5 студентів. У контрольній групі навчальної секції фізичного виховання до початку експерименту високі показники за фактором зафіксовано у 12 студентів, що склало 36 \%. По закінченні експерименту таких студентів стало 13 (39 \%). Збільшення чисельності відбулося за рахунок переходу на цей рівень із більш низького одного студента.

Таблиия 24

Статистичні показники експериментальної і контрольної груп навчальної секції спортивного виховання до і після експерименту за фактором «адекватність самооцінки»

\begin{tabular}{|c|c|c|c|c|}
\hline \multirow{2}{*}{ Показник } & \multicolumn{2}{|c|}{ Експериментальна група } & \multicolumn{2}{|c|}{ Контрольна група } \\
\hline & $\begin{array}{c}\text { До } \\
\text { експерименту }\end{array}$ & $\begin{array}{c}\text { Після } \\
\text { експерименту }\end{array}$ & $\begin{array}{c}\text { До } \\
\text { експерименту }\end{array}$ & $\begin{array}{c}\text { Після } \\
\text { експерименту }\end{array}$ \\
\hline $\begin{array}{l}\text { Середнє арифмети- } \\
\text { чне }\end{array}$ & 6,18 & 5,72 & 6,12 & 6,18 \\
\hline Медіана & 6 & 6 & 6 & 6 \\
\hline Мода & 6 & 6 & 6 & 6 \\
\hline $\begin{array}{c}\text { Стандартне } \text { відхи- } \\
\text { лення }\end{array}$ & 2,53 & 2,03 & 2,16 & 2,06 \\
\hline
\end{tabular}

За інтервалами групування розподіл студентів навчальної секції спортивного виховання за фактором «адекватність самооцінки» був таким. В експериментальній групі низький рівень показників за фактором до початку експерименту зафіксовано у 6 студентів (18\%). По закінченні експерименту кількісних змін у групі на цьому рівні не відбулось. У контрольній групі навчальної секції спортивного виховання до початку експерименту низький рівень показників за фактором зафіксовано у 5 студентів (15\%). По закінченні експерименту таких студентів стало 4 (12 \%). Зменшення чисельності відбулось за рахунок переходу з цього рівня на більш високий одного студента.

Середній рівень результатів за фактором в експериментальній групі навчальної секції спортивного виховання до початку експерименту було зафіксовано у 13 студентів, що склало 39 \%. По закінченні експерименту таких студентів стало 14 (43\%). Збільшення чисельності відбулося за рахунок зміщення на цей рівень із більш високого одного студента. У контрольній групі навчальної секції спортивного 
виховання до початку експерименту результати на середньому рівні за фактором показали 15 студентів, що склало 46 \%. По закінченні експерименту результатів на цьому рівні в групі стало 16 (49 \%). Збільшення чисельності на цьому рівні відбулося за рахунок переходу на цей рівень із більш низького одного студента.

Високий рівень показників за фактором «адекватність самооцінки» в експериментальній групі навчальної секції спортивного виховання до початку експерименту було зафіксовано у 14 студентів, що склало 43 \%. По закінченні експерименту показників такого рівня було виявлено 13 (39 \%). Зменшення чисельності на цьому рівні відбулося за рахунок опускання 3 цього рівня на більш низький одного студента. У контрольній групі навчальної секції спортивного виховання до початку експерименту високі показники за фактором виявлено у 13 студентів, що склало 39 \%. По закінченні експерименту таких студентів було також 13 (39\%). Кількісних змін на цьому рівні не виявлено.

Вторинну статистичну обробку даних, отриманих за фактором «адекватність самооцінки», виконано 3 використанням $t$-критерію Стьюдента для залежних вибірок. Маємо такі результати. Для експериментальної групи навчальної секції фізичного виховання $t$ емпіричне становить 3,7 . Критичним значенням $t$ на рівні статистичної значущості $0,01 \in 2,74$. Отримане емпіричне значення розташоване в зоні значущості. На підставі цього відхилено нульову гіпотезу стосовно експериментальної групи навчальної секції фізичного виховання і підтверджено правильність альтернативної.

Для контрольної групи навчальної секції фізичного виховання $t$ емпіричне становить 0,2 . Критичним значенням $t$ на рівні статистичної значущості $0,05 € 2,04$. Отримане емпіричне значення розташоване в зоні незначущості. На підставі цього зроблено висновок про правильність нульової гіпотези стосовно контрольної групи навчальної секції фізичного виховання.

Для експериментальної групи навчальної секції спортивного виховання $t$ емпіричне становить 4,1 . Критичним значенням $t$ на рівні статистичної значущості $0,01 \in 2,74$. Отримане емпіричне значення розташоване в зоні значущості. На підставі цього відхилено нульову гіпотезу стосовно експериментальної групи навчальної секції спортивного виховання і підтверджено правильність альтернативної. 
Для контрольної групи навчальної секції спортивного виховання $t$ емпіричне становить 1,5 . Критичним значенням $t$ на рівні статистичної значущості $0,05 \in 2,04$. Отримане емпіричне значення розташоване в зоні незначущості. На підставі цього зроблено висновок про правильність нульової гіпотези стосовно контрольної групи навчальної секції спортивного виховання.

Дані, отримані в ході експерименту стосовно формування особистості студентів за фактором «адекватність самооцінки», також показали неефективність традиційно організованого навчального процесу 3 дисципліни фізичне виховання для вирішення цього завдання. Це видно зі статистичних даних контрольних груп, де проводилися такі заняття і де не зафіксовано статистично значущого зсуву у рівні показників за фактором.

На відміну від контрольних, в експериментальних групах навчальний процес 3 фізичного виховання включав таку складову, як блок психологічної і психофізичної підготовки. Результатом цього стало суттєве зниження показників за фактором в обох експериментальних групах. Це свідчить про покращення адекватності самооцінки в цих групах і про дієвість запропонованих засобів. Ми пояснюємо отриманий результат дієвістю (у плані позитивного впливу на фактор особистості) таких складових психологічної і психофізичної підготовки, як:

а) вивчення теоретичного розділу психологічної просвіти;

б) виконання вправ для формування навиків саморегуляції психічного стану;

в) участь у спортивних змаганнях проти сильного суперника.

Звертають на себе увагу суттєво вищі вихідні показники за фактором «адекватність самооцінки» у студентів груп навчальної секції спортивного виховання порівняно зі студентами навчальної секції фізичного виховання. На нашу думку, це свідчить про дещо завищену самооцінку в студентів-спортсменів. Саме для них найбільш актуальною $є$ психологічна і психофізична підготовка, спрямована на формування особистості за фактором «адекватність самооцінки». 


\section{3. Формування у студентів копінг-стратегій як складових психологічної готовності до праці у процесі психологічної і психофізичної підготовки}

Високі вимоги до професійної діяльності сучасного фахівця, складність і великі витрати на його підготовку, у ряді випадків екстремальність умов праці, вимагають, крім іншого, відповідної психологічної і психофізичної підготовленості. В їі структурі важливе місце займають так звані «копінг-стратегії». Це пов'язано з тим, що результативність професійної діяльності у складних (а тим більше в екстремальних) умовах значною мірою залежить від сформованості у фахівців необхідних стратегій копінг-поведінки. Особливо важливими копінг-стратегії $\epsilon$ для фахівців, які у своїй професійній діяльності піддаються стресу або зазнають підвищених емоційних навантажень.

У психології під копінг-стратегією розуміють усвідомлену, раціональну, адаптивну поведінку, спрямовану на усунення або психологічне подолання критичної ситуації. Вважається, що копінг залежить від особистості людини, реальної ситуації, умов соціальної підтримки. Він проявляється в поведінці, в емоційній та пізнавальній сферах особистості. Відзначається, що психологічне значення копінгу полягає в тому, щоб ефективно адаптувати людину до вимог ситуації, дозволяючи оволодіти нею, постаратися уникнути або звикнути до неї і таким чином загасити негативну, стресову дію ситуації.

Свій внесок у вирішення завдання підготовки студентів до ефективної копінг-поведінки може зробити і така навчальна дисципліна, як фізичне виховання. Одним із завдань, яке, на думку автора, може ефективно вирішуватися в рамках психологічної і психофізичної підготовки під час навчальних занять з фізичного виховання [280, 285], $\epsilon$ підготовка студентів до ефективного використання копінг-стратегій у майбутній професійній діяльності. Про важливість вирішення цього завдання свідчить і той факт, що психологи (наприклад, Д. О. Леонтьєв) включають копінг-стратегії до структури особистісного потенціалу. Останній розглядається як інтегральна системна характеристика індивідуально-психологічних особливостей особистості, яка складає основу здатності особистості виходити зі стійких внутрішніх критеріїв і орієнтирів у своїй життєдіяльності і зберігати стабільність смислових орієнтацій і ефективність діяльності на фоні тиску і змін- 
них зовнішніх умов [210]. На нашу думку, ця складова надзвичайно важлива саме для професійної діяльності і тому повинна цілеспрямовано формуватись у вищих навчальних закладах.

При плануванні роботи щодо формування у студентів уміння ефективно використовувати копінг-стратегії необхідно мати чітке уявлення про існуючі тенденції відносно цих складових психологічної готовності до майбутньої професійної діяльності. 3'ясування цього питання дасть змогу виробити критерії і вимоги до студентів у процесі психологічної і психофізичної підготовки, розробити ефективні методики формування психологічної підготовленості до праці в процесі фізичного виховання.

У наш час проблематика копінг-поведінки людей досліджується як на матеріалі різноманітних видів діяльності, так і на матеріалі представників різних вікових і соціальних груп. Слід відзначити роботи Л. А. Александрової [8], К. І. Корнєва [168], А. І. Прихідько [299], С. І. Рассказової і Т. О. Гордеєвої [315], О. І. Склень [355], С. А. Хазової [411], I. В. Шагарової [430], G. Bouchard [455], B. Compas [458], R. Lasarus [487]. Значний інтерес викликають і такі праці, як [71, 98, 188, 375, 452, 456, 459] та багато ін. Вивчались такі питання: механізм дії копінг-стратегій, їх зв'язок з особистісними ресурсами людини та іншими психологічними характеристиками, вікові й статеві відмінності копінг-поведінки та ін. Встановлено, що для подолання стресу людина використовує власні копінг-стратегії. Їх вибір залежить від особистого досвіду та психологічних резервів.

У фізичному вихованні теж спостерігається інтерес до вивчення психологічних складових у студентів. У цьому контексті слід виділити роботу С. І. Белих [27].

У психології базовими копінг-статегіями вважаються: стратегія «вирішення проблем», стратегія «пошуку соціальної підтримки» і стратегія «уникання». Першу класифікують як активну поведінкову стратегію, застосовуючи яку людина використовує особистісні ресурси для пошуку можливих способів вирішення проблем. Друга також розглядається як активна поведінкова стратегія, за якої для вирішення проблеми людина звертається за допомогою до свого оточення (сім’я, друзі та ін.). Третю стратегію відносять до поведінкової стратегії, застосовуючи яку людина прагне уникати контакту з оточуючими, намагається витіснити необхідність розв'язання проблеми. 
Вважається, що найбільш ефективним є ситуативне використання всіх 3 стратегій.

Методику вивчення копінг-статегій розробив Е. Неim. Він виділив когнітивні, емоційні й поведінкові копінг-статегії. Ці стратегії, у свою чергу, було розподілено також на 3 групи: адаптивні варіанти копінг-поведінки, неадаптивні варіанти копінг-поведінки і відносно адаптивні варіанти копінг-поведінки. На нашу думку, методику Е. Неim доцільно використовувати і при вивченні копінг-стратегій студентів. Вона дає змогу дослідити 26 ситуаційно-специфічних варіантів копінгу. При цьому діагностична процедура не займає багато часу. Досить простою $є$ і обробка отриманих матеріалів.

Мета роботи - з'ясувати існуючі тенденції щодо використання копінг-стратегій у життєдіяльності студентів.

Завдання дослідження:

1. Виявити копінг-стратегії, які використовують студенти в когнітивній, емоційній і поведінковій сферах.

2. Виявити адаптивні, неадаптивні й відносно адаптивні копінгстратегії, які використовують студенти.

У дослідженні брали участь 600 студентів Дніпропетровського національного університету залізничного транспорту ім. акад. В. Лазаряна, з них 300 - юнаки, і 300 - дівчата. Вік учасників дослідження складав 17-19 років. Діагностика копінг-стратегій, які використовують студенти у своїй життєдіяльності, виконувалася за методикою Е. Неim в адаптації Л. І. Вассермана.

Із статистичних методів було використано групування і графічне представлення експериментальних даних. Виявлено таке.

Копінг-стратегії, які використовують юнаки та дівчата, наведено у таблицях: когнітивні - табл. 25; емоційні - табл. 26; поведінкові табл. 27.

Таблиия 25

Когнітивні копінг-стратегії, які використовують студенти (юнаки/дівчата) $(n=300)$

\begin{tabular}{l|c|c}
\hline \multicolumn{1}{c|}{ Когнітивні копінг-стратегії } & Кількість & $\%$ \\
\hline Ігнорування & $8 / 4$ & $3 / 1,33$ \\
Смиренність & $4 / 0$ & $1,5 / 0$ \\
Дисимуляція & $31 / 52$ & $10 / 17,33$
\end{tabular}


Закінчення табл. 25

\begin{tabular}{l|c|c}
\hline \multicolumn{1}{c|}{ Когнітивні копінг-стратегії } & Кількість & $\%$ \\
\hline Збереження самовладання & $78 / 66$ & $26 / 22$ \\
Проблемний аналіз & $55 / 30$ & $18 / 10$ \\
Відносність & $31 / 39$ & $10 / 13$ \\
Релігіозність & $5 / 13$ & $2 / 4,33$ \\
Розгубленість & $4 / 9$ & $1,5 / 3$ \\
Надання сенсу & $61 / 44$ & $20 / 14,66$ \\
Встановлення власної цінності & $23 / 43$ & $8 / 14,33$
\end{tabular}

Табличя 26

Емоційні копінг-стратегії, які використовують студенти (юнаки/дівчата)

$$
(n=300)
$$

\begin{tabular}{l|c|c}
\hline \multicolumn{1}{c|}{ Емоційні копінг-стратегії } & Кількість & $\%$ \\
\hline Протест & $16 / 13$ & $5,33 / 4,33$ \\
Емоційна розрядка & $0 / 9$ & $0 / 3$ \\
Придушення емоцій & $43 / 61$ & $14,33 / 20,33$ \\
Оптимізм & $210 / 174$ & $70 / 58$ \\
Пасивна кооперація & $4 / 13$ & $1,33 / 4,33$ \\
Покірність & $0 / 13$ & $0 / 4,33$ \\
Самозвинувачення & $27 / 4$ & $9 / 1,33$ \\
Агресивність & $0 / 13$ & $0 / 4,33$
\end{tabular}

Таблиця 27

Поведінкові копінг-стратегї, які використовують студенти (юнаки)

$$
(n=300)
$$

\begin{tabular}{l|c|c}
\hline \multicolumn{1}{c|}{ Поведінкові копінг-стратегії } & Кількість & $\%$ \\
\hline Відволікання & $97 / 87$ & $32,33 / 29$ \\
Альтруїзм & $12 / 30$ & $4 / 10$ \\
Активне уникнення & $27 / 65$ & $9 / 21,66$
\end{tabular}


Закінчення табл. 27

\begin{tabular}{l|c|c}
\hline \multicolumn{1}{c|}{ Поведінкові копінг-стратегії } & Кількість & $\%$ \\
\hline Компенсація & $12 / 13$ & $4 / 4,33$ \\
Конструктивна активність & $16 / 22$ & $5,33 / 7,33$ \\
Відступ & $27 / 48$ & $9 / 16$ \\
Співробітництво & $74 / 26$ & $24,66 / 8,66$ \\
Звернення & $35 / 9$ & $11,66 / 3$
\end{tabular}

Е. Неim до адаптивних когнітивних копінг-стратегій відніс: «проблемний аналіз», «установку власної цінності» і «збереження самовладання». Це форми поведінки, які спрямовані на аналіз труднощів, що виникають, і можливих шляхів виходу 3 них, підвищення самооцінки й самоконтролю, більш глибоке усвідомлення власної особистості як цінності, наявність віри у власні ресурси в подоланні важких ситуацій. До адаптивних емоційних копінг-стратегій віднесено: «протест», «оптимізм». Ці стратегії характеризуються емоційним станом 3 активним обуренням і протестом стосовно труднощів і впевненістю в наявності виходу у будь-якій, навіть найскладнішій ситуації. До складу адаптивних поведінкових копінг-стратегій віднесено: «співробітництво», «звернення», «альтруїзм». Це стратегії, за яких особистість вступає у співробітництво із значущими (більш досвідченими) людьми, шукає підтримки у найближчому соціальному оточенні або сама пропонує її близьким у подоланні труднощів.

До неадаптивних когнітивних стратегій віднесено: «смиренність», «розгубленість», «дисимуляцію» і «ігнорування». Це пасивні форми поведінки, які характеризуються відмовою від подолання труднощів, що спричинено невірою у свої сили і інтелектуальні ресурси, свідомою недооцінкою неприємностей. Серед неадаптивних емоційних копінг-стратегій названо: «придушення емоцій», «покірність», «самозвинувачення», «агресивність». Ці варіанти поведінки характеризуються подавленим емоційним станом, станом безнадії, покірності, переживанням злості й покладанням вини на себе та інших. Як неадаптивні поведінкові стратегії класифіковано: «активне уникання», «відступ». Для таких варіантів поведінки властивим є уникання думок про неприємності, пасивність, самітність, спокій, ізоляція, намагання уникати активних контактів, відмова від вирішення проблем. 
До відносно адаптивних когнітивних копінг-стратегій Е. Неiт відніс: «відносність», «надання сенсу» і «релігійність». При таких формах поведінки активність особи спрямовується на оцінку труднощів порівняно з іншими, на надання особливого сенсу їх подоланню, на віру в Бога і стійкість у вірі при зіткненні зі складними проблемами. Відносно адаптивними емоційними стратегіями $є$ : «емоційна розрядка» $\mathrm{i}$ «пасивна кооперація». Вони характеризуються поведінкою, яка спрямована або на зняття напруги, що пов'язана з проблемами, емоційним відреагуванням, або на передачу відповідальності за вирішення труднощів іншим особам. До складу відносно адаптивних поведінкових стратегій включені: «компенсація», «відволікання», «конструктивна активність». При використанні таких стратегій поведінка людини характеризується прагненням до тимчасового відходу від вирішення проблем з допомогою алкоголю, лікарських засобів, зануренням в улюблену справу, подорожі, виконанням своїх заповітних бажань.

У ході дослідження за методикою Е. Неіт отримано такі дані щодо використання копінг-стратегій студентами (окремо юнаками та дівчатами) (табл. 28).

Табличяя 28

Адаптивні, неадаптивні й відносно адаптивні копінг-стратегії студентів (юнаки/дівчата), \% $(n=300)$

\begin{tabular}{l|c|c|c|}
\hline \multirow{2}{*}{$\begin{array}{c}\text { Варіанти } \\
\text { копінг поведінки }\end{array}$} & \multicolumn{3}{|c|}{ Копінг-стратегії } \\
\cline { 1 - 4 } & Когнітивні & Емоційні & Поведінкові \\
\hline Адаптивні & $52 / 46,33$ & $75,33 / 62,33$ & $40,32 / 21,66$ \\
Неадаптивні & $16 / 21,66$ & $23,33 / 30,32$ & $18 / 37,66$ \\
Відносно адаптивні & $32 / 31,99$ & $1,33 / 7,33$ & $41,66 / 40,66$
\end{tabular}

Аналізуючи отримані дані, відзначимо таке. У когнітивній сфері найбільш поширеною копінг-стратегією $\epsilon$ «збереження самовладання». У юнаків вона склала $26 \%$, у дівчат - $22 \%$. У сфері емоцій найбільш поширеною стратегією виявилась стратегія «оптимізм». У юнаків вона була зафіксована на рівні 70 \%, у дівчат - на рівні 58 \%. У поведінковій сфері зафіксовано найбільше поширення такої стратегії, як «відволікання». У юнаків цю стратегію діагностовано на рівні 32,33 \%, у дівчат - на рівні $29 \%$. 
Відзначаємо кількісну перевагу у використанні студентами адаптивних стратегій порівняно $з$ неадаптивними й відносно адаптивними. При цьому це стосується і когнітивних, i емоційних, і поведінкових стратегій (за винятком поведінкових адаптивних стратегій у дівчат і юнаків).

Серед адаптивних копінг-стратегій звертає на себе увагу кількісна перевага використання студентами адаптивних емоційних стратегій порівняно з адаптивними когнітивними і поведінковими. У дівчат вони досягли рівня $62,33 \%$, у юнаків - 75, 33 \%. Для порівняння, адаптивні когнітивні стратегії зафіксовано на рівні 46,33 \% у дівчат, і $52 \%$ у юнаків. Адаптивні поведінкові стратегії зафіксовано на рівні $21,66 \%$ у дівчат і 40,32 \% у юнаків. На нашу думку, для пояснення цього факту необхідно провести спеціальне психологічне дослідження.

Відзначаємо також, що серед неадаптивних копінг-стратегій найменше використовуються: когнітивні неадаптивні стратегії у дівчат $(21,66 \%)$, когнітивні неадаптивні стратегії у юнаків (16 \%), поведінкові неадаптивні стратегії у юнаків (18\%). Звертаємо увагу на те, що ці цифри досить значні й потребують відповідної педагогічної роботи. Значним $є$ використання таких неадаптивних стратегій: емоційних неадаптивних стратегій у дівчат (30,32 \%), поведінкових неадаптивних стратегій у дівчат $(37,66 \%)$, емоційних неадаптивних стратегій у юнаків $(23,33$ \%). Тут також повинна проводитись цілеспрямована робота.

Серед відносно адаптивних копінг-стратегій найменше використовуються студентами емоційні відносно адаптивні стратегії у дівчат $(7,33 \%)$ і емоційні відносно адаптивні стратегії у юнаків $(1,33 \%)$. $\mathrm{У}$ той же час, досить значним $є$ використання таких відносно адаптивних стратегій: когнітивних відносно адптивних стратегій у дівчат $(31,99 \%)$, поведінкових відносно адаптивних стратегій у дівчат $(40,66 \%)$, поведінкових відносно адаптивних стратегій у юнаків $(41,66 \%)$.

На нашу думку, педагогічну роботу щодо вирішення питання про ефективне використання студентами копінг-стратегій доцільно проводити в процесі фізичного виховання за умови реалізації в його структурі психологічної і психофізичної підготовки [285]. Головним завданням при цьому буде, з одного боку, формування у студентів системи знань стосовно доцільності використання тих чи інших стра- 
тегій у різних обставинах, а 3 іншого - формування професійно значущих структурних компонентів особистості, які можуть бути сформованими в процесі фізкультурної і спортивної діяльності.

Наступним етапом цього дослідження стала перевірка припущення про те, що реалізація в ході навчальних занять 3 фізичного виховання розроблених автором основ психологічної і психофізичної підготовки студентів залізничних ВНЗ суттєво позитивно впливає на використання студентами адаптивних і відносно адаптивних копінгстратегій. Як незалежна змінна приймалося використання в ході навчальних занять 3 фізичного виховання складових психологічної і психофізичної підготовки студентів залізничних ВНЗ. Як залежна змінна розглядалися кількісні зміни у студентів щодо використання адаптивних і відносно адаптивних копінг-стратегій.

У цьому дослідженні взяли участь 282 студенти Дніпропетровського національного університету залізничного транспорту із числа тих, які були залучені на першому етапі, з них 144 - юнаки, 138 дівчата. Для участі в експерименті було сформовано одну експериментальну й одну контрольну групу в юнаків і одну експериментальну та одну контрольну групу в дівчат. Кількісно кожна із груп юнаків складала 77 осіб, а кожна із груп дівчат по 69 осіб. Експериментальні й контрольні групи формувались таким чином, щоб до їх складу входила приблизно однакова кількість студентів, які використовують адаптивні, неадаптивні й відносно адаптивні копінг-стратегії.

Студентів експериментальних груп було залучено до навчальних занять 3 фізичного виховання, які включали вивчення основ психологічної і психофізичної підготовки студентів залізничних ВНЗ. Заняття включали:

1. Вивчення теоретичного матеріалу, включеного до розділу психологічної просвіти. До складу цього розділу входив блок вивчення психології копінг-поведінки людей.

2. Заняття професійно значущими видами спорту (відповідно до майбутньої спеціальності це були такі види, як спортивна гімнастика, спортивні ігри, легка атлетика, спортивне орієнтування).

3. Участь у спортивних змаганнях з професійно значущих видів спорту.

4. Виконання вправ для розвитку навиків саморегуляції психічного стану (аутогенне тренування). 
5. Виконання спеціальних фізичних вправ для розвитку психомоторики.

6. Заняття з використанням засобів для розвитку характеристик уваги.

У ході навчальних занять в експериментальних групах проводилась також робота 3 вирішення завдань фізичного виховання щодо формування рухових навичок, умінь та розвитку фізичних якостей студентів. Навчальні заняття з фізичного виховання в експериментальних групах мали таку структуру. Підготовча частина складала 10 хв. Головна частина - 75 хв. 3 них 25 хв відводилося для вирішення завдань фізичного виховання студентів 3 формування в них рухових навичок та умінь і розвитку фізичних якостей. 20 хв у структурі заняття відводилось або на виконання студентами спеціальних фізичних вправ, або на роботу із засобами розвитку характеристик уваги, або на виконання вправ для розвитку навиків саморегуляції психічного стану. У структурі конкретного заняття використовувався один із трьох вищезгаданих блоків засобів. 30 хв основної частини заняття відводилося для вдосконалення з професійно значущого виду спорту. Заключна частина заняття складала 5 хв. Участь студентів експериментальних груп у спортивних змаганнях з професійно значущих видів спорту було організовано в позаурочний час.

Студенти контрольних груп вивчали курс фізичного виховання відповідно до навчальної програми для вищих навчальних закладів.

Студенти експериментальних і контрольних груп відвідували навчальні заняття з фізичного виховання в обсязі 4 навчальних годин на тиждень протягом першого і другого років навчання у ВНЗ. За результатами першого зрізу (на початку першого семестру) експериментальну і контрольну групу юнаків, як і експериментальну та контрольну групу дівчат, характеризували показники (щодо використання адаптивних, неадаптивних і відносно адаптивних стратегій), які статистично значущі не відрізнялись.

Динаміку використання когнітивних, емоційних, поведінкових копінг-стратегій у процесі експерименту юнаками наведено в табл. 2931, дівчатами - табл. 32-34. 
Адаптивні, відносно адаптивні й неадаптивні когнітивні копінг-стратегії студентів до і після експерименту $(n=144)$

\begin{tabular}{|c|c|c|c|c|c|c|c|c|}
\hline \multirow{3}{*}{$\begin{array}{c}\text { Варіанти } \\
\text { копінг поведінки }\end{array}$} & \multicolumn{4}{|c|}{ Експериментальна група } & \multicolumn{4}{|c|}{ Контрольна група } \\
\hline & \multicolumn{2}{|c|}{$\begin{array}{c}\text { До } \\
\text { експерименту }\end{array}$} & \multicolumn{2}{|c|}{$\begin{array}{c}\text { Після } \\
\text { експерименту }\end{array}$} & \multicolumn{2}{|c|}{$\begin{array}{c}\text { До } \\
\text { експерименту }\end{array}$} & \multicolumn{2}{|c|}{$\begin{array}{c}\text { Після } \\
\text { експерименту }\end{array}$} \\
\hline & К-сть & $\%$ & К-сть & $\%$ & К-сть & $\%$ & К-сть & $\%$ \\
\hline Адаптивні & 40 & 52 & 43 & 56 & 41 & 53 & 40 & 52 \\
\hline Відносно адаптивні & 25 & 32 & 28 & 36 & 21 & 27 & 23 & 30 \\
\hline Неадаптивні & 12 & 16 & 6 & 8 & 15 & 20 & 14 & 18 \\
\hline
\end{tabular}

Таблиця 30

Адаптивні, відносно адаптивні й неадаптивні емоційні копінг-стратегії студентів до і після експерименту $(n=144)$

\begin{tabular}{|c|c|c|c|c|c|c|c|c|}
\hline \multirow{3}{*}{$\begin{array}{c}\text { Варіанти } \\
\text { копінг поведінки }\end{array}$} & \multicolumn{4}{|c|}{ Експериментальна група } & \multicolumn{4}{|c|}{ Контрольна група } \\
\hline & \multicolumn{2}{|c|}{$\begin{array}{c}\text { До } \\
\text { експерименту }\end{array}$} & \multicolumn{2}{|c|}{$\begin{array}{c}\text { Після } \\
\text { експерименту }\end{array}$} & \multicolumn{2}{|c|}{$\begin{array}{c}\text { До } \\
\text { експерименту }\end{array}$} & \multicolumn{2}{|c|}{$\begin{array}{c}\text { Після } \\
\text { експерименту }\end{array}$} \\
\hline & К-сть & $\%$ & К-сть & $\%$ & К-сть & $\%$ & К-сть & $\%$ \\
\hline Адаптивні & 58 & 75 & 59 & 77 & 56 & 73 & 56 & 73 \\
\hline Відносно адаптивні & 1 & 1 & 1 & 1 & 2 & 2 & 3 & 4 \\
\hline Неадаптивні & 18 & 24 & 17 & 22 & 19 & 25 & 18 & 23 \\
\hline
\end{tabular}

Таблиця 31

Адаптивні, відносно адаптивні й неадаптивні поведінкові копінг-стратегії студентів до і після експерименту $(n=144)$

\begin{tabular}{|c|c|c|c|c|c|c|c|c|}
\hline \multirow{3}{*}{$\begin{array}{c}\text { Варіанти } \\
\text { копінг поведінки }\end{array}$} & \multicolumn{4}{|c|}{ Експериментальна група } & \multicolumn{4}{|c|}{ Контрольна група } \\
\hline & \multicolumn{2}{|c|}{$\begin{array}{c}\text { До } \\
\text { експерименту }\end{array}$} & \multicolumn{2}{|c|}{$\begin{array}{c}\text { Після } \\
\text { експерименту }\end{array}$} & \multicolumn{2}{|c|}{$\begin{array}{c}\text { До } \\
\text { експерименту }\end{array}$} & \multicolumn{2}{|c|}{$\begin{array}{c}\text { Після } \\
\text { експерименту }\end{array}$} \\
\hline & К-сть & $\%$ & К-сть & $\%$ & К-сть & $\%$ & К-сть & $\%$ \\
\hline Адаптивні & 31 & 40 & 36 & 47 & 32 & 42 & 33 & 43 \\
\hline Відносно адаптивні & 32 & 42 & 37 & 48 & 30 & 39 & 29 & 38 \\
\hline Неадаптивні & 14 & 18 & 4 & 5 & 15 & 19 & 15 & 19 \\
\hline
\end{tabular}


Адаптивні, відносно адаптивні й неадаптивні когнітивні копінг-стратегії студенток до і після експерименту $(n=138)$

\begin{tabular}{|c|c|c|c|c|c|c|c|c|}
\hline \multirow{3}{*}{$\begin{array}{c}\text { Варіанти } \\
\text { копінг поведінки }\end{array}$} & \multicolumn{4}{|c|}{ Експериментальна група } & \multicolumn{4}{|c|}{ Контрольна група } \\
\hline & \multicolumn{2}{|c|}{$\begin{array}{c}\text { До } \\
\text { експерименту }\end{array}$} & \multicolumn{2}{|c|}{$\begin{array}{c}\text { Після } \\
\text { експерименту }\end{array}$} & \multicolumn{2}{|c|}{$\begin{array}{c}\text { До } \\
\text { експерименту }\end{array}$} & \multicolumn{2}{|c|}{$\begin{array}{c}\text { Після } \\
\text { експерименту }\end{array}$} \\
\hline & К-сть & $\%$ & К-сть & $\%$ & К-сть & $\%$ & К-сть & $\%$ \\
\hline Адаптивні & 32 & 46 & 34 & 49 & 31 & 45 & 32 & 46 \\
\hline Відносно адаптивні & 22 & 32 & 27 & 39 & 24 & 35 & 22 & 32 \\
\hline Неадаптивні & 15 & 22 & 8 & 12 & 14 & 20 & 15 & 22 \\
\hline
\end{tabular}

Табличя 33

Адаптивні, відносно адаптивні й неадаптивні емоційні копінг-стратегії студенток до і після експерименту $(n=138)$

\begin{tabular}{|c|c|c|c|c|c|c|c|c|}
\hline \multirow{3}{*}{$\begin{array}{c}\text { Варіанти } \\
\text { копінг поведінки }\end{array}$} & \multicolumn{4}{|c|}{ Експериментальна група } & \multicolumn{4}{|c|}{ Контрольна група } \\
\hline & \multicolumn{2}{|c|}{$\begin{array}{c}\text { До } \\
\text { експерименту }\end{array}$} & \multicolumn{2}{|c|}{$\begin{array}{c}\text { Після } \\
\text { експерименту }\end{array}$} & \multicolumn{2}{|c|}{$\begin{array}{c}\text { До } \\
\text { експерименту }\end{array}$} & \multicolumn{2}{|c|}{$\begin{array}{c}\text { Після } \\
\text { експерименту }\end{array}$} \\
\hline & К-сть & $\%$ & К-сть & $\%$ & К-сть & $\%$ & К-сть & $\%$ \\
\hline Адаптивні & 43 & 62 & 43 & 62 & 41 & 59 & 41 & 59 \\
\hline Відносно адаптивні & 5 & 7 & 6 & 9 & 6 & 9 & 7 & 10 \\
\hline Неадаптивні & 21 & 31 & 20 & 29 & 22 & 32 & 21 & 31 \\
\hline
\end{tabular}

Таблиия 34

Адаптивні, відносно адаптивні й неадаптивні поведінкові копінг-стратегії студенток до і після експерименту $(n=138)$

\begin{tabular}{l|c|c|c|c|c|c|c|c}
\hline \multirow{2}{*}{$\begin{array}{c}\text { Варіанти } \\
\text { копінг поведінки }\end{array}$} & \multicolumn{3}{|c|}{ Експериментальна група } & \multicolumn{3}{c}{ Контрольна група } \\
\cline { 2 - 9 } & \multicolumn{2}{|c|}{ До } & \multicolumn{2}{c|}{$\begin{array}{c}\text { Після } \\
\text { експерименту }\end{array}$} & \multicolumn{2}{c}{$\begin{array}{c}\text { До } \\
\text { експерименту }\end{array}$} & \multicolumn{2}{c}{$\begin{array}{l}\text { Після } \\
\text { експериментуенту }\end{array}$} \\
\cline { 2 - 9 } & К-сть & $\%$ & К-сть & $\%$ & К-сть & $\%$ & К-сть & $\%$ \\
\hline Адаптивні & 15 & 22 & 18 & 26 & 17 & 25 & 16 & 23 \\
Відносно адаптивні & 28 & 40 & 32 & 46 & 27 & 39 & 26 & 38 \\
Неадаптивні & 26 & 38 & 19 & 28 & 25 & 36 & 27 & 39
\end{tabular}


Аналіз даних, отриманих в ході експерименту i наведених у табл. 29-34, дає підстави стверджувати таке. Традиційні заняття 3 фізичного виховання, які проводились у контрольній групі юнаків і контрольній групі дівчат, не здійснюють суттєвого позитивного впливу на формування у студентів адаптивних і відносно адаптивних копінг-стратегій. Як видно із таблиць, у ході експерименту в контрольних групах не зафіксовано суттєвої позитивної динаміки. При цьому це стосується і когнітивних, і емоційних, і поведінкових копінг-стратегій.

Використання в ході навчальних занять 3 фізичного виховання складових психологічної і психофізичної підготовки студентів залізничних ВНЗ суттєво позитивно вплинуло на формування у студентів (i юнаків, і дівчат) адаптивних і відносно адаптивних когнітивних і поведінкових копінг-стратегій. Так, в експериментальній групі юнаків використання неадаптивних когнітивних копінг-стратегій в ході експерименту зменшилось 316 до 8 \%. При цьому використання адаптивних когнітивних копінг-стратегій зросло з 52 до 56 \%, а використання відносно адаптивних - 332 до $36 \%$. У цій же групі використання неадаптивних поведінкових копінг-стратегій зменшилося з 18 до $5 \%$. При цьому виявлено зростання використання адаптивних поведінкових (з 40 до 47 \%) і відносно адаптивних поведінкових (з 42 до $48 \%$ ).

В експериментальній групі дівчат використання неадаптивних когнітивних копінг-стратегій зменшилось 322 до 12 \%. При цьому виявлено зростання використання адаптивних когнітивних стратегій (з 46 до 49 \%) і відносно адаптивних (з 32 до 39 \%). У цій же групі використання неадаптивних поведінкових копінг-стратегій зменшилось 338 до 28 \%. При цьому діагностовано зростання використання адаптивних поведінкових стратегій (з 22 до 26 \%) і відносно адаптивних поведінкових стратегій (з 40 до $46 \%$ ).

Використання в ході навчальних занять 3 фізичного виховання складових психологічної і психофізичної підготовки студентів залізничних ВНЗ суттєво не вплинуло на формування у студентів (і юнаків, і дівчат) адаптивних і відносно адаптивних емоційних копінгстратегій. Так, в експериментальній групі юнаків використання неадаптивних емоційних стратегій до початку експерименту складало $24 \%$, по його закінченні - $22 \%$. Констатуємо несуттєві зміни. Використання адаптивних емоційних стратегій у цій групі до початку 
експерименту складало 75 \%, по його закінченні - 77 \%. Констатуємо несуттєві зміни. Змін щодо використання відносно адаптивних емоційних копінг-стратегій у цій групі не відбулось.

В експериментальній групі дівчат використання неадаптивних емоційних стратегій до початку експерименту складало $31 \%$, по його закінченні - 29 \%. Констатуємо несуттєві зміни. Використання відносно адаптивних емоційних копінг-стратегій у цій групі до початку експерименту складало 7 \%, по його закінченні - 9 \%. Констатуємо несуттєві зміни. Змін щодо використання адаптивних емоційних стратегій у цій групі не виявлено.

Результати, отримані в ході експериментальної роботи, ми пояснюємо ефективністю використаного змісту психологічної і психофізичної підготовки щодо формування адаптивних і відносно адаптивних когнітивних і поведінкових копінг-стратегій у студентів. На нашу думку, це, насамперед, стосується вивчення розділу психологічної просвіти, до складу якого було включено питання психології копінгповедінки людей. Важливу роль також відіграли такі складові, як заняття професійно значущими видами спорту, участь у змаганнях 3 професійно значущих видів спорту, виконання вправ для розвитку навиків саморегуляції психічного стану. Відсутність суттєвих позитивних змін щодо формування у студентів експериментальних груп адаптивних і відносно адаптивних емоційних копінг-стратегій спричинене, на нашу думку, неефективністю запропонованих засобів стосовно їх формування. Більш доцільним, на нашу думку, тут буде використання спеціальних психотерапевтичних засобів.

Висновки дослідження:

1. Найбільш поширеними копінг-стратегіями серед студентів $є$ :

a) у когнітивній сфері - «збереження самовладання»;

б) в емоційній сфері - «оптимізм»;

в) у поведінковій сфері - «відволікання».

2. Серед студентів кількісно переважає використання адаптивних стратегій порівняно 3 неадаптивними й відносно адаптивними (ця тенденція не стосується поведінкових адаптивних стратегій у юнаків і дівчат).

3. Серед адаптивних копінг-стратегій найбільш поширеними серед студентів (і юнаків, і дівчат) $є$ адаптивні емоційні стратегії.

4. Серед неадаптивних копінг-стратегій найбільш поширене використання серед студентів мають: емоційні неадаптивні стратегії у дів- 
чат, поведінкові неадаптивні стратегії у дівчат, емоційні неадаптивні стратегії у юнаків.

5. Серед відносно адаптивних копінг-стратегій найбільш поширеними серед студентів $\epsilon$ : когнітивні відносно адаптивні стратегії у дівчат, поведінкові відносно адаптивні стратегії у дівчат, когнітивні відносно адаптивні стратегії у юнаків.

6. Студенти потребують спеціальної підготовки у сфері копінгу.

7. Традиційні заняття з фізичного виховання не здійснюють суттєвого позитивного впливу на формування у студентів адаптивних і відносно адаптивних копінг-стратегій.

8. Використання в ході навчальних занять з фізичного виховання складових психологічної і психофізичної підготовки студентів залізничних ВНЗ суттєво позитивно впливає на формування у студентів адаптивних і відносно адаптивних когнітивних і поведінкових копінгстратегій.

9. Використання в ході навчальних занять з фізичного виховання складових психологічної і психофізичної підготовки студентів залізничних ВНЗ суттєво не впливає на формування у студентів адаптивних і відносно адаптивних емоційних копінг-стратегій.

\section{4. Формування толерантності до невизначеності як складової психологічної готовності до праці у процесі психологічної і психофізичної підготовки}

Психологічна готовність сучасного фахівця до професійної праці визначається низкою чинників. Важливе місце серед них займає і така характеристика особистості, як толерантність до невизначеності. У психології іiї розглядають як самостійний психологічний конструкт, який впливає на сприйняття, мислення, емоційно-вольову і поведінкову сфери. Вважається, що толерантність до невизначеності є важливою властивістю особистості, яка забезпечує успішність іiі функціонування в умовах сучасного світу.

На сьогодні серед психологів немає єдності щодо визначення поняття «толерантність до невизначеності». Крім цього, у науковій літературі використовується і поняття «інтолерантність до невизначеності». На нашу думку, найбільш вдалим є підхід П. В. Лушина [218], 
який трактує толерантність до невизначеності як особистісну характеристику, яка проявляється в здатності зносити (витримувати) ситуації невизначеності.

Свій внесок у процес формування у студентів такої характеристики їх особистості, як толерантність до невизначеності може зробити i така навчальна дисципліна, як фізичне виховання. Фізкультура i спорт надають широкий простір для вибору діяльності, при якій особистість потрапляє в ситуації невизначеності, множини варіантів вибору. У процесі такої діяльності створюються необхідні умови для формування у студентів толерантності до невизначеності. На нашу думку, початковим етапом при проведенні такої роботи повинно стати виявлення реального становища щодо сформованості у студентів складових толерантності до невизначеності. Це дасть змогу цілеспрямовано організувати фізкультурну діяльність під час навчальних занять 3 фізичного виховання для вирішення завдання. Не менш важливо дослідити особливості формування у студентів складових толерантності до невизначеності в процесі фізичного виховання.

У психології проблема толерантності до невизначеності досліджувалась за такими напрямками:

- дослідження власне феномену толерантності до невизначеності;

- дослідження взаємодії толерантності до невизначеності й інших психологічних складових;

- дослідження властивостей особистості толерантних і інтолерантних до невизначеності осіб;

- дослідження питання формування толерантності до невизначеності стосовно сфер діяльності.

Було встановлено ряд властивостей, характерних для толерантних та інтолерантних особистостей. Для перших властивими є:

- пошук ситуації невизначеності;

- відчуття комфорту під час перебування в ситуації невизначеності;

- сприйняття невизначених ситуацій як бажаних;

- здатність розмірковувати над проблемою навіть у випадку, коли невідомими є усі факти і можливі наслідки прийнятого рішення;

- здатність приймати конфлікт і напругу, які виникають в ситуації подвійності;

- здатність протистояти нескладності і суперечливості інформації; 
- здатність приймати невідоме;

- здатність витримувати напругу кризових, проблемних ситуацій;

- сприйняття нових, ризикованих ситуацій як таких, що стимулюють;

- готовність пристосовуватись до явно неоднозначних ситуацій або ідей.

Для других притаманні:

- сприйняття невизначених ситуацій як джерела загрози;

- тенденція приходити до рішень по типу «чорне - біле»;

- прагнення приймати поспішні рішення, зазвичай не враховуючи реального стану справ;

- прагнення до безумовного прийняття або відторгнення у відносинах з іншими людьми;

- нездатність мислити в категоріях ймовірностей і прагнення уникати неясного і неконкретного;

- схильність реагувати на неясні ситуації занепокоєнням і замиканням у собі;

- потреба в категоризації;

- нездатність допускати наявність позитивних і негативних характеристик у одному і тому ж об'єкті;

- дихотомічність сприйняття;

- несприйнятливість до змінюючихся і суперечливих стимулів;

- пошук безпеки і уникання невизначеності;

- віддання переваги знайомому перед незнайомим, відторгнення усього незвичного.

У контексті нашого дослідження особливий інтерес становлять роботи, у яких розглянуто питання формування толерантності до невизначеності стосовно сфер діяльності. До них слід віднести праці П. Дж. Клампітт і М. Л. Уільямс [457], У. Оуена і Р. Свіні [498], Р. Крейк [460], Н. Хабер [477], А. І. Гусєва [107], М. С. Маримонової та А. С. Обухова [227] та багато інших. Їх грунтовно аналізує у своїй публікації А. І. Гусєв [108]. Зі свого боку відзначаємо, що досліджень питання формування (розвитку) толерантності до невизначеності у фізкультурній діяльності нами не виявлено.

Мета роботи - з'ясувати рівень розвитку толерантності до невизначеності у студентів та вивчити особливості іiі формування в процесі різних за змістом навчальних занять з фізичного виховання. 
Завдання дослідження:

1. Виявити рівень розвитку складових толерантності до невизначеності у студентів.

2. Встановити рівень розвитку складових толерантності до невизначеності у студенток.

3. Виявити можливі відмінності у рівні розвитку складових толерантності до невизначеності у студентів і студенток.

4. Виявити особливості впливу на формування складових толерантності до невизначеності традиційних занять 3 фізичного виховання і занять, до складу яких входить блок психологічної і психофізичної підготовки.

У дослідженні брали участь 180 студентів Дніпропетровського національного університету залізничного транспорту ім. акад. В. Лазаряна, з них 102 - юнаки і 78 - дівчата. Усі студенти навчались на першому або другому курсі. Вік учасників дослідження складав 1719 років.

Діагностика толерантності до невизначеності виконувалася за методикою PCRS (Personal change readiness survey) в адаптації Н. А. Бажанова і Г. Л. Бардієр. Вона спрямована на оцінку таких діагностичних конструктів: пристрасність (розглядається як енергійність, невтомність, підвищений життєвий тонус), винахідливість (розглядається як уміння знаходити вихід із складних ситуацій, звертатися до нових джерел для вирішення нових проблем), оптимізм (розглядається як великі надії, віра в успіх, небажання орієнтуватись на гірший розвиток подій, намагання зосередитись не на проблемах, а на можливості їх вирішення), сміливість, підприємливість (трактується як потяг до нового, невідомого, відмова від перевіреного і надійного), адаптивність (розглядається як уміння змінювати свої плани і рішення, перебудовуватись у нових ситуаціях, не наполягати на своєму, якщо цього вимагає ситуація), упевненість (розглядається як віра в себе, у свої позитивні якості й у свої сили, у те, що все є можливим, варто тільки захотіти), толерантність до двозначності (розглядається як спокійне ставлення до відсутності зрозумілих відповідей, самовладання в ситуаціях, коли незрозумілою $є$ сутність того, що відбувається або незрозумілим є кінець справи, коли не визначеними є цілі й очікування, коли розпочата справа залишається незавершеною). Підраховувалась кількість балів по кожній із 7 шкал. Сума від 21 бала i нижче розглядалась як низький рівень розвитку властивості, яка 
оцінювалась. Сума, яка була в діапазоні від 22 до 26 балів, оцінювалась як середній рівень розвитку властивості. Сума від 27 балів і вище оцінювалась як високий рівень розвитку властивості.

Встановлено таке. Розподіл показників студентів за результатами діагностики подано в табл. 35. Статистичні показники цієї підгрупи наведено в табл. 36.

Розподіл показників, діагностованих у студенток, подано в табл. 37. Статистичні показники, які характеризують цю підгрупу, наведено в табл. 38.

Табличя 35

Розподіл показників студентів за методикою PCRS $(\boldsymbol{n}=102)$

\begin{tabular}{|c|c|c|c|c|c|c|c|c|c|c|c|c|c|c|}
\hline \multirow[t]{2}{*}{$\begin{array}{c}\text { Рівень } \\
\text { розвитку }\end{array}$} & \multicolumn{2}{|c|}{$\begin{array}{c}\text { Прист- } \\
\text { расність }\end{array}$} & \multicolumn{2}{|c|}{$\begin{array}{c}\text { Винахід- } \\
\text { ливість }\end{array}$} & \multicolumn{2}{|c|}{$\begin{array}{c}\text { Опти- } \\
\text { мізм }\end{array}$} & \multicolumn{2}{|c|}{$\begin{array}{c}\text { Сміливість, } \\
\text { підприєм- } \\
\text { ливість }\end{array}$} & \multicolumn{2}{|c|}{$\begin{array}{c}\text { Адаптив- } \\
\text { ність }\end{array}$} & \multicolumn{2}{|c|}{$\begin{array}{c}\text { Упевне- } \\
\text { ність }\end{array}$} & \multicolumn{2}{|c|}{$\begin{array}{c}\text { Толерант- } \\
\text { ність до } \\
\text { двознач- } \\
\text { ності }\end{array}$} \\
\hline & K-ть & $\%$ & К-ть & $\%$ & К-ть & $\%$ & К-ть & $\%$ & К-ть & $\%$ & К-ть & $\%$ & К-ть & $\%$ \\
\hline Низький & 60 & 59 & 62 & 61 & 78 & 76 & 102 & 100 & 102 & 100 & 76 & 74 & 94 & 92 \\
\hline Середній & 28 & 27 & 34 & 33 & 22 & 22 & 0 & 0 & 0 & 0 & 24 & 24 & 8 & 8 \\
\hline Високий & 14 & 14 & 6 & 6 & 2 & 2 & 0 & 0 & 0 & 0 & 2 & 2 & 0 & 0 \\
\hline
\end{tabular}

Таблиия 36

Статистичні показники студентів за методикою PCRS ( $n=102)$

\begin{tabular}{l|c|c|c|c|c|c|c}
\hline $\begin{array}{c}\text { Статистичні } \\
\text { показники }\end{array}$ & $\begin{array}{c}\text { Прист- } \\
\text { расність }\end{array}$ & $\begin{array}{c}\text { Винахід- } \\
\text { ливість }\end{array}$ & $\begin{array}{c}\text { Опти- } \\
\text { мізм }\end{array}$ & $\begin{array}{c}\text { Сміливість, } \\
\text { підприєм- } \\
\text { ливість }\end{array}$ & $\begin{array}{c}\text { Адаптив- } \\
\text { ність }\end{array}$ & $\begin{array}{c}\text { Упевне-- } \\
\text { ність }\end{array}$ & $\begin{array}{c}\text { Толерант- } \\
\text { ність до } \\
\text { двознач- } \\
\text { ності }\end{array}$ \\
\hline $\begin{array}{l}\text { Середнє ариф- } \\
\text { метичне }\end{array}$ & 21,19 & 20,56 & 18,94 & 13,23 & 14,23 & 19,39 & 14,68 \\
Медіана & 21 & 20 & 19 & 13 & 15 & 19 & 15 \\
$\begin{array}{l}\text { Мода } \\
\begin{array}{c}\text { Стандартне від- } \\
\text { хилення }\end{array}\end{array}$ & 4,02 & 3,44 & 3,79 & 3,45 & 3,4 & 3,82 & 4 \\
\end{tabular}


Розподіл показників студенток за методикою $\operatorname{PCRS}(\boldsymbol{n}=78)$

\begin{tabular}{|c|c|c|c|c|c|c|c|c|c|c|c|c|c|c|}
\hline \multirow[t]{2}{*}{$\begin{array}{c}\text { Рівень } \\
\text { розвитку }\end{array}$} & \multicolumn{2}{|c|}{$\begin{array}{l}\text { Прист- } \\
\text { расність }\end{array}$} & \multicolumn{2}{|c|}{$\begin{array}{c}\text { Винахід- } \\
\text { ливість }\end{array}$} & \multicolumn{2}{|c|}{$\begin{array}{l}\text { Опти- } \\
\text { мізм }\end{array}$} & \multicolumn{2}{|c|}{$\begin{array}{c}\text { Сміливість, } \\
\text { підприєм- } \\
\text { ливість }\end{array}$} & \multicolumn{2}{|c|}{$\begin{array}{c}\text { Адаптив- } \\
\text { ність }\end{array}$} & \multicolumn{2}{|c|}{$\begin{array}{c}\text { Упевне- } \\
\text { ність }\end{array}$} & \multicolumn{2}{|c|}{$\begin{array}{c}\text { Толерант- } \\
\text { ність до } \\
\text { двознач- } \\
\text { ності }\end{array}$} \\
\hline & К-ть & $\%$ & К-ть & $\%$ & К-ть & $\%$ & К-ть & $\%$ & К-ть & $\%$ & К-ть & $\%$ & К-ть & $\%$ \\
\hline Низький & 56 & 72 & 56 & 72 & 64 & 82 & 78 & 100 & 76 & 97 & 52 & 67 & 78 & 100 \\
\hline Середній & 20 & 26 & 20 & 26 & 14 & 18 & 0 & 0 & 2 & 3 & 24 & 31 & 0 & 0 \\
\hline Високий & 2 & 2 & 2 & 2 & 0 & 0 & 0 & 0 & 0 & 0 & 2 & 2 & 0 & 0 \\
\hline
\end{tabular}

Табличя 38

Статистичні показники студенток за методикою PCRS $(n=78)$

\begin{tabular}{|c|c|c|c|c|c|c|c|}
\hline $\begin{array}{c}\text { Статистичні } \\
\text { показники }\end{array}$ & $\begin{array}{l}\text { Прист- } \\
\text { расність }\end{array}$ & $\begin{array}{l}\text { Винахід- } \\
\text { ливість }\end{array}$ & $\begin{array}{l}\text { Опти- } \\
\text { мізм }\end{array}$ & $\begin{array}{c}\text { Сміливість, } \\
\text { підприєм- } \\
\text { ливість }\end{array}$ & $\begin{array}{c}\text { Адаптив- } \\
\text { ність }\end{array}$ & $\begin{array}{c}\text { Упевне- } \\
\text { ність }\end{array}$ & $\begin{array}{l}\text { Толерант- } \\
\text { ність до } \\
\text { двознач- } \\
\text { ності }\end{array}$ \\
\hline $\begin{array}{c}\text { Середнє ариф- } \\
\text { метичне }\end{array}$ & 19,76 & 20,17 & 18 & 12,69 & 14,23 & 19,61 & 13,1 \\
\hline Медіана & 20 & 20 & 18 & 13 & 14 & 19 & 13 \\
\hline Мода & 20 & 18 & 18 & 16 & 11 & 19 & 13 \\
\hline $\begin{array}{c}\text { Стандартне від- } \\
\text { хилення }\end{array}$ & 3,92 & 3,64 & 3,61 & 3,18 & 2,95 & 3,18 & 3,17 \\
\hline
\end{tabular}

У ході аналізу результатів психологічної діагностики студентів нами також було проведено перевірку припущення про наявність статистично значущих відмінностей у юнаків і дівчат за діагностичними конструктами, що розглядаються. При цьому статистичною нульовою гіпотезою стало припущення про те, що достовірність відмінностей між показниками юнаків і дівчат за методикою PCRS значуще не відрізняється від нуля. Альтернативною статистичною гіпотезою стало припущення про те, що достовірність відмінностей між показниками юнаків і дівчат за методикою PCRS значуще відрізняється від нуля. Статистичну обробку отриманих даних проведено з використанням $t$-критерія Стьюдента для незалежних вибірок. За результатами цієї роботи було встановлено відсутність достовірних відміннос- 
тей у юнаків і дівчат за такими діагностичними конструктами, як «винахідливість», «оптимізм», «сміливість, підприємливість», «адаптивність», «упевненість». У той же час, виявлено достовірні відмінності юнаків і дівчат за діагностичними конструктами «пристрасність» (у юнаків результати суттєво вищі) і «толерантність до двозначності» (у юнаків результати суттєво вищі). В першому випадку, статистична значущість на рівні 0,05 , у другому - на рівні 0,01 .

Оцінюючи отримані в дослідженні результати, загалом слід відзначити домінування показників низького рівня розвитку за всіма діагностичними конструктами. При цьому це стосується як студенток, так і студентів. Про це свідчать показники середнього арифметичного. За жодним із діагностичних конструктів ні в юнаків, ні в дівчат цей показник не вийшов на рівень середніх, а тим більше високих результатів. Можна говорити про наближення до результатів середнього рівня за шкалами «пристрасність», «винахідливість», «упевненість», «оптимізм» у юнаків і дівчат. В той же час, за такими шкалами як «сміливість, підприємливість», «адаптивність», «толерантність до двозначності» навіть це не спостерігається.

Наступним етапом дослідження стала перевірка припущення про те, що реалізація в процесі навчальних занять з фізичного виховання розроблених автором основ психологічної і психофізичної підготовки студентів залізничних вузів суттєво позитивно впливає на формування складових толерантності до невизначеності, які розглядаються в даному дослідженні.

Як незалежна змінна приймалося використання в ході навчальних занять 3 фізичного виховання складових психологічної і психофізичної підготовки студентів-залізничників. Як залежна змінна розглядалися показники рівня розвитку у студентів складових толерантності до невизначеності («пристрасності», «винахідливості», «оптимізму», «сміливості, підприємливості», «адаптивності», «упевненості», «толерантності до двозначності»).

Статистичною нульовою гіпотезою виступало припущення про те, що зсув між показниками рівня розвитку складових толерантності до невизначеності у студентів експериментальних і контрольних груп у початковому і кінечному зрізі значимо не відрізняється від нуля. Альтернативною статистичною гіпотезою було припущення про те, що зсув між показниками складових толерантності до невизначеності у студентів експериментальних і контрольних груп у початковому 
і кінечному зрізі значимо відрізняється від нуля. Для статистичної перевірки висунутих гіпотез було використано $t$-критерій Стьюдента для залежних вибірок.

В цій частині дослідження приймали участь 176 студентів Дніпропетровського національного університету залізничного транспорту ім. акад. В. Лазаряна, які були залучені на першому етапі. 3 них $100-$ юнаки, 76 - дівчата. Для участі в експерименті було сформовано одну експериментальну і одну контрольну групу у юнаків і одну експериментальну та одну контрольну групу у дівчат. Кількісно, кожна із груп юнаків складала 50 осіб, а кожна із груп дівчат - 38 осіб. Експериментальні і контрольні групи формувались таким чином, щоб до їх складу входила однакова кількість студентів, які мали високий, середній і низький рівень показників складових толерантності до невизначеності.

Студентів експериментальних груп було залучено до навчальних занять $з$ фізичного виховання, які включали вивчення основ психологічної і психофізичної підготовки студентів залізничних вузів. Заняття включали:

1. Вивчення теоретичного матеріалу включеного до розділу психологічної просвіти.

2. Заняття професійно значущими видами спорту (в даному випадку використовувались заняття з міні-футболу і баскетболу для юнаків, і заняття волейболом для дівчат). Ці види спорту були професійно значущими для спеціальностей студентів, що приймали участь в експерименті.

3. Участь у спортивних змаганнях з професійно значущих видів спорту.

4. Виконання вправ для розвитку навиків саморегуляції психічного стану (аутогенне тренування).

5. Заняття з використанням спеціальних фізичних вправ для розвитку психомоторики.

6. Заняття з використанням засобів для розвитку характеристик уваги.

У ході навчальних занять в експериментальних групах проводилась і робота щодо вирішення завдань фізичного виховання 3 формування рухових навичок, умінь та розвитку фізичних якостей.

Навчальні заняття 3 фізичного виховання в експериментальних групах мали таку структуру. Підготовча частина складала 10 хв. 
Головна частина - 75 хв. 3 них 25 хв відводилось для вирішення традиційних завдань фізичного виховання студентів з формування у них рухових навичок та умінь і розвитку фізичних якостей. 20 хв в структурі заняття відводилось або на виконання студентами спеціальних фізичних вправ, або на роботу з засобами розвитку характеристик уваги, або на виконання спеціальних вправ для розвитку навиків саморегуляції психічного стану. В структурі конкретного заняття використовувався один із трьох вищезгаданих блоків засобів. 30 хв основної частини заняття відводилось для вдосконалення у професійно значущому виді спорту. Заключна частина заняття складала 5 хв. Участь студентів експериментальних груп у спортивних змаганнях 3 професійно значущих видів спорту було організовано в позаурочний час.

Студенти контрольних груп вивчали курс фізичного виховання у відповідності до навчальної програми для вищих навчальних закладів.

Студенти експериментальних і контрольних груп відвідували навчальні заняття з фізичного виховання в обсязі 4 навчальних годин на тиждень на протязі першого і другого років навчання у ВНЗ. За результатами першого зрізу (на початку першого семестру) експериментальну і контрольну групу юнаків характеризували показники, які статистично значуще не відрізнялись. Те ж саме було характерним і для експериментальної та контрольної групи дівчат.

По закінченні експерименту (наприкінці четвертого семестру) за такими діагностичними конструктами, як «пристрасність», «винахідливість», «оптимізм», «упевненість» в жодній із 4 груп, які брали участь у ньому, не відбулось статистично значущих змін рівня розвитку.

У той же час, по закінченні експерименту, виявлено статистично значущі позитивні зміни рівня розвитку за такими шкалами, як «сміливість, підприємливість», «адаптивність», «толерантність до двозначності» в експериментальній групі юнаків і в експериментальній групі дівчат (статистична значимість на рівні 0,01). Динаміку змін, які відбулись в процесі експерименту в експериментальній та контрольній групах юнаків наведено в табл. 39.

Зміни, які відбулись в ході експерименту в експериментальній та контрольній групах дівчат, відображено у статистичних показниках, поданих у табл. 40. 


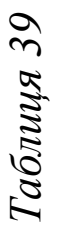

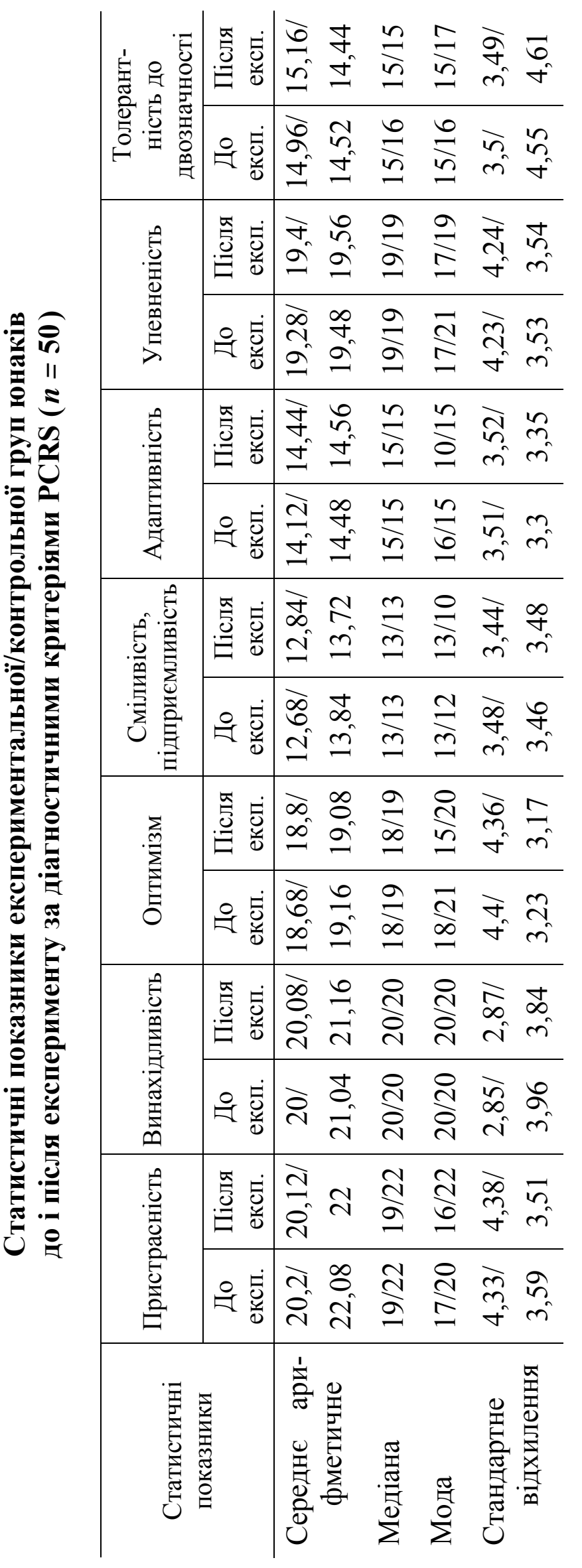


$\sqrt{8}$
0
$\frac{1}{2}$
$\frac{1}{2}$
2

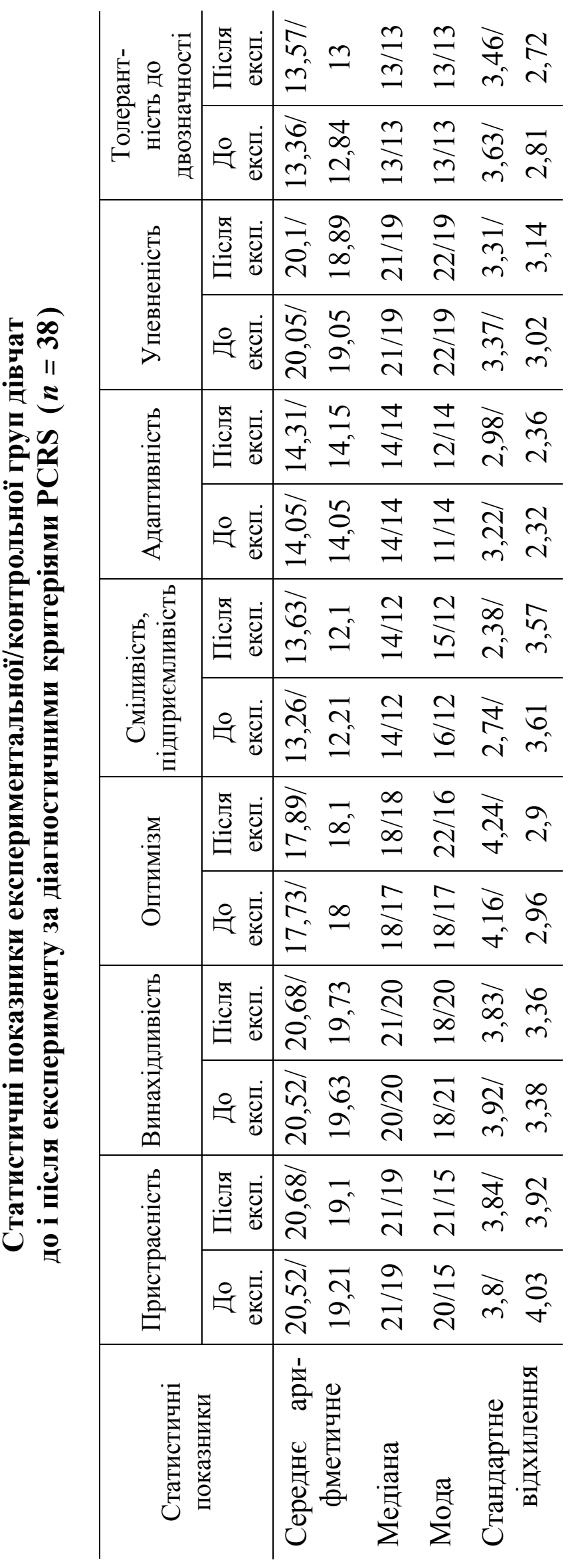


На нашу думку, отримані дані дають підстави стверджувати, що традиційні заняття з фізичного виховання, які проводились у контрольних групах, статистично значуще не впливають на формування у студентів таких складових толерантності до невизначеності, як «пристрасність», «винахідливість», «оптимізм», «сміливість, підприємливість», «адаптивність», «упевненість», «толерантність до двозначності». На відміну від цього, в експериментальних групах, де до змісту навчальних занять 3 фізичного виховання було включено блок психологічної і психофізичної підготовки, зафіксовано статистично значущі позитивні зміни у розвитку таких складових толерантності до невизначеності як «сміливість, підприємливість», «адаптивність», «толерантність до двозначності». У той же час, в експериментальних групах не виявлено статистично значущих змін щодо розвитку таких складових як «пристрасність», «винахідливість», «оптимізм», «упевненість».

Отримані в ході експериментальної роботи дані пояснюються, на нашу думку, ефективністю використаного змісту психологічної і психофізичної підготовки щодо формування у студентів таких характеристик, як «сміливість, підприємливість», «адаптивність», «толерантність до двозначності». У першу чергу це стосується використання спортивних ігор як професійно значущих видів спорту, участі у спортивних змаганнях зі спортивних ігор, вивчення розділу психологічної просвіти, використання вправ для розвитку навиків саморегуляції психічного стану.

Висновки дослідження:

1. Для студентів (і юнаків, і дівчат) характерним є низький рівень розвитку таких складових толерантності до невизначеності, як «пристрасність», «винахідливість», «оптимізм», «сміливість, підприємливість», «адаптивність», «упевненість», «толерантність до двозначності».

2. Не виявлено статистично значущих відмінностей у юнаків і дівчат за рівнем розвитку таких складових, як «винахідливість», «оптимізм», «сміливість, підприємливість», «адаптивність», «упевненість».

3. Встановлено статистично значущі відмінності у юнаків і дівчат за такими складовими, як «пристрасність» і «толерантність до двозначності». Ці показники у юнаків є достовірно вищими. 
4. Психологічна і психофізична підготовка, яка реалізується в процесі фізичного виховання (i до складу якої входять розглянуті блоки засобів) є ефективним засобом розвитку у студентів таких складових толерантності до невизначеності як «сміливість, підприємливість», «адаптивність», «толерантність до двозначності».

\section{5. Психологічна і психофізична підготовка як фактор зниження особистісної тривожності у студентів}

3 точки зору професійної значущості для залізничного транспорту особливий інтерес становить така риса (характеристика) особистості фахівця, як особистісна тривожність. У психології вона розглядається як індивідуальна психологічна особливість, яка проявляється в схильності людини до частих і інтенсивних переживань стану тривоги, а також у низькому порозі її виникнення. У свою чергу тривога трактується як переживання емоційного дискомфорту, що пов'язане з очікуванням неблагополуччя, передчуттям загрози небезпеки.

3 одного боку, ця риса допомогає фахівцю мобілізуватись, сприяє усвідомленню своєї відповідальності за життя і здоров'я пасажирів та збереження вантажів і тим самим сприяє продуктивності його праці. 3 іншого - вона підвищує емоційність у діяльності людини і може довести ії до такого рівня, коли продуктивність праці різко знижується або виконання професійних обов'язків взагалі стає неможливим. У деяких професіограмах залізничних спеціальностей на тривожність вказують як на якість, яка перешкоджає ефективному виконанню професійної діяльності (організація перевезень і управління на залізничному транспорті, мости і транспортні тунелі). На нашу думку, високі показники особистісної тривожності у студентів слід намагатися знизити. Таку думку, очевидно, поділяє і С. О. Ставицька, яка вивчила у своїй роботі психолого-педагогічні умови подолання особистісної тривожності у дітей молодшого шкільного віку [371]. У психотерапії звертають увагу на зв'язок цієї характеристики з невротичною поведінкою людей [86]. Вона також суттєво негативно впливає на таку комплексну характеристику сучасного фахівця, як його емоційна стійкість. Остання в багатьох випадках визначає ефективність 
діяльності й розглядається як здатність людини до збереження стійкості психічних і психомоторних процесів, до підтримання професійної ефективності в умовах впливу емоціогенних чинників [125].

Проблему тривожності вивчали 3. Фрейд, К. Хорні, Ч. Спілбергер, А. М. Прихожан, Ф. Б. Березін, Ю. Л. Ханін, Р. Мей та ін. В останні роки проблему досліджували А. В. Скуратова [358], С. Ю. Тарасова [383], О. В. Кузнєцова [190], О. О. Царьова [423], О. П. Гредюшко [103], І. В. Волженцева [78], Г. А. Мамадалієва [226], В. В. Краснова [182], Ю. А. Зайцев [136], О. Л. Гірченко [90], С. М. Калюжна [156]. Особливо слід відзначити роботу О. В. Кузнєцової, яка вивчала взаємозв'язок рівня тривожності й механізмів адаптації особистості в період юності [190]. Метою дослідження стало встановлення взаємозв'язку між рівнями ситуативної і особистісної тривожності з рівнем адаптації особистості, а також виявлення механізмів адаптації при різних рівнях тривожності. Дослідник припустила, що рівні особистісної і ситуативної тривожності пов'язані з індивідуальними способами адаптації, при цьому ресурсами адаптаційного процесу є особливості самовідношення.

У ході експерименту О. В. Кузнєцова встановила, що висока особистісна тривожність пов'язана з труднощами задоволення значущих потреб, які пов'язані з обмеженнями здоров'я. Було встановлено також, що в юнацькому віці між людьми з різною мірою обмеження можливостей здоров'я існують відмінності за рівнем ситуативної тривожності.

О. В. Кузнєцова виділила типи індивідуальної адаптації залежно від поєднання рівнів ситуативної і особистісної тривожності з рівнем адаптації особистості. До них віднесено: помірно адаптований тип, традиційно адаптований тип, парадоксально адаптований тип, традиційно неадаптований тип.

Т. А. Арутюнян виконала дослідження особливостей співвідношення товариськості й тривожності підлітків [17]. У більш товариських підлітків було зафіксовано низький або нормативний рівень тривожності. Підвищений або високий рівень тривожності було зафіксовано в менш товариських підлітків.

Т. А. Арутюнян виявила також певну специфіку в проявах тривожності у підлітків залежно від типу навчального закладу, де вони навчаються. Так, більш товариські підлітки, що навчались в загальноосвітніх школах, більшою мірою проявляли загальну тривожність, 
тривогу в ситуаціях перевірки знань і вегетативну реактивність у зв'язку з тривогою. Ця ж категорія підлітків, що навчалась у ліцеях, більшою мірою проявляла тривожність у міжособистісних стосунках 3 однолітками і батьками. Для менш товариських підлітків, які навчались у загальноосвітніх школах, більшою мірою була властива тривожність, що пов'язана з успішністю в навчанні. Для цієї ж категорії підлітків, які навчались у ліцеях, більше властива загальна тривожність, тривожність при взаємодії з учителями, батьками, однолітками, тривожність у зв'язку з оцінкою оточуючих, підвищення вегетативної реактивності й зниження психічної активності внаслідок тривоги.

У рамках дослідження формування професійно значущих рис особистості в процесі психологічної і психофізичної підготовки нами було вивчено її вплив на показники особистісної тривожності у студентів. Експеримент було проведено 3 метою перевірки припущення про можливість застосування психологічної і психофізичної підготовки в процесі фізичного виховання для зниження рівня особистісної тривожності у студентів, які мають ii високий рівень. За задумом, включення до блоку професійно значущих видів спорту (який входить як складова до розроблених автором основ психологічної і психофізичної підготовки студентів-залізничників) для цієї категорії студентів тих видів, які піднімають впевненість у собі, позитивно вплине на зниження у студентів високих показників особистісної тривожності.

Експериментальною гіпотезою дослідження стало припущення про те, що заняття атлетизмом і пауерліфтингом, які включено до блоку психологічної і психофізичної підготовки студентів-залізничників, ефективно впливають на зниження особистісної тривожності у юнаків, а заняття аеробікою і сахаджа-йогою мають такий же ефект для дівчат.

Як незалежна змінна прийняті: для юнаків - виконання в ході навчальних занять 3 фізичного виховання вправ атлетичної гімнастики й пауерліфтінгу; для дівчат - виконання в ході навчальних занять вправ аеробіки і сахаджа-йоги. У ході навчальних занять використовувались і інші блоки засобів психологічної і психофізичної підготовки студентів-залізничників.

Як залежна змінна розглядалися показники рівня особистісної тривожності студентів. 
Статистичною нульовою гіпотезою стало припущення про те, що зсув між показниками особистісної тривожності у студентів експериментальних і контрольних груп у початковому і кінцевому зрізі значуще не відрізняється від нуля.

Альтернативною статистичною гіпотезою було припущення про те, що зсув між показниками особистісної тривожності у студентів експериментальних і контрольних груп у початковому і кінцевому зрізі значуще відрізняється від нуля.

Для статистичної обробки отриманих даних використано $t$-критерій Стьюдента для залежних вибірок.

У дослідженні взяли участь 120 студентів Дніпропетровського національного університету залізничного транспорту. 3 них 60 юнаки і 60 дівчата. Вік учасників дослідження складав 17-19 років. Вибірка формувалася таким чином. На початку навчального року було проведено психологічну діагностику рівня ситуативної й особистісної тривожності у студентів, які вступили на перший курс. За результатами обробки матеріалів було виявлено студентів 3 високим рівнем особистісної тривожності. Цим студентам було запропоновано стати учасниками дослідження. Було сформовано одну експериментальну й одну контрольну групу у юнаків і одну експериментальну та одну контрольну групу в дівчат (по 30 осіб у кожній).

Студентів (і юнаків, і дівчат) експериментальних груп було залучено до навчальних занять з фізичного виховання, які включали вивчення розроблених автором основ психологічної і психофізичної підготовки студентів-залізничників. Заняття містили:

1. Вивчення теоретичного матеріалу, включенного до розділу психологічної просвіти.

2. Заняття видами спорту, які за задумом автора повинні підняти впевненість студентів у собі i, як наслідок, вплинути на зниження рівня особистісної тривожності. Для юнаків це були заняття з атлетичної гімнастики і пауерліфтингу, для дівчат - заняття з сахаджа-йоги та аеробіки.

3. Заняття з використанням психотренувальних засобів, зокрема методики для діагностики характеристик уваги (коректурна проба Бурдона, тест «переплутані лінії», методика «відшукування чисел 3 переключенням уваги за червоно-чорними таблицями»).

4. Заняття з використанням спеціальних фізичних вправ для розвитку психомоторики студентів. 
5. Участь у спортивних змаганнях.

6. Вправи для розвитку навиків саморегуляції психічного стану (аутогенне тренування).

У ході навчальних занять проводилась і робота з вирішення традиційних завдань фізичного виховання щодо формування рухових навичок, умінь та розвитку фізичних якостей студентів.

Студенти контрольних груп вивчали курс фізичного виховання відповідно до навчальної програми для вищих навчальних закладів [253].

Навчальні заняття 3 фізичного виховання в експериментальних групах мали таку структуру. Підготовча частина заняття складала 10 хв. Головна частина - 75 хв. 3 них 25 хв відводилося для вирішення традиційних завдань фізичного виховання студентів з формування у них рухових навичок і умінь та розвитку фізичних якостей. 20 хв в структурі заняття відводилось або на виконання студентами спеціальних фізичних вправ, або на їх роботу з психотренувальними засобами, або на використання вправ для розвитку навиків саморегуляції психічного стану. У структурі конкретного заняття використовувався тільки один із названих блоків. 30 хв структури основної частини заняття присвячувалося заняттю професійно значущим видом спорту. Заключна частина складала п'ять хвилин.

Аналізуючи приведену вище структуру навчального заняття, може скластися враження, що для вирішення традиційних завдань фізичного виховання відведено мало часу. Це помилкова думка, оскільки майже всі запропоновані блоки засобів (за винятком психологічних засобів для розвитку характеристик уваги) є ефективними у плані вирішення як традиційних, так і нових завдань психологічної і психофізичної підготовки студентів. Це стосується і професійно значущих видів спорту, і спеціальних фізичних вправ, і нетрадиційних засобів фізичного виховання, і спортивних змагань. Завдання полягає в реалізації комплексного підходу при підборі засобів для навчальних занять. Необхідно підібрати такі з них, які є ефективними і в одному, і в іншому плані. У цьому, на нашу думку, і полягає педагогічна майстерність викладача.

На першому курсі студентам експериментальних груп було прочитано 16 годин лекцій, що входили до блоку психологічної просвіти. Протягом 49 занять студенти (по 30 хв) займалися професійно значущими видами спорту. Спеціальні фізичні вправи для розвитку 
психомоторики використовувалися на 23 заняттях (по 20 хв на кожному). Психотренувальні засоби для розвитку характеристик уваги було застосовано в ході 12 занять (по 20 хв на кожному). Вправи для формування навиків саморегуляції психічного стану використано на двох заняттях (по 20 хв на кожному). Спортивні змагання з професійно значущих видів спорту було організовано в ході 8 занять. Контрольні заходи проводились на 4 заняттях.

На другому курсі в ході 53 занять студенти експериментальних груп займалися професійно значущими видами спорту. Спеціальні фізичні вправи для розвитку психомоторики виконувалися в ході 24 занять. Психотренувальні засоби для розвитку характеристик уваги застосовувалися на 16 заняттях. Вправи для формування навиків саморегуляції психічного стану було використано в ході 12 занять. Спортивні змагання з професійно значущих видів спорту організовано на 8 заняттях. На 4 заняттях проводилися контрольні заходи.

Психологічна діагностика рівня особистісної тривожності у студентів проводилася 3 використанням шкали оцінки рівня реактивної і особистісної тривожності Ч. Спілбергера (дод. 5).

Студентам експериментальних груп ставилося завдання освоїти програму психологічної і психофізичної підготовки. Їм пояснювали, що оцінка за цей розділ входить як складова до загальної оцінки з навчальної дисципліни «Фізичне виховання». Підсумкова оцінка 3 фізичного виховання виставлялася з урахуванням усіх розділів: теоретична підготовленість 3 фізичного виховання, методична підготовленість 3 фізичного виховання, фізична підготовленість, психологічна і психофізична підготовленість. Якщо за одним із зазначених розділів студент отримував незадовільну оцінку, то 3 дисципліни «Фізичне виховання» виставлялася залікова оцінка «незадовільно». Формою семестрового контролю був диференційований залік, який впливав на призначення стипендії. Окремо наголошувалося на необхідності досягти успіху у виді спорту, який було обрано для експериментальних груп. Юнаків орієнтували на виконання третього спортивного розряду з пауерліфтингу, дівчат - на участь в університетських змаганнях зі спортивної гімнастики та аеробіки.

Оцінка з розділу «Психологічна і психофізична підготовка» проводилася за результатами діагностики у студентів таких складових, як знання основ психологічної просвіти, показники рівня розвитку вибірковості та концентрації і стійкості уваги, показники рівня роз- 
витку психомоторних процесів студентів (вестибулярна стійкість, швидкість у діях). Показники сформованості професійно значущих рис особистості студентів кількісно не оцінювались, але враховувалися під час оцінювання студентів з розділу.

Теоретична підготовленість перевірялась і оцінювалась за результатами відповіді студента по білету, складеному відповідно до змісту підрозділу психологічної просвіти студентів. До білетів включалось 2-3 питання. Відповіді були усними або письмовими.

Нарахування балів за теоретичну підготовленість здійснювалося таким чином. Оцінка «відмінно» ставилась у тому разі, якщо відповідь на поставлені запитання була повна і правильна. Оцінку «добре» студент отримував за умови, що його відповідь на поставлені запитання була по суті правильна, але не повна. Оцінка «задовільно» ставилась студентам, які на поставлені запитання давали неповну, із суттєвими помилками відповідь. Якщо відповідь студента на поставлені запитання не розкривала суті питань або не було спроби відповісти на них, ставилась оцінка «незадовільно».

Показники рівня розвитку характеристик уваги студентів оцінювались за результатами виконання відповідних тестів. Так, вибірковість уваги оцінювалась за результатами виконання тесту Мюнстерберга за шкалою від 1 до 5. Один бал нараховувався за результат від 0 до 5 слів. Два бали - за результат від 6 до 10 слів. У три бали оцінювали результат від 11 до 15 слів. Чотири бали давав студенту результат від 16 до 20 слів. П'ять балів ставилось за результат від 21 до 25 слів.

Показники розвитку концентрації і стійкості уваги у студентів оцінювались за результатами виконання завдань за коректурною пробою Бурдона. Робота виконувалася протягом десяти хвилин. Її продуктивність на рівні від 2001 знака і вище оцінювалась оцінкою «відмінно». Результат в діапазоні від 1701 до 2000 знаків давав оцінку «добре». Ті студенти, які показували результат в діапазоні 1351-1700 знаків, отримували «задовільно». Результат нижче 1351 знака розглядався як незадовільний.

Рівень розвитку психомоторних процесів у студентів оцінювався за результатами виконання спеціальних фізичних вправ. Так, стійкість вестибулярних реакцій оцінювалася за результатами виконання п'яти перекидань за десять секунд. Якщо студент після виконання цієї вправи міг впевнено зберігати основну стійку - ставилась оцінка 
«відмінно». За наявності в студента нестійкості зі сходженням 3 місця до одного кроку ставилась оцінка «добре», до двох кроків - «задовільно». У разі більш значних відхилень або у випадку падіння ставилося «незадовільно».

Швидкість у діях у студентів оцінювалась за результатами виконання двадцяти кидків баскетбольного м'яча в стіну (у коло діаметром 50 см) з відстані два метри. Результат 22 с і вищий оцінювався як незадовільний. Студенти, які показували результат 20-21 с, отримували оцінку «задовільно». У випадку коли результат складав 18-19 с, ставилась оцінка «добре». Результат, що дорівнював 17 с або менше, давав право на оцінку «відмінно».

Кожен із вказаних підрозділів (показників) оцінювався за 5-бальною шкалою. Підсумкова оцінка з розділу «психологічна і психофізична підготовка» виставлялась з урахуванням оцінки всіх п'яти підрозділів. Якщо по одному із підрозділів студент отримував незадовільну оцінку, виставлялось «незадовільно» з розділу «психологічна і психофізична підготовка».

За результатами першого зрізу особистісної тривожності в студентів було сформовано експериментальні й контрольні групи. Їх характеризували статистичні показники, наведені в табл. 41.

Таблицฺя 41

Рівень особистісної тривожності студентів експериментальних і контрольних груп до початку експерименту $(n=120)$

\begin{tabular}{l|c|c|c|c}
\hline \multirow{2}{*}{ Показник } & \multicolumn{2}{|c|}{ Юнаки } & \multicolumn{2}{c}{ Дівчата } \\
\cline { 2 - 5 } & $\begin{array}{c}\text { Експеримен- } \\
\text { тальна група }\end{array}$ & $\begin{array}{c}\text { Контрольна } \\
\text { група }\end{array}$ & $\begin{array}{c}\text { Експеримен- } \\
\text { тальна група }\end{array}$ & $\begin{array}{c}\text { Контрольна } \\
\text { група }\end{array}$ \\
\hline $\begin{array}{l}\text { Середнє арифмети- } \\
\text { чне }\end{array}$ & 49,6 & 49,46 & 53,1 & 52,96 \\
$\begin{array}{l}\text { Медіана } \\
\text { Мода }\end{array}$ & 48,5 & 48,5 & 52 & 52 \\
$\begin{array}{l}\text { Стандартне відхи- } \\
\text { лення }\end{array}$ & 3,69 & 46 & 61 & 61 \\
\end{tabular}

Як видно з таблиці, студенти експериментальної й контрольної групи, що брали участь в експерименті, до його початку характеризувались дуже близькими показниками рівня особистісної тривожності. 
Повторний зріз було проведено наприкінці четвертого семестру. Експериментальні й контрольні групи тепер характеризували такі показники (табл. 42).

Таблиия 42

Рівень особистісної тривожності студентів експериментальних і контрольних груп по закінченні експерименту $(n=120)$

\begin{tabular}{l|c|c|c|c}
\hline \multirow{2}{*}{\multicolumn{1}{c|}{ Показник }} & \multicolumn{2}{|c|}{ Юнаки } & \multicolumn{2}{c}{ Дівчата } \\
\cline { 2 - 5 } & $\begin{array}{c}\text { Експеримен- } \\
\text { тальна група }\end{array}$ & $\begin{array}{c}\text { Контрольна } \\
\text { група }\end{array}$ & $\begin{array}{c}\text { Експеримен- } \\
\text { тальна група }\end{array}$ & $\begin{array}{c}\text { Контрольна } \\
\text { група }\end{array}$ \\
\hline $\begin{array}{l}\text { Середнє арифмети- } \\
\text { чне }\end{array}$ & 48,2 & 49,43 & 52,23 & 53,13 \\
$\begin{array}{l}\text { Медіана } \\
\text { Мода }\end{array}$ & 48 & 48,5 & 52 & 52 \\
$\begin{array}{l}\text { Стандартне відхи- } \\
\text { лення }\end{array}$ & 3,94 & 46 & 60 & 61 \\
\end{tabular}

На основі порівняння даних табл. 41 і 42 можна зробити висновки про динаміку змін особистісної тривожності у студентів експериментальних і контрольних груп. Звертає на себе увагу зниження статистичних показників особистісної тривожності у студентів експериментальних груп. Насамперед це стосується такого показника, як середнє арифметичне. Так, у юнаків експериментальної групи середне арифметичне рівня особистісної тривожності знизилось з 49,6 до 48,2 бала. Це досить значний прогрес. Для порівняння, у юнаків контрольної групи середне арифметичне рівня особистісної тривожності залишилось майже без змін. На початку експерименту воно становило 49,46 бала. В кінці - 49,43 бала. У дівчат експериментальної групи середнє арифметичне також знизилось з 53,1 до 52,23 бали, що можна кваліфікувати як суттєві зміни (враховуючи природу показника). На відміну від цього, у контрольній групі дівчат відбулося навіть несуттєве зростання середнього арифметичного особистісної тривожності з 52,96 (до початку експерименту) до 53,13 (по його закінченні).

В експериментальній групі юнаків також зафіксовано зниження показника медіани. До початку експерименту в цій групі вона 
складала 48,5 бали, а по його закінченні - 48 балів. В експериментальній групі дівчат зміни показника медіани не зафіксовано. До і після експерименту вона складала 52 бали. Не зафіксовано зміну медіани і в контрольних групах. У юнаків вона залишилась на рівні 48,5 бала. У дівчат - на рівні 52 балів.

Такий статистичний показник, як стандартне відхилення в експериментальних і контрольних групах зазнав таких змін. В експериментальній групі юнаків відбулось його зростання з 3,69 (до початку експерименту) до 3,94 бали (по закінченні експерименту). У контрольній групі юнаків також зафіксовано невелике зростання стандартного відхилення 3 3,62 бали (до початку експерименту) до 3,69 бали (по закінченні експерименту). В експериментальній групі дівчат показник стандартного відхилення зріс з 5,34 бали (до початку експерименту) до 5,99 бали (по закінченні експерименту). У контрольній групі дівчат відбулось менш суттєве зростання. На початку експерименту було зафіксовано 5,49 бала, по його закінченні - 5,61 бала.

Вторинну статистичну обробку даних експерименту виконано з використанням $t$-критерію Стьюдента для залежних вибірок. У результаті цієї роботи встановлено таке. Для контрольної групи юнаків $t$ емпіричне становить 0,3 . Критичними значеннями $t \epsilon:$ a) при рівні статистичної значущості (рівні достовірності результату дослідження) 0,01-2,76; б) при рівні статистичної значущості 0,05-2,05. Отже, отримане емпіричне значення $t(0,3)$ розташоване в зоні незначущості. На підставі цього зроблено висновок про правильність нульової гіпотези стосовно контрольної групи юнаків.

Статистична обробка даних, отриманих у ході експерименту в експериментальній групі юнаків, показала, що $t$ емпіричне становить 4,4. Критичними значеннями $t$, як і в попередньому випадку, $є$ : а) на рівні статистичної значущості $0,01-2,76$; б) на рівні статистичної значущості 0,05-2,05. Отже, отримане емпіричне значення $t(4,4)$ розташоване в зоні значущості. На підставі цього відхилено нулову гіпотезу стосовно експериментальної групи юнаків і підтверджено правильність альтернативної.

Виконавши статистичну обробку даних, отриманих у ході експерименту в контрольній групі дівчат, ми виявили, що $t$ емпіричне для неї становить 1,7. Критичні значення $t$ : а) на рівні $0,01-2,76$; б) на рівні $0,05-2,05$. Отже, отримане емпіричне значення розташоване в зоні 
незначущості. На підставі цього зроблено висновок про правильність нульової гіпотези стосовно контрольної групи дівчат.

Статистична обробка даних, отриманих у ході експерименту в експериментальній групі дівчат, показала таке. $t$ емпіричне становить 3,2 . Критичними значеннями $t \epsilon$ : а) на рівні $0,01-2,76$; б) на рівні $0,05-2,05$. Отже, отримане емпіричне значення $t(3,2)$ розташоване в зоні значущості. На підставі цього відхилено нульову гіпотезу стосовно експериментальної групи дівчат і підтверджено правильність альтернативної.

Плануючи проведення експерименту, ми виходили 3 того, що професійна праця на залізничному транспорті часто супроводжується значним емоційним напруженням, яке пов'язане з великою відповідальністю за життя і здоров'я пасажирів та збереження вантажів. Це негативно впливає на працездатність спеціалістів, призводить до помилок, аварій, негативно відбивається на стані їх здоров'я. Одним із напрямків, які доцільно досліджувати для вирішення цієї проблеми, $\epsilon$ можливість формування на стадії професійної підготовки у вищих навчальних закладах особистісного потенціалу стресостійкості особистості (або емоційної стійкості). Мова йде, насамперед, про формування в майбутнього залізничника таких рис особистості, які допомагають справитися з емоційним напруженням.

Вивчення професіограм залізничних спеціальностей показало, що для таких важливих залізничних спеціальностей, як «Організація перевезень і управління на залізничному транспорті», «Електричний транспорт», «Мости і транспортні тунелі» та інших $\epsilon$ перелік рис особистості, які перешкоджають ефективному виконанню професійної діяльності. Серед них названо і особистісну тривожність. Виконані автором дослідження показали, що високі показники рівня розвитку особистісної тривожності зафіксовано у 14 \% юнаків і 49 \% дівчат, які навчаються у залізничних ВН3 [284]. Ситуація потребує відповідного «реагування», проведення роботи зі зниження показників особистісної тривожності в цієї категорії студентів. На нашу думку, суттєво допомогти у вирішенні питання може обстоюване автором проведення психологічної і психофізичної підготовки студентівзалізничників у процесі фізичного виховання. Для перевірки цього й було проведено експеримент. У своїй експериментальній гіпотезі ми припустили, що спеціально зорієнтована на зниження особистісної тривожності психологічна і психофізична підготовка в процесі 
фізичного виховання суттєво вплине на зниження особистісної тривожності у студентів, які мають їі високий рівень. Для перевірки експериментальної гіпотези було проведено експеримент, у якому взяли участь чотири групи студентів: дві експериментальні (одна - юнаки, одна - дівчата) і дві контрольні (одна - юнаки, одна - дівчата). Змістом навчальної діяльності студентів контрольних груп було освоєння навчальної програми 3 фізичного виховання для студентів ВНЗ третього і четвертого рівнів акредитації. До змісту навчальної діяльності студентів експериментальних груп, окрім вищезгаданих, входило освоєння зорієнтованого на зниження особистісної тривожності, специфічного для юнаків і специфічного для дівчат блоку психологічної і психофізичної підготовки.

Дані, отримані в ході експериментальної роботи стосовно динаміки змін рівня особистісної тривожності у студентів-залізничників, що мали високі показники, свідчать про таке. У контрольних групах (і юнаків, і дівчат), у яких проводилися традиційні заняття з фізичного виховання, не відбулося суттєвого (статистично значущого) зниження рівня особистісної тривожності. На користь цього твердження свідчить відсутність відповідних статистичних показників. На нашу думку, пояснити ситуацію можна недостатнім використанням у ході традиційних занять з фізичного виховання ефективної для зниження особистісної тривожності фізкультурної і спортивної діяльності.

Що стосується експериментальних груп (і юнаків, і дівчат), то в них на кінець експерименту отримано статистичні дані, які показують суттєве зниження показників рівня особистісної тривожності. Динаміка цих змін, статистично визначена 3 використанням $t$-критерію Стьюдента для залежних виборок, показала, що вони розташовані в зоні значущості. При цьому в експериментальній групі юнаків зафіксовано більш суттєве зниження ( $t$ емпіричне становить 4,4$)$ порівняно $з$ експериментальною групою дівчат ( $t$ емпіричне становить $3,2)$. На нашу думку, це доцільно пояснити різною дієвістю для юнаків і дівчат тих засобів, що застосовувалися в ході навчальних занять.

Результати, отримані в експериментальних групах, дають підстави стверджувати, що експериментальна гіпотеза підтвердилась. Використання в процесі психологічної і психофізичної підготовки на заняттях $з$ фізичного виховання як значущих видів спорту атлетизму й пауерліфтингу у юнаків та аеробіки й сахаджа-йоги в дівчат статис- 
тично значуще вплинуло на зниження у них рівня особистісної тривожності.

Отримані в ході експериментального дослідження дані підтверджують думку відомого російського психотерапевта В. І. Гарбузова, який вважає, що в складному, неусвідомленому сприйнятті Я «м'язове відчуття» відіграє величезну роль. Міцний кістяк, розвинені м'язи породжують у чоловіка відчуття впевненості у собі [83, с. 43]. Для дівчат так само важливими він вважає набуття стрункості й спритності. На нашу думку, саме підвищення впевненості у собі у студентів, яке відбулось в процесі роботи в експериментальних групах, спричинило зниження рівня особистісної тривожності.

Формулюючи головні висновки експерименту, відзначаємо:

1. За результатами виконаної роботи експериментальне підтвердження отримала гіпотеза про те, що спеціальна психологічна й психофізична підготовка в ході фізичного виховання є ефективним засобом зниження високого рівня особистісної тривожності у студентів.

2. В експериментальній групі юнаків 3 високим рівнем особистісної тривожності свою ефективність (у плані їі зниження) показали заняття атлетичною гімнастикою і пауерліфтингом, які були головним блоком системи психологічної і психофізичної підготовки цієї категорії студентів.

3. В експериментальній групі дівчат з високим рівнем особистісної тривожності свою ефективність (у плані їі зниження) показали заняття аеробікою і сахаджа-йогою, які були головним блоком системи психологічної і психофізичної підготовки цієї категорії студентів.

\section{Висновки до розділу}

1. Експериментальне підтвердження отримала гіпотеза про суттєвий вплив на формування особистості студентів навчальних занять 3 фізичного виховання у навчальній секції спортивного виховання. Це стосується таких факторів (за Р. Кеттеллом), як «емоційна нестійкість - емоційна стійкість», «несміливість - сміливість», «довірливість - підозрілість». Виявлено також особливості впливу на особистість студентів занять такими видами спорту, як легка атлетика, важка атлетика, футбол, плавання, спортивна гімнастика. 
2. Експериментальне підтвердження отримала гіпотеза про те, що традиційні навчальні заняття з фізичного виховання суттєво не впливають на формування особистості студентів (за факторами за Р. Кеттеллом).

3. Експериментальне підтвердження отримала гіпотеза про суттєвий позитивний вплив на формування ряду професійно значущих факторів особистості студентів-залізничників («емоційна нестійкість емоційної стійкість», «схильність до почуттів - висока нормативність поведінки», «впевненість у собі - тривожність», «низький самоконтроль - високий самоконтроль», «адекватність самооцінки») реалізації в ході навчальних занять з фізичного виховання розроблених автором основ психологічної і психофізичної підготовки.

4. Найбільш поширеними копінг-стратегіями серед студентів є:

a) у когнітивній сфері - «збереження самовладання»;

б) в емоційній сфері - «оптимізм»;

в) у поведінковій сфері - «відволікання».

5. Серед студентів кількісно переважає використання адаптивних стратегій порівняно з неадаптивними і відносно адаптивними (ця тенденція не стосується поведінкових адаптивних стратегій у юнаків і дівчат).

6. Серед адаптивних копінг-стратегій найбільш поширеними серед студентів (і юнаків, і дівчат) $є$ адаптивні емоційні стратегії.

7. Серед неадаптивних копінг-стратегій найбільш поширене використання серед студентів мають: емоційні неадаптивні стратегії у дівчат, поведінкові неадаптивні стратегії у дівчат, емоційні неадаптивні стратегії у юнаків.

8. Серед відносно адаптивних копінг-стратегій найбільш поширеними серед студентів $є$ : когнітивні відносно адаптивні стратегії у дівчат, поведінкові відносно адаптивні стратегії у дівчат, когнітивні відносно адаптивні стратегії у юнаків.

9. Використання в ході навчальних занять з фізичного виховання складових психологічної і психофізичної підготовки студентів залізничних ВНЗ суттєво позитивно впливає на формування у студентів адаптивних і відносно адаптивних когнітивних і поведінкових копінгстратегій.

10. Використання в ході навчальних занять з фізичного виховання складових психологічної і психофізичної підготовки студентів за- 
лізничних ВНЗ суттєво не впливає на формування у студентів адаптивних і відносно адаптивних емоційних копінг-стратегій.

11. Для студентів (і юнаків, і дівчат) характерним $є$ низький рівень розвитку таких складових толерантності до невизначеності, як «пристрасність», «винахідливість», «оптимізм», «сміливість, підприємливість», «адаптивність», «упевненість», «толерантність до двозначності».

12. Не виявлено статистично значущих відмінностей у юнаків і дівчат за рівнем розвитку таких складових, як «винахідливість», «оптимізм», «сміливість, підприємливість», «адаптивність», «упевненість».

13. Встановлено статистично значущі відмінності у юнаків і дівчат за такими складовими, як «пристрасність» i «толерантність до двозначності». Ці показники у юнаків є достовірно вищими.

14. Психологічна і психофізична підготовка, яка реалізується в процесі фізичного виховання (і до складу якої входять розглянуті блоки засобів) $є$ ефективним засобом розвитку у студентів таких складових толерантності до невизначеності як «сміливість, підприємливість», «адаптивність», «толерантність до двозначності».

15. Експериментальне підтвердження отримала гіпотеза про те, що спеціальна психологічна і психофізична підготовка в ході фізичного виховання $\epsilon$ ефективним засобом зниження високого рівня особистісної тривожності у студентів.

16. В експериментальній групі юнаків з високим рівнем особистісної тривожності свою ефективність (в плані ії зниження) показали заняття атлетичною гімнастикою і пауерліфтингом, які були головним блоком системи психологічної і психофізичної підготовки цієї категорії студентів.

17. В експериментальній групі дівчат з високим рівнем особистісної тривожності свою ефективність (у плані їі зниження) показали заняття аеробікою і сахаджа-йогою, які приймалися головним блоком системи психологічної і психофізичної підготовки цієї категорії студентів. 


\section{Формування пізнавальних процесів і психомоторики студентів у процесі психологічної і психофізичної підготовки (експериментальне дослідження)}

\section{1. Розвиток концентрації і стійкості уваги студентів-залізничників у процесі психологічної і психофізичної підготовки}

Переважна більшість головних професій залізничного транспорту висувають високі вимоги до різноманітних характеристик уваги фахівця. Насамперед це стосується концентрації і стійкості. У психології увага розглядається як спрямованість і зосередженість психічної діяльності людини. При цьому під спрямованістю розуміють вибірковий характер активності, а під зосередженістю - заглиблення в дану діяльність [296, с. 120]. Концентрація і стійкість є одними з головних характеристик уваги. Концентрація відображає здатність суб'єкта зберігати зосередженість на об'єкті уваги за наявності перешкод. Стійкість - характеризує здатність суб'єкта не відхилятися від спрямованості психічної активності й зберігати зосередженість на об'єкті уваги.

Враховуючи велику професійну значущість, нами було проведено дослідження ефективності розвитку концентрації і стійкості уваги у студентів-залізничників в процесі їх психологічної і психофізичної підготовки під час занять з фізичного виховання.

Експериментальною гіпотезою дослідження стало припущення про те, що розроблена автором система спеціально організованої психологічної і психофізичної підготовки в процесі фізичного виховання студентів є ефективним засобом розвитку в них концентрації і стійкості уваги. 
Як незалежна змінна приймався зміст розроблених автором основ психологічної і психофізичної підготовки студентів-залізничників, який включав: блок психологічної просвіти, заняття професійно значущими видами спорту, використання психотренувальних засобів, виконання спеціальних фізичних вправ для розвитку уваги, виконання вправ для розвитку навиків саморегуляції, участь у спортивних змаганнях з професійно значущих видів спорту. Залежною змінною були показники динаміки рівня розвитку концентрації і стійкості уваги у студентів.

Як статистична нульова гіпотеза приймалося припущення про те, що інтенсивність зсуву концентрації і стійкості уваги в студентів експериментальної і контрольної груп в типовому напрямку не перевищує інтенсивності зсуву в нетиповому.

Альтернативною статистичною гіпотезою було припущення про те, що інтенсивність зсуву концентрації і стійкості уваги у студентів експериментальних і контрольних груп в типовому напрямку перевищує інтенсивність зсуву в нетиповому напрямку.

У дослідженні взяли участь 64 студенти Дніпропетровського національного університету залізничного транспорту, для майбутньої професії яких ці характеристики уваги надзвичайно важливі. Це були студенти, що навчалися за спеціальностями «Організація перевезень і управління на залізничному транспорті», «Електричний транспорт», «Електромеханічні системи автоматизації та електропривід», «Вагони та вагонне господарство», «Локомотиви та локомотивне господарство». Вік учасників дослідження складав 17-19 років.

Вибірка формувалася таким чином. На початку навчального року було проведено психологічну діагностику рівня розвитку концентрації і стійкості уваги у студентів. Провівши обробку матеріалів діагностики, ми виявили студентів 3 високим, середнім і низьким рівнем розвитку цих характеристик уваги. Цим студентам було запропоновано взяти участь у дослідженні. Було сформовано одну експериментальну й одну контрольну групу. Кількісно кожна із груп складала 32 особи. До експериментальної і контрольної груп входила однакова кількість студентів з високим, середнім і низьким рівнем розвитку концентрації і стійкості уваги.

Студентів експериментальної групи було залучено до навчальних занять з фізичного виховання, які включали вивчення розроблених 
автором основ психологічної і психофізичної підготовки студентівзалізничників. Заняття містили:

1. Вивчення теоретичного матеріалу, включеного до розділу психологічної просвіти.

2. Заняття професійно значущими видами спорту, зокрема використовувалися спортивні ігри (футбол, футзал, баскетбол).

3. Використання психотренувальних засобів, зокрема тест «переплутані лінії», методика «відшукування чисел з переключенням уваги за червоно-чорними таблицями», коректурна проба Бурдона.

4. Спеціальні фізичні вправи для розвитку уваги [240, с. 206-208].

5. Вправи для формування навиків саморегуляції психічного стану (аутогенне тренування, медитація).

6. Участь у спортивних змаганнях з професійно значущих видів спорту.

У ході навчального процессу вирішувались і традиційні завдання фізичного виховання студентів з формування у них рухових навичок, умінь та розвитку фізичних якостей. Студенти контрольної групи вивчали курс фізичного виховання відповідно до навчальної програми для вищих навчальних закладів [253].

Перед студентами експериментальної групи було поставлено завдання освоїти програму психологічної і психофізичної підготовки. Оцінка за цей розділ входила як складова до загальної оцінки з дисципліни «Фізичне виховання». У свою чергу оцінка рівня розвитку концентрації і стійкості уваги входила як складова до загальної оцінки з розділу психологічної і психофізичної підготовки. Рівень розвитку концентрації і стійкості уваги у студентів оцінювався з використанням коректурної проби Бурдона. Робота виконувалася протягом десяти хвилин. Її продуктивність на рівні від 2001 знаку і вище оцінювалась оцінкою «відмінно». Результат в діапазоні від 1701 до 2000 знаків давав оцінку «добре». Ті студенти, які показували результат в діапазоні 1351-1700 знаків, отримували «задовільно». Результат нижче 1351 знака розглядався як незадовільний.

Формою семестрового контролю був диференційований залік, результати якого впливали на призначення стипендії.

Навчальні заняття 3 фізичного виховання в експериментальній групі мали таку структуру. Підготовча частина заняття складала 10 хв. Головна частина - 75 хв. 3 них 25 хв відводилося для вирішення традиційних завдань фізичного виховання студентів 3 формування 
в них рухових навичок і умінь та розвитку фізичних якостей. 20 хв в структурі заняття відводилось: або на виконання студентами спеціальних фізичних вправ, або на їх роботу з психотренувальними засобами, або на використання нетрадиційних засобів фізичного виховання. У структурі конкретного заняття використовувався тільки один 3 названих блоків. 30 хв структури основної частини заняття присвячувалося заняттю професійно значущим видом спорту. Заключна частина складала п'ять хвилин.

На першому курсі студентам експериментальної групи було прочитано 16 годин лекцій, що входили до блоку психологічної просвіти. Протягом 49 занять студенти (по 30 хв) займалися професійно значущими видами спорту. Спеціальні фізичні вправи для розвитку психомоторики використовувалися на 23 заняттях (по 20 хв на кожному). Психотренувальні засоби для розвитку характеристик уваги було застосовано в ході 12 занять (по 20 хв на кожному). Впави для формування навиків саморегуляції психічного стану використано на двох заняттях (по 20 хв на кожному). Спортивні змагання 3 професійно значущих видів спорту було організовано в ході 8 занять. Контрольні заходи проводилися на 4 заняттях.

На другому курсі в ході 53 занять студенти експериментальної групи займалися професійно значущими видами спорту. Спеціальні фізичні вправи для розвитку психомоторики виконувались в ході 24 занять. Психотренувальні засоби для розвитку характеристик уваги застосовувалися на 16 заняттях. Вправи для формування навиків саморегуляції психічного стану було використано в ході 12 занять. Спортивні змагання з професійно значущих видів спорту організовано на 8 заняттях. На 4 заняттях проводилися контрольні заходи.

За результатами першого зрізу (на початку першого семестру) експериментальну й контрольну групу характеризували показники, наведені в табл. 43.

Статистичні показники експериментальної групи такі:

1. Середне арифметичне - 1297 знаків;

2. Медіана - 1270,5 знака;

3. Стандартне відхилення - 321 знак.

Статистичні показники контрольної групи такі:

1. Середне арифметичне - 1300 знаків;

2. Медіана - 1265 знаків;

3. Стандартне відхилення - 322,6 знака. 
Концентрація і стійкість уваги студентів експериментальної і контрольної груп до початку експерименту (у балах $),(n=64)$

\begin{tabular}{|c|c|c|c|c|c|c|c|c|c|c|}
\hline \multirow{2}{*}{\multicolumn{2}{|c|}{ Група }} & \multicolumn{9}{|c|}{ Бали } \\
\hline & & 1 & 2 & 3 & 4 & 5 & 6 & 7 & 8 & \\
\hline \multirow[t]{2}{*}{ Експериментальна } & Кількість & 5 & 7 & 8 & 4 & 3 & 3 & 1 & 1 & 0 \\
\hline & $\%$ & 16 & 22 & 25 & 13 & 9 & 9 & 3 & 3 & 0 \\
\hline \multirow[t]{2}{*}{ Контрольна } & Кількість & 5 & 7 & 8 & 4 & 3 & 3 & 1 & 1 & \\
\hline & $\%$ & 16 & 22 & 25 & 13 & 9 & 9 & 3 & 3 & 0 \\
\hline
\end{tabular}

Повторний зріз було проведено наприкінці четвертого семестру і виявлено такі показники (табл. 44).

Статистичні показники експериментальної групи такі:

1. Середнє арифметичне - 1554 знаки;

2. Медіана - 1537 знаків;

3. Стандартне відхилення - 382 знаки.

Статистичні показники контрольної групи такі:

1. Середнє арифметичне - 1309 знаків;

2. Медіана - 1285 знаків;

3. Стандартне відхилення - 317 знаків.

Таблиия 44

Концентрація і стійкість уваги студентів експериментальної і контрольної груп по закінченні експерименту (у балах), $(n=64)$

\begin{tabular}{|c|c|c|c|c|c|c|c|c|c|c|}
\hline \multirow{2}{*}{\multicolumn{2}{|c|}{ Група }} & \multicolumn{9}{|c|}{ Бали } \\
\hline & & \multirow{3}{*}{1} & \multirow{2}{*}{$\frac{2}{2}$} & \multirow{2}{*}{$\frac{3}{3}$} & \multirow[b]{2}{*}{7} & \multirow[b]{2}{*}{7} & \multirow[b]{2}{*}{2} & \multirow[b]{2}{*}{3} & \multirow[b]{2}{*}{2} & \multirow{2}{*}{$\frac{9}{3}$} \\
\hline Експериментальна & Кількість & & & & & & & & & \\
\hline & $\%$ & & 6 & 9,5 & 22 & 22 & 6 & 9,5 & 6 & 9,5 \\
\hline \multirow[t]{2}{*}{ Контрольна } & Кількість & 4 & 7 & 9 & 3 & 5 & 3 & 0 & 1 & 0 \\
\hline & $\%$ & 12 & 22 & 28 & 9,5 & 16 & 9,5 & 0 & 3 & 0 \\
\hline
\end{tabular}


Порівняння даних, наведених у таблицях, дає підстави для висновку про динаміку змін концентрації і стійкості уваги студентів експериментальної і контрольної груп. Насамперед привертає увагу суттєве зростання статистичних показників (середнього арифметичного, медіани) в експериментальній групі. Якщо на початку експерименту ці показники в експериментальній і контрольній групі були майже на одному рівні, то на кінець експерименту вони стали суттєво відрізнятись. При цьому в контрольній групі показники середнього арифметичного і медіани збільшилися несуттєво, а в експериментальній спостерігається їх значне зростання.

Загальну картину динаміки змін у рівні розвитку концентрації і стійкості уваги студентів, які брали участь в експерименті, добре видно і за загальною кількістю та процентним співвідношенням студентів по інтервалах групування (рівню розвитку концентрації і стійкості уваги за шкалою від 1 до 9). Так, у контрольній групі до початку експерименту на рівні одного балу було показано 5 результатів, що складало $16 \%$. По закінченні експерименту таких студентів було 4, що складає 12 \%. Спостерігається невелике покращення, оскільки один із студентів цієї групи на кінець експерименту показав результат на рівні двох балів. В експериментальній групі студентів 3 таким рівнем розвитку концентрації і стійкості уваги на початку експерименту було також 5, що складало 16 \%. По закінченні експерименту їх залишилось 3 , що складає 9,5\%. Спостерігаємо суттєве покращення, оскільки 2 із 5 студентів показали результати більш високого рівня.

До початку експерименту результат на рівні двох балів в контрольній групі показували 7 студентів, що становило $22 \%$. Показники експериментальної групи були такими ж. На кінець експерименту чисельність і відсоток студентів контрольної групи не змінились. В експериментальній групі чисельність і відповідно відсоток студентів цієї категорії суттєво зменшились. Їх залишилось 2, що склало 6 \%. Спостерігається суттєве покращення, оскільки 5 із 7 студентів показали результат більш високого рівня.

Трьома балами оцінено результат, який показали до початку експерименту 8 студентів контрольної (25\%) і 8 студентів експериментальної (25\%) груп. На кінець експерименту в контрольній групі таких студентів стало 9 (28 \%). Збільшення відбулось за рахунок переходу на цей рівень (з більш низького) одного студента. Констатуємо 
невелике покращення. В експериментальній групі на кінець експерименту таких студентів виявилось 3 , що склало 9,5 \%. Констатуємо суттєве покращення, оскільки 5 студентів із 8 показали результат більш високого рівня.

На рівні чотирьох балів до початку експерименту себе показали по 4 студенти з експериментальної і контрольної груп, що становить по $13 \%$. По закінченні експерименту в контрольній групі на цьому рівні зафіксовано 3 результати (9,5 \%). Зменшення відбулося за рахунок виходу на більш високий рівень одного студента. Спостерігається невелике покращення. В експериментальній групі на кінець експерименту зафіксовано 7 результатів (22\%). Збільшення відбулось за рахунок виходу на цей рівень (з більш низьких) 3 студентів. Спостерігається суттєве покращення.

Результат на рівні п'яти балів до початку експерименту показували по 3 студенти в експериментальній і контрольній групах, що складало по 9 \%. По закінченні експерименту в контрольній групі на цьому рівні показано 5 результатів (16 \%). Збільшення відбулось за рахунок, з одного боку, переходу на цей рівень (з більш низького) одного студента, 3 іншого, за рахунок опускання на цей рівень 3 більш високого також одного студента. Констатуємо невелике покращення. В експериментальній групі на кінець експерименту зафіксовано 7 результатів такого рівня (22 \%). Збільшення відбулось за рахунок переходу на цей рівень (з більш низького) 4 студентів. Констатуємо значне покращення.

У шість балів оцінено результат, який показували до початку експерименту 3 студенти контрольної і 3 студенти експериментальної груп. Це становило по 9 \%. На кінець експерименту в контрольній групі змін не відбулося. В експериментальній на цьому рівні зафіксовано 2 результати (6 \%). Зменшення відбулось за рахунок переходу на більш високий рівень одного студента.

На рівні семи балів до початку експерименту себе проявили по одному студенту з експериментальної і контрольної групи (по 3 \%). На кінець експерименту в контрольній групі результатів на цьому рівні не зафіксовано. Зменшення відбулось за рахунок опускання на більш низький рівень одного студента. В експериментальній групі на кінець експерименту було зафіксовано 3 таких результати $(9,5 \%)$. Збільшення відбулось за рахунок переходу на цей рівень (з більш низьких) 2 студентів. Спостерігається суттєве покращення. 
Результат на рівні восьми балів до початку експерименту показали по одному студенту в експериментальній і контрольній групі, що становило по $3 \%$. По закінченні експерименту в контрольній групі змін не відбулось. В експериментальній групі - зафіксовано 2 результати (6 \%). Збільшення відбулось за рахунок виходу на цей рівень ( з більш низького ) одного студента.

На рівні дев'яти балів до початку експерименту не було зафіксовано жодного результату. Після проведення експерименту в контрольній групі ситуація не змінилась. В експериментальній - зафіксовано 3 результати, що складає 9,5 \%. Збільшення відбулось за рахунок переходу на цей рівень (з більш низьких) 3 студентів. Спостерігається суттєве покращення.

Вторинну статистичну обробку даних експерименту проведено 3 використанням $T$-критерію Вілкоксона. Встановлено, що для контрольної групи сума рангів нетипових зсувів дорівнює 181 ( $T$ емпіричне $=181)$. Критичними значеннями $T$ є: а) на рівні статистичної значущості (рівні достовірності результату) 0,01 - 140; б) на рівні статистичної значущості $0,05-175$. Отже, отримане емпіричне значення розташоване в зоні незначущості. На підставі цього робимо висновок про правильність нульової гіпотези стосовно контрольної групи, оскільки достовірність переваги зсувів у ній ні в одному з напрямків не встановлено.

Статистична обробка даних, отриманих у ході експерименту в експериментальній групі, показала таке. Сума рангів нетипових зсувів у ній дорівнювала $1(T$ емпіричне $=1)$. Критичними значеннями $T$, як і в попередньому випадку (оскільки $n=32$ ), є: а) на рівні статистичної значущості $0,01-140$; б) на рівні статистичної значущості 0,05 175. Отже, отримане емпіричне значення знаходиться в зоні значущості. На підставі цього відхиляємо нульову гіпотезу стосовно експериментальної групи і підтверджуємо правильність альтернативної.

Плануючи проведення експерименту, ми виходили з важливості для успішної професійної діяльності у залізничній галузі достатнього рівня розвитку у фахівця концентрації і стійкості уваги. У цьому контексті нас цікавило питання можливості розвитку вищезгаданих характеристик уваги у студентів-залізничників у процесі фізичного виховання.

Отримані по закінченні експерименту статистичні дані, які характеризують динаміку змін концентрації і стійкості уваги у студентів- 
залізничників, показали таке. Традиційні заняття з фізичного виховання, що проводилися зі студентами контрольної групи, суттєво (статистично значуще) не вплинули на розвиток у них концентрації і стійкості уваги. Про це свідчить той факт, що протягом двох років таких занять у студентів контрольної групи не відбулося суттєвого зростання відповідних показників. Ми пояснюємо це тим, що в ході традиційних занять не ставляться конкретні завдання 3 розвитку в студентів концентрації і стійкості уваги, не здійснюється підбір ефективних засобів з їх розвитку, і взагалі, така діяльність не планується.

Що стосується експериментальної групи, то тут на кінець експерименту отримано статистичні дані, які показують суттєве зростання у студентів показників концентрації і стійкості уваги. При цьому позитивна динаміка спостерігається на всіх рівнях розвитку. Насамперед це стосується позитивного зсуву великої кількості студентів 3 рівня двох і трьох балів (22 \% і 25 \% відповідно до початку експерименту) на рівень чотирьох і п'яти балів (22 \% і $22 \%$ відповідно по закінченні експерименту). Звертає на себе увагу і суттєвий приріст результатів на рівнях семи, восьми і дев'яти балів. На рівні дев'яти балів до початку експерименту результатів взагалі не було зафіксовано. На кінець їх виявилось 3 , що склало 9,5 \%.

Результати, які отримано в експериментальній групі в ході експерименту, дають підстави стверджувати, що експериментальна гіпотеза підтвердилась. Розроблена автором система основ психологічної і психофізичної підготовки студентів-залізничників у процесі фізичного виховання показала себе як ефективний засіб розвитку у них концентрації і стійкості уваги. На нашу думку, ефективність системи пов'язана із залученням студентів до ефективної (у плані розвитку концентрації і стійкості уваги), різнопланової діяльності, у ході виконання якої і відбувається розвиток. Це стосується використання і професійно значущих видів спорту (у даному випадку це були спортивні ігри), і психотренувальних засобів (з метою розвитку застосовувалися засоби для психологічної діагностики ), і спеціальних фізичних вправ, і спортивних змагань з професійно значущих видів спорту. На нашу думку, використання вправ для формування навиків саморегуляції психічного стану у студентів також позитивно (хоч i опосередковано) впливає на рівень прояву в них концентрації і стійкості уваги. Такий вплив може бути в екстремальних (стресових) 
ситуаціях. Навики саморегуляції допомагають опанувати себе в таких ситуаціях, що забезпечує підтримання концентрації і стійкості уваги на необхідному рівні. Блок психологічної просвіти, окрім своїх специфічних завдань, допомагає реалізувати в навчальному процесі принцип свідомого засвоєння навчального матеріалу. Маючи загальне уявлення про психіку людини, студент краще розуміє, для чого йому необхідно розвивати в себе концентрацію і стійкість уваги. Це, у свою чергу, позитивно впливає на його мотивацію щодо занять.

На нашу думку, запропонований для розвитку концентрації і стійкості уваги студентів-залізничників блок засобів психологічної і психофізичної підготовки $є$ оптимальним і довів у ході експерименту свою ефективність.

Формулюючи головні висновки експерименту, слід відзначити:

1. У ході дослідження експериментальне підтвердження отримала гіпотеза про те, що реалізація в ході навчальних занять 3 фізичного виховання авторської системи основ психологічної і психофізичної підготовки студентів-залізничників $\epsilon$ ефективним засобом розвитку в них концентрації і стійкості уваги.

2. Традиційні заняття з фізичного виховання не забезпечують ефективного розвитку концентрації і стійкості уваги в студентів.

\section{2. Розвиток вестибулярної стійкості студентів-залізничників у процесі психологічної і психофізичної підготовки}

Певні види професійної праці в галузі залізничного транспорту потребують від людини високого рівня розвитку такої характеристики іiі психомоторики, як вестибулярна стійкість (здатність зберігати гарну працездатність при подразненні вестибулярного апарату, який забезпечує сприйняття і аналіз інформації про переміщення і положення тіла в просторі). Насамперед це стосується таких спеціальностей, як «Мости і транспортні тунелі», «Електричний транспорт», «Електромеханічні системи автоматизації та електропривід», «Рухомий склад та спеціальна техніка залізничного транспорту». Це потребує відповідної підготовки під час професійного навчання таких спеціалістів. Значний потенціал для вирішення завдання має навчальна 
дисципліна «Фізичне виховання», проте її можливості використовуються хаотично (безсистемно). Постає питання про дослідження умов ефективного використання фізичного виховання для розвитку в майбутніх фахівців вестибулярної стійкості. Виходячи з цього, плануючи дослідження розвитку психомоторики студентів-залізничників у процесі психологічної і психофізичної підготовки, ми зупинили свій вибір на вивченні динаміки розвитку в них вестибулярної стійкості під час різних за змістом навчальних занять з фізичного виховання.

Проблема вестибулярної стійкості була предметом вивчення багатьох науковців. Цікаве дослідження питання комплексного розвитку вестибулярної стійкості в художній гімнастиці виконала Н. О. Чертихіна [429]. Метою дослідження була розробка й наукове обгрунтування методики комплексного розвитку вестибулярної стійкості в художній гімнастиці на етапі початкової підготовки.

У ході виконання роботи було встановлено, що найбільш інформативними функціональними пробами для визначення рівня вестибулярної стійкості гімнасток 5-7 років $є$ проба Ромберга (перша та друга позиції), проба Яроцького, підрахунок часу ністагму, відхилення від прямої лінії після обертання, оцінка рівня вестибулярної стійкості за зміною частоти серцевих скорочень та артеріального тиску.

Автор виявила значущу кореляцію якості виконання обертальних елементів художньої гімнастики вищої групи складності 3 рівнем розвитку вестибулярної стійкості.

Встановлено позитивний вплив на розвиток вестибулярної стійкості гімнасток роботи на тренажерних пристроях. Найбільш ефективними серед них дослідник вважає модифікований диск «Здоров'я».

Н. О. Чертіхіна експериментально перевірила ефективність авторської методики розвитку вестибулярної стійкості. Суттєвою особливістю методики стало використання такого набору вправ, який сприяє розвитку всіх відділів вестибулярного апарату. Підбір вправ здійснювався таким чином, щоб обирати ті із них, які викликають вестибулярні подразнення, специфічні для стаичних і динамічних вправ художньої гімнастики. Головними методами, які використано в методиці, $\epsilon$ методи строго регламентованої вправи. Як організаційна форма занять використано колове тренування. Наведені в роботі дані свідчать про ефективність розробленої методики. В експериментальній групі, де іiі було використано, зафіксовано суттєво значуще, порівняно 3 контрольною, зростання показників проби Ромберга по першій позиції, 
проби Ромберга за другою позицією, проби Яроцького. В експериментальній групі зафіксовано також більше зниження величини відхилення при проходженні по прямій після вестибулярного подразнення. Час ністагму в контрольній групі скоротився майже на $10 \%$. Цей же показник у експериментальній групі скоротився на 3,6 \%.

На користь ефективності запропонованої методики комплексного розвитку вестибулярної стійкості свідчать і наведені дані стосовно покращення якості виконання базових елементів художньої гімнастики гімнастками експериментальної групи.

Д. В. Сишко виконав грунтовне дослідження типологічних особливостей вестибуловегетативних реакцій у спортсменів [353]. В. Г. Стрілець вивчав питання управління вестибулярними реакціями людини в спорті та професійній діяльності [377]. О. У. Холтобіна досліджувала вплив спеціальних вправ на підвищення стійкості вестибулярного аналізатора в дітей 2-5 років [420]. Предметом дослідження Г. В. Бикової, І. П. Закарко та В. В. Білик стали методичні засади використання фізичних вправ, спрямованих на підвищення статодинамічної стійкості в студентів [35]. Взаємозв'язок стійкості вестибулярного аналізатора й рівня розвитку спритності школярів вивчали І. П. Масляк, Л. Є. Шестерова та Н. Н. Терентьєва [234]. В. А. Романенко зі співавторами досліджував особливості вестибулярної стійкості у агресивних і неагресивних студенток гуманітарного ВНЗ [326]. Слід відзначити також роботи В. Л. Ботяєва [56], О. Г. Біленко [36], В. О. Клімачова [157], В. Л. Друшевської [123], які роблять значний внесок у розуміння різних аспектів формування вестибулярної стійкості у сфері фізичної культури і спорту. Незважаючи на це, питання розвитку вестиблулярної стійкості в студентів у процесі навчальних занять з фізичного виховання залишаються вивченими недостатньо.

Експериментальною гіпотезою дослідження стало припущення про те, що психологічна й психофізична підготовка студентів-залізничників, до складу якої входять блоки професійно значущих видів спорту, спеціальних фізичних вправ, спеціальних психотренувальних засобів, $є$ ефективною для розвитку вестибулярної стійкості.

Як незалежна змінна приймався зміст основ психологічної і психофізичної підготовки студентів-залізничників, який включав блок професійно значущих видів спорту, блок спеціально підібраних фізичних вправ і блок спеціальних психотренувальних засобів. Залежною 
змінною були показники рівня розвитку вестибулярної стійкості студентів.

Статистичною нульовою гіпотезою було припущення, що зсув між показниками вестибулярної стійкості у студентів експериментальних і контрольних груп у початковому і кінцевому зрізі значуще не відрізняється від нуля.

Альтернативною статистичною гіпотезою було припущення, що зсув між показниками вестибулярної стійкості у студентів експериментальних і контрольних груп у початковому і кінцевому зрізі значуще відрізняється від нуля.

Для статистичної обробки отриманих даних використано $t$-критерій Стьюдента для залежних виборок.

У дослідженні брали участь 60 студентів Дніпропетровського національного університету залізничного транспорту, які навчалися за спеціальностями «Мости і транспортні тунелі», «Електричний транспорт», «Електромеханічні системи автоматизації та електропривід», «Рухомий склад та спеціальна техніка залізничного транспорту». Вік учасників дослідження складав 17-19 років.

Експериментальна вибірка формувалася таким чином. На початку навчального року було проведено діагностику рівня розвитку вестибулярної стійкості студентів. Вона оцінювалася за чотирибальною шкалою («відмінно», «добре», «задовільно», «незадовільно»). Студентам було запропоновано взяти участь у дослідженні. Було сформовано одну експериментальну й одну контрольну групу. Кількісно кожна із груп складала 30 осіб. При цьому до експериментальної і контрольної групи було включено однакову кількість студентів, вестибулярну стійкість яких оцінено двома, трьома, чотирма чи п’ятьма балами.

Студентів експериментальної групи було залучено до навчальних занять $з$ фізичного виховання, які включали вивчення блоку психологічної і психофізичної підготовки студентів-залізничників. Планграфік проведення цих занять наведено в дод. 8. Заняття включали такі блоки засобів:

1) вивчення теоретичного матеріалу, включеного до розділу психологічної просвіти (див. підрозд. 4.2);

2) заняття професійно значущими видами спорту (як такі використовувалися спортивна і прикладна гімнастика, акробатика, спортивні ігри); 
3) використання психотренувальних засобів для розвитку вестибулярної стійкості (крісло Барані);

4) спеціальні фізичні вправи для розвитку вестибулярної стійкості;

5) вправи для формування навиків саморегуляції психічного стану (аутогенне тренування);

6) участь у спортивних змаганнях 3 професійно значущих видів спорту.

Наведемо приклади спеціальних фізичних вправ, які використовувалися на заняттях:

1. Колові рухи й повороти голови на місці. Вправа виконувалася студентами 10-15 с зі швидкістю 2 рухи за $1 \mathrm{c}$.

2. Колові рухи й повороти голови зі збереженням рівноваги під час ходьби, бігу (ставилося завдання не відхилятися від прямої лінії).

3. Із вихідного положення широка стійка, нахил вперед, руки в сторони, повороти тулубу вліво і вправо.

4. Повороти на 90 або 180 градусів із вихідного положення присід на одній нозі.

5. Різноманітні рухи руками й тулубом із вихідного положення стійка на одній нозі.

6. Стрибки на місці з обертанням направо й наліво на 180 або $360^{\circ}$.

7. Біг на 25 м по розмітці шириною 5 см 3 максимальною швидкістю (ставилося завдання не сходити з розмітки під час бігу).

8. Біг зі зміною швидкості й напрямку.

9. Вправи на рівновагу.

10. Пробігання лабіринтів та ін.

Місцем проведення більшості занять 3 розвитку вестибулярної стійкості студентів був спеціалізований зал спортивної гімнастики університету.

У процесі навчальних занять з фізичного виховання вирішувались і традиційні завдання фізичного виховання студентів з формування у них рухових навичок, умінь та розвитку фізичних якостей.

Навчальні заняття 3 фізичного виховання в експериментальній групі мали таку структуру. Підготовча частина заняття складала 10 хв. Головна частина - 75 хв. 3 них 25 хв відводилося для вирішення традиційних завдань фізичного виховання студентів 3 формування в них рухових навичок і умінь та розвитку фізичних якостей. 20 хв 
у структурі заняття відводилось: або на виконання студентами спеціальних фізичних вправ, або на їх роботу з психотренувальними засобами, або на використання нетрадиційних засобів фізичного виховання. У структурі конкретного заняття використовувався тільки один із названих блоків. 30 хвилин структури основної частини заняття присвячувалося заняттю професійно значущим видом спорту. Заключна частина складала п'ять хвилин.

На першому курсі студентам експериментальних груп було прочитано 16 годин лекцій, що входили до блоку психологічної просвіти. Протягом 49 занять студенти (по 30 хв) займалися професійно значущими видами спорту. Спеціальні фізичні вправи для розвитку психомоторики використовувалися на 23 заняттях (по 20 хв на кожному). Психотренувальні засоби для розвитку вестибулярної стійкості було застосовано в ході 12 занять (по 20 хв на кожному). Вправи для формування навиків саморегуляції психічного стану використано на двох заняттях (по 20 хв на кожному). Спортивні змагання 3 професійно значущих видів спорту було організовано в ході 8 занять. Контрольні заходи проводилися на 4 заняттях.

На другому курсі в ході 53 занять студенти експериментальної групи займалися професійно значущими видами спорту. Спеціальні фізичні вправи для розвитку психомоторики виконувалися в ході 24 занять. Психотренувальні засоби для розвитку вестибулярної стійкості застосовувалися на 16 заняттях. Вправи для формування навиків саморегуляції психічного стану було використано в ході 12 занять. Спортивні змагання з професійно значущих видів спорту організовано на 8 заняттях. На 4 заняттях проводилися контрольні заходи.

Студенти контрольної групи вивчали курс фізичного виховання відповідно до навчальної програми для вищих навчальних закладів.

Діагностика рівня розвитку вестибулярної стійкості студентів здійснювалася за результатами виконання п'яти перекидань вперед за 10 с. Здатність впевнено зберігати основну стійку після виконання перекидань оцінювалась оцінкою «відмінно». За наявності нестійкості зі зходженням $з$ місця до одного кроку ставилась оцінка «добре», до двох кроків - «задовільно», при більш значних відхиленнях або падінні - «незадовільно».

Перед студентами експериментальної групи було поставлено завдання освоїти програму психологічної і психофізичної підготовки для їх спеціальностей. Оцінка за цей розділ входила як складова до 
загальної оцінки 3 навчальної дисципліни «фізичне виховання». У свою чергу оцінка рівня розвитку вестибулярної стійкості входила як складова до загальної оцінки з розділу психологічної і психофізичної підготовки. Формою семестрового контролю був диференційований залік, результати якого впливали на призначення стипендії студентам.

За результатами початкового зрізу експериментальну і контрольну групу характеризували показники вестибулярної стійкості, наведені у табл. 45.

Статистичні показники вибірки такі:

1. Середнє арифметичне - 2,86 бала;

2. Медіана - 2,5 бала;

3. Мода - 2 бали;

4. Стандартне відхилення - 1 бал.

Табличя 45

Вестибулярна стійкість студентів експериментальної і контрольної груп до початку експерименту (у балах $),(n=60)$

\begin{tabular}{|c|c|c|c|c|c|}
\hline \multirow{2}{*}{\multicolumn{2}{|c|}{ Група }} & \multicolumn{4}{|c|}{ Бали } \\
\hline & & \multirow{2}{*}{$\frac{2}{15}$} & \multirow{2}{*}{$\frac{3}{6}$} & \multirow{2}{*}{$\begin{array}{l}4 \\
7\end{array}$} & \multirow{2}{*}{$\begin{array}{l}5 \\
2\end{array}$} \\
\hline Експериментальна & Кількість & & & & \\
\hline & $\%$ & 50 & 20 & 23 & 7 \\
\hline \multirow[t]{2}{*}{ Контрольна } & Кількість & 15 & 6 & 7 & 2 \\
\hline & $\%$ & 50 & 20 & 23 & 7 \\
\hline
\end{tabular}

Як видно з таблиці, експериментальна і контрольна групи, що взяли участь в експерименті, до його початку мали однакові показники рівня вестибулярної стійкості студентів, які до них входили.

Повторний зріз було проведено наприкінці четвертого семестру. Експериментальну й контрольну групи тепер характеризували показники, наведені у табл. 46.

Статистичні показники контрольної групи стали такими:

1. Середнє арифметичне - 2,9 бала;

2. Медіана - 3 бали;

3. Мода - 2 бали;

4. Стандартне відхилення - 0,97 бала. 
Статистичні показники експериментальної групи:

1. Середне арифметичне - 3,56 бала;

2. Медіана - 3,5 бала;

3. Мода - 3 бали;

4. Стандартне відхилення - 0,95 бала.

Таблиия 46

Вестибулярна стійкість студентів експериментальної і контрольної груп по закінченні експерименту (у балах $),(n=60)$

\begin{tabular}{l|l|c|c|c|c}
\hline \multicolumn{2}{c|}{ Група } & \multicolumn{4}{c}{ Бали } \\
\cline { 5 - 6 } \multicolumn{2}{c|}{} & 2 & 3 & 4 & 5 \\
\hline Експериментальна & Кількість & 4 & 11 & 9 & 6 \\
\cline { 2 - 2 } & $\%$ & 13 & 37 & 30 & 20 \\
\cline { 2 - 2 } Контрольна & Кількість & 13 & 9 & 6 & 2 \\
\cline { 2 - 3 } & $\%$ & 43 & 30 & 20 & 7
\end{tabular}

Порівнявши дані табл. 45 і 46 та ознайомившись із іншими статистичними показниками, можна зробити висновки стосовно динаміки змін вестибулярної стійкості студентів експериментальної і контрольної груп. Насамперед звертає на себе увагу зростання статистичних показників в експериментальній групі. Так, середнє арифметичне показників вестибулярної стійкості у цій групі до початку експерименту складало 2,86 бала, а по його закінченні - 3,56 бала. Відзначаємо суттєве зростання. У той же час у контрольній групі зафіксовано дуже незначний зсув цього показника в сторону збільшення. Так, до експерименту середнє арифметичне у цій групі складало 2,86 бала, а по його закінченні - 2,9 бала. Така ж тенденція стосовно динаміки змін вестибулярної стійкості в експериментальній і контрольній групі зберігається і за показниками медіани та моди. В експериментальній групі до початку експерименту медіана становила 2,5 бала, а по його закінченні - 3,5 бала. У контрольній групі до початку експерименту 2,5 бала, а по закінченні - 3 бали. Показник моди в експериментальній групі до початку експерименту складав 2 бали, а по його закінченні - 3 бали. У контрольній групі він не змінився (до і після експерименту складав 2 бали). 
Динаміку розвитку вестибулярної стійкості добре ілюструють і зміни, які відбулись в експериментальній і контрольній групах у ході експерименту, у загальній кількості й процентному співвідношенні студентів за інтервалами групування.

Так, у контрольній групі до початку експерименту на рівні двох балів було оцінено вестибулярну стійкість 15 студентів, що склало 50 \%. По закінченні експерименту таких студентів виявилось 13, що складає 43 \%. Спостерігається невелике покращення, оскільки двоє із студентів цієї групи показали результат на рівні трьох балів. В експериментальній групі студентів 3 таким рівнем розвитку вестибулярної стійкості було також 15 студентів, що складало 50 \%. По закінченні експерименту їх стало 4, що складає $13 \%$. Спостерігається суттєве покращення, оскільки 11 із 15 студентів цієї групи показали результати більш високого рівня.

Результат на рівні трьох балів до початку експерименту в контрольній групі показували 6 студентів, що складало $20 \%$. На кінець експерименту таких студентів стало 9, що становить 30 \%. Збільшення чисельності відбулось за рахунок переходу на цей рівень (з більш низького) двох студентів і за рахунок опускання на цей рівень (з більш високого) одного студента. Констатуємо невелике покращення. В експериментальній групі чисельність студентів цієї категоpiї суттєво збільшилась. Якщо до початку експерименту їх було 6, що складало $20 \%$, то по закінченні експерименту чисельність таких студентів становила 11, що складає 37 \%. Збільшення чисельності відбулося за рахунок переходу на цей рівень (з більш низького) 5 студентів. Констатуємо суттєве покращення на цьому рівні в експериментальній групі.

У чотири бали оцінено результат, який до початку експерименту показували 7 студентів контрольної і 7 студентів експериментальної гупи, що складало по 23 \%. По закінченні експерименту в контрольній групі на цьому рівні зафіксовано 6 результатів (20\%). Зменшення відбулось за рахунок опускання з цього рівня на більш низький одного студента. Спостерігається невелике погіршення. В експериментальній групі на цьому рівні зафіксовано 9 результатів (30 \%). Збільшення відбулось за рахунок переходу на цей рівень (з більш низьких) двох студентів. Констатуємо покращення результатів на цьому рівні.

Результат на рівні п'яти балів до початку експерименту показували по 2 студенти із контрольної і експериментальної груп, що 
складало по 7 \%. По закінченні експерименту в контрольній групі на цьому рівні змін не відбулось. В експериментальній групі на кінець експерименту зафіксовано 6 результатів такого рівня $(20 \%)$. Збільшення відбулось за рахунок переходу на цей рівень (з більш низького) 4 студентів. Констатуємо суттєве покращення на цьому рівні в експериментальній групі.

Вторинну статистичну обробку даних експерименту проведено 3 використанням $t$-критерію Стьюдента для залежних вибірок. У результаті цієї роботи встановлено таке. Для контрольної групи $t$ емпіричне становить 0,7 . Критичними значеннями $t \epsilon$ : а) на рівні статистичної значущості $0,01-2,76$; б) на рівні статистичної значущості $0,05-2,05$. Отже, отримане емпіричне значення розташоване в зоні незначущості. На підставі цього робимо висновок про правильність нульової гіпотези стосовно контрольної групи.

Статистична обробка даних експериментальної групи показала, що тут $t$ емпіричне становить 8,8 . Критичними значеннями $t \epsilon$ : а) на рівні статистичної значущості $0,01-2,76$; б) на рівні статистичної значущості $0,05-2,05$. Отже, отримане емпіричне значення розташоване в зоні значущості. На підставі цього відхиляємо нулову гіпотезу стосовно експериментальної групи й підтверджуємо правильність альтернативної.

Плануючи проведення експерименту, ми виходили з важливості для ряду спеціальностей залізничного транспорту високого рівня розвитку у фахівців вестибулярної стійкості. Дослідження рівня розвитку цієї характеристики психомоторики в студентів-залізничників показало, що в значної кількості студентів вона розвинена явно недостатньо [284].

Дані, отримані в ході експерименту стосовно розвитку у студентів-залізничників вестибулярної стійкості, показали, що традиційні заняття 3 фізичного виховання (проводились у контрольній групі) статистично значуще не впливають на ії розвиток. Про це свідчить той факт, що двох років занять у контрольній групі виявилося недостатньо для того, щоб відбулося статистично значуще зростання показників. На нашу думку, це пояснюється відсутністю в процесі традиційних занять цілеспрямованої роботи з організації і проведення ефективної для розвитку вестибулярної стійкості діяльності.

На відміну від контрольної, в експериментальній групі така діяльність планувалась і була реалізована в ході навчальних занять. Як на- 
слідок, відбулося статистично значуще зростання показників вестибулярної стійкості у студентів. Отримані в експериментальній групі в ході дослідження результати дають підстави стверджувати, що експериментальна гіпотеза підтвердилась.

Організація психологічної і психофізичної підготовки в процесі фізичного виховання студентів забезпечує можливість цілеспрямовано проводити роботу з розвитку в студентів професійно значущих психологічних і психофізичних складових.

Формулюючи головні висновки експерименту, відзначаємо:

1. Психологічна і психофізична підготовка студентів-залізничників, до складу якої входили блоки професійно значущих видів спорту, спеціальних фізичних вправ для розвитку вестибулярної стійкості, спеціальних психотренувальних засобів, є ефективною для розвитку вестибулярної стійкості.

2. Традиційні заняття 3 фізичного виховання не забезпечують ефективний розвиток вестибулярної стійкості у студентів.

\section{Висновки до розділу}

1. Експериментальне підтвердження отримала гіпотеза про те, що реалізація в ході навчальних занять 3 фізичного виховання основ психологічної і психофізичної підготовки студентів-залізничників є ефективним засобом розвитку у них концентрації і стійкості уваги.

2. Традиційні заняття з фізичного виховання не забезпечують ефективний розвиток концентрації і стійкості уваги у студентів.

3. Психологічна i психофізична підготовка студентів-залізничників, до складу якої входили блоки професійно значущих видів спорту, спеціальних фізичних вправ для розвитку вестибулярної стійкості, спеціальних психотренувальних засобів, $є$ ефективною для розвитку вестибулярної стійкості.

4. Традиційні заняття з фізичного виховання не забезпечують ефективний розвиток вестибулярної стійкості у студентів.

5. У ході вивчення навчальної дисципліни «Фізичне виховання» студентами можна ефективно вирішувати завдання професійно орієнтованої психологічної і психофізичної підготовки. 
6. Зміст діяльності навчальних секцій і навчальних груп є головним чинником, що визначає особливості психологічної і психофізичної підготовленості студентів. 


\section{ВИСНОВКИ}

На підставі теоретичного аналізу та експериментальної перевірки основних положень роботи про зміст теоретико-методологічних і педагогічних основ психологічної і психофізичної підготовки студентів залізничних ВНЗ у процесі фізичного виховання зроблено такі основні висновки:

1. Дослідження теоретико-методологічних і організаційних основ психологічної і психофізичної підготовки студентів-залізничників пов'язане з необхідністю вирішення як практичних, так і теоретичних питань. Практичні пов'язані з необхідністю реагувати в системі освіти на постійно зростаючі вимоги в залізничній галузі до цієї складової загальної підготовки фахівців, теоретичні - 3 актуальним станом теорії фізичного виховання. У цій сфері останнім часом з'явилася велика кількість нових концепцій, педагогічних технологій, які суттєво розширюють існуючі уявлення про його виховні можливості. Ефективним фізичне виховання $\epsilon$ і в плані психологічної і психофізичної підготовки студентів. У цьому напрямку виконано певні дослідження. У той же час, наукове обгрунтування постановки самого питання про психологічну і психофізичну підготовку студентів під час навчальних занять з фізичного виховання ще не зроблено. Значна частина даної роботи являє собою спробу автора виконати це завдання. Решта - присвячена питанням розробки основ психологічної і психофізичної підготовки студентів-залізничників під час навчальних занять 3 фізичного виховання.

2. Поняття «психологічна і психофізична підготовка» найчастіше пов'язується:

а) $з$ комплексом різнопланових заходів спеціального психологічного спрямування;

б) з процесом формування особистості до умов певної діяльності; 
в) з психологічним налаштуванням на виконання певної діяльності. Психологічна і психофізична підготовка проводиться в різних сферах професійної діяльності.

3. Психологічну й психофізичну підготовку студентів у процесі фізичного виховання доцільно розглядати як частину (сторону) фізичного виховання, спеціалізовану (спрямовану) стосовно психологічних і психофізичних особливостей їх майбутньої професійної діяльності. Результатом такої підготовки є відповідна підготовленість студентів.

4. Якщо виходити з того, що фізичне виховання безпосередньо пов'язане із впливом на організм людини, а психологічна і психофізична підготовка спрямована головним чином на психічні складові, теоретико-методологічні основи для iї проведення в процесі фізичного виховання виявляються при розгляді у філософії і психології таких питань, як психофізична проблема, взаємовплив організму і психіки людини, психологія особистості. Їх аналіз показує, що вплив на організм людини призводить до впливу (тією чи іншою мірою) і на її психіку. Вплив на психіку людини так чи інакше призводить до змін в іiї організмі.

5. Основи організації психологічної і психофізичної підготовки майбутніх інженерів-залізничників у процесі фізичного виховання визначаються вимогами до їх психологічної і психофізичної підготовки й можливістю реалізації цих вимог у процесі навчальних занять 3 фізичного виховання. Головними факторами, які визначають зміст психологічної і психофізичної підготовки студентів-залізничників, є: домінування розумової праці під час виконання професійних функцій, велика відповідальність за безпеку людей та збереження вантажів і пов'язане $з$ цим психоемоційне перевантаження, високі специфічні вимоги до різноманітних компонентів структури особистості фахівця, необхідність знання основ психології людей.

5.1. Розроблено модель психологічної і психофізичної підготовленості особистості до професійної праці. Головною особливістю моделі є iï ієрархічність. Основу моделі складають професійно значущі риси особистості, мотивація професійної діяльності та емоційна стійкість особистості. Над ними розташована система знань стосовно структури психіки людини, можливостей регулювання власних емоцій і взаємовідносин з оточуючими. Компоненти перших двох рівнів найбільшою мірою визначають психологічну готовність до праці. 
Наступний рівень складають особливості окремих психічних процесів (уваги, відчуття, сприйняття, пам яті, мислення, уяви). Ці складові характеризують головним чином психофізичну сторону готовності до праці. Наступний рівень психофізичної готовності складає психомоторика фахівця.

5.2. Встановлено психологічну й психофізичну непідготовленість студентів-залізничників за такими показниками, як рівень особистісної тривожності, вибірковість та концентрація і стійкість уваги, швидкість у діях, стійкість вестибулярних реакцій. Обгрунтовано можливість вирішення цього питання в процесі спеціальної, цілеспрямованої психологічної і психофізичної підготовки в ході навчальних занять $з$ фізичного виховання.

5.3. Розроблено питання про зміст, засоби й основи організації психологічної і психофізичної підготовки студентів залізничних ВНЗ в процесі фізичного виховання. Як головні напрямки психологічної і психофізичної підготовки запропоновано:

а) проведення роботи 3 психологічної просвіти студентів;

б) навчання навичкам психічної саморегуляції, формування емоційної стійкості особистості та профілактика засобами фізичного виховання невротичної поведінки у схильних до цього студентів;

в) розвиток професійно значущих компонентів психомоторики, використання механізму профілактичного впливу рухової діяльності на психіку людини та використання фізичного виховання для зняття агресивності у студентів;

г) формування професійно значущих структурних компонентів особистості.

Визначено етапи формування психологічної і психофізичної готовності студентів. На першому виявляється вихідний рівень готовності конкретного студента (відповідно до обраної спеціальності). На другому - проводиться підбір виду рухової активності, у ході якої можна ефективно формувати необхідні складові. Третій етап передбачає залучення студентів до систематичних занять професійно значущим видом спорту і активне використання в ході занять психотренувальних засобів для розвитку професійно значущих психологічних і психофізичних складових. На четвертому етапі виконується діагностика (контроль) рівня сформованості психологічних і психофізичних компонентів, які вдосконалювалися. 
Як головний засіб психологічної і психофізичної підготовки студентів розглядаються фізичні вправи. Підбір комплексу засобів психологічної і психофізичної підготовки студентів-залізничників запропоновано виконувати відповідно до особливостей майбутньої професійної діяльності. Запропоновано їх розподіл на блоки таким чином:

а) блок психологічної просвіти;

б) блок професійно значущих видів спорту;

в) блок психотренувальних засобів для розвитку психічних процесів;

г) спеціальні фізичні вправи для розвитку психомоторики;

д) вправи для освоєння навиків саморегуляції психічного стану і зменшення наслідків стресу (аутогенне тренування, медитація, сахаджа-йога);

е) спортивні змагання з професійно значущих видів спорту.

6. При розробці основ формування складових психологічної і психофізичної готовності вихідним посилом було врахування специфіки конкретної залізничної професії. Для реалізації такого підходу було вивчено професіограми і кваліфікаційні характеристики головних інженерних професій працівників залізничного транспорту. Відповідно до їх змісту проведено підбір засобів психологічної і психофізичної підготовки студентів.

6.1. Для спеціальності «Організація перевезень і управління на залізничному транспорті» до засобів психологічної і психофізичної підготовки включено:

а) блок психологічної просвіти;

б) блок професійно значущих видів спорту (баскетбол, волейбол, гандбол, футбол, футзал, легка атлетика, плавання, шахи);

в) психотренувальні засоби для розвитку характеристик уваги;

г) спеціальні фізичні вправи для розвитку швидкості простої і складної рухової реакції, швидкості в діях;

д) вправи для освоєння навиків саморегуляції психічного стану і зниження наслідків стресу (аутогенне тренування, медитація, сахаджа-йога);

е) спортивні змагання з професійно значущих видів спорту.

6.2. До числа засобів психологічної і психофізичної підготовки студентів, що навчаються за спеціальностями «Вагони та вагонне господарство», «Локомотиви та локомотивне господарство», включено: 
а) блок психологічної просвіти;

б) професійно значущі види спорту (професійно-прикладну гімнастику, баскетбол, волейбол, гандбол, футбол, футзал, легка атлетика, шахи);

в) психотренувальні засоби для розвитку характеристик уваги;

г) спеціальні фізичні вправи для розвитку психомоторики (швидкості простої і складної рухової реакції, вестибулярної стійкості, швидкості у діях);

д) вправи для освоєння навиків саморегуляції психічного стану і зменшення наслідків стресу (аутогенне тренування, медитація, сахаджа-йога);

е) спортивні змагання з професійно значущих видів спорту.

6.3. Для спеціальностей «Електричний транспорт», «Електромеханічні системи автоматизації та електропривод» засобами психологічної і психофізичної підготовки є:

а) блок психологічної просвіти;

б) професійно значущі види спорту (баскетбол, волейбол, гандбол, футбол, гімнастика, акробатика, легка атлетика, шахи);

в) психотрнувальні засоби для розвитку характеристик уваги;

г) спеціальні фізичні вправи для розвитку психомоторики (швидкості простої і складної рухової реакції, вестибулярної стійкості, швидкості в діях);

д) вправи для освоєння навиків саморегуляції психічного стану й зменшення наслідків стресу (аутогенне тренування, медитація, сахаджа-йога);

е) спортивні змагання з професійно значущих видів спорту.

6.4. Як засоби психологічної і психофізичної підготовки студентів спеціальності «Залізничні споруди та колійне господарство» визначено:

а) блок психологічної просвіти;

б) професійно значущі види спорту (спортивне орієнтування, туризм, кросова підготовка, спортивні ігри, шахи);

в) психотренувальні засоби для розвитку характеристик уваги;

г) спеціальні фізичні вправи для розвитку психомоторики;

д) вправи для освоєння навиків саморегуляції психічного стану й зменшення наслідків стресу (аутогенне тренування, медитація, сахаджа-йога);

е) спортивні змагання з професійно значущих видів спорту. 
6.5. Для спеціальності «Мости і транспортні тунелі» засобами психологічної і психофізичної підготовки обрано:

а) блок психологічної просвіти;

б) професійно значущі види спорту (спортивна і прикладна гімнастика, акробатика, прикладне плавання, веслування, спортивні ігри, легка атлетика, шахи);

в) психотренувальні засоби для розвитку характеристик уваги;

г) спеціальні фізичні вправи для розвитку психомоторики (швидкості простої і складної рухової реакції, вестибулярної стійкості, швидкості у діях);

д) вправи для освоєння навиків саморегуляції психічного стану й зменшення наслідків стресу (аутогенне тренування, медитація, сахаджа-йога);

е) спортивні змагання з професійно значущих видів спорту.

7. Розроблено основи індивідуального підходу при проведенні психологічної і психофізичної підготовки студентів-залізничників. Для його реалізації в процесі занять 3 фізичного виховання запропоновано впровадження таких заходів:

a) психологічна діагностика на початку першого семестру головних показників психологічної і психофізичної готовності до обраної спеціальності;

б) визначення оптимального для конкретного студента змісту психологічної і психофізичної підготовки і його направлення у відповідну навчальну групу.

Суттєвою особливістю запропонованого підходу до організації психологічної і психофізичної підготовки в процесі фізичного виховання $є$ те, що вплив професійно значущого виду спорту доповнюється (збалансовується) використанням інших змістовних блоків.

8. Психологічна і психофізична підготовка, що розглядається в цій роботі, поєднана із завданнями фізичного виховання студентів. Ïї складові підлягають контролю. Підготовленість студентів з розділу психологічна і психофізична підготовка входить як складова до загальної оцінки з дисципліни «Фізичне виховання».

8.1. Психологічна і психофізична підготовка забезпечується проведенням відповідної спеціалізованої підготовки як у навчальний так i в позанавчальний час. Під час навчальних занять вона будується відповідно до робочої навчальної програми з дисципліни «Фізичне виховання», яка складається з врахуванням психологічної і психофі- 
зичної специфіки майбутньої професійної діяльності студентів факультету (напряму підготовки, спеціальності). Поглиблена психологічна і психофізична підготовка студентів забезпечується створенням у структурі навчальної секції фізичного виховання спеціалізованих навчальних груп психологічної і психофізичної підготовки. У рамках навчальної секції спортивного виховання з цією метою створюються навчальні групи з прикладних видів спорту. Для студентів, яких за станом здоров'я віднесено до навчальної секції фізичної реабілітації, пропонуються доступні їм частини психологічної і психофізичної підготовки.

Робота 3 психологічної і психофізичної підготовки, яка організовується в позанавчальний час, доповнює ту, що проводиться під час навчальних занять. Формами її організації $є$ :

a) самостійна теоретична підготовка;

б) заняття професійно значущими видами спорту під керівництвом тренера;

в) самостійні практичні заняття;

г) участь у змаганнях з професійно значущих видів спорту.

9. Результати діагностики ряду характеристик психологічної і психофізичної підготовки студентів-залізничників показали їх відповідну непідготовленість за такими показниками, як рівень особистісної тривожності, вибірковість уваги, концентрація і стійкість уваги, швидкість у діях, стійкість вестибулярних реакцій. Вони потребують спеціальної, цілеспрямованої психологічної і психофізичної підготовки в ході навчальних занять 3 фізичного виховання.

10. Встановлено особливості впливу фізкультурної активності під час навчальних занять 3 фізичного виховання на формування деяких компонентів психологічної і психофізичної підготовленості. Виявлено, що студентів, які займались такими видами спорту, як легка атлетика і футбол, характеризують високі показники таких якостей особистості, як «домінантність - конформність», «сила Я - слабкість Я», «сила «зверх Я» - слабість «зверх Я», «пармія - тректія», «проникливість, розважливість - наївність, простота», «самодостатність - соціабельність», «контроль бажань - імпульсивність». Характерними для них є також висока екстраверсія, емоційна стійкість, напористість, впевненість у собі і здатність переносити стрес. У цих студентів зафіксовано також як збіг, так і відмінності показників характеристик особистості. 
10.1. Вивчено особливості формування вольових якостей особистості у студентів навчальних секцій футболу, спортивної гімнастики і легкої атлетики. Встановлено, що заняття легкою атлетикою і спортивною гімнастикою $\epsilon$ ефективними для формування більшості вольових якостей особистості. Заняття футболом - ефективний засіб формування таких вольових якостей, як наполегливість, ініціативність, рішучість, сміливість. Заняття футболом, спортивною гімнастикою і легкою атлетикою суттєво не впливають на формування самовладання особистості.

10.2. Виявлено особливості розвитку вибірковості та концентрації і стійкості уваги студентів у процесі занять футболом. Встановлено, що заняття футболом не здійснюють вирішальний вплив на розвиток вибірковості уваги у студентів. Показники концентрації і стійкості уваги студентів є достатньо інформативними для визначення рівня психофізичної готовності. Заняття футболом є ефективним засобом розвитку вибірковості та концентрації і стійкості уваги у студентів.

10.3. Вивчено вплив рівня контролю особистості на прояви агресивності студентів у процесі гри у футбол. Встановлено, що рівень контролю особистості має відношення до агресії в багатьох ситуаціях гри у футбол.

11. Експериментально перевірено ефективність розроблених основ формування психологічної і психофізичної готовності студентів. У рамках вирішення цього завдання досліджено ряд питань. Встановлено суттєвий позитивний вплив на формування особистості майбутнього фахівця розроблених автором основ психологічної і психофізичної підготовки студентів-залізничників (за такими професійно значущими факторами особистості, як «емоційна нестійкість - емоційна стійкість», «схильність до почуттів - висока нормативність поведінки», «впевненість у собі - тривожність», «низький самоконтроль високий самоконтроль», «адекватність самооцінки»).

11.1. Встановлено, що найбільш поширеними копінг-стратегіями серед студентів $є$ : «збереження самовладання» (у когнітивній сфері), «оптимізм» (у емоційній сфері), «відволікання» (у поведінковій сфері). Серед студентів кількісно переважає використання адаптивних стратегій порівняно 3 неадаптивними і відносно адаптивними (ця тенденція не стосується поведінкових адаптивних стратегій у юнаків і дівчат). 


\section{2. Встановлено:}

a) серед адаптивних копінг-стратегій найбільш поширеними серед студентів $є$ адаптивні емоційні стратегії;

б) серед неадаптивних копінг-стратегій найбільш поширене використання у середовищі студентів мають емоційні неадаптивні стратегії у дівчат, поведінкові неадаптивні стратегії у дівчат, емоційні неадаптивні стратегії у юнаків;

в) серед відносно адаптивних копінг-стратегій найбільш поширеними є когнітивні відносно адаптивні стратегії у дівчат, поведінкові відносно адаптивні стратегії у дівчат, когнітивні відносно адаптивні стратегії у юнаків.

11.3. Експериментально підтверджено, що:

a) традиційні заняття з фізичного виховання суттєво не впливають на формування у студентів адаптивних і відносно адаптивних копінгстратегій;

б) використання в ході навчальних занять з фізичного виховання складових психологічної і психофізичної підготовки студентів залізничних ВНЗ суттєво позитивно впливає на формування у студентів адаптивних когнітивних і поведінкових копінг-стратегій;

в) використання в ході навчальних занять 3 фізичного виховання складових психологічної і психофізичної підготовки студентів залізничних ВНЗ суттєво не впливає на формування у студентів адаптивних і відносно адаптивних емоційних копінг-стратегій.

11.4. Встановлено, що для студентів характерним $\epsilon$ низький рівень розвитку таких складових толерантності до невизначеності, як «пристрасність», «винахідливість», «оптимізм», «сміливість, підприємливість», «адаптивність», «упевненість», «толерантність до двозначності».

11.5. Встановлено статистично значущі відмінності у юнаків і дівчат за рівнем розвитку таких складових толерантності до невизначеності як «пристрасність» й «толерантність до двозначності». Ці показники у юнаків є достовірно вищими. В той же час, не виявлено статистично значущих відмінностей у юнаків і дівчат за такими складовими як «винахідливість», «оптимізм», «сміливість, підприємливість», «адаптивність», «упевненість».

11.6. Експериментально підтверджено, що психологічна і психофізична підготовка, яка реалізується в процесі фізичного виховання, $\epsilon$ ефективною для розвитку у студентів таких складових толерантності 
до невизначеності, як «сміливість, підприємливість», «адаптивність», «толерантність до двозначності».

11.7. Встановлено, що спеціальна психологічна і психофізична підготовка в процесі фізичного виховання є ефективним засобом зниження високого рівня особистісної тривожності у студентів. В експериментальній групі юнаків 3 високим рівнем особистісної тривожності виявлено можливість ефективного використання занять атлетичною гімнастикою і пауерліфтингом для зниження іiі рівня. В експериментальній групі дівчат з високим рівнем особистісної тривожності зафіксовано можливість ефективного використання (у плані зниження рівня особистісної тривожності) занять аеробікою і сахаджайогою.

11.8. Досліджено питання можливості ефективного розвитку концентрації і стійкості уваги у студентів-залізничників в процесі психологічної і психофізичної підготовки. Встановлено, що реалізація в ході навчальних занять 3 фізичного виховання основ психологічної і психофізичної підготовки суттєво впливає на розвиток у студентів концентрації і стійкості уваги. Традиційні заняття з фізичного виховання не забезпечують ефективний розвиток концентрації і стійкості уваги у студентів.

11.9. Досліджено питання розвитку вестибулярної стійкості студентів у ході психологічної і психофізичної підготовки. Встановлено, що спеціальна психологічна і психофізична підготовка студентів, до складу якої входили блоки професійно значущих видів спорту, спеціальних фізичних вправ для розвитку вестибулярної стійкості, спеціальних психотренувальних засобів $\epsilon$ ефективною для розвитку вестибулярної стійкості у студентів. Традиційні заняття 3 фізичного виховання не забезпечують ефективний розвиток вестибулярної стійкості. 


\section{СПИСОК ВИКОРИСТАНИХ ДЖЕРЕЛ}

1. Аболин, Л. М. Эмоциональная устойчивость в напряжённой деятельности, её психологические механизмы и пути повышения [Текст]: автореф. дис. ... д-ра психол. наук: 19.00.01 / Л. М. Аболин. - Москва, 1989. - 43 с.

2. Абульханова-Славская, К. А. Личность в процессе деятельности и общения [Текст] / К. А. Абульханова-Славская // Психология личности. Т. 2. Хрестоматия / Ред.-сост. Д. Я. Райгородский. - Самара : Издательский дом «Бахрах - М», 2002. - С. $301-317$.

3. Абульханова-Славская, К. А. Стратегия жизни [Текст] / К. А. АбульхановаСлавская. - Москва: Мысль, 1991. - 299 с.

4. Авершин, А. О. Діагностика професійної придатності операторів підземних шахтних електросистем [Текст]: автореф. дис. ... канд. психол. наук : 19.00.03 / А. О. Авершин. - Харків, 2005. - 19 с.

5. Акбиева, 3. С. Развитие психологического соответствия человека и профессии в поликультурной образовательной среде вуза [Текст]: автореф. дис. ... д-ра психол. наук : 19.00 .07 / 3. С. Акбиева. - Москва, 2009. - 47 с.

6. Акулова, К. Ю. Педагогические условия формирования у студентов готовности к самопознанию в процессе физического воспитания [Текст] : автореф. дис. ... канд. пед. наук: 13.00.04 / К. Ю. Акулова. - Москва, 2006. $24 \mathrm{c}$.

7. Александер, Ф. Человек и его душа: познание и врачевание от древности и до наших дней [Текст] / Ф. Александер, Ш. Селесник. - Москва : Прогрес - Культура, 1995. - 608 с.

8. Александрова, Л. А. Психологические условия адаптации личности к условиям повышенного риска природных катастроф [Текст]: дис. ... канд. психол. наук: 19.00.01 / Л. А. Александрова. - Москва, 2004. - 207 с.

9. Алексеєва, Т. В. Соціально-психологічні аспекти становлення особистості як суб'єкта майбутньої професійної діяльності в умовах вишу [Текст] / Т. В. Алексеєва // Проблеми загальної та педагогічної психології : зб. наук. пр. ін-ту психології ім. Г. С. Костюка АПН України / за ред. С. Д. Максименка. - Т. 13, ч. 2. $-2011 .-$ С. 9-17.

10. Алексєєва, М. І. Про розвиток професійно-ціннісних мотивів навчальної діяльності особистості в умовах вищої школи [Текст] / М. І. Алексєєва, 
В. Д. Федоров // Вісн. Київського ун-ту. Питання філос. наук. - 1982. Вип. 14. - С. 8-12.

11. Алябьев, А. А. Оценка и развитие эмоциональной устойчивости у курсантов военного института физической культуры [Текст] : автореф. дис. ... канд. психол. наук: 13.00.04 / А. А. Алябьев. - Санкт-Петербург, 2009. $23 \mathrm{c}$.

12. Андреев, В. В. Индивидуальные особенности психологической защиты личности в спортивной деятельности [Текст] / : автореф. дис. ... канд. психол. наук: 13.00.04 / В. В. Андреев. - Санкт-Петербург, 2006. - 22 с.

13. Андреев, Ю. Ю. Педагогическая технология воспитания позитивных межличностных отношений курсантов вузов внутренних войск МВД России средствами физической культуры [Текст] : автореф. дис. ... канд. пед. наук: 13.00.01 / Ю. Ю. Андреев. - Санкт-Петербург, 2012. - 24 с.

14. Анцупов, А. Я. Словарь конфликтолога [Текст] / А. Я. Анцупов, А. И. Шипилов. - Санкт-Петербург, 2006. -528 с.

15. Анцыферова, Л. И. Личность с позиций динамического подхода [Текст] / Л. И. Анцыферова // Психология личности в социалистическом обществе: Личность и её жизненный путь. - Москва : Наука, 1990. - С. 7-17.

16. Артюшенко, А. О. Теоретико-методичні засади формування в учнів загальноосвітньої школи особистісної мобільності у процесі фізичного виховання [Текст]: автореф. дис. ... д-ра пед. наук: 13.00.07 / А. О. Артюшенко. - Київ, 2012. -38 с.

17. Арутюнян, Т. А. Особенности соотношения общительности и тревожности подростков [Текст] : автореф. дис. ... канд. психол. наук: 19.00.01 / Т. А. Арутюнян. - Москва, 2013. -25 с.

18. Аршава, І. Ф. Деякі аспекти вивчення феномену адаптивності як методу імпліцитної діагностики емоційної стійкості спортсменів у спорті вищих досягень [Текст] / І. Ф. Аршава, Т. О. Гаврилюк // Проблеми загальної та педагогічної психології : зб. наук. пр. ін-ту психології ім. Г. С. Костюка АПН України / за ред. С. Д. Максименка. - Київ, 2009. - Т. 11, ч. 2. C. $15-24$.

19. Аршава, І. Ф. Емоційна стійкість людини та ії діагнгостика: автореф. дис. ... д-ра психол. наук: 19.00.02 [Текст] / І. Ф. Аршава. - Київ, 2007. - 33 с.

20. Ашкинази, С. М. Рукопашный бой и преодоление препятствий, как средства психологической подготовки военнослужащих [Текст] / С. М. Ашкинази, А. Н. Потапчук // Тезисы докладов итоговой научной конференции. Санкт-Петербург, 1997. - С. 35-36.

21. Балл, Г. А. Понятие адаптации и его значение для психологии личности [Текст] / Г. А. Балл // Вопросы психологии. - 1989. - № 1. - С. 92-100.

22. Балл, Г. А. Психология в рациогуманистической перспективе [Текст] / Г. А. Балл. - Київ : Основа, 2006. -408 с.

23. Балл, Г. Методолого-психологічні роздуми в гуманістичному контексті [Текст] / Г. Балл // Соціальна психологія. - 2006. - № 4. - С. 3-14. 
24. Балл, Г. О. Категорія особистості у психології: спроба впорядкування поняттєвого поля [Текст] / Г. О. Балл // Психолого-педагогічні засади розвитку особистості в освітньому просторі: матеріали методологічного семінару АПН України 19 березня 2008 р. - Київ, 2008. - С. 103-110.

25. Баранов-Крылов, И. Н. Психофизиологические механизмы произвольного и непроизвольного внимания у человека [Текст] : дис. ... д-ра биол. наук: 03.00.13 / И. Н. Баранов-Крылов. - Санкт-Петербург, 1999. - 268 с.

26. Белоус, В. А. Организация научных исследований по физической культуре в вузе: учебно-методическое пособие [Текст] / В. А. Белоус, В. А. Щёголев, Ю. Н. Щедрин. - Санкт-Петербург : ГУИТ-МО, 2005. - 72 с.

27. Белых, С. И. Особенности ценностей и психического состояния студентов современного университета [Текст] / С. И. Белых // Педагогіка, психологія та медико-біологічні проблеми фізичного виховання і спорту. - 2013. № 7. - C. 7-14. doi:10.6084/m9.figshare.736501

28. Беляева, И. Н. Соотношение стилей профессионального поведения и личностных характеристик (на примере специалистов по продажам) [Текст] : автореф. дис. ... канд. психол. наук: 19.00 .03 / И. Н. Беляева. - СанктПетербург, 2012. -24 с.

29. Берн, Э. Введение в психиатрию и психоанализ для непосвящённых [Текст] / Э. Берн. - Санкт-Петербург : Талисман, 1994. - 432 с.

30. Берн, Э. Игры, в которые играют люди. Люди, которые играют в игры [Текст] / Э. Берн. - Санкт-Петербург : Спец. лит-ра, 1995. $398 \mathrm{c}$.

31. Берн, Э. Трансакционный анализ и психотерапия [Текст] / Э. Берн. Санкт-Петербург : «Братство», 1992. - 224 с.

32. Берон, Р. Агрессия [Текст] / Р. Берон, Д. Ричардсон. - Санкт-Петербург : Питер, 1997. $-336 \mathrm{c}$.

33. Бех, І. Д. Від волі до особистості [Текст] / І. Д. Бех. - Київ : Україна-Віта, 1995. -202 c.

34. Бикмаев, И. А. Профессиональная психофизическая подготовка студентов специальности «безопасность жизнедеятельности» в физкультурных вузах [Текст]: дис. ... канд. пед. наук: 13.00 .08 / И. А. Бикмаев. - Омск, 2004. $195 \mathrm{c}$.

35. Бикова, Г. В. Методичні засади використання фізичних вправ, спрямованих на підвищення статодинамічної стійкості у студентів [Текст] / Г. В. Бикова, I. П. Закорко, В. В. Білик // Наукові записки. Т. 19. Спеціальний випуск у двох частинах. Ч. 2 / Національний університет «Києво-Могилянська академія». - Київ, 2001. - С. 338-339.

36. Биленко, А. Г. Биомеханика вертикальной устойчивости и оценка её в спорте [Текст] : дис. ... канд. пед. наук: 01.02.08, 13.00.04 / А. Г. Биленко. - Санкт-Петербург, 2008. - 212 с.

37. Бир, С. Кибернетика и управление производством [Текст] / С. Бир. - Москва : Физматгиз, 1963. - 275 с. 
38. Білогур, В. Є. Теоретико-методичне забезпечення фізичного виховання у вищих закладах освіти [Текст] : автореф. дис. ... канд. наук з фізичного виховання і спорту: 24.00.02 / В. С. Білогур. - Рівне, 2002. - 16 с.

39. Блажко, Ю. И. Психологическая подготовка военнослужащих в процессе практических занятий по преодолению препятствий [Текст] / Ю. И. Блажко. - Ленинград : ВДКИФК, 1978. - 66 с.

40. Бобрищев, А. А. Психолого-акмеологическая концепция психологической готовности спортсменов высшей квалификации силовых единоборств [Текст] : автореф. дис. ... д-ра психол. наук: 19.00.13, 13.00.04 / А. А. Бобрищев. - Белгород, 2009. - 42 с.

41. Бовть, О. Б. Агресивні реакції та шляхи їх корекції у молодших школярів [Текст]: дис. ... канд. психол. наук: 19.00.07 / О. Б. Бовть. - Київ, 2001. $265 \mathrm{c}$.

42. Богданов, В. А. Причинный и целевой подходы в развитии теорий личности [Текст] / В. А. Богданов // Вопр. психологии. - 1991. - № 3. C. $45-53$.

43. Бодров В. А. Современные исследования фундаментальных и прикладных проблем психологии профессиональной деятельности. Ч. 1 [Текст] / В. А. Бодров // Психологический журнал. - 2008. - Т. 29, № 5. - С. 83-90.

44. Бодров, В. А. Исследование структуры и динамики развития лётных способностей [Текст] / В. А. Бодров, Ю. Э. Писаренко // Психологический журнал. - 1994. - № 3. - С. 65-77.

45. Бодров, В. А. Психологические исследования проблемы профессионализации личности [Текст] / В. А. Бодров // Психологические исследования проблемы формирования личности профессионала под ред. В. А. Бодрова. Москва : Ин-т психологии АН СССР, 1991. - 464 с.

46. Бодров, В. А. Психология профессиональной пригодности [Текст]: учеб. пособие для вузов / В. А. Бодров. - Москва : ПЕР СЕ, 2001. - 511 с.

47. Бодров, В. А. Психофизиологический отбор военных специалистов: метод. пособие [Текст] / В. А. Бодров, В. И. Медведев, Т. Т. Джамгаров. - Москва : Воениздат, 1973. - 206 с.

48. Бодров, В. А. Работоспособность человека-оператора и пути её повышения [Текст] / В. А. Бодров // Психологический журнал. - 1987. - № 3. C. $107-117$.

49. Большая энциклопедия психологических тестов. - Москва : Эксмо, 2009. $416 \mathrm{c}$.

50. Бондаревский, Е. Я. Педагогические основы контроля за физической подготовленностью учащейся молодежи [Текст]: автореф. дис. ... д-ра пед. наук: 13.00 .04 / Е. Я. Бондаревский. - Москва, 1983. - 45 с.

51. Бондаренко, I. Г. Засоби професійно-прикладної фізичної підготовки у фізичному вихованні студентів-екологів [Текст]: автореф. дис. ... канд. наук 3 фізичного виховання і спорту: 24.00 .02 / I. Г. Бондаренко. Дніпропетровськ, 2009. - 20 с. 
52. Борейко, Н.Ю.Педагогічні умови професійно-прикладної фізичної підготовки студентів вищих технічних навчальних закладів [Текст] : автореф. дис. ... канд. пед. наук: 13.00.04 / Н. Ю. Борейко. - Луганськ, 2008. $22 \mathrm{c}$.

53. Борейко, Н. Ю. Технологія професійно-прикладної фізичної підготовки студентів вищих технічних навчальних закладів / Н. Ю. Борейко // Проблеми фізичного виховання студентів: Матеріали регіональної науковопрак. конф. - Дніпропетровськ : ДНУ, 2005. - С. 89-92.

54. Борисюк, А. С. Психологічні особливості формування професійних якостей майбутнього медичного психолога [Текст] : автореф. дис. ... канд. психол. наук: 19.00.07 / А. С. Борисюк. - Івано-Франківськ, 2004. - 20 с.

55. Борщов, С. М. Психофізична підготовка юних гімнастів [Текст] : автореф. дис. ... канд. наук з фізичного виховання і спорту: 24.00 .01 / С. М. Борщов. - Львів, 2003. - 17 с.

56. Ботяев, В. Л. Координационные способности, вестибулярная устойчивость и их роль в освоении программы по гимнастике студентами педвузов [Текст] : дис. ... канд. пед. наук: 13.00.04 / В. Л. Ботяев. - Москва, 1999. $127 \mathrm{c}$.

57. Брайент Дж. Кретти. Психология в современном спорте [Текст] / Б. Д. Кретти. - Москва : ФиС, 1978. - 224 с.

58. Бургин, М. С. Личность школьника и его жизненная позиция как цель учебно-воспитательного процесса [Текст] / М. С. Бургин, В. В. Пичурин // Научные достижения и передовой опыт в области педагогики и народного образования: информ. сб. НИИТиИП АПН СССР. - 1991. - № 3(15). C. $1-22$.

59. Бургин, М. С. Методологический уровень практических задач педагогики [Текст] / М. С. Бургин, С. У. Гончаренко // Философская и социологическая мысль. - 1989. - № 4. - С. 3-11.

60. Бургин, М. С. Функторная семантика в категориях именованных множеств [Текст] / М. С. Бургин // Рациональность, рассуждение, коммуникация. Киев : Наук. думка, 1987. - С. 183- 198.

61. Бурлачук, Л. Ф. Психодиагностика [Текст] / Л. Ф. Бурлачук. - СанктПетербург : Питер, 2002. - 352 с.

62. Бурлачук, Л. Ф. Словарь-справочник по психологической диагностике [Текст] / Л. Ф. Бурлачук, С. М. Морозов. - Киев : Наук. думка, 1989. $200 \mathrm{c}$.

63. Бут, В. П. Формування професійно важливих якостей газодимозахисниківрятувальників МНС України [Текст] : автореф. дис. ... канд. психол. наук: 19.00.09 / В. П. Бут. - Київ, 2008. - 20 с.

64. Бысюк, А. С. Психологические факторы успешности профессиональной деятельности инженеров-метрологов [Текст] : автореф. дис. ... канд. психол. наук: 19.00 .03 / А. С. Бысюк. - Тверь, 2012. - 25 с.

65. Вайник, Г. А. Дифференцированный подход в физическом воспитании студентов на основе контроля их психофизического состояния (на прим. групп 
ОФП) [Текст]: дис. ... канд. пед. наук: 13.00.04 / Г. А. Вайник. - СанктПетербург, 1995. - 182 с.

66. Валеева, Г. В. Профессионально-прикладная физическая подготовка будущих инженеров химиков-технологов и механиков нефтяного производства [Текст]: автореф. дис. ... канд. пед. наук: 13.00.04 / Г. В. Валеева. - Ленинград, 1988. - 22 с.

67. Василенко, М. М. Сучасні напрями психологічних досліджень копінгстатегій [Текст] / М. М. Василенко // Проблеми загальної та педагогічної психології: зб. наук. пр. ін-ту психології ім. Г. С. Костюка АПН України / за ред. С. Д. Максименка. - Т. 11, ч. 7. - 2009. - С. 95-106.

68. Василенко, Т. Д. Телесность и субъективная картина жизненного пути личности [Текст]: автореф. дис. ... д-ра психол. наук: 19.00.04 / Т. Д. Василенко. - Санкт-Петербург, 2012. - 48 с.

69. Василюк, Ф. Е. Методологический анализ в психологии [Текст] / Ф. Е. Василюк. - Москва : МГППУ; Смысл, 2003. - 240 с.

70. Василюк, Ф. Е. Психология переживания (анализ преодоления критических ситуаций) [Текст] / Ф. Е. Василюк. - Москва : МГУ, 1984. - 200 с.

71. Вассерман, Л. И. Совладание со стрессом. Теория и психодиагностика [Текст] / Л. И. Вассерман, В. А. Абабков, Е. А. Трифонова. - СанктПетербург : Речь, 2010. - 192 с.

72. Величковский, Б. Б. Многомерная оценка индивидуальной устойчивости к стрессу [Текст] : автореф. дис. ... канд. психол. наук: 19.00.01 / Б. Б. Величковский. - Москва, 2007. - 27 с.

73. Велумян, Н. А. Индивидуально-психологические предпосылки выбора профессии в подростковом и юношеском возрасте [Текст] : автореф. дис. ... канд. психол. наук: 19.00.13 / Н. А. Велумян. - Москва, 2013. - 32 с.

74. Визитова, С. Ю. Психологические особенности стресоустойчивости педагога и пути ее повышения [Текст] : дис. ... канд. психол. наук: 19.00.07 / С. Ю. Визитова. - Елец, 2012. - 197 с.

75. Виленский, М. Я. Повышение воспитательно-образовательного потенциала физической культуры в формировании личности современного специалиста [Текст] / М. Я. Виленский // Теория и практика физической культуры. 1987. - № 10. - С. 11-13.

76. Виленский, М. Я. Физическая культура личности студента как объект и субъект образовательных технологий [Текст] / М. Я. Виленский // Образовательная, воспитательная и оздоровительная роль физического воспитания и спорта в современных условиях: материалы международной научнопрактической конференции. - Москва : Изд-во РУДН, 2000. - С. 24-25.

77. Витун, В. Г. Формирование адаптационного потенциала студентов вузов в процессе физического воспитания [Текст] : автореф. дис. ... канд. пед. наук: 13.00.08 / В. Г. Витун. - Магнитогорск, 2009. - 22 с.

78. Волженцева, I. В. Динаміка стану тривожності студентів у навчальному процесі [Текст] В. В. Волженцева // Педагогічний процес: теорія і практика: зб. наук. пр. - Київ : ПП ЕКМО. - 2004. - Вип. 2. - С. 319-329. 
79. Воробьёва, К. И. Психологический анализ операторской деятельности машинистов локомотивов в контексте выявления их профессионально важных качеств [Текст] / К. И. Воробьёва, А.К.Максимов // Материалы межрегиональной науч.-метод. конференции «Современные технологи в высшем профессиональном образовании». - Хабаровск : Изд-во ДвГУПС, 2004. C. $72-77$.

80. Вяткин, Б. А. Управление психическим стрессом в спортивных соревнованиях [Текст] / Б. А. Вяткин. - Москва : ФиС, 1981. - 112 с.

81. Гаврилюк, М. Ю. Психологическая оценка и профотбор персонала производственного объекта «Железная дорога» [Текст]: дис. ... канд. психол. наук 19.00.03 / М. Ю. Гаврилюк. - Москва, 1998. - 146 с.

82. Газарова, Е. Э. Психология телесности [Текст] / Е. Э. Газарова. - Москва : Институт общегуманитарных исследований, 2002. - 192 с.

83. Газиева, М. 3. Развитие структур интегральной индивидуальности стрессонеустойчивых студентов [Текст] : автореф. дис. ... канд. психол. наук: 19.00.01 / М. 3. Газиева. - Ставрополь, 2012. - 20 с.

84. Гайдукевич, Г. А. Прояви агресивності у курсантів вищих військових закладів освіти на різних етапах підготовки [Текст] : автореф. дис. ... канд. психол. наук: 19.00 .07 / Г. А. Гайдукевич. - Київ, 2000. - 16 с.

85. Галицын, С. В. Педагогическая система физкультурной деятельности как средство профилактики социально-негативного поведения подростков [Текст] : автореф. дис. ... д-ра пед. наук: 13.00 .04 / С. В. Галицын. - СанктПетербург, 2011. - 48 с.

86. Гарбузов, В. И. Практическая психотерапия, или как вернуть ребёнку и подростку уверенность в себе, истинное достоинство и здоровье [Текст] / В. И. Гарбузов. - Санкт-Петербург : АО «Сфера», 1994. - 160 с.

87. Гафарова, Н. В. Роль личностных особенностей в профессиональной и социальной дезадаптации (на примере медицинских работников) [Текст] : автореф. дис. ... канд. психол. наук: $19.00 .01,19.00 .05$ / Н. В. Гафарова. Екатеринбург, 2012. - 21 с.

88. Гимнастика: учебник для институтов физической культуры [Текст] / под ред. А. М. Шлемина и А.Т. Брыкина. - Москва : Физкультура и спорт, 1979. - 399 c.

89. Гиппенрейтер, Ю. Б. Деятельность и внимание [Текст] / Ю. Б. Гиппенрейтер // Хрестоматия по вниманию / под. ред. Ю. Б. Гиппенрейтер и В. Я. Романова. - Москва : ЧеРо, 2001. - С. 543-558.

90. Гірченко, О. Л. Комп' ютерні ігри як фактор впливу на тривожність дітей молодшого шкільного віку [Текст] : автореф. дис. ... канд. психол. наук: 19.00.07 / О. Л. Гірченко. - Київ, 2010. - 18 с.

91. Гласс, Д. Статистические методы в педагогике и психологии [Текст] / Д. Гласс, Д. Стенли. - Москва : Прогресс, 1976. - 495 с.

92. Глушко, Л. О. Психологічна парадигма категорії «впевненості в собі» [Текст] / Л. О. Глушко // Проблеми загальної та педагогічної психології: 
зб. наук. пр. ін-ту психології ім. Г. С. Костюка АПН України / за ред. С. Д. Максименка. - 2010. - Т. 12, ч. 4. - С. 90-98.

93. Головченко, О. І. Особливості впливу фізичного виховання на формування особистості учнів середнього шкільного віку [Текст] : автореф. дис. ... канд. наук з фізичного виховання та спорту: 24.00.02 / О. I. Головченко. Харків, 2011. - 19 с.

94. Гольева, Г. Ю. Формирование эмоциональной устойчивости как ключевой компоненты у будущих педагогов-психологов [Текст] : автореф. дис. ... канд. психол. наук: 19.00.07 / Г. Ю. Гольева. - Челябинск, 2010. - 23 с.

95. Голян, О. І. Агресивність як особистісний чинник діяльності вчителя [Текст] / О. І. Голян, І. М. Голян // Психологія: зб. наук. пр. НПУ ім. М. П. Драгоманова. - 2000. - Вип. 9, ч. 2. - С. 222-227.

96. Гомілко, О. Метафізика тілесності: концепт тіла у філософському дискурсі [Текст] / О. Гомілко. - Київ : Наук. думка, 2001. - 340 с.

97. Гонтарь, О. П. Развитие физической культуры личности студента технического вуза [Текст] : автореф. дис. ... канд. пед. наук : 13.00 .08 / О. П. Гонтарь. - Барнаул, 2012. - 25 с.

98. Гордеева, Т. О. Гендерные различия в академической и социальной самоэффективности и копинг-стратегиях у современных российских подростков [Текст] / Т. О. Гордеева, Е. А. Шепелева // Вест. Моск. ун-та. Сер. 14. Психология. - 2006. - № 3. - С. 78-85.

99. Гордеева, Т. О. Мотивация учебной деятельности школьников и студентов: структура, механизмы, условия развития [Текст] : автореф. дис. ... д-ра психол. наук: 19.00.07 / Т. О. Гордеева. - Москва, 2013. - 46 с.

100. Горєлов, І. Ю. Психологічна готовність працівників ОВС до застосування вогнепально-силового впливу [Текст] : автореф. дис. ... канд. психол. наук: 19.00.09 / І. Ю. Горєлов. - Харків, 2008. - 19 с.

101. Гориневский, В. В. Избранные сочинения. Т. 1 [Текст] / В. В. Гориневский. - Москва, 1951. - С. 274-275.

102. Горностай, П. П. Формирование психологической готовности старшеклассников к педагогической деятельности [Текст]: автореф. дис... канд. психол. наук : 19.00.07 / П. П. Горностай. - Киев, 1988. - 18 с.

103. Гредюшко, О. П. Социально-психологические факторы тревожности студентов ССУЗ педагогического профиля: [Текст] : автореф. дис. ... канд. психол. наук: 19.00.05 / О. П. Гредюшко. - Казань, 2004. - 19 с.

104. Гримак, Л. П. Психологическая подготовка парашютистов [Текст] / Л. П. Гримак. - Москва : ДОСААФ, 1966. - 118 с.

105. Гулидов, И. Н. Педагогический контроль и его обеспечение [Текст]: учебное пособие / И. Н. Гулидов. - Москва : ФОРУМ, 2005. - 240 с.

106. Гура, О. I. Теоретико-методологічні основи формування психологопедагогічної компетентності викладача вищого навчального закладу в умовах магістратури [Текст] : автореф. дис. ... д-ра пед. наук: 13.00.04 / О. І. Гура. - Київ, 2008. - 38 с. 
107. Гусєв, А. І. До проблеми формування та розвитку толерантності до невизначеності [Текст] / А. I. Гусєв // Науковий часопис національного педагогічного університету ім. М.П.Драгоманова. Сер. 12, Психологічні науки. - Київ, 2007. - № 17 (41). Ч. 1. - С. 165-170.

108. Гусев, А. И. Толерантность к неопределённости: проблематика исследований [Текст] / А. И. Гусев // Практична психологія та соціальна робота. 2007. - № 8. - С. 75-80.

109. Гусева, Н. Л. Организация физического воспитания студентов на основе развития общественно-самодеятельной формы физкультурно-спортивной деятельности в вузе [Текст] : автореф. дис. ... канд. пед. наук: 13.00.04 / Н. Л. Гусева. - Москва, 2012. - 23 с.

110. Гуцыкова, С. В. Взаимосвязь интегративных профессионально-важных качеств и личностных характеристик специалистов с разной эффективностью деятельности [Текст] : автореф. дис. ... канд. психол. наук: 19.00.03 / С. В. Гуцыкова. - Москва, 2012. - 30 с.

111. Давыдов, В. В. О понятии личности в современной психологии [Текст] / В. В. Давыдов // Психологический журнал. - 1988. - Т. 9, № 4. - С. 22-32.

112. Давыдов, В. В. Проблемы развивающего обучения: опыт теоретического и экспериментального психологического исследования [Текст] / В. В. Давыдов. - Москва : Педагогика, 1986. - 240 с.

113. Данаил, С. Н. Физкультурное образование в контексте современных разработок теории деятельности [Текст] / С. Н. Данаил // Спортивний вісник Придніпров'я. - 2013. - № 2. - С. 18-26.

114. Деманов, А. В. Разработка и применение учебных нормативов по профессионально-прикладной физической подготовке для учащихся СПТУ строительного профиля [Текст]: автореф. дис. ... канд. пед. наук: 13.00.04 / А. В. Деманов. - Москва, 1991. -23 с.

115. Демьяненко, Ю. К. Физические упражнения в системе военнопрофессионального отбора [Текст] / Ю. К. Демьяненко, В. А. Щёголев, В. В. Орлова. - Ленинград : ВДКИФК, 1984. - 72 с.

116. Державні вимоги до системи фізичного виховання дітей, учнівської і студентської молоді. Затв.: Наказ Міністерства освіти України 25.05.1998. № 188 [Текст] / Міністерство освіти України. - Київ, 1998. - 6 с.

117. Державні тести і нормативи оцінки фізичної підготовленості населення України [Текст] / за ред. М. Д. Зубалія. - Київ, 1997. - 35 с.

118. Джамгаров, Т. Т. Психологическая систематика видов спорта и соревновательных упражнений [Текст] / Т. Т. Джамгаров // Психология и современный спорт. - Москва : ФиС, 1982. - С. 12-21.

119. Джемс, У. Психология [Текст] / У. Джемс. - Москва : Педагогика, 1991. $368 \mathrm{c}$.

120. Довідник кваліфікаційних характеристик професій працівників. Випуск 66. «Залізничний транспорт і метрополітен». Частина 1. Розділи «Керівники», «Професіонали», «Фахівці», «Технічні службовці» [Текст]. - Краматорськ, 2002. $-184 \mathrm{c}$. 
121. Дроздов, О. Ю. Соціально-психологічні фактори динаміки агресивної поведінки молоді [Текст]: дис... канд. психол. наук: 19.00.05 / О. Ю. Дроздов. - Чернігів, 2003. -225 с.

122. Дружинин, В. Н. Экспериментальная психология [Текст] / В. Н. Дружинин. - Санкт-Петербург : «Питер», 2000. - 320 с.

123. Друшевская, В. Л. Физиологические особенности адаптации сенсомоторных систем организма акробатов разной квалификации [Текст] : автореф. дис. ... канд. биол. наук: 03.03.01 / В. Л. Друшевская. - Краснодар, 2011. $25 \mathrm{c}$.

124. Дурай-Новакова, К. М. Формирование профессиональной готовности студентов к педагогической деятельности [Текст]: автореф. дис... д-ра пед. наук: 13.00 .04 / К. М. Дурай-Новакова. - Москва, 1983. - 39 с.

125. Душков, Б. А. Энциклопедический словарь: психология труда, управления, инженерная психология и эргономика [Текст] / Б. А. Душков, А. В. Королёв, Б. А. Смирнов. - Москва, 2005. - 848 с.

126. Дьяченко, М. И. Психологические проблемы готовности к деятельности [Текст] / М. И. Дьяченко, Л. А. Кандибович. - Минск, 1976. - 176 с.

127. Евдокимов, И. М. Поддержание оптимального психического состояния средствами физической подготовки у курсантов в процессе обучения [Текст]: автореф. дис. ... канд. пед. наук: 13.00 .04 / И. М. Евдокимов. Санкт-Петербург, 2001. - 24 с.

128. Евдокимова, О. М. Технология валеометрии и интегрированная психофизическая тренировка в оздоровительной физической культуре [Текст]: автореферат дис. ... д-ра пед. наук: 13.00 .04 / О. М. Евдокимова. - СанктПетербург, 2000. - 48 с.

129. Евсеев, Ю. И. Определение содержания профилированного физического воспитания студентов полевых и експедиционных профессий [Текст] / Ю. И. Евсеев // Теория и практика физической культуры. - 1981. - № 8. C. 41-43.

130. Егорычев, А. О. Методика контроля и коррекции уровня развития профессионально-важных физических качеств студентов с использованием ЭВМ [Текст]: дис. ... канд. пед. наук / А. О. Егорычев. - Москва, 1992. - 170 с.

131. Егорычев, А. О. Психолого-педагогические основы профессиональноприкладной физической подготовки студентов [Текст]: монография / А. О. Егорычев. - Москва, 2003. - 151 с.

132. Егорычев, А. О. Теория и технология управления психофизической подготовкой студентов к профессиональной деятельности [Текст]: дис. ... д-ра пед. наук : 13.00 .04 / А. О. Егорычев. - Ярославль, 2005. - 317 с.

133. Свдокімова, О. О. Теорія і практика психологічного супроводу навчальновиховного процесу у вищому технічному навчальному закладі [Текст]: автореф. дис. ... д-ра психол. наук: 19.00.07 / О. О. Свдокімова. - Київ, 2011. $-42 \mathrm{c}$. 
134. Завирохин, Д. С. Воспитание эмоциональной устойчивости юных спортсменов в области пулевой стрельбы [Текст] : автореф. дис. ... канд. пед. наук : 13.00 .04 / Д. С. Завирохин. - Челябинск, 2012. - 24 с.

135. Загорский, Б. И. О содержании основних понятий теории и методики профессионально-прикладной физической подготовки [Текст] / Б. И. Загорский // Теория и практика физической культуры. - 1984. - № 9. - С. 44-46.

136. Зайцев, Ю. А. Диагностика и коррекция подростково-юношеской тревожности относительно будущого [Текст] : дис. ... канд. психол. наук: 19.00.13 / Ю. А. Зайцев. - Новокузнецк, 2008. - 225 с.

137. Заплатина, О. А. Роль физического воспитания в подготовке студентов вуза к будущей профессиональной деятельности [Текст]: дис. ... канд. пед. наук: 13.00.08 / О. А. Заплатина. - Кемерово, 2007. - 237 с.

138. Захарова, Л. Н. Психологические основы подготовки к профессиональной деятельности [Текст]: автореф. дис. ... д-ра психол. наук: 19.00.01 / Л. Н. Захарова. - Новосибирск, 1997. - 38 с.

139. Зинченко, В. П. Методологические вопросы психологии [Текст] / В. П. Зинченко, С. Д. Смирнов. - Москва : МГУ, 1983. - 165 с.

140. Зобнина, Т. В. Система психологической подготовки студентов - будущих педагогов в инновационной образовательной среде педагогического вуза [Текст]: автореф. дис. ... д-ра психол. наук: 19.00.07 / Т. В. Зобнина. Нижний Новгород, 2012. - 47 с.

141. Зонь, В. В. Виховання волових якостей у курсантів вищих військових навчальних закладів [Текст] : автореф. дис. ... канд. пед. наук: 13.00 .04 / В. В. Зонь. - К., 2002. -20 c.

142. Зуев, С. Н. Профессиональная психофизическая готовность [Текст] / С. Н. Зуев // Физическая культура: учебное пособие / под ред. В. А. Коваленко. - Москва, 2000. - С. 293-317.

143. Иванников, В. А. Психологические механизмы волевой регуляции [Текст] / В. А. Иванников. - Москва : МГУ, 1991. - 142 с.

144. Иванова, Е. А. Педагогические условия эффективной реализации адаптационного потенциала физкультурно-спортивной деятельности студентов технического вуза [Текст] : автореф. дис. ... канд. пед. наук: 13.00 .08 / Е. А. Иванова. - Магнитогорск, 2007. - 22 с.

145. Изотова, Н. В. Крректирующий контроль как фактор повышения качества обучения в вузе (на материале предметов гуманітарного цикла) [Текст] : дис. ... канд. пед. наук: 13.00 .08 / Н. В. Изотова. - Брянск, 2004. - 217 с.

146. Ильин, Е. П. Психология спорта [Текст] / Е. П. Ильин. - Санкт-Петербург : Питер, 2010. - 352 c.

147. Ильин, Е. П. Психофизиология физического воспитания [Текст] / Е. П. Ильин. - Москва : Просвещение, 1980. - 200 с.

148. Ильин, Е. П. Связь волевих качеств с индивидуальным стилем деятельности [Текст] / Е. П. Ильин // Психология воли. - Санкт-Петербург : Питер, 2009. $-368 \mathrm{c}$. 
149. Ильинич, В. И. Профессионально-прикладная физическая подготовка студентов (научно-методические и организационные основы) [Текст] / В. И. Ильинич. - Москва : Высш. шк., 1978. - 144 с.

150. Исаева, Д. А. Особенности становлення личностной и профессиональной идентичности в юности и ранней взрослости [Текст] : автореф. дис. ... канд. психол. наук: 19.00.13 / Д. А. Исаева. - Санкт-Петербург, 2013. - 26 с.

151. Інструкція з організації психологічного забезпечення службової діяльності аварійно-рятувальних служб. Затв.: Наказ міністерства України з питань надзвичайних ситуацій та у справах захисту населення від наслідків Чорнобильської катастрофи 23.02.2004 № 89 [Текст] // Офіц. вісн. України. - 2004. - № 11. - С. 696.

152. Кабачков, В. А. Основы физического воспитания с профессиональной направленностью в учебных заведениях профтехобразования [Текст]: автореф. дис. ... д-ра пед. наук: 13.00 .04 / В. А. Кабачков. - Москва, 1996. $63 \mathrm{c}$.

153. Кабирова, О. Р. Эстетическое воспитание студентов технического вуза средствами физической культуры [Текст] : автореф. дис. ... канд. пед. наук: 13.00.08 / О. Р. Кабирова. - Магнитогорск, 2007. - 24 с.

154. Каган, М. С. Человеческая деятельность [Текст] / М. С. Каган. - Москва : Политиздат, 1974. - $328 \mathrm{c.}$

155. Калугина, Н. А. Психолого-педагогическая подготовка студентов музыкальных специализаций в вузе [Текст]: автореф. дис. ... д-ра пед. наук: 13.00.08 / Н. А. Калугина. - Москва, 2011. - 51 с.

156. Калюжна, С. М. Психологічні механізми особистісної тривожності у підлітковому віці [Текст] : автореф. дис. ... канд. психол. наук: 19.00.07 / Є. М. Калюжна. - Київ, 2008. - 29 с.

157. Климачов, В. А. Экспресс-контроль и индивидуализация технической подготовки юных боксёров с учётом вестибулярной устойчивости [Текст] : дис. ... канд. пед. наук: 13.00.04 / В. А. Климачов. - Санкт-Петербург, 2000. $-178 \mathrm{c}$.

158. Климов, Е. А. Для чего чувство локтя [Текст] / Е. А. Климов // Психологическая газета. - 2002. - №1/76, январь. - С. 10-11.

159. Климов, Е. А. Основы психологи [Текст] / Е. А. Климов. - Москва : Культура и спорт, ЮНИТИ, 1997. -295 с.

160. Климов, Е. А. Психология профессионального самоопределения [Текст] / Е. А. Климов. - Ростов : Феникс, 1996. - 512 с.

161. Ковалёв, А. Г. Психология личности [Текст] /А. Г. Ковалёв. - Москва : Просвещение, 1970. - 391 с.

162. Коваленко, В.А. Физическая культура в обеспечении здоровья и профессиональной психофизической готовности студентов [Текст] / В. А. Коваленко // Физическая культура и спорт в Российской Федерации (студенческий спорт). - Москва : Полиграфсервис, 2002. - С. 43-66.

163. Козіброцький, С. П. Програмно-нормативні основи фізичного виховання студентів (історико-методологічний аналіз) [Текст] : автореф. дис. ... канд. 
наук 3 фізичного виховання і спорту: 24.00 .02 / С. П. Козіброцький. Львів, 2002. - 18 с.

164. Козубенко, В. Г. Безопасное управление поездом: вопросы и ответы [Текст] / В. Г. Козубенко. - Москва : Транспорт,1992. - 254 с.

165. Коледа, В. А. Теоретико-методические основы формирования профессионально-личностных качеств студентов в процессе физического воспитания [Текст]: автореф. дис. ... д-ра пед. наук : 13.00 .04 / В. А. Коледа. - Минск, 2001. $-33 \mathrm{c}$.

166. Колокатова, Л. Ф. Дидактическая система информационной поддержки психофизической подготовки студентов технических вузов [Текст] / : автореф. дис. ... д-ра пед. наук: 13.00.04, 13.00 .08 / Л. Ф. Колокатова. - Москва, 2007. $-50 \mathrm{c}$.

167. Кораблина, Э. П. Становление психологической готовности к инженерной деятельности у студентов технического вуза [Текст]: автореф. дис... канд. психол. наук: 19.00 .03 / Э. П. Кораблина. - Ленинград, 1990. - 17 с.

168. Корнев, К. И. Проблема совладающего поведения ВИЧ-инфицированных больных [Текст] / К. И. Корнев // Вест. Омского ун-та. Сер. Психология. 2006. - № 2. - C. 17-24.

169. Корнилов, Ю. П. Активизация произвольного внимания квалифицированных гребцов в процессе спортивного совершенствования [Текст] : дис. ... канд. пед. наук: 13.00.04 / Ю. П. Корнилов. - Киев, 1983. - 155 с.

170. Корнилова, Т. В. Методологические основы психологии [Текст] / Т. В. Корнилова, С. Д. Смирнов. - Санкт-Петербург : Питер, 2006. - 320 с.

171. Корнійко, У. В. Психологічні зміни особистості яхтсмена у процесі спортивної діяльності під впливом психотравмуючих факторів [Текст] : автореф. дис. ... канд. наук з фізичного виховання і спорту: 24.00.01 / У. В. Корнійко. - Київ, 2003. - 21 с.

172. Коровин, С. С. Профессиональная физическая культура и формирование личности [Текст]: монография / С. С. Коровин, В. А. Кабачков. - Оренбург : ОГПУ, 1998. -259 с.

173. Короленко, Ц. П. Психофизиология человека в экстремальных условиях [Текст] / Ц. П. Короленко. - Ленинград : Медицина, 1978. - 272 с.

174. Корольчук, В. М. Психологія стресостійкості особистості [Текст]: автореф. дис. ... д-ра психол. наук: 19.00.01 / В. М. Корольчук. - Київ, 2009. - 39 с.

175. Корсини, Р. Психологическая энциклопедия [Текст] / Р. Корсини, А. Ауэрбах. - Санкт-Петербург : Питер, 2003. - 1096 с.

176. Кочергин, А. Н. Интеграция технико-тактической, физической и психологической подготовки к рукопашному бою [Текст] : автореф. дис. ... канд. пед. наук: 13.00.04 / А. Н. Кочергин. - Санкт-Петербург, 2011. - 26 с.

177. Кочкина, Л. В. Становление физического Я в дошкольном возрасте [Текст] : автореф. дис. ... канд. психол. наук: 19.00 .13 / Л. В. Кочкина. - Москва, 2007. $-20 \mathrm{c}$. 
178. Кравчук, Л. С. Особливості психологічних детермінант агресивних проявів особистості [Текст]: автореф. дис... канд. психол. наук: 19.00.01 / Л. С. Кравчук. - Київ, 2002. - 21 с.

179. Кравчук, С. Л. Статеві відмінності в особливостях застосування агресії особистістю в житті [Текст] / С. Л. Кравчук // Вісник КНУ ім. Т. Шевченка «Соціологія. Психологія. Педагогіка». - Київ, 2007. - Вип. 27. - С. 40-42.

180. Краевский, В. В. Проблемы научного обоснования обучения: методологический анализ [Текст] / В. В. Краевский. - Москва : Педагогика, 1977. 262 c.

181. Краснов, Н. В. Физические упражнения в процессе формирования у курсантов вузов психологической устойчивости к экстремальным факторам военного труда [Текст]: дис. ... канд. пед. наук: 13.00 .04 / Н. В. Краснов. Санкт-Петербург : ВИФК, 1986. - 220 с.

182. Краснова, В. В. Социальная тревожность как фактор нарушений интерперсональных отношений и трудностей в учебной деятельности у студентов [Текст] : автореф. дис. ... канд. психол. наук: 19.00 .13 / В. В. Краснова. Москва, 2013. -25 с.

183. Крейхи, Б. Социальная психология агрессии [Текст] / Б. Крейхи. - СанктПетербург : Питер, 2003. - 334 с.

184. Крук, В. М. Психологическое обеспечение личностной надёжности специалиста силових структур [Текст] : автореф. дис. ... д-ра психол. наук: 19.00.03 / В. М. Крук. - Москва, 2013. - 44 с.

185. Круцевич, Т. Ю. Контроль в физическом воспитании детей, подростков и юношей [Текст] / Т. Ю. Круцевич, М. И. Воробьев. - Киев : Олимп. литpa, 2005. -195 c.

186. Круцевич, Т. Ю. Контроль у фізичному вихованні дітей, підлітків і молоді [Текст]: навч. посібник / Т. Ю. Круцевич, М. І. Воробйов, Г. В. Безверхня. Київ : Олімп. л-ра, 2011. - 224 с.

187. Крэйг, Г. Психология развития [Текст] / Г. Крейг. - Санкт-Петербург : Издво «Питер», 2000. - 992 с.

188. Крюкова, Т. Л. Возрастные и кросс-культурные различия в стратегиях совладающего поведения [Текст] / Т. Л. Крюкова // Психологический журнал. - 2005. - T. 26, № 2. - C. 5-15.

189. Кузма, Л. П. Виды нарушений произвольного внимания у учащихся младших класов [Текст] : дис. ... канд. психол. наук: 19.00.07 / Л. П. Кузма. Ярославль, 2005. - 149 с.

190. Кузнецова, О. В. Взаимосвязь уровней тревожности и механизмов адаптации личности в период юности [Текст] : автореф. дис. ... канд. психол. наук: 19.00 .13 / О. В. Кузнецова. - Москва, 2009. - 22 с.

191. Кулагин, Б. В. Основы профессиональной психодиагностики [Текст] / Б. В. Кулагин. - Ленинград : Медицина, 1984. -216 с.

192. Кулиш, Н. В. Личностно-ориентированный контроль знаний как фактор самоопределения студентов университета [Текст] : автореф. дис. ... канд. пед. наук: 13.00.01 / Н. В. Кулиш. - Оренбург, 2012. - 23 с. 
193. Кульбіда, Н. М. Особистісні детермінанти успішної професійної підготовки майбутніх підприємців [Текст] : автореф. дис. ... канд. психол. наук: 19.00.07 / Н. М. Кульбіда. - Київ, 2005. - 20 с.

194. Кун, Л. Всеобщая история физической культуры и спорта [Текст] / Л. Кун. - Москва : Радуга, 1982. - 399 с.

195. Курдюкова, Н. А. Оценивание успешности учебной деятельности как психолого-педагогическая проблема [Текст]: автореф. дис. ... канд. психол. наук: 19.00.07 / Н. А. Курдюкова. - Санкт-Петербург, 1997. - 22 с.

196. Лазарус, Р. Теория стресса и психофизиологические исследования [Текст] / Р. Лазарус // Эмоциональный стресс. - Ленинград : Медицина, 1970. C. $178-208$.

197. Леднёв, В. С. Содержание образования [Текст] / В. С. Леднёв. - Москва : Высш. шк., 1989. - 360 с.

198. Леженкина, Т. И. Психологическая классификация опасных ситуаций в деятельности локомотивных бригад [Текст] / Т. И. Леженкина // Психологический журнал. - 2009. - Т. 30, № 2. - С. 92-98.

199. Леонгард, К. Акцентуированные личности [Текст] / К. Леонгард. - Киев: Выща шк., 1981. - 375 с.

200. Леонова, А. Б. Психодиагностики функциональных состояний человека [Текст] / А. Б. Леонова. - Москва : Изд-во Моск. ун-та, 1984. - 200 с.

201. Леонтьев, А. Н. Деятельность и личность [Текст] / А. Н. Леонтьев // Психология личности. Т. 2. Хрестоматия / Ред.-сост. Д. Я. Райгородский. - Самара : Изд. дом «Бахрах - М», 2002. - С. 165-196.

202. Леонтьев, А. Н. Деятельность. Сознание. Личность. [Текст] / А. Н. Леонтьев. - Москва : Политиздат, 1975. - 304 с.

203. Леонтьев, А. Н. Проблемы развития психики [Текст] / А. Н. Леонтьев Москва : МГУ, 1981. - 584 с.

204. Леонтьев, Д. А. Личность: человек в мире и мир в человеке [Текст] / Д. А. Леонтьев // Вопр. психологии. - 1989. - № 3. - С. 11-21.

205. Леонтьев, Д. А. Новые ориентиры понимания личности в психологии: от необходимого к возможному [Текст] / Д. А. Леонтьев // Вопр. психологии. - 2011. - № 1. - C. 3-27.

206. Лесгафт, П. Ф. Труды комиссии по техническому образованию (1889-1890) [Текст] / П. Ф. Лесгафт. - Москва, 1981. - С. 52.

207. Липчанский, В. А. Научное обоснование физической подготовки инженеров на базе психолого-математического моделирования надёжности профессиональной деятельности [Текст]: дис. ... канд. пед. наук: 13.00.04 / В. А. Липчанский. - Кировоград, 1992. - 198 с.

208. Лисюк, С. Г. Забезпечення психологічної стійкості військовослужбовців до екстремальних ситуацій професійної діяльності [Текст] : автореф. дис. ... канд. психол. наук: 19.00.09 / С. Г. Лисюк. - Хмельницький, 2011. -20 с.

209. Литвиненко, О. В. Психологические и психофизические особенности внимания у здорових детей и детей с синдромом дефицита внимания [Текст] : 
дис. ... канд. психол. наук / О. В. Литвиненко. - Ростов-на-Дону, 2002. $137 \mathrm{c}$.

210. Личностный потенциал: структура и диагностика [Текст] / под ред. Д. А. Леонтьева. - Москва : Смысл, 2011. - 680 с.

211. Ломов, Б. Ф. Методологические и теоретические проблемы психологи [Текст] / Б. Ф. Ломов. - Москва : Наука, 1984. - 444 с.

212. Ломова, Т. О. Психологічні особливості агресивної поведінки старшокласників та іï корекція в процесі навчальної діяльності [Текст] : автореф. дис. ... канд. психол. наук: 19.00.07 / Т. О. Ломова. - Одеса, 2009. $-23 \mathrm{c}$.

213. Лоуэн, А. Психология тела [Текст] / А. Лоуэн. - Москва : Ин-т общегуманитарных исследований, 2000. - 199 с.

214. Лоуэн, А. Терапия, которая использует язик тела (Биоэнергетика) [Текст] / А. Лоуэн. - Санкт-Петербург : Речь, 2000. - 272 с.

215. Лоуэн, А. Физическая динамика структуры характера [Текст] / А. Лоуэн. Москва : ПАНИ, 1996. - 320 с.

216. Лубышева, Л. И. Социальное и биологическое в физической культуре человека в аспекте методологического анализа [Текст] / Л. И. Лубышева // Теория и практика физической культуры. - 1996. - № 1. - С. 2-4.

217. Лубышева, Л. И. Теоретико-методологические и организационные основы формирования физической культуры студентов [Текст]: автореф. дис.... д-ра пед. наук: 13.00 .04 / Л. И. Лубышева. - Москва, 1992. - 60 с.

218. Лушин, П. В. Психологія педагогічної зміни (екофасилітація) [Текст]: науково-методичний посібник для студентів вищих навчальних закладів / П. В. Лушин. - Кіровоград : Імекс ЛТД, 2002. - 76 с.

219. Магомадов, Р. А. Формирование базовой профессионально-прикладной физической культуры курсантов морских вузов, осваивающих плавательные специальности [Текст] : автореф. дис. ... канд. пед. наук: 13.00 .04 / Р. А. Магомадов. - Краснодар, 2013. - 25 с.

220. Мазоха, I. С. Індивідуально-психологічні особливості агресивності особистості [Текст]: автореф. дис...канд. психол. наук: 19.00.01 / I. С. Мазоха. - Одеса, 2008. - 20 c.

221. Майнина, И. Н. Оценка «глубинных» индивидуально-психологических характеристик человека по выражению его лица [Текст] : автореф. дис. ... канд. психол. наук: 19.00.01 / И. Н. Майнина. - Москва, 2011. - 24 с.

222. Максименко, С. Д. Генеза здійснення особистості [Текст] / С. Д. Максименко. - Київ : ТОВ «КММ», 2006. - $240 \mathrm{c.}$

223. Максименко, С. Д. Психологія особистості : підруч. для студ. вищ. навч. закл. [Текст] / С. Д. Максименко, К. С. Максименко, М. В. Папуча. - Київ : TOB «КМM», 2007. - $296 \mathrm{c}$.

224. Максименко, С. Д. Фахівця потрібно моделювати (наукові основи готовності випускника педвузу до педагогічної діяльності) [Текст] / С. Д. Максименко, О. М. Пелех // Рідна школа. - 1994. - № 3-4. - С. 6-10. 
225. Малімон, О. О. Диференційований підхід у процесі фізичного виховання студентів [Текст] : автореф. дис. ... канд. наук з фізичного виховання і спорту: 24.00.02 / О. О. Малімон. - Луцьк, 1999. - 17 с.

226. Мамадалиева, Г. А. Психолого-педагогическая профилактика и коррекция тревожности современного подростка [Текст] : дис. ... канд. психол. наук: 19.00.07 / Г. А. Мамадалиева. - Нижний Новгород, 2011. - 262 с.

227. Маримонова, М. С. Воспитание толерантности через социокультурное взаимодействие [Текст] / М. С. Маримонова, А. С. Обухов // Развитие исследовательской деятельности учащихся: метод. сб. - Москва : Народное образование, 2001. - С. 88-98.

228. Марищук, В. Л. Психологические основы формирования профессиональнозначимых качеств [Текст]: дис. ... д-ра психол. наук: 19.00.03 / В. Л. Марищук. - Ленинград : ЛГУ, 1982. - 351 с.

229. Марищук, В. Л. К вопросу об эмоциональной устойчивости курсантовлётчиков и возможностях её совершенствования с применением средств физической підготовки [Текст]: автореф. дис. ... канд. пед. наук / В. Л. Марищук. - Ленинград, 1964. - 22 с.

230. Марищук, В. Л. Оценка некоторых двигательных и психических качеств с помощью физических упражнений и методом наблюдений [Текст] / В. Л. Марищук, Н. К. Меньшиков // Тезисы докладов научной конференции, посвящённой итогам НИР факультета за 1965 г. - Ленинград : ВДКИФК, 1966. - С. 22.

231. Маркелова, Т. В. Теоретико-методологические основы заблаговременной устойчивости будущих офицеров запаса к условиям военно-профессиональной деятельности [Текст]: автореф. дис. ... д-ра психол. наук: 19.00 .03 / Т. В. Маркелова. - Москва, 2011. - 56 с.

232. Масалов, С. А. Психологическая готовность сотрудников частных охранных предприятий к экстремальным ситуациям [Текст] : дис. ... канд. психол. наук: 19.00 .13 / С. А. Масалов. - Тамбов, 2007. - 151 с.

233. Маслоу, А. Новые рубежи человеческой природы [Текст] / А. Маслоу. Москва : Смысл, 1999. - 425 с.

234. Масляк, И. П. Взаимосвязь устойчивости вестибулярного анализатора и уровня развития ловкости школьников [Текст] / И. П. Масляк, Л. Е. Шестерова, Н. Н. Терентьева // Слобожанский научно-спортивный вестник. 2004. - Вип. 7. - С. 14-17.

235. Матвеев, Е. Г. Физическое развитие курсантов как фактор личностнопрофессионального становления будущего военного специалиста [Текст] : автореф. дис. ... канд. пед. наук: 13.00.01 / Е. Г. Матвеев. - Воронеж, 2012. $-24 \mathrm{c}$.

236. Матвеев, Л. П. Теория и методика физической культуры [Текст]: ученик для институтов физической культуры / Л. П. Матвеев. - Москва : ФиС, 1991. $-450 \mathrm{c}$.

237. Махотнюк, Л. О. Формування психологічної готовності майбутніх інженерів-прикордонників до професійної діяльності [Текст]: автореф. дис. 
... канд. психол. наук: 19.00.07 / Л. О. Махотнюк. - Хмельницький, 2006. $20 \mathrm{c}$.

238. Медников, С. В. Психологические составляющие агресивного поведения футбольних болельщиков [Текст] : автореф. дис. ... канд. психол. наук: 19.00.01 / С. В. Медников. - Санкт-Петербург, 2012. - 21 с.

239. Меньшиков, В. М. Дидактические основы профессионально-прикладной физической культуры учащейся молодёжи [Текст]: дис. ... д-ра пед. наук: 13.00.04 / В. М. Меньшиков. - Челябинск, 2001. - 394 с.

240. Методики психодиагностики в спорте [Текст]: учеб. пособие для студентов пед. ин-тов / В. Л. Марищук, Ю. М. Блудов, В. А. Плахтиенко, Л. К. Серова. - Москва : Просвещение, 1990. - 256 с.

241. Методологическое сознание в современной науке [Текст] / - Киев : Наук. думка, 1989. - 336 с.

242. Мироненко, И. А. О классификации концепций личности и имплицитных основаниях психологических теорий [Текст] / И. А. Мироненко // Вопр. психологии. - 2006. - № 4. - С. 95-105.

243. Мироненко, И. А. Об интеграции психологического знания [Текст] / И. А. Мироненко // Вопр. психологии. - 2004. - № 3. - С. 153-155.

244. Миронов, А. Г. Совершенствование профессионально-прикладной физической подготовки студентов юридических специальностей вузов на основе применения айкидо [Текст] : автореф. дис. ... канд. пед. наук: 13.00 .08 / А. Г. Миронов. - Йошкар-Ола, 2012. -24 с.

245. Митина, Л. М. Личностное и профессиональное развитие человека [Текст] / Л. М. Митина // Вопр. психологи. - 1997. - № 4. - С. 28-38.

246. Мойсеєва, О. Є. Психологічний аналіз агресивності особистості [Текст] / О. Є. Мойсеєва // Проблеми загальної та педагогічної психології: зб. наук. пр. ін-ту психології ім. Г. С. Костюка АПН України / за ред. С. Д. Максименка. - 2010. - Т. 12, ч. 1. - С. 393-403.

247. Молотай, В. А. Формування психологічної готовності військовослужбовців внутрішніх військ МВС України до діяльності по охороні громадського порятунку [Текст]: автореф. дис. ... канд. психол. наук: 19.00.09 / В. А. Молотай. - Хмельницький, 2006. - 20 с.

248. Моляко, В. А. Психологическая готовность к труду на современном производстве [Текст] / В. А. Моляко, М. Л. Смульсон. - Киев, 1985. - 96 с.

249. Морган, У. П. Ситуативная тревога и результативность деятельности [Текст] / У. П. Морган, К. А. Эликсон // Вопр. психологии. - 1990. - № 3. C. $155-161$.

250. Москова, М. В. Личностные факторы эмоциональной дезадаптации студентов [Текст] : автореф. дис. ... канд. психол. наук: 19.00.13 / М. В. Москова. - Москва, 2008. - 26 с.

251. Мул, С. А. Психологічна готовність персоналу прикордонного контролю до дії в екстремальних умовах [Текст]: автореф. дис. ... канд. психол. наук: 19.00.07 / С. А. Мул. - Київ, 2011. - 20 с. 
252. Мысина, Г. А. Создание условий для обеспечения физического, психического и социального благополучия студентов в здоровьесберегающей образовательной среде вуза [Текст]: автореф. дис. ... д-ра пед. наук: 13.00 .08 / Г. А. Мысина. - Тула, 2011. - 44 с.

253. Навчальна програма 3 фізичного виховання для ВНЗ 3 - 4 рівнів акредитації. Затв.: Наказ Міністерства освіти і науки України 14.11.03. № 757 [Текст] / Мін-во освіти і науки України. - Київ, 2003 - 22 с.

254. Наказ Міністерства внутрішніх справ України 25.11.2003. № 1444 «Про організацію професійної підготовки рядового і молодшого начальницького складу органів внутрішніх справ» [Текст] / Мін-во внутрішніх справ України. - Київ, 2003. - 10 с.

255. Наказ Міністерства внутрішніх справ України 28.07.2004. № 842 «Про подальший розвиток служби психологічного забезпечення оперативнослужбової діяльності органів внутрішніх справ України» [Текст] / Мін-во внутрішніх справ України. - Київ, 2004. - 16 с.

256. Наказ Міністерства внутрішніх справ України 7.04.2008. № 161 «Про затвердження програм психопрофілактичної роботи 3 особовим складом MBC України на 2008-2012 роки» [Текст] / Мін-во внутрішніх справ України. - Київ, 2008. - 12 с.

257. Налчаджян, А. Агрессивность человека [Текст] / А. Налчаджян. - СанктПетербург : Питер, 2007. - 734 с.

258. Наследов, А. Д. Математические методы психологического исследования. Анализ и интерпретация данных [Текст]: учебное пособие / А. Д. Наследов. - Санкт-Петербург : Речь, 2004. - 392 с.

259. Невенчанный, С. В. Психолого-педагогические условия снижения агресивного поведения военнослужащих по призыву [Текст] / автореф. дис. ... канд. психол. наук: 19.00.07 / С. В. Невенчанный. - Москва, 2012. - 23 с.

260. Немов, Р. С. Психология: учебник для студентов высших пед. учеб. заведений. В 3 кн. Кн. 2. Психология образования [Текст] / Р. С. Немов. - Москва : Просвещение, 1995. - $496 \mathrm{c.}$

261. Немов, Р. С. Психология: учебник для студентов высших пед. учеб. заведений. В 3 кн. Кн. 3. Экспериментальная педагогическая психология и психодиагностика [Текст] / Р. С. Немов. - Москва : Просвещение, 1995. $512 \mathrm{c}$.

262. Нерсесян, Л. С. Железнодорожная психология [Текст] / Л. С. Нерсесян. Москва : РЕИНФОР, 2005. $-533 \mathrm{c}$.

263. Нерсесян, Л. С. Психологические аспекты повышения надёжности управления движущимися объектами [Текст] / Л. С. Нерсесян. - Москва : Промедек, 1992. - 288 с.

264. Носкова, О. Г. Железнодорожная психология И. И. Рихтера [Текст] / О. Г. Носкова // Вестн. Моск. ун-та. Сер. 14. Психология. - 1985. - № 1. C. 55-64. 
265. Нурмухаметова, И. Ф. Психолого-педагогические условия снижения агрессивности учащихся младших класов [Текст] : дис. ... канд. психол. наук: 19.00.07 / И. Ф. Нурмухаметова. - Уфа, 2011. - $176 \mathrm{c.}$

266. Общая психодиагностика [Текст] / под. ред. А. А. Бодалёва, В. В. Столина. - Москва : МГУ, 1987. - 304 с.

267. Овчинников, В. А. Система формирования профессионально-прикладной физической культуры курсантов и слушателей вузов МВД России [Текст] : автореф. дис. ... д-ра пед. наук: 13.00 .04 / В. А. Овчинников. - Волгоград, 2012. $-55 \mathrm{c}$.

268. Озеров, В. П. Психомоторные способности человека [Текст] / В. П. Озеров. - Дубна : Феникс+, 2002. -320 с.

269. Опыт системного исследования психики ребёнка [Текст] / под ред. Н. И. Непомнящей. - Москва : Педагогика, 1975. - 231 с.

270. Орлов, А. Б. Склонность и профессия [Текст] / А. Б. Орлов. - Москва, 1981. $-95 \mathrm{c}$.

271. Основы теории и методики физической культуры [Текст]: учебник для техникумов физической культуры / под ред. А. А. Гужаловского. - Москва : ФиС, 1986. - 352 с.

272. Павлова, Т. А. Формирование профессионально-важных качеств проводников пассажирских вагонов в процессе их деятельности [Текст] : дис. ... канд. психол. наук: 19.00.03 / Т. А. Павлова. - Москва, 2011. - 201 с.

273. Падун, М. А. Регуляция эмоций: процесс, формы, механизмы [Текст] / М. А. Падун // Психологический журнал. - 2010. - Т. 31, № 6. - С. 57-69.

274. Пангелова, Н. Є. Теоретико-методичні засади формування гармонійно розвиненої особистості дитини дошкільного віку в процесі фізичного виховання [Текст] : автореф. дис. ... д-ра наук з фізичного виховання і спорту: 24.00.02 / Н. С. Пангелова. - Київ, 2014. - 39 с.

275. Панченко, Т. Л. Формування психологічної готовності студентів з обмеженими фізичними можливостями до самостійної навчальної діяльності [Текст] : автореф. дис. ... канд. психол. наук: 19.00.07 / Т. Л. Панченко. Хмельницький, 2011. - 20 с.

276. Пархоменко, П. П. Изучение и совершенствование внимания курсантовлётчиков средствами физической подготовки и спорта [Текст]: автореф. дис. ... канд. пед. наук: 13.00 .04 / П. П. Пархоменко. - Ейск, 1973. - 22 с.

277. Пахомова, Н. А. Развитие произвольного внимания у первоклассников в зависимости от условий обучения [Текст] : дис. ... канд. психол. наук: 19.00.07 / Н. А. Пахомова. - Нижний Новгород, 2003. - 201 с.

278. Петров, Д. А. Формирование психологической готовности к действиям в экстремальных условиях у сотрудников подразделений специального назначения МВД РФ средствами физической подготовки [Текст]: дис. ... канд. пед. наук: 13.00 .04 / Д. А. Петров. - Санкт-Петербург, 2005. - 150 с.

279. Пічурін, В. В. Рівень суб' єктивного контролю студентів-футболістів як чинник їх ігрових агресивних дій [Текст] / В. В. Пічурін // Матеріали Всеукраїнської науково-практичної конференції «Актуальні проблеми 
фізичного виховання студентів в умовах кредитно-модульної системи навчання». - Дніпропетровськ, 2014. - С. 342-345.

280. Пічурін, В. В. Основи організації психологічної і психофізичної підготовки студентів залізничних вузів в процесі фізичного виховання [Текст] / В. В. Пічурін // Науковий часопис НПУ ім. Драгоманова. Сер. 15. «Науково-педагогічні проблеми фізичної культури (фізична культура і спорт)». Зб. наук. пр. / за ред. Г. М. Арзютова. - Київ : Вид-во НПУ ім. М. П. Драгоманова, 2012. - Вип. 26. - С. 84-90.

281. Пічурін, В. В. Особистість і спортивна діяльність [Текст] / В. В. Пічурін // Спортивний вісник Придніпров'я. - 2010. - № 3. - С. 14-17.

282. Пічурін, В. В. Проблема контролю у фізичному вихованні студентів [Текст] / В. В. Пічурін // Спортивний вісник Придніпров’я. - 2011. - № 1. C. 25-27.

283. Пічурін, В. В. Професійна адекватність спеціаліста і проблема психофізичної підготовки студентів у вищій школі [Текст] / В. В. Пічурін // Матеріали міжнародної науково-практ. конф. «Формування, збереження і зміцнення здоров'я підростаючого покоління як обов'язковий компонент системи національної освіти». - Київ, 1997. - С. 74-78.

284. Пічурін, В. В. Психологічна i психофізична готовність студентівзалізничників до професійної праці [Текст] / В. В. Пічурін // Науковий часопис НПУ ім. М.П.Драгоманова. Сер. 15 «Науково-педагогічні проблеми фізичної культури (фізична культура і спорт)». - Київ : НПУ імені М. П. Драгоманова, 2013. - Вип. 37. - С. 95-103.

285. Пічурін, В. В. Психологічна і психофізична підготовка як складова фізичного виховання студентів вищих навчальних закладів [Текст] / В. В. Пічурін // Педагогіка, психологія та медико-біологічні проблеми фізичного виховання і спорту. - 2014. - № 11. - С. 44-48. doi: $10.15561 / 18189172.2014 .1108$

286. Пічурін, В. В. Психофізична проблема і фізичне виховання [Текст] / В. В. Пічурін // Спортивний вісник Придніпров’я. - 2005. - № 3. - С. 23-26.

287. Платонов, К. К. Структура и развитие личности [Текст] / К. К. Платонов. Москва : Наука, 1986. - 254 с.

288. Платонов, Н. Н. Формирование волевого развития личности в процессе физкультурно-спортивной деятельности с оздоровительной направленностью в условиях Севера [Текст] : дис. ... канд. пед. наук: 13.00.01 / Н. Н. Платонов. - Якутск, 1998. - 141 с.

289. Плахтиенко, В. А. Надёжность в спорте [Текст] / В. А. Плахтиенко, Ю. М. Блудов. - Москва : ФиС, 1983. - 176 с.

290. Поваренков, Ю. П. Системогенетическая концепция профессионального становления человека [Текст] / Ю. П. Поваренков // Идея системности в современной психологии / под ред. В. А. Барабанщикова. - Москва : Институт психологии РАН, 2005. - С. 360-384.

291. Полиевский, С. А. Физкультура и профессия [Текст] / С. А. Полиевский, И. Д. Старцев. - Москва : ФиС, 1988. - 160 с. 
292. Положення про заліки з фізичного виховання. Затв.: Наказ Міністерства освіти України 07.08.1998 № 500/2942 [Текст] / Мін-во освіти України. Київ, 1998. - 3 с.

293. Положення про організацію фізичного виховання і масового спорту у вищих навчальних закладах. Затв.: Наказ Міністерства освіти і науки України 11.01.2006 № 4 [Текст] / Мін-во освіти і науки України. - Київ, 2006. - 23 с.

294. Полянский, В. П. Теоретико-методические основы совершенствования прикладной физической культуры (её содержания и форм) в современном обществе [Текст]: автореф. дис. ... д-ра пед. наук: 13.00.04 / В. П. Полянский. - Москва, 1999. - 62 с.

295. Пономарёв, Я. А. Методологическое введение в психологию [Текст] / Я. А. Пономарёв. - Москва : Наука, 1983. - 205 с.

296. Практикум по общей и экспериментальной психологии [Текст]: учебное пособие / под общ. ред. А. А. Крылова. - Ленинград : ЛГУ, 1987. - 255 с.

297. Практическая психодиагностика. Методики и тесты [Текст]: учебное пособие / под ред. Д. Я. Райгородского. - Самара : Изд. Дом «Бахрах - М», 2002. -672 c.

298. Пристав, О. В. Формирование и поддержание психического состояния курсантов военно-транспортного университета железнодорожных войск физическими упражнениями и ментальным тренингом [Текст]: автореф. дис. ... канд. психол. наук: 13.00.04 / О. В. Пристав. - Санкт-Петербург, 2005. $22 \mathrm{c}$.

299. Прихидько, А. И. Социально-психологический анализ адаптации учёних к социальным изменениям [Текст] : автореф. дис. ... канд. психол. наук: 19.00.05 / А. И. Прихидько. - Москва, 2006. - 29 с.

300. Приходько, В. В. Креативна валеологія. Концепція і педагогічна технологія формування студентів технічних i гуманітарних спеціальностей як будівничих власного здоров'я[Текст]: навчальний посібник / В. В. Приходько, В. П. Кузьмінський. - Дніпропетровськ : НГУ, 2004. - 230 с.

301. Про Державну національну програму «Освіта» (Україна 21 століття)» Затв.: Постанова Кабінету Міністрів України від 03.11.1993 № 896 [Текст] / Кабінет Міністрів України. - Київ, 1993. - 4 с.

302. Про затвердження Інструкції про порядок організації та проведення психопрофілактичної роботи з персоналом Державної прикордонної служби України: Наказ Адміністрації Державної прикордонної служби України від 14.04.2008 р. № 318. - Офіц. вид. - Київ, 2008. - 43 с.

303. Прядко, Н. О. Формування психологічної готовності вчителя до регуляції взаємин між старшокласниками [Текст]: автореф. дис. ... канд. психол. наук: 19.00.07 / Н. О. Прядко. - Київ, 2006. - 20 с.

304. Психологические и психофизиологические особенности студентов [Текст] / под ред. Н. М. Пейсахова. - Казань : Изд-во Казанского ун-та, 1977. 296 c.

305. Психология 21 века [Текст]: учеб. для вузов / под ред. В. Н. Дружинина. Москва : ПЕР СЭ, 2003. - 863 с. 
306. Психотерапевтическая энциклопедия [Текст] / под ред. Б. Д. Карвасарского. - Санкт-Петербург : Питер Ком, 1998. - 752 с.

307. Пуни, А. Ц. О системе звеньев психологической подготовки спортсмена к соревнованию [Текст] / А. Ц. Пуни // Теория и практика физической культуры. - 1964. - № 7. - С. 16-19.

308. Пуни, А. Ц. Очерки психологии спорта [Текст] / А. Ц. Пуни. - Москва : Физкультура и спорт, 1959. - 308 с.

309. Пуни, А. Ц. Психологические основы волевой подготовки в спорте [Текст] / А. Ц. Пуни. - Ленинград, 1977. - С. 21-22.

310. Пустовой, А. П. Профессионально-прикладная физическая подготовка студентов высших учебных заведений [Текст]: учебно-методическое пособие / А. П. Пустовой, Н. Г. Скачков, М. Г. Царева. - Санкт-Петербург : СПб ГТУРП, 2008. -60 с.

311. Раевский, Р. Т. Профессионально-прикладная физическая подготовка студентов высших учебных заведений [Текст]: учебно-методическое пособие / Р. Т. Раевский, С. М. Канишевский. - Одесса : Наука и техника, 2010. $380 \mathrm{c}$.

312. Раевский, Р. Т. Профессионально-прикладная физическая подготовка студентов технического вуза [Текст] / Р. Т. Раевский. - Москва : Высш. шк., 1985. - $168 \mathrm{c.}$

313. Райгородский, Д. Я. Практическая психодиагностика. Методики и тесты: учебное пособие [Текст] / Д. Я. Райгородский. - Самара : Изд. дом «Бахpax-M», 2001. $-672 \mathrm{c}$.

314. Райх, В. Функция оргазма [Текст] / В. Райх. - Санкт-Петербург - Москва : Университетская книга, 1997. - 303 с.

315. Рассказова, Е. И. Копинг-статегии в психологии стресса: подходы, методы и перспективы [Текст] [Электронный ресурс ] / Е. И. Рассказова, Е. И. Гордеева // Психологические исследования: электрон. науч. журн. - 2011. № 3 (17). URL: http: // psystudy. ru (дата обращения: rr.mm. 2222). $0421100116 / 0027$

316. Реан, А. А. Агрессия и агрессивность личности [Текст] / А. А. Реан // Психологический журнал. - 1996. - № 5. - С. 3-18.

317. Ребрина, А. А. Ретроспективний аналіз програмного забезпечення професійно-прикладної фізичної підготовки студентів вищих навчальних закладів [Текст] / А. А. Ребрина // Науковий часопис НПУ ім. Драгоманова. Сер. 15. «Науково-педагогічні проблеми фізичної культури (фізична культура і спорт)». Зб. наук. пр. / за ред. Г. М. Арзютова. - Київ : Вид-во НПУ ім. М. П. Драгоманова, 2013. - Вип. 30. - С. 242-248.

318. Рева, О. М. Формування емоційної стійкості у ранньому юнацькому віці [Текст] : автореф. дис. ... канд. психол. наук: 19.00.07 / О. М. Рева. - Київ, 2005. $-20 \mathrm{c}$.

319. Рекало, В. І. Принцип багатовимірності знання про особистість в світлі психотерапевтичних завдань [Текст] / В. І. Рекало // Практична психологія та соціальна робота. - 2004. - № 7. - С. 77-80. 
320. Родин, Ю. И. Психическое развитие детей дошкольного возраста в процессе обучения движениям [Текст] / : автореф. дис. ... д-ра психол. наук: 19.00.13 / Ю. И. Родин. - Тула, 2009. - 43 с.

321. Родионов, А. В. Психическая подготовка спортсмена [Текст] / А. В. Родионов // Современная система спортивной подготовки. - Москва: Изд-во «CAAM», 1995. - C. 194-213.

322. Родионов, А. В. История развития психологии спорта [Текст] / А. В. Родионов, Л. Г. Уляева // Психологический журнал. - 2011. - Т. 32, № 1. C. $111-119$.

323. Родионов, А. В. Предмет и история психологии спорта [Текст] / А. В. Родионов, В. Н. Неповалов // Психология физического воспитания и спорта: учебник для вузов. - Москва : Академический проект, 2004. - С. 179-195.

324. Рождественський, А. Ю. Рефлексія тілесного потенціалу в життєвому самовизначенні старшокласників [Текст] : автореф. дис. ... канд. психол. наук: 19.00.07 / А. Ю. Рождественський. - Київ, 2002. - 19 с.

325. Рожновский, А. Ф. Профессионально-прикладная физическая подготовка в инженерно-морских вузах [Текст]: автореф. дис. ... канд. пед. наук : 13.00.04 / А. Ф. Рожновский. - Москва, 1988. - 26 с.

326. Романенко, В. А. Особенности вестибулярной устойчивости у агрессивных и неагрессивных студенток гуманитарного вуза [Текст] / В. А. Романенко, В. М. Приходько, В. Ю. Соколова, С. Д. Иванова // Педагогика, психология та медико-биологические проблемы физического воспитания и спорта. 2011. - № 11. - C. 99-102.

327. Романова, М. Л. Технология применения методов и средств контроля учебной деятельности студентов в педагогическом управлении [Текст] / М. Л. Романова // Фундаментальные исследования. - 2008. - № 3. С. 42-45.

328. Рубинштейн, С. Л. Принципы и пути развития психологии [Текст] / С. Л. Рубинштейн. - Москва : АН СССР, 1959. - 354 с.

329. Рубинштейн, С. Л. Проблемы общей психологии [Текст] / С. Л. Рубинштейн. - Москва : Педагогика, 1973. - 423 с.

330. Руденко, Г. В. Индивидуализация профессионально-прикладной физической подготовки к деятельности, связанной с риском для жизни и здоровья (на примере горно-геологических специальностей) [Текст] / : автореф. дис. ... д-ра пед. наук: 13.00.04 / Г. В. Руденко. - Санкт-Петербург, 2013. - 47 с.

331. Рудестам, К. Групповая психотерапия [Текст] / К. Рудестам. - СанктПетербург : ЗАО «Изд-во «Питер», 1999. - 384 с.

332. Рудик, П. А. Актуальные проблемы психологической подготовки спортсмена $[$ Текст] / П. А. Рудик // Психологическая подготовка спортсменов разных видов спорта к соревнованиям. - Москва : ФиС, 1968. - С. 3-8.

333. Рудик, П. А. Актуальные проблемы психологической подготовки спортсменов [Текст] / П. А. Рудик // Теория и практика физической культуры. 1970. - № 5. - C. 61-64. 
334. Рудик, П. А. Психология [Текст] / П. А. Рудик. - Москва : Физкультура и спорт, 1958. $-501 \mathrm{c}$.

335. Рудик, П. А. Психология [Текст] / П. А. Рудик. - Москва : Физкультура и спорт, 1976. - 239 с.

336. Савина, Т. А. Формирование эмоцинальной устойчивости будущого педагога [Текст] : автореф. дис. ... канд. пед. наук: 13.00 .08 / Т. А. Савина. Москва, 2010. $-21 \mathrm{c}$.

337. Савченков, А. В. Развитие эмоциональной устойчивости будущих педагогов в высшем учебном заведении [Текст] : автореф. дис. ... канд. пед. наук: 13.00.08 / А. В. Савченков. - Челябинск, 2010. - 27 с.

338. Садовский, В. А. Формирование двигательной готовности специалистов железнодорожного транспорта в условиях профессионально ориентированной системы физического воспитания [Текст]: автореф. дис. ... д-ра пед. наук: 13.00.04 / В. А. Садовский. - Улан-Уде, 2012. - 49 с.

339. Санжаева, Р. Д. Психологические механизмы формирования готовности человека к деяльности [Текст]: автореф. дис. ... д-ра психол. наук: 19.00.01 / Р. Д. Санжаева. - Новосибирск, 1997. - 36 с.

340. Саракул, А. Г. Психологическая подготовка личного состава подразделений специального назначения путём применения физических упражнений, сочетаемых с приёмами психоэмоционального самоуправления [Текст]: автореф. дис. ... канд. психол. наук: 13.00 .04 / А. Г. Саракул. - СанктПетербург, 2005. - 22 с.

341. Сары-Гузель, В. Р. Оптимизация эмоциональной устойчивости личности студента через учебную деятельность [Текст] : дис. ... канд. психол. наук: 19.00 .07 / В. Р. Сары-Гузель. - Нижний Новгород, 2002. - 221 с.

342. Свешникова, Е. М. Особенности формирования волевых качеств младших школьников различных систем обучения [Текст] : дис. ... канд. психол. наук: 19.00 .07 / Е. М. Свешникова. - Санкт-Петербург, 2010. - 137 с.

343. Селиванов, В. И. Взаимосвязь воли и самоконтроля в учебной деятельности студентов [Текст] / В. И. Селиванов, С. А. Гаврилина // Психологический журнал. - 1991. - Т. 12, № 5. - С. 44-50.

344. Селье, Г. От мечты к открытию [Текст] / Г. Селье. - Москва : Прогресс, 1987. $-368 \mathrm{c}$.

345. Семёнов, С. А. Управление развитием социально-значимых качеств у студентов высших учебных заведений с использованием средств физической культуры и спорта [Текст]: дис. ... канд. пед. наук: 13.00 .04 / С. А. Семёнов. - Санкт-Петербург, 2004. - 170 с.

346. Сенюшина, Л. Н. Профессионально-прикладная физическая подготовка студентов геологического факультета [Текст]: дис. ...канд. пед. наук: 13.00 .04 / Л. Н. Сенюшина. - Ленинград, 1983. - 187 с.

347. Сергеева, А. А. Особенности самореализации личности в спортивной деятельности [Текст] / А. А. Сергеева // Психологический журнал международного университета природы, общества и человека «Дубна». - 2011. № 1. - C. 56-67. 
348. Сергеева, О. Н. Формирование психофизической готовности к профессиональной деятельности будущих специалистов по организации и безопасности движения средствами физической культуры и спорта в вузе [Текст] : автореф. дис. ... канд. пед. наук: 13.00.08 / О. Н. Сергеева. - Йошкар-Ола, 2012. $-23 \mathrm{c}$.

349. Сиваш, О. Н. Личностно-ориентированная експертиза профессиональной пригодности лётчиков [Текст] : автореф. дис. ... канд. психол. наук: 19.00 .03 / О. Н. Сиваш. - Москва, 2009. - 21 с.

350. Силич, Е. В. Индивидуализация психологической подготовки юных спортсменов в сложнокоординированных видах спорта [Текст]: автореф. дис. ... канд. пед. наук: 13.00 .04 / Е. В. Силич. - Минск, 2012. - 30 с.

351. Симонов, Н. В. Темперамент, характер, личность [Текст] / Н. В. Симонов, П. М. Ершов. - Москва : Наука, 1984. - 161 с.

352. Сичов, С. О. Теоретико-методичні засади прилучення студентської молоді до цінностей фізичної культури [Текст]: автореф. дис. ... д-ра пед. наук: 13.00.07 / С. О. Сичов. - Київ, 2011. - 39 с.

353. Сишко, Д. В. Типологічні особливості вестибуловегетативних реакцій у спортсменів [Текст] : автореф. дис...д-ра наук з фізичного виховання та спорту: 24.00.01 / Д. В. Сишко. - Київ, 2009. - 44 с.

354. Скидан, С. О. Наукові основи контролю знань студентів [Текст] / С. О. Скидан // Засоби навчальної та науково-дослідної роботи: зб. наук. пр. за ред. проф. В. І. Євдокімова і проф. О. М. Микитюка. - Харків, 1998. - Вип. 6. - С. 234-241.

355. Склень, О. І. Базисні стратегії копінг-поведінки працівників аварійнорятувальних підрозділів МНС України, динаміка та особливості їх зміни в різноманітних стресових ситуаціях [Текст] / О. І. Склень // Наук. зап. ін.ту психології ім. Г. С. Костюка АПН України. - Київ : Міленіум, 2006. Вип. 27. - С. 476-486.

356. Скляренко, И. С. Теория и практика формирования профессиональных ценностных установок у студентов высших учебных заведений [Текст]: автореф. дис. ... д-ра пед. наук: 13.00.01 / И. С. Скляренко. - Москва, 2011. - 42 c.

357. Скотникова, И. Г. Проблема уверенности: история и современное состояние [Текст] / И. Г. Скотникова // Психологический журнал. - 2002. - Т. 23, № $1 .-$ C. 52-60.

358. Скуратова, А. В. Развитие личностно-значимых паттернов поведения как условие преодоления тревожности у учащихся начальных классов [Текст] : автореф. дис. ... канд. психол. наук: 19.00.07 / А. В. Скуратова. - Тамбов, 2012. $-23 \mathrm{c}$.

359. Сметанський, М. I. Контроль за навчально-пізнавальною діяльністю студентів: проблеми, шляхи розв'язання [Текст] / М. Сметанський // Вища школа. - 2004. - № 4. - С. 63-68.

360. Смирнов, В. Н. Профессионально-психологическая подготовка сотрудников специальных подразделений органов внутренних дел к действиям 
в экстремальных условиях [Текст]: автореф. дис. ... д-ра психол. наук: 19.00.06/ В. Н. Смирнов. - Москва, 2004. - 60 с.

361. Смирнова, В. В. Динамика личностных характеристик спортсменов в процессе психологического сопровождения (на прим. борцов высокой квалификации) [Текст]: автореф. дис. ... канд. психол. наук: 19.00.01 / В. В. Смирнова. - Санкт-Петербург, 2012. - 26 с.

362. Современная система спортивной подготовки [Текст]: монография / под общ. ред. Ф. П. Суслова, В. Л. Сыча, Б. Н. Шустина. - Москва : Изд-во «СAM», 1885. - $448 \mathrm{c}$.

363. Сокольская, М. В. Личностное здоровье профессионала [Текст] : автореф. дис. ... д-ра психол. наук: 19.00.03 / М. В. Сокольская. - Хабаровск, 2012. $54 \mathrm{c}$.

364. Солнцева, Л. К. Влияние занятий физическими упражнениями и спортом на развитие некоторых психических функцій [Текст] / Л. К. Солнцева, И. Г. Келишев. - Москва : ФиС, 1980. - 47 с.

365. Соломатин, Е. В. Совершенствование морально-психологической подготовки начинающих преподавателей вузов ВВ МВД России [Текст] : автореф. дис. ... канд. пед. наук: 13.00.08 / Е. В. Соломатин. - Москва, 2012. $25 \mathrm{c}$.

366. Соломко, А. Д. Формирование игровых навыков и эмоциональноперцептивной сферы у детей $5-7$ лет с расстройствами аутистического спектра средствами физического воспитания [Текст] : автореф. дис. ... канд. психол. наук: 13.00.04 / Е. В. Соломко. - Краснодар, 2012. - 24 с.

367. Солонский, В. Ю. Психологические характеристики курсантов военного вуза как субъектов учебной деятельности и их развитие средствами физической культуры [Текст] : автореф. дис. ... канд. психол. наук: 19.00.07 / В. Ю. Солонский. - Санкт-Петербург, 2012. - 21 с.

368. Сосонко, В. Е. Формы и методы контроля учебной деятельности студентов в средних специальных учебных заведениях с применением рейтинговой системы [Текст] : дис. ... канд. пед. наук: 13.00.01 / В. Е. Сосонко. - Москва, 1996. - 159 с.

369. Социальное познание: принципы, формы, функции [Текст]. - Київ : Наук. думка, 1989. - 204 с.

370. Спринська, 3. В. Співвідношення агресивної поведінки та ціннісних орієнтацій особистості [Текст] : автореф. дис. ... канд. психол. наук: 19.00.01 / 3. В. Спринська. - Одеса, 2008. - 20 с.

371. Ставицька, С. О. Психолого-педагогічні умови подолання особистісної тривожності у дітей молодшого шкільного віку [Текст] : автореф. дис. ... канд. психол. наук: 19.00.07 / С. О. Ставицька. - Київ, 1999. - 20 с.

372. Стадник, В. А. Розвиток механізмів особистісної корекції емоційної напруженості при діяльності в екстремальних умовах (на прикладі спортивної діяльності) [Текст]: автореф. дис. ... канд. психол. наук: 19.00.03 / В. А. Стадник. - Київ, 1999. - 19 с. 
373. Становов, В. В. Физическая культура как фактор социальной адаптации учащейся молодёжи [Текст]: автореф. дис. ... д-ра пед. наук : 13.00.01 / В. В. Становов. - Москва, 2002. - 42 с.

374. Старовойтов, А. В. Психологічні особливості тілесно-орієнтованої корекції поведінки підлітків з акцентуаціями характеру [Текст] : автореф. дис. ... канд. психол. наук: 19.00.07 / А. В. Старовойтов. - Одеса, 2004. - 18 с.

375. Старченкова, Е. С. Концепция проактивного совладающего поведения [Текст] / Е. С. Старченкова // Вест. СПб. гос. ун-та. Сер. 12. Психология. 2009. - Вып. 2. Ч. 1. - С. 198-205.

376. Стасюк, Р. М. Оптимізація соціальної адаптації студентів початкових курсів засобами фізичної культури [Текст] : автореф. дис. ... канд. наук 3 фізичного виховання та спорту: 24.00.02 / Р. М. Стасюк. - Харків, 2008. $21 \mathrm{c}$.

377. Стрелец, В. Г. Теория и практика управления вестибулярными реакциями человека в спорте и профессиональной деятельности [Текст] / В. Г. Стрелец, А. А. Горелов. - Санкт-Петербург : ВИФК, 1995. - С. 72-83.

378. Строгова, Н. А. Формирование профессионально значимых качеств личности будущих специалистов по адаптивной физической культуре [Текст] : автореф. дис. ... до-ра пед. наук: 13.00.08 / Н. А. Строгова. - Москва, 2012. $-38 \mathrm{c}$.

379. Строгова, Н. А. Формирование профессионально-значимых качеств личности у будущих специалистов по адаптивной физической культуре в процессе профессиональной подготовки / Н. А. Строгова // Физическая культура: воспитание, образование, тренировка. - 2011. - № 1. - С. 26-28.

380. Стуколова, Л. 3. Психолого-педагогическая составляющая в подготовке современных менеджеров [Текст]: автореф. дис. ... д-ра пед. наук: 13.00.01 / Л. З. Стуколова. - Казань, 2010. - 39 с.

381. Суворов, Ю. А. Профессионально-прикладная физическая подготовка студентов: учебно-методическое пособие [Текст] / Ю. А. Суворов, В. А. Платонова. - Санкт-Петербург : СПб ГУИТМО, 2006. - 90 с.

382. Сыркина, А. Л. Ценностно-смысловые компонеты профессиональной мотивации (на примере специалистов локомотивних бригад) [Текст] : автореф. дис. ... канд. психол. наук: 19.00.03 / А. Л. Сыркина. - Москва, 2009. $26 \mathrm{c}$.

383. Тарасова, С. Ю. Индикаторы школьной тревожности и дезадаптации на начальной ступени обучения [Текст] : автореф. дис. ... канд. психол. наук: 19.00.01 / С. Ю. Тарасова. - Москва, 2012. -25 с.

384. Татенко, В. А. Шляхи формування особистості учня [Текст] / В. А. Татенко. - Київ, 1985. - 356 с.

385. Теория и методика физического воспитания [Текст]. В 2 т. / под общ. ред. Л. П. Матвеева и А. Д. Новикова. - Москва : Физкультура и спорт, 1976. T. $1-303$ c., T. $2-256$ c. 
386. Теория и методика физического воспитания [Текст]: учеб. для студентов фак. физ. культуры пед. ин-тов по спец. 03.03 «Физическая культура» / под ред. Б. А. Ашмарина. - Москва : Просвещение, 1990. - 287 с.

387. Теорія і методика фізичного виховання [Текст] / за ред. Т. Ю. Круцевич. Київ, 2008. - Т. 1. -391 с.

388. Терещенко, В. А. Формування психологічної готовності майбутніх учителів до інтерактивної взаємодії з учнями [Текст]: автореф. дис. ... канд. психол. наук: 19.00.07 / В. А. Терещенко. - Київ, 2009. - 20 с.

389. Тодорова, В. Г. Емоційно-воловий образ «Я» студентів, що займаються різними видами фізичної культури [Текст] : автореф. дис. ... канд. психол. наук: 19.00 .07 / В. Г. Тодорова. - Одеса, 2005. - 20 с.

390. Тополов, Є. В. Поняття агресії та агресивності в сучасній науковій літературі [Текст] / Є. В. Тополов // Проблеми загальної та педагогічної психології : зб. наук. пр. ін-ту психології ім. Г. С. Костюка АПН України / за ред. С. Д. Максименка. - 2011. - Т. 13, ч. 5. - С. 358-365.

391. Тополов, Є. В. Сучасні наукові уявлення щодо чинників агресивної поведінки людини [Текст] / Є. В. Тополов // Проблеми загальної та педагогічної психології : зб. наук. пр. ін-ту психології ім. Г. С. Костюка АПН України / за ред. С. Д. Максименка.- 2009. - Т. 11, ч. 3. - С. 402-410.

392. Третьяков, С. П. Особистісно-ситуаційна детермінація агресивної поведінки людини [Текст] : автореф. дис. ... канд. психол. наук: 19.00.01 / С. П. Третьяков. - Київ, 2005. -20 с.

393. Трефилов, В. А. Формирование физической готовности выпускников вуза к профессиональной деятельности [Текст] / В. А. Трефилов, А. В. Дубровский // Теория и практика физической культуры. - 2001. - № 7. - С. 49-51.

394. Тумаров, К. Б. Содержание и организация личностно ориентированного физического воспитания студентов на основе мини-футбола [Текст] : автореф. дис. ... канд. пед. наук: 13.00.04 / К. Б. Тумаров. - Набережные Челны, 2012. $-24 \mathrm{c}$.

395. Туревский, И. М. Структура психофизической подготовленности человека [Текст]: автореф. дис. ... д-ра пед. наук: 13.00 .04 / И. М. Туревский. - Москва, 1998. - 50 с.

396. Тюптя, О. В. Формування психологічної готовності до соціономічної професійної діяльності (на прикладі професії «соціальний педагог») [Текст] : автореф. дис. ... канд. психол. наук: 19.00 .01 / О. В. Тюптя. - Київ, 1999. $-22 \mathrm{c}$.

397. Фальова, О. Є. Психологічні особливості особистісного розвитку студентів різних спеціальностей у навчальному процесі вищого навчального закладу [Текст] : автореф. дис. ... канд. психол. наук: 19.00.07 / О. С. Фальова. Харків, 2006. - 20 с.

398. Фарапонтова, Э. А. Воспитание психологической готовности к труду [Текст] / Э. А. Фарапонтова // Вопр. психологии. - 1985. - № 6. - С. 59-68. 
399. Федик, О. П. Психологічні особливості професійної підготовки студентів до майбутньої спортивно-педагогічної діяльності [Текст] : автореф. дис. ... канд. психол. наук: 19.00.07 / О. П. Федик. - Київ, 1999. - 16 с.

400. Федоренко, Т. Н. Личностные особенности машинистов локомотивов, эффективных в профессиональной деятельности [Текст]: дис. ... канд. психол. наук: 19.00 .03 / Т. Н. Федоренко. - Хабаровск, 2005. - 226 с.

401. Федотов, Л. Ю. Индивидуальный психофизический тренинг как средство повышения эффективности деятельности воинов-десантников в трудных ситуаціях [Текст]: автореф. дис. ... канд. психол. наук: 19.00.03 / Л. Ю. Федотов. - Москва, 1995. - 18 с.

402. Физическая культура студента: учебник / под ред. В. И. Ильинича. - Москва : Гардарики, 2000. - 448 с.

403. Физическая культура: учебное пособие для подготовки к экзаменам [Текст]. - Санкт-Петербург : Питер, 2004. - 224 с.

404. Философия науки [Текст]: хрестоматия / отв. ред.- сост. Л. А. Микешина. Москва : Прогресс-Традиция; МПСИ; Флинта, 2005. - 992 с.

405. Філатова, І. В. Діагностика та прогнозування професійної придатності до діяльності поїзних диспетчерів [Текст]: автореф. дис. ... канд. психол. наук: 19.00 .10 / І. В. Філатова. - Київ, 2010. - 20 с.

406. Формирование учебной деятельности студентов [Текст] / под. ред. В. Я. Ляудис. - Москва : МГУ, 1989. - 240 с.

407. Франкл, В. Человек в поисках смысла [Текст] / В. Франкл. - Москва : Прогресс, 1990. - $368 \mathrm{c}$.

408. Фресс, П. Экспериментальная психология [Текст] / П. Фресс, Ж. Пиаже. Москва : Прогресс, 1973. - 343 с.

409. Фудимов, В. В. Технология использования различных видов спорта для повышения личностно ориентированной направленности тренировочных занятий спортсменов [Текст] : автореф. дис. ... канд. пед. наук: 13.00.04 / В. В. Фудимов. - Санкт-Петербург, 2012. - 26 с.

410. Хагай, В. С. Рукопашный бой как средство формирования психоэмоциональной устойчивости военнослужащих [Текст]: автореф. дис. ... канд. пед. наук: 13.00 .04 / В. С. Хагай. - Майкоп, 2008. - 26 с.

411. Хазова, С. А. Совладающее поведение одарённых старшеклассников [Текст] : дис. ... канд. психол. наук: 19.00 .01 / С. А. Хазова. - Кострома, 2002. $-246 \mathrm{c}$.

412. Ханин, Ю. Л. Управление эмоциональным состоянием студентов средствами физического воспитания [Текст] / Ю. Л. Ханин, Г. В. Буланова // Стресс и тревога в спорте: международный сб. научн. ст. / сост. Ю. Л. Ханин. - Москва : ФиС, 1983. - С. 261-267.

413. Ханова, 3. Г. Формирование психологической готовности студентов вуза к предпринимательской деятельности: предикторы и технологии [Текст] / : автореф. дис. ... д-ра психол. наук: 19.00.07 / 3. Г. Ханова. - Сочи, 2012. $46 \mathrm{c}$. 
414. Хащенко, Т. Г. Личностная готовность студентов к предпринимательской деятельности [Текст] : автореф. дис. ... д-ра психол. наук: 19.00.13 / Т. Г. Хащенко. - Тамбов, 2012. - 55 с.

415. Хекхаузен, Х. Мотивация и деятельность [Текст] / Х. Хекхаузен. - СанктПетербург : Питер, - Москва : Смысл, 2003. - 860 с.

416. Хекхаузен, Х. Мотивация и деятельность [Текст]. В 2 т. / Х. Хекхаузен. Москва : Педагогика, 1986. - Т. 1 - 406 с., Т. 2 - 392 с.

417. Хмель, Н. М. Формування психологічної готовності майбутніх педагогів до роботи в умовах соціально-економічних змін [Текст]: автореф. дис. ... канд. психол. наук: 19.00.07 / Н. М. Хмель. - Київ, 2011. - 20 с.

418. Холл, К. Теории личности [Текст] / К. Холл, Г. Линдсей. - Москва : ЗАО Изд-во ЭКСМО-Пресс, 1999. - 592 с.

419. Холодов, Ж. К. Теория и методика физического воспитания и спорта [Текст]: учеб. пособ. для студентов высших учебных заведений / Ж. К. Холодов, В. С. Кузнецов. - Москва : Изд. центр «Академия», 2001. - 480 с.

420. Холтобина, А. У. Влияние специальных упражнений на повышение стойкости вестибулярного анализатора у детей $2-5$ лет [Текст]: автореф. дис. ... канд. пед. наук: 13.00.04 / А. У. Холтобина. - Харьков, 1994. - 20 с.

421. Хуртенко, О. В. Формування у майбутніх організаторів-тренерів психологічної готовності до прийняття рішень у екстремальних ситуаціях [Текст]: автореф. дис. ... канд. психол. наук: 19.00 .09 / О. В. Хуртенко. Хмельницький, 2008. - 20 с.

422. Хьелл, Л. Теории личности [Текст] / Л. Хьелл, Д. Зиглер. - СанктПетербург : Питер Пресс, 1997. - 608 с.

423. Царёва, О. А. Влияние тревожности учащихся подросткового возраста на тратегии поведения в конфликтных ситуациях [Текст] : дис. ... канд. психол. наук: 19.00.07 / О. А. Царёва. - Москва, 2007. - 187 с.

424. Церковна, О.В.Професійно-прикладна фізична підготовка студентів технічних вищих навчальних закладів на основі факторної структури ї рухової та психофізіологічної підготовленості [Текст] : автореф. дис. ... канд. наук з фізичного виховання і спорту: 24.00.02 / О. В. Церковна. Харків, 2002. - 25 с.

425. Чарнецкі, К. Психологія професійного розвитку особистості [Текст]: автореф. дис. ... д-ра психол. наук: 19.00 .07 / К. Чарнецкі. - Київ, 1999. - 48 с.

426. Чедова, Т. И. Воспитание морально-волевых качеств подростков в условиях школьных спортивных клубов [Текст] : автореф. дис. ... канд. пед. наук: 13.00.01 / Т. И. Чадова. - Ижевск, 2012. - 22 с.

427. Чепик, В. Д. Физическая культура в социальных процессах [Текст] / В. Д. Чепик. - Москва : ФиС, 1994. - 180 с.

428. Черепехіна, О. А. Особливості психологічної готовності психологів до професійної діяльності у спорті [Текст]: автореф. дис. ... канд. психол. наук: 19.00.01 / О. А. Черепехіна. - Київ, 2006. - 23 с.

429. Чертихина, Н. А. Комплексное развитие вестибулярной устойчивости в художественной гимнастике на этапе начальной подготовки [Текст] : авто- 
реф. дис. ... канд. пед. наук: 13.00.04 / Н. А. Чертихина. - Волгоград, 2013. $-24 \mathrm{c}$.

430. Шагарова, И. В. Личностные детерминанты и типы копинг-поведения в ситуации потери работы [Текст] : дис. ... канд. психол. наук: 19.00.03; 19.00.05 / И. В. Шагарова. - Ярославль, 2008. - 228 с.

431. Шадриков, В. Д. Психологический анализ деятельности как системы [Текст] / В. Д. Шадриков // Психологический журнал. - 1980. - № 3. C. $31-42$.

432. Шадриков, В. Д. Деятельность и способности [Текст] / В. Д. Шадриков. Москва : Логос, 1996. - 320 с.

433. Шадриков, В. Д. О содержании понятий «способности» и «одарённость» [Текст] / В. Д. Шадриков // Психологический журнал. - 1983. - № 5. C. $3-10$.

434. Шебеко, В. Н. Формирование личности ребёнка дошкольного возраста средствами физической культуры [Текст] : автореф. дис. ... д-ра пед. наук: 13.00.02 / В. Н. Шебеко. - Москва, 2011. - 53 с.

435. Шевандрин, Н. И. Психодиагностика, коррекция и развитие личности [Текст] / Н. И. Шевандрин. - Москва : ВЛАДОС, 1998. - 507 с.

436. Шевченко, А. А. Психологическое содержание и особенности возникновения профессиональных деструкций личности [Текст] : автореф. дис. ... канд. психол. наук: 19.00.01 / А. А. Шевченко. - Челябинск, 2012. - 23 с.

437. Шляпников, В. Н. Исследования волевой регуляции в современной зарубежной психологии [Текст] / В. Н. Шляпников // Вопросы психологии. 2009. - № 2. - С. 135-144.

438. Шляпников, В. Н. Роль волевой регуляции в процессе профессиональной адаптации молодых специалистов [Текст] / В. Н. Шляпников // Вопр. психологии. -2010 . - № 6. - С. 78-90.

439. Шорохова, Е. В. Тенденции исследования личности в современной психологии [Текст] / Е. В. Шорохова // Психологический журнал. - 1980. - Т. 1, № 1. - С. 45-57.

440. Щёголев, В. А. Воспитание и сплочение воинских коллективов в процессе физкультурно-спортивной деятельности: дис. ... д-ра пед. наук [Текст] / В. А. Щёголев. - Санкт-Петербург, 1991. - 418 с.

441. Щёголев, В. А. Опыт использования физических упражнений для оценки психофизиологических и психологических качеств военнослужащих [Текст] / В. А. Щёголев, В. Л. Марищук // Межвузовский сб. научн. тр. Ленинград : ВДКИФК, 1984. - Вып. 4. - С. 20-25.

442. Эммерт, М. С. Профессионально-прикладная физическая подготовка будущих специалистов по управлению персоналом [Текст] : автореф. дис. ... канд. пед. наук: 13.00.04 / М. С. Эммерт. - Москва, 2012. - 24 с.

443. Эмоционально-волевая подготовка спортсменов [Текст]. - Киев : Здоров’я, 1982. - 295 c.

444. Юревич, А. В. Психология и методология [Текст] / А. В. Юревич // Психологический журнал. - 2000. - Т. 21, № 5. - С. 35-47. 
445. Ягупов, В. В. Морально-психологічне забезпечення [Текст]: курс лекцій / В. В. Ягупов. - Київ : Видавничо-поліграфічний центр «Київський університет», 2002. $-43 \mathrm{c}$.

446. Якиманская, И. С. Разработка технологи личностно-ориентированного обучения [Текст] / И. С. Якиманская // Вопр. психологии. - 1995. - № 2. C. $31-42$.

447. Янкевич, С. М. Теоретичний аналіз проблеми психологічної готовності до професійної діяльності [Текст] / С. М. Янкевич // Проблеми загальної та педагогічної психології : зб. наук. пр. ін-ту психології ім. Г. С. Костюка АПН України / за ред. С. Д. Максименка. - 2012. - Т. 14, ч. 2. - С. 417-426.

448. Яныхбаш, А. В. Взаимосвязь рискованного поведения с психологическими характеристиками личности [Текст] : автореф. дис. ... канд. психол. наук: 19.00.01 / А. В. Яныхбаш. - Москва, 2013. - 24 с.

449. Ajzen, I. From intentions to actions: A theory of planned behavior / I. Ajzen // Kuhl J., Beckmann J. (eds). Action control: From cognition to behavior. - Berlin; New York : Springer-Verlag, 1985. P. 11-40.

450. Arnold, M. B. The human person / M. B. Arnold, J.A. Jassov. - New York, 1954. $-368 \mathrm{p}$.

451. Bagozzi, R. P. On neglect of volition in consumer research: A critique and proposal / R. P. Bagozzi // Psychol. \& Marketing. -1993. - May / June. - Vol. 10 (3). - P. 215-237.

452. Bedi, G. Optimism, coping style and emotional well-being in cardiac patients / G. Bedi, S. Brown // British Journal of Health Psychology. - 2005. - Vol. 1. P. 57-70.

453. Bergmann, G. Funktionelle Pathologie / G. Bergmann. - Berlin : Springer, 1936. $-154 \mathrm{p}$.

454. Birren, J. E. Research on the psychology of aging: Principles, concepts and theory / J. E Birren, W.R. Cunningham // Handbook of the psychology of aging. J.E.Birren and K.W.Schaie, Eds. - New York : Van Nostrand Reinhold, 2nd ed., 1985. - P. 3-34.

455. Bouchard, G. Situational and dispositional coping: an examination of their personality cognitive appraisals and psychological distress / G. Bouchard, A. Guillemette, N. Landry-Leger // European Journal of Personality. - 2004. - Vol. 18. - P. 221-238.

456. Carver, C. S. Personality and Coping / C. S. Carver, J. Connor-Smith // Annual Review of Psychology. - 2010. - Vol. 61. - P. 679-704.

457. Clampitt, P. G. Managing organizational uncertainty: conceptualization and measurement / P. G. Clampitt, M. L. Williams // Communication Research Reports. - 2005. -Vol. 22. - № 4. - P. 315-324.

458. Compas, B. Coping with stress during childhood and adolescence: problems, progress and potential in theory and research / B. Compas, J. Connor-Smith, S. Saltzman, A. Thomsen, S. Wadsworth // Psychological Bulletin. - 2001. Vol. 127. - № 1. - P. 87-127. 
459. Connor-Smit, J. K. Relations between personality and coping: a meta-analysis / J. K. Connor-Smit, C. Flachsbart // Journal of Personality and Social Psychology. - 2007. - Vol. 93. - P. 1080-1107.

460. Craik, R. L. A tolerance for ambiguity / R. L. Craik // Physical Therapy. -2001. - July. -Vol. 81. - P. 1292-1298.

461. Datan, N. Life-span developmental psychology / N. Datan \& L. Ginsberg (Eds.). - New York: Academic Press, 1975. - 934 p.

462. Davidson, R.J. Affective style and affective disorders: perspectives from affective neuroscience / R. J. Davidson // Cognition and Emotion. - 1998. - Vol. 12. - P. 307-330.

463. Dunbar, F. Emotions and bodily changes / F. Dunbar. - New York : Columbia University Press, 1954. $-1192 \mathrm{p}$.

464. Dunbar, F. Mind and Body: psychosomatic medicine / F. Dunbar. - New York : Random House, 1947. - 263 p.

465. Dunbar, H. F. Psychosomatic Diagnosis / H. F. Dunbar. - New York, Hoeber, 1943. $-741 \mathrm{p}$.

466. Dunbar, H. F. Synopsis of psychosomatic diagnosis and treatment / H. F. Dunbar. - St.Lousis : Mosby, 1948. -243 p.

467. Farrell, P. A. Influence of endogenous opioids on the response of selected hormones to exercise in humans / P. A. Farrell et al. // J. of Appl. Physiol. - 1986. 61. - P. 1051-1057.

468. Feather, N.T. The relationship of persistence at a task to expectation of success and achievement related motives / N. T. Feather // J. Abnorm. Soc. Psychol. 1961. - Vol. 63. - P. 552-561.

469. Frankl,V. Jahrbuch fur Psychologie und Psychotherapiel / V. Frankl. - 1953. $186 \mathrm{~s}$.

470. Goldstein, K. Human nature in the light of psychopathology / K. Goldstein. Cambridges Harvard university press, 1940. $-258 \mathrm{p}$.

471. Goldstein, K. The organism. A holistic approach to biology / K. Goldstein. New Yorks American book,1939. - 533 p.

472. Gross, J. J. Emotion Regulation: Conceptual foundation / J. J. Gross, R. A. Thompson // Handbook of Emotion Regulation / Ed. J.J. Gross. - New York : Guilford Press, 2007. - P. 3-24.

473. Gross, J. J. Individual differences in two emotion regulation processes: implications for affect, relationships, and well-being / J. J. Gross , O. P. John // Journal of Personality and Social Psychology. - 2003. - Vol. 85(2). - P. 348-362.

474. Hammer, W. H. A comparison of differences in manifest anxiety in university athletes and nonathletes / W. H. Hammer // J. of Sports Medicine and Physial Fitness. -1967 . - № 7. - P. 31-34.

475. Hammer, W. H. Anxiety and sport performance / W. H. Hammer // Kenion G.S. (ed.) Contemporary psychology of sport. - Chicago: Athletic Institute, 1968. $340 \mathrm{p}$. 
476. Hanin, Y. L. A study of anxiety in sports / Y. L. Hanin // W. F. Straub (ed.). Sport psychology: An analysis of athlete behavior. - Ithaca, New York : Mouvement Publication, 1980. - P. 236-249.

477. Huber, N. An experiential leadership approach for teaching tolerance for ambiguity / N. Huber // Journal of Education for Business. - 2003. - Sept. - Oct. Vol. 79. - P. 52-56.

478. Hull, C. L. Principles of behavior : An introductionto behavior theory / C. L. Hull. - New York : Appleton-Century-Crofts, 1943. - 422 p.

479. John, O. P. Healthy and Unhealthy Emotion Regulation: Personality Processes, Individual Differences and Life Span Development / O. P. John, J. J. Gross // Journal of Personality. - 2004. - Vol. 72. Is. 6. - P. 1301-1334.

480. Jores, A. Praktische Psychosomatik / A. Jores. - Bern, Stuttgart, Wien : Huber, 1976. $-473 \mathrm{~s}$.

481. Kehr, H.M. Self-regulation, self-control, and management training transfer / H. M. Kehr, P.Bles, L. Rosenstiel // Intern. J. Educat. Res. - 1999. - Vol. 31. P. 487-498.

482. Kuhl, J. Self-discrimination and memory: State orientation and false selfascription of assigned activities / J. Kuhl, M. Kazen // J. Pers. \& Soc. Psychol. 1994. - June. - Vol. 66(6). - P. 1103-1115.

483. Kuhl, J. Volitional mediators of cognition-behavior consistency: Self-regulatory processes and action versus state orientation / J. Kuhl, J. Beckmann // Action control: From cognition to behavior. - Berlin : Springer-Verlag, 1985. P. 101-128.

484. Kuhl, J. Who control whom when «I control my-self»? / J. Kuhl // Psychol. Inquiry. - 1996. - Vol. 7(1). - P. 61-68.

485. Labouvie-Vief, G. Growth and aging in life-span perspectives / G. LabouvieVief // M. L. Commons, F. A. Richards \& C. Armon (Eds.) Beyond formal operations: Late adolescent and adult cognitive development. - New York : Praeger, 1984. - P. 92-119.

486. Landers, D.M. The arousal-performance relationship revisited / D. M. Landers // Res. Quart. - 1980. - P. 77-90.

487. Lasarus, R. Emotions and interpersonal relationships: toward a person-centered conceptualization of emotions and coping / R. Lasarus // Journal of Personality. - 2006. - Vol. 74. - № 1. - P. 9-43.

488. Lazarus, R. S. Stress, appraisal, and coping / R. S. Lazarus, S. Folkman. - New York : Springer, 1984. $-445 \mathrm{p}$.

489. Lewin, K. A dynamic theory of personality / K. Lewin. - New York, 1935. $286 \mathrm{p}$.

490. Mahoney, M. J. Psychology of elite athlete: an explorational study / M. J. Mahoney, M. Avener // Cognitive therapy and research. - 1977. - № 1. P. 135-141.

491. Mayer, John D., Korogodsky M.A. Really Big Picture of Personality / John D. Mayer, M. A. Korogodsky // Social and Personality Psychology Compass. 2011. - Vol. 5, is. 2. - P. 104-117. 
492. Milne, S. Combining motivation and volitional interventions to promote exercise participation: Protection motivation theory and implementation intentions / S. Milne, S. Orbell, P. Sheeran // Brit. J. Health Psychol. - 2002. - May. Vol. 7, N 2. - P. 163-184.

493. Morgan ,W. P. Exercise and mental health / W. P. Morgan, S. E Goldson (eds.). - New Yor : Hemisphere Publishing, 1987. - 196 p.

494. Morgan, W. P. Anxiety reduction following acute physical activity / W. P. Morgan // Psychiatric Annals. - 1979. - 9. - P. 36-45.

495. Morgan, W. P. Influence of competitive wrestling upon state anxiety / W. P. Morgan, W. H. Hammer // Medicine and Science in Sports. - 1974. - 8. P. 58-61.

496. Morgan, W.P. Physical activity and mental health / W. P. Morgan // Montoye H. J., Eckert H. M. (eds.) Exercise and health.: Human Kinetics Publishers, 1983. - P. 132-145.

497. Neugarten, B.L. Adult personality: towards a psychology of the life cycle in Middle Age and Aging / B. L. Neugarten. - Chicago : University of Chicago Press, 1968. - P. 137-147.

498. Owen, W. Ambiguity tolerance, performance, learning, and satisfaction: a research direction / W. Owen, R. Sweeney // The Proceedings of ISECON (San Antonio). - 2002. - Vol. 19. - P. 242-248.

499. Perry, W. G. Forms of intellectual and ethical development in the college years / W. G. Perry. - New York : Holt, Rinehart \& Winston, 1970. - 256 p.

500. Raglin, J. S. Influence of exercise and quiet rest on state anxiety and blood pressure / J. S. Raglin , W. P. Morgan // Medicine and Science in Sports and Exercise. -1987 . - P. 456-463.

501. Raglin, J. S. Influence of vigorous exercise on mood state / J. S. Raglin, W.P. Morgan // Behavior Therapy. - 1985. - 8. - P. 179-183.

502. Riegel, K. F. (1973). Dialectical operations: The final period of cognitive development. Human Development, 16, 346-370.

503. Riegel, K. F. Adult life crises: A dialectical interpretation of development / K. F. Riegel // M.Datan \& L.H.Ginsberg (Eds.). Life-span developmental psychology: Normative life crises. - Orlando, F. L. : Academic Press, 1975. P. 99-128.

504. Schaie, K.W. Beyond calendar definitions of age, period and cohort: The general developmental model revisited / K. W. Schaie // Developmental Review. - 1986. -6. - P. 252-277. 


\section{ТАБЛИЦЯ ДЛЯ ОЦІНКИ ПРОЯВУ ЯКОСТЕЙ ОСОБИСТОСТІ СТУДЕНТІВ-СПОРТСМЕНІВ}

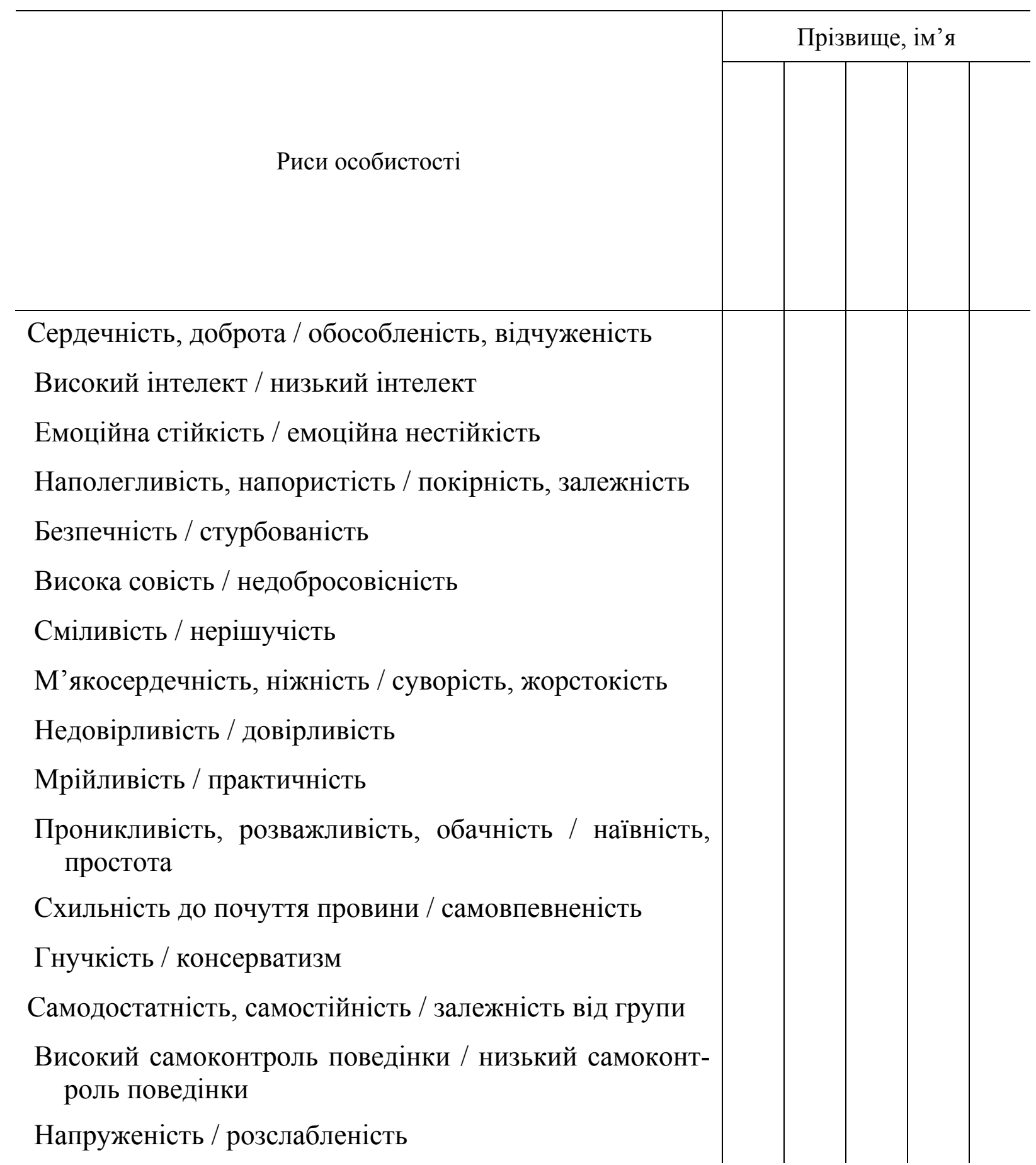

Оцініть за п’ятибальною шкалою (від 0 до 5) міру вираженості рис особистості у студентів. 


\section{ДОДАТОК 2}

\section{ТЕСТ МЮНСТЕРБЕРГА}

Інструкція: Серед буквеного тексту є слова. Ваше завдання - переглядаючи рядок за рядком, як можна швидше знайти ці слова. Знайдені слова підкреслюйте. Час виконання завдання - 2 хв.

\section{Бланк:}

бсолнцевтргщоцрайонзгучновостьхэьгчяфактуекэкзаментроч ягшгцкпрокуроргурстабюетеорияентсджэбьамхоккейтрсицы фцуйгзхтелевизорсолджщзхюэлгщьбапамятьшогхеюжпждргщ хэнздвосприятиейцукенгшщзхъвафыапролдблюбовьавфырпл ослдспектакльячсмитьбюжюерадостьвуфцпэждлорпкнародш лджьхэшщгиенакуыфйшрепортажэждорлафывюефбьконкурс йфячыцувскапрличностьзхжэьеюдшщглоджэпрплаваниедтлж эзбьтрдщшжнпркывкомедияшлдкцуйфотчаяниейфоячвтлджэ хьфтасенлабораториягщдщнруцтргшщтлроснованиезщдэркэ нтаопрукгвсмтрпсихиатриябплмстчьйсмтзацэъагнтэхт

Оцінка результатів: Методика спрямована на визначення вибірковості уваги. Оцінюється кількість виділених слів і кількість помилок, тобто пропущених і неправильно виділених слів. У тексті міститься 25 слів.

\section{Ключ:}

бсолнцевтргщоцрайонзгучновостьхэьгчяфактуекэкзаментроч ягшгцкпрокуроргурстабюетеорияентсджэбьамхоккейтрсицы фцуйгзхтелевизорсолджщзхюэлгщьбапамятьшогхеюжпждргщ хэнздвосприятиейцукенгшщзхъвафыапролдблюбовьавфырпл ослдспектакльячсмитьбюжюерадостьвуфцпэждлорпкнародш лджьхэшщгиенакуыфйшрепортажэждорлафывюефбьконкурс йфячыцувскапрличностьзхжэьеюдшщглоджэпрплаваниедтлж эзбьтрдщшжнпркывкомедияшлдкцуйфотчаяниейфоячвтлджэ хьфтасенлабораториягщдщнруцтргшщтлроснованиезщдэркэ нтаопрукгвсмтрпсихиатриябплмстчьйсмтзацэъагнтэхт 
КОРЕКТУРНА ПРОБА БУРДОНА

СХАВСХЕВИХНАИСНХВХВКСНАИСЕХВХЕНАИСНЕВХАК ВНХИВСНАВСАВСНАЕКЕАХВКЕСВСНАИСАИСНАВХНВК НХИСХВХЕКВХИВХЕИСНЕИНАИЕНКХКИКХЕКВКИСВХИ ХАКХНСКАИСВЕКВХНАИСНХЕКХИСНАКСКВХКВНАВСН ИСНАИКАЕХКИСНАИКХЕХЕИСНАХКЕКХВИСНАИХВИКХ СНАИСВНКХВАИСНАХЕКЕХСНАКСВЕЕВЕАИСНАСНКИВ КХКЕКНВИСНКХВЕХСНАИСКЕСИКНАЕСНКХКВИХКАКС АИСНАЕХКВЕНВХКЕАИСНКАИКНВЕВНКВХАВЕИВИСНА КАХВЕИВНАХИЕНАИКВИЕАКЕИВАКСВЕИКСНАВАКЕСВ НКЕСНКСВХИЕСВХКНВВСКВЕВКНИЕСАВИЕХЕВНАИЕН ХЕИВКАИСНАСНАИСХАКВННАКСХАИЕНАСНАИСВКХЕВ ЕВХКХСНЕИСНАИСНКВКХВЕКЕВКВНАИСНАИСНКЕВКХ АВСНАХКАСЕСНАИСЕСХКВАИСНАСАВКХСНЕИСХИХЕК ВИКВЕНАИЕНЕКХАВИХНВИХКХЕХНВИСНВСАЕХИСНАИ НКЕХВИВНАЕИСНВИАЕВАЕНХВХВИСНАЕИЕКАИВЕКЕХ КЕИСНЕСАЕИХВКЕВЕИСНАЕАИСНКВЕХИКХНКЕАИСНА ЕАКАЕКХЕВСКХЕКХНАИСНКВЕВЕСНАИСЕКХЕКНАИСН ИСНЕИСНВИЕХКВХЕИВНАКИСХАИЕВКЕВКИЕХЕИСНАИ СНАИСАКВСНХАЕСХАИСНАЕНКИСХКЕХВХВСКНЕИЕНА ЕКХЕКНАИВКВКХЕХИСНАИХКАХЕНАИЕНИКВКЕИСНАИ ЕХВКВИЕХАИЕХЕКВСНЕИЕСВНЕВИСНАЕАХНХКСНАХС ИСНАИЕИНЕВИСНАИВЕВХСИСВАИЕВХЕИХСКЕИЕХКИЕ КЕВХВАЕСНАСНКИСХЕАЕХКВЕХЕАИСНАСВАИСЕВЕКЕ ХВЕКХСНКИСЕКАЕКСНАИИЕХСЕХСНАИСВНЕКХСНАИА АВЕНАХИАКХВЕИВЕАИКВАВИХНАХКСВХЕХИВХАИСНА ВНСИЕАХСНАНАЕСНВКСНХАЕВИКАИКНКНАВСНЕКВХК СИАЕСВКХЕКСНАКСХВХКВСНХКСВЕХКАСНАИСКСХКЕ НАИСНХАВКЕВХКИЕИСНАИНХАСНЕХКСХЕВКХЕИХНАИ ХЕВХЕНВИХНКВХЕКНАИСНХАИВЕНАИХНХКВХЕНАИСН ВКЕВХАИСНАХКВНВАИЕНСХВКХЕАИСНАВХСВКАХСНА КИСНКЕКНСВАИСВАЕХСХВАИСНАЕКХЕКАИВНАВЕКВЕ АЕНКАИСХАИСНХИСВКВСЕКХВЕКИСНАИСНАИСКВЕСВ ИСКАИКВККНВХСКВНАИЕНИСНАИХАВКНВЕХВАНКИЕХ ЕВХЕВНАИСКАИАНАКХКВКЕВЕКВНХИСКАИСНВХАВХВ НАИСНХСХВКИСНАИЕХЕКХНАИСНВЕХВЕИСНХВКХКВН ХКВНХВКСНХНАИСНВКАХСВКХВХАИСНАНАХСНХВХВХ АИСХААИКХАЕВЕХКСНВИВАИСНАХКИВХЕКИАХИНАИС 
Методика проведення: протягом 10-15 хв (час залежить від кількості бланків, але не менше 7 хв і не більше 20 хв) буква К на кожному рядку підкреслюється, а I - закреслюється. За сигналом «хвилина» ставиться вертикальна риска на тому місці, де вас зупинив сигнал.

Обробка даних: підрахунок проводиться по кожній хвилині за формулою:

$$
A 1=\frac{C-W}{C+O},
$$

де $A-$ показник правильності;

$C$ - загальна кількість закреслених и підкреслених букв;

$W$ - кількість помилково підкреслених або закреслених букв;

$O$ - кількість помилково пропущених букв.

Показник продуктивності

$$
E=S \cdot A,
$$

де $S$ - швидкість перегляду (кількість рядків, помножена на кількість знаків у рядку).

\section{ДОДАТОК 4}

ТАБЛИЦЯ ДЛЯ ОЦІНКИ ПРОЯВУ ВОЛЬОВИХ ЯКОСТЕЙ ОСОБИСТОСТІ У СТУДЕНТІВ

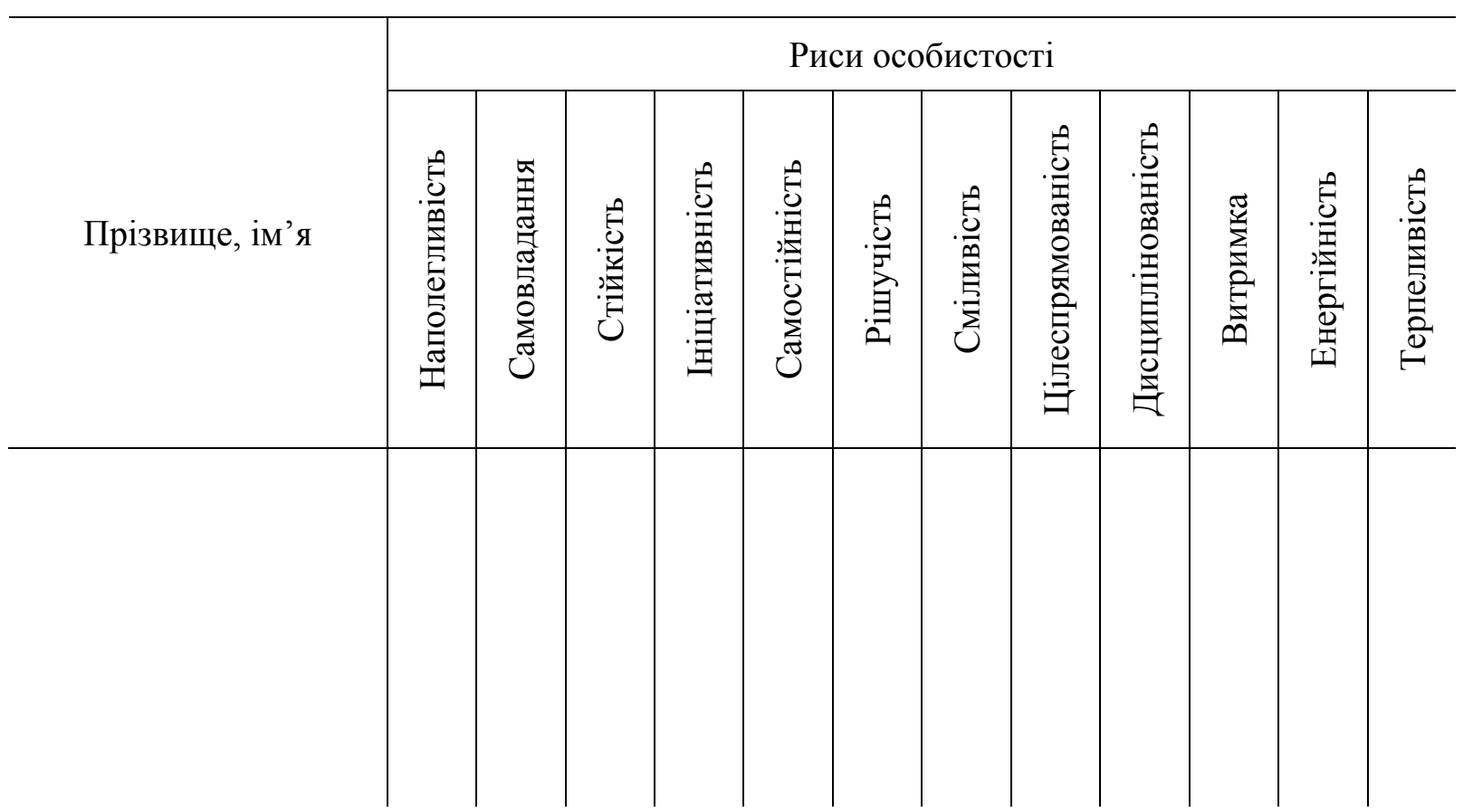

Оцініть за 10-бальною шкалою (від 0 до 10) ступінь прояву вказаних якостей особистості у студентів. 
ШКАЛА ОЦІНКИ РІВНЯ РЕАКТИВНОЇ ТА ОСОБИСТІСНОЇ ТРИВОЖНОСТІ

(Ч. Д. СПІЛБЕРГ, Ю. Л. ХАНІНА)

Бланк для відповідей

ШКАЛА САМООЦІКК

Прізвище, ім'я

Дата Група

Інструкція: Прочитайте уважно кожне 3 наведених нижче тверджень і закресліть відповідну цифру праворуч залежно від того, як ви себе почуваєте в даний момент (пункти 1-20), як ви себя почуваєте звичайно (пункти 2140). Над питаннями довго не замислюйтесь, оскільки правильних або неправильних відповідей немає.

$\mathbf{A}$ - Нi, це не так. B - Мабуть, так. $\mathbf{C}$ - Правильно. D - Абсолютно правильно.

\begin{tabular}{r|r|r|r|r|r}
\hline № п. & Стан & А & Б & С & D \\
\hline
\end{tabular}

Як ви себя почувасте в даний момент

\begin{tabular}{r|l|l|l|l|l} 
1. & Я спокійний & 1 & 2 & 3 & 4 \\
2. & Мені ніщо не загрожує & 1 & 2 & 3 & 4 \\
3. Я перебуваю в напруженні & 1 & 2 & 3 & 4 \\
4. & Я відчуваю жаль & 1 & 2 & 3 & 4 \\
5. & Я відчуваю себе вільно & 1 & 2 & 3 & 4 \\
6. & Я засмучений & 1 & 2 & 3 & 4 \\
7. & Яене хвилюють можливі невдачі & 1 & 2 & 3 & 4 \\
8. & Я відчуваю себе відпочившим & 1 & 2 & 3 & 4 \\
9. & Я не задоволений собою & 1 & 2 & 3 & 4 \\
10. & Я відчуваю почуття внутрішнього задоволення & 1 & 2 & 3 & 4 \\
11. & Я впевнений у собі & 1 & 2 & 3 & 4 \\
12. & Я нервую & 1 & 2 & 3 & 4 \\
13. & Я не знаходжу собі місця & 1 & 2 & 3 & 4 \\
14. & Я збуджений & 1 & 2 & 3 & 4 \\
15. & Я не відчуваю скутості & 1 & 2 & 3 & 4 \\
16. & Я задоволений & 1 & 2 & 3 & 4
\end{tabular}


Закінчення табличі

\begin{tabular}{r|l|c|c|c|c}
\hline \multicolumn{1}{|c|}{ № п. } & \multicolumn{1}{|c|}{ Стан } & А & Б & С & D \\
\hline 17. & Я стурбований & 1 & 2 & 3 & 4 \\
18. & Я занадто збуджений і мені не по собі & 1 & 2 & 3 & 4 \\
19. & Мені радісно & 1 & 2 & 3 & 4 \\
20. & Мені приємно & 1 & 2 & 3 & 4 \\
\hline
\end{tabular}

\section{Як ви себя почуваєте звичайно}

21. Я відчуваю задоволення

22. Я дуже швидко втомлююся

23. Я легко можу заплакати

24. Я хотів бы бути таким же щасливым, як і інші

25. Нерідко я програю через те, що недостатньо швидко приймаю рішення

26. Зазвичай я відчуваю себе бадьорим

27. Я спокійний, холоднокровний і зібраний

28. Очікувані труднощі зазвичай дуже турбують мене

29. Я занадто переживаю через дрібниці

30. Я цілком щасливий

31. Я приймаю все занадто близько до серця

32. Мені не вистачає впевненості в собі

33. Зазвичай я відчуваю себе в безпеці

34. Я намагаюся уникати критичних ситуацій

35. У мене буває хандра

36. Я задоволений

37. Будь-які дрібниці відволікають і хвилюють мене

38. Я так сильно переживаю свої розчарувания, що потім довго не можу про них забути

39. Я врівноважена людина

40. Мене охоплює сильне занепокоєння, коли я думаю про свої справи і турботи

\begin{tabular}{|l|l|l|l}
1 & 2 & 3 & 4 \\
1 & 2 & 3 & 4 \\
1 & 2 & 3 & 4 \\
1 & 2 & 3 & 4 \\
1 & 2 & 3 & 4 \\
1 & 2 & 3 & 4 \\
1 & 2 & 3 & 4 \\
1 & 2 & 3 & 4 \\
1 & 2 & 3 & 4 \\
1 & 2 & 3 & 4 \\
1 & 2 & 3 & 4 \\
1 & 2 & 3 & 4 \\
1 & 2 & 3 & 4 \\
1 & 2 & 3 & 4 \\
1 & 2 & 3 & 4 \\
1 & 2 & 3 & 4 \\
1 & 2 & 3 & 4 \\
1 & 2 & 3 & 4 \\
1 & 2 & 3 & 4 \\
1 & 2 & 3 & 4
\end{tabular}


Показники реактивної (РТ) і особистісної (ОТ) тривожності обчислюються за формулами:

$$
\mathrm{PT}=\Sigma_{1}-\Sigma_{2}+35,
$$

где $\sum_{1}$ - сума закреслених цифр на бланку по пунктах шкали $3,4,6,7,9,12-14$, 17,18

$\Sigma_{2}$ - сума інших закреслених цифр (пункти $1,2,5,8,10,11,15,16,19,20$ ).

$$
\mathrm{OT}=\Sigma_{1}-\Sigma_{2}+35
$$

где $\sum_{1}$ - сума закреслених цифр на бланку по пунктах шкали $22-25,28,29,31$, $32,34,35,37,38,40$;

$\Sigma_{2}$ - сума інших закреслених цифр (пункти $21,26,27,30,33,36,39$ ).

При інтерпретації результат можна оцінювати так:

до 30 - низька тривожність;

31-45 - помірна тривожність;

46 і більше - висока тривожність.

\section{ДОДАТОК 6}

\section{РІВЕНЬ СУБ' ЄКТИВНОГО КОНТРОЛЮ (РСК)}

1. Просування по службі більше залежить від вдалого збігу обставин, ніж від особливостей і власних зусиль людини.

2. Більшість розлучень відбувається від того, що люди не хочуть поступатися і пристосовуватися один до одного.

3. Хвороба - справа випадку, і якщо вже судилося комусь занедужати, то 3 цим нічого не поробиш.

4. Люди опиняються самотніми через те, що самі не виявляють інтересу і дружелюбності до оточуючих.

5. Здійснення моїх бажань часто залежить від везіння.

6. Марно докладати зусилля для того, щоб завоювати симпатії інших людей.

7. Зовнішні обставини - батьки і добробут - впливають на сімейне щастя не менше, ніж стосунки подружжя.

8. Я часто відчуваю, що мало впливаю на те, що відбувається зі мною.

9. Як правило, керівництво виявляється більш ефективним, коли керівники повністю контролюють дії підлеглих, а не покладаються на їх самостійність.

10. Мої оцінки в школі часто залежали від випадкових обставин, наприклад від настрою вчителя, а не від моїх власних зусиль.

11. Коли я будую плани, то загалом вірю в те, що зможу їх здійснити. 
12. Те, що багатьом людям здається удачею чи везінням, насправді є результатом довгих цілеспрямованих зусиль.

13. Думаю, що правильний спосіб життя може більше допомогти здоров’ю, ніж ліки і лікарі.

14. Якщо люди не підходять один одному, то, як би вони не старалися налагодити спільне життя, у них все одно нічого не вийде.

15. Те хороше, що я роблю в житті, переважно гідно оцінюється іншими.

16. Діти виростають такими, якими їх виховують батьки.

17. Я думаю, що випадок або доля не відіграють важливої ролі в моєму житті.

18. Я не намагаюся планувати своє життя далеко вперед, тому що багато залежить не від мене, а від того, як складуться обставини.

19. Мої оцінки в школі більше залежали від моїх зусиль і ступеня підготовленості.

20. У сімейних конфліктах я частіше відчуваю провину за собою, ніж за протилежною стороною.

21. Життя більшості людей залежить від збігу обставин.

22. Я надаю перевагу такому керівництву, при якому можна самостійно визначати, що і як робити.

23. Думаю, що мій спосіб життя жодною мірою не є причиною моїх хвороб.

24. Як правило, саме невдалий збіг обставин заважає людям добитися успіху в своїй справі.

25. Зрештою, за погане управління організацією відповідальні самі люди, які в ній працюють.

26. Я часто відчуваю, що нічого не можу змінити у сформованих відносинах в сім'ї.

27. Якщо я дуже захочу, то можу позитивно налаштувати по відношенню до себе майже будь-яку людину.

28. На підростаюче покоління впливає так багато різних обставин, що зусилля батьків щодо їх виховання часто виявляються марними.

29. Те, що зі мною трапляється, - це справа моїх власних рук.

30. Іноді важко буває зрозуміти, чому керівники чинять так, а не інакше.

31. Людина, яка не змогла досягти успіху у своїй роботі, швидше за все просто не проявила достатньо зусиль.

32. Найчастіше я можу домогтися від членів моєї сім’ї того, що я хочу.

33. У неприємностях і невдачах, які були в моєму житті, частіше були винні інші люди, а не я.

34. Дитину завжди можна вберегти від простуди, якщо за нею стежити і правильно ії одягати.

35. У складних обставинах я вважаю за краще почекати, поки проблеми не вирішаться самі собою.

36. Успіх є результатом наполегливої праці й мало залежить від успіху чи везіння.

37. Я відчуваю, що від мене більше, ніж від інших, залежить щастя моєї сім’ї. 
38. Мені завжди було важко зрозуміти, чому я подобаюсь одним людям і не подобаюсь іншим.

39. Я завжди віддаю перевагу приймати рішення і діяти самостійно, не сподіваючись на допомогу інших людей і не покладаючись на долю.

40. На жаль, заслуги людини часто залишаються невизнаними, незважаючи на всі її старання.

41. У сімейному житті бувають такі ситуації, які неможливо вирішити навіть при дуже сильному бажанні.

42. Здібні люди, які не змогли реалізувати свої можливості, мають звинувачувати в цьому тільки себе.

43. Багато моїх успіхів стали можливими тільки завдяки допомозі інших людей.

44. Більшість невдач у моєму житті відбулися від невміння, незнання чи ліні і мало що залежало від везіння чи невезіння.

\section{Ключ до методики:}

Ствердні відповіді «так» на запитання: 2, 4, 11, 12, 13, 15, 16, 17, 19, 20, 22 , $25,27,29,31,32,34,36,37,39,42,43,44$ оцінюються по одному балу і свідчать про розвиненість суб'єктивного контролю. Те ж саме стосується негативних відповідей «ні» на такі питання: 1, 3, 5, 6, 7, 8, 9, 10, 14, 18, 21, 23, 24, 26, 28, 30, 33, 35, 38 , 40, 41. За такі відповіді суб'єктивному контролю особистості також приписується по одному балу.

Максимальна кількість балів, які можна отримати за рівнем розвитку суб'єктивного контролю, дорівнює 44.

Вважається, що особи, які отримали від 33 до 44 балів, здатні взяти на себе відповідальність за те, що відбувається з ними і з іншими залежними від них людьми. Люди, що отримали від 12 до 32 балів, володіють середнім рівнем розвиненості суб'єктивного контролю і майже настільки ж часто в житті беруть на себе відповідальність, скільки покладають ії на інших людей, тим самим знімаючи особисто з себе відповідальність за те, що відбувається. Ті, чий сумарний показник у балах за даною методикою виявився 11 і нижче, характеризуються тим, що в більшості випадків знімають із себе відповідальність за події і пере-

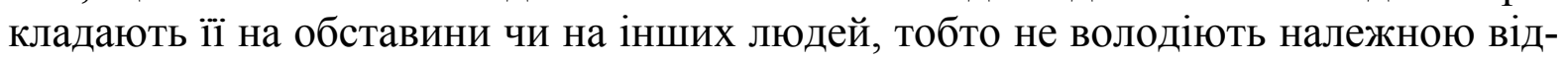
повідальністю. 


\section{MIC T}

ВСТУП

СУЧАСНИЙ СТАН РОЗРОБКИ ПРОБЛЕМИ ПСИХОЛОГІЧНОЇ

І ПСИХОФІЗИЧНОЇ ПІДГОТОВКИ ОСОБИСТОСТІ

ДО ПРОФЕСІЙНОЇ ПРАЦІ.

1.1. Психологічна і психофізична підготовка як об’єкт

наукових досліджень

1.2. Професійна придатність фахівця і його психологічна та психофізична підготовленість

1.3. Фізичне виховання як засіб підготовки особистості до професійної праці

ОРГАНІЗАЦІЯ Й МЕТОДИ ДОСЛІДЖЕННЯ ПРОБЛЕМИ

ПСИХОЛОГІЧНОЇ І ПСИХОФІЗИЧНОЇ ПІДГОТОВКИ СТУДЕНТІВ

ЗАЛІЗНИЧНИХ ВНЗ У ПРОЦЕСІ ФІЗИЧНОГО ВИХОВАННЯ ........................ 74

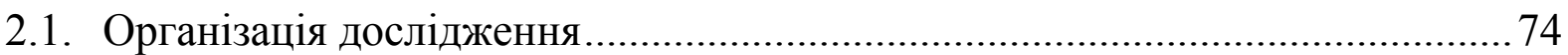

2.2. Характеристика методів дослідження ..................................................... 77

ТЕОРЕТИКО-МЕТОДОЛОГІЧНЕ ОБГРУНТУВАННЯ

ПСИХОЛОГІЧНОЇ І ПСИХОФІЗИЧНОЇ ПІДГОТОВКИ

ОСОБИСТОСТІ В ПРОЦЕСІ ФІЗИЧНОГО ВИХОВАННЯ.

3.1. Психофізична проблема як методологічне підгрунтя для постановки питання про психологічну й психофізичну підготовку у фізичному вихованні

3.2. Взаємовплив організму і психіки людини як теоретична основа використання фізичного виховання для вирішення завдань психологічної і психофізичної підготовки.

3.3. Психологія особистості як методологічний базис психологічної і психофізичної підготовки особистості у фізичному вихованні

ОСНОВИ ОРГАНІЗАЦІЇ ПСИХОЛОГІЧНОЇ І ПСИХОФІЗИЧНОЇ

ПІДГОТОВКИ СТУДЕНТІВ ЗАЛІЗНИЧНИХ ВНЗ

У ПРОЦЕСІ ФІЗИЧНОГО ВИХОВАННЯ

4.1. Психологічна й психофізична специфіка роботи на залізничному транспорті

4.2. Зміст, засоби й основи організації психологічної

і психофізичної підготовки студентів-залізничників

4.3. Психологічна й психофізична підготовка студентів-залізничників у структурі фізичного виховання

4.4. Діагностика актуального стану психологічної і психофізичної підготовленості студентів-залізничників 
ОСОБЛИВОСТІ ВПЛИВУ ФІЗКУЛЬТУРНОЇ СПОРТИВНОЇ

ДІЯЛЬНОСТІ НА СКЛАДОВІ ПСИХОЛОГІЧНОЇ

І ПСИХОФІЗИЧНОЇ ГОТОВНОСТІ СТУДЕНТІВ

5.1. Специфіка структурних компонентів особистості студентів навчальних секцій легкої атлетики і футболу ...

5.2. Особливості формування вольових якостей особистості

студентів навчальних секцій футболу, спортивної гімнастики, легкої атлетики.

5.3. Особливості розвитку уваги студентів у процесі занять футболом

5.4. Рівень контролю особистості та його вплив на агресивність у футболі

ФОРМУВАННЯ ПРОФЕСІЙНО ЗНАЧУЩИХ РИС ОСОБИСТОСТІ

СТУДЕНТІВ У ПРОЦЕСІ ПСИХОЛОГІЧНОЇ І ПСИХОФІЗИЧНОЇ

ПІДГОТОВКИ (ЕКСПЕРИМЕНТАЛЬНЕ ДОСЛІДЖЕННЯ)

6.1. Процедура й основні характеристики формувального експериментального дослідження психологічної і психофізичної підготовки студентів.

6.2. Формування професійно значущих рис особистості студентів

у процесі психологічної і психофізичної підготовки

6.3. Формування в студентів копінг-стратегій як складових психологічної готовності до праці у процесі психологічної і психофізичної підготовки.

6.4. Формування толерантності до невизначеності як складової психологічної готовності до праці у процесі психологічної і психофізичної підготовки.

6.5. Психологічна і психофізична підготовка як фактор зниження особистісної тривожності у студентів.

ФОРМУВАННЯ ПІЗНАВАЛЬНИХ ПРОЦЕСІВ І ПСИХОМОТОРИКИ

СТУДЕНТІВ У ПРОЦЕСІ ПСИХОЛОГІЧНОЇ І ПСИХОФІЗИЧНОЇ

ПІДГОТОВКИ (ЕКСПЕРИМЕНТАЛЬНЕ ДОСЛІДЖЕННЯ)

7.1. Розвиток концентрації і стійкості уваги студентів-залізничників

у процесі психологічної і психофізичної підготовки.

7.2. Розвиток вестибулярної стійкості студентів-залізничників у процесі психологічної і психофізичної підготовки.

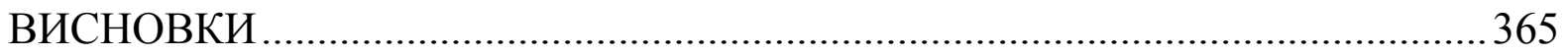

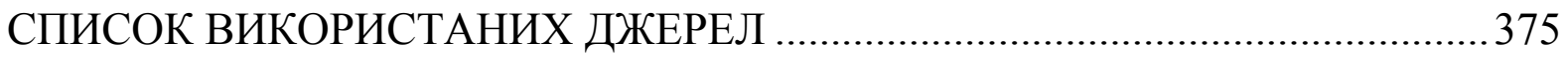

ДОДАТКИ 
Для нотаток 
Для нотаток 


\section{Теоретико-методологічні й організаційні основи психологічної і психофізичної підготовки студентів залізничних вищих навчальних закладів у процесі фізичного виховання}

Монографія

Редактор О. О. Котова

Комп'ютерна верстка О. М. Гончаренко

Формат $60 \times 84$ 1/16. УМ. друк. арк. 24,64. Обл.-вид. арк. 24,83.

Тираж 300 пр. Зам. №

Дніпропетровський національний університет залізничного транспорту імені академіка В. Лазаряна Свідоцтво суб’єкта видавничої справи ДК № 1315 від 31.03.2003 р.

Адреса видавця та дільниці оперативної поліграфії:

Дніпропетровський національний університет залізничного транспорту імені академіка В. Лазаряна, вул. Лазаряна, 2, Дніпропетровськ, 49010 